\title{
LEREN VAN HET VERLEDEN VOOR HET HEDEN
}

Een dossierstudie naar de rechtvaardiging van jeugdbescherming in de praktijk

Joost Huijer 
Leren van het verleden voor het heden

Een dossierstudie naar de rechtvaardiging van jeugdbescherming in de praktijk

\section{Learning from the past for the present}

An empirical study concerning the justification of child protection in practice

(with a summary in English)

\section{Proefschrift}

ter verkrijging van de graad van doctor aan de

Universiteit Utrecht

op gezag van de

rector magnificus, prof.dr. H.R.B.M. Kummeling, ingevolge het besluit van het college voor promoties in het openbaar te verdedigen op

maandag 23 november 2020 des avonds te 6.00 uur

door

Joost Izak Huijer

geboren op 26 januari 1987

te Vlaardingen 
Promotoren:

Prof. dr. I. Weijers

Prof. dr. K.R.S.D. Boele-Woelki 


\section{Inhoudsopgave}

Inhoudsopgave

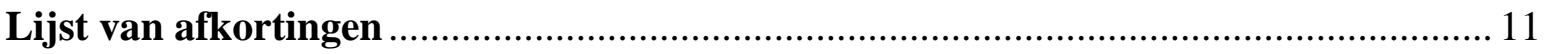

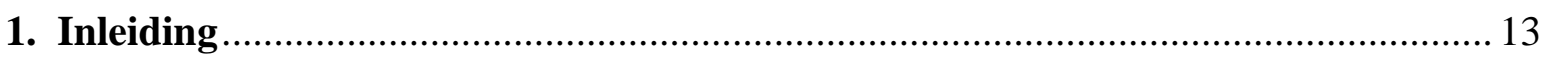

1.1 Rechtvaardiging van jeugdbescherming in de praktijk ........................................ 15

1.2 Dossieronderzoek over de jaren 2013-2014 .......................................................... 19

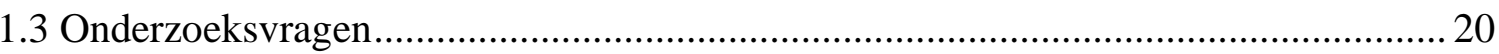

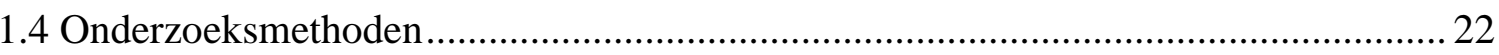

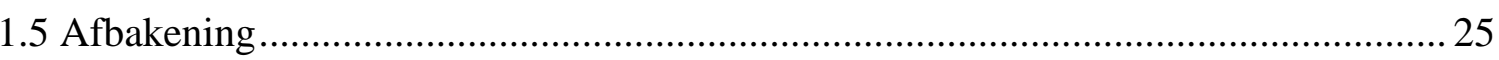

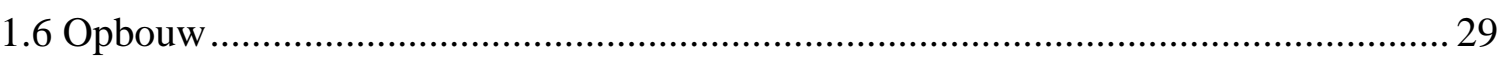

Deel I Het Nederlandse systeem van jeugdbescherming (2013-2014) ........................... 31

2. De besluitvorming in jeugdbeschermingszaken: procedurele aspecten en formele

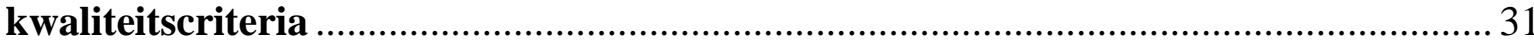

2.1 Kenmerken en uitgangspunten van de besluitvorming in jeugdbeschermingszaken.. 32 2.1.1 De negatieve en positieve verplichting van de overheid in jeugdbeschermingszaken

2.1.2 De verhouding tussen het (functioneren van het) systeem van jeugdzorg en de

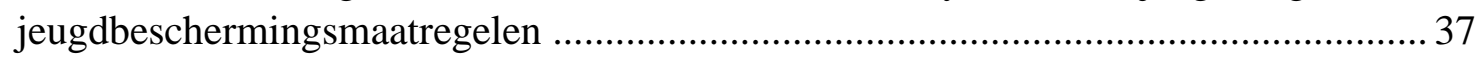

2.2 Het verzamelen en beoordelen van bewijs in jeugdbeschermingszaken ..................... 40

2.2.1 De algemene regels van bewijsrecht in civiele zaken ....................................... 41

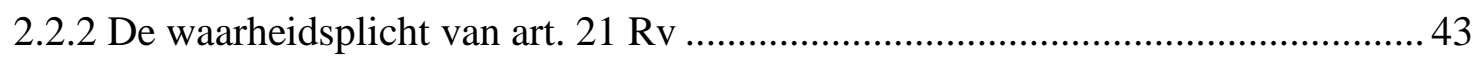

2.3 De discussie omtrent waarheidsvinding in jeugdbeschermingszaken ....................... 45

2.3.1 Kritiek op de jeugdbeschermingsautoriteiten ................................................ 46

2.3.2 Overeenkomsten en verschillen met waarheidsvinding in strafrechtelijke zin .... 48

2.3.3 Het onderscheid tussen feiten en meningen ..................................................... 52

2.4 Het beschermingsonderzoek door de Raad voor de Kinderbescherming .................. 55

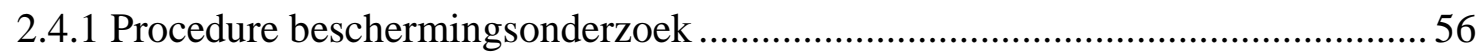

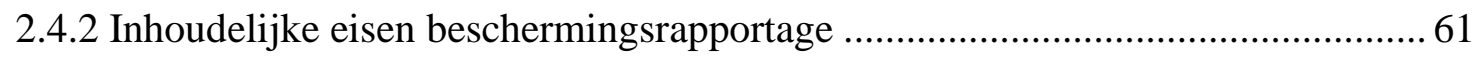

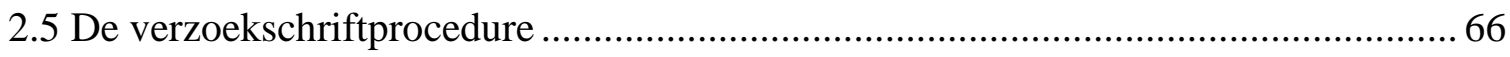

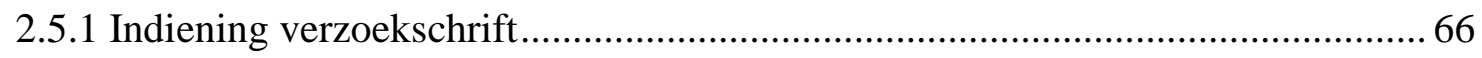

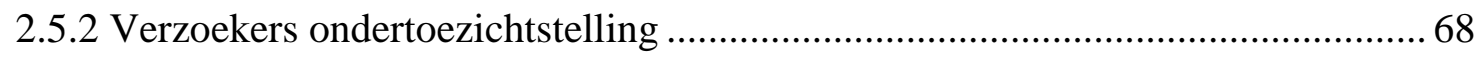

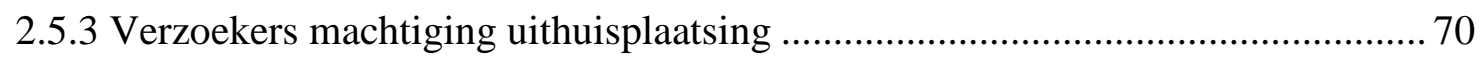

2.5.4 Inhoudelijke eisen verzoek- en verweerschrift................................................ 71

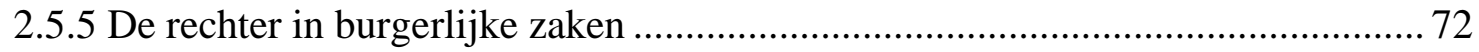

2.5.6 De mondelinge behandeling van het verzoek................................................ 74 
2.5.7 De (schriftelijke) motivering van de beschikking. .77

2.6 Uitgangspunten voor het dossieronderzoek in jeugdbeschermingszaken .82

3. Rechtspositie van minderjarige en ouders in de jeugdbeschermingsprocedure ....... 84

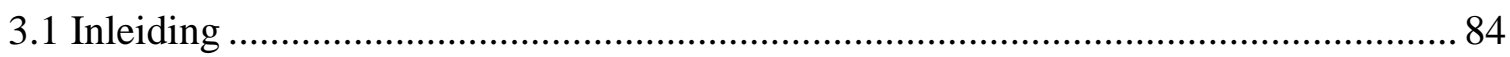

3.2 Ouderlijk gezag en de handelings(on)bekwaamheid van de minderjarige ................ 87

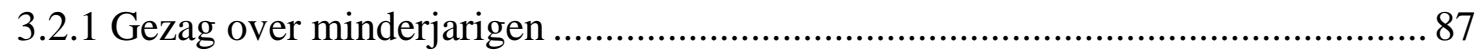

3.2.2 Ontwikkelingen ten aanzien van de handelings(on)bekwaamheid van de

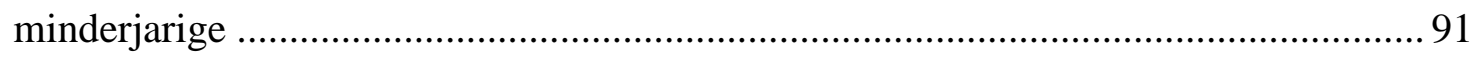

3.2.3 Materiële handelings(on)bekwaamheid minderjarige .................................... 92

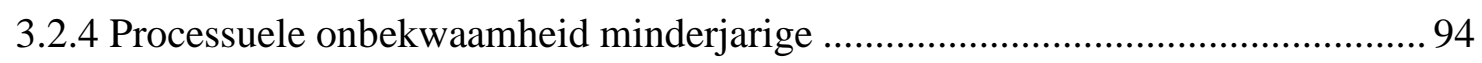

3.2.5 Uitzonderingen binnen het jeugdbeschermingsrecht op het uitgangspunt van

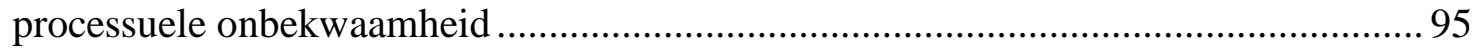

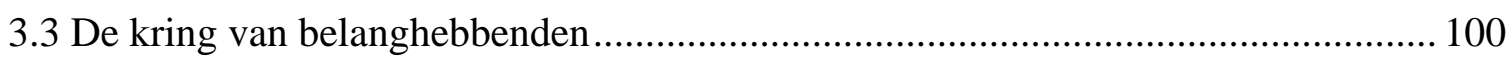

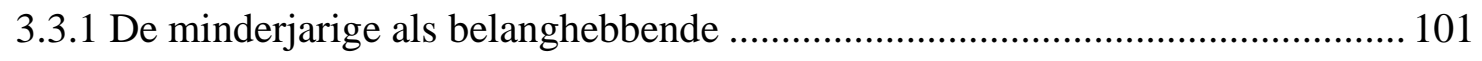

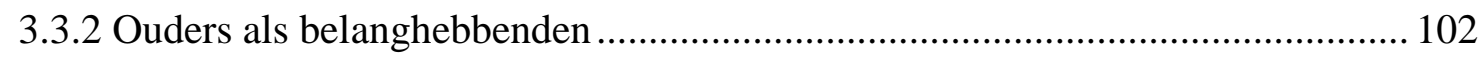

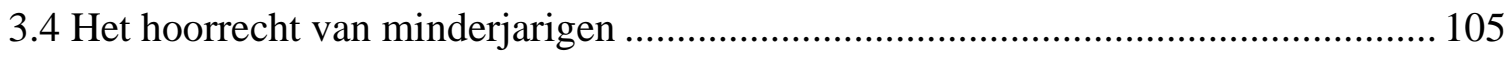

3.4.1 Hoorrecht van de minderjarige op grond van art. 12 IVRK.............................. 106

3.4.2 Hoorrecht bij scheiding van kind en ouders: art. 9 IVRK ................................ 113

3.4.3 Hoorrecht minderjarige op grond van het EVRM........................................ 115

3.4.4 Het hoorrecht van minderjarigen op grond van art. $809 \mathrm{Rv}$............................ 120

3.5 Uitgangspunten voor het dossieronderzoek in jeugdbeschermingszaken ................. 127

4. Gronden en doelstellingen van de jeugdbeschermingsmaatregelen ....................... 130

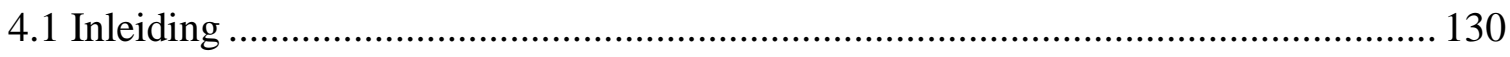

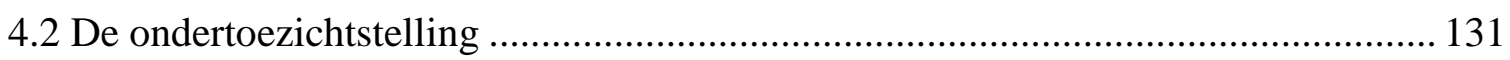

4.2.1 Achtergronden en kenmerken van de ondertoezichtstelling ............................ 131

4.2.2 Rechtsgrond ondertoezichtstelling: de ernstige bedreiging van de zedelijke of geestelijke belangen of gezondheid van de minderjarige........................................ 134

4.2.3 Rechtsgrond van de ondertoezichtstelling: het (voorzienbaar) falen van andere

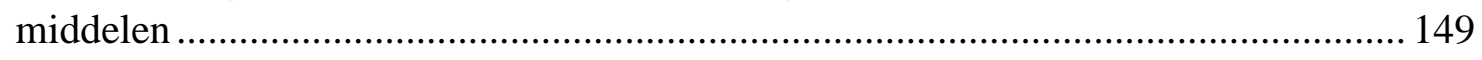

4.2.4 De wettelijke doelstelling van de ondertoezichtstelling ................................. 151

4.2.5 Het vertalen van de wettelijke doelstelling van de ondertoezichtstelling in

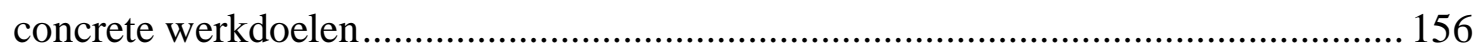

4.2.6 Duur, verlenging en beëindiging van de ondertoezichtstelling ......................... 158

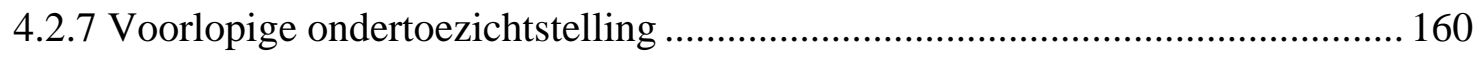

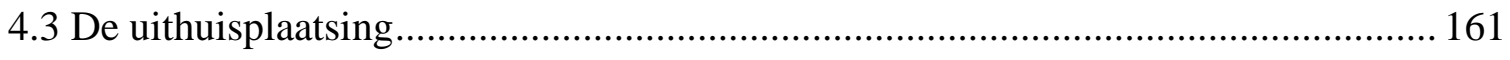

4.3.1 Rechtsgrond van de machtiging tot uithuisplaatsing ..................................... 164 
4.3.2 De noodzaak tot uithuisplaatsing in het licht van art. 8 EVRM 166

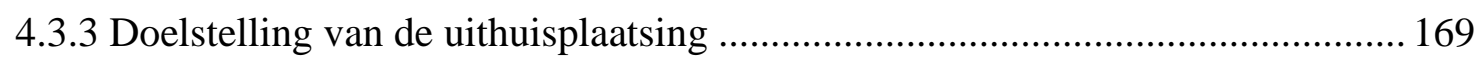

4.3.4 De doelstelling van de uithuisplaatsing in het licht van art. 8 EVRM ............... 171

4.3.5 Duur, verlenging en beëindiging van de machtiging uithuisplaatsing ............... 172

4.4 De machtiging uithuisplaatsing in een accommodatie voor gesloten jeugdzorg ...... 174

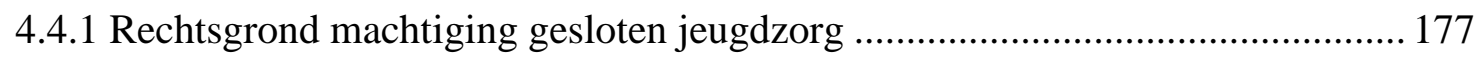

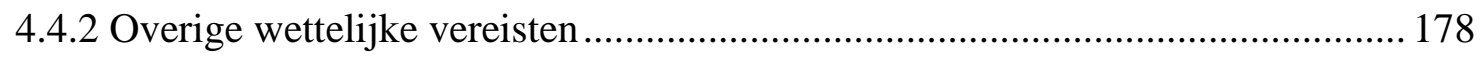

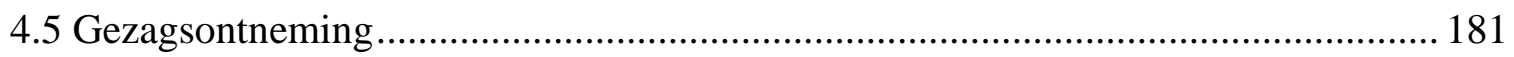

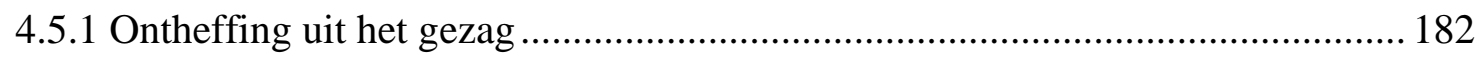

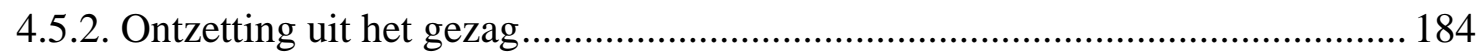

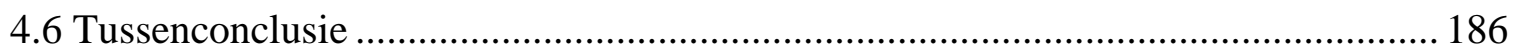

Deel II Dossieronderzoek naar de rechtvaardiging van jeugdbescherming in de praktijk

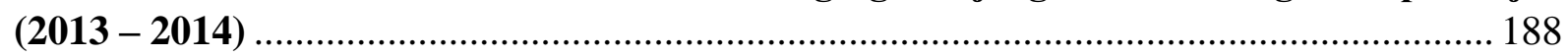

5. Opzet en uitvoering dossieronderzoek en kenmerken onderzoekspopulatie .......... 188

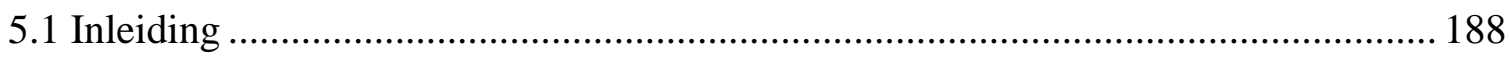

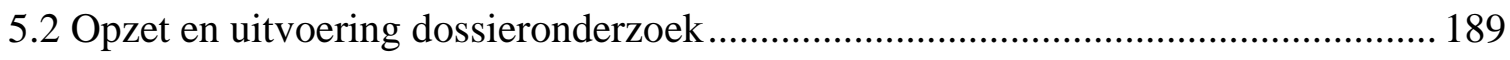

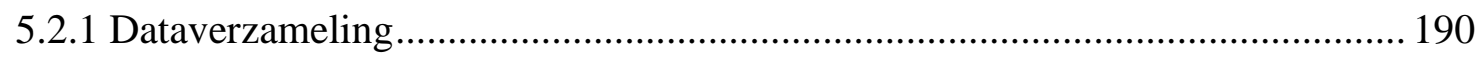

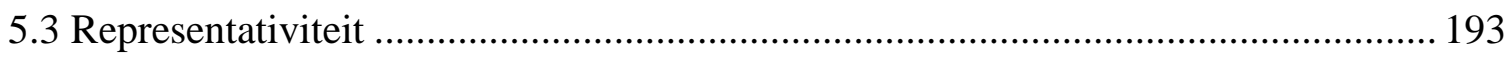

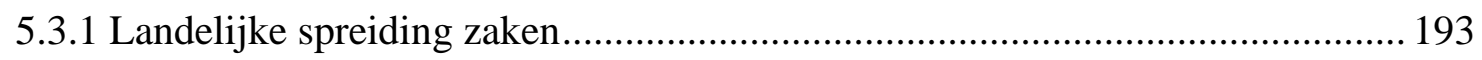

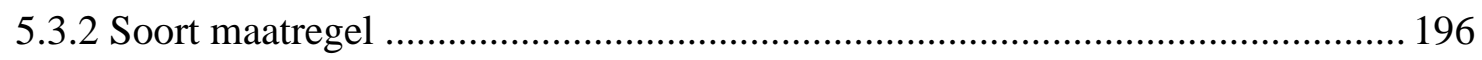

5.4 Achtergrondkenmerken kind en opvoedingsomgeving ....................................... 198

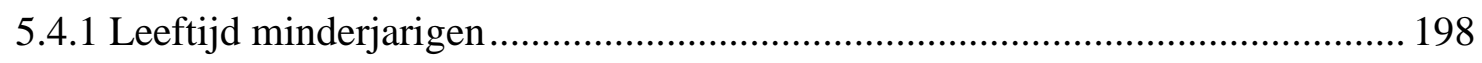

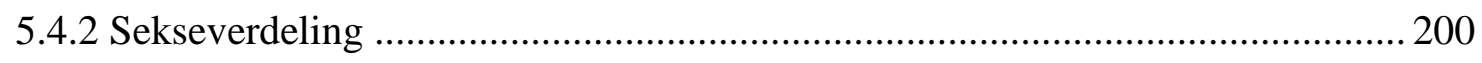

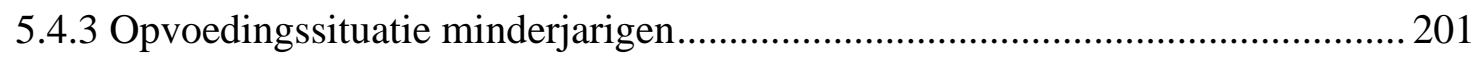

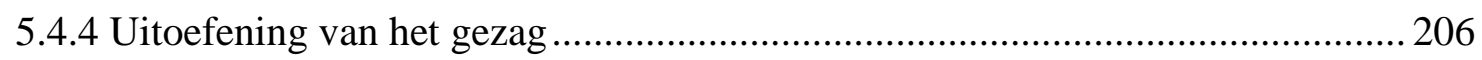

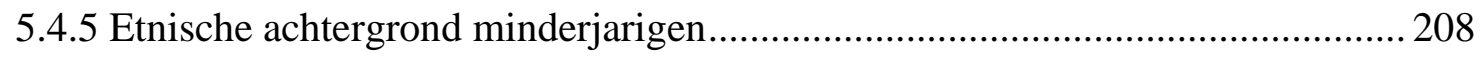

6. Dossieronderzoek naar de rechtvaardiging van de ondertoezichtstelling door de

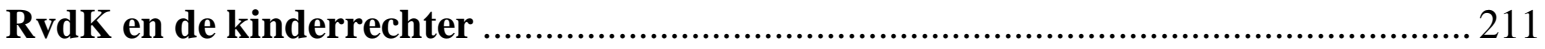

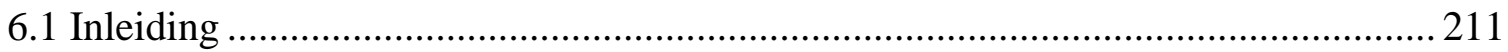

6.2 Verzoek tot ondertoezichtstelling: wettelijke gronden ....................................... 212

6.2.1 Ernstige bedreiging van de zedelijke of geestelijke belangen of gezondheid.... 212

6.2.2 (Voorzienbaar) falen van andere middelen ................................................... 223

6.3 Verzoek tot ondertoezichtstelling: doelstelling....................................................... 228

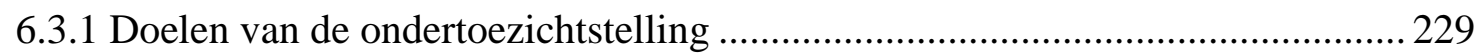

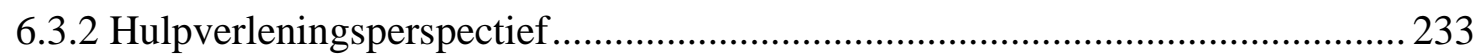

6.4 Beschikking op het verzoek tot ondertoezichtstelling ......................................... 233 
6.4.1 Beslissing van de kinderrechter

6.4.2 Onderbouwing ernstige bedreiging van de zedelijke of geestelijke belangen of gezondheid van de minderjarige door de kinderrechter....

6.4.3 Onderbouwing (voorzienbaar) falen van andere middelen door de kinderrechter

6.5 Tussenconclusie 236

7. Dossieronderzoek naar de rechtvaardiging van de uithuisplaatsing door de RvdK en de kinderrechter

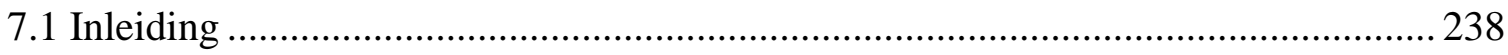

7.2 Verzoek tot machtiging uithuisplaatsing: wettelijke vereisten .............................. 240

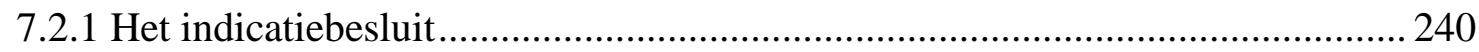

7.2.2 Onderbouwing van het verzoek tot machtiging uithuisplaatsing - algemene bevindingen

7.2.3 Het onderzoek naar minder ingrijpende alternatieven ter voorkoming van de

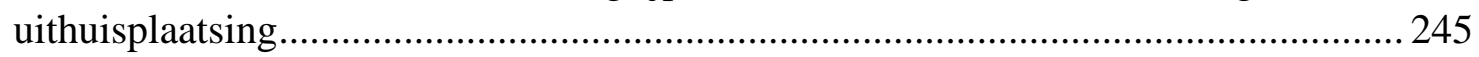

7.3 Verzoek machtiging uithuisplaatsing: doelstelling ............................................... 248

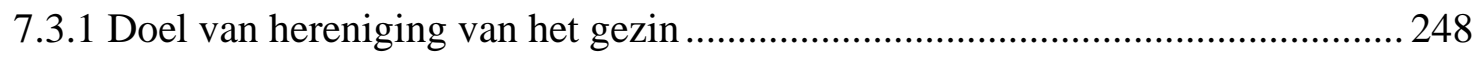

7.4 Beschikking op het verzoek tot machtiging uithuisplaatsing ................................ 249

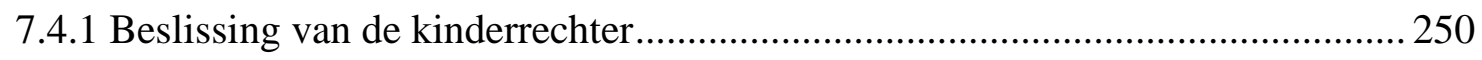

7.4.2 Onderbouwing van de noodzaak van een plaatsing buiten het gezin................ 251

7.5 Het verzoek machtiging gesloten jeugdzorg: wettelijke vereisten........................... 252

7.5.1 Instemmingsverklaring van gedragswetenschapper ...................................... 253

7.5.2 Ernstige opgroei/opvoedingsproblemen die de ontwikkeling naar volwassenheid

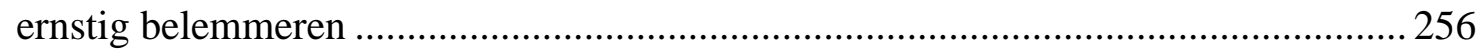

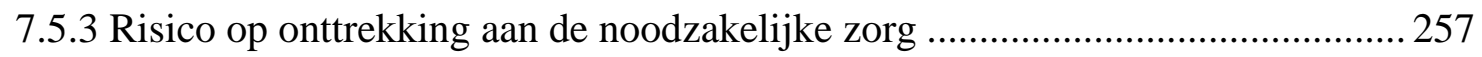

7.6 Beschikking op het verzoek machtiging gesloten jeugdzorg .................................. 258

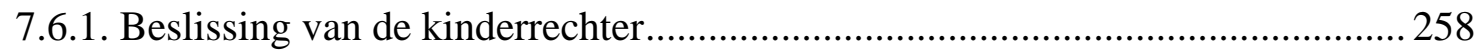

7.6.2 Ernstige opgroei- en opvoedingsproblemen die de ontwikkeling ernstig

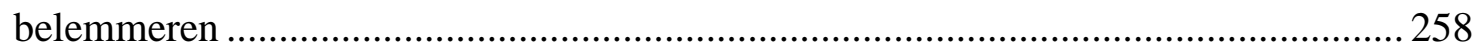

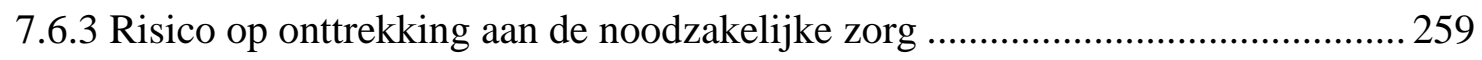

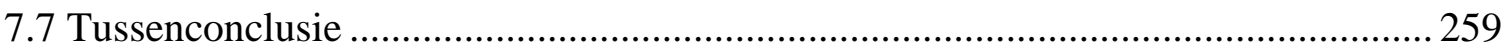

\section{Dossieronderzoek naar de zorgvuldigheid van het feitenonderzoek en de} rechtspositie van de minderjarige en zijn ouders ............................................... 261

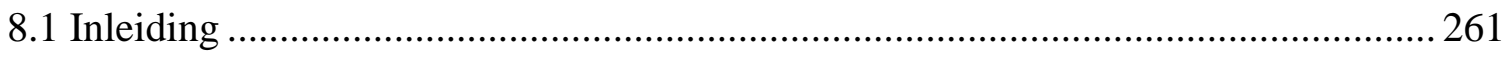

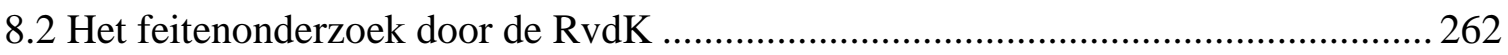

8.2.1. Accorderen en dateren van de ingebrachte informatie .................................... 263

8.2.2. Het onderscheid tussen feiten en meningen in de beschermingsrapportage ..... 265 
8.3 De rechtspositie van de minderjarige en zijn ouders tijdens het beschermingsonderzoek

8.3.1 Het horen van de minderjarige en zijn ouders tijdens het beschermingsonderzoek

8.3.2 Inzage in de conceptrapportage voor de minderjarige en zijn ouders 273

8.3.3 Adviesgesprek met de minderjarige en zijn ouders 274

8.4 De rechtspositie van de minderjarige en zijn ouders tijdens de gerechtelijke procedure 276

8.4.1 Het horen van de minderjarige. 277

8.4.2 De mening van de minderjarige in de beschikking. 278

8.5 Tussenconclusie 280

9. Conclusies dossieronderzoek naar de rechtvaardiging van jeugdbescherming in de

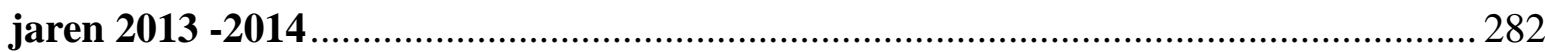

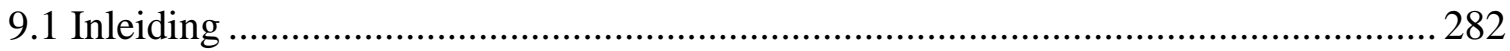

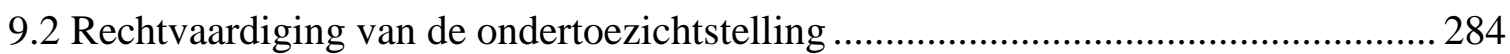

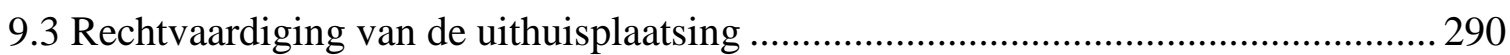

9.4 Rechtvaardiging van de machtiging gesloten jeugdzorg ....................................... 295

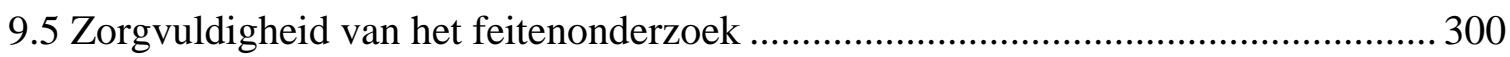

9.6 De rechtspositie van de minderjarige (en ouders) in de jeugdbeschermingsprocedure 304

9.7 Afsluitende conclusies deel I \& deel II ................................................................ 310

Deel III Bevindingen en reflecties op de jeugdbeschermingspraktijk vanaf 2015 ........ 314

10. De rechtvaardiging van jeugdbescherming vanaf 1 januari 2015 ...................... 314

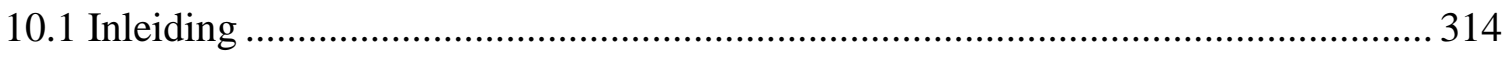

10.2 De Wet herziening kinderbeschermingsmaatregelen en de Jeugdwet: achtergronden

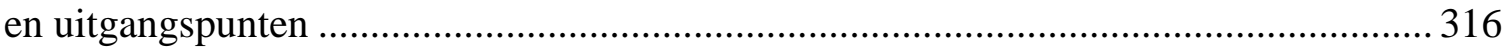

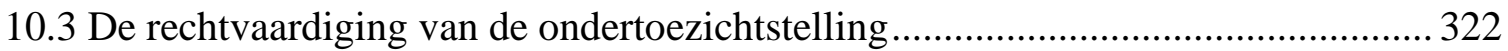

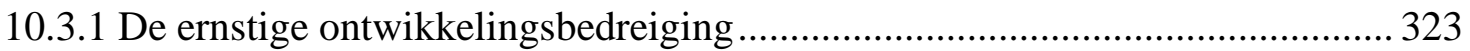

10.3.2 Het niet of onvoldoende accepteren van de noodzakelijke zorg ...................... 326

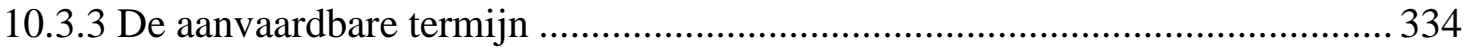

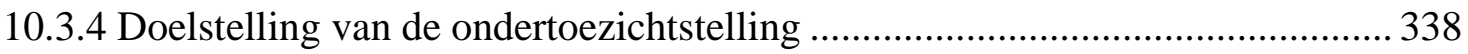

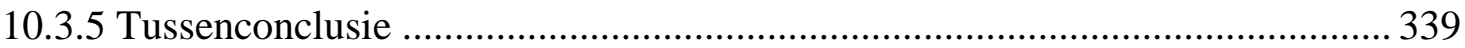

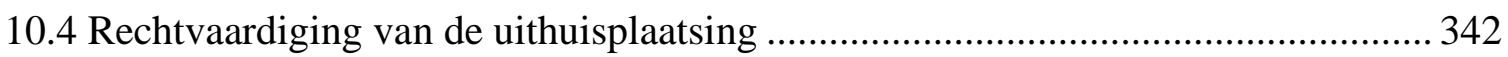

10.4.1. Het verleningsbesluit na inwerkingtreding van de Jeugdwet.......................... 344

10.4.2. De onderbouwing van de noodzaak tot uithuisplaatsing ................................3. 346

10.4.3 Het doel van hereniging van het gezin na uithuisplaatsing ............................ 347

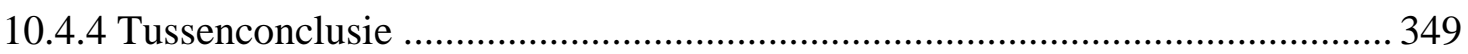




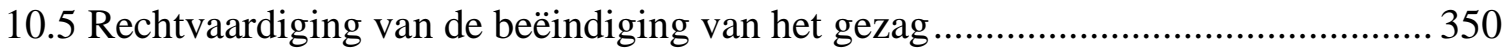

10.5.1 De toepassing van de gezagsbeëindigende maatregel - uitgangspunten .......... 352

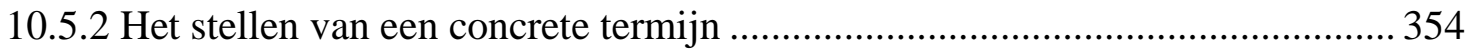

10.5.3 De onzekerheid over het opvoedperspectief van de minderjarige en de noodzaak

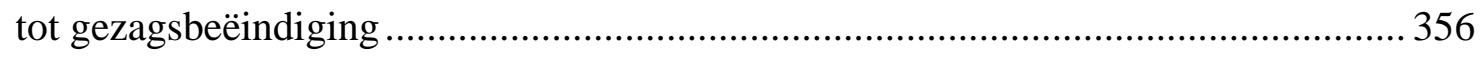

10.5.4 Het doel van gezinshereniging en de noodzaak tot gezagsbeëindiging ........... 360

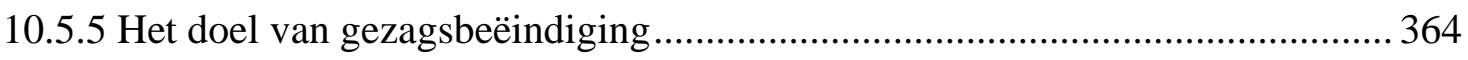

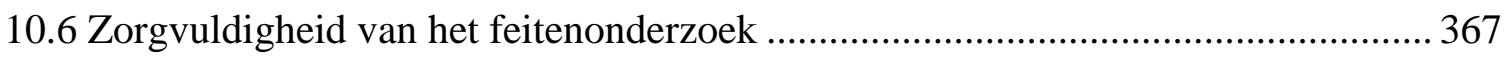

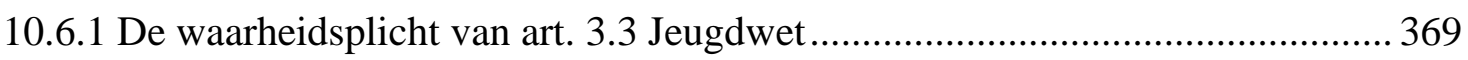

10.6.2 Overige ontwikkelingen ten aanzien van het feitenonderzoek in

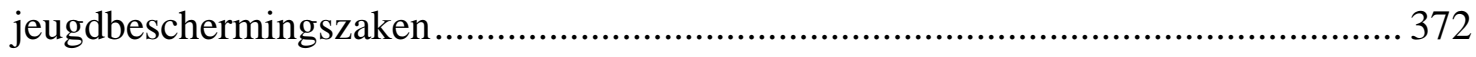

10.6.3 De relevantie van het dossieronderzoek naar de feitenvaststelling voor de

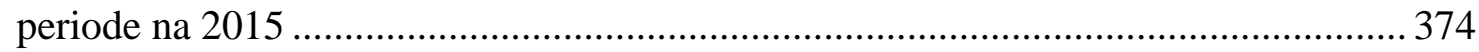

10.7 De rechtspositie van de minderjarige en zijn ouders ............................................ 375

10.7.1 De concrete bedreigingen in het verzoekschrift en de beschikking ..................376

10.7.2 Het horen van de minderjarige: belangrijkste ontwikkelingen ....................... 379

10.7.3 De relevantie van het dossieronderzoek voor het horen van de minderjarige door

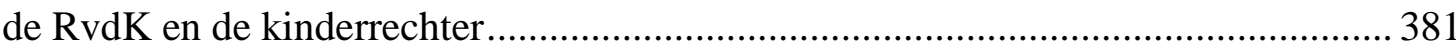

10.7.4 De relevantie van het dossieronderzoek voor het betrekken van de minderjarige in de besluitvorming door de RvdK en de kinderrechter ....................................... 382

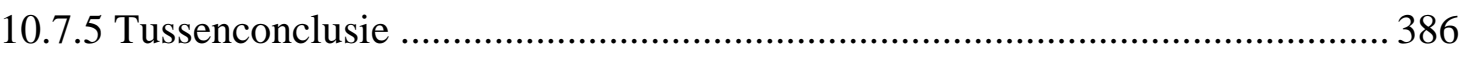

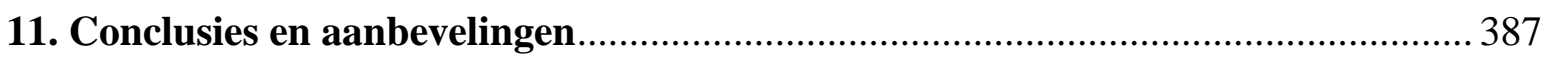

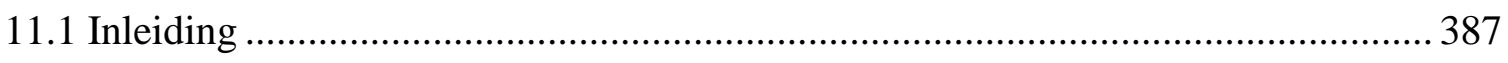

11.2 Samenvattende conclusies per onderdeel ten aanzien van de rechtvaardiging van

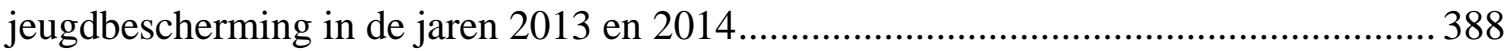

11.3 Samenvattende bevindingen en reflecties op de jeugdbeschermingspraktijk vanaf

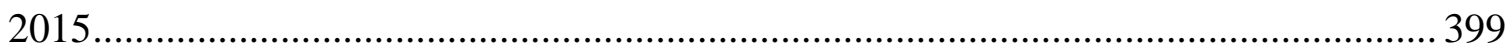

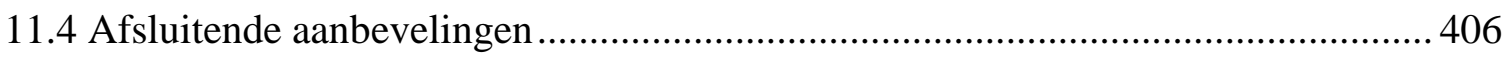

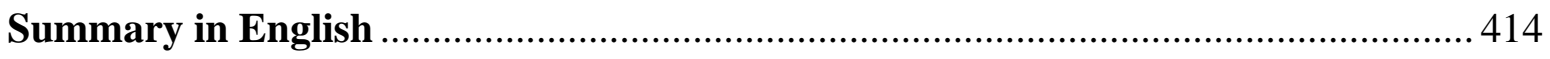

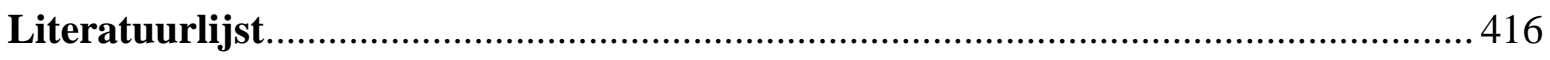

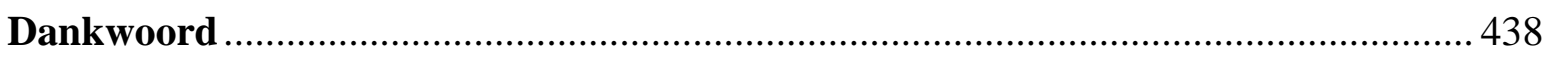

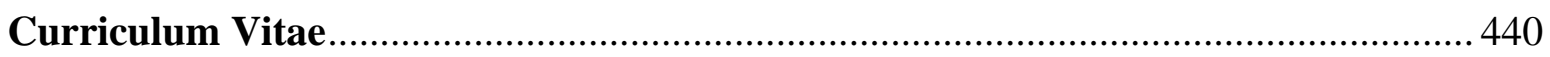




\section{Lijst van afkortingen}

$A A$

Ars Aequi

ADHD Attention Deficit Hyperactivity Disorder

A-G Advocaat-Generaal

AMK Advies- en Meldpunt Kindermishandeling

ASAA Afstand, Screening, Adoptie en Afstamming

Awb Algemene wet bestuursrecht

AWBZ Algemene Wet Bijzondere Ziektekosten

$\mathrm{Bjj} \quad$ Beginselenwet justitiële jeugdinrichtingen

BJZ Bureau Jeugdzorg

BW Burgerlijk Wetboek

$\mathrm{B} \& \mathrm{~W} \quad$ Burgermeester en wethouders

CBS Centraal Bureau voor de Statistiek

CITO Centraal Instituut voor Toetsontwikkeling

CIZ Centrum Indicatiestelling Zorg

CRC Convention on the Rights of the Child

D66 Democraten 66

EB Tijdschrift voor Scheidingsrecht

EHRM Europees Hof voor de Rechten van de Mens

EVRM Europees Verdrag voor de Rechten van de Mens

FJR Tijdschrift voor Familie- en Jeugdrecht

GC General Comment

GI Gecertificeerde Instelling

G\&O Gezag \& Omgang

GS Groene Serie

$\mathrm{Gw} \quad$ Grondwet

Hof Gerechtshof

HR Hoge Raad

IVBPR Internationaal Verdrag inzake Burgerrechten en Politieke Rechten

IVRK Internationaal Verdrag inzake de Rechten van het Kind

JH Joost Huijer

JJI Justitiële Jeugdinrichting

Jw Jeugdwet

KBPS Kinderbescherming Bedrijfsprocessen Systeem

LWI Landelijk Werkende Instellingen

m.nt. met noot van

MvA Memorie van antwoord

MvT Memorie van toelichting

MUHP machtiging uithuisplaatsing

NAO (persoonlijkheidsstoornis) niet anders omschreven

NJ Nederlandse Jurisprudentie

$\mathrm{OM} \quad$ Openbaar ministerie

OTS Ondertoezichtstelling

Pcj Procesreglement

PvdA Partij van de Arbeid

$\mathrm{Rb} \quad$ Rechtbank 
Wetboek van Burgerlijke Rechtsvordering

RvdK

Raad voor de Kinderbescherming

SGP

SP

Staatkundig Gereformeerde Partij

Stb

Socialistische Partij

Stcrt

Staatsblad

$\mathrm{Sv}$

Staatscourant

$\mathrm{T} \& \mathrm{C}$

Wetboek van Strafvordering

UN

Tekst en Commentaar

Uwjz

United Nations

$\mathrm{VN}$

Uitvoeringsbesluit Wet op de jeugdzorg

VOTS

Verenigde Naties

VoVo

Voorlopige ondertoezichtstelling

VVD

Voorlopige voogdij

$\mathrm{Wjz}$

Volkspartij voor Vrijheid en Democratie

Wet op de Jeugdzorg 


\section{Inleiding}

Ieder kind in Nederland heeft het recht om onbedreigd op te groeien naar volwassenheid. De primaire verantwoordelijkheid voor de verzorging en opvoeding van het kind ligt bij het gezin. Niet ieder gezin is echter in staat een opvoedingsklimaat te bieden dat in het licht van wettelijke- en maatschappelijke normen als veilig en pedagogisch verantwoord kan worden beschouwd. In dergelijke gevallen rust op de overheid de positieve verplichting om het kind te garanderen dat het zonder ernstige ontwikkelingsbedreigingen kan opgroeien.

Al ruim honderd jaar geeft de overheid invulling aan deze positieve verplichting het kind te beschermen aan de hand van het wettelijke systeem van jeugdbescherming, neergelegd in Boek 1 Burgerlijk Wetboek (hierna: BW). De hoofddoelstelling van het systeem van jeugdbescherming is het waarborgen van een opvoedings- en leefsituatie die voldoet aan minimale vereisten zodat de minderjarige zich op gezonde en evenwichtige wijze kan ontwikkelen. Deze formulering geeft de verhoudingen binnen de trias pedagogica - de driehoeksverhouding kind, ouders en overheid - helder weer. Zowel vanuit juridisch als pedagogisch oogpunt heeft als uitgangspunt te gelden dat de minderjarige het beste bij zijn ouders kan opgroeien. Ontstaan er problemen in de opvoedingssituatie dan zal eerst op basis van vrijwilligheid moeten worden getracht om de situatie zodanig te verbeteren dat de ouders met gezag weer volledig zelfstandig de verantwoordelijkheid voor de verzorging en opvoeding van de minderjarige kunnen dragen. De ouders zijn primair verantwoordelijk voor de verzorging en opvoeding van de minderjarige, een positie die de overheid onder meer op grond van art. 5 Internationaal Verdrag inzake de Rechten van het Kind (hierna: IVRK) heeft te respecteren.

Het recht van het kind en zijn ouders op eerbiediging van hun privéleven, familie- en gezinsleven op grond van art. 8 Europees Verdrag voor de Rechten van de Mens betekent onder meer dat zij in beginsel ongestoord moeten kunnen genieten van elkaars gezelschap. Ouders met gezag hebben het recht en de plicht de minderjarige te verzorgen en op te voeden en in de uitoefening van dit recht komt hen een grote mate van vrijheid toe om hierin naar eigen inzicht keuzes te maken. Volgens art. 1:247 lid 2 BW zijn de ouders met gezag verantwoordelijk voor het geestelijk en lichamelijk welzijn en de veiligheid van het kind. Volgens het geldende recht moet het gezag van ouders worden beschouwd als een doelbevoegdheid. De rechten van de ouders die voortvloeien uit het ouderlijk gezag kunnen worden beperkt, of in uitzonderlijke gevallen worden ontnomen, indien dit in het belang van de ontwikkeling van het kind noodzakelijk is. 
Ook zonder nog te kijken naar de concrete regels die bepalend zijn voor de vraag wanneer gedwongen overheidsingrijpen gerechtvaardigd kan zijn, is duidelijk dat jeugdbescherming een precaire aangelegenheid is. Uitzonderingen daargelaten wenst iedere ouder het beste voor zijn kind. Dit betekent echter niet dat iedere ouder daar ook naar weet te handelen. Er zijn tal van redenen die aanleiding kunnen geven een ernstige bedreiging in de ontwikkeling van de minderjarige te constateren. ${ }^{1}$ Aan de jeugdbeschermingsautoriteiten de moeilijke maar noodzakelijke taak om hierover te oordelen. De uitkomst van dit proces is in veel gevallen ingrijpend voor de minderjarige en confronterend en pijnlijk voor de ouders.

Daarbij moeten de jeugdbeschermingsautoriteiten, meer specifiek de Raad voor de Kinderbescherming (hierna: RvdK), beslissingen nemen die liggen in een grijs gebied. Gedwongen overheidsingrijpen in het gezinsleven is mogelijk als er concreet en overtuigend kan worden aangetoond dat er schade voor de ontwikkeling van de minderjarige dreigt. De schade hoeft echter niet aantoonbaar al te zijn ingetreden. Het is immers de taak van de jeugdbescherming om die schade zoveel mogelijk te voorkomen. Dit leidt ertoe dat het juiste moment om in te grijpen bijzonder moeilijk is te bepalen. De dagelijkse praktijk inzake jeugdbescherming kenmerkt zich door een spanningsveld tussen de vereiste terughoudende opstelling waar het gaat om gedwongen interveniëren in het gezinsleven en de verplichting het kind te beschermen tegen schadelijke invloeden, verwaarlozing of ander pedagogisch onverantwoord handelen.

Rechtvaardigt het streven naar de bescherming van het kind preventief overheidsingrijpen met als bijkomend risico dat misschien wel te snel en te vergaand wordt ingegrepen in het gezinsleven van kind en ouders? Of heerst juist een klimaat waarin ouderlijke rechten te lang prevaleren boven de belangen van het kind? Beide zienswijzen zijn in de achterliggende eeuw jeugdbescherming veelvuldig verdedigd, niet zelden ook gelijktijdig. ${ }^{2}$ Het is typerend voor een systeem van jeugdbescherming waarin grote onzekerheid heerst ten aanzien van de vraag wanneer en onder welke voorwaarden ingrijpen in het gezinsleven gerechtvaardigd is. Om de zojuist benoemde onzekerheid te verkleinen loont het om (beter) inzichtelijk te maken hoe de

\footnotetext{
${ }^{1}$ Voor de duidelijkheid moet hier al worden opgemerkt dat een bedreigde ontwikkeling van de minderjarige niet per definitie hoeft voort te komen uit een doen of nalaten van de ouders.

${ }^{2}$ Zo was de wetgever in 2009 nog van mening dat met invoering van de Wet herziening kinderbeschermingsmaatregelen de drempel voor ingrijpen middels een jeugdbeschermingsmaatregel moest worden verlaagd. Zie: Kamerstukken II 2008/9, 32 015, nr. 3 (MvT). Niet veel later stuurde een groep jeugdrechtadvocaten een brandbrief naar de Rechtbank Rotterdam waarin een tegengeluid was te horen. Te snel zou worden overgegaan tot jeugdbeschermingsmaatregelen en de toetsing van de verzoeken door kinderrechters zou onvoldoende diepgaand zijn. Zie voor een uitgebreide toelichting: Uit Beijerse, Logtenberg \& Ruitenberg 2010 .
} 
rechtvaardiging van een jeugdbeschermingsmaatregel in juridische zin in de praktijk is vormgegeven. Dit onderzoek beoogt primair inzicht te verschaffen in de wijze waarop de RvdK en de kinderrechter in de jaren 2013 en 2014 de juridische rechtvaardiging van een ondertoezichtstelling met of zonder uithuisplaatsing hebben vormgegeven. Het begrip 'rechtvaardiging' speelt daarmee een centrale rol in dit onderzoek. Rechtvaardiging heeft hier de betekenis van 'onderbouwing' of 'verantwoording' en ziet op verschillende juridische aspecten in de besluitvorming.

\subsection{Rechtvaardiging van jeugdbescherming in de praktijk}

In vrijwel alle gevallen wordt een jeugdbeschermingsmaatregel geïnitieerd door de RvdK. De RvdK heeft de wettelijke taak om onderzoek te doen naar de opvoedingssituatie van minderjarigen en moet besluiten of een verzoek tot jeugdbeschermingsmaatregel wordt ingediend. ${ }^{3}$ De kinderrechter beslist uiteindelijk of een jeugdbeschermingsmaatregel in het concrete geval gerechtvaardigd is. Het inhoudelijke besluitvormingsproces van de RvdK en de kinderrechter (en van de jeugdbeschermingsautoriteiten in bredere zin), wordt genormeerd door nationale wetgeving, toepasselijk verdragsrecht en interne kwaliteitscriteria voor zorgvuldig onderzoek. Deze regels geven niet alleen aan hoe het materiële jeugdbeschermingsrecht moet worden toegepast, maar bepalen ook hoe de (gerechtelijke) procedure vorm krijgt en welke positie de minderjarige en zijn ouders kunnen innemen in de besluitvormingsprocedure.

\section{Rechtmatigheid, zorgvuldigheid en oog voor de rechtspositie van de minderjarige en de ouders}

Een zo volledig mogelijk antwoord op de vraag te formuleren of in de praktijk voldoende rechtvaardiging wordt geboden voor de inzet van een jeugdbeschermingsmaatregel vraagt om een analyse van deze drie componenten: rechtmatigheid, zorgvuldigheid en oog voor de rechtspositie van de minderjarige en de ouders. Een analyse van de wijze waarop het materiële jeugdbeschermingsrecht wordt toegepast en of dat naar de letter en intentie van de wet gebeurt, zou een te beperkt beeld opleveren van de rechtvaardiging van jeugdbescherming. Het correct toepassen van de gronden van de jeugdbeschermingsmaatregelen verliest immers voor een groot deel zijn waarde indien de informatie op basis waarvan de juridische toets plaatsvindt onvolledig of incorrect is. De vaststelling van het feitencomplex binnen het onderzoek en de toepassing van het materiële

\footnotetext{
${ }^{3}$ Zie art. 1:238 BW. Specifiek ten aanzien van het verzoek tot ondertoezichtstelling volgt uit art. 1:255 lid 2 BW dat het initiatief ligt bij de Rvdk.
} 
recht is weer sterk afhankelijk van processuele kaders. Het is om deze reden dat in dit onderzoek niet alleen een analyse van de toepassing van het materiële jeugdbeschermingsrecht plaatsvindt, maar ook wordt gekeken naar de zorgvuldigheid van het feitenonderzoek (waarmee wordt bedoeld de feitenvaststelling door de RvdK) en naar de wijze waarop de minderjarige (en in mindere mate zijn ouders) hebben kunnen participeren in de procedure.

\section{Het materiële jeugdbeschermingsrecht: de rechtmatigheid}

De analyse van de wijze waarop het materiële jeugdbeschermingsrecht is toegepast valt uiteen in verschillende vragen. In de eerste plaats de vraag of, en zo ja hoe wordt onderbouwd dat aan de wettelijke gronden in nationale wetgeving is voldaan; vervolgens de vraag of duidelijk is welke doelen met de maatregel worden nagestreefd en of deze doelen in lijn zijn met de wettelijke doelstelling op grond van nationale wetgeving. Daarnaast moet de wijze waarop de gronden worden toegepast en doelstellingen worden geformuleerd in lijn zijn met de eisen die volgen uit art. 8 Europees Verdrag voor de Rechten van de Mens (hierna: EVRM). De wettelijke gronden van de ondertoezichtstelling en machtiging uithuisplaatsing zoals neergelegd in het Burgerlijk Wetboek behoren een duidelijke grondslag op te leveren ten aanzien van de vraag in welke gevallen en op welke wijze gedwongen overheidsingrijpen in het gezinsleven gerechtvaardigd is. Het is echter twijfelachtig of de wettelijke gronden hiervoor voldoende houvast bieden. ${ }^{4}$ Sinds de introductie van het jeugdbeschermingsrecht in Nederland heeft de wetgever consequent gekozen voor een systeem waarin veel ruimte wordt gelaten aan de uitvoeringspraktijk om zelfstandig een afweging te maken over de noodzaak van een jeugdbeschermingsmaatregel. Het duidelijkst komt dit naar voren bij de maatregel van ondertoezichtstelling. Zowel voor de jeugdbeschermingsautoriteiten als voor veel betrokken gezinnen is het onduidelijk wanneer de concrete situatie ernstig genoeg is om een ondertoezichtstelling te rechtvaardigen.

Voor een deel is de zojuist benoemde onzekerheid inherent aan de keuze van de wetgever voor een wettelijk systeem met open normen. Aangezien aan de hand van de feiten en omstandigheden in iedere zaak afzonderlijk de noodzaak van een maatregel moet worden bepaald, heeft de besluitvorming in jeugdbeschermingszaken een sterk casuïstisch karakter. Daar komt bij dat de wijze waarop de wettelijke gronden invulling krijgen lange tijd niet op

\footnotetext{
${ }^{4}$ Zie hierover zeer uitvoerig: Bruning 2001.
} 
veel belangstelling vanuit de praktijk en de wetenschap heeft kunnen rekenen. ${ }^{5}$ Het juridisch onderzoek naar de maatregelen van jeugdbescherming is tot op heden grotendeels theoretisch van aard geweest. ${ }^{6}$ Dit onderzoek beoogt meer inzicht te bieden in de wijze waarop de RvdK en de kinderrechter het materiële jeugdbeschermingsrecht toepassen. Zeker naar de juridische besluitvorming door de RvdK in beschermingszaken is tot op heden niet of nauwelijks onderzoek verricht. Dit onderzoek kan daarom belangrijk zijn voor de RvdK, omdat duidelijk wordt waar eventuele tekortkomingen zitten in de besluitvorming. Het kan daarnaast ook betrokken gezinnen meer duidelijkheid verschaffen over de juridische rechtmatigheid van het besluitvormingsproces ${ }^{7}$ en kan tevens een belangrijk signaal afgeven richting de wetgever indien blijkt dat de wettelijke gronden geheel of ten dele niet aansluiten bij wat in de praktijk nodig wordt gevonden om minderjarigen effectief te beschermen.

\section{De feitenvaststelling: de zorgvuldigheid}

Het tweede belangrijke element om te bepalen hoe de rechtvaardiging van jeugdbescherming in de praktijk is vormgegeven ziet toe op de zorgvuldigheid van het feitenonderzoek door de RvdK. De jeugdbeschermingsmaatregelen waartoe de RvdK kan verzoeken hebben verstrekkende gevolgen voor het familie- en gezinsleven van kind en ouders. Het spreekt dan ook voor zich dat het verzamelen, selecteren en interpreteren van de informatie tijdens het beschermingsonderzoek met de grootst mogelijke zorgvuldigheid dient te gebeuren. De keuze om de feitenvaststelling door de RvdK tijdens het beschermingsonderzoek te analyseren komt voort uit de bredere discussie over de rol van waarheidsvinding in de jeugdbescherming. In de achterliggende jaren is veel discussie geweest over de vraag of, en zo ja hoe waarheidsvinding een plek heeft of behoort te hebben in jeugdbeschermingszaken. ${ }^{8}$ Meest vergaand is de stelling dat waarheidsvinding niet mogelijk is in jeugdbeschermingszaken omdat het primair gaat om het concretiseren van de zorgen in het gezin. Dit standpunt, overigens ook lange tijd uitgedragen door de ketenpartners zelf, lijkt inmiddels achterhaald. Op jeugdbeschermingszaken zijn de wettelijke bepalingen van het civiele bewijsrecht van toepassing en tevens zijn door de RvdK interne kwaliteitscriteria voor het feitenonderzoek in jeugdbeschermingszaken opgesteld. Er zijn dus wel degelijk waarborgen tegen onzorgvuldig

\footnotetext{
${ }^{5}$ Van Wijk geeft hiervoor enkele verklaringen. Zo wordt onder meer betoogd dat de complexe (kind)problematiek niet uitnodigt tot een juridisch debat. In het verlengde daarvan wordt gesteld dat de besluitvorming sterk aanleunt tegen de hulpverlening. Van Wijk 1999, p. 268.

${ }^{6}$ Vgl: Doek 1972; Mertens 1993; Van Wijk 1999; Bruning 2001.

${ }^{7}$ Waarmee niet is gezegd dat een rapportage of beschikking waar de wettelijke gronden niet (geheel correct) worden toegepast ook vanzelfsprekend ongerechtvaardigd overheidsingrijpen impliceert.

${ }^{8}$ Vgl. Van Zanten \& Brenninkmeijer FJR 2011/76; Huijer NJB 2014/673. En specifiek ten aanzien van de rol van de RvdK waar het gaat om het streven naar waarheidsvinding: Cardol, Galama \& Kuipers FJR 2013/41.
} 
en/of onvolledig feitenonderzoek in jeugdbeschermingszaken. Waar het aan ontbreekt is een preciezere bepaling van de manier waarop waarheidsvinding in jeugdbeschermingszaken vorm zou kunnen krijgen. Duidelijk is dat er onder een groep ouders (en kinderen) grote onvrede heerst over de wijze waarop de jeugdbeschermingsautoriteiten het feitenonderzoek uitvoeren. Volgens deze ouders worden op basis van onzorgvuldig onderzoek en foutieve informatie ingrijpende beslissingen genomen. ${ }^{9}$ Tot op heden is echter goeddeels onduidelijk of de klachten van ouders op dit punt terecht zijn, en zo ja, hoe groot de omvang van het probleem is. Dit leidt ertoe dat lastig te bepalen is of de wettelijke vereisten en interne kwaliteitscriteria voor het feitenonderzoek volstaan of dat aanscherping noodzakelijk is. De enige manier om dit inzichtelijk te maken is een grondige analyse van het feitenonderzoek in jeugdbeschermingszaken, waarbij aandacht wordt geschonken aan de mogelijkheden en onmogelijkheden om informatie te selecteren en te beoordelen.

\section{Rechtdoen aan de rechtspositie minderjarige en ouders}

Ten derde kan de vraag hoe de rechtvaardiging van jeugdbeschermingsmaatregelen in de praktijk is vormgegeven niet los worden gezien van de mate waarin recht wordt gedaan aan de (rechts)positie van de minderjarige en zijn ouders in de jeugdbeschermingsprocedure. De verhouding tussen kind en ouders en de rechten en verplichtingen die voor beiden hebben te gelden is bepalend voor de wijze waarop zij kunnen participeren in het besluitvormingsproces. De directe ingreep in de ouder-kindrelatie middels de inzet van een jeugdbeschermingsmaatregel impliceert dat zowel de belangen van het kind als de belangen van de ouders een rol behoren te spelen in het besluitvormingsproces. Deze belangen zijn nauw met elkaar verbonden maar kunnen onder omstandigheden ook conflicteren in jeugdbeschermingszaken. De ouders met gezag zijn de eerstverantwoordelijken voor de verzorging en opvoeding van de minderjarige, zo volgt uit nationale wetgeving en toepasselijk verdragsrecht. Die verantwoordelijkheid kan (deels) worden ingeperkt door de inzet van een jeugdbeschermingsmaatregel. Daarnaast omvat het gezag over de minderjarige ook de vertegenwoordiging in burgerlijke handelingen, zowel in als buiten rechte. Dit heeft als consequentie dat de ouders met gezag in de (gerechtelijke) procedure de minderjarige vertegenwoordigen. De ouders met gezag zullen daarbij het belang van de minderjarige moeten dienen maar kunnen onmogelijk hun eigen belangen negeren. Zo zal de gemiddelde ouder zich hevig verzetten tegen een uithuisplaatsing van zijn kind, ook in die gevallen waarin het geen twijfel lijdt dat het kind daarbij is gebaat. Het leidt tot een belangrijk spanningsveld

\footnotetext{
${ }^{9}$ Kamerstukken II 2017/18, 31 839, nr. 622.
} 
in jeugdbeschermingszaken. De minderjarige en zijn ouders moeten zo goed mogelijk in de gelegenheid worden gesteld om te participeren in het besluitvormingsproces, maar dit mag niet ten koste gaan van de minderjarige.

Heel lang is het niet noodzakelijk gevonden ouders en minderjarigen te betrekken bij de besluitvorming in jeugdbeschermingszaken. In de huidige wet- en regelgeving is de rechtspositie van betrokkenen inmiddels stevig verankerd. Zo hebben ouders en minderjarigen recht op informatie over de besluitvorming, moeten zij worden gehoord en moeten de RvdK en de kinderrechter de visie van betrokkenen serieus meewegen. Daarnaast kunnen betrokkenen gebruik maken van het klachtrecht en staat (in de meeste gevallen) een rechtsmiddel open tegen de beslissing van de kinderrechter. Toch zijn veel betrokkenen ontevreden over de invloed die zij hebben kunnen uitoefenen op het jeugdbeschermingsproces. ${ }^{10}$ Het is belangrijk om te onderzoeken in hoeverre die kritiek terecht is. Op grond van art. 8 EVRM hebben de minderjarige en de ouders het recht in iedere fase van het proces geïnformeerd te worden en moeten zij de ingebrachte informatie effectief aan de kaak kunnen stellen. ${ }^{11}$ Daarnaast geldt, primair op grond van art. 12 IVRK, dat de minderjarige in alle fasen van het besluitvormingsproces moet worden gehoord en dat afhankelijk van zijn leeftijd en ontwikkelingsniveau - passend belang moet worden gehecht aan zijn mening. Deze studie beoogt tenslotte ook een antwoord te bieden op de vraag of in het besluitvormingsproces in jeugdbeschermingszaken voldoende tegemoet wordt gekomen aan deze vereisten.

\subsection{Dossieronderzoek over de jaren 2013-2014}

De delen I en II van dit onderzoek zijn gericht op de rechtvaardiging van jeugdbescherming in de jaren 2013 en 2014. Om te kijken hoe deze rechtvaardiging in de toenmalige praktijk werd vormgegeven is uitgebreid dossieronderzoek verricht. Het dossieronderzoek betreft een analyse van beschermingsrapporten opgesteld door de RvdK en beschikkingen van de kinderrechter. De keuze voor de jaren 2013 en 2014 verdient een nadere toelichting omdat het belangrijke consequenties heeft gehad voor de opzet, uitvoering en inhoud van het onderzoek. In mei 2013 is een start gemaakt met het onderzoeksvoorstel en het opstellen van een

\footnotetext{
${ }^{10} \mathrm{Zie}$ bv: Actieplan verbetering feitenonderzoek in de jeugdbeschermingsketen. Te raadplegen via https://www.tweedekamer.nl/kamerstukken/detail?id=2018D32524\&did=2018D32524.

${ }^{11}$ Zie EHRM 17 december 2002, appl. nr. $35731 / 97$ (Venema t. Nederland); EHRM 8 april 2004, appl.nr.

11057/02 (Haase t. Duitsland).
} 
analysekader voor het dossieronderzoek. Op dat moment is de keuze gemaakt om een steekproef te trekken uit zo actueel mogelijke dossiers van de RvdK. Begin 2014 zijn de eerste 100 dossiers geselecteerd, waarin door de RvdK in 2013 een ondertoezichtstelling is verzocht. Begin 2015 zijn nog eens 100 dossiers geselecteerd, met als peiljaar 2014 waarin door de RvdK een ondertoezichtstelling met machtiging uithuisplaatsing is verzocht. Het dossieronderzoek is afgerond in september 2017. Na deze datum heeft het analyseren en verwerken van de onderzoeksresultaten nog geruime tijd in beslag genomen.

Uit het voorgaande volgt dat het analysekader voor de dossiers, ontleent aan (inter)nationale wet- en regelgeving, gebaseerd is op de regels zoals geldend in de peiljaren waar de steekproef op ziet (2013-2014). De kern van het onderzoek - deel I \& deel II - richt zich derhalve niet op het ingrijpend gewijzigde jeugdbeschermingsrecht vanaf 1 januari 2015. Met het oog op de actualiteit worden in deel III de relevante wijzigingen besproken die vanaf 1 januari 2015 zijn doorgevoerd met de Wet herziening kinderbeschermingsmaatregelen ${ }^{12}$ en de Jeugdwet. ${ }^{13}$ Hierbij komen alleen de gewijzigde onderdelen van de jeugdbeschermingswetgeving terug die direct in het verlengde liggen van hetgeen is besproken in deel I en deel II. Het doel hiervan is om een overzicht te geven van de belangrijkste wijzigingen om zo de relevantie van de onderzoeksresultaten over de jaren 2013/2014 voor het huidige jeugdbeschermingsrecht te bepalen. Op de voor dit onderzoek relevante punten worden de resultaten vergeleken met de resultaten van de evaluaties van de Wet herziening kinderbeschermingsmaatregelen en de Jeugdwet. ${ }^{14}$ De terugblik op de toepassing van het jeugdbeschermingsrecht in de jaren 2013 en 2014 geeft de mogelijkheid om te kijken welke knelpunten ook thans nog gelden en waar door wijzigingen in wetgeving en beleid die knelpunten mogelijk al zijn weggenomen of verminderd.

\subsection{Onderzoeksvragen}

Dit onderzoek beoogt inzicht te verschaffen in de wijze waarop voornoemde juridische elementen vorm kregen en krijgen in de jeugdbeschermingspraktijk. Het onderzoek presenteert een analyse van de rechtmatigheid waarmee de RvdK en de kinderrechter het materiële jeugdbeschermingsrecht toepassen, de zorgvuldigheid in de wijze waarop de RvdK

\footnotetext{
${ }^{12}$ Wet tot wijziging van Boek 1 van het Burgerlijk Wetboek, het Wetboek van Burgerlijke Rechtsvordering, de Wet op de jeugdzorg en de Pleegkinderenwet in verband met herziening van de maatregelen van kinderbescherming, Stb. 2014, 130.

${ }^{13}$ Wet inzake regels over de gemeentelijke verantwoordelijkheid voor preventie, ondersteuning, hulp en zorg aan jeugdigen en ouders bij opgroei- en opvoedingsproblemen, psychische problemen en stoornissen, Stb. $2014,105$.

${ }^{14}$ Zie voor de tussenevaluatie van de Wet herziening kinderbeschermingsmaatregelen: Lunneman, Huijer e.a.

2018. En voor de eerste tussenevaluatie van de Jeugdwet: Friele e.a. 2018.
} 
het feitenonderzoek heeft vormgegeven en van de manier waarop recht wordt gedaan aan de rechtspositie van de minderjarige en zijn ouders tijdens het beschermingsonderzoek en de gerechtelijke procedure. Omdat de delen I \& II van dit onderzoek zijn gericht op de jaren 2013 en 2014 en deel III op de periode na 1 januari 2015 zijn twee hoofdvragen geformuleerd die in het onderzoek worden beantwoord:

1. In hoeverre was de wijze waarop de RvdK en de kinderrechter in de jaren 2013 en 2014 de rechtvaardiging van de ondertoezichtstelling met of zonder machtiging uithuisplaatsing hebben vormgegeven in overeenstemming met de toen geldende (inter)nationale wet- en regelgeving?

2. In hoeverre zijn de in dit onderzoek voor de jaren 2013 en 2014 getrokken conclusies ten aanzien van de rechtvaardiging van de ondertoezichtstelling met of zonder machtiging uithuisplaatsing nog steeds relevant, gelet op de doorgevoerde wijzingen in de jeugdbeschermingswetgeving en uitvoeringspraktijk?

De beantwoording van de centrale onderzoeksvragen geschiedt aan de hand van de volgende deelvragen:

a. Welke procedurele aspecten en formele kwaliteitscriteria waren van toepassing op het beschermingsonderzoek en de gerechtelijke procedure tot oplegging van een ondertoezichtstelling en machtiging uithuisplaatsing?

b. Welke positie namen de minderjarige en zijn ouders in gedurende het beschermingsonderzoek en de gerechtelijke procedure en welke uitgangspunten op grond van (inter)nationale wet- en regelgeving golden ten aanzien van het hoorrecht van de minderjarige?

c. Welke criteria voor de vraag wanneer oplegging van een ondertoezichtstelling en uithuisplaatsing gerechtvaardigd was konden worden ontleend aan uitgangspunten op grond van (inter)nationale wet- en regelgeving?

d. Op welke wijze werden de criteria voor de rechtvaardiging van de ondertoezichtstelling die zijn ontleend aan (inter)nationale wet- en regelgeving toegepast door de RvdK in het beschermingsrapport en door de kinderrechter in de beschikking?

e. Op welke wijze werden de criteria voor de rechtvaardiging van de uithuisplaatsing die zijn ontleend aan (inter)nationale wet- en regelgeving toegepast door de RvdK in het beschermingsrapport en door de kinderrechter in de beschikking? 
f. Hoe gaf de RvdK in het beschermingsrapport invulling aan het feitenonderzoek op grond van het bewijsrecht in civiele zaken en de interne regelgeving van de RvdK voor zorgvuldig onderzoek?

g. Hoe werd tijdens het beschermingsonderzoek en in de gerechtelijke procedure invulling gegeven aan de rechtspositie van de minderjarige (en zijn ouders), meer in het bijzonder het recht van de minderjarige (en zijn ouders) om te worden gehoord en voldoende te worden betrokken in de besluitvorming?

h. Welke voor dit onderzoek relevante wijzigingen zijn doorgevoerd op of na 1 januari 2015 ten aanzien van het materiële jeugdbeschermingsrecht, het feitenonderzoek in jeugdbeschermingszaken en de rechtspositie van de minderjarige (en zijn ouders)?

\subsection{Onderzoeksmethoden}

In dit onderzoek is gebruik gemaakt van verschillende onderzoeksmethoden. Onder de bredere noemer 'rechtswetenschappelijk onderzoek' is gekozen voor een triangulatie van onderzoeksmethoden. Op deze manier is het mogelijk niet alleen een theoretische schets van het jeugdbeschermingsrecht te geven maar ook de toepassing van het recht in de praktijk systematisch te analyseren.

\section{Juridisch onderzoek}

In het eerste deel van het onderzoek (hoofdstukken 1 -4) wordt het Nederlandse systeem van jeugdbescherming voor de periode 2013/2014 beschreven. Dit deel van het onderzoek kan worden aangemerkt als 'klassiek' juridisch onderzoek of ook wel de juridisch-dogmatische methode. Het juridisch dogmatisch onderzoek kenmerkt zich door bestudering van het positieve recht, geschreven en ongeschreven en bezien vanuit nationaal en internationaal perspectief. ${ }^{15}$ Voor deze studie betreft het de bestudering van de belangrijkste rechtsbronnen op het gebied van de jeugdbescherming. Met name is gekeken naar de totstandkomingsgeschiedenis van de wettelijke gronden van de jeugdbeschermingsmaatregelen, de wettelijke regeling zoals neergelegd in het Burgerlijk Wetboek en de wetssystematiek. Verder is voor de vraag hoe de toepassing van de gronden tot nu toe heeft plaatsgevonden in de praktijk rechtspraak en relevante literatuur geraadpleegd. De wettelijke uitgangspunten en vereisten die in het eerste deel van deze studie worden beschreven vormen de basis voor de analyse van dossiers in het tweede, empirische deel van

\footnotetext{
${ }^{15}$ Asser/Vranken Algemeen deel**** 2014/8.
} 
de studie (hoofdstukken 5 -9), waarin wordt gekeken hoe deze vereisten werden toegepast door de RvdK en de kinderrechter.

\section{Empirisch onderzoek}

Een empirische studie naar de toepassing van het jeugdbeschermingsrecht geeft inzicht in de wijze waaarop in de praktijk rechtvaardiging wordt geboden voor gedwongen overheidsingrijpen in het gezinsleven. ${ }^{16}$ Dit onderzoek vertrekt vanuit het uitgangspunt dat voor een gedegen rechtvaardiging van de ondertoezichtstelling/uithuisplaatsing, de wettelijke gronden en de wettelijke doelstelling correct worden toegepast, de informatie op basis waarvan het besluit is genomen zorgvuldig tot stand is gekomen en de minderjarige en zijn ouders volgens de geldende processuele vereisten voldoende zijn betrokken bij de besluitvorming.

Tot op heden is er weinig kennis over de wijze waarop het jeugdbeschermingsrecht in de praktijk wordt toegepast. Onderzoek op het gebied van het jeugdbeschermingsrecht heeft zich vooral gericht op bestudering van parlementaire stukken, de wet en wetssytematiek, en waar het gaat om de toepassing van de maatregelen van jeugdbescherming, op een analyse van rechtspraak en relevante literatuur. ${ }^{17}$ Bovendien lijkt het (functioneren van) het systeem van jeugdzorg en de uitvoering van de jeugdbeschermingsmaatregelen binnen dat systeem zeker de laatste jaren meer aandacht te krijgen dan de toepassing van het materiële jeugdbeschermingsrecht. Voor een goed functionerend systeem van jeugdzorg is gedegen kennis over de juridische afwegingen in jeugdbeschermingszaken echter onontbeerlijk. Het juridisch-empirisch deel van deze studie moet duidelijk maken op welke wijze nationale weten regelgeving en toepasselijk verdragsrecht zijn geïntegreerd in de besluitvorming in jeugdbeschermingszaken. Om dit doel te bereiken is een systematische analyse van jeugdbeschermingsdossiers uitgevoerd.

De analyse heeft betrekking op twee juridische eindbesluiten in de jeugdbeschermingsprocedure: de beslissing van de RvdK een verzoek tot ondertoezichtstelling met of zonder uithuisplaatsing in te dienen en de beslissing op het verzoek door de kinderrechter. De inhoudelijke onderbouwing van het verzoek door de RvdK vindt plaats in het beschermingsrapport. Omdat het beschermingsrapport zo veel relevante

\footnotetext{
${ }^{16}$ Zie de dissertatie van Bruning waarin rechterlijke uitspraken op systematische wijze zijn geanalyseerd: Bruning 2001.

${ }^{17}$ Zonder volledigheid na te streven enkele uitgebreide studies ten aanzien van de maatregelen en het systeem van jeugdbescherming: Doek 1972; Mertens 1993; Van Wijk 1999; Bruning 2001; Slot e.a 2002.
} 
informatie bevat is een veel gedetailleerdere analyse mogelijk gebleken dan wanneer alleen was gekeken naar (gepubliceerde) rechtspraak. Dit neemt niet weg dat de beslissing van de kinderrechter zoals neergelegd in de beschikking op het verzoek een cruciaal onderdeel is in de besluitvorming. Hoewel de beschikking veel minder informatie bevat dan het beschermingsrapport is het belangrijk om te zien welke juridische overwegingen aan de beslissing van de kinderrechter ten grondslag liggen.

\section{Dataverzameling}

Voor het dossieronderzoek is gebruik gemaakt van het digitale programma van de RvdK waarin alle onderzoeken van de RvdK worden gearchiveerd. In het programma Kinderbescherming Bedrijfsprocessen Systeem (KBPS) is een aselecte steekproef getrokken binnen de categorie 'onderzoek kinderbeschermingsmaatregel'. ${ }^{18} \mathrm{Er}$ is gekozen voor een analyse van 200 afgeronde beschermingsonderzoeken in de peiljaren 2013 en 2014. Meer specifiek gaat het om 100 verzoeken tot ondertoezichtstelling die in het jaar 2013 aan de kinderrechter zijn voorgelegd en 100 verzoeken tot ondertoezichtstelling met machtiging uithuisplaatsing die in het jaar 2014 aan de kinderrechter zijn voorgelegd. Deze 200 zaken zijn identificeerbaar via een zogenaamd kindzaaknummer dat kan worden ingevoerd in KBPS. Het kindzaaknummer leidt uiteindelijk naar een beschermingsonderzoek waaruit een verzoek tot ondertoezichtstelling met of zonder machtiging uithuisplaatsing is voortgekomen. De beschikking op het verzoek tot ondertoezichtstelling met of zonder machtiging uithuisplaatsing wordt ook gearchiveerd in KBPS en kon ook onder het kindzaaknummer waar ook het beschermingsrapport was gehangen, worden geraadpleegd. De beschermingsrapporten van de RvdK bevatten vertrouwelijke informatie en zijn daarom niet openbaar. Inhoudelijke informatie uit de beschermingsrapporten die terugkomt in het onderzoek is geanonimiseerd.

\section{Analysekader}

Het analysekader voor het dossieronderzoek is vastgesteld op basis van (inter)nationale weten regelgeving. Op basis van de indicatoren die hieraan kunnen worden ontleend heeft een systematische analyse van de beschermingsrapporten en beschikkingen plaatsgevonden. De analyse kent voor zover mogelijk een vaste structuur. Eerst is gekeken of een bepaalde indicator voorkomt in de rapportage of beschikking. Dit kan bijvoorbeeld gaan om de vraag of

\footnotetext{
${ }^{18}$ De overige categorieën onderzoek door de RvdK zijn: Gezag en Omgang (G\&O), Afstand, Screening, Adoptie en Afstammingsvragen (ASAA), advisering Strafzaken en overige onderzoeken inzake jeugdbescherming (zoals de toetsende taak en het onderzoek naar een verderstrekkende maatregel.
} 
de wettelijke gronden worden genoemd in de rapportage of de vraag of de minderjarige overeenkomstig de wettelijke vereisten is gehoord. Vervolgens is voor de zaken waarin dit het geval is gekeken op welke manier de indicator terugkomt. Tot slot is gekeken hoe de manier waarop de indicator terugkomt zich verhoudt tot de uitgangspunten die kunnen worden ontleend aan (inter)nationale wet- en regelgeving. De analyse is uitgevoerd door een en dezelfde onderzoeker. Om de potentiële risico's hiervan voor de betrouwbaarheid van het onderzoek te ondervangen is getracht de indicatoren zo concreet mogelijk af te bakenen. Zeker voor de eerste stap in de analyse, de vraag of een bepaalde indicator voorkomt, is dit geen probleem gebleken. Desondanks zijn er indicatoren in het onderzoek die enige mate van interpretatie aan de zijde van de onderzoeker hebben gevergd. Zo is het niet eenvoudig te bepalen of ouders en minderjarigen instemmen met een maatregel als zij dagelijks van mening veranderen hierover. Dit is getracht te ondervangen door zo concreet mogelijk aan te geven op welke manier de indicator is gescoord. De analyse heeft zich verder beperkt tot de schriftelijke beschermingsrapportage opgesteld door de RvdK en de schriftelijke uitwerking van de motivering van de kinderrechter in de beschikking. Informatie over de gesprekken die de RvdK en kinderrechter hebben gevoerd met kind en ouders is dus alleen meegenomen in het dossieronderzoek als er iets over is vermeld in de schriftelijke stukken.

\subsection{Afbakening}

Nationale wet- en regelgeving 2013-2014

Voor de jaren 2013 en 2014 is gekeken naar het toen geldende jeugdbeschermingsrecht. Specifiek gaat het dan om de algemene regels inzake de gerechtelijke civiele procedure, Titel 1 van het Wetboek van Burgerlijke Rechtsvordering (Rv), de algemene regels inzake verzoekschriftprocedures (artt. $261-291 \mathrm{Rv}$ voor procedures in eerste aanleg) en de bijzondere regels in familierechtelijke procedures (artt. $798-828 \mathrm{Rv}$ ). Waar het gaat om het beschrijven van de procedure gedurende het beschermingsonderzoek door de RvdK en de rechtspositie van de minderjarige en zijn ouders, zijn relevante bepalingen geraadpleegd uit het interne Kwaliteitskader 2013 en het protocol Beschermingstaken 2013 van de RvdK. Wanneer en op welke manier gedwongen kan worden ingegrepen in het gezinsleven van kind en ouder werd en wordt gedomineerd door het materiële jeugdbeschermingsrecht, opgenomen in Boek 1, Titel 14, Afdeling 4 Burgerlijk Wetboek. Naast de wettelijke gronden en de wettelijke doelstelling van de ondertoezichtstelling en uithuisplaatsing worden ter volledigheid ook de toen geldende maatregelen van ontheffing en ontzetting uit het gezag 
beschreven. Daarnaast bevat de steekproef diverse zaken waarin de RvdK een machtiging gesloten jeugdzorg heeft verzocht. In de jaren 2013/2014 was de wettelijke regeling voor gesloten jeugdzorg neergelegd in de Wet op de Jeugdzorg (artt. 29a - 29y Wjz). De Wet op de Jeugdzorg bevatte het kader op basis waarvan de hulp aan kinderen en gezinnen met opgroeien opvoedproblemen was georganiseerd en moest worden uitgevoerd. In dit onderzoek komen alleen de wettelijke vereisten van de machtiging gesloten jeugdzorg terug. Overige regels uit de Wjz over de organisatie en uitvoering van jeugdbeschermingsmaatregelen zijn buiten beschouwing gebleven.

\section{Nationale wet- en regelgeving vanaf 2015}

De voor dit onderzoek meest relevante wijzigingen in de jeugdbeschermingswetgeving zijn doorgevoerd met de op 1 januari 2015 in werking getreden Wet herziening kinderbeschermingsmaatregelen. Deze wet heeft gezorgd voor belangrijke aanpassingen in Boek 1, Titel 14, Afdeling 4 Burgerlijk Wetboek. De rechtsgrond van de ondertoezichtstelling is ingrijpend gewijzigd en nu neergelegd in art. 1:255 BW. De rechtsgrond van de machtiging uithuisplaatsing is inhoudelijk ongewijzigd overgenomen en thans te vinden in art. 1:265b BW. De gezagsontnemende maatregelen van ontheffing en ontzetting uit het gezag zijn vervangen door één gezagsbeëindigende maatregel (art. 1:266 BW). De gezagsbeëindigende maatregel neemt sinds 2015 een belangrijke positie in binnen het jeugdbeschermingsrecht. Om die reden is bij de beschrijving van het jeugdbeschermingsrecht vanaf 2015 (deel III) beduidend meer aandacht voor de beëindiging van het gezag. De Wet herziening kinderbeschermingsmaatregelen heeft tevens gezorgd voor enkele aanpassingen in het deel van het Wetboek van Burgerlijke Rechtsvordering gericht op de rechtspleging in zaken betreffende het personen- en familierecht. Voor dit onderzoek zijn met name de aanvullende vereisten voor verzoekschriften zoals opgenomen in art. 799a Rv van belang. Wat betreft de de kwaliteitscriteria die gelden voor de opzet, uitvoering en inhoud van het beschermingsonderzoek en de beschermingsrapportage zijn thans van kracht het Kwaliteitskader 2016 en het protocol Beschermingstaken 2016 van de RvdK.

Ook zijn voor dit onderzoek enkele wettelijke bepalingen relevant die zijn ingevoerd met de Jeugdwet. Ten aanzien van het feitenonderzoek in jeugdbeschermingszaken bevat art. 3.3 Jeugdwet nu de (aanvullende) eis voor de RvdK en de Gecertificeerde Instellingen (voorheen Bureaus Jeugdzorg), om in rapportages en/of verzoekschriften de feiten volledig en naar 
waarheid aan te voeren. ${ }^{19}$ De rechtsgrond voor de machtiging gesloten jeugdzorg is nagenoeg ongewijzigd overgenomen uit de Wet op de Jeugdzorg en thans te vinden in art. 6.1.2 Jeugdwet. Wel is de terminologie in de Jeugdwet aangepast, waardoor nu wordt gesproken van jeugdhulp in plaats van jeugdzorg. ${ }^{20}$ De overige bepalingen uit de Jeugdwet gericht op de organisatie en de uitvoering van de jeugdhulp blijven grotendeels buiten beschouwing. Slechts kort worden een aantal belangrijke ontwikkelingen die deels voortkomen uit- of samenhangen met de Jeugdwet aangestipt. Een korte bespreking is noodzakelijk aangezien de wijze waarop het systeem van jeugdhulp functioneert onder de Jeugdwet van invloed is op de vraag wanneer en onder welke voorwaarden een jeugdbeschermingsmaatregel kan worden opgelegd, en andersom. Een uitgebreide analyse van het (functioneren van het) systeem van jeugdhulp valt echter gezien de aard en omvang van het onderwerp buiten het bereik van dit onderzoek.

\section{Toepasselijk verdragsrecht}

Bij de vraag of de inzet van een jeugdbeschermingsmaatregel in het concrete geval gerechtvaardigd is spelen kinder- en mensenrechtelijke bepalingen een grote rol. Het lijdt geen twijfel dat het EVRM en het IVRK de belangrijkste mensenrechtelijke verdragen zijn voor het Nederlandse familierecht en het jeugdbeschermingsrecht in het bijzonder. ${ }^{21}$ Om die reden is ervoor gekozen de relevante bepalingen uit deze twee verdragen terug te laten komen in dit onderzoek. Wat betreft het EVRM gaat het dan bovenal om art. 8 EVRM (het recht op privé, familie- en gezinsleven) en in mindere mate om art. 6 EVRM (het recht op een eerlijk proces) en specifiek in het geval van vrijheidsbeneming, art. 5 EVRM (het recht op persoonlijke vrijheid en veiligheid). Gedwongen overheidsingrijpen maakt inbreuk op het in art. 8 EVRM neergelegde recht op eerbiediging van het privéleven, familie- en gezinsleven. De vraag of die inbreuk gerechtvaardigd kan worden aan de hand van de vereisten in art. 8 lid 2 EVRM heeft geleid tot een groot aantal richtinggevende uitspraken van het Europees Hof voor de Rechten van de Mens (hierna: EHRM) op dit terrein. Primair gaan die uitspraken over de vereisten die in acht moeten worden genomen bij een scheiding van kind en ouder door de inzet van een jeugdbeschermingsmaatregel. Ook levert de rechtspraak van het EHRM belangrijke gezichtspunten op ten aanzien van de algemene verplichtingen van de overheid in jeugdbeschermingszaken. Tot slot is het EVRM ook belangrijk met het oog op de rechtspositie van de minderjarige en zijn ouders. De vereisten die kunnen worden ontleend

\footnotetext{
${ }^{19}$ Aanvullend ten opzichte van art. $21 \mathrm{Rv}$ waarin deze eis voor alle partijen in de civiele procedure is neergelegd.

${ }^{20}$ Zie art. 1.1 Jeugdwet voor de (wettelijke) definite van jeugdhulp.

${ }^{21}$ Boele-Woelki 2015, p. 25.
} 
aan voornoemde verdragsrechtelijke bepalingen worden beschreven voor de jaren waar het dossieronderzoek op ziet (2013/2014). In deel III van het onderzoek komen verschillende belangrijke uitspraken van het EHRM terug, die zijn gedaan in de periode na 2015.

Het is niet verrassend dat in jeugdbeschermingszaken, waarin het kind centraal staat of behoort te staan, een groot aantal bepalingen uit het kinderrechtenverdrag (IVRK) van belang is. Een cruciaal verschil met het EVRM is dat van relevante bepalingen uit het IVRK niet helder is of deze bepalingen rechtstreekse werking toekomt. ${ }^{22}$ Dit doet echter weinig af aan de grote invloed die het IVRK heeft op de besluitvorming in jeugdbeschermingszaken. Zo blijken rechters in Nederland met regelmaat, en waarschijnlijk steeds vaker, het IVRK mee te laten wegen in de beslissing. ${ }^{23}$ Voor dit onderzoek is in de eerste plaats art. 3 IVRK van belang. Op grond van dit artikel geldt dat bij alle maatregelen en beslissingen over kinderen, de belangen van het kind een eerste overweging vormen. Daarnaast is specifiek voor de situatie waarin het kind uit huis wordt geplaatst art. 9 IVRK van belang. Art. 9 IVRK bevat het recht van het kind niet van zijn ouders gescheiden te worden, tenzij dat in het belang van het kind noodzakelijk is. Wordt het kind uit huis geplaatst in een accommodatie voor gesloten jeugdzorg dan gelden strikte eisen voor vrijheidsbeneming van minderjarigen op grond van art. 37b IVRK. Tot slot is voor de rechtspositie van de minderjarige art. 12 IVRK van groot belang. Art. 12 IVRK bevat het recht van de minderjarige om zijn mening vrijelijk te uiten en de verplichting (voor professionals) passend belang te hechten aan de mening van de minderjarige. De vereisten die volgen uit het IVRK zijn beschreven voor de periode 2013/2014. In deel III gericht op de periode vanaf 2015 worden kort enkele ontwikkelingen besproken die samenhangen met art. 12 IVRK. Het gaat dan om ontwikkelingen in het kader van de participatie van minderjarigen in de jeugdbeschermingsprocedure.

\section{Het dossieronderzoek naar de ondertoezichtstelling en machtiging uithuisplaatsing}

Er is voor gekozen de dossieranalyse te beperken tot de maatregel van ondertoezichtstelling en de machtiging uithuisplaatsing. De reden hiervoor is dat in 2013 en 2014 de ondertoezichtstelling, eventueel gecombineerd met een machtiging uithuisplaatsing, de kern vormde van de jeugdbeschermingsmodaliteiten. In het overgrote deel van de jeugdbeschermingszaken werd gekozen voor een (verlenging van de) ondertoezichtstelling/uithuisplaatsing, ook indien het duidelijk was dat de minderjarige in termen van verzorging en opvoeding niks meer van de ouders met gezag had te verwachten.

\footnotetext{
${ }^{22}$ Zie hierover Pulles FJR 2012/64.

${ }^{23}$ De Graaf e.a. 2012.
} 
De ondertoezichtstelling werd daarmee gezien als voor de hand liggende maatregel in zaken die qua ernst en omvang van de problematiek zeer uiteenlopend waren. Gezien het (in getalsmatig opzicht) geringe belang van de gezagsontnemende maatregelen van ontheffing en ontzetting in de periode voor 2015, zijn deze maatregelen niet meegenomen in de dossieranalyse.

Alleen zaken waarin de RvdK in 2013 en 2014 heeft besloten een verzoek tot ondertoezichtstelling met of zonder machtiging uithuisplaatsing in te dienen maken deel uit van de steekproef. Belangrijk om op te merken is dat het beschermingsonderzoek van de RvdK ook kan leiden tot de conclusie dat geen jeugdbeschermingsmaatregel noodzakelijk is. Deze zaken vallen buiten het bereik van het onderzoek aangezien de focus ligt op de rechtvaardiging van de (gevraagde) inzet van een jeugdbeschermingsmaatregel. In het dossieronderzoek zijn alleen nieuwe verzoeken tot ondertoezichtstelling met of zonder machtiging uithuisplaatsing meegenomen, aangezien het de RvdK is die dergelijke verzoeken in de regel indient.

\subsection{Opbouw}

Deze studie bestaat uit drie delen en elf hoofdstukken. In het eerste deel worden het formele en materiële jeugdbeschermingsrecht en de rechtspositie van de minderjarige en zijn ouders beschreven. In hoofdstuk 2 wordt de jeugdbeschermingsprocedure beschreven waarbij de focus ligt op het voor dit onderzoek relevante deel van de procedure: het beschermingsonderzoek van de RvdK en de daaropvolgende gerechtelijke procedure. In hoofdstuk 3 wordt de rechtspositie van de minderjarige en zijn ouders in de jeugdbeschermingsprocedure beschreven waarbij de positie van de minderjarige centraal staat. De regels omtrent de materiële en formele handelingsbekwaamheid van de minderjarige zijn neergelegd in het Burgerlijk Wetboek en het Wetboek van Burgerlijke Rechtsvordering. Bijzondere aandacht wordt in dit hoofdstuk geschonken aan het recht van de minderjarige om te worden gehoord. Het fundamentele recht om te worden gehoord wordt in belangrijke mate beïnvloed door kinder- en mensenrechtenbepalingen. Om deze reden wordt het recht om te worden gehoord besproken in het licht van art. 12 IVRK en art. 8 EVRM. In hoofdstuk 4 staat het materiële jeugdbeschermingsrecht centraal. Er vindt een uitgebreide analyse plaats van de wettelijke gronden en de wettelijke doelstelling van de ondertoezichtstelling en uithuisplaatsing. Op basis van parlementaire stukken, relevante literatuur en gepubliceerde rechtspraak wordt gekeken of meer duidelijkheid is te verkrijgen over de vraag wanneer en op 
welke wijze een ondertoezichtstelling en uithuisplaatsing kunnen worden ingezet.

De uitgangspunten die kunnen worden ontleend aan de eerste 4 hoofdstukken vormen de basis voor de analyse van beschermingsrapporten en beschikkingen in deel II van het onderzoek

Het tweede empirische deel van deze studie betreft een dossieronderzoek naar de rechtvaardiging van jeugdbeschermingsmaatregelen in de jaren 2013/2014. In hoofdstuk 5 wordt de opzet en uitvoering van het dossieronderzoek nader toegelicht. Het hoofdstuk vangt aan met de methodologische verantwoording waarna de belangrijkste kenmerken van de onderzoekspopulatie worden beschreven. In hoofdstuk 6 en 7 worden de resultaten beschreven van het dossieronderzoek naar de toepassing van respectievelijk de ondertoezichtstelling en de uithuisplaatsing in de praktijk. De analyse van beide maatregelen is op een vergelijkbare manier uitgevoerd. In de eerste plaats is de vraag gesteld naar de rechtmatigheid - kwamen de wettelijke gronden en doelen terug in het beschermingsrapport van de RvdK en de beschikking op het verzoek? Vervolgens is voor de zaken waarin dit gebeurde zo concreet mogelijk beschreven op welke manier de wettelijke gronden en doelstelling terugkwamen. In hoofdstuk 8 worden de resultaten besproken van de twee andere inhoudelijke componenten van dit onderzoek: de zorgvuldigheid van het feitenonderzoek door de RvdK en de vraag in hoeverre recht werd gedaan aan de rechtspositie van kind en ouder in de besluitvormingsprocedure. In hoofdstuk 9 worden eerst de belangrijkste bevindingen voor de periode tot 2015 samengevat en wordt vervolgens in de conclusie antwoord gegeven op de eerste centrale onderzoeksvraag.

In deel III worden de voor dit onderzoek belangrijkste wijzigingen in de jeugdbeschermingswetgeving besproken. In hoofdstuk 10 worden de resultaten van het dossieronderzoek over de jaren 2013/2014 afgezet tegen de belangrijkste wijzigingen in het jeugdbeschermingsrecht vanaf 2015, ter beantwoording van de tweede onderzoeksvraag. Tenslotte wordt in hoofdstuk 11 het onderzoek afgesloten. Het presenteert allereerst een kort overzicht van de belangrijkste conclusies voor de periode tot 2015. Vervolgens worden de belangrijkste conclusies voor de periode na 2015 gepresenteerd en wordt het onderzoek afgesloten met enkele gerichte aanbevelingen ter verbetering van de jeugdbeschermingspraktijk. 


\section{Deel I Het Nederlandse systeem van jeugdbescherming (2013-2014)}

\section{De besluitvorming in jeugdbeschermingszaken: procedurele aspecten en formele kwaliteitscriteria}

Dit hoofdstuk vangt in paragraaf 2.1 aan met een beschrijving van enkele algemene kenmerken- en uitgangspunten van de besluitvorming in jeugdbeschermingszaken. Twee elementen worden specifiek uitgelicht die noodzakelijk zijn voor een goed begrip van de werking van het jeugdbeschermingsrecht. In de eerste plaats wordt aandacht besteed aan de positieve en negatieve verplichtingen van de overheid in het kader van jeugdbescherming. Vervolgens wordt de verhouding tussen het (functioneren van het) systeem van jeugdbescherming en het materiële jeugdbeschermingsrecht besproken.

In paragraaf 2.2 wordt beschreven welke invloed het civielrechtelijke bewijsrecht op de besluitvorming in jeugdbeschermingszaken heeft. In de discussie over de rol van waarheidsvinding in jeugdbeschermingszaken is het civiele bewijsrecht tot nu toe grotendeels buiten beschouwing gebleven, terwijl de regels van bewijsrecht in de eerste plaats bepalen aan welke eisen de informatieverzameling- en beoordeling moet voldoen. De algemene regels van bewijsrecht zoals opgenomen in het Wetboek van Burgerlijke Rechtsvordering worden op hoofdlijnen benoemd, waarna specifiek aandacht wordt besteed aan de 'waarheidsplicht' voor partijen (art. $21 \mathrm{Rv}$ ). Binnen het streven naar waarheidsvinding is dit een cruciaal artikel omdat het partijen (waaronder de RvdK) verplicht de feiten in de procedure volledig en naar waarheid aan te voeren.

Hierna worden in paragraaf 2.3 de belangrijkste elementen beschreven uit de discussie over de rol van waarheidsvinding in de jeugdbescherming. De beschrijving vangt aan met een overzicht van de discussie over waarheidsvinding in jeugdbeschermingszaken. Vervolgens worden twee elementen uit die discussie uitgelicht. In de eerste plaats is veelvuldig de vergelijking gemaakt met waarheidsvinding in strafrechtelijke zin, maar eigenlijk alleen om aan te geven dat het strafrecht en het jeugdbeschermingsrecht niet met elkaar zijn te vergelijken. In dit deel van het hoofdstuk wordt aangetoond dat ondanks belangrijke verschillen het streven naar een beslissing op basis van correcte en volledige informatie in beide rechtsgebieden is verankerd. Afgesloten wordt met een van de kernelementen in de 
discussie over waarheidsvinding, namelijk het veronderstelde gebrek aan onderscheid tussen feiten en meningen in de rapportages van de jeugdbeschermingsautoriteiten.

Vervolgens wordt de procedure tot oplegging van een jeugdbeschermingsmaatregel besproken volgens de wet- en regelgeving die van kracht was in de jaren 2013 en 2014. De bespreking beperkt zich tot het voor dit onderzoek relevante deel van de jeugdbeschermingsprocedure. Dat wil zeggen, vanaf de start van het beschermingsonderzoek door de RvdK tot en met de schriftelijke uitwerking van de beslissing van de kinderrechter in de beschikking. In paragraaf 2.4 staat het beschermingsonderzoek zoals uitgevoerd door de RvdK centraal. Uitgebreid aandacht wordt besteed aan de eisen voor de uitvoering van het beschermingsonderzoek en de kwaliteitscriteria voor het opstellen van de beschermingsrapportage. Vervolgens wordt in paragraaf 2.5 aandacht besteed aan het verdere procesverloop van de verzoekschriftprocedure. Onder meer de wettelijke eisen die zijn gesteld ten aanzien van de inhoud van verzoekschriften, de behandeling van het verzoek ter zitting, de positionering van de kinderrechter en de wettelijke uitgangspunten ten aanzien van de beschikking op het verzoek tot jeugdbeschermingsmaatregel komen aan bod.

\subsection{Kenmerken en uitgangspunten van de besluitvorming in jeugdbeschermingszaken}

In de $19^{\mathrm{e}}$ eeuw had de ouderlijke macht vooral te gelden als het geheel aan rechten en bevoegdheden van de vader met betrekking tot het kind. Aan het begin van de $20^{\mathrm{e}}$ eeuw groeide echter de overtuiging dat de ouderlijke macht bestond ter wille van het kind en niet ter wille van de ouders, hetgeen de overheid ook het recht gaf te beoordelen of het gezag daadwerkelijk ter wille van het kind werd uitgeoefend. ${ }^{24}$ Met de invoering van de Burgerlijke Kinderwet in 1901 onstond een wettelijk kader waarmee ingrijpen in het gezag, ter bescherming van de belangen van het kind, mogelijk werd. ${ }^{25}$ De opkomst van een wettelijk systeem van jeugdbescherming in Nederland ging gepaard met de erkenning dat inbreuken op de ouderlijke macht mogelijk moesten kunnen zijn. De maatregelen van ontheffing en ontzetting werden opgenomen in het Burgerlijk Wetboek en de uitvoering van de maatregelen was primair particulier geregeld. ${ }^{26}$ De belangrijkste uitbreiding van het maatregelenpakket

\footnotetext{
${ }^{24}$ Asser/De Boer $1 * 2010 / 815$.

${ }^{25}$ Wet tot wijziging en aanvulling van de bepalingen in het Burgerlijke Wetboek omtrent de vaderlijke machgt en de voogdij en daarmee samenhangende artikelen, Stb 1901, 62. Vgl. voor een nadere toelichting omtrent de totstandkoming van de Burgerlijke Kinderwet: Brands-Bottema 1998; Bruning 2001.

${ }^{26}$ De Vries \& van Tricht 1905, p. 37.
} 
vond vervolgens plaats in 1922 met de komst van de gezagsbeperkende maatregel van ondertoezichtstelling. ${ }^{27}$

Het voorgaande laat zien dat de maatregelen van jeugdbescherming vanaf de introductie van de Burgerlijke Kinderwet, onderdeel hebben uitgemaakt van het privaatrecht, meer specifiek van het familierecht. Het familierecht regelt de rechtsverhoudingen tussen natuurlijke personen op het terrein van families en relaties. ${ }^{28}$ Het jeugdbeschermingsrecht lijkt niet direct onder deze definitie te plaatsen. Hier is immers sprake van staatsinterventie, waardoor inbreuk wordt gemaakt op de rechten van kind en ouders. De verticale verhouding tussen de procesdeelnemers in de jeugdbeschermingsprocedure - doorgaans het gezin tegenover een overheidsinstantie - lijkt eerder te passen bij het publiekrecht. Een ander aspect maakt de keuze voor het privaatrecht echter te billijken. Zo is de plek van het jeugdbeschermingsrecht in Boek 1 van het Burgerlijk Wetboek logisch met het oog op de directe connectie tussen het opleggen van een maatregel en de beperking of ontneming van het gezag dat daarmee is gemoeid. Het voorgaande leidt tot de vaststelling dat het jeugdbeschermingsrecht, hoewel privaatrechtelijk geworteld, overeenkomsten vertoont- en samenhangt met publiekrechtelijk georiënteerde rechtsgebieden als het bestuursrecht en het strafrecht. ${ }^{29}$ Rechtsgebieden waar de verhouding tussen de overheid en burgers centraal staat en daarom logischerwijs ook veel aandacht wordt besteed aan de vraag wat de rol van de overheid is of zou moeten zijn. In het vervolg wordt deze vraag op hoofdlijnen beantwoord voor het jeugdbeschermingsrecht.

\subsubsection{De negatieve en positieve verplichting van de overheid in jeugdbeschermingszaken}

De overheid geeft met de jeugdbeschermingswetgeving de uiterste grenzen aan van de opvoedingsvrijheid die iedere ouder of wettelijke vertegenwoordiger toekomt. De grenzen van wat in pedagogisch en juridisch opzicht aanvaardbaar is, kijkend naar de ontwikkeling van minderjarigen, zijn tijd- en contextgebonden. ${ }^{30}$ Onze samenleving kenmerkt zich door pluriformiteit op allerlei gebieden, niet in de laatste plaats op het gebied van de opvoeding en verzorging van minderjarigen. Ondanks de grote inhoudelijke verschillen ten aanzien van

\footnotetext{
${ }^{27}$ Wet van 5 juli 1921 houdende invoering van den kinderrechter en van de ondertoezichtstelling van minderjarigen, Stb. 1921, 834. De wet is uteindelijk op 1 november 1922 in werking getreden.

${ }^{28}$ Schrama \& Antokolskaia 2015, p. 19.

${ }^{29}$ Het bestuursrecht als rechtsgebied gaat primair over actieve overheidsbemoeienis met de samenleving. Zie Van Wijk, Konijnenbelt \& Van Male 2011. Vgl. voor een andere visie op de verhouding privaatrecht publiekrecht: Van Ommeren AA 2012/7.

${ }^{30} \mathrm{Vgl}$. voor een overzicht van de historische ontwikkeling van de jeugdbeschermingsmaatregelen: BrandsBottema 1988; Bruning 2001.
} 
opvoedingswaarden en pedagogische noties, bestaat er op een belangrijk punt wel consensus: de overheid behoort een rol te hebben in die gevallen waarin de ouders/opvoeders tekort schieten en de ontwikkeling van de minderjarige ernstig wordt bedreigd. ${ }^{31}$ De overheid als parens patriae moet in de uitoefening van die rol een balans zien te vinden tussen de negatieve verplichting zich te onthouden van ongerechtvaardigde inbreuken op het familie- en gezinsleven van kind en ouders en de positieve verplichting de minderjarige de nodige zorg en bescherming te bieden. ${ }^{32}$

De negatieve verplichting houdt in dat de overheid zich terughoudend opstelt om zo de relatie tussen kind en ouders te eerbiedigen. Dit uitgangspunt kan worden afgeleid uit nationale wetgeving en is expliciet verwoord in het IVRK. ${ }^{33}$ Zo blijkt uit art. 5 IVRK dat ouders een centrale rol spelen bij de ontwikkeling van het kind. Staten dienen de rechten, plichten en verantwoordelijkheden van ouders en/of andere opvoeders te eerbiedigen en te voorzien in passende begeleiding waarbij rekening wordt gehouden met de zich ontwikkelende vermogens van het kind. In art. 18 IVRK wordt de rol van ouders nog concreter uitgewerkt. Staten moeten alles doen wat in hun vermogen ligt om de erkenning te verzekeren van het beginsel dat beide ouders gezamenlijk verantwoordelijk zijn voor de opvoeding en ontwikkeling van het kind. Ouders zijn eerstverantwoordelijk en de opvoeding en ontwikkeling van het kind is hun allereerste zorg.

Daarnaast ziet ook het EHRM de opvoeding en verzorging van de minderjarige als primaire taak van de ouders. ${ }^{34}$ Het in art. 8 EVRM neergelegde recht op bescherming van privéleven, familie- en gezinsleven, brengt de negatieve verplichting voor de overheid met zich mee om zich te onthouden van ongeoorloofde inmenging in familierelaties. Inbreuken op het recht op family life zijn alleen mogelijk als er een duidelijke wettelijke basis is, een geoorloofd doel wordt nagestreefd en de noodzaak van een ingreep overtuigend kan worden aangetoond, zo volgt uit art. 8 lid 2 EVRM. Een overheid die te voortvarend is met de inzet van jeugdbeschermingsmaatregelen handelt in strijd met het uitgangspunt van jeugdbescherming als ultimum remedium. De inzet van een jeugdbeschermingsmaatregel als ultimum remedium houdt in dat in alle gevallen moet worden gekeken of het beoogde doel van bescherming van de minderjarige niet op een andere, minder ingrijpende manier kan worden bereikt. Andere

\footnotetext{
${ }^{31}$ Vgl. Brands-Bottema 1988; Weijers 2012; Weijers 2016.

${ }^{32}$ Weijers 2012, p. 17.

${ }^{33}$ In het Burgerlijk Wetboek is niet met zoveel woorden gesteld dat de overheid de rechten van ouders heeft te respecteren. Op grond van de artt. 1:245 lid 3 BW en 1:247 lid 2 BW is wel duidelijk dat de ouders primair verantwoordelijk zijn voor de verzorging en opvoeding van de minderjarige.

${ }^{34}$ Zie Forder 2008, p. 41.
} 
formuleringen die worden gebruikt om dit uitgangspunt te duiden zijn het noodzakelijkheidsvereiste of het beginsel van subsidiariteit.

Hier tegenover staat een aantal positieve verplichtingen dat op de overheid rust inzake jeugdbescherming. Waar de negatieve verplichtingen vragen om onthouding aan de zijde van de autoriteiten, daar dwingen de positieve verplichtingen tot actief handelen. Deels gaat het dan om handelen ter voorkoming van kindermishandeling of andere vormen van pedagogische verwaarlozing. Zo geldt op grond van art. 3 lid 2 IVRK dat Staten het kind de noodzakelijke zorg en bescherming moeten garanderen die nodig is voor zijn of haar welzijn, daarbij rekening houdend met de rechten en plichten van ouders, wettige voogden of andere wettelijke verantwoordelijken. Staten dienen hiertoe alle passende wettelijke en bestuurlijke maatregelen te nemen. Dit vereiste krijgt nader invulling in art. 19 IVRK op grond waarvan Staten gehouden zijn maatregelen te nemen op sociaal en opvoedkundig gebied om kinderen te beschermen tegen alle vormen van geestelijk en lichamelijk geweld, letsel of misbruik, lichamelijke of geestelijke verwaarlozing of nalatige behandeling, mishandeling of exploitatie, met inbegrip van seksueel misbruik. Ondanks alle inspanningen van de Nederlandse overheid op dit terrein krijgt een fors aantal kinderen in Nederland jaarlijks te maken met een vorm van kindermishandeling. ${ }^{35}$

Een ander deel van de positieve verplichtingen van de overheid in jeugdbeschermingszaken ontstaat op het moment dat een maatregel is uitgesproken. De rechtvaardiging voor de inbreuk op het gezinsleven volgt of zou moeten volgen uit het feit dat de overheid aannemelijk kan maken dat de maatregel een positief effect heeft op de ontwikkeling van de minderjarige. Indien redelijkerwijs geen nuttig of opbouwend gevolg van de maatregel is te verwachten dan vervalt de basis voor gedwongen overheidsingrijpen. ${ }^{36}$ Een verdere concretisering van de inspanningsverplichting van de overheid volgt op grond van art. 8 EVRM. Zo is de overheid gehouden de band tussen kind en ouder te behouden en waar mogelijk te versterken. ${ }^{37}$ In het bijzonder geldt dat voor het kind dat door de inzet van een jeugdbeschermingsmaatregel van de ouders is gescheiden. Voor de overheid geldt in deze gevallen de verplichting de ouders

\footnotetext{
35 Alink, Ijzendoorn \& Bakermans 2011.

${ }^{36}$ Asser/de Boer 2010/856. Hier ten aanzien van de oplegging van een machtiging uithuisplaatsing maar zonder twijfel is dit uitgangspunt ook van toepassing op de overige jeugdbeschermingsmaatregelen.

${ }^{37}$ EHRM 24 maart 1988, appl.nr. 10465/83 (Olsson t. Zweden I).
} 
zoveel mogelijk te ondersteunen, het contact tussen kind en ouders in stand te houden en te werken aan het doel van hereniging. ${ }^{38}$

Het is duidelijk dat het vinden van een balans tussen de negatieve en positieve verplichtingen spanning op kan leveren. De uitgangspunten zijn diametraal. Aan de ene kant wordt uiterste terughoudendheid gevraagd van de overheid, terwijl anderzijds de bescherming van de minderjarige vraagt om actief handelen. Deze spanning laat zich goed illustreren door te kijken naar de ontwikkelingen op het gebied van jeugdbescherming in de periode van 2000 tot 2010. Aan het begin van de $21^{\mathrm{e}}$ eeuw werd Nederland opgeschrikt door een serie schokkende gezinsdrama's, waarvan de zaak van het Maasmeisje, de zaak van het Meisje van Nulde en de Savanna-zaak vermoedelijk de bekendsten zijn. Deze zaken hadden met elkaar gemeen dat de betrokken minderjarigen na jarenlange mishandeling en verwaarlozing door de ouder(s) of verzorgers zijn overleden. Dit leidde tot forse kritiek op het handelen van de jeugdbeschermingsautoriteiten vanuit de politiek en de maatschappij. ${ }^{39}$ Feitelijk kwam die kritiek erop neer dat de jeugdbescherming niet voldeed aan de positieve verplichting minderjarigen de noodzakelijke zorg en bescherming te bieden. De zaken hadden immers ook met elkaar gemeen dat bij alle gezinnen al (diverse) hulpverleningsinstanties waren betrokken, maar deze instanties onvoldoende regie voerden en zicht hielden op de veiligheid van de minderjarigen. Het leidde tot een serie vernietigende inspectierapporten over de rol van 'jeugdzorg' en specifiek in de Savanna-zaak, tot strafrechtelijke vervolging van de betrokken gezinsvoogd..$^{40}$

In de nasleep hiervan was in de periode van 2005 tot 2010 een aanzienlijke stijging van het aantal jeugdbeschermingsmaatregelen zichtbaar. ${ }^{41}$ Een van de oorzaken die deels een verklaring bood voor de stijging bleek de angst voor nieuwe incidenten en de daaropvolgende kritiek op jeugdbeschermingsprofessionals- en organisaties. ${ }^{42}$ Het pertinent willen uitsluiten

\footnotetext{
${ }^{38}$ De herenigingsdoelstelling is door het EHRM in een groot aantal zaken bevestigd zie onder meer: EHRM 24 maart 1988, nr. 10465/83 (Olsson/Zweden nr. 1), r.o. 72. EHRM 22 juni 1989, nr. 11373/85 (Eriksson t. Zweden), r.o. 71; EHRM 27 november 1992, nr. 13441/87 (Olsson t. Zweden nr. 2), r.o. 90; EHRM 12 juli 2001, appl. nr. 25702/94 (K. en T. t.Finland), r.o. 178.

${ }^{39}$ Zie voor een schets van deze zaken en de politieke reacties daarop: Weijers 2012.

${ }^{40} \mathrm{Vgl}$. de inspectierapporten in de drie voornoemde zaken: Onderzoek IGZ/IJZ naar de hulpverlening rond het meisje Gessica, Utrecht, mei 2007 (Maasmeisje), het meisje van Nulde. Voor de politieke discussie over de Savanna zaak zie: Kamerstukken II 2004/05 29815, nr. 58.

${ }^{41}$ Zo steeg het aantal ondertoezichtstellingen in de periode van $2005 \mathrm{t} / \mathrm{m} 2009$ met maar liefst 38,5\% (gemeten op peildatum 31 december van ieder jaar. Zie Berends e.a 2010, p. 15-16. Tussen 2009 en 2012 daalde het aantal ondertoezichtstellingen licht. In de jaren hierna daalde het aantal maatregelen sneller. In 2014 stonden op 31 december nog ruim 25.000 minderjarigen onder toezicht. Zie CBS ‘jeugdbescherming en jeugdreclassering 2015'.

${ }^{42}$ Berends e.a 2010, p. 36-37.
} 
van risico's door sneller en diepgaander in te grijpen in het gezinsleven, is ook wel aangeduid als preventionisme, of doorschietende preventie. ${ }^{43}$ Het leidde tot forse kritiek met name vanuit ouders en jeugdrechtadvocaten. Gesteld werd dat de ultimum remedium gedachte was losgelaten en te snel werd overgegaan tot gedwongen maatregelen. ${ }^{44}$ Kritiek die overigens op dat moment (2009) niet werd gedeeld door de wetgever. Zo gaf het in dezelfde periode uitgekomen wetsvoorstel tot herziening van de kinderbeschermingsmaatregelen blijk van de wens om sneller in te kunnen grijpen in het gezinsleven met zwaardere maatregelen. ${ }^{45}$ Of de kritiek zoals geschetst op de overheid volledig terecht was of niet, het maakt in ieder geval duidelijk dat het streven naar een goede balans tussen beide verplichtingen een uitdaging is voor de jeugdbeschermingsautoriteiten. In zekere zin kunnen de jeugdbeschermingsautoriteiten het nooit goed doen, hetgeen een feitelijke constatering is en niet betekent dat het functioneren van de autoriteiten niet kritisch kan worden beschouwd.

\subsubsection{De verhouding tussen het (functioneren van het) systeem van jeugdzorg en de} jeugdbeschermingsmaatregelen

De maatregelen van jeugdbescherming staan niet op zichzelf. Zij maken deel uit van het complete systeem van zorg voor minderjarigen in Nederland. In dit onderzoek staat het (functioneren van het) systeem van jeugdzorg niet centraal maar het onderwerp verdient wel enige aandacht. Bovenal omdat het de wijze waarop het systeem van jeugdzorg is vormgegeven en functioneert van invloed is op de vraag wanneer en onder welke voorwaarden een jeugdbeschermingsmaatregel kan worden opgelegd. Om een concreet voorbeeld te geven, indien er sprake is van een ruim hulpverleningsaanbod in het vrijwillig kader en de vrijwillige hulpverlening aan minderjarigen effectief en efficiënt is, dan zal de importantie van gedwongen maatregelen afnemen. Daarnaast geldt in algemene zin dat de hulp die noodzakelijk is voor de minderjarige - of dat nu binnen het vrijwillige of gedwongen kader is - tijdig beschikbaar en effectief moet zijn. In de achterliggende decennia zijn er vrijwel constant grote zorgen geweest over het functioneren van het systeem van jeugdzorg. Dit heeft geleid tot frequente en ingrijpende stelselherzieningen in de afgelopen 30 jaar, zeker als de vergelijking wordt gemaakt met de geringe wijzigingen ten aanzien van het materiële jeugdbeschermingsrecht. Typerend in dit verband was de gang van zaken na inwerkingtreding

\footnotetext{
${ }^{43}$ Weijers 2012, p. 25 e.v.

${ }^{44}$ Zie voor meer informatie: Uit Beijerse, Logtenberg \& Rietbergen 2010.

${ }^{45}$ Bruning $A A$ 2011/11.
} 
van de Wet op de Jeugdhulpverlening in 1990. Na een lange aanlooptijd trad deze wet volledig in werking op 1 januari 1990. Binnen enkele jaren na de inwerkingtreding werd echter al besloten tot een nieuwe wetswijziging omdat er tal van knelpunten werden gesignaleerd in de opzet en uitvoering van de hulp aan minderjarigen. ${ }^{46}$ Het betekende het begin van een nieuw traject dat uiteindelijk in 2005 leidde tot invoering van de Wet op de Jeugdzorg.

\section{Wet op de jeugdzorg}

De wettelijke regeling voor vrijwillige en gedwongen zorg aan jeugdigen in Nederland was in de periode van 2005-2015 neergelegd in de Wet op de Jeugdzorg (Wjz). De wet moest een oplossing vormen voor diverse knelpunten, zoals capaciteitsproblemen, een slecht afgestemd hulpverleningsaanbod en een gebrekkinge onderlinge afstemming in de keten. ${ }^{47}$ De Wet op de Jeugdzorg was het raamwerk waarbinnen de jeugdzorg, inclusief de (justitiële) jeugdbescherming vorm moest krijgen. Onder jeugdzorg werd op grond van art. 1 lid 1 sub 3 Wjz verstaan:

'alle vormen van ondersteuning en hulp aan jeugdigen, hun ouders, stiefouders of anderen die een jeugdige als behorende tot hun gezin verzorgen en opvoeden, met uitzondering van pleegouders, bij (dreigende) opgroei- of opvoedingsproblemen.'

De Wet op de Jeugdzorg kende verschillende doelstellingen: het versterken van de jeugdzorgvoorzieningen; het vestigen van een wettelijke aanspraak op jeugdzorg (recht op zorg) en daarmee het versterken van de positie van de cliënt; de totstandkoming van een centrale herkenbare, bekende, laagdrempelige toegang tot de jeugdzorg via Bureau Jeugdzorg en het realiseren van een passend en samenhangend zorgaanbod. ${ }^{48}$ De stichting die een Bureau Jeugdzorg in stand hield nam een centrale positie in binnen het systeem van jeugdzorg. ${ }^{49}$ Op grond van art. $5 \mathrm{Wjz}$ was het de taak van Bureau Jeugdzorg te bezien of een cliënt zorg nodig had in verband met opgroei-, opvoedings- of psychiatrische problemen, dan wel in verband met problemen van een cliënt, niet zijnde een jeugdige, die het onbedreigd

\footnotetext{
${ }^{46}$ Zie voor een compleet overzicht: Vlaardingerbroek FJR 2004/101.

${ }^{47}$ Kamerstukken II 2001/02, 28 168, nr. 3 (MvT),

${ }^{48}$ Kamerstukken II 2001/02, 28 168, nr. 3 (MvT), p. 5-6.

${ }^{49}$ Voor de volledigheid moet hier worden vermeld dat er tevens enkele landelijk werkende instellingen op mandaat van Bureau Jeugdzorg met de uitvoering van jeugdbeschermingsmaatregelen konden worden belast (zoals b.v. de William Schrikker Groep en Leger des Heils Jeugdbescherming en Reclassering). Omwille van de leesbaarheid wordt in het vervolg enkel gesproken over Bureau Jeugdzorg.
} 
opgroeien van de jeugdige bedreigden. Indien Bureau Jeugdzorg of het Advies- en Meldpunt Kindermishandeling (AMK) als onderdeel van BJZ, tot het oordeel kwamen dat een jeugdbeschermingsmaatregel overwogen diende te worden, dan stelden zij de Raad voor de Kinderbescherming hiervan op de hoogte (art. 9 Wjz). De Raad voor de Kinderbescherming ging daarmee feitelijk fungeren als tweedelijnsvoorziening. ${ }^{50}$

Daarnaast had Bureau Jeugdzorg blijkens art. 10 lid 1 sub a/b Wjz als taak het uitvoeren van de maatregelen van jeugdbescherming die door de rechter waren opgelegd. Door deze taak bij Bureau Jeugdzorg neer te leggen werd een betere aansluiting beoogd tussen het vrijwillige en gedwongen kader, waardoor de hulpverlening aan minderjarigen met een jeugdbeschermingsmaatregel verbeterd zou kunnen worden. ${ }^{51}$ Het zou ook moeten leiden tot een betere samenwerking tussen de ketenpartners, in het bijzonder Bureau Jeugdzorg en de RvdK. Voor de besluitvorming over de noodzaak van een jeugdbeschermingsmaatregel was van belang dat Bureau Jeugdzorg de situatie beoordeelde en waar nodig de RvdK inschakelde om een beschermingsonderzoek uit te voeren. De intensievere samenwerking tussen de gezinsvoogdij en de RvdK bleek ook uit de introductie van de casusoverleggen bescherming, waarin de ketenpartners al in een vroeg stadium de problematiek van de minderjarige (en het gezin) beoordeelden. De evaluatie van de Wet op de Jeugdzorg na de inwerkingtreding van de wet liet zien dat op het punt van de samenwerking positieve verbeteringen zichtbaar waren, althans volgens de medewerkers van de betrokken organisaties zelf. ${ }^{52}$ In de evaluatie werd de substantiële groei van het aantal jeugdbeschermingsmaatregelen in de periode na inwerkingtreding van de Wet op de Jeugdzorg nog niet als groot probleem aangemerkt. ${ }^{53}$ Ook de instroom van het aantal zaken bij Bureau Jeugdzorg nam toe, waardoor de relatieve stijging mee leek te vallen volgens de toenmalige verantwoordelijke minister Rouvoet. ${ }^{54}$ Enkele jaren later werd de groei van dure specialistische zorg (waaronder zorg in het kader van jeugdbescherming) wel als belangrijk knelpunt aangemerkt. In 2013 volgde alweer een nieuw voorstel van wet met betrekking tot de regels voor preventie, ondersteuning, hulp en zorg aan jeugdigen. ${ }^{55}$ Belangrijk voor de toepassing van jeugdbeschermingsmaatregelen was dat werd aangegeven dat de Wet op de Jeugdzorg, anders dan werd beoogd, niet had geleid tot snelle

\footnotetext{
${ }^{50}$ Zie Stcrt. 2002, nr. 116, p. 13

${ }^{51}$ Kamerstukken II 2001/02, 28 168, nr. 3 (MvT).

${ }^{52}$ Baecke e.a. 2009, p. 10 e.v.

${ }^{53}$ Baecke e.a. 2009.

${ }^{54}$ Kamerstukken II 2009/10, 32202, nr. 1.

${ }^{55}$ Kamerstukken II 2013/14, 33 684, nr. 1.
} 
en passende jeugdzorg voor de cliënt. ${ }^{56}$ Aangenomen mag worden dat deze conclusie ook betrekking had op de jeugdzorg die in het kader van een jeugdbeschermingsmaatregel werd verleend. Een nieuwe wet gericht op alle vormen van zorg aan minderjarigen moest de knelpunten wegnemen. Belangrijke kernpunten van de voorgestelde wijziging in wetgeving waren dat het beroep op specialistische zorg moest worden verminderd en de samenwerking in de hulpverlening aan kinderen en gezinnen moest worden verbeterd. ${ }^{57}$ Uiteindelijk heeft dit voorstel van wet geleid tot invoering van de Jeugdwet op 1 januari 2015. ${ }^{58}$ De invloed van de Jeugdwet op het jeugdbeschermingsrecht wordt besproken in deel III van dit onderzoek.

\subsection{Het verzamelen en beoordelen van bewijs in jeugdbeschermingszaken}

Zoals gesteld maakt het jeugdbeschermingsrecht onderdeel uit van het civiele recht. De regels van het materiële jeugdbeschermingsrecht zijn voor het grootste deel neergelegd in Boek 1 Burgerlijk Wetboek. De procedurele regels van het jeugdbeschermingsrecht vindt men in het Wetboek van Burgerlijke Rechtsvordering. Dit betekent dat de algemene voorschriften voor procedures in civiele zaken in beginsel onverkort van toepassing zijn op jeugdbeschermingszaken. Dit geldt onder meer voor het beginsel van hoor en wederhoor (art. $19 \mathrm{Rv}$ ), de informatieplicht voor partijen (art. $22 \mathrm{Rv}$ ) en de rechterlijke motiveringsplicht (art. $30 \mathrm{Rv}$ ). De regels voor het verzamelen en beoordelen van het aangedragen bewijs die gelden in jeugdbeschermingszaken zijn voornamelijk neergelegd in het Wetboek van Burgerlijke Rechtsvordering. Het civiele bewijsrecht is daarmee onderdeel van het huidige civiele procesrecht. De bewijslevering op grond van bewijsrechtelijke regels moet bijdragen aan de totstandkoming van een eerlijk proces met zoveel mogelijk gelijke middelen en kansen voor beide procespartijen. Het bewijsrecht in civiele zaken is op verschillende plekken in het Wetboek van Burgerlijke Rechtsvordering opgenomen. Het is belangrijk op hoofdlijnen aandacht te besteden aan het bewijsrecht dat van toepassing is op jeugdbeschermingszaken. In de discussie over het verzamelen en beoordelen van bewijs in jeugdbeschermingszaken wordt wel eens de indruk gewekt dat het jeugdbeschermingsrecht als onderdeel van het civiele recht 'bewijsvrij' is. ${ }^{59}$ Daarmee worden de regels voor het aanbrengen van bewijs door

\footnotetext{
${ }^{56}$ Kamerstukken II 2013/14, 33 684, nr. 3 (MvT).

${ }^{57}$ Kamerstukken II 2013/14, 33 684, nr. 3 (MvT).

${ }^{58}$ Wet van 1 maart 2014 inzake regels over de gemeentelijke verantwoordelijkheid voor preventie, ondersteuning, hulp en zorg aan jeugdigen en ouders bij opgroei- en opvoedingsproblemen, psychische problemen en stoornissen (Jeugdwet), Stb. 2014, 105.

${ }^{59}$ Zie bv. Prinsen NRC 19 maart 2011.
} 
partijen en de weging van die informatie door de rechter te gemakkelijk genegeerd. Het voert te ver om alle bepalingen van bewijsrecht in civiele zaken uitputtend te behandelen maar enkele voor dit onderzoek belangrijke elementen worden in het vervolg op hoofdlijnen toegelicht.

\subsubsection{De algemene regels van bewijsrecht in civiele zaken}

De algemene regels van bewijsrecht voor dagvaardingsprocedures zijn opgenomen in de artt. $149-155 \mathrm{Rv}$. Via de schakelbepaling van art. $284 \mathrm{Rv}$ zijn voornoemde wettelijke bepalingen ook van toepassing op verzoekschriftprocedures (waaronder de jeugdbeschermingsprocedure). Als hoofdregel van het bewijsrecht heeft volgens art. 149 lid 1 $\mathrm{Rv}$ te gelden dat de rechter slechts de feiten of rechten aan zijn beslissing ten grondslag mag leggen die in het geding aan hem ter kennis zijn gekomen of zijn gesteld. Dit uitgangspunt komt voort uit het beginsel van partijautonomie en het daarmee corresponderende beginsel van lijdelijkheid van de rechter. De regels van art. $149 \mathrm{Rv}$ bepalen welke door een partij gestelde feiten en rechten aan de beslissing ten grondslag mogen worden gelegd. Die regels zijn voor de rechter ook van belang om te beoordelen of bepaalde feiten als vaststaand kunnen worden aangenomen, dan wel of van bepaalde feiten bewijs moet worden geleverd voordat zij vast kunnen komen te staan. Bovendien kan de rechter in de uitspraak terug laten komen dat bepaalde feiten met toepassing van een bepaalde regel van art. $149 \mathrm{Rv}$ zijn vastgesteld. ${ }^{60}$ Hiermee kan het proces van de feitenvaststelling in de uitspraak inzichtelijk worden gemaakt. Hoewel partijen in beginsel gezamenlijk de feiten moeten aandragen op basis waarvan de rechter zijn beslissing neemt, kunnen de partijen niet volstaan met een feitenbestand zonder enige duiding. Partijen dienen enige structuur in de feiten aan te brengen en zij moeten de kern aangeven van de vordering of het verzoek. ${ }^{61}$ Partijen moeten ten behoeve van hun eigen standpunt ieder een selectie maken, hetzij door op concrete feiten een beroep te doen, hetzij door feitelijk juridische stellingen aan te voeren waar deze feiten in passen. ${ }^{62}$

In tegenstelling tot het strafrecht kent het civiele bewijsrecht een vrije bewijsleer (art. 152 Rv). In beginsel kan door alle middelen bewijs worden geleverd. In de praktijk zijn de belangrijkste bewijsmiddelen: schriftelijk bewijs ( $\operatorname{artt} .152-162 \mathrm{Rv}$ ), bewijs door het horen van getuigen ten overstaan van de rechter (de artt. 163-193 Rv, bewijs door deskundigen (de artt. 194-200 Rv en 202-207 Rv, bewijs door plaatsopneming (artikel $201 \mathrm{Rv}$ ), bewijs door

\footnotetext{
${ }^{60}$ Van Tiggele-van der Velde 2008.

${ }^{61}$ Tjong Tjin Tai, in: T\&C Burgerlijke rechtsvordering 2002, afl. 2, p. 29 e.v.

${ }^{62}$ Tjong Tjin Tai, in: T\&C Burgerlijke rechtsvordering 2002, afl. 2, p. 30.
} 
eigen waarneming van de rechter, bewijsmiddelen die worden verkregen door exhibitie (artikel 843a-843b Rv) en bewijs op (andere) gegevensdragers. Voor de jeugdbeschermingspraktijk is schriftelijk bewijs met afstand het belangrijkste bewijsmiddel aangezien de kinderrechter zich primair zal baseren op de schriftelijke rapportage van de RvdK en de toelichting op de informatie in de rapportage op zitting. De rechter is vervolgens vrij in zijn waardering van het bewijs tenzij de wet anders bepaalt (art. 152 lid 2 Rv). Relevant voor het bewijsrecht in jeugdbeschermingszaken is de samenhang tussen de waardering van bewijs en de mogelijke rechtsgevolgen van het proces voor de betrokken partijen. Naarmate de belangen groter zijn en de rechtsgevolgen ingrijpender, zou de rechter hogere eisen moeten stellen aan het aangeleverde bewijs, zo is aangegeven in de literatuur:

'De waardering door de rechter van het bewijs zal niet los gezien kunnen worden van de aard van het geschil en het gewicht van de daarbij betrokken wederzijdse belangen enerzijds en de aard van het geding anderzijds. Men zij er dus op bedacht dat als het gaat om bijv. het bewijs van feiten waarvan de rechtsgevolgen diep ingrijpen in fundamentele rechten van de wederpartij (bijv. zijn huisvesting of arbeidsverhouding) de rechter geneigd zal kunnen zijn zwaardere eisen aan de intrinsieke waarde van het bewijs te stellen dan in andere zaken. (..) Ten aanzien van bepaalde onderdelen van het geschil (bijvoorbeeld de hoogte van de schade) zal de rechter eerder tevreden met weinig bewijsmateriaal zijn dan ten aanzien van de primaire vraag van de aansprakelijkheid. De aan bewijs te stellen eisen en de wijze waarop de rechter het bewijs waardeert vallen dus in het algemeen niet nader te bepalen. ${ }^{93}$

Voornoemde redenering volgend zou de kinderrechter extra kritisch moeten kijken of de informatie op basis waarvan het verzoek tot ondertoezichtstelling/machtiging uithuisplaatsing is gedaan, volledig en correct is. De maatregel maakt immers inbreuk op wat door velen als een van de meest fundamentele rechten wordt beschouwd: het recht op eerbiediging van het familie- en gezinsleven. Tegelijkertijd moet de kinderrechter in jeugdbeschermingszaken tot op zekere hoogte kunnen vertrouwen op de gegevens die worden aangedragen door partijen. De waarheidsplicht voor partijen op grond van art. $21 \mathrm{Rv}$ speelt een cruciale rol waar het gaat om de eisen die aan de ingebrachte informatie kunnen worden gesteld.

\footnotetext{
${ }^{63}$ Asser Procesrecht/Giesen 1 2015, aant. 3.3.
} 


\subsubsection{De waarheidsplicht van art. $21 \mathrm{Rv}$}

Volgens art. $21 \mathrm{Rv}$ dienen partijen de voor de beslissing van belang zijnde feiten volledig en naar waarheid aan te voeren. De verplichting tot een volledige en juiste voorlichting van de rechter en de wederpartij geldt voor alle in het Wetboek van Burgerlijke Rechtsvordering geregelde procedures. Op basis van 'de waarheidsplicht' zijn partijen gehouden alle voor het geschil relevante feiten aan te voeren waarbij zij zich dienen te onthouden van bewuste leugens. ${ }^{64}$ Hoewel art. $21 \mathrm{Rv}$. vrij stevig is geformuleerd wordt primair beoogd te voorkomen dat bewust onjuiste informatie in de procedure wordt ingebracht. Het staat partijen dan ook vrij relevante informatie naar eigen inzicht te interpreteren en te selecteren. ${ }^{65}$ In uitzonderlijke gevallen kan schending van art. $21 \mathrm{Rv}$ onrechtmatig handelen opleveren vanwege misbruik van procesrecht. De Hoge Raad heeft bepaald dat sprake kan zijn van misbruik van procesrecht indien het instellen van een vordering, gelet op de evidente ongegrondheid ervan, in verband met de belangen van de wederpartij achterwege had moeten blijven. ${ }^{66}$ Primair gaat het dan om feiten en omstandigheden waarvan de eiser wist of behoorde te weten dat deze onjuist waren.

Er is in algemene zin dus terughoudendheid geboden bij het oordeel dat in strijd is gehandeld met de waarheidsplicht van art. $21 \mathrm{Rv}$. Dit blijkt tevens uit de consequenties van niet-naleving zoals opgenomen in de wet. Art. $21 \mathrm{Rv}$ beperkt zich tot de vaststelling dat bij niet-naleving van de waarheidsplicht de rechter daaruit de gevolgtrekking kan maken die hij geraden acht. In dit verband kan worden gedacht aan verlies van geloofwaardigheid van de 'gebrekige' partij hetgeen in meer of mindere mate van invloed kan zijn op de rechterlijke oordeelsvorming. ${ }^{67}$ Ook sanctionerende gevolgtrekkingen behoren tot de mogelijkheden zoals een matiging of nihilstelling van de aan de in het gelijk gestelde partij toe te wijzen proceskosten of het buiten beschouwing laten van nieuwe feiten die de gebrekige partij wenst in te brengen. ${ }^{68}$ Dit zou in theorie kunnen betekenen dat de RvdK geen mogelijkheid wordt geboden om eventuele tekortkomingen in de rapportage aan te vullen of te verbeteren op zitting. In de praktijk is dit om meerdere redenen echter moeilijk voorstelbaar. In de eerste plaats is het niet waarschijnlijk dat de kinderrechter tot het oordeel komt dat de RvdK bewust onjuiste informatie heeft verstrekt. Zoals gesteld ligt de lat omtrent dit oordeel hoog en het

\footnotetext{
${ }^{64}$ Van Mierlo, in: T\&C Rurgerlijke Rechtsvordering, art. $21 \mathrm{Rv}$.

${ }^{65}$ Kamerstukken II 1999-2000, 26 855, nr. 3.

${ }^{66}$ Hoge Raad 25 maart 2011, ECLI:NL:HR:2011:BO9675.

${ }^{67}$ Van Mierlo, in: T\&C Rurgerlijke Rechtsvordering, art. 21 Rv., aant. 4.

${ }^{68}$ Van Mierlo, in: T\&C Rurgerlijke Rechtsvordering, art. 21 Rv., aant. 4.
} 
belang voor de RvdK om zo te handelen lijkt niet aanwezig. Daarnaast moet, in het zeer uitzonderlijke geval dat de kinderrechter wel tot dit oordeel zou komen, nog steeds een beslissing worden genomen waarbij het belang van het kind voorop staat. Het buiten beschouwing laten van potentieel belangrijke informatie zal in de regel niet in het belang van het kind zijn. Het is dan ook niet verrassend dat binnen de gepubliceerde rechtspraak tot 2015 op het terrein van het jeugdbeschermingsrecht geen zaken zijn gepubliceerd waarin een schending van art. $21 \mathrm{Rv}$ werd aangevoerd.

De waarheidsplicht van art. $21 \mathrm{Rv}$ hangt nauw samen met de informatieplicht voor partijen zoals neergelegd in art. $22 \mathrm{Rv}$. De rechter kan op grond van laatstgenoemd artikel partijen in de procedure bevelen bepaalde stellingen toe te lichten of bepaalde bescheiden te overleggen. Ook hier geldt dat als partijen weigeren aan het verzoek van de rechter te voldoen hij daaruit de gevolgtrekking kan maken die hij geraden acht. Ondanks de bewust vaag gehouden sancties op overtreding van de artt. 21 en $22 \mathrm{Rv}$ zou het niet terecht zijn beide artikelen af te doen als symboolwetgeving, zonder waarde voor de jeugdbeschermingsprocedure. Het is logisch dat niet iedere onjuistheid leidt tot een schending van de waarheids- of informatieplicht. Dit zou in de weg komen te staan van een efficiënte afdoening van procedures. Tegelijkertijd markeren beide artikelen wel de ondergrens die kan worden gesteld voor het verzamelen en aanbrengen van feiten. Er is zo gezegd wel een grens aan de slordigheid waarmee door partijen met de feiten kan worden omgegaan. ${ }^{69}$ Indien een beschermingsrapport van de RvdK vol staat met vage omschrijvingen en/of feitelijke onjuistheden dan kan een punt worden bereikt waarop de kinderrechter een schending van de waarheidsplicht vaststelt. Daarnaast geven beide artikelen uitdrukking aan het bredere streven naar materiële waarheidsvinding. ${ }^{70}$ Dat wil in dit geval zeggen, het zoveel mogelijk op waarheid laten berusten van de beslissing van de kinderrechter op het verzoek tot oplegging van een jeugdbeschermingsmaatregel. De RvdK speelt in jeugdbeschermingszaken hierbij een cruciale rol. De RvdK doet immers als professionale overheidsinstantie onderzoek naar de zorgen in het gezin en maakt daarbij een afweging over de waarde van het verkregen bewijs. Het civiele bewijsrecht stimuleert dat hetgeen in de beschermingsrapporten wordt weergegeven zoveel mogelijk overeenkomt met het werkelijk gebeurde.

\footnotetext{
${ }^{69}$ Zie hierover uitgebreid: Seinen TCR 2014/3.

${ }^{70} \mathrm{Zie}$ voor een uitgebreide toelichting omtrent de waarheidsplicht en het doel daarvan: De Bock 2011.
} 


\subsection{De discussie omtrent waarheidsvinding in jeugdbeschermingszaken}

Het begrip waarheidsvinding wordt vaak onderverdeeld in materiële waarheidsvinding en formele waarheidsvinding. Met materiële waarheidsvinding wordt bedoeld het achterhalen van hetgeen werkelijk is gebeurd. De formele waarheid daarentegen betreft de waarheid zoals deze binnen de begrenzingen van het proces is vast komen te staan, wat niet per definitie het werkelijk gebeurde hoeft te zijn. Beide begrippen zijn echter niet zomaar tegenover elkaar te plaatsen. ${ }^{71}$ Materiële waarheidsvinding kent duidelijk zijn beperkingen en impliceert geen absolute eis om het werkelijk gebeurde te achterhalen, maar het streven om het verschil tussen de formele waarheid - de waarheid die in het proces vast komt te staan - zo min mogelijk af te laten wijken van de materiële waarheid. Op deze manier wordt draagvlak gecreëerd ten aanzien van de te nemen beslissing. Dit is belangrijk, ervan uitgaande dat een van de functies van de juridische procedure het bewerkstelligen is van een uitkomst die door de betrokken partijen kan worden geaccepteerd.

In de achterliggende jaren is intensief gediscussieerd over de rol van waarheidsvinding in jeugdbeschermingszaken. Een aantal elementen was kenmerkend voor de discussie zoals gevoerd. In de eerste plaats leek aanhoudende kritiek van ouders en belangenorganisaties op de besluitvorming in jeugdbeschermingszaken aan de basis te liggen van de toegenomen aandacht voor het fenoneem waarheidsvinding. De kritiek concentreerde zich voornamelijk op de wijze waarop het feitenonderzoek werd uitgevoerd en informatie werd verwerkt in de rapportages. Ten tweede viel op dat de vergelijking werd gemaakt met het strafrecht, om aan te geven dat waarheidsvinding in jeugdbeschermingszaken niet de vorm kan hebben van waarheidsvinding in strafzaken. ${ }^{72}$ Hoewel deze vaststelling op zichzelf correct is werd verder weinig tot geen inzicht geboden in de kenmerkende verschillen én overeenkomsten tussen beide rechtsgebieden, laat staan dat de vraag werd beantwoord wat de reikwijdte is of zou moeten zijn van het begrip waarheidsvinding binnen het jeugdbeschermingsrecht. Ten derde en cruciaal, inhoudelijk leek het belangrijkste kritiekpunt het vermeende gebrek aan onderscheid tussen feiten en meningen in de jeugdbeschermingsrapportages. De kritiek bleef echter oppervlakkig omdat een belangrijke voorvraag niet werd beantwoord: wanneer is sprake van feitelijke (objectief verifieerbare) informatie en wanneer is er sprake van een mening/visie van een betrokkene of professional die als informant optreedt? Zonder aandacht te besteden aan deze vraag kan niet goed worden beoordeeld of feiten en meningen door

\footnotetext{
${ }^{71}$ De Bock 2011, p. 73.

${ }^{72}$ Cardol, Galama \& Kuipers FJR 2013/41.
} 
elkaar lopen in de rapportages, en zo ja, hoe vaak dit voorkomt. In de zojuist gehanteerde volgorde wordt de discussie ten aanzien van deze drie elementen nader toegelicht.

\subsubsection{Kritiek op de jeugdbeschermingsautoriteiten}

Een ondertoezichtstelling, al dan niet gecombineerd met een machtiging uithuisplaatsing is voor de minderjarige, zijn ouders en overige betrokkenen een maatregel met zeer ingrijpende gevolgen. De besluitvorming op basis waarvan dergelijk ingrijpende maatregelen kunnen worden opgelegd, behoort dan ook zo zorgvuldig mogelijk te verlopen. Over de vraag of de onderzoeken en rapportages in de jeugdbeschermingsketen van voldoende kwaliteit zijn is de afgelopen jaren gediscussieerd. ${ }^{73}$ Noemenswaardig is het rapport van de Kinderombudsman uit 2013 waarin het feitenonderzoek in de jeugdbeschermingsketen werd geanalyseerd, teneinde antwoord te kunnen geven op de vraag of toendertijd (voldoende) aan waarheidsvinding werd gedaan. ${ }^{74}$ Die vraag liet zich echter moeilijk beantwoorden, met name omdat het antwoord vereiste dat inzicht werd geboden in de prevalentie van 'fouten' in de rapportages. In het onderzoek van de Kinderombudsman werd dit aantal geschat door de geïnterviewden, waardoor een precies antwoord niet te geven was.

Ook als wel vastgesteld had kunnen worden in hoeveel gevallen fouten werden gemaakt zijn er nog complicerende factoren. Zo tast lang niet iedere fout de juistheid van het inhoudelijke oordeel van de onderzoekende instantie aan. De naam van de betrokken minderjarige incorrect weergeven in de rapportage is bijzonder slordig en pijnlijk, maar het heeft in beginsel geen invloed op de vraag of een ondertoezichtstelling noodzakelijk is. Daarnaast is inherent aan de jeugdbescherming dat een deel van de ouders (en soms minderjarigen) ontevreden is over het functioneren van de jeugdbeschermingsautoriteiten. Ouders die worden geconfronteerd worden met een maatregel en hierdoor mogelijk zelfs gescheiden worden van hun kind, kunnen dat begrijpelijkerwijs vaak moeilijk accepteren. Nog moeilijker is de acceptatie van hun eigen rol in het geheel. De jeugdbeschermingsautoriteiten zijn dan een voor de hand liggende zondebok. Hiermee wordt overigens geenszins betoogd dat klachten van ouders en/of de minderjarige om die reden minder serieus genomen zouden moeten worden. Het betekent echter wel dat rekening moet worden gehouden met het feit dat een

\footnotetext{
${ }^{73}$ Vgl. De Kinderombudsman 2013; Van Zanten \& Brenninkmeijer FJR 2011/76; Huijer NJB 2014/673; Cardol, Galama \& Kuipers FJR 2013/41; Prinsen FJR 2012/86.

${ }^{74}$ De Kinderombudsman 2013.
} 
zekere mate van onvrede bij de betrokkenen over de besluitvorming in jeugdbeschermingszaken onvermijdelijk is. ${ }^{75}$

In het onderzoek van de Kinderombudsman zijn jongeren geïnterviewd die recentelijk zijn geconfronteerd met een jeugdbeschermingsmaatregel. Hoewel slechts enkele ervaringen van jongeren terugkomen, zijn verschillende elementen toch noemenswaardig. De geïnterviewde jongeren geven onder meer aan dat het proces van informatieverzameling ondoorzichtig is, met name omdat ze geen terugkoppeling van hun gesprekken met professionals krijgen. ${ }^{76}$ Verder wordt aangegeven dat in rapportages soms (feitelijke) onjuistheden voorkomen. ${ }^{77}$ Meest in het oog springt echter het pleidooi van jongeren om meer betrokken te worden bij de afwegingen die door professionals worden gemaakt. Duidelijkheid omtrent de redenen die ten grondslag hebben gelegen aan de inzet van een maatregel en een duidelijk plan voor kind en gezin waarin staat welke stappen nodig zijn om de situatie te verbeteren.

In de meeste gevallen komt de kritiek op het feitenonderzoek in jeugdbeschermingszaken van ouders die de minderjarige in rechte vertegenwoordigen en emotioneel zeer betrokken zijn bij de besluitvorming. Voor ouders lijkt het begrip te appelleren aan een 'eerlijk' of 'rechtvaardig' onderzoek hetgeen moet leiden tot een beslissing op basis van de waarheid. ${ }^{78}$ Complicerend is dat betrokkenen - al dan niet verwikkeld in een heftige strijd - soms vooral hun eigen waarheid bevestigd wensen te zien. Tussen ouders, maar ook zeker tussen de minderjarige, zijn ouders en de betrokken autoriteiten kunnen derhalve grote verschillen bestaan in perceptie ten aanzien van de veronderstelde zorgelijke opvoedingssituatie van de minderjarige. Desondanks moeten de klachten die ouders aandragen serieus worden genomen, aangezien de aard van de klachten consistent is en veel klachten al jarenlang terugkomen. Zo klagen ouders onder meer over het feit dat zij in rapportages erop worden afgerekend als zij een kritische houding aannemen. ${ }^{79}$ Verder wordt aangegeven dat informatie verkregen van informanten vaak niet wordt gecontroleerd en voor waar wordt aangenomen. Tot slot geven ouders aan dat zorgelijke signalen zwaar worden aangezet door de ketenpartners in de

\footnotetext{
${ }^{75}$ Daarbij zij gewezen op de vele websites en facebookpagina's van betrokken ouders die pogen allerlei misstanden in de jeugdzorg aan te kaarten of in bredere zin van mening zijn dat het systeem van jeugdbescherming in Nederland niet deugt.

${ }^{76}$ De Kinderombudsman 2013, p. 17 e.v.

${ }^{77}$ De Kinderombudsman 2013, p. 17 e.v.

${ }^{78}$ De Kinderombudsman 2013.

${ }^{79}$ De Kinderombudsman 2013, p. 22.
} 
rapportage ${ }^{80}$ Psychiatrische stoornissen worden in rapportages zonder officiële diagnose opgenomen en een enkele uitspraak of enkel incident wordt ouders zwaar aangerekend.

De toenmalige verantwoordelijke staatssecretarissen Teeven (Veiligheid en Justitie) en Van Rijn (Volksgezondheid, Welzijn \& Sport) lieten in 2013 weten de conclusies en aanbevelingen van de Kinderombudsman te delen en gingen in gesprek met de betrokken ketenpartners over de vraag hoe de gewenste verbeteringen op dit vlak te realiseren. ${ }^{81}$ De RvdK liet in een reactie weten dat de aanbevelingen in algemene zin aansloten bij de koers die reeds was ingezet ter verbetering van de kwaliteit van de rapportages en dat waar nodig aanvullende maatregelen zouden worden genomen. ${ }^{82}$

\subsubsection{Overeenkomsten en verschillen met waarheidsvinding in strafrechtelijke zin}

Om tot uitdrukking te brengen dat waarheidsvinding in strafrechtelijke zin een onhaalbaar en onwenselijk streven is binnen de jeugdbescherming is lang de boodschap uitgedragen dat 'niet aan waarheidsvinding wordt gedaan'. ${ }^{83}$ Iedere vorm van discussie over de wijze waarop onderzoek wordt gedaan in de jeugdbeschermingsketen wordt daarmee in de kiem gesmoord. Nog belangrijker is dat hiermee onbedoeld de suggestie is gewekt dat het verzamelen, selecteren en wegen van de verzamelde informatie minder zorgvuldig plaats zou kunnen vinden in vergelijking met bijvoorbeeld het strafrecht. Hiermee is ten onrechte een tegenstelling gecreëerd: in het strafrecht moet op basis van objectieve gegevens wettig en overtuigend bewezen worden dat de verdachte zich schuldig heeft gemaakt aan het tenlastegelegde, hetgeen wordt gezien als waarheidsvinding. In het jeugdbeschermingsrecht gaat het slechts om het concretiseren van zorgen rondom de ontwikkeling van de minderjarige, waardoor waarheidsvinding niet mogelijk zou zijn. Dit alles-of-niets standpunt doet geen recht aan de beperkingen omtrent het achterhalen van het werkelijk gebeurde die inherent zijn aan iedere gerechtelijke procedure. Tevens kan hierdoor de indruk worden gewekt dat, om te voldoen aan het streven naar waarheidsvinding, slechts nog objectiefverifieerbare informatie terug mag komen in jeugdbeschermingsrapportages. Dat is niet noodzakelijkerwijs het geval, hoewel het wenselijk lijkt te streven naar een oordeel op basis van informatie die zo veel mogelijk als feitelijk is aan te merken. Dit is waarschijnlijk wat

\footnotetext{
${ }^{80}$ De Kinderombudsman 2013, p. 23.

${ }^{81}$ Kamerstukken II 2013/14 31839 , nr. 347, p. 3.

${ }^{82}$ Kamerstukken II 2013/14 31 839, nr. 347, p. 5-6.

${ }^{83}$ Zie hierover Van Zanten \& Brenninkmeijer FJR 2011/76.
} 
toenmalig minister van der Steur bedoelt in zijn reactie op vragen vanuit de Tweede Kamer waarin hij spreekt over de noodzaak van 'een objectivering van het professionele niet-pluis gevoel van de medewerkers in het jeugdbeschermingsveld'. ${ }^{84}$ Het 'niet pluis gevoel' duidt op een onbestemd gevoel dat leidt zorgen over de ontwikkeling van de minderjarige zonder dat die zorgen ook direct hard kunnen worden gemaakt. Een 'niet-pluis gevoel' kan leiden tot vervolgonderzoek of het nadrukkelijk volgen van een gezin maar lijkt als concept problematisch te objectiveren. ${ }^{85}$ Wordt immers op basis van verifieerbare informatie het niet pluis gevoel bevestigd dan kan de situatie worden bestempeld als aantoonbaar 'niet pluis'. Hetzelfde geldt in omgekeerde zin indien het niet pluis gevoel op basis van nader onderzoek onterecht blijkt. Het voorgaande maakt duidelijk dat professionals in het jeugdbeschermingsveld niet kunnen volstaan met slechts een voorgevoel. De zorgen ten aanzien van de minderjarige dienen zo concreet mogelijk te worden onderbouwd aan de hand van de feiten en omstandigheden van het geval.

Het proces van waarheidsvinding moet er uiteindelijk toe leiden dat de besluitvorming zoveel mogelijk plaatsvindt op basis van vastgestelde feiten. Niet kan worden ontkend dat waarheidsvinding van oorsprong steviger is gepositioneerd in het strafrecht in vergelijking met het privaatrecht. In het strafrechtelijk onderzoek wordt gestreefd naar het achterhalen van de werkelijke toedracht van strafrechtelijk relevante handelingen. De rechter dient er vervolgens volledig van overtuigd te zijn dat het feitencomplex zoals geschetst door het Openbaar Ministerie correct is en de verdachte daarmee het strafbare feit waarvan hij wordt verdacht, ook daadwerkelijk heeft gepleegd. ${ }^{86}$ Ook al is het in de literatuur minder gebruikelijk waarheidsvinding als centrale doelstelling binnen het civiele recht aan te merken, het zou een misvatting zijn op basis daarvan te concluderen dat waarheidsvinding daarom niet van belang is. Zowel waarheidsvinding gericht op het resultaat (materieel) als waarheidsvinding als proces (processueel) neemt een centrale positie in binnen het civiele recht. ${ }^{87}$ Ook als in detail wordt gekeken naar verschillende aspecten binnen beide rechtsgebieden die samenhangen met de notie van waarheidsvinding zijn de verschillen minder groot dan ze wellicht op het eerste gezicht lijken.

\footnotetext{
${ }^{84}$ Kamerstukken II 2015/16, 31839, nr. 510.

${ }^{85}$ Hetgeen ook als zodanig wordt genoemd in het handboek Deltamethode Gezinsvoogdij waarin de werkwijze van de gezinsvoogd in het kader van een ondertoezichtstelling is uitgewerkt: Van Montfoort \& Slot 2008, p. 82. ${ }^{86}$ Corstens 2018, p. 6.

${ }^{87}$ Vgl. Giesen/Asser 2015, p. 83-98; De Bock 2011, p.69.
} 
Eerder is al genoemd dat het civiele recht uitgaat van een vrije bewijsleer. In het strafrecht moet de rechter op grond van wettige bewijsmiddelen tot de overtuiging komen dat de verdachte het ten laste gelegde feit heeft begaan, ook wel aangeduid als het negatief-wettelijk stelsel. De bewijsmiddelen die hebben te gelden als wettige bewijsmiddelen in het strafrecht zijn opgenomen in art. 339 lid $1 \mathrm{~Sv}$. Het feit dat de bewijsmiddelen in de wet zijn opgenomen beperkt de mogelijkheden van de strafrechter, in die zin dat zijn beslissing gebaseerd moet zijn op één/of meerdere wettige bewijsmiddelen. De civiele rechter is vrij in zijn waardering van het bewijs. Inhoudelijk gaat het in beide rechtsgebieden echter vrijwel altijd om dezelfde bewijsmiddelen: schriftelijke bescheiden, verklaringen van getuigen of deskundigen, verklaringen van betrokkenen en de eigen waarneming van de rechter.

Ten aanzien van de rol die de partijen en de rechter in het proces spelen valt ook het nodige op te merken. De rechter wordt in het Nederlandse strafproces beschouwd als een actieve rechter, hetgeen moet bijdragen aan een correcte vaststelling van de feiten. De civiele rechter is lijdelijk, zo volgt uit art. $24 \mathrm{Rv}$. Dit betekent dat de civiele rechter beslist op grondslag van hetgeen partijen aan hun verzoek ten gronde hebben gelegd. Het is echter maar de vraag of de kinderrechter in jeugdbeschermingszaken volledig als lijdelijk kan worden beschouwd. Zo is betoogd dat de lijdelijkheid van de rechter niet, althans minder zou moeten gelden in zaken waarin de rechtsgevolgen niet ter vrije beschikking van de partijen staan, zoals in het jeugdbeschermingsrecht. Koens verwoordt dat treffend en draagt nog enkele argumenten voor een actieve opstelling van de rechter in familiezaken:

'De familierechter heeft meer dan de civiele rechter mogelijkheden om door inschakeling van derden op zoek te gaan naar de materiële waarheid. Dit geldt met name in familiezaken over onderwerpen waarvan de rechtsgevolgen niet ter vrije beoordeling van partijen staan en de belangen van de kinderen in het geding zijn. ${ }^{88}$

Een actieve opstelling van de rechter in civiele zaken wordt in de eerste plaats gerechtvaardigd door de doelmatigheid. Indien de feiten in eerste aanleg niet volledig of niet correct aan de orde zijn gekomen is de kans groter dat betrokkenen in hoger beroep gaan of later nieuwe procedures starten. Daarnaast draagt een actieve rechter, die streeft naar materiële waarheidsvinding bij aan de kwaliteit van de rechtspraak. Een rechterlijke uitspraak die door de betrokkenen als juist wordt aanvaard kan een doelmatige uitvoering van de maatregel bevorderen.

\footnotetext{
${ }^{88}$ Koens, FJR 2006/49.
} 
Ook als wordt gekeken naar de positie van de procespartijen in de straf- en jeugdbeschermingsprocedure zijn duidelijke overeenkomsten zichtbaar. In strafzaken vervult het OM een spilfunctie. Het OM is verantwoordelijk voor het verzamelen van de feiten (de waardering van de feiten ligt uiteindelijk bij de strafrechter) en beslist het OM over mogelijke vervolging. De RvdK is in jeugdbeschermingszaken ook primair verantwoordelijk voor de feitenverzameling en beslist in de meeste gevallen over een verzoek aan de kinderrechter. De RvdK kan als onderdeel van het ministerie van Justitie en Veiligheid worden aangemerkt als bestuursorgaan en hoewel de besluitvorming zich afspeelt binnen het privaatrecht is hier primair sprake van een verticale verhouding tussen de procesdeelnemers De RvdK heeft als publiekrechtelijk orgaan vergaande onderzoeksbevoegdheden gekregen en werkt daarnaast met een gespecialiseerd (multidisciplinair) team van professionals aan jeugdbeschermingszaken. Het doel waarmee de feiten worden verzameld in beide rechtsgebieden is verschillend, maar duidelijk is dat het in beide gevallen gaat om professionele organisaties met vergaande onderzoeksbevoegdheden.

De formele bevoegdheden die ouders en kinderen toekomen - zeker in de fase voorafgaand aan een maatregel - steken daar schril bij af. Daarbij moet niet worden vergeten dat veel gezinnen en minderjarigen die met jeugdbescherming in aanraking komen kwetsbaar zijn en de grootst mogelijk moeite hebben om hun weg te vinden in gerechtelijke procedures. Eerder heeft Doek er al op gewezen dat het maar zeer de vraag is of minderjarigen die worden geconfronteerd met een ondertoezichtstelling weet hebben van de wettelijke bevoegdheden die hen toekomen. ${ }^{89}$ Een advocaat zou voor de ouders en de minderjarige een belangrijke rol kunnen vervullen waar het gaat om de informatievoorziening en uiteraard het kritisch analyseren van de rapportage. In de jeugdbeschermingsprocedure is echter niet voorzien in de ambtshalve toevoeging van een raadsman noch is er iets geregeld met betrekking tot het informeren van ouders over de mogelijkheid van rechtsbijstand. Relevant in dit verband is dat onderzoek naar rechtsbijstand voor ouders in jeugdbeschermingszaken heeft laten zien dat in het merendeel van de zaken helemaal geen advocaat ter zitting aanwezig is om de ouders/minderjarige te ondersteunen. ${ }^{90}$

Om het belang van waarheidsvinding in het jeugdbeschermingsrecht te benadrukken is op een aantal punten de vergelijking gemaakt met het strafrecht. Het is echter duidelijk dat het proces van waarheidsvinding niet op dezelfde wijze vorm kan krijgen in het jeugdbeschermingsrecht.

\footnotetext{
${ }^{89}$ Doek, FJR 2008/97.

${ }^{90}$ Hepping 2017.
} 
In jeugdbeschermingszaken worden de zorgen omtrent de minderjarige doorgaans geconcretiseerd aan de hand van de visie van de ouders, de minderjarige en informanten (zoals de leerkracht, reeds betrokken hulpverleners of de huisarts). Een dergelijke manier van informatieverzameling is inherent aan een systeem waarin wordt getracht in te grijpen in geval er een concrete dreiging van schade voor de ontwikkeling van de minderjarige zich aandient, maar er nog geen daadwerkelijke schade hoeft te zijn. Met andere woorden, de dreigende schade die wordt geconstateerd is niet (altijd) zodanig objectiveerbaar dat een vast punt kan worden bepaald wanneer ingrijpen noodzakelijk is. De vergelijking met het strafrecht heeft wel duidelijk gemaakt dat er goede argumenten zijn om ook in het jeugdbeschermingsrecht te streven naar zorgvuldig onderzoek en besluitvorming op basis van zoveel mogelijk feitelijke informatie. Evenals in het strafrecht is er in het jeugdbeschermingsrecht sprake van een 'zwakke partij' die tegenover een 'sterke partij' staat. Maar in het strafrecht is die zwakkere partij doorgaans wel beter beschermd tegen ongerechtvaardigd overheidsingrijpen.

\subsubsection{Het onderscheid tussen feiten en meningen}

Het door elkaar lopen van feiten en meningen in de rapportages van de RvdK en Bureau Jeugdzorg is waarschijnlijk het belangrijkste kritiekpunt dat naar voren is gekomen in de discussie over waarheidsvinding. ${ }^{91}$ Zo concludeerde de Kinderombudsman in 2013 na analyse van het feitenonderzoek in jeugdbeschermingszaken dat het aannemelijk was dat 'met enige regelmaat' fouten werden gemaakt tijdens het feitenonderzoek en in de rapportage. ${ }^{92}$ Op basis van indicatief dossieronderzoek werd gesteld dat feiten en meningen niet altijd duidelijk van elkaar waren te onderscheiden, bronvermeldingen soms onvolledig waren en conclusies niet altijd navolgbaar waren geformuleerd. ${ }^{93}$ De meeste klachten op dit vlak kwamen echter van de betrokken gezinnen. De zienswijze van betrokkenen dat de informatie die in het kader van onderzoek en rapportage in de jeugdbeschermingsketen werd verzameld niet correct en zorgvuldig werd verwerkt, keert vaker terug. ${ }^{94}$ Zo liet de klachtenanalyse van de RvdK over 2014 zien dat ongeveer de helft van de klachten waren gericht op de kwaliteit van het

\footnotetext{
${ }^{91}$ Kamerstukken II 2013/14 31 839, nr. 347.

${ }^{92}$ De Kinderombudsman 2013, p. 9 . Overigens is het oordeel ten aanzien van de rapportages opgesteld door de Raad voor de Kinderbescherming positiever dan de uiteindelijke conclusies doen vermoeden; De Kinderombudsman 2013, p. 75.

${ }^{93}$ De Kinderombudsman 2013, p. 1-2.

${ }^{94}$ Zie de cijfers over 2014 van de RvdK, aangehaald in: Kamerstukken II 2015/16 31 839, nr. 510.
} 
onderzoek en de rapportage. ${ }^{95}$ In de rapportages werd gebruikt gemaakt van vage formuleringen of voor de ouders en minderjarige moeilijk te begrijpen jargon. Hierdoor was een navolgbare weging van de feiten en omstandigheden die hadden geleid tot de beslissing voor de betrokkenen niet mogelijk. Ook werd aangedragen dat verouderde informatie in de rapportages bleef terugkomen en/of dat onduidelijk was uit welke bron de informatie was verkregen. ${ }^{96}$

De kritiek ten aanzien van het feitenonderzoek, meer specifiek het onderscheid tussen feiten en meningen in de rapportages, kwam niet alleen van betrokken ouders. De familiekamer van de Rechtbank Amsterdam heeft in 2013 in een brief aan de RvdK en Bureau Jeugdzorg laten weten in het vervolg strenger te gaan toetsen of de informatievoorziening in de rapportages deugdelijk is. ${ }^{97}$ In de brief werd onder meer gesteld:

'Bij een toegewezen verzoek (verlenging) ondertoezichtstelling en/of uithuisplaatsing is sprake van een aanzienlijke inbreuk op o.a. artikel 8 EVRM. Bij een dergelijke inbreuk past een volle toetsing van de verzoeken die namens de overheid worden ingediend. Eveneens past daarbij dat de kinderrechter alle betrokken partijen als gelijkwaardige procespartijen beschouwt waarbij de uitgangspunten van het civiele procesrecht ten volle van toepassing zijn. Dit betekent met name dat op de verzoekende partij een stelplicht en bij betwisting hiervan een plicht tot concrete onderbouwing rust.'

Voorts werd benadrukt dat stellingen die terugkwamen in het verzoek waar mogelijk moesten worden gestaafd met documenten of verslagen van betrokken instanties of ondervraagde informanten. ${ }^{98}$ Concrete voorbeelden zijn het bijvoegen van een verzuimoverzicht indien melding werd gemaakt van (ernstig) schoolverzuim door de minderjarige; een mutatieoverzicht van de politie indien sprake zou zijn politiecontacten en hulpverleningsverslagen waaruit zou kunnen blijken dat onvoldoende werd meegewerkt of resultaat was geboekt in het vrijwillig kader. ${ }^{99}$

Duidelijk is in ieder geval dat verzoeken voor zover mogelijk moeten worden voorzien van documenten/verslagen van betrokken personen en instanties. ${ }^{100}$ Impliciet wordt daarmee aangegeven dat ook de visie van betrokkenen ten aanzien van zorgen van belang kan zijn,

\footnotetext{
${ }^{95}$ Klachtenanalyse RvdK 2014.

${ }^{96}$ Zie Prinsen FJR 2012/86 en de reactie op deze bijdrage vanuit de RvdK: Cardol, Galama \& Kuipers FJR 2013/41.

${ }^{97}$ Aangehaald in: De Kinderombudsman 2013 p. 82.

${ }^{98}$ De Kinderombudsman 2013 p. 82.

${ }^{99}$ De Kinderombudsman 2013 p. 82.

${ }^{100}$ De Kinderombudsman 2013, p. 82.
} 
mits de zorgen voldoende concreet worden gemaakt. Een voorbeeld kan dit verduidelijken. Indien de RvdK concludeert dat er sprake is van problematische schoolgang van de minderjarige dan geeft een door school verstrekt verzuimoverzicht een objectief en concreet toetsbaar beeld van de situatie. Echter ook bij het ontbreken van een dergelijk overzicht kunnen de problemen rond de schoolgang van de minderjarige ook concreet worden gemaakt. Bijvoorbeeld doordat de leraar als informant wordt gehoord en zeer precies beschrijft welk gedrag de minderjarige op school vertoont. Het lijkt er dan met name om te gaan hoe de RvdK deze ingebrachte informatie beschrijft en weegt. Zijn de concrete zorgen van de leraar ook nog als zodanig herkenbaar of wordt zijn visie als vaststaand feit ingebracht? De verschillen op dit vlak lijken klein maar voor betrokkenen kan dit verschil betekenen tussen een stempel van alcoholist of een (niet bevestigd) vermoeden van alcoholmisbruik. Het includeren van de oorspronkelijke bron moet voorkomen dat er interpretatieverschillen ontstaan tussen het verzoek van de RvdK en de informatie die volgt uit de oorspronkelijke bron. ${ }^{101}$ Zonder die informatie is het namelijk voor ouders zeer moeilijk, zo niet onmogelijk om bepaalde stellingen van de RvdK (en overige ketenpartners) te betwisten.

Uit het voorgaande blijkt wel dat het correct interpreteren van de informatie die door betrokkenen is ingebracht een complex proces is dat met uiterste zorgvuldigheid dient te gebeuren. Tussen objectieve informatie (zoals een duidelijk gedocumenteerde diagnose) en evident subjectieve informatie (zoals een vaag vermoeden of een beschuldiging van de ene ouder richting de andere ouder) zit veel informatie waarvan het maar de vraag is of die als feitelijk kan worden aangemerkt. Voor het dossieronderzoek in deel II van deze studie is het noodzakelijk dat eerst een beoordeling plaatsvindt van de ingebrachte informatie. Zonder een duidelijk onderscheid tussen feitelijke informatie en de mening van betrokkenen kan immers ook niet bepaald worden of de informatie correct is geïnterpreteerd door de RvdK. Voor het dossieronderzoek in deel II van dit onderzoek zijn de volgende uitgangspunten geformuleerd: informatie is als feitelijk aangemerkt indien de informatie is gebaseerd op objectieve gegevens (documentatie zoals een persoonlijkheidsonderzoek of een proces-verbaal); de RvdK zelf een bepaalde situatie heeft vast kunnen stellen (bijvoorbeeld drankmisbruik van ouders tijdens een huisbezoek) of wanneer vermoedens of zorgen tijdens het onderzoek door alle betrokkenen worden bevestigd zonder dat er direct zwart op wit bewijs van is (bijvoorbeeld ouders geven toe de minderjarige fysiek te hebben gestraft). Kenmerkend onderscheid daarbij is dat informatie die als feitelijk wordt aangemerkt op basis van de

\footnotetext{
${ }^{101}$ De Kinderombudsman 2013, p . 82.
} 
gegevens onweerlegbaar en overtuigend kan worden vastgesteld. Alle informatie waar dat niet voor geldt, hoe sterk de aanwijzingen ook zijn, dienen bij voorkeur als mening of vermoeden terug te komen in de rapportages.

\subsection{Het beschermingsonderzoek door de Raad voor de Kinderbescherming}

In deze paragraaf worden de belangrijkste regels met betrekking tot de inhoud en uitvoering van het beschermingsonderzoek zoals die golden in de jaren 2013 en 2014 beschreven. In deze jaren lag het initiatief tot het opstarten van een beschermingsonderzoek bij Bureau Jeugdzorg (BJZ). In beginsel nam de RvdK slechts zaken in onderzoek na melding van BJZ dat een beschermingsonderzoek diende te worden overwogen (art. 57 Uitvoeringsbesluit Wet op de Jeugdzorg). Een uitzondering gold met het oog op de bescherming van de minderjarige in zaken waarin er sprake was van een acute en ernstige dreiging (art. 57 lid 2 sub a Uitvoeringsbesluit Wet op de Jeugdzorg) of wanneer de RvdK in het kader van enige andere wettelijke taak - bijvoorbeeld de advisering inzake gezag en omgang - tot het oordeel kwam dat een jeugdbeschermingsmaatregel moest worden overwogen. In die gevallen kon de RvdK ambtshalve een zaak in onderzoek nemen. Het was in het licht van het voorgaande belangrijk dat tussen de RvdK en BJZ heldere afspraken werden gemaakt over de samenwerking en overdracht van gegevens. Onderzoek van de Inspectie Jeugdzorg uitgevoerd in 2010 liet op dit punt geen rooskleurig beeld zien. De Inspectie Jeugdzorg kwam tot de conclusie dat de zorgvuldigheid waarmee de RvdK en BJZ besluiten namen omtrent de noodzaak van een beschermingsonderzoek onvoldoende was, met name door de wisselende kwaliteit van de meldingen van BJZ. ${ }^{102}$ Een vervolgonderzoek van de Inspectie Jeugdzorg in 2012 liet duidelijke verbeteringen zien ten aanzien van de kwaliteit van de meldingen door BJZ. ${ }^{103}$ De samenwerking tussen de RvdK en BJZ bij de beoordeling van de noodzaak van een beschermingsonderzoek kreeg doorgaans vorm in het casusoverleg bescherming. In dit overleg bespraken de ketenpartners de beschikbare informatie over het gezin. Het besluit om een beschermingsonderzoek te starten werd genomen door de raadsmedewerker die betrokken was bij het casusoverleg. ${ }^{104}$ Een besluit om geen beschermingsonderzoek te starten diende door minimaal twee raadsmedewerkers te worden genomen. ${ }^{105}$ Het verschil tussen het besluit

\footnotetext{
102 Inspectie Jeugdzorg 2010, p. 3-4.

${ }^{103}$ Inspectie Jeugdzorg 2012, p. 7-10.

${ }^{104}$ Protocol Beschermingstaken RvdK 2013, par. 2.1.2.

105 Protocol Beschermingstaken RvdK 2013, p. 12.
} 
een onderzoek te starten (kennelijk door één raadsmedewerker) en het besluit geen onderzoek te starten (minimaal twee raadsmedewerkers) werd in de interne regeling van de Rvdk niet verder verklaard. In het casusoverleg bescherming diende de RvdK zich er tevens van te vergewissen dat er afspraken waren gemaakt over de continuering van de hulpverlening tijdens het beschermingsonderzoek en de wijze waarop de veiligheid van het kind tijdens het onderzoek was geborgd. ${ }^{106}$

\subsubsection{Procedure beschermingsonderzoek}

De wijze waarop de RvdK zijn onderzoeken inhoudelijk moest vormgeven was grotendeels neergelegd in het Kwaliteitskader 2013 en het Protocol Beschermingstaken 2013. Op basis van beide regelingen worden de belangrijkste uitgangspunten en specifieke kwaliteitseisen voor de uitvoering van beschermingsonderzoeken in 2013 en 2014 beschreven.

Volgens het Kwaliteitskader 2013 gold als algemeen uitgangspunt voor het onderzoek en de rapportage dat deze gericht waren op het beschrijven, analyseren en beoordelen van de geconstateerde problematiek in relatie tot het toekomstperspectief van het kind. ${ }^{107} \mathrm{Om}$ aan dit uitgangspunt te voldoen waren er verschillende elementen die tenminste in het beschermingsonderzoek aan de orde moesten komen: de ernst van de bedreiging van de minderjarige(n) (niet alleen de directe aanleiding of symptomen maar ook de onderliggende problematiek); zorgpunten en sterke punten in de ontwikkeling van de minderjarige(n) en aandacht voor de ontwikkelingsfase; zorgpunten en sterke punten van het persoonlijk functioneren van de ouder(s) en/of verzorger(s) en van de minderjarige(n), opvoedingsomgeving, aandacht voor basale zorg en veiligheid, opvoedershandelen en perspectieven: wat is nodig om te zorgen dat het kind veilig op kan groeien; ten aanzien van de hulpverlening: de mogelijkheden van ouder(s)/verzorger(s)/minderjarige(n) om de nodige hulp te accepteren en te benutten met daarbij aandacht voor de eventuele hulpverleningsgeschiedenis (inclusief de eventueel behaalde resultaten) en de toekomstverwachtingen; opvragen van justitiële documentatie, als het kind in een netwerkgezin verbleef (tenzij het netwerkgezin al in bezit was van een 'Verklaring van geen bezwaar'). ${ }^{108}$ De weergegeven elementen vormden tevens het raamwerk voor de

\footnotetext{
106 Protocol Beschermingstaken RvdK 2013, p. 12.

${ }^{107}$ Kwaliteitskader RvdK 2013, p. 13.

${ }^{108}$ Protocol Beschermingstaken RvdK 2013, par. 2.2.
} 
standaardmethodiek en het bijbehorende rapportageformat voor de schriftelijke uitwerking van de resultaten van het onderzoek.

\section{Uitvoering van het beschermingsonderzoek}

Het beschermingsonderzoek werd in de regel verricht door een medewerker van de RvdK, werkzaam binnen het arrondissement waar de minderjarige woonde dan wel verbleef (art. 1:239 lid 2 BW). ${ }^{109}$ Het Kwaliteitskader 2013 gaf blijk van het multidisciplinaire karakter van de besluitvorming in jeugdbeschermingszaken. In het zogenoemde 'multidisciplinair overleg' (doorgaans de betrokken raadsmedewerker en een gedragsdeskundige) werd aan het begin van het onderzoek op basis van de melding en het verzoek tot onderzoek en eventueel andere bijgevoegde stukken, een onderzoeksplan vastgesteld. ${ }^{110}$ Tevens was het ook mogelijk om in iedere fase van het proces een juridisch deskundige in te schakelen. In enkele specifieke situaties was het noodzakelijk om binnen het beschermingsonderzoek een juridisch deskundige in te schakelen: in een beschermingszaak bij het voornemen van een verzoek tot ondertoezichtstelling en/of een uithuisplaatsing op tegenspraak, een ontheffing of ontzetting van het gezag, een voorlopige maatregel (voorlopige ondertoezichtstelling of voorlopige voogdij), of het voornemen tot verlenging van een ondertoezichtstelling en/of uithuisplaatsing in het kader van de toetsende taak van de $\mathrm{RvdK} .{ }^{111} \mathrm{Bij}$ aanvang van het onderzoek ontvingen de ouders/verzorgers een brochure met informatie die op de betreffende categorie van onderzoek van toepassing was. ${ }^{112}$ Daarnaast mocht worden verwacht dat tijdens het eerste contact met ouders en kind nadere uitleg werd gegeven over de aanleiding, het doel, de opzet en de verwachte termijn van het onderzoek. ${ }^{113}$

\section{Het horen van kind en ouder}

Uitgangspunt op basis van het door de RvdK vastgestelde Kwaliteitskader 2013 was dat gedurende het onderzoek altijd een gesprek met de ouders plaatsvond. Mocht dit om wat voor reden dan ook niet mogelijk zijn, dan behoorde in het beschermingsrapport gemotiveerd te worden welke reden hieraan ten grondslag lag. ${ }^{114}$ De RvdK verstond in dit verband onder 'ouder', de juridische ouder met of zonder gezag en de biologische ouder met family life. Derhalve leek de RvdK waar het ging om het horen van de ouder tijdens het

\footnotetext{
${ }^{109}$ Art. 1:239 lid 2 BW sprak van 'de werkeenheden' van de RvdK binnen het arrondissement waar de minderjarige zijn woonplaats had of werkelijk verbleef. Zie tevens Kwaliteitskader RvdK 2013, par. 3.2.1.

${ }^{110}$ Protocol Beschermingstaken RvdK 2013, par. 2.2.

${ }^{111}$ Kwaliteitskader RvdK 2013, p.15.

112 Kwaliteitskader RvdK 2013, p. 16.

${ }^{113}$ Kwaliteitskader RvdK 2013, p. 16.

${ }^{114}$ Kwaliteitskader RvdK 2013, p. 17.
} 
beschermingsonderzoek zich niet te beperken tot de ouder die in de verzoekschriftprocedure als belanghebbende kon worden aangemerkt. ${ }^{115}$ Het betrekken van de ouder kon door de RvdK wel achterwege worden gelaten indien er al geruime tijd geen contact meer was tussen het kind en de (niet-verzorgende) ouder. ${ }^{116}$ Tevens konden andere personen die als verzorger of opvoeder optraden (zoals pleegouders, verzorgende stiefouders) in het onderzoek worden betrokken. Het hing van de categorie onderzoek af of andere personen (konden) worden betrokken. ${ }^{117}$

De RvdK had in beginsel ook altijd contact met het kind tijdens het beschermingsonderzoek. Tijdens het eerste contact werd een jongerenbrochure overhandigd met daarin informatie over de procedurele aspecten van het beschermingsonderzoek en over de aard en inhoud van de eventueel te verzoeken maatregel. Uitgangspunt was dat in ieder beschermingsonderzoek een gesprek plaatsvond met het kind. ${ }^{118}$ Indien het niet mogelijk bleek het kind vanwege zijn leeftijd en/of ontwikkelingsniveau te spreken binnen het onderzoek, dan diende het kind tenminste door de raadsmedewerker te worden geobserveerd. ${ }^{119}$ Bleek ook dit niet mogelijk dan werd in het beschermingsrapport gemotiveerd weergegeven waarom het horen/observeren binnen het onderzoek niet had plaatsgevonden. ${ }^{120}$ De betreffende reglementen van de RvdK kwamen daarmee op royale wijze tegemoet aan het recht van het kind om te worden gehoord in alle fasen van de procedure. ${ }^{121}$

Het horen van ieder kind door de RvdK was om verschillende redenen cruciaal in de procedure tot oplegging van een jeugdbeschermingsmaatregel. In de eerste plaats vond het horen van het kind doorgaans thuis plaats of op de betrokken locatie van de RvdK. Dat gaf de mogelijkheid om het kind in een informele en meestal vertrouwde omgeving te spreken. ${ }^{122}$ Daarnaast mocht er van worden uitgegaan dat de raadsmedewerker veel meer tijd had en nam om het kind te horen in vergelijking met het vaak korte kindgesprek, tussen het kind en de kinderrechter voorafgaand aan de zitting. Het gesprek tussen de raadsmedewerker en het kind bood aan het kind dus in principe meer mogelijkheden zijn mening vrijelijk te uiten. Voor de

\footnotetext{
115 De Hoge Raad beschouwde als belanghebbende in de jeugdbeschermingsprocedure in beginsel slechts de ouder met gezag; Zie HR 12 september 2014, ECLI:NL:HR:2014:2665, r.o. 3.3.6. (conclusie A-G F.F. Langemeijer), en de toelichting hieromtrent in paragraaf 3.3.

${ }^{116}$ Kwaliteitskader RvdK 2013, p. 17.

${ }^{117}$ Kwaliteitskader RvdK 2013, p. 17.

${ }^{118}$ Kwaliteitskader RvdK 2013, p. 16.

${ }^{119}$ Kwaliteitskader RvdK 2013, p. 16.

${ }^{120}$ Kwaliteitskader RvdK 2013, p. 16.

${ }^{121} \mathrm{Zie}$ voor een verdere toelichting omtrent het (belang) van het hoorrecht voor minderjarigen paragraaf 3.4.

${ }^{122} \mathrm{Vgl}$. voor de invloed van de setting op de mogelijkheden tot participatie van de minderjarige: Rap 2013.
} 
kinderrechter gaf het tevens de mogelijkheid om middels de rapportage kennis te nemen van de (uitgebreide) mening van het kind, ervan uitgaande dat zijn mening werd weergegeven in het beschermingsrapport. Dit gold in het bijzonder voor kinderen onder de twaalf jaar aangezien zij in de regel niet bij de kinderrechter kwamen om te worden gehoord.

\section{Het benaderen van informanten}

Aan het begin van het beschermingsonderzoek werd in het eerdergenoemde multidisciplinair overleg besloten of, en zo ja welke, informanten zouden worden benaderd. Het benaderen van informanten had tot doel om een volledig beeld te krijgen van de veronderstelde bedreigde ontwikkeling van de minderjarige. In de meeste gevallen was het noodzakelijk om naast de informatie van kind en ouders nog verdere informatie in te winnen bij de betrokken professionals. Welke professionals werden benaderd hing in overwegende mate af van de aard en inhoud van de melding ten aanzien van het kind (gedacht kan worden aan de leerkracht van het kind, de huisarts, het kinderdagverblijf of de wijkagent).

In de onderzoeksperiode werd in de regel vooraf aan de ouders meegedeeld bij welke personen of instanties de RvdK informatie wilde inwinnen en werd gevraagd hier een toestemmingsverklaring voor te tekenen. ${ }^{123}$ De ouders konden evenwel ook aangeven niet in te stemmen met het benaderen van een of meerdere informanten. In dat geval kon de RvdK toch besluiten de informant te benaderen indien het voor het onderzoek noodzakelijk werd geacht. In het rapport moest dan wel worden aangegeven waarom de specifieke informant ondanks het ontbreken van toestemming van de ouders was benaderd. Ook de informant zelf moest op de hoogte worden gebracht van het ontbreken van de toestemming. ${ }^{124}$ De ouders of het kind konden ook zelf een verzoek bij de RvdK neerleggen om een bepaalde informant te horen. ${ }^{125}$ De weergave van de verstrekte informatie in het rapport moest door de informant worden geaccordeerd, zo volgde uit het Kwaliteitskader 2013. ${ }^{126}$ Het accorderen van de informatie was belangrijk omdat hiermee ieder geval werd bevestigd dat (externe) informanten akkoord waren met de informatie die zij tijdens het onderzoek hadden verstrekt. Dit kon worden bestempeld als een belangrijke kwaliteitswaarborg. Hier kon immers mee worden voorkomen dat de visie of van de informant naar zijn inzicht onjuist of onvolledig in het rapport werd opgenomen.

\footnotetext{
${ }^{123}$ Kwaliteitskader RvdK 2013, p. 17.

${ }^{124}$ Kwaliteitskader RvdK 2013, p. 17.

${ }^{125}$ Kwaliteitskader RvdK 2013, p. 17.

${ }^{126}$ Kwaliteitskader RvdK 2013, p. 17.
} 


\section{Inzage en adviesgesprek}

Blijkens het Kwaliteitskader van de RvdK werd ieder beschermingsonderzoek afgesloten met een gesprek met kind en ouders over het voorgenomen raadsbesluit, dan wel met een gesprek waarin inzage werd gegeven in de conceptrapportage. ${ }^{127}$ Op basis van het Kwaliteitskader 2013 mocht dus worden verwacht dat het kind en de ouders - indien mogelijk - tenminste twee keer werden gezien en gesproken door de raadsmedewerker. Het afsluitende gesprek was bij uitstek het geschikte moment om het kind uit te leggen in hoeverre zijn mening bij de besluitvorming was betrokken. ${ }^{128} \mathrm{Nu}$ het dossieronderzoek in deel II van dit onderzoek ziet op de feitelijke rechtvaardiging voor de beslissing tot ingrijpen in het gezinsleven, zijn alleen zaken geanalyseerd waarin het raadsbesluit luidde dat een beschermingsmaatregel noodzakelijk was. De uitkomst van het beschermingsonderzoek kon uiteraard ook zijn dat geen jeugdbeschermingsmaatregel werd verzocht. De zaak werd dan in de regel terugverwezen naar de vrijwillige hulpverlening. Gedurende het beschermingsonderzoek van de RvdK waren er dus tenminste twee (formele) toetsingsmomenten waar kon worden bepaald dat gedwongen hulpverlening niet noodzakelijk was: bij aanvang (het besluit om de zaak wel of niet in onderzoek te nemen) en na afronding van het beschermingonderzoek.

De ouders of verzorgers ontvingen de conceptrapportage ter inzage, evenals de minderjarige van zestien jaar en ouder, tenzij het belang van de minderjarige zich hiertegen verzette. ${ }^{129}$ De minderjarige in de leeftijd tussen twaalf en zestien jaar kreeg minimaal zijn gedeelte (kinddeel) van de conceptrapportage toegestuurd, tenzij diens belang zich hiertegen verzette. Het kinddeel bevatte een weergave van het gesprek tussen de raadsonderzoeker en de minderjarige, maar verder geen informatie over de inhoudelijke onderzoeksafwegingen. Voor de minderjarige onder de twaalf jaar was het niet direct duidelijk of hij werd uitgenodigd voor een adviesgesprek. Het Kwaliteitskader 2013 noemde geen leeftijdgrens, al lijkt het voor de hand te liggen dat in de praktijk werd aangesloten bij de wettelijke leeftijdsgrens van twaalf jaar voor het hoorrecht in de gerechtelijke procedure (art. $809 \mathrm{Rv}$ ). Duidelijk is wel dat de minderjarige onder de twaalf jaar niet de conceptrapportage ontving ter inzage. Een dergelijke algemene beperking van het inzagerecht voor minderjarigen onder de twaalf was volgens de wetgever in overeenstemming met art. $811 \mathrm{Rv} .{ }^{130}$ De ouders, en het kind van twaalf jaar en ouder kregen de mogelijkheid mondeling dan wel schriftelijk op het conceptrapport te

\footnotetext{
${ }^{127}$ Kwaliteitskader RvdK 2013, p. 19

${ }^{128}$ Kwaliteitskader RvdK 2013, p. 19.

${ }^{129}$ Kwaliteitskader RvdK 2013, p. 19.

${ }^{130}$ Kamerstukken II 1992/93, 22 487, nr. 6, p. 18.
} 
reageren. ${ }^{131}$ De inzagetermijn van het conceptrapport was in principe vijf werkdagen. Binnen deze termijn konden de ouders of het kind reageren op de informatie in het beschermingsrapport. De reactie en de eventueel aan de hand de reactie doorgevoerde wijzigingen moesten in het definitieve beschermingsrapport worden opgenomen. ${ }^{132}$

\subsubsection{Inhoudelijke eisen beschermingsrapportage}

Het definitieve beschermingsrapport zoals opgesteld in de jaren 2013 en 2104 bevatte een systematische weergave van de onderzoeksgegevens ter onderbouwing van het besluit dat was genomen. ${ }^{133}$ Inhoudelijk golden ten aanzien van de beschermingsrapportage een aantal algemene uitgangspunten en specifieke criteria. Uitgangspunt was dat de rapportage in beginsel werd opgesteld aan de hand van het landelijk vastgestelde rapportageformat van de betreffende categorie onderzoek. ${ }^{134}$ Het rapport diende in correct en begrijpelijk Nederlands te zijn opgesteld en er diende een duidelijk onderscheid gemaakt te worden tussen feiten en visies van betrokkenen enerzijds en de interpretatie daarvan door de RvdK anderzijds. ${ }^{135}$ Het Kwaliteitskader 2013 gaf verder geen aanwijzingen ten aanzien van de vraag hoe de beoordeling van de aangedragen informatie moest plaatsvinden. Wel maakte het duidelijk dat de rapportage in twee delen werd gesplitst: een deel waarin alle informatie werd weergegeven en een deel waarin de interpretatie van die gegevens plaatsvond door de RvdK.

\footnotetext{
${ }^{131}$ Kwaliteitskader RvdK 2013, p. 19.

132 Kwaliteitskader RvdK 2013, p. 19.

${ }^{133}$ Kwaliteitskader RvdK 2013, p. 20.

${ }^{134}$ Kwaliteitskader RvdK 2013, p. 20.

${ }^{135}$ Kwaliteitskader RvdK 2013, p. 20.
} 
Figuur 1. Voorbeeld gehanteerde rapportageformat beschermingsonderzoek RvdK in 2013/2014

\section{Informatie}

Toelichting besluit om onderzoek te starten.

\section{Onderzoeksvraag}

Is er sprake van een zodanig bedreigde ontwikkeling van de minderjarige dat een kinderbeschermingsmaatregel noodzakelijk is?

\section{Werkwijze}

De Raad analyseert de beschikbare informatie en maakt op grond daarvan een onderzoeksplan. Onder punt 3 worden de namen van betrokken raadsonderzoeker, teamleider en eventueel betrokken gedragsdeskundige/juridisch deskundige genoemd.

\section{Samenvatting van de beschikbare informatie}

\section{Gezinssamenstelling}

Informatie afkomstig uit de melding.

Ontwikkeling minderjarige

Informatie afkomstig uit de melding.

\section{Opvoedingsomgeving}

Informatie afkomstig uit de melding

\section{Hulpverlening}

Samenvatting van eerder ingezette hulpverlening. Informatie over eerdere onderzoeken door de RvdK en/of het openbaar ministerie. Informatie over eerder opgelegde sancties of beschermingsmaatregelen.

\section{Onderzoeksplan}

Op grond van de beschikbare informatie besluit de Raad onderzoek te doen naar de volgende aandachtsgebieden:

- Ontwikkeling kind.

- Opvoedingsomgeving/-context.

- Hulpverlening

\section{Contacten}

Overzicht van alle contacten tijdens het onderzoek

\section{Relevante factoren tijdens het verloop van het onderzoek}

Hier worden opvallende en belangrijke factoren die tijdens de uitvoering van het onderzoek hebben plaatsgevonden genoemd. Bijvoorbeeld de wijze waarop ouders hebben meegewerkt aan het onderzoek, de opstelling van de minderjarige, het functioneren van de ouders en minderjarige. Ev. veroordelingen of andere procedures.

\section{Informatie uit onderzoek}

Inhoudelijk is dit de kern van het onderzoek. Op systematische wijze wordt de informatie verkregen van kind, ouders en informanten uitgewerkt ten aanzien van de onderwerpen: ontwikkeling kind, opvoedingsomgeving en hulpverlening.

\section{Akkoordverklaring informanten}

Accordering ingebrachte informatie. 


\section{Beantwoording onderzoeksvraag}

Om deze vraag te kunnen beantwoorden maakt de Raad de volgende afwegingen:

1. Wat zijn de zorgpunten en sterke punten in de ontwikkeling van de minderjarige en wat heeft hij nodig naast de basale zorg en veiligheid?

2. Wat zijn de zorgpunten en sterke punten in de opvoedingsomgeving / -context en in hoeverre komt deze tegemoet aan wat de minderjarige nodig heeft?

3. Welke doelen moeten behaald worden om de ontwikkelingsperspectieven van de minderjarige veilig te stellen?

4. Welke hulp is nodig en wat zijn de mogelijkheden om de noodzakelijke hulpverlening te accepteren en te benutten?

Bovenstaande afwegingen leiden tot de volgende beantwoording van de onderzoeksvraag:

Is er sprake van een zodanig bedreigde ontwikkeling van de minderjarige dat een kinderbeschermingsmaatregel noodzakelijk is?

\section{Raadsbesluit}

Formele besluit van de RvdK.

\section{Belanghebbenden}

Overzicht van alle belanghebbenden.

\section{Inzage}

Overzicht van inzage door ouders en eventueel minderjarige.

\section{Reactie op het verzoek en rapport}

Reactie van de ouders/minderjarige op het verzoek en rapport.

\section{Ondertekening}

\section{Bijlage(n)}

\section{Inhoudelijke vereisten beschermingsrapportage}

Naast de algemene uitgangspunten ten aanzien van de rapportage waren in het

Kwaliteitskader 2013 diverse inhoudelijke eisen gesteld. Voor een deel ging het dan om achtergrondinformatie die relevant was ter identificatie van de betrokken partijen en de specifieke rol die deze partijen innamen binnen de procedure (verzoeker, belanghebbende, informant). Zo diende ieder beschermingsrapport de relevante gegevens te bevatten van het kind en de ouders, zoals (voor)namen, adres of verblijfplaats, de feitelijke gezags- en omgangssituatie en de gezinssamenstelling. ${ }^{136}$ (onder punt 4 - rapportageformat). Daarnaast

\footnotetext{
${ }^{136}$ Kwaliteitskader RvdK 2013, p. 20.
} 
moest in het rapport aandacht worden besteed aan de melding/melder en de aanleiding voor het onderzoek en eventuele factoren en omstandigheden die het onderzoek beïnvloed konden hebben. ${ }^{137}$ (onder punt 7 - rapportageformat). Een onderzoek kon om verschillende redenen bijvoorbeeld langer hebben geduurd dan de landelijk vastgestelde onderzoekstermijnen. Ook kwam het voor dat tijdens het onderzoek er geen mogelijkheid was om de betrokken ouder(s) of verzorger(s) te spreken. ${ }^{138}$ Indien het beschermingsonderzoek voortkwam uit een onderzoek van de RvdK ter advisering inzake gezag en omgang dan werd dit ook hier vermeld in het rapport.

Uiteindelijk vormde het onderzoek naar de minderjarige en zijn opvoedingsomgeving de kern van het beschermingsonderzoek (onder punt 8 - rapportageformat). Ten aanzien van de minderjarige en zijn opvoedingsomgeving dienden in ieder geval alle relevante feiten en omstandigheden te worden beschreven die hadden geleid tot de beantwoording van de onderzoeksvragen. ${ }^{139}$ Het rapportageformat inzake bescherming kende een heldere structuur waarin doorgaans een weergave was te vinden van de gesprekken met het kind, de ouders/verzorgers en eventuele informanten. De gesprekken richtten zich op drie hoofdthema's: de ontwikkeling van de minderjarige, de opvoedingsomgeving en de wijze waarop de hulpverlening was verlopen, of moest gaan verlopen ingeval nog geen hulpverlening bij het gezin was betrokken. ${ }^{140}$ Bovenal moest het onderzoek zo concreet mogelijk in beeld brengen in hoeverre er sprake was van een concrete bedreiging van de zedelijke of geestelijke belangen of gezondheid van de minderjarige. De RvdK gebruikte voor deze aan de wet ontleende formulering de overkoepelende term 'ontwikkelingsbedreiging'.

De bedreiging van de belangen van de minderjarige kreeg in het beschermingsrapport inhoudelijk invulling aan de hand van zorgpunten die door de RvdK werden aangedragen. De RvdK maakte daarbij onderscheid tussen zorgpunten op kindniveau en zorgpunten op het niveau van de opvoedingsomgeving (ook wel ouderniveau). Zorgpunten op kindniveau betroffen zorgen ten aanzien van het functioneren van de minderjarige zelf, waarbij kon worden gedacht aan ontwikkelingsachterstanden, probleemgedragingen, stoornissen of

\footnotetext{
${ }^{137}$ Kwaliteitskader RvdK 2013, p. 20.

${ }^{138}$ De termijn voor het onderzoek ving aan op de dag waarop de aanvraag voor onderzoek of de melding was ontvangen en eindigde op de dag dat het definitieve rapport werd verstuurd. De op basis van het Kwaliteitskader 2013 gehanteerde normtijd voor een beschermingsonderzoek was 56 kalenderdagen. Uitgangspunt was dat $80 \%$ van de zaken binnen de gestelde normtijd werden gerealiseerd; Kwaliteitskader RvdK 2013, p. 36.

${ }^{139}$ Kwaliteitskader RvdK 2013, p. 21.

${ }^{140}$ Indien nog geen eerdere hulpverlening is geboden of de hulpverleningsgeschiedenis niet bekend is wordt geanticipeerd op hetgeen nodig lijkt in toekomst om de ontwikkeling van de minderjarige veilig te stellen.
} 
bijvoorbeeld bedreigingen vanuit de opvoedingsomgeving. ${ }^{141}$ Zorgpunten op het niveau van de opvoedingsomgeving betroffen het functioneren van het gezin, bijvoorbeeld problematisch gedrag tussen ouders onderling, individuele problemen op ouderniveau, zoals depressie of middelenmisbruik, of een inadequate opvoedingsstijl van de ouder jegens het kind.

Het voorgaande laat zien dat de term 'zorgpunt' een cruciaal begrip was in het beschermingsrapport van de RvdK. De informatie verzameld uit deze gesprekken en eventueel aanvullende informatie van externe deskundigen leidde tot de beantwoording van de onderzoeksvragen door de $\operatorname{RvdK}$ (onder punt 10 - rapportageformat). Op dit punt ging het dus om de interpretatie/weging van de onderzoeksgegevens door de RvdK. De raadsonderzoeker werd geacht de onderzoeksvragen volgens een vaste structuur te beantwoorden. In de eerste plaats de vraag welke zorgpunten en beschermende factoren op kindniveau waren gevonden; vervolgens een weergave van de zorgpunten en beschermde factoren in de opvoedingsomgeving. Beide elementen moesten leiden tot een conclusie ten aanzien van de vraag hoe de minderjarige op kindniveau functioneerde en in hoeverre de ouders/verzorgers voldoende tegemoet kwamen aan hetgeen het kind nodig had. Vervolgens werd de vraag beantwoord welke doelen moesten worden behaald om de ontwikkelingsperspectieven van de minderjarige veilig te stellen. De doelen werden gesteld aan de hand van de informatie verkregen ten aanzien van het functioneren van de minderjarige en zijn opvoedingsomgeving. Daarna werd de vraag beantwoord welke hulp nodig werd geacht en wat de mogelijkheden van kind en ouders/verzorgers waren om de noodzakelijke hulp te accepteren en te benutten. Het geheel van afwegingen volgend uit voorgaande vragen moest uiteindelijk leiden tot de beantwoording van de centrale onderzoeksvraag: is er sprake van een zodanig bedreigde ontwikkeling van de minderjarige dat een kinderbeschermingsmaatregel noodzakelijk is? Het raadsrapport werd afgesloten met het formele raadsbesluit en de eventuele reacties van de belanghebbenden hierop (onder punt 11-14-rapportageformat). Het formele raadsbesluit was tevens weergegeven op het verzoekschrift dat werd ingediend bij de rechtbank.

\footnotetext{
${ }^{141}$ Slot e.a 2002.
} 


\subsection{De verzoekschriftprocedure}

De procedure tot oplegging van een jeugdbeschermingsmaatregel was en is evenals alle andere familierechtelijke procedures een verzoekschriftprocedure. In dit onderzoek wordt gekeken naar zaken waarin het verzoek tot ondertoezichtstelling/machtiging uithuisplaatsing werd ingediend door de RvdK, hoewel ook anderen volgens het geldende recht in 2013 en 2014 bevoegd waren een dergelijk verzoek in te dienen. ${ }^{142}$ Het zojuist besproken rapport beschermingszaken vormde de onderbouwing van het verzoek tot oplegging van de maatregel en werd altijd bij het verzoekschrift gevoegd. Ook een eventuele afzonderlijke rapportage die was opgesteld door een externe deskundige werd als bijlage aan het beschermingsrapport toegevoegd en werd met het verzoekschrift meegezonden. ${ }^{143}$

\subsubsection{Indiening verzoekschrift}

Uitgangspunt was dat het verzoekschrift werd ingediend - althans werd ondertekend - door de advocaat van de verzoeker, tenzij indiening bij de kantonrechter plaatsvond of ingevolge een bijzondere wettelijke bepaling geen ondertekening door een advocaat noodzakelijk was (art. 278 lid $3 \mathrm{Rv}$ ). De RvdK hoefde zich voor de indiening van een verzoek tot jeugdbeschermingsmaatregel niet te laten vertegenwoordigen door een advocaat, op grond van art. 1:243 lid 4 BW. Dat gold eveneens voor Bureau Jeugdzorg indien zij een verzoek tot verlenging van de ondertoezichtstelling/machtiging uithuisplaatsing verzocht (art. 1:265 lid 4 oud BW). In het enkele geval dat het verzoek tot ondertoezichtstelling werd gedaan door de ouder of degene die de minderjarige behorende tot zijn gezin verzorgde en opvoedde, dan diende indiening van het verzoekschrift wel te geschieden door tussenkomst van een advocaat (art. 278 lid $3 \mathrm{Rv).} \mathrm{Voorgaande} \mathrm{impliceerde} \mathrm{echter} \mathrm{niet} \mathrm{dat} \mathrm{de} \mathrm{ouder} \mathrm{(in} \mathrm{zijn} \mathrm{hoedanigheid} \mathrm{als}$ verzoeker of belanghebbende) ambtshalve een advocaat kreeg toegevoegd in de procedure tot oplegging van een jeugdbeschermingsmaatregel.

Voor de situatie die van toepassing is op dit deel van het onderzoek, te weten indiening van het verzoekschrift door de RvdK en de ouder die gold als belanghebbende, betekende dit dat het zeer wel mogelijk was dat de ouder in rechte niet werd vertegenwoordigd door een advocaat. De vraag naar de wenselijkheid van een ambtshalve toevoeging van een advocaat aan procederende partijen, waaronder dus de ouders, werd laatstelijk besproken tijdens de

\footnotetext{
${ }^{142}$ Zie paragraaf 2.3.2.

${ }^{143}$ Kwaliteitskader RvdK 2013, p. 21.
} 
parlementaire behandeling van herziening van de ondertoezichtstelling in 1995. Toenmalig staatssecretaris Kosto zag echter geen aanleiding voor ambtshalve toevoeging van een advocaat aan de ouders vanwege het informele karakter van de rechtsgang. ${ }^{144}$ Iedere belanghebbende kon volgens hem tegen een vergoeding de bijstand van een advocaat inroepen. ${ }^{145}$

Uit de gehanteerde terminologie ten aanzien van de verzoekschriftprocedure kon worden afgeleid dat het verzoekschrift in beginsel schriftelijk moest worden ingediend. Voor het verzoek tot vervanging van het Bureau Jeugdzorg dat was belast met het toezicht over de minderjarige en verzoeken op grond van de artt. 1:256 - 1:264 oud BW (waaronder het verzoek machtiging uithuisplaatsing), gaf art. 1:265 lid 1 oud BW expliciet aan dat deze schriftelijk moesten worden ingediend. Opvallend genoeg was het verzoek tot ondertoezichtstelling op grond van art. 1:254 lid 4 oud BW hierbij niet was inbegrepen, hoewel in algemene zin werd aangenomen dat ook dit verzoek schriftelijk moest worden gedaan. ${ }^{146}$

Zulks was echter niet op te maken uit het in 2014 geldende Procesreglement Civiel Jeugdrecht (PCJ) op grond waarvan de vereisten voor verzoeken in jeugdbeschermingszaken nader waren gespecificeerd. Blijkens Bijlage A sub b PJC kon een verzoek tot ondertoezichtstelling (art. 1:254 lid 1 oud BW) zowel mondeling als schriftelijk worden ingediend. Voor verzoeken met een spoedeisend karakter op grond van art. 800 lid $3 \mathrm{Rv}$, te weten een verzoek tot voorlopige ondertoezichtstelling, vaak gecombineerd met een verzoek (spoed)machtiging uithuisplaatsing of een verzoek tot voorlopige voogdij, gold dat de beschikking alleen aanstonds werd gegeven indien de behandeling niet kon worden afgewacht zonder onmiddellijk en ernstig gevaar voor de minderjarige. In art. 2.7 PJC werd dit expliciet bevestigd: dergelijke crisisverzoeken dienden binnen openingstijden van de griffie schriftelijk te worden ingediend, tenzij er sprake was van een zeer spoedeisend geval. De conclusie moet dan zijn dat in deze categorie crisiszaken doorgaans sprake was van een dreigende- en spoedeisende situatie ten aanzien van de minderjarige nu in de praktijk zichtbaar was dat een

\footnotetext{
${ }^{144}$ Kamerstukken II 1992/93, 23 003, nr. 3 (MvT), p. 46-47.

145 Kamerstukken II 1992/93, 23 003, nr. 3 (MvT), p. 46-47.

${ }^{146}$ Forder, in: GS Personen- en familierecht, artikel 1:265 BW, aant. 2. (actueel tot 01-01-2015).
} 
dergelijk verzoek in de regel mondeling dan wel per fax werd gedaan. ${ }^{147}$ Wel behoorde ook in deze gevallen het verzoek onverwijld schriftelijk te worden bevestigd (art. 2.7 PCJ).

\subsubsection{Verzoekers ondertoezichtstelling}

Wie bevoegd waren tot het indienen van een verzoek tot ondertoezichtstelling werd bepaald in art. 1:254 lid 4 oud BW. De kinderrechter kon de minderjarige onder toezicht stellen op verzoek van een ouder, een ander die de minderjarige als behorende tot zijn gezin verzorgde en opvoedde, de RvdK of het Openbaar Ministerie. In de praktijk werden en worden bijna alle verzoeken tot ondertoezichtstelling door de RvdK ingediend. ${ }^{148}$ De Raad voor de Kinderbescherming is de aangewezen instantie om naar aanleiding van een zorgmelding onafhankelijk onderzoek te doen naar de noodzaak van een jeugdbeschermingsmaatregel.

Komt de RvdK na onderzoek naar de problematiek van het kind en het gezin tot de conclusie dat een ondertoezichtstelling noodzakelijk is, dan wordt een rekest ingediend.

Naast de RvdK was het Openbaar Ministerie bevoegd een verzoek tot ondertoezichtstelling in te dienen maar van deze bevoegdheid werd slechts zelden gebruik gemaakt. Gedacht kon worden aan gevallen waarin de minderjarige nog niet de leeftijd van twaalf jaar had bereikt en daarom nog niet strafrechtelijk kon worden vervolgd, of gevallen waarin het strafwaardige gedrag van de minderjarige overduidelijk een uitvloeisel was van onderliggende persoonlijke problematiek of gezinsproblematiek. Tijdens de parlementaire behandeling van de herziening van de ondertoezichtstelling in 1995 heeft de RvdK vragen gesteld over deze mogelijkheid nu er in de praktijk maar zelden gebruik van werd gemaakt. Daarnaast zou de officier van justitie, indien hij een ondertoezichtstelling nodig vond, de RvdK kunnen inschakelen. ${ }^{149}$ De staatssecretaris vond het echter van belang dat deze bevoegdheid voor de officier van justitie behouden bleef. Belangrijkste argument was dat in spoedeisende zaken het in het belang van de minderjarige noodzakelijk kon zijn zonder nader onderzoek van de RvdK een verzoek tot ondertoezichtstelling in te dienen. ${ }^{150}$ Dit standpunt is niet geheel overtuigend nu in spoedeisende gevallen ook via de RvdK snel kon worden gehandeld middels de procedure van

\footnotetext{
${ }^{147}$ Zie toelichting hieromtrent in: Bruning, Liefaard \& Vlaardingerbroek 2014, p. 391. Het feit dat deze verzoeken mondeling werden toegewezen liet zich rechtvaardigen door de acute en ernstige dreiging voor de minderjarige.

${ }^{148}$ Forder, in: GS Personen- en familierecht, 8.2 De Raad/het OM bij: Burgerlijk Wetboek Boek 1, Artikel 255 (Actueel tot 01-01-2015).

${ }^{149}$ Kamerstukken II 1992/93, 23 003, nr. 3 (MvT), p.15.

${ }^{150}$ Kamerstukken II 1992/93 23 003, nr. 4.
} 
de voorlopige ondertoezichtstelling. ${ }^{151}$ Dit werd ook naar voren gebracht door de VVD-fractie in de Tweede Kamer, die zich afvroeg of geen gebruik zou moeten worden gemaakt van de specifieke expertise van de RvdK. ${ }^{152}$ De staatssecretaris bleef echter van mening dat de officier van justitie feiten kon constateren waaruit bleek dat de ontwikkeling van de minderjarige ernstig werd bedreigd. Een tweede, aanvullend onderzoek door de RvdK werd in die situatie verondersteld geen meerwaarde te hebben en slechts tijdsverlies op te leveren. ${ }^{153}$

Ook een ouder was op grond van art. 1:254 lid 4 oud BW bevoegd tot het verzoeken van een ondertoezichtstelling. Ook indien de andere ouder zich niet kon verenigen met het verzoek tot ondertoezichtstelling kon de ouder zich wenden tot de kinderrechter. Onder ouder werd hier in ieder geval verstaan de juridisch ouder van de minderjarige. Louter een biologische band was onvoldoende om als ouder ontvankelijk te worden verklaard in het verzoek tot ondertoezichtstelling. Bijkomende omstandigheden die een nauwe persoonlijke betrekking tussen de biologische ouder en kind aannemelijk maakten konden wel leiden tot ontvankelijkheid. ${ }^{154}$ Overigens kon ook de niet-ouder die gezamenlijk met de ouder het gezag uitoefende een verzoek tot ondertoezichtstelling indienen.

Tot slot was een verzoek tot ondertoezichtstelling ook mogelijk door 'een ander' die de minderjarige als behorende tot zijn gezin verzorgde en opvoedde. Met 'een ander' werd hier in beginsel gedoeld op de bevoegdheid van pleegouders om zelf een verzoek tot ondertoezichtstelling in te dienen ten behoeve van het kind dat in hun gezin werd verzorgd en opgevoed. De wetgever heeft deze bevoegdheid in de wet geformaliseerd met de herziening van de ondertoezichtstelling in 1995, nadat de Hoge Raad in diverse zaken besliste dat pleegouders ten aanzien van wie gezinsleven in de zin van art. 8 EVRM kon worden aangenomen, het recht hadden zich met een verzoek tot ondertoezichtstelling tot de kinderrechter te wenden. ${ }^{155}$ De oude formulering die voornoemde bevoegdheid toekende aan 'bloed- of aanverwanten tot en met de vierde graad' was derhalve niet meer passend en werd vervangen door een formulering die beter aansloot bij de omschrijving van family life in art. 8 EVRM. ${ }^{156}$ Ten aanzien van de formulering 'een ander die de minderjarige als behorende tot zijn gezin verzorgde en opvoedde' werden een aantal uitgangspunten geformuleerd:

\footnotetext{
${ }^{151}$ Op grond van het toen geldende art. 1:257 oud BW, thans neergelegd in art. 1:255 BW.

152 Kamerstukken II 1992/93 23 003, nr. 4, p. 21.

${ }^{153}$ Kamerstukken II 1993/94 23 003, nr. 5, p. 13.

${ }^{154}$ Zie Gerechtshof 's-Gravenhage 2 december 2009, ECLI:NL:GHSGR:2009:BK8239, r.o. 6.

155 Zie o.a. HR 10 maart 1989, NJ 1990/24; HR 23 maart 1990, NJ 1991/149 en HR 23 maart 1990, NJ 1991/150, m.nt. E. Luijten.

${ }^{156}$ Wet van 26 april 1995, Stb 1995, 255.
} 
- Feitelijke verzorging en opvoeding als behorend tot het gezin verlangde meer dan het slechts hebben van family life in de zin van art. 8 EVRM

- De verzorging en opvoeding als bedoeld in het artikel vereiste geen bepaalde minimumperiode. De bevoegdheid kwam dus ook toe aan tijdelijke verzorgers en opvoeders van de minderjarige

- Met de omschrijving 'een ander' werd ieder ander bedoeld die voldeed aan de eis van feitelijke verzorging en opvoeding behorend tot het gezin

- Hoewel bij 'een ander' in de eerste plaats kon worden gedacht aan pleegouder(s) was het blijkens de formulering niet beperkt tot deze categorie. Ook kon worden gedacht aan degene die in het gezin van de met gezag belaste ouder samen met deze de minderjarige verzorgde en opvoedde. $^{157}$

De minderjarige was (en is) zelf niet bevoegd tot het indienen van een verzoek tot (verlenging) van een ondertoezichtstelling. De Nederlandse wet voorzag niet in een formele rechtsingang voor minderjarigen nu ouders op grond van art. 1:245 lid 4 BW de wettelijke vertegenwoordigers van de minderjarige in rechte zijn. In hoofdstuk 3 wordt uitgebreid aandacht besteed aan de processuele onbekwaamheid van de minderjarige in de jeugdbeschermingsprocedure.

\subsubsection{Verzoekers machtiging uithuisplaatsing}

Het verzoek tot machtiging uithuisplaatsing kon worden gedaan door Bureau Jeugdzorg, de Raad voor de Kinderbescherming en het Openbaar Ministerie (art. 1:261 lid 1 oud BW). In het geval het verzoek machtiging uithuisplaatsing gelijktijdig werd ingediend met het verzoek tot ondertoezichtstelling was het aannemelijk dat zulks werd gedaan door de RvdK. De RvdK kon gedurende het onderzoek naar de noodzaak van een ondertoezichtstelling tot de conclusie komen dat een uithuisplaatsing noodzakelijk was om de belangen van de minderjarige te waarborgen. Indien er sprake was van een lopende ondertoezichtstelling dan lag het voor de hand dat het verzoek werd ingediend door Bureau Jeugdzorg. De verantwoordelijke partij voor de uitvoering was in dit geval tevens de verzoeker van de maatregel. Gedurende de parlementaire behandeling die heeft geleid tot wijziging van de ondertoezichtstelling in 1995 is gediscussieerd over de vraag of het initiatief tot uithuisplaatsing wel bij Bureau Jeugdzorg

\footnotetext{
${ }^{157}$ Forder, in: GS Personen- en familierecht, 8.2 De Raad/het OM bij: Burgerlijk Wetboek Boek 1, Artikel 255 (actueel tot 01-01-2015).
} 
zou moeten liggen. De kern van de vraag was gelegen in het uitgangspunt dat een uithuisplaatsing als ernstige inbreuk op het gezinsleven heeft te gelden hetgeen een hoge mate van rechtsbescherming voor de betrokkenen rechtvaardigde. Volgens verschillende partijen zou het wenselijker zijn dat Bureau Jeugdzorg, indien zij een uithuisplaatsing noodzakelijk achtte, de RvdK verzocht het verzoek aan de kinderrechter voor te leggen. De toenmalige staatssecretaris zag echter geen meerwaarde in deze optie. In de eerste plaats omdat hij het voldoende vond dat de kinderrechter onafhankelijk kon beslissen over de noodzaak van een uithuisplaatsing. Daarnaast zou het niet passen binnen de voorgestelde gewijzigde organisatie van het systeem van jeugdbescherming waarin Bureau Jeugdzorg als verantwoordelijke partij voor de uitvoering zich zou kunnen verschuilen achter het besluit van de RvdK. ${ }^{158}$

\subsubsection{Inhoudelijke eisen verzoek- en verweerschrift}

Het verdere verloop van de gerechtelijke procedure liet zich onderscheiden in drie verschillende fasen: een schriftelijke ronde, de mondelinge behandeling gevolgd door de beschikking. ${ }^{159}$ De schriftelijke ronde werd aangevangen met de indiening van het verzoekschrift. Blijkens art. 278 lid 1 Rv gaf het verzoekschrift naast enkele algemene gegevens (zoals (voor)naam en woon/verblijfplaats verzoeker) een duidelijke omschrijving van het verzoek en de gronden waarop het berustte. Art. 799 lid 1 Rv voegde daar specifiek voor het verzoekschrift in familiezaken aan toe dat voor zover bekend, de naam en woonplaats van de belanghebbenden en informanten werden vermeld, evenals de bescheiden die konden dienen tot bewijs van de gestelde feiten (art. 799 lid $2 \mathrm{Rv}$ ). Op basis van voornoemde voorschriften mocht in ieder geval worden verwacht dat het verzoekschrift duidelijkheid verschafte ten aanzien van de vraag waarom een jeugdbeschermingsmaatregel noodzakelijk was. ${ }^{160}$ Het Procesreglement Civiel Jeugdrecht 2014 bevatte aanvullende gedetailleerde vereisten die golden voor het verzoek tot (verlenging) ondertoezichtstelling met of zonder machtiging uithuisplaatsing alsmede het verzoek tot machtiging uithuisplaatsing in een accommodatie voor gesloten jeugdzorg. ${ }^{161}$ Zo diende het verzoek tot verlenging van de

\footnotetext{
${ }^{158}$ Kamerstukken II 1993/94, 23 003, nr.5, p. 21.

${ }^{159}$ Coenraad 2015, p. 48.

${ }^{160} \mathrm{Vgl}$. de visie hieromtrent van Staatssecretaris Kosto bij het wetgevingsproces omtrent de herziening van de ondertoezichtstelling in 1995; Kamerstukken II 1992/92, 23003, nr. 3 (MvT), p. 11.

${ }^{161}$ Procesreglement Civiel Jeugdrecht 2014, p. 109 e.v.
} 
ondertoezichtstelling en machtiging uithuisplaatsing onder meer een verslag van het verloop van de ondertoezichtstelling en een plan van aanpak te bevatten. ${ }^{162}$

\section{Verweer}

De ouder of verzorger die in de procedure tot oplegging van een jeugdbeschermingsmaatregel als belanghebbende kon worden aangemerkt, kon tegen het ingediende verzoekschrift tot aanvang van de behandeling, of indien de rechter het toestond in de loop van de behandeling, een verweerschrift indienen (art. 282 lid $1 \mathrm{Rv}$ ). Dat gold overigens voor iedere belanghebbende, dus ook de belanghebbende die om wat voor reden dan ook niet was opgeroepen, mocht een verweerschrift indienen, mits hij werkelijk belang hierbij had. ${ }^{163}$ Het was evenwel niet verplicht voor de belanghebbende een verweerschrift in te dienen, er kon ook tijdens de behandeling mondeling verweer worden gevoerd. Indien de verzoeker hierdoor mogelijkerwijs in zijn belangen werd geschaad - hetgeen niet direct voor de hand lag met de RvdK als verzoeker - dan lag het voor de hand dat de rechter in deze gevallen de zitting aanhield. Ten aanzien van de inhoud, wijze van ondertekening en moment en wijze van indiening van het verweerschrift, was art. $278 \mathrm{Rv}$ van overeenkomstige toepassing. Voor een verdere bespreking van de inhoudelijke eisen die worden gesteld aan het verweerschrift wordt derhalve verwezen naar de hiervoor besproken toelichting omtrent het verzoekschrift.

\subsubsection{De rechter in burgerlijke zaken}

Voordat specifiek kan worden ingegaan op de rol van de kinderrechter in jeugdbeschermingszaken, moet eerst kort aandacht worden besteed aan de positie van de rechter in burgerlijke zaken. De bevoegdheden van de kinderrechter worden bepaald door de regels van burgerlijk (proces)recht. In het privaatrecht geldt zoals gesteld op grond van art. 24 Rv het beginsel van partijautonomie en de daaraan verbonden lijdelijkheid van de burgerlijke rechter. Partijautonomie en de lijdelijkheid van de burgerlijke rechter zijn de leidende concepten waar het gaat om de zeggenschaps- en bevoegdheidsverdeling tussen procespartijen en de rechter. ${ }^{164}$ De partijautonomie is van toepassing op drie aspecten van de procedure: de aanleg en voortzetting van het proces, de omvang van de rechtsstrijd en de bepaling wie kan deelnemen aan het proces. ${ }^{165}$ De lijdelijkheid van de rechter wordt gezien

\footnotetext{
162 Procesreglement Civiel Jeugdrecht 2014, p. 109 e.v.

${ }^{163}$ Kamerstukken II 1963/64, 7753, nr. 3 (MvT) p. 6.

${ }^{164}$ De Groot 2008, $R \& P$ nr. 165. 2.4.2.

165 Asser e.a. 2003, p. 65.
} 
als keerzijde van de autonomie van partijen en gaat primair over de houding van de rechter in de procedure. Alleen feiten en omstandigheden die daadwerkelijk door een partij aan de vordering of verweer ten grondslag zijn gelegd mogen door de rechter worden betrokken in de besluitvorming. Het gegeven dat partijen de aard en omvang van de rechtsstrijd bepalen leidt er automatisch toe dat de rechter zich terughoudend dient op te stellen, maar alleen ten aanzien van de aspecten waar partijen zeggenschap over hebben. Juridisch gezien gaat het dan om het verbod op aanvulling van de feiten (art. $149 \mathrm{Rv}$.) en het verbod voor de rechter om zijn beslissing te baseren op rechtsfeiten die niet door partijen zijn ingeroepen (art. 24 Rv.)

\section{Positionering van de kinderrechter}

Bij inwerkingtreding van de wet tot invoering van de kinderrechter en de maatregel van ondertoezichtstelling in $1922 \mathrm{kreeg}$ de kinderrechter niet alleen de taak recht te spreken maar was hij ook verantwoordelijk voor de uitvoering van het toezicht op de minderjarige. ${ }^{166}$ Vanaf dat moment had de kinderrechter zowel een centrale rol in het besluitvormingsproces als ten aanzien van het verloop van de maatregel. Hij diende vast te stellen of de gronden voor de maatregel aanwezig waren en indien aanwezig de maatregel uit te spreken en een gezinsvoogd te benoemen. Daarnaast was de kinderrechter belast met de leiding over het toezicht dat werd uitgeoefend door de gezinsvoogd en had hij de taak recht te spreken in geschillen tussen ouders enerzijds en de gezinsvoogd anderzijds. ${ }^{167}$ Deze dubbelfunctie, bestaande uit leiding geven aan de gezinsvoogd en het uitzetten van de koers van de hulpverlening en het beslissen in juridische geschillen, koos de wetgever destijds bewust om middels het gezag van de kinderrechter de positie van de gezinsvoogd te versterken. ${ }^{168}$ Vaak was ook sprake van een nauwe betrokkenheid tussen de kinderrechter en het gezin in kwestie.

De dubbelfunctie van de kinderrechter leidde echter tot kritiek, onder andere van ouders die werden geconfronteerd met een jeugdbeschermingsmaatregel. Er bestond onduidelijkheid over de positie van de kinderrechter ten opzichte van de gezinsvoogdij-instelling waardoor de kinderrechter nogal eens als verlengstuk van de gezinsvoogdij-instelling werd gezien. ${ }^{169} \mathrm{De}$ commissie Wiarda pleitte in 1971 al voor een scheiding tussen de rechtsprekende en coördinerende taak van de kinderrechter. De commissie wist concreet te benoemen waar de dubbelfunctie knelde: 'de kinderrechter bezit geen specifieke kennis over hulpverlening aan

\footnotetext{
166 Zie hierover uitgebreid: Doek 1972.

${ }^{167}$ Kamerstukken II 1992/93, 23 003, nr. 3 (MvT), p. 3.

${ }^{168}$ Kamerstukken II 1992/93, 23 003, nr. 3 (MvT), p. 3.

${ }^{169}$ Bruning 2001, p. 299.
} 
minderjarigen en geeft mede uitvoering aan de maatregel die hij zelf in een eerder stadium heeft opgelegd. 170

Het zou echter na het uitkomen van het rapport van commissie Wiarda nog geruime tijd duren voor een einde werd gemaakt aan de dubbelfunctie van de kinderrechter. Pas met de wettelijke herziening van de ondertoezichtstelling in 1995 werd besloten om de functie van de kinderrechter te beperken tot de rechtsprekende taak. Mede in het licht van het recht op toegang tot een onafhankelijke rechter, zoals volgde uit art. 6 EVRM, werd de dubbelfunctie ook door de wetgever als onwenselijk aangemerkt. Een rol speelde daarbij ook dat in de uitvoering van de hulpverlening aan minderjarigen sprake was van een toenemende professionalisering. ${ }^{171}$ De noodzaak voor kinderrechters om strikt de regie te voeren over de uitvoering van de ondertoezichtstelling, nam daarmee af. De gezinsvoogdij-instelling kreeg de verantwoordelijkheid over de uitvoering van de ondertoezichtstelling en via amendering kreeg de Raad voor de Kinderbescherming een toetsende taak in het geval de gezinsvoogd voornemens was de ondertoezichtstelling niet te verlengen (op grond van art. 1:256 lid 3 oud BW), de uithuisplaatsing niet wilde verlengen (op grond van art. 1:262 lid 2 oud BW) of indien de gezinsvoogdij-instelling de uithuisplaatsing wilde beëindigen (op grond van 1:263 lid 1 oud BW). ${ }^{172}$ De kinderrechter werd lijdelijk en besliste voortaan alleen nog op verzoek. ${ }^{173}$

\subsubsection{De mondelinge behandeling van het verzoek}

Op jeugdbeschermingszaken waren van toepassing de algemene voorschriften voor procedures zoals opgenomen in Afdeling 1.3 Wetboek van Burgerlijke Rechtsvordering; de algemene wettelijke voorschriften voor verzoekschriftprocedures (art. $261 \mathrm{Rv}$ e.v).; de specfieke regels ten aanzien van de rechtspleging in personen- en familierechtzaken, anders dan scheidingszaken (art. $798-813 \mathrm{Rv}$ ) en de toepasselijke procesreglementen.

Tenzij de rechter aanstonds een beschikking gaf waarin hij zich onbevoegd verklaarde of het verzoek toewees, werd aan belanghebbenden waarvan de woonplaats bekend was, een

\footnotetext{
${ }^{170}$ Rapport commissie Wiarda 1971, p. 176.

${ }^{171}$ Kamerstukken II 1992/93, 23 003, nr. 3 (MvT), p. 3.

172 Zie voor meer informatie over de totstandkoming- en het functioneren van de toetsende taak van de RvdK na inwerkingtreding van de Wet tot herziening van de ondertoezichtstelling: Kok, Van de Berg \& Cardol, FJR 2003, p. 74.

${ }^{173}$ Kamerstukken II 1992-1993, 23 003, nr. 3 (MvT), p. 2.
} 
afschrift van het verzoekschrift en bijbehorende bescheiden verzonden en werden de belanghebbenden opgeroepen voor de zitting (art. 800 lid 1 Rv). Voor de jaren 2013 en 2014 bepaalde het Procesreglement Civiel Jeugdrecht 2014 dat voor een zittingsdatum een oproepingstermijn van één tot vier weken voorafgaand aan de datum van de zitting gold (art. 5.1 PCJ). De verzoeker en de belanghebbenden werden indien noodzakelijk opgeroepen via hun advocaat, op grond van art. 5.1.3 PCJ. Voor het overige was de algemene regeling inzake de oproeping in verzoekschriftprocedures, op grond van de artt. $271-277 \mathrm{Rv}$, van toepassing. Op basis van art. $15 \mathrm{Rv}$ gold dat zaken bij de rechtbank behoudens wettelijke uitzonderingen behandeld en beslist werden door een enkelvoudige kamer. Art. 808 Rv sloot hierop aan en bepaalde dat zaken betreffende minderjarigen die bij de rechtbank aanhangig werden gemaakt, uitgezonderd zaken die het levensonderhoud van de minderjarige betroffen, werden behandeld door de kinderrechter. De kinderrechter kon op grond van art. 15 lid 3 Rv de zaak in elke stand van de procedure verwijzen naar een meervoudige kamer, indien de zaak ongeschikt was voor behandeling en beslissing door een rechter, of in andere gevallen (art. 15 lid 2 Rv). Bij verwijzing naar een meervoudige kamer nam de kinderrechter deel aan de inhoudelijke behandeling (art. $808 \mathrm{Rv}$ ).

\section{Gesloten karakter van de jeugdbeschermingszitting}

De mondelinge behandeling van het verzoek tot jeugdbeschermingsmaatregel vond in beginsel plaats achter gesloten deuren hetgeen een uitzondering vormde op het algemene beginsel van openbaarheid in civiele procedures, ex art. $27 \mathrm{Rv}$. In art. 803 lid $1 \mathrm{Rv}$ werd bepaald dat de behandeling in zaken betreffende het personen- en familierecht, anders dan scheidingszaken, geschiedde met gesloten deuren, in verband met de belangen van minderjarigen of de eerbiediging van de persoonlijke levenssfeer van belanghebbenden. De rechter kon hier op verzoek van een belanghebbende een uitzondering op maken en bepalen dat de behandeling geheel of gedeeltelijk openbaar was indien zwaarwegende belangen bij openbaarheid daartoe aanleiding gaven, en de belangen als bedoeld in lid 1 van art. $803 \mathrm{Rv}$ zich daartegen niet verzetten (art. 803 lid $2 \mathrm{Rv}$ ).

In 2013 werd voornoemde uitzondering op de behandeling achter gesloten deuren in art. 803 Rv opgenomen naar aanleiding van twee uitspraken van het EHRM: de zaak Moser t. Oostenrijk en de zaak B. en P t. Verenigd Koninkrijk. ${ }^{174}$ Volgens de wetgever volgde uit beide zaken dat het in beginsel mogelijk moest zijn een bepaalde categorie uit te sluiten van

\footnotetext{
${ }^{174}$ Kamerstukken II 2010/11, 32 856, nr. 3 (MvT), p. 2-3.
} 
openbaarheid van behandeling, mits de rechter in individuele gevallen op verzoek van een belanghebbende kon besluiten tot openbare behandeling. ${ }^{175}$ Tot aan de wetswijziging voorzag de Nederlandse regeling op dit punt niet in de mogelijkheid om de zitting in openbaarheid plaats te laten vinden. De toevoeging in lid 2 van art. $803 \mathrm{Rv}$ bracht de Nederlandse regeling in overeenstemming met art. 6 EVRM en de uitleg daaraan door het EHRM in voornoemde zaken, maar deed en doet niks af aan het uitgangspunt dat zaken betreffende het personen- en familierecht in beginsel achter gesloten deuren worden behandeld. ${ }^{176}$ Niet snel mocht dus worden aangenomen dat er sprake was van zwaarwegende belangen die noopten tot openbaarheid, maar het werd aan de rechtspraktijk over gelaten om invulling te geven aan deze uitzonderingsmogelijkheid. Toenmalig verantwoordelijk minister Opstelten gaf daarbij op voorhand al aan dat belanghebbenden slechts zelden prijs zullen stellen op een openbare behandeling en dat rechters - zeker in deze categorie zaken - in algemene zin ook geen voorstander zijn van de aanwezigheid van derden. ${ }^{177}$

\section{De zitting}

Tijdens de mondelinge behandeling van het verzoekschrift stelt de rechter de partijen over en weer in de gelegenheid hun standpunten naar voren te brengen en toe te lichten en zich uit te laten over elkaars standpunten en over alle bescheiden en andere gegevens die in de procedure ter kennis van de rechter zijn gebracht, tenzij uit de wet anders voortvloeit. Bij zijn beslissing baseert de rechter zijn oordeel, ten nadele van één der partijen, niet op bescheiden of andere gegevens waarover die partij zich niet voldoende heeft kunnen uitlaten (art. $19 \mathrm{Rv}$ ). Het in art. $19 \mathrm{Rv}$ neergelegde recht op rechterlijk gehoor wordt wel beschouwd als het meest fundamentele beginsel van burgerlijk procesrecht en geeft eenieder die procedeert het recht op een behoorlijke verdediging. ${ }^{178}$

In de procedure tot oplegging van een jeugdbeschermingsmaatregel zoals geanalyseerd in dit onderzoek lichtte de RvdK het verzoek op zitting toe, waarna de belanghebbende(n), doorgaans de ouders met gezag, in de gelegenheid werden gesteld hierop te reageren. Indien het ingediende verzoekschrift van de RvdK afkomstig was dan werd het Bureau Jeugdzorg niet als belanghebbende aangemerkt (art. 5.6 PCJ). Het was niet ongebruikelijk dat de beoogde gezinsvoogd namens Bureau Jeugdzorg aanwezig was op zitting. Het Bureau Jeugdzorg was dan slechts op uitnodiging van de kinderrechter bij de behandeling van het

\footnotetext{
${ }^{175}$ Kamerstukken II 2010/11, 32 856, nr. 3 (MvT), p. 2-3.

${ }^{176}$ Kamerstukken II 2010/11, 32 856, nr. 3 (MvT), p. 5-6

${ }^{177}$ Kamerstukken II 2010/11, 32 856, nr. 3 (MvT), p. 5-6

178 Tjong Tjin Tai, in: GS Burgerlijke Rechtsvordering, artikel 19 Rv., aant. A2.
} 
verzoek aanwezig en nam geen formele procespositie in (art. 5.6 PCJ). Vanuit het streven naar een zo effectief mogelijke uitvoering van de (beoogde) ondertoezichtstelling viel dit te begrijpen. Voor de ouders en minderjarige kon echter het beeld ontstaan dat de beslissing tot ondertoezichtstelling al vaststond, een opvatting waar begrip voor valt op te brengen.

\subsubsection{De (schriftelijke) motivering van de beschikking}

$\mathrm{Na}$ afloop van de mondelinge behandeling in familiezaken deelde de rechter aan de ter behandeling verschenen personen mede op welke terechtzitting de beschikking zou worden uitgesproken (art. $804 \mathrm{Rv}$ ). Volgens de wetgever was de behandeling niet alleen een geschikte gelegenheid om de dag te bepalen waarop de eindbeschikking werd gegeven, maar ook om de bepaalde datum aan de personen die verschenen, mede te delen. ${ }^{179}$ In het Wetboek van Burgerlijke Rechtsvordering waren verder geen concrete termijnen opgenomen. Ten aanzien van de verzoekschriftprocedure in jeugdbeschermingszaken vermeldde het Procesreglement Civiel Jeugdrecht 2014 wel specifieke termijnen voor de uitspraak. Indien werd afgezien van een behandeling ter zitting: uiterlijk vier weken nadat was geconstateerd dat de zaak gereed was voor beschikking doch tenminste voor het einde van de geldigheidsduur van de lopende ondertoezichtstelling en/of machtiging uithuisplaatsing. ${ }^{180}$ Bij zaken waarin wel een behandeling ter zitting had plaatsgevonden: in beginsel mondeling ter zitting dan wel uiterlijk twee weken na de datum van de zitting of - indien nog een termijn voor overlegging van nadere informatie en een reactie daarop werd gegund - twee weken na afloop van de laatstgenoemde termijn doch in ieder geval voor het einde van de geldigheidsduur van de lopende ondertoezichtstelling en/of machtiging tot uithuisplaatsing. ${ }^{181}$ In de meeste gevallen mocht dus worden verwacht dat de kinderrechter direct uitspraak deed na behandeling ter zitting van het verzoek tot ondertoezichtstelling met of zonder machtiging uithuisplaatsing. In tegenstelling tot de behandeling ter zitting gold voor de uitspraak dat deze in het openbaar dient te geschieden op grond van art. $28 \mathrm{Rv}$.

\section{Motivering van de beschikking}

De beslissing van de rechter op het verzoek tot jeugdbeschermingsmaatregel wordt schriftelijk uitgewerkt in een beschikking. Ten aanzien van de inhoudelijke eisen die kunnen worden

\footnotetext{
179 Kamerstukken II 1991/92, 22 487, nr. 3 (MvT), p. 10.

${ }^{180}$ Art. 8.1 Procesreglement Civiel Jeugdrecht 2014.

${ }^{181}$ Art. 8.1 Procesreglement Civiel Jeugdrecht 2014.
} 
gesteld aan de motivering van de beschikking wordt in de wet verwezen naar de regeling inzake vonnissen (art. 287 lid $1 \mathrm{Rv}$ jo. art. $230 \mathrm{Rv}$ ). Naast enkele algemene gegevens dient de beschikking de gronden van de beslissing te bevatten, daaronder begrepen de feiten waarop de beslissing rust. ${ }^{182}$ Daarnaast geldt tevens de algemene motiveringsplicht voor vonnissen, arresten en beschikkingen, ex art. $30 \mathrm{Rv}$, waaruit volgt dat dezen de gronden moeten inhouden waarop zij rusten, tenzij anders uit de wet voortvloeit. De motiveringsplicht ligt tevens besloten in de vereisten die gelden voor een fair trial op grond van art. 6 EVRM. ${ }^{183}$ De Hoge Raad heeft het belang van de motiveringsplicht meermalen bevestigd. ${ }^{184}$ Hij beschouwt als één van de grondbeginselen van een behoorlijke rechtspleging dat elke rechterlijke beslissing in ieder geval zodanig wordt gemotiveerd dat voldoende inzicht wordt gegeven in de daaraan ten grondslag liggende gedachtegang, om de beslissing zowel voor partijen als derden, controleerbaar en aanvaardbaar te maken. ${ }^{185}$

Hoewel op basis van voornoemde artikelen en de visie van de Hoge Raad kan worden geconcludeerd dat de motiveringsplicht van belang is, vertelt het nog weinig over de inhoudelijke eisen die worden gesteld aan de motivering van beschikkingen. In algemene zin wordt de omvang van de motiveringsplicht bepaald door de omstandigheden van het geval, hetgeen met name betekent aan de hand van hetgeen is gevorderd en het eventuele verweer in de procedure. ${ }^{186}$ De motiveringsplicht is daarmee primair afhankelijk van hetgeen ter processe is vast komen te staan, hoewel de rechter niet is gehouden te oordelen over alle aangevoerde stellingen van de partijen. ${ }^{187}$ Indien tegen een verzoek tot ondertoezichtstelling en/of uithuisplaatsing geen verweer wordt gevoerd, kan de rechter in de regel volstaan met een minder diepgaande motivering. Toenmalig staatssecretaris Kosto gaf tijdens de behandeling van de wettelijke herziening van de ondertoezichtstelling in 1995 aan dat in een niet onaanzienlijk deel van de procedures tot ondertoezichtstelling geen meningsverschil bestond tussen de betrokkenen over de noodzaak van een maatregel. ${ }^{188}$ In die gevallen was het aannemelijk dat de motivering uit de aard der zaak beperkter was dan wanneer er procedure op tegenspraak werd gevoerd. ${ }^{189}$ Het is overigens niet duidelijk wat moest worden verstaan

\footnotetext{
182 Zie art. $230 \mathrm{Rv}$.

183 Van den Hoogen 2007, p. 37.

${ }^{184}$ Zie onder meer HR 25 oktober 2002, NJ 2003/171; HR 13 juli 2007, NJ 2007/586 (De Oorsprong/Gem. Utrecht)

185 Zie o.a. HR 4 juni 1993, NJ 1993/659 (Vredo/Veenhuis).

${ }^{186}$ Zoals voortvloeit uit art. $24 \mathrm{Rv}$.

187 Zie Asser/Giesen 1 2015/457.

${ }^{188}$ Kamerstukken II 1993/94, 23 003, nr. 5 (MvA), p. 30

${ }^{189}$ Kamerstukken II 1993/94, 23 003, nr. 5 (MvA), p. 30
} 
onder 'een niet onaanzienlijk deel van de procedures' nu geen verdere indicatie werd gegeven. Het is daarbij ook de vraag of van de kinderrechter niet mag worden verwacht dat in zaken waarin geen verweer wordt gevoerd, toch een inhoudelijke motivering wordt gegeven.

Daarnaast wordt de omvang van de motiveringsplicht mede bepaald door de aard van de beslissing of van het geding. ${ }^{190}$ Zo worden ten aanzien van de motivering van uitspraken in kort geding en de beslissing tot het treffen van een voorlopige voorziening minder hoge eisen gesteld. ${ }^{191}$ Naarmate de ingrijpende aard van de procedure en/of de beslissing toenemen mogen ook hogere motiveringseisen worden gesteld. Zo blijkt bijvoorbeeld dat aan beschikkingen inhoudende de beëindiging van een alimentatieverplichting zware motiveringseisen worden gesteld. ${ }^{192}$ Dit algemene uitgangspunt rechtvaardigt dat in jeugdbeschermingszaken ook een verzwaarde motiveringsplicht geldt voor de rechter. Zowel de procedure tot oplegging van een jeugdbeschermingsmaatregel als de uiteindelijke beslissing zijn in de regel bijzonder ingrijpend voor de minderjarige en zijn ouders.

Er is nog een belangrijke reden op basis waarvan het belang van een gedegen inhoudelijke motivering van beschikkingen in jeugdbeschermingszaken moet worden benadrukt. Anders dan in veel andere civiele procedures is in de jeugdbeschermingsprocedure sprake van ongelijkheid tussen de procespartijen. De RvdK en de gezinsvoogdij-instelling zijn, hoewel ontstaan uit particuliere initiatieven, inmiddels professionele overheidsorganisaties. In het proces staan de ouders en minderjarige daar met veel beperktere middelen tegenover. Een helder gemotiveerde beschikking kan deze ongelijkheid deels 'compenseren'.

Met de herziening van de ondertoezichtstelling in 1995 wenste de wetgever geen verdere aanscherping van de motiveringsplicht voor de rechter in de wet op te nemen. Hoewel het belang van een heldere motivering in de beschikking werd onderschreven, werd de mogelijkheid om een motiveringsgebrek in hoger beroep voor te leggen afdoende gevonden. ${ }^{193}$ In de jaren na inwerkingtreding van de Wet tot herziening van de ondertoezichtstelling 1995 verstomde de kritiek ten aanzien van de rechterlijke motivering in jeugdbeschermingszaken niet, integendeel. De evaluatie van voornoemde wet bevatte de aanbeveling om te streven naar meer conformiteit in de uitvoering, hetgeen onder meer zou moeten worden bereikt door het uitvoeriger motiveren van rechterlijke uitspraken. ${ }^{194}$ Ook

\footnotetext{
190 Tjong Tjin Tai, in: GS Burgerlijke Rechtsvordering, artikel 30 Rv, aant. 4.

191 Tjong Tjin Tai, in: GS Burgerlijke Rechtsvordering, artikel 30 Rv, aant. 4.

192 Zie bijvoorbeeld HR 22 januari 1993, NJ 1993, 233.

${ }^{193}$ Kamerstukken II 1993/94, 23 003, nr.5, p. 29.

${ }^{194}$ De Savornin Lohman e.a 2000.
} 
vanuit de wetenschap ${ }^{195}$ en praktijk ${ }^{196}$ bleef kritiek klinken op de vaak summier gemotiveerde beschikkingen in jeugdbeschermingszaken.

Van Wijk gaf in haar dissertatie een historisch overzicht van de motiveringsplicht van de rechter in jeugdbeschermingszaken. ${ }^{197} \mathrm{Zij}$ stelde dat er vanuit de literatuur en praktijk historisch gezien nooit veel aandacht is geweest voor de eisen die aan de motivering door de kinderrechter mogen worden gesteld. ${ }^{198} \mathrm{Zij}$ benadrukte het belang van een gedegen rechterlijke motivering, juist omdat de wettelijke gronden van de jeugdbeschermingsmaatregelen veel ruimte lieten aan de praktijk om te beslissen over de noodzaak van een maatregel. Ook Bruning wees in haar dissertatie op het belang van de rechterlijke motivering in jeugdbeschermingszaken. Zij bekritiseerde het gebruik van standaardmotiveringen en formuleerde een aantal eisen waaraan de beschikking op het verzoek tot ondertoezichtstelling zou moeten voldoen. In de eerste plaats zou gemotiveerd moeten worden welke feiten en omstandigheden hebben geleid tot het oordeel dat de minderjarige ernstig in zijn ontwikkeling werd bedreigd en waarom vrijwillige hulpverlening niet meer haalbaar was. ${ }^{199}$ Dit lijkt het minimale wat van de kinderrechter mag worden verwacht, aangezien dan in ieder geval aan de hand van de feiten en omstandigheden van het specifieke geval invulling is gegeven aan de gronden van de maatregel van ondertoezichtstelling. ${ }^{200}$ Daarnaast zou moeten worden gemotiveerd waarom van de maatregel een positief effect is te verwachten. Tot slot zouden de doelen terug moeten komen in de beschikking zodat de onderbouwing van de kinderrechter niet alleen probleem- maar ook oplossingsgericht is. Overigens concludeerde Bruning dat in de toenmalige praktijk (2001) maar zelden aan deze eisen werd voldaan, zeker bij beschikkingen in eerste aanleg. ${ }^{201}$

\section{Motivering van de beslissing tot uithuisplaatsing}

Het inhoudelijk motiveren van de beschikking is extra belangrijk in de situatie waarin de minderjarige en zijn ouders van elkaar gescheiden kunnen worden door oplegging van een uithuisplaatsing of een verderstrekkende maatregel. In een uitspraak van 4 oktober 2011 heeft het gerechtshof Leeuwarden bepaald dat bij de toepassing van een zeer ingrijpende

\footnotetext{
195 Zie Bruning 2001.

${ }^{196}$ Uit Beijerse, Logtenberg \& Rietbergen 2010.

197 Van Wijk 1999, p. 103 e.v.

198 Van Wijk 1999, p. 116.

${ }^{199}$ Bruning 2001, p. 4.

${ }^{200}$ Zie voor een uitgebreide beschrijving van de gronden zoals opgenomen in Boek 1 Burgerlijk Wetboek paragraaf 4.2

${ }^{201}$ Bruning 2001, p. 6.
} 
kinderbeschermingsmaatregel als een uithuisplaatsing niet kon worden volstaan met een standaardmotivering. ${ }^{202}$ Dat geldt ook nadrukkelijk voor de beschikking op het verzoek machtiging gesloten jeugdzorg, nu hier sprake is van vrijheidsbeneming van minderjarigen. Mede op basis van het recht op persoonlijke vrijheid (art. 5 EVRM) en de zeer strikte eisen die gelden voor toepassing van vrijheidsbeneming van minderjarigen (o.a. art. 37b IVRK) zal de rechter bij ieder beoordelingsmoment de noodzaak van de vrijheidsbeneming concreet moeten onderbouwen. ${ }^{203}$ De wetgever heeft in het wetgevingsproces tot herziening van de maatregelen van kinderbescherimg nog eens benadrukt dat het de kinderrechter is die uiteindelijk een machtiging kan verlenen indien het verzoek in lijn is met nationale wetgeving, de Grondwet en internationale verdragen. ${ }^{204}$ Het past niet bij een dergelijk ingrijpend middel om in de beschikking te volstaan met een standaardformulering luidende dat aan alle wettelijke gronden is voldaan. In deel II van de studie waarin beschikkingen op het verzoek tot ondertoezichtstelling/machtiging uithuisplaatsing worden geanalyseerd, wordt gekeken of kinderrechters in de praktijk de noodzaak van een scheiding van kind en ouders inhoudelijk motiveren.

Ook het EHRM benadrukt het belang van gedegen onderzoek en een diepgaande motivering aan de zijde van de autoriteiten in zaken waarin kind en ouders worden gescheiden van elkaar. ${ }^{205}$ Een uithuisplaatsing maakt inbreuk op het recht op family life van kind en ouders en kan alleen onder strikte voorwaarden gerechtvaardigd zijn. Het EHRM hecht belang aan de kwaliteit van het besluitvormingsproces leidend tot de uithuisplaatsing, daaronder ook de motivering van de rechter begrepen. ${ }^{206}$ Meer specifiek mag worden verwacht dat de rechter in zijn uitspraak zich niet slechts baseert op de informatie uit rapportages. Er dient een expliciete beoordeling plaats te vinden ten aanzien van de vraag of de kinderbeschermingsautoriteiten voldoende inspanning hebben geleverd om een uithuisplaatsing door de inzet van minder ingrijpende alternatieven te voorkomen. ${ }^{207}$ Voor de Nederlandse praktijk veronderstelt het voorgaande dat aan de hand van rechtsgrond zoals opgenomen in het Burgerlijk Wetboek,

\footnotetext{
202 Gerechtshof Leeuwarden 4 oktober 2011, ECLI:NL:GHLEE:2011:BT7523, r.o. 4.

${ }^{203}$ Zie HR 2 december 1982, NJ 1984/306; In casu was sprake van een verzoek tot inbewaringstelling. Het lijdt echter geen twijfel dat het algemene uitgangspunt van de Hoge Raad inzake de motivering van vrijheidsbenemende maatregelen ook van toepassing is op het verzoek tot machtiging gesloten jeugdzorg.

${ }^{204}$ Kamerstukken II 2012/13 33 684, nr. 3 (MvT), p. 47.

205 Zie bv. EHRM 13 juli 2000, appl. nrs. 39221/98 \& 41963/98 (Scozzari t. Italie).

${ }^{206}$ EHRM 18 december 2008, appl. nr. 39948/06 (Saviny t. Oekraine).

${ }^{207}$ EHRM 18 december 2008, appl. nr. 39948/06 (Saviny t. Oekraine), par. 58.
} 
tenminste de noodzaak van een scheiding tussen kind en ouders inhoudelijk wordt onderbouwd.

\subsection{Uitgangspunten voor het dossieronderzoek in jeugdbeschermingszaken}

In dit hoofdstuk zijn de belangrijkste uitgangspunten en kenmerken voor de besluitvorming in jeugdbeschermingszaken beschreven. Meer concreet bevat het hoofdstuk een overzicht van de belangrijkste uitgangspunten, procedurele regels en formele (inhoudelijke) kwaliteitscriteria voor het beschermingsonderzoek en de gerechtelijke procedure in jeugdbeschermingszaken in de jaren 2013 en 2014. Deze elementen vormen de basis voor de analyse van dossiers in deel II van het onderzoek.

In de eerste plaats is een kort overzicht gegeven van de belangrijkste regels van bewijsrecht die van toepassing zijn op jeugdbeschermingszaken. Hoewel het civiele recht uitgaat van een vrije bewijsleer en partijen veel ruimte hebben om naar eigen inzicht informatie te selecteren en in te brengen in het proces, is het jeugdbeschermingsrecht zeker niet aan te merken als 'bewijsvrij'. Vastgesteld is dat de RvdK als partij (verzoeker) in de jeugdbeschermingsprocedure gehouden is de feiten volledig en naar waarheid aan te voeren (art. $21 \mathrm{Rv}$ ). Hoewel in de praktijk niet snel zal worden geoordeeld dat sprake is van strijd met de waarheidsplicht, volgt hieruit wel dat de RvdK de feiten niet mag verdraaien of uitzonderlijk slordig kan omgaan met de informatie in de beschermingsrapporten. Daarnaast verwoord art. $21 \mathrm{Rv}$ het streven naar materiële waarheidsvinding. In het beschermingsonderzoek door de RvdK moet getracht worden de besluitvorming zoveel mogelijk te baseren op feitelijke informatie die verifieerbaar is. Lukt dit niet dan moet dit ook expliciet blijken uit de gekozen formulering in het beschermingsrapport. In dit hoofdstuk is laten zien dat de kritiek van betrokkenen zich toespitst op dit element. Er zou sprake zijn van een gebrek aan onderscheid tussen feiten, meningen en de interpretatie daarvan door de RvdK.

Om in deel II van het onderzoek te kunnen analyseren in hoeverre deze kritiek terecht is, moet eerst worden gekeken hoe, en op basis van welke criteria de RvdK dit onderscheid maakt in de beschermingsrapportage. Hiervoor is gekeken naar het Kwaliteitskader 2013 en het protocol Beschermingstaken 2013 van de RvdK. Beide interne regelingen bevatten gedetailleerde aanwijzingen voor de uitvoering en inhoud van het beschermingsonderzoek en het opstellen van de beschermingsrapportage. Door de RvdK zijn verschillende 
kwaliteitseisen gesteld met betrekking tot de zorgvuldigheid van het feitenonderzoek. In de eerste plaats moet de bron van de informatie helder zijn en moet duidelijk blijken of de gegevens actueel zijn. Specifiek ten aanzien van het onderscheid tussen feiten en meningen wordt in het Kwaliteitskader 2013 aangegeven dat feiten en meningen gescheiden van elkaar moeten worden beschreven. Het is echter nergens duidelijk gemaakt wat onder feitelijke informatie wordt verstaan en wanneer sprake is een niet-bevestigde zorg of visie van een betrokkene. Voor de analyse van dossiers in deel II is daarom een indeling gemaakt van informatie die als feitelijk en als niet feitelijk aangemerkt kan worden. Op deze manier kan in de dossiers worden beoordeeld of de RvdK daadwerkelijk in de uitvoering van het onderzoek de informatie correct weergeeft en interpreteert.

Vervolgens is de verzoekschriftprocedure tot oplegging van een ondertoezichtstelling en machtiging uithuisplaatsing besproken. Extra aandacht is besteed aan de inhoudelijke eisen die gelden, of zouden moeten gelden voor de motivering van de beschikking op het verzoek tot ondertoezichtstelling. Voor wat betreft de wettelijke plicht om de beschikking te motiveren kan worden verwezen naar art. 287 lid $1 \mathrm{Rv}$ jo. art. $230 \mathrm{Rv}$, de algemene motiveringsplicht in art. $30 \mathrm{Rv}$ en de vereisten die voortvloeien uit art. 6 EVRM. Hoewel op basis van deze bepalingen het belang van een deugdelijke motivering wordt benadrukt, zijn standaardmotiveringen waarin alleen de wettelijke gronden worden herhaald vermoedelijk geen uitzondering. In het hoofdstuk zijn verschillende argumenten aangedragen waarom een standaardmotivering onvoldoende is met het oog op de rechtvaardiging van een ondertoezichtstelling en uithuisplaatsing. De ingrijpende gevolgen van de beslissingen in jeugdbeschermingszaken en de ongelijkwaardige positie van de procesdeelnemers, maakt dat de kinderrechter tenminste zou moeten beargumenteren welke feiten en omstandigheden hebben geleid tot het oordeel dat sprake is van een ernstige bedreiging van de zedelijke of geestelijke belangen of gezondheid en waarom vrijwillige hulpverlening voorzienbaar niet het gewenste resultaat heeft opgeleverd. Ten aanzien van de uithuisplaatsing zou de kinderrechter tenminste inhoudelijk moeten onderbouwen welke feiten en omstandigheden een scheiding van kind en ouders noodzakelijk maakt. 


\section{Rechtspositie van minderjarige en ouders in de jeugdbeschermingsprocedure}

\subsection{Inleiding}

De inzet van een jeugdbeschermingsmaatregel betekent een inbreuk op het recht op eerbiediging van het familie- en gezinsleven van de minderjarige en zijn ouders. Onder strikte voorwaarden kan die inbreuk gerechtvaardigd zijn. De overheid dient invulling te geven aan zijn positieve verplichting de minderjarige van noodzakelijke bescherming en zorg te verzekeren. Het jeugdbeschermingsrecht onderscheidt zich daarin van andere terreinen binnen het civiele recht waarin primair de verhouding tussen burgers onderling wordt gereguleerd. In het jeugdbeschermingsrecht is sprake van een overwegend afhankelijke situatie van minderjarige en ouders ten opzichte van publieke organen die maatregelen kunnen verzoeken met een vergaande impact op familieleven van de betrokkenen. Het is derhalve niet verwonderlijk dat de rechtspositie van minderjarige en zijn ouders, als 'zwakke partijen' in de procedure, in de achterliggende decennia een prominent onderwerp is geweest in publicaties ten aanzien van het jeugdbeschermingsrecht. ${ }^{208}$

De verhouding tussen kind en ouders en de rechten en verplichtingen die voor beiden hebben te gelden is van groot belang voor de vraag in welke mate en op welke wijze inbreuk wordt gemaakt op de toepasselijke rechten van beide partijen. De directe ingreep in de ouder-kind relatie middels de inzet van een jeugdbeschermingsmaatregel impliceert dat zowel de belangen van het kind als de belangen van de ouders een rol behoren te spelen in het besluitvormingsproces. In sommige gevallen wordt met name gewezen op de conflicterende belangen tussen kind en ouders die zich kunnen voordoen in jeugdbeschermingszaken: het kind heeft op grond van het IVRK recht op een gezonde en evenwichtige ontwikkeling en groei naar zelfstandigheid en de ouders hebben op grond van art. 8 EVRM het recht de opvoeding en verzorging van het kind vorm te geven op een manier die zij juist achten. ${ }^{209}$ Daarmee blijft in de eerste plaats onbenoemd dat beide voornoemde verdragen belangrijke overeenkomstige uitgangspunten kennen ten aanzien van de verhouding tussen het kind, de ouders en de Staat.

Ouders hebben te gelden als eerstverantwoordelijken voor de verzorging en opvoeding van de minderjarige en de minderjarige heeft het recht bij zijn ouders op te groeien. Alleen in uiterste

\footnotetext{
${ }^{208}$ Zonder volledigheid te pretenderen enkele belangwekkende publicaties ten aanzien van de rechtspositie van de minderjarige en zijn ouders in het burgerlijk recht: De Langen 1973; Doek \& Slagter 1976; Fiege 1993; Scheffer e.a 1977; De Bruijn-Luckers 1994; Vlaardingerbroek 1994.

${ }^{209}$ Zie in dit verband bv. Kamerstukken II 2010/11, 32 015, nr.3 (MvT).
} 
gevallen, met toepassing van relevante regelgeving en onder voorbehoud van een rechterlijke toetsing, mogen bevoegde autoriteiten inbreuk maken op het recht op een ongestoord privé, familie- en gezinsleven van de minderjarige en zijn ouders. ${ }^{210}$

Gezien de verstrekkende gevolgen van de verschillende maatregelen is een goede rechtspositie voor de minderjarige en ouders in de jeugdbeschermingsprocedure onontbeerlijk. Voor een goed begrip van de rechtspositie binnen de jeugdbeschermingsprocedure is het noodzakelijk eerst aandacht te besteden aan twee met elkaar samenhangende factoren die zien op de (formele) verhouding tussen de minderjarige en zijn ouders. De minderjarige moet volgens de wet onder gezag staan (art. 1:245 lid 1 BW) en het gezag heeft betrekking op de persoon van de minderjarige, het bewind over zijn vermogen en zijn vertegenwoordiging in burgerlijke handelingen. In paragraaf 3.2 wordt eerst aandacht besteed aan de inhoud van het gezag en de gevolgen voor de rechtspositie van de ouders in de jeugdbeschermingsprocedure. Het feit dat de minderjarige door de ouders met gezag wordt vertegenwoordigd in burgerlijke handelingen heeft gevolgen voor de positie die de mindejarige inneemt binnen het rechtsverkeer en specifiek in de jeugdbeschermingsprocedure. Het vraagstuk ten aanzien van de handelingsbekwaamheid van de minderjarige wordt in het vervolg van paragraaf 3.2 verdeeld in de materiële handelings(on)bekwaamheid en de formele (of processuele) handelingsonbekwaamheid.

Met betrekking tot de materiële handelingsbekwaamheid geldt dat de minderjarige sinds 1995 handelingsbekwaam is indien hij met toestemming van zijn wettelijke vertegenwoordiger handelt. Betreft het een voor de leeftijd van de minderjarige gebruikelijke rechtshandeling dan wordt de toestemming verondersteld te zijn verleend. ${ }^{211}$ In de jeugdbeschermingsprocedure geldt als uitgangspunt dat de minderjarige in rechte vertegenwoordigd door zijn wettelijke vertegenwoordigers en daardoor formeel handelingsonbekwaam is. Een belangrijke conclusie hiervan is dat hoewel de ondertoezichtstelling wordt opgelegd aan de minderjarige, deze in gerechtelijke procedure tot oplegging van de maatregel geen formele procespartij is. Een voor dit onderzoek relevante uitzondering op deze processuele onbekwaamheid van de minderjarige (van in beginsel twaalf jaar en ouder) werd gemaakt in de procedure op grond

\footnotetext{
${ }^{210}$ Het uitgangspunt dat ouders eerstverantwoordelijk zijn voor de verzorging en opvoeding van de minderjarige is onder meer neergelegd in art. 3 lid 2 IVRK, art. 5 IVRK en art. 18 IVRK. Het uitgangspunt dat een scheiding van kind en ouder (door de inzet van een jeugdbeschermingsmaatregel) als uiterste maatregel heeft te gelden volgt uit art. 9 IVRK.

${ }^{211}$ Wet van 6 april 1995, Stb. 240.
} 
van hoofdstuk IVa Wet op de Jeugdzorg (machtiging gesloten jeugdzorg). Dit onderwerp verdient derhalve aparte behandeling.

In paragraaf 3.3 wordt aandacht besteed aan de kring van personen die als belanghebbenden kunnen worden beschouwd in de jeugdbeschermingsprocedure, waarbij de nadruk ligt op de minderjarige en zijn ouders. Het zijn van belanghebbende heeft belangrijke processuele gevolge zoals bijvoorbeeld het recht om hoger beroep in te stellen (art. 806 lid 1 onder b Rv). De minderjarige is in de familieverzoekschriftprocedure belanghebbende maar met beperkte processuele bevoegdheden. Voor ouders geldt dat veel afhangt van de vraag of zij met het gezag over de minderjarige zijn belast.

Tot slot wordt in paragraaf 3.4 uitgebreid aandacht besteed aan het hoorrecht van de minderjarige in de jeugdbeschermingsprocedure. Gezien de beperkte processuele bevoegdheden van de minderjarige moet het hoorrecht worden beschouwd als één van de kernelementen van de rechtspositie van de minderjarige in zaken betreffende een ondertoezichtstelling/uithuisplaatsing. Vanuit verdragsrechtelijk perspectief is met name de totstandkoming en toenemende invloed van het Internationaal Verdrag voor de Rechten van het Kind (IVRK) van groot belang geweest voor het hoorrecht van de minderjarige. ${ }^{212}$ Het IVRK beschouwt de minderjarige ondanks zijn kwetsbare positie als rechtssubject. Enerzijds betekent dit dat het kind in verband met zijn leeftijd en daarmee gepaard gaande kwetsbaarheid bijzondere bescherming behoeft, anderzijds moet het kind in staat worden geacht op een bij de leeftijd passende wijze, de rechten en bevoegdheden uit te oefenen die eenieder krachtens mensenrechtelijke verdragen toekomen. Vervolgens wordt de rol die het hoorrecht van minderjarigen speelt binnen de uitgebreide jurisprudentie van het Europees Hof voor de Rechten van de Mens op grond van art. 8 EVRM toegelicht. Afgesloten wordt met het hoorrecht op grond van nationale wetgeving. Het hoorrecht van de minderjarige in zaken betreffende het personen- en familierecht is neergelegd in art. $809 \mathrm{Rv}$ en doet de minderjarige het fundamentele recht op hoor en wederhoor toekomen in de jeugdbeschermingsprocedure. De specifieke regels op grond van nationale wetgeving en uitgangspunten op basis van verdragsrecht vormen uiteindelijk het kader voor de analyse van dossiers in deel II van het onderzoek.

\footnotetext{
${ }^{212}$ Het Internationaal Verdrag voor de Rechten van het Kind werd op 20 november 1989 unaniem goedgekeurd door de Algemene Vergadering van de Verenigde Naties (Res.44/25). Nederland ratificeerde het verdrag op 6 februari 1995, waarna het verdrag dertig dagen later in werking trad; Wet van 24 november 1994, Stb. 862.
} 


\subsection{Ouderlijk gezag en de handelings(on)bekwaamheid van de minderjarige}

In de $19^{\mathrm{e}}$ eeuw had de ouderlijke macht te gelden als het geheel aan rechten en bevoegdheden van de vader met betrekking tot het kind. Aan het begin van de $20^{\mathrm{e}}$ eeuw groeide echter de overtuiging dat de ouderlijke macht bestond ter wille van het kind en niet ter wille van de ouders, hetgeen de overheid ook het recht gaf te beoordelen of het gezag daadwerkelijk ter wille van het kind werd uitgeoefend. ${ }^{213}$ Met invoering van de Burgerlijke Kinderwet in 1901 ontstond een wettelijk kader waarmee ingrijpen in het gezag, ter bescherming van de belangen van het kind, mogelijk werd. ${ }^{214}$ De opkomst van een wettelijk systeem van jeugdbescherming in Nederland ging gepaard met de erkenning dat inbreuken op de ouderlijke macht mogelijk moesten kunnen zijn. Met de wetswijziging van 6 april 1995 werd de term 'ouderlijke macht' vervangen door 'ouderlijk gezag'. ${ }^{215}$ Een eerder voorstel om te spreken van ouderlijke zorg werd verworpen. De gekozen terminologie (ouderlijk gezag) maakte volgens de wetgever duidelijk dat het gaat om de uitoefening van ouderlijke bevoegdheden die juridisch van aard zijn. ${ }^{216}$ Sindsdien is de regeling inzake de aard en de omvang van het gezag te vinden in titel 14, Boek 1 BW.

\subsubsection{Gezag over minderjarigen}

Het wettelijk uitgangspunt op basis van art. 1:245 lid $1 \mathrm{BW}$ is dat minderjarigen onder gezag behoren te staan. Staan zij dat niet, dan moet zo spoedig mogelijk een gezagsvoorziening worden getroffen. Hieruit is tevens af te leiden dat het in beginsel in het belang van het kind is om bij zijn ouders op te groeien. Ouders dragen de verantwoordelijkheid voor de verzorging en opvoeding van de minderjarige. Inbreuken op het ouderlijk gezag moeten worden gemotiveerd met zodanig ernstige omstandigheden dat het veronderstelde belang van het kind bij de gezagsuitoefening moet wijken voor het (klaarblijkelijk) grotere belang van het kind bij de inbreuk daarop. ${ }^{217}$ Het voorgaande leidt tot twee hoofdoverwegingen die maken dat de aard en omvang van het ouderlijk gezag en de inzet van jeugdbeschermingsmaatregel direct met

\footnotetext{
${ }^{213}$ Asser/De Boer 1*2010/815.

${ }^{214}$ Stb 1901, 62. Vgl. voor een nadere toelichting omtrent de totstandkoming van de Burgerlijke Kinderwet: Brands-Bottema 1998; Bruning 2001.

${ }^{215}$ Wet van 6 april 1995 tot nadere regeling van het gezag over en van de omgang met minderjarige kinderen, Stb.1195, 240.

${ }^{216}$ Kamerstukken II 1992/93, 23 012, nr. 3., p. 5.

217 Asser/De Boer 1* 2010/814.
} 
elkaar zijn verbonden: Het opleggen van een maatregel van ondertoezichtstelling met of zonder uithuisplaatsing is slechts mogelijk ten aanzien van minderjarigen. Op grond van art. 1:233 lid 1 BW zijn minderjarigen 'zij die de leeftijd van achttien jaren nog niet hebben bereikt, niet gehuwd of geregistreerd zijn, dan wel gehuwd of geregistreerd zijn geweest of meerderjarig waren verklaard.'

In de tweede plaats raken de gevolgen van het opleggen van een maatregel van jeugdbescherming direct het ouderlijk gezag. In het geval van een ondertoezichtstelling betreft dit een beperking van het gezag van de ouders. Deze beperking krijgt vorm in de praktische uitvoering van de maatregel. Op papier zijn ouders ook na oplegging van de ondertoezichtstelling nog degenen die het gezag dragen. Zij kunnen echter niet meer geheel vrij beslissen over alle aspecten van de verzorging en opvoeding. Ouders zijn gehouden de aanwijzingen van de gezinsvoogd op te volgen. De mate waarin het gezag wordt beperkt is mede afhankelijk van de eventuele oplegging van een schriftelijke aanwijzing of de oplegging van een uithuisplaatsing. Met name een uithuisplaatsing betreft een (veel) verdere inperking van het gezag aangezien het ouders de mogelijkheid ontneemt te beslissen over een fundamenteel aspect van de verzorging en opvoeding: het bepalen van de plek waar de minderjarige verblijft.

Gezag kan worden onderscheiden in ouderlijk gezag (eenoudergezag of gezamenlijk gezag) en voogdij indien het gezag wordt uitgeoefend door een natuurlijk persoon of rechtspersoon, niet zijnde de juridische ouder (art. 1:245 lid 3 BW). Voor dit onderzoek is de meest voor de hand liggende situatie dat één of beide ouders met het gezag zijn belast op het moment dat de RvdK start met een beschermingsonderzoek. Als er sprake is van eenhoofdig gezag dan is dit vaak de moeder. Dit kan het geval zijn als alleen het moederschap is vastgesteld of wanneer de ouders niet met elkaar gehuwd zijn en niet samen het gezag uitoefenen. ${ }^{218}$ Ook kan het zo zijn dat ouders wel gezamenlijk het gezag hebben uitgeoefend maar dat na scheiding het gezag aan een van de ouders is toegewezen. Uitgangspunt is dat ouders na scheiding gezamenlijk het gezag blijven uitoefenen. ${ }^{219}$ Dreigt het kind klem of verloren te raken tussen de ouders en is niet de verwachting dat hierin binnen afzienbare tijd verandering komt, of is

\footnotetext{
${ }^{218}$ Bruning, Liefaard \& Vlaardingerbroek 2014, p. 387.

${ }^{219}$ Dit uitgangspunt is vastgesteld bij wet van 30 oktober 1997; Stb. 1997,105. en aangescherpt bij wet in 2009. Wet van 27 november 2008 tot wijziging van Boek 1 BW en Rv in verband met het bevorderen van voortgezet ouderschap na scheiding en de mogelijkheid tot het omzetten van een huwelijk in een geregistreerd partnerschap; Stb. 200, 56.
} 
wijziging in het gezag anderszins in het belang van het kind, dan kan het gezag aan één ouder toebedeeld worden (art. 1:251a lid $1 \mathrm{BW}$ ).

Ouderlijk gezag moet worden beschouwd als aan ouders toekomend recht, maar dit recht is gegeven in het belang van het kind en kan daarom niet los worden gezien van de verplichting het belang van het kind te dienen. ${ }^{220}$ Het is evenwel niet zo dat met een beroep op het belang van het kind een inbreuk op het ouderlijk gezag zich zonder meer laat rechtvaardigen, aldus de Hoge Raad: 'een dergelijke inbreuk van overheidswege is in beginsel alleen dan aanvaardbaar, indien zij geschiedt door of op verzoek van de daartoe bij wet aangewezen instantie, op de door de wet aangewezen wijze en met inachtneming van de door de wet voorgeschreven vormen en genoemde redenen. '221

\section{Inhoud van het gezag}

Door gezag staan de gezagsdrager en de minderjarige in een bijzondere, familierechtelijke relatie tot elkaar, waarvan in de wet is bepaald welke rechten en plichten daaraan zijn verbonden. Het gezag van de ouders heeft volgens art. 1:245 lid 4 BW betrekking op de persoon van de minderjarige, het bewind over zijn vermogen en de vertegenwoordiging in burgerlijke rechtshandelingen, zowel in als buiten rechte. Ten aanzien van de persoon van de minderjarige geldt het uitgangspunt dat ouders en de minderjarige op voet van gelijkwaardigheid met elkaar dienen om te gaan. ${ }^{222}$ Naarmate de minderjarige zich verder ontwikkelt behoren de ouders de minderjarige in toenemende mate de ruimte te bieden zelfstandig beslissingen te nemen. Dit uitgangspunt is onder meer terug te zien in art. 5 IVRK. Art. 5 IVRK stelt dat Staten de verantwoordelijkheden, rechten en plichten van de ouders eerbiedigen voor het voorzien in passende begeleiding bij de uitoefening door het kind van de in het IVRK neergelegde rechten, op een wijze die verenigbaar is met de zich ontwikkelende vermogens van het kind. Enerzijds wordt hiermee de erkenning gegeven voor het ouderlijk gezag en de daaruit voortvloeiende verantwoordelijkheid voor de verzorging en opvoeding van het kind, anderzijds wordt ten aanzien van de ouders gesteld dat deze rekening moeten houden met de zich ontwikkelende vermogens, en in bredere zin de rechten van het kind. Ondanks het feit dat ouders dus rekening dienen te houden met de ontwikkeling van hun kind

\footnotetext{
${ }^{220}$ Zie voor de connectie tussen de notie 'het belang van het kind en de rechten en plichten van ouders: Asser/De Boer $1 * 2010 / 813$.

${ }^{221}$ HR 25 september 1998, ECLI:NL:HR:1998:ZC2714, r.o. 1.2.

${ }^{222}$ Kamerstukken II 1992/93, 23 012, nr. 3., p. 11.
} 
komt hen in beginsel grote vrijheid toe inzake beslissingen die de verzorging en opvoeding van het kind betreffen.

Een nadere uitwerking van de inhoud van het ouderlijk gezag ten aanzien van de persoon van de minderjarige is te vinden in de art. 1:247 BW. Art 1:247 lid $1 \mathrm{BW}$ stelt dat ouderlijk gezag de plicht en het recht omvat van de ouder zijn minderjarig kind te verzorgen en op te voeden. In de dagelijkse praktijk veronderstelt dit onder meer dat de ouders met gezag, voor zover mogelijk en noodzakelijk in overleg met het kind, beslissingen nemen ten aanzien van de verzorging en opvoeding zoals de schoolkeuze, de verblijfplaats van de minderjarige (indien niet tevens een machtiging uithuisplaatsing is uitgesproken) en beslissingen omtrent medische behandelingen van de minderjarige. ${ }^{223}$

Onder verzorging en opvoeding moet volgens art. 1:247 lid 2 mede worden verstaan de zorg en verantwoordelijkheid voor het geestelijk en lichamelijk welzijn en de veiligheid van het kind alsmede het bevorderen van de ontwikkeling van zijn persoonlijkheid. Bij wet van 8 maart 2007 is aan het tweede lid van 1: 247 BW toegevoegd dat ouders in de verzorging en opvoeding van het kind geen geestelijk of lichamelijk geweld of enige andere vernederende behandeling toepassen met als doel preventie van kindermishandeling. ${ }^{224}$ Een expliciet wettelijk verbod op geweld in de opvoeding werd lange tijd niet noodzakelijk geacht aangezien wettelijke strafbepalingen van toepassing zijn op geweldshandelingen. De wetgever heeft het verbod op geweld in de opvoeding toch in de wet opgenomen vanuit de gedachte dat het leidt tot meer bewustwording onder ouders. ${ }^{225}$

De overige twee elementen waarop het ouderlijk gezag betrekking heeft (art. 1:245 lid 4 BW) is het bewind over het vermogen dat de minderjarige toekomt en de vertegenwoordiging van de minderjarige in burgerlijke handelingen zowel in als buiten rechte. Een nadere uitwerking hieromtrent is te vinden in art. 1:253i BW en verder. Uitgangspunt is dat de ouders in geval van gezamenlijke gezagsuitoefening ook gezamenlijk het bewind voeren over het vermogen van de minderjarige en de vertegenwoordiging in burgerlijke handelingen. Om redenen van praktische aard voegt art. 1: 253i lid 1 BW daar aan toe dat ook de ouder alleen hiertoe bevoegd is, mits niet is gebleken van bezwaar van de andere ouder met gezag. Gedacht moet worden aan de schriftelijke toestemming voor allerlei minder ingrijpende beslissingen inzake

\footnotetext{
${ }^{223}$ Bruning, Liefaard \& Vlaardingerbroek 2014, p. 174.

${ }^{224}$ Stb. 2007, 145.

${ }^{225}$ Niet duidelijk is in hoeverre de verwachting gerechtvaardigd is dat deze wijziging leidt tot een afname van geweld in de opvoeding. Zie Kamerstukken II 2005/6, 30 316, nr. 3. (MvT).
} 
het bewind en burgerlijke rechtshandelingen, waarbij het onpraktisch zou zijn te allen tijde een handtekening van beide ouders met gezag te verlangen. Oefent de ouder alleen het gezag uit, dan is hij op grond van art. 1:253i lid 3 ook alleen belast met het bewind over het vermogen en de vertegenwoordiging in burgerlijke rechtshandelingen.

\subsubsection{Ontwikkelingen ten aanzien van de handelings(on)bekwaamheid van de minderjarige}

De vergrote aandacht voor de rechtspositie van de minderjarige kreeg pas echt vorm in de jaren '70 van de vorige eeuw en kon niet los worden gezien van zowel nationale als internationale ontwikkelingen. Op nationaal niveau was het de commissie Wiarda die met het invloedrijke rapport 'Jeugdbeschermingsrecht' prominent de aandacht vestigde op de rechtspositie van de minderjarige. Een belangrijk element van het rapport vormde de mondigheid van het individu en het streven naar gelijke rechten voor minderjarigen hetgeen de eenzijdige nadruk op de beschermende functie van het systeem van jeugdbescherming moest verminderen. ${ }^{226}$ De voorstellen ten aanzien van de maatregelen van jeugdbescherming beoogden dan ook 'een accentverschuiving te realiseren van toezicht op de uitoefening van de ouderplicht naar het bewaken van de rechten van het kind'. ${ }^{227}$ Voorts stelde de commissie Wiarda dat een geleidelijke toename van de handelingsbekwaamheid van de minderjarige zou aansluiten bij de maatschappelijke werkelijkheid. Niet meer zou moeten worden uitgegaan van een stelsel met daarin schaarse uitzonderingen op de principiële handelingsonbekwaamheid van de minderjarige, maar juist een principiële, met de jaren toenemende handelingsbekwaamheid moest het uitgangspunt worden. ${ }^{228}$ Het rapport van de commissie Wiarda vormde de opmaat tot diverse publicaties in de daaropvolgende jaren over de rechtspositie van de minderjarige. ${ }^{229}$ In 1990 toonden de toenmalige bewindslieden van Justitie zich in een regeringsnotitie voorstander van een nadere precisering van de gezagsrelatie tussen kind en ouders, waarbij ook aandacht werd besteed aan de handelingsbekwaamheid van de minderjarige. ${ }^{230}$ Uiteindelijk hebben voorgaande

\footnotetext{
${ }^{226}$ Rapport commissie. Wiarda 'Jeugdbeschermingsrecht' 1971, p. 58.

${ }^{227}$ Rapport commissie. Wiarda 'Jeugdbeschermingsrecht' 1971, p. 60.

${ }^{228}$ Rapport commissie. Wiarda 'Jeugdbeschermingsrecht' 1971, p. 57.

${ }^{229}$ Vgl. De Langen 1973; Rutten-Roos 1975; Hammerstein-Schoonderwoerd 1975; Doek \& Slagter 1976; Fiege 1993.

${ }^{230}$ Kamerstukken II 1989/90, 21 309, nr. 2.
} 
ontwikkelingen geleid tot een voorstel van wet betreffende een nadere regeling van het gezag over- en van de omgang met minderjarige kinderen. ${ }^{231}$

Tot op dat moment was het wettelijk uitgangspunt op basis van art. 1:234 lid 1 oud BW dat minderjarigen onbekwaam waren rechtshandelingen te verrichten voor zover de wet niet anders bepaalde. De wetgever achtte het uitgangspunt van handelingsonbekwaamheid echter niet meer passend bij hetgeen in het dagelijks leven gebruikelijk was, namelijk dat minderjarigen van verschillende leeftijden dagelijks op grote schaal rechtshandelingen verrichten. ${ }^{232}$ Nadrukkelijk werd daarbij gewezen op de veronderstelde toegenomen mondigheid van minderjarigen, waardoor zij naarmate de leeftijd vorderde steeds vaker - al dan niet met toestemming van hun wettelijke vertegenwoordigers- rechtshandelingen uitvoerden. Een nieuwe wettelijke regeling inzake de handelingsbekwaamheid van minderjarigen moest minder de nadruk leggen op de bescherming van de minderjarige. Getracht werd aan te sluiten bij het idee van een groeiende verantwoordelijkheid van jongeren in het maatschappelijk verkeer. ${ }^{233}$

\subsubsection{Materiële handelings(on)bekwaamheid minderjarige}

Op 2 november 1995 trad de nieuwe wettelijke regeling in werking. ${ }^{234}$ Vanaf dat moment lijkt op grond van art. 1:234 BW de wet de handelingsbekwaamheid van de minderjarige als uitgangspunt te nemen. ${ }^{235}$ Volgens art. 1:234 lid $1 \mathrm{BW}$ is een minderjarige, mits hij met toestemming handelt van zijn wettelijke vertegenwoordiger, bekwaam rechtshandelingen te verrichten voor zover de wet niet anders bepaalt. ${ }^{236}$ Er kunnen dus wettelijke uitzonderingen gelden op basis van het Burgerlijk Wetboek op grond waarvan de minderjarige ook zonder toestemming van de ouder bekwaam is rechtshandelingen te verrichten.

In lid 3 van art. 1:234 BW wordt daaraan toegevoegd dat de toestemming aan de minderjarige wordt verondersteld te zijn verleend, indien het een rechtshandeling betreft ten aanzien

\footnotetext{
${ }^{231}$ Kamerstukken II 1992/93, 23 012, nr. 2.

${ }^{232}$ Kamerstukken II 1992/93, 23 012, nr. 3, p. 12.

${ }^{233}$ Kamerstukken II 1992/93, 23 012, nr. 3, p. 12-13.

${ }^{234}$ Wet van wet van 6 april 1995, Stb. 240, in werking is getreden op 2 november 1995.

235 Zie Bruning, Liefaard \& Vlaardingerbroek 2014, p. 431.

${ }^{236}$ Gelet op deze formulering is betoogd dat handelingsonbekwaamheid nog steeds het wettelijk uitgangspunt is. Er moet immers in beginsel toestemming worden gegeven voor rechtshandelingen verricht door de minderjarige. In de literatuur heeft dit geleid tot een levendige discussie over de vraag of de regeling nu uitgaat van bekwaamheid of onbekwaamheid van de minderjarige. Vgl. Wortmann FJR 1995/9; Gras 2010, p. 79; Ter Haar FJR 2011/15.
} 
waarvan het in het maatschappelijk verkeer gebruikelijk is dat een minderjarige van zijn leeftijd die zelfstandig verricht. Aldus mag worden aangenomen dat de formulering 'wordt verondersteld te zijn verleend' duidt op een onweerlegbaar wettelijk vermoeden. Is er sprake van een rechtshandeling die kan worden beschouwd als 'gebruikelijk in het maatschappelijk verkeer gezien de leeftijd van de persoon' dan moet worden aangenomen dat de rechtshandeling met toestemming van de wettelijk vertegenwoordiger is verricht. De wetgever zoekt met de term 'in het maatschappelijk verkeer gebruikelijk' aansluiting bij de formulering die de commissie Wiarda heeft voorgesteld, maar gaat niet mee in het advies een geleidelijke toename van de handelingsbekwaamheid te koppelen aan specifieke leeftijdsgrenzen. ${ }^{237}$ De bepaling van leeftijdsgrenzen kenmerkt zich altijd door een zekere willekeurigheid en behelst bovendien het risico van onnodige discussie over de gebruikelijkheid van bepaalde rechtshandelingen op een bepaalde leeftijd. Een flexibele omgang met de open norm 'in het maatschappelijk verkeer gebruikelijk' moet minderjarigen de mogelijkheid geven zonder al te veel restricties bij hun leeftijd passende rechtshandelingen te verrichten.

De wetgever heeft in het licht van de toenmalige tijdsgeest enige indicaties verstrekt ten aanzien van de vraag wat in het maatschappelijk verkeer gebruikelijke rechtshandelingen zijn: het kopen van levensmiddelen, ook voor minderjarigen onder de twaalf jaar, het kopen van een buskaartje of kaartje voor de film, het aanschaffen van studieboeken en geluidsbanden en het verrichten van rechtshandelingen in het kader van het ontplooien van sport- en spelactiviteiten. ${ }^{238}$ Indien de minderjarige zonder toestemming van zijn ouders zelfstandig een rechtshandeling verricht die in het maatschappelijk verkeer als ongebruikelijk moet worden beschouwd, dan is de rechtshandeling vernietigbaar op grond van art. 3:32 lid $2 \mathrm{BW}$.

\footnotetext{
${ }^{237}$ Het voorstel van de commissie Wiarda hield in dat minderjarigen onder de twaalf jaar handelingsonbekwaam zijn, tenzij er in het maatschappelijk verkeer een ander gebruik bestaat. Tussen de twaalf en zestien jaar is de minderjarige met toestemming handelingsbekwaam, of zonder toestemming indien het maatschappelijk verkeer het toelaat en de wettelijk vertegenwoordiger van geen bezwaar doet blijken. De minderjarige van zestien jaar en ouder is handelingsbekwaam tenzij het maatschappelijk gebruik toestemming vereist; Rapport cie. Wiarda 'Jeugdbeschermingsrecht' 1971, p. 58.

${ }^{238}$ Kamerstukken II 1992/93, 23 012, nr. 3, p. 13.
} 


\subsubsection{Processuele onbekwaamheid minderjarige}

Algemeen wordt aangenomen dat het uitgangspunt van materiële

handelings(on)bekwaamheid van de minderjarige ook met zich meebrengt dat de minderjarige niet zelfstandig in rechte op kan treden. ${ }^{239}$ De minderjarige is onbekwaam om als eiser of gedaagde op te treden (in een dagvaardingsprocedure), of als verzoeker of verweerder (in een verzoekschriftprocedure). Hoewel niet expliciet verwoord in de wet kan de formele (of processuele) handelingsonbekwaamheid worden afgeleid uit art. 1:245 lid $4 \mathrm{BW}$ en art. 1:253i lid 1 BW. In beide artikelen wordt gesteld dat (ouderlijk) gezag de vertegenwoordiging van de minderjarige in burgerlijke handelingen omvat, zowel in als buiten rechte. Behoudens de nog te bespreken wettelijke uitzonderingen komt de minderjarige dus geen zelfstandige rechtsingang toe en wordt een verzoek van de zijde van de minderjarige in de regel niet ontvankelijk verklaard. Specifiek ten aanzien van de jeugdbeschermingsprocedure betekent dit dat de minderjarige niet zelfstandig een verzoek tot ondertoezichtstelling met of zonder uithuisplaatsing kan indienen en ook niet zelfstandig hoger beroep kan instellen tegen een beslissing in eerste aanleg.

De vraag naar de wenselijkheid van een zelfstandige rechtsingang voor de minderjarige is de afgelopen decennia een prominent onderwerp geweest in het wetenschappelijke en politieke debat. ${ }^{240}$ De wetgever heeft een zelfstandige rechtsingang voor de minderjarige echter consequent afgewezen. Zo liet de minister in 1989 weten geen voorstander te zijn omdat een zelfstandige rechtsingang het risico inhield van een (verdere) juridisering van gezinsconflicten. ${ }^{241}$ De verhouding tussen ouders en kinderen en de persoonlijke aard van de gezinsverhoudingen zou zich er tegen verzetten dat ouders en kinderen als partijen tegenover elkaar komen te staan. ${ }^{242}$ Daarnaast zou een eigen rechtsingang voor de minderjarige ook onwenselijk zijn gelet op de aard en de omvang van het ouderlijk gezag. ${ }^{243}$

In 2003 publiceerde het Verwey-Jonker Instituut in opdracht van het ministerie van Justitie een onderzoek naar het functioneren van de bijzondere curator (op grond van art. 1:250 BW) en in bredere zin, de wenselijkheid van een algemeen geldende zelfstandige rechtsingang voor minderjarigen. ${ }^{244}$ In de eerste plaats werd op basis van dossieronderzoek geconcludeerd dat

\footnotetext{
${ }^{239}$ Zie bv. Asser/De Boer $1 * 2010 / 791$; Bruning, Liefaard \& Vlaardingerbroek, p. 341.

${ }^{240}$ Kamerstukken II 2003/04, 29200 VI, nr. 116.

${ }^{241}$ Kamerstukken II 1989/90, 21309, 2, p. 18 e.v.

${ }^{242}$ Kamerstukken II 1989/90, 21309, 2, p. 18 e.v

${ }^{243}$ Kamerstukken II 1989/90, 21309, 2, p. 18 e.v

${ }^{244}$ Steketee, Overgaag \& Lünnemann 2003.
} 
van de mogelijkheid om een bijzondere curator te benoemen maar zeer beperkt gebruik werd gemaakt. Daarnaast concludeerden de onderzoekers op grond van de vereisten die voortvloeien uit de artt. 9 en 12 IVRK, art. 6 EVRM en de visie van de geraadpleegde respondenten (waaronder minderjarigen zelf) dat het wenselijk zou zijn om minderjarigen een zelfstandige rechtsingang te verschaffen. ${ }^{245}$ Toenmalig minister van justitie Donner liet echter in een korte reactie weten onvoldoende grond te zien om een formele rechtsingang voor minderjarigen in het burgerlijk recht te introduceren, voornamelijk omdat een bijzondere curator de belangen van de minderjarige kon behartigen. ${ }^{246}$

De belangrijkste reden om de minderjarige geen zelfstandige rechtsingang toe te kennen leek derhalve de angst voor een verdere escalatie van conflicten in de gezinssituatie. In het geval van jeugdbeschermingsmaatregelen was dat niet ondenkbaar. De wetgever wees in het kader van een verzoek tot ondertoezichtstelling erop dat de minderjarige in een moeilijke positie zou geraken op het moment dat hij zelf zou kunnen verzoeken het gezag van zijn ouders te beperken. ${ }^{247}$ De wetgever gaf in dit verband aan dat de minderjarige indien hij een ondertoezichtstelling wenste zich tot de RvdK moest wenden om ze te overtuigen van de noodzaak hiervan. ${ }^{248}$ Hoe dat er in de praktijk uit zou moeten zien werd niet nader toegelicht. Het initiatief zou in dat geval bij de minderjarige zelf moeten liggen. Het lijkt niet heel waarschijnlijk dat minderjarigen zelf aan de bel zouden trekken bij een overheidsinstantie als de RvdK, ook niet als er thuis sprake was van een problematische opvoedsituatie. Wel is denkbaar dat de minderjarige een signaal zou afgeven aan eventueel betrokken hulpverleners of zich zou wenden tot een Kinder- en Jongerenrechtswinkel voor juridisch advies.

3.2.5 Uitzonderingen binnen het jeugdbeschermingsrecht op het uitgangspunt van processuele onbekwaamheid

Binnen het civiele recht zijn in de loop der tijd verschillende uitzonderingen in de wet opgenomen op het uitgangspunt van processuele onbekwaamheid van de minderjarige. Dit heeft geleid tot een complex en onoverzichtelijk stelsel als wordt gekeken naar alle procedures inzake het personen- en familierecht. ${ }^{249}$ Het uitgangspunt van processuele

\footnotetext{
${ }^{245}$ Steketee, Overgaag \& Lunnemann 2003, p. 95.

${ }^{246}$ Kamerstukken II 2003/04, 29200 VI, nr. 116.

${ }^{247}$ Kamerstukken II 1992/93, 23 003, nr 3.

${ }^{248}$ Kamerstukken II 1992/93, 23 003, nr 3.

${ }^{249}$ Zie hierover bv. Mink, EB 2012, p. 113 e.v.; Van Leuven \& De Klerk, EB 2013/32, par. 2.9.
} 
onbekwaamheid van de minderjarige gold en geldt ook in de jeugdbeschermingsprocedure. In het vervolg van deze paragraaf worden de uitzonderingen binnen het jeugdbeschermingsrecht op het uitgangspunt van processuele onbekwaamheid onder oude wetgeving toegelicht.

\section{Verzoeken in het kader van de uitvoering van de ondertoezichtstelling}

De wetgever heeft met de wettelijke herziening van de ondertoezichtstelling in 1995 de keuze gemaakt om de minderjarige de bevoegdheid te geven verschillende verzoeken te doen gericht op de uitvoering van de ondertoezichtstelling. De belangrijkste reden hiervoor was dat de toegang van de minderjarige tot de rechter gewaarborgd diende te blijven. ${ }^{250}$ Het feit dat op deze wijze een (verdere) beperking van het gezag van de ouders mogelijk was werd niet als probleem gezien omdat de inbreuk door oplegging van de ondertoezichtstelling al tot stand was gekomen. ${ }^{251}$ In de jaren 2013 en 2014 kon de minderjarige van twaalf jaar en ouder zich richten tot de kinderrechter met het verzoek Bureau Jeugdzorg te vervangen door een soortgelijke stichting in een andere provincie (art. 1:254 lid 5 oud BW); met het verzoek de ondertoezichtstelling op te heffen (art. 1:256 lid 4 oud BW); een schriftelijke aanwijzing vervallen te laten verklaren of in te trekken (artt. 1:259 lid 1 oud BW en 1:260 lid 1 oud BW); de machtiging uithuisplaatsing geheel of gedeeltelijk in te trekken of de duur ervan bekorten (art. 1:263 lid 4 oud BW); de beslissing van Bureau Jeugdzorg om de contacten tussen kind en ouder met gezag te beperken vervallen te verklaren of in te trekken (art. 1:263a lid 2 oud BW); of de gewijzigde omgangsregeling tijdens de lopende ondertoezichtstelling wederom te wijzigen (art. 1:263b lid 2 oud BW).

\section{Processuele bekwaamheid minderjarige inzake machtiging gesloten jeugdzorg}

De opname van een minderjarige in een accommodatie voor gesloten jeugdzorg is een vorm van vrijheidsbeneming die gezien het ingrijpende karakter aan strikte eisen is gebonden. Zo is een inperking van de persoonlijke vrijheid van de minderjarige op grond van art. 37b IVRK slechts toegestaan in uitzonderlijke gevallen en indien toegepast, slechts mogelijk voor de kortst mogelijke duur. Mede in dit licht heeft de wetgever ook gekozen voor aanvullende wettelijke vereisten, die in de periode waar dit deel van het onderzoek op ziet waren neergelegd in art. 29b lid 3 Wet op de Jeugdzorg. De noodzaak van goede rechtspositie teneinde onwettige of willekeurige vrijheidsbeneming te voorkomen heeft echter ook consequenties gehad voor de processuele bevoegdheden die de minderjarige waren toebedeeld in deze procedure. Blijkens art. 29a lid $2 \mathrm{Wjz}$ was de minderjarige die de leeftijd van twaalf

\footnotetext{
${ }^{250}$ Kamerstukken II 1992/93, 23 003, nr 3.

${ }^{251}$ Kamerstukken II 1992/93, 23 003, nr 3.
} 
jaar had bereikt in zaken betreffende een machtiging gesloten jeugdzorg bekwaam in rechte op te treden. Hetzelfde gold voor de minderjarige die de leeftijd van twaalf jaar nog niet had bereikt maar in staat kon worden geacht tot een redelijke waardering van zijn belangen terzake. Daarnaast kreeg de minderjarige ambtshalve een raadsman toegewezen op grond van art. 29f lid 2 WJZ.

De processuele bekwaamheid van de minderjarige in de procedure tot machtiging gesloten jeugdzorg werd wettelijk vastgelegd bij de invoering van de Wet gesloten jeugdzorg in 2007 waarmee ook de scheiding tussen strafrechtelijk- en civielrechtelijk geplaatste minderjarigen werd bewerkstelligd. De regeling van art. 29a lid $2 \mathrm{Wjz}$ vormde daarmee een codificatie van de praktijk nu rechters voor die tijd zonder duidelijke wettelijke basis minderjarigen verschillende malen ontvankelijk hadden verklaard in een door hen ingesteld hoger beroep. Zo verklaarde het gerechtshof 's-Hertogenbosch in een uitspraak van 8 september 1999 een door de minderjarige ingesteld hoger beroep ontvankelijk. De minderjarige had volgens het hof het recht de rechtmatigheid van de vrijheidsbeneming te laten toetsen door een rechter of een andere bevoegde, onafhankelijke en onpartijdige autoriteit en hij diende tevens onverwijld juridische bijstand te krijgen. ${ }^{252}$ In een andere zaak oordeelde het gerechtshof Arnhem dat de benoeming van een bijzondere curator op grond van 1:250 BW niet kon worden afgewacht en de minderjarige ontvankelijk was in hoger beroep gezien de ernst van de situatie van vrijheidsbeneming. ${ }^{253}$

Het is echter opvallend dat de wetgever nauwelijks enige toelichting heeft gegeven omtrent de achtergronden van het creëren van deze wettelijke uitzonderingsmogelijkheid op de processuele onbekwaamheid van de minderjarigen in het burgerlijk procesrecht. Daarmee is grotendeels onduidelijk gebleven waarin de rechtvaardiging is gelegen van het verschil in procesrechtelijke bevoegdheden van de minderjarige in 'reguliere' beschermingszaken en in zaken waarin een machtiging gesloten jeugdzorg werd verzocht. Aangenomen mag worden dat vanwege het feit dat in laatstgenoemde categorie zaken sprake is van vrijheidsbeneming van de minderjarige een verstevigde rechtspositie is toebedeeld. In de memorie van toelichting horende bij de Wet gesloten jeugdzorg werd volstaan met de opmerking dat de huidige regeling ten aanzien van de procedure machtiging gesloten jeugdzorg de betrokkenheid van de jeugdige zelf in de procedure garandeerde. ${ }^{254}$ In de procedure tot

\footnotetext{
${ }^{252}$ Gerechtshof 's-Hertogenbosch 8 september 1999, NJ 401, r.o. 4.1.4.

${ }^{253}$ Gerechtshof Arnhem 19 januari 1993, NJ 1994, 711, r.o.4.

${ }^{254}$ Kamerstukken II 2005/06, 30 644, nr. 3, p. 19-20, (MvT). Doek vraagt zich onder verwijzing naar de wetsgeschiedenis af of de wetgever hier werkelijk wenst te kiezen voor de procesbekwaamheid van de
} 
ondertoezichtstelling, ontheffing of ontzetting is deze betrokkenheid van de minderjarige dus veel minder vanzelfsprekend aangezien hij in rechte wordt vertegenwoordigd door zijn wettelijke vertegenwoordigers.

\section{Bijzondere curator ex art. 1:250 BW}

Het uitgangspunt van processuele onbekwaamheid van de minderjarige in jeugdbeschermingszaken zoals dat tot op heden geldt heeft een belangrijke consequentie: de minderjarige is voor de behartiging van zijn belangen in een gerechtelijke procedure in grote mate afhankelijk van zijn wettelijke vertegenwoordigers. Er zijn zaken waarin dit geen enkel probleem oplevert. Er ontstaat echter een potentieel zeer nadelige situatie voor de minderjarige indien zijn belangen kennelijk niet samenvallen met de belangen van de wettelijke vertegenwoordigers. Om de rechtspositie van de minderjarige in die gevallen te waarborgen is gekozen voor de mogelijkheid tot benoeming van een bijzondere curator, ex. art. 1:250 BW. Ingevolge art. 1:250 BW kan de rechter een bijzondere curator benoemen in aangelegenheden betreffende de verzorging en opvoeding, dan wel het vermogen van de minderjarige, indien de belangen van de met gezag belaste ouder(s) of voogd(en) in strijd zijn met die van de minderjarige.

Waar de benoeming van een bijzondere curator in de eerste plaats was bedoeld voor vermogensrechtelijke belangentegenstellingen geldt sinds de herziening van art. 1:250 BW in 1995 dat ook aangelegenheden betreffende de verzorging en opvoeding hiervoor in aanmerking komen. De benoeming van een bijzondere curator moet in het belang van het kind noodzakelijk zijn, mede gelet op de aard van de belangenstrijd. ${ }^{255}$ Blijkens de parlementaire geschiedenis is het niet de bedoeling geweest algemene opvoedingsproblemen te verhelpen met de inzet van een bijzondere curator nu dit een te verstrekkende beperking zou inhouden van rechten van de wettelijke vertegenwoordigers met betrekking tot de verzorging en opvoeding. ${ }^{256}$ Er moet sprake zijn van een wezenlijk (en concreet) conflict over de verzorging en opvoeding tussen de minderjarige en diens wettelijke vertegenwoordigers. ${ }^{257}$ Procedures waarin de bijzondere curator van toegevoegde waarde kan zijn, zijn bijvoorbeeld procedures inzake echtscheiding, gezag, verblijf en omgang en ook de ondertoezichtstelling en

\footnotetext{
minderjarige. Mocht deze vraag bevestigend worden beantwoord dan is in ieder geval verduidelijking gewenst omtrent het verschil met de procedure tot ondertoezichtstelling; Doek 2008, p. 38.

${ }^{255} \mathrm{Zie}$ voor meer informatie over de benoeming van de bijzondere curator op grond van art. 1:250 BW: Bruning FJR 2012/68; Pieters FJR 2012/36.

${ }^{256}$ Kamerstukken II 1992/93, 23 012, nr. 3, p. 12.

${ }^{257}$ Kamerstukken II 1992/93, 23 012, nr. 3, p. 12.
} 
uithuisplaatsing. ${ }^{258} \mathrm{Het}$ (formele) verzoek tot benoeming van een bijzondere curator op grond van art. 1:250 BW kan ook worden gedaan door de minderjarige. ${ }^{259}$ Daarmee vormt mogelijkheid tot verzoek van benoeming van een bijzondere curator tevens een wettelijke uitzondering op het uitgangspunt van processuele handelingsonbekwaamheid van de minderjarige. Daarnaast kan de rechter eveneens na een informeel verzoek van de minderjarige overgaan tot ambtshalve benoeming van een bijzondere curator. De bijzondere curator dient vervolgens de belangen van de minderjarige te behartigen zowel binnen als buiten rechte maar slechts ten aanzien van het conflict dat aanleiding heeft gegeven tot de benoeming. Een bredere taakstelling kan mogelijk leiden tot spanning met de rechten van de wettelijke vertegenwoordigers, en indien een jeugdbeschermingsmaatregel is opgelegd, met de taak van de gezinsvoogd.

In 2012 kwam een adviesrapport van de Kinderombudsman uit waarin is gekeken naar de rol van de bijzondere curator in het Nederlandse personen- en familierecht. ${ }^{260}$ In het rapport werd geconcludeerd dat er nauwelijks informatie bekend was over het aantal bijzondere curatoren en benoemingen, dat de figuur van de bijzondere curator onbekend was bij kinderen, ouders maar ook bij professionals en dat er nog altijd veel discussie bestond over de situaties en conflicten waarin de bijzondere curator benoemd zou moeten of kunnen worden. ${ }^{261}$ Hierdoor, zo concludeerde de Kinderombudsman, bleven kinderen die ernstig in de knel zaten verstoken van steun en hulp van iemand die hun belangen en stem kon vertegenwoordigen. Het rapport heeft ervoor gezorgd dat de figuur van de bijzondere curator meer aandacht heeft gekregen. Of dat in de jaren na het uitkomen van het rapport ook heeft geleid tot een toename van het aantal benoemingen van bijzondere curatoren is hoogst twijfelachtig. ${ }^{262}$

Ondanks voornoemde mogelijkheden voor de minderjarige zich formeel tot de rechter te wenden, of zich te laten bijstaan door een bijzondere curator, zorgt het algemene uitgangspunt van formele handelingsonbekwaamheid in het civiele jeugdrecht ervoor dat de minderjarige in beginsel geen formele procespartij is en alleen daarom al verregaand in zijn rechten is beperkt. Het recht op toegang tot de rechter vormt immers een noodzakelijke voorwaarde om overige processuele rechten, onder meer vervat in art. 6 EVRM, uit te kunnen oefenen. ${ }^{263}$ De

\footnotetext{
${ }^{258}$ Kamerstukken II 1992/93, 23 012, nr. 3.

${ }^{259}$ Kamerstukken II 1992/93, 23 012, nr. 3, p. 11.

${ }^{260}$ De Kinderombudsman 2012.

${ }^{261}$ De Kinderombudsman 2012, p. 47.

${ }^{262}$ Zie hierover Kentie \& Hendriks EB 2013/93. Zij wijzen erop dat het criterium 'belangenstrijd' te strikt wordt opgevat in de rechtspraktijk.

${ }^{263}$ Zie hierover uitgebreid Asser/Giesen I 156 e.v.
} 
Hoge Raad heeft echter in een uitspraak van 5 december 2014 geoordeeld dat uit art. 6 EVRM niet volgt dat een effectieve uitoefening van het recht op toegang tot de rechter veronderstelt dat een minderjarige direct, dus zonder tussenkomst van een wettelijk vertegenwoordiger, in rechte kennis moet kunnen nemen van alle gedingstukken. ${ }^{264}$ Liefaard plaatst mede in het licht van relevant verdragsrecht enkele kanttekeningen bij voornoemde uitspraak van de Hoge Raad. ${ }^{265}$ Hij betoogt dat uit art. 5 IVRK in samenhang met art. 12 IVRK volgt dat het kind in zijn ontwikkeling naar volwassenheid in toenemende mate in staat moet worden gesteld zelfstandig rechten uit te kunnen oefenen. Deze toename in autonomie veronderstelt ook dat het accent van bescherming van de minderjarige naarmate zijn vermogens zich ontwikkelen, komt te liggen op participatie en mogelijkheden tot het nemen van autonome beslissingen. Art. 12 IVRK voegt daar aan toe dat de minderjarige het recht moet hebben om zijn mening te geven in alle aangelegenheden die hem betreffen en dat, hoe ouder de minderjarige is en hoe meer capaciteiten hij heeft, hoe serieuzer er met zijn mening moet worden omgegaan. Beide artikelen geven daarmee blijk van de wenselijkheid van een 'dynamische rechtspositie' voor het kind.

\subsection{De kring van belanghebbenden}

Het zijn van belanghebbende brengt belangrijke rechten mee voor de personen die betrokken zijn in de procedure. Sinds de inwerkingtreding van de Wet herziening procesrecht in personen- en familiezaken in 1995 bepaalt art. 798 lid $1 \mathrm{Rv}$ ten aanzien van zaken betreffende het personen- en familierecht wie kan worden beschouwd als belanghebbende: degene op wiens rechten of verplichtingen de zaak rechtstreeks betrekking heeft. Door de toevoeging de omschrijving 'rechtstreeks' beoogt de wetgever allerlei prealabele procedures te voorkomen waarin eerst moet worden beslist wie als belanghebbende kan worden aangemerkt. ${ }^{266}$ Daarmee is niet tegemoet gekomen aan het advies van de Nederlandse Vereniging van Rechtspraak om per procedure (vooraf) te bepalen wie belanghebbende is. ${ }^{267}$ Een dergelijke (limitatieve) opsomming zou zich ook slecht verhouden met het uitgangspunt in art. 8 EVRM inhoudende dat indien sprake is van family life degene die een verzoek doet ten aanzien van

\footnotetext{
${ }^{264}$ HR 5 december 2014, ECLI:NL:HR:2014:3535, r.o.3.6.2., NJ 2015/57, m.nt. S. Wortmann.

${ }^{265}$ Liefaard, FJR 2015/12.

${ }^{266}$ Wet van e Wet van 7 juli 1994, Stb. 570 (inwerkingtreding 1 april 1995, Stb. 774). Zie voor een toelichting over het belanghebbendenbegrip: Kamerstukken II 1991/92, 22 487, nr. 3, p.7. (MvT).

${ }^{267}$ Kamerstukken II 1991/92, 22 487, nr. 3, p. 6-7. (MvT).
} 
de 'familiaire' relatie, in beginsel kan worden aangemerkt als belanghebbende. ${ }^{268}$ Dit heeft evenwel tot gevolg dat het de rechter is die moet bepalen of iemand 'rechtstreeks' belanghebbend is ten aanzien van het verzoek, hetgeen ook uiting komt in de diverse en uitgebreide jurisprudentie op dit punt. In ieder geval volgt de conclusie uit het voorgaande dat niet iedereen die pretendeert een belang in de zin van betrokkenheid bij (sympathie voor) de zaak te hebben ook in de procedure als belanghebbende zal worden erkend. ${ }^{269}$ Nadere invulling van de regels die gelden voor de verschillende familieverzoekschriftprocedures zijn neergelegd in toepasselijke procesreglementen, die gelden als recht in de zin van art. 79 Wet op de Rechterlijke Organisatie.

\subsubsection{De minderjarige als belanghebbende}

De wetgever heeft in 1992 aangegeven dat de minderjarige in de hem betreffende familierechtelijke procedures belanghebbende is. ${ }^{270}$ De Hoge Raad bevestigde dit in een uitspraak van 21 mei 2010. ${ }^{271}$ Naast de instellingen en organen die een maatregel van jeugdbescherming kunnen verzoeken, zijn de met gezag belaste ouder(s), een ander die het minderjarige kind als behorende tot zijn gezin verzorgt en opvoedt, en de minderjarige belanghebbende, mits hij twaalf jaren of ouder is. ${ }^{272}$

In de periode waar dit deel van het onderzoek (2013/2014) op ziet werd in het toen geldende Procesreglement Civiel Jeugdrecht 2014 de minderjarige van twaalf jaar en ouder als belanghebbende aangemerkt in zaken betreffende een verzoek tot ondertoezichtstelling met of zonder uithuisplaatsing. ${ }^{273}$ Hetzelfde gold voor de minderjarige onder de twaalf jaar indien hij in staat kon worden geacht tot een redelijke waardering van zijn belangen in geval het een verzoek betreft op grond van hoofdstuk $4 \mathrm{~b}$ Wet op de Jeugdzorg (machtiging gesloten jeugdzorg). Verder werden in art. 2.3 van het Procesreglement Civiel Jeugdrecht vermeld als belanghebbenden: de ouder(s) met gezag; de juridische ouder(s) zonder gezag, tenzij er geen sprake meer was van family life; de stiefouder in de zin van art. 1:395 BW, zolang deze met de verzorgende ouder samenleefde, en de minderjarige tot zijn gezin behoorde; de biologische vader indien sprake was van family life met de minderjarige; de perspectief biedende pleegouder of de pleegouder die de minderjarige een jaar of langer had verzorgd en opgevoed.

\footnotetext{
${ }^{268}$ Kamerstukken II 1991/92, 22 487, nr. 3, p.7. (MvT).

${ }^{269}$ Kamerstukken II 1991/92, 22 487, nr. 3, p.6. (MvT).

${ }^{270}$ Kamerstukken II 1991/92, 22 487, nr. 3, p.7. (MvT).

${ }^{271}$ HR 21 mei 2010, ECLI:NL:HR:2010:BL7043.

${ }^{272}$ HR 21 mei 2010, ECLI:NL:HR:2010:BL7043, r.o. 4.3.3., m.nt. S.Wortmann.

${ }^{273}$ Stcrt. 2014, 7820.
} 
Voorgaande bracht echter niet zonder meer met zich mee dat de minderjarige ook alle processuele bevoegdheden die de wetgever aan belanghebbenden had doen toekomen, ook kon uitoefenen zonder tussenkomst van een wettelijk vertegenwoordiger of een daartoe benoemde bijzondere curator. ${ }^{274}$ De minderjarige onderscheidde zich in die zin van andere belanghebbenden dat hij - wettelijke uitzonderingen daargelaten - niet zelfstandig als verzoeker, gerekwestreerde of als appellant kon optreden. ${ }^{275} \mathrm{Wel}$ had de minderjarige het recht om te worden geïnformeerd hetgeen ook bleek uit art. 2.2 Procesreglement Civiel Jeugdrecht 2014, waarin stond dat de minderjarige van twaalf jaar en ouder een eigen kopie van het verzoekschrift zonder bijlagen kreeg toegestuurd.

In een uitspraak van 5 december 2014 oordeelde de Hoge Raad over het recht van de minderjarige op inzage en afschrift van de processtukken in een hem betreffende procedure. ${ }^{276}$ De minderjarige verzocht als belanghebbende in deze zaak inzage en afschrift van de op de zaak betrekking hebbende bescheiden, op grond van art. $290 \mathrm{Rv}$, teneinde de wenselijkheid van de uitoefening van zijn hoorrecht te kunnen beoordelen. ${ }^{277}$ De Hoge Raad begon met de vaststelling dat op basis van de wetsgeschiedenis het belanghebbendenbegrip als in art. $290 \mathrm{Rv}$, voor familieverzoekschriftprocedures moest worden uitgelegd in het licht van de betekenis die het had volgens art. $798 \mathrm{Rv} .{ }^{278}$ Op basis van laatstgenoemde bepaling was de minderjarige belanghebbende in zaken die hem betreffen. Vervolgens concludeerde de Hoge Raad dat het zijn van belanghebbende niet zonder meer meebracht dat de minderjarige aan belanghebbenden processuele bevoegdheden zonder tussenkomst van een wettelijk vertegenwoordiger kon uitoefenen. ${ }^{279}$ De minderjarige diende zich voor uitoefening van het recht op inzage en afschrift van de processtukken derhalve te wenden tot zijn wettelijk vertegenwoordiger, of diende indien deze zijn belangen onvoldoende behartigde, de benoeming van een bijzondere curator te verzoeken. ${ }^{280}$

\subsubsection{Ouders als belanghebbenden}

Of ouders in een procedure tot oplegging van een jeugdbeschermingsmaatregel als belanghebbenden konden worden aangemerkt, hing in de eerste plaats af van de vraag of zij

\footnotetext{
${ }^{274}$ Kamerstukken II 1991/92, 22 487, nr. 3, p.7. (MvT).

${ }^{275}$ Nauta, in: GS Burgerlijke rechtsvordering, art. 809 Rv, aant. 4 (bijgewerkt tot 15 mei 2014).

${ }^{276}$ HR 5 december 2014, ECLI:NL:HR:2014:3535, m.nt. S. Wortmann.

${ }^{277}$ HR 5 december 2014, ECLI:NL:HR:2014:3535, r.o. 3.3.2, m.nt. S. Wortmann.

${ }^{278}$ HR 5 december 2014, ECLI:NL:HR:2014:3535, r.o. 3.5.1 e.v., m.nt. S. Wortmann.

${ }^{279}$ HR 5 december 2014, ECLI:NL:HR:2014:3535, r.o. 3.5.2., m.nt. S. Wortmann.

${ }^{280}$ HR 5 december 2014, ECLI:NL:HR:2014:3535, r.o. 3.6.1. e.v, m.nt. S. Wortmann.
} 
met het gezag waren belast. De maatregel van ondertoezichtstelling heeft directe gevolgen voor de rechtsbetrekking tussen de met gezag belaste ouders en de minderjarige. ${ }^{281}$ Waren de ouders gezamenlijk belast met het gezag dan waren zij zonder meer belanghebbende in zaken betreffende een ondertoezichtstelling/uithuisplaatsing, zoals ook volgde uit het eerder aangehaalde art. 2.3 Procesreglement Civiel Jeugdrecht 2014. Ten aanzien van ouders die geen gezag (meer) hadden gold dat zij belanghebbende konden zijn indien er sprake was van family life, zo werd tevens vermeld in art. 2.3 Procesreglement Civiel Jeugdrecht. Het procesreglement sloot aan bij de visie van de wetgever op dit punt:

'De door internationale verdragen, zoals het Europees Verdrag tot Bescherming van de Rechten van de Mens en de fundamentele vrijheden (EVRM) en het Verdrag van New York inzake Burgerrechten en Politieke Rechten (IVBPR), beschermde rechten, voorzover daarop door een burger rechtstreeks een beroep kan worden gedaan, worden tot de in artikel 798 lid 1 bedoelde rechten en verplichtingen gerekend. lemand die stelt in een relatie te staan die als «family life/vie familiale» in de zin van artikel 8 EVRM kan worden gekwalificeerd, en die daarom bij voorbeeld een omgangsregeling verzoekt, zal als belanghebbende kunnen worden aangemerkt' ${ }^{282}$

In een uitspraak 21 mei 2010 gaf de Hoge Raad nadere uitleg over hoe het begrip family life te interpreteren in zaken betreffende een ondertoezichtstelling (met uithuisplaatsing). ${ }^{283}$ In casu ging het primair om de vraag in hoeverre een broer of zus moest worden beschouwd als belanghebbende in de zin van art. $798 \mathrm{Rv}$. ten aanzien van een verzoek tot ondertoezichtstelling en uithuisplaatsing van de overige broers/zussen, op basis van het bestaan van family life als in art. 8 EVRM. De uitspraak was echter ook richtinggevend ten aanzien van de vraag in welke gevallen anderen, waaronder ouders, in voornoemde procedure konden worden aangemerkt als belanghebbenden. De Hoge Raad begon met de overweging dat tussen het oudste kind en zijn broers en zusters (en hun ouders) 'family life' bestond in de zin van art. 8 EVRM en dat het oudste kind en zijn broers en zusters daaraan hun belang ontleenden om in gezinsverband met elkaar (en met hun ouders) samen te leven. Ook is juist dat het oudste kind in het door art. 8 EVRM gewaarborgde recht op gezinsleven met zijn broers en zusters werd getroffen door de uithuisplaatsing van zijn broers en zusters. ${ }^{284}$ De Hoge Raad concludeerde dat de ondertoezichtstelling een maatregel betreft met betrekking tot het ouderlijk gezag. Dat gezag wordt over elk minderjarig kind afzonderlijk uitgeoefend en

\footnotetext{
${ }^{281}$ Zie bv. HR 12 september 2014, ECLI:NL:HR:2014:2665 , r.o. 3.3.5, m.nt. S. Wortmann

${ }^{282}$ Kamerstukken II 1991/92, 22 487, nr. 3, p.7. (MvT).

${ }^{283}$ HR 21 mei 2010, ECLI:NL:HR:2010:BL7043.

${ }^{284}$ HR 21 mei 2010, ECLI:NL:HR:2010:BL7043, r.o. 4.3.1.
} 
ten aanzien van elk kind afzonderlijk moest worden beoordeeld of was voldaan aan de wettelijke criteria die golden voor toepassing van de maatregel. Hieruit volgde de conclusie dat de zaak van elk individueel minderjarig kind enkel de uit het gezag over dat kind voortvloeiende rechten en verplichtingen van dit kind en van de ouders die het gezag over dit kind uitoefenden dan wel van anderen die dit kind als behorend tot hun gezin verzorgden en opvoedden (de pleegouders) zijn betrokken. ${ }^{285}$ Aangezien voor de overige minderjarigen in het gezin geen rechten en verplichtingen voortvloeiden uit het ouderlijk gezag over het betreffende kind, werden zij niet als belanghebbenden aangemerkt in deze procedure.

Een verdere specificering van het vraagstuk omtrent het belanghebbendenbegrip ten aanzien van ouders - hetgeen tot de nodige discussie heeft geleid in de rechtspraktijk - volgde uit een uitspraak van de Hoge Raad van 12 september $2014 .{ }^{286}$ In casu werd de vraag voorgelegd of een ouder zonder gezag, die niet het verzoek had gedaan tot (verlenging) van de ondertoezichtstelling, kon worden aangemerkt als belanghebbende in deze procedure. De Hoge Raad beantwoordde deze vraag in navolging van A-G Langemeijer, in zijn uitspraak van 12 september 2014, ontkennend. ${ }^{287}$ De aard van de ondertoezichtstelling als gezagsbeperkende maatregel, maakt dat de maatregelen die in kader van de ondertoezichtstelling kunnen worden getroffen (schriftelijke aanwijzing, uithuisplaatsing) rechtstreeks inbreuk makeen op het gezag. De rechten en verplichtingen van de niet met gezag belaste ouder worden door de ondertoezichtstelling volgens de Hoge Raad niet rechtstreeks geraakt in de zin van art. 798 Rv. ${ }^{288}$ De niet met gezag belaste ouder behoudt wel de mogelijkheid om zijn uit art. 8 EVRM voortvloeiende recht op bescherming van zijn family life met de minderjarige te effectueren. ${ }^{289}$ Dit betekent (onder meer) dat de ouder zonder gezag de mogelijkheid heeft de rechter te verzoeken een omgangsregeling te treffen. ${ }^{290}$

Het feit dat de wetgever aan de ouder zonder gezag de bevoegdheid heeft toegekend om een ondertoezichtstelling te verzoeken, hetgeen een beperking inhoudt van het gezag van de andere ouder, maakt geen verschil ten aanzien van de vraag of de ouder zonder gezag als belanghebbende kan worden aangemerkt. ${ }^{291}$ De wetgever heeft een duidelijk onderscheid willen maken tussen degenen die een verzoek kunnen doen en degenen die als

\footnotetext{
${ }^{285}$ HR 21 mei 2010, ECLI:NL:HR:2010:BL7043, r.o. 4.3.3.

${ }^{286}$ HR 12 september 2014, ECLI:NL:HR:2014:2665.

${ }^{287}$ HR 12 september 2014, ECLI:NL:HR:2014:2665, r.o. 3.3.6. (conclusie A-G F.F. Langemeijer).

${ }^{288}$ HR 12 september 2014, ECLI:NL:HR:2014:2665, r.o. 3.3.8.

${ }^{289}$ HR 12 september 2014, ECLI:NL:HR:2014:2665, r.o. 3.3.8.

${ }^{290}$ HR 27 juni 2014, ECLI:NL:PHR:2014:703, r.o. 2.21. (conclusie A-G F.F. Langemeijer).

${ }^{291}$ HR 12 september 2014, ECLI:NL:HR:2014:2665 (conclusie A-G F.F. Langemeijer), r.o. 3.3.6.
} 
belanghebbenden moeten worden beschouwd. Overigens kan de ouder die geen verzoeker of belanghebbende is door de rechter worden opgeroepen om ter terechtzitting te verschijnen, indien zijn verklaring in verband met de beoordeling van het familierechtelijk verzoek van betekenis kan zijn (art. 800 lid 2 Rv). Deze 'anderen' worden in de regel beschouwd als informant. Het kan bijvoorbeeld gaan om een grootouder die in het kader van een omgangsregeling tussen ouder en minderjarige door de rechter wordt gehoord. ${ }^{292} \mathrm{Zij}$ hebben geen recht op afschriften van het verzoekschrift en overige bescheiden en zijn zelf vrij om te bepalen of wordt ingegaan op de oproep van de rechter.

\subsection{Het hoorrecht van minderjarigen}

Het recht van de minderjarige om te worden gehoord in alle zaken die hem betreffen, doet de in beginsel processueel onbekwame minderjarige het fundamentele recht op hoor en wederhoor toekomen. ${ }^{293}$ Het belang van het hoorrecht voor minderjarigen in jeugdbeschermingszaken kan nauwelijks worden overschat. Niet alleen vanwege de kwetsbare positie van de minderjarige voortkomend uit zijn processuele onbekwaamheid, maar mede gezien de ernstige inbreuk op zijn rechten en vrijheden die verbonden zijn aan de inzet van een jeugdbeschermingsmaatregel. Zeker waar het een scheiding van minderjarige en ouders betreft door een uithuisplaatsing is sprake van één van de meest verstrekkende bevoegdheden die de overheid toekomt om in te grijpen in het gezinsleven. Om in deze zaken recht te doen aan het belang van het kind behoort het honoreren van de eigen inbreng van het kind als basisvoorwaarde te gelden. Het is echter lange tijd gebruikelijk geweest om minderjarigen zoveel mogelijk buiten familierechtelijke procedures te houden vanuit een beschermende gedachte, juist vanwege de kwetsbare positie van de minderjarige en de gevoelige aard van veel familiezaken, zoals conflicten inzake gezag en omgang of een uithuisplaatsing. Mede onder invloed van relevant verdragsrecht is de nadruk op bescherming van de minderjarige door hem buiten gerechtelijke procedures te houden langzaam verschoven naar de erkenning van het belang van participatie.

De invloed van internationale kinder- en mensenrechtenstandaarden waar het gaat om de erkenning van het belang van het hoorrecht van minderjarigen is groot. Het recht van minderjarigen om gehoord te worden is één van de vier algemene beginselen van het IVRK.

\footnotetext{
${ }^{292}$ HR 12 september 2014, ECLI:NL:HR:2014:2665 (conclusie A-G Langemeijer), r.o. 2.26.

${ }^{293}$ Chin-A-Fat, in: GS Burgerlijke rechtsvordering, art. $809 \mathrm{Rv}$, aant. A1.
} 
De erkenning van het belang van het hoorrecht van de minderjarige is ook terug te zien in de rechtspraak van het EHRM. Deze erkenning toont de verschuiving over de rol die kinderen spelen in de besluitvorming: de benadering van het kind als object waarover wordt beslist naar rechtssubject dat een eigenstandige inbreng heeft in beslissingen die hem of haar aangaan. ${ }^{294}$ In het vervolg van deze paragraaf worden de uitgangspunten ten aanzien van het hoorrecht die kunnen worden ontleend aan art. 12 IVRK en art. 9 IVRK en het EVRM eerst toegelicht. Hierna wordt het hoorrecht voor minderjarigen op grond van nationale wetgeving toegelicht en wordt gekeken op welke manier voornoemde kinder- en mensenrechtelijke bepalingen doorwerken in de nationale regeling.

\subsubsection{Hoorrecht van de minderjarige op grond van art. 12 IVRK}

Sinds de inwerkingtreding van het IVRK is zowel in de Nederlandse rechtspraktijk als in de wetenschap de aandacht voor en de erkenning van het kind als drager van rechten sterk toegenomen. ${ }^{295}$ Het is niet overdreven te stellen dat art. 12 IVRK (het recht om te worden gehoord) hier in het bijzonder aan heeft bijgedragen. ${ }^{296}$ Art. 12 IVRK is één van de vier algemene beginselen die in het IVRK zijn geformuleerd, naast het recht op non-discriminatie (art. 2 IVRK), het recht op leven en ontwikkeling (art. 6 IVRK) en het belang van het kind (art. 3 IVRK). Art. 3 IVRK en art. 12 IVRK worden geacht complementair te zijn, in die zin dat het recht van het kind om zijn mening vrijelijk te kunnen uiten bij alle maatregelen die hem betreffen cruciaal is om recht te doen aan het belang van het kind. Art. 12 IVRK garandeert niet alleen het recht om te worden gehoord maar verplicht ook om de mening van de minderjarige serieus in overweging te nemen. Met name dit laatste element uit art. 12 IVRK heeft een geheel nieuwe dimensie toegevoegd aan het hoorrecht, waardoor zeker in vergelijking met enkele decennia terug, de uitingen, wensen, gevoelens en meningen van de minderjarige veel nadrukkelijker worden betrokken in de besluitvorming. Hoewel de term 'participatie' niet voorkomt in de tekst van art. 12 IVRK wordt het hoorrecht in algemene zin beschouwd als kernelement om te komen tot effectieve participatie. Het VN-Comité voor de Rechten van het Kind (hierna VN-Comité) ziet participatie als voortdurend proces, waarin informatie wordt uitgewisseld tussen kinderen en volwassenen op basis dialoog en wederzijds

\footnotetext{
294 Parkes 2013, p. 482.

${ }^{295}$ Vgl. Doek 2000; Doek 2006. Zie voor de doorwerking van het IVRK in de rechtspraak: Ruitenberg 2003; Van Emmerik 2005, p. 700 ev.; De Graaf e.a. 2013.

${ }^{296}$ Liefaard \& Rap, FJR 2018/41. Vgl. Parkes 2013, p. 482.
} 
respect. ${ }^{297}$ Een eerste en absolute voorwaarde is dan ook dat het kind door degene die het kind hoort wordt geïnformeerd over het recht om zijn mening te uiten, over de wijze waarop dat wordt vormgegeven en in hoeverre zijn mening wordt betrokken in de besluitvorming. ${ }^{298}$ Zonder deugdelijk te zijn geïnformeerd is het kind niet op de hoogte van zijn rechten en wordt de mogelijkheid te participeren op voorhand ernstig bemoeilijkt.

Art. 12 lid 1 IVRK verplicht Staten die partij zijn het kind dat in staat is zijn of haar eigen mening te vormen, het recht te verzekeren die mening vrijelijk te uiten in alle aangelegenheden die het kind betreffen, waarbij aan de mening van het kind passend belang moet worden gehecht in overeenstemming met zijn of haar leeftijd en rijpheid. Art. 12 lid 2 IVRK stelt vervolgens dat het kind hiertoe met name in de gelegenheid wordt gesteld te worden gehoord in iedere gerechtelijke en bestuurlijke procedure die het kind betreft, hetzij rechtstreeks, hetzij door tussenkomst van een vertegenwoordiger of een daarvoor geschikte instelling, op een wijze die verenigbaar is met de procedureregels van het nationale recht. De vereisten die kunnen worden ontleend aan de verschillende uitgangspunten in art. 12 IVRK worden in het vervolg nader toegelicht aan de hand van de visie van het VN-Comité voor de Rechten van het Kind in General Comment 12.

Het VN-Comité benadrukt dat art. 12 IVRK een unieke mensenrechtelijke bepaling is: het bevestigt de juridische en sociale status van kinderen, van wie nog niet kan worden verwacht dat ze een mate van autonomie bezitten vergelijkbaar met volwassenen, maar die tegelijkertijd wel moeten worden beschouwd als zelfstandige dragers van rechten. ${ }^{299}$ Lidstaten dienen blijkens de eerste zinsnede van art. 12 IVRK het recht om te worden gehoord voor kinderen te verzekeren. De gekozen formulering benadrukt nogmaals het belang van hoorrecht en laat geen discretionaire ruimte aan de lidstaten, zij zijn verplicht alle noodzakelijk maatregelen te nemen om dit recht voor alle kinderen te realiseren en te waarborgen. ${ }^{300}$ Het recht om te worden gehoord is een individueel recht, toekomend aan het kind, maar moet ook worden beschouwd als een recht voor groepen kinderen, hetgeen ook impliceert dat hiermee rekening gehouden moet worden bij het ontwikkelen en evalueren van beleid en wet- en regelgeving. ${ }^{301}$

\footnotetext{
${ }^{297}$ General Comment No. 12 (CRC/C/GC/12), par. 3.

${ }^{298}$ General Comment No. 12 (CRC/C/GC/12), par. 25.

${ }^{299}$ Zie over het begrip 'autonomie' en de invloed van het IVRK : Lansdown 2005, p. 4.

${ }^{300}$ General Comment No. 12 (CRC/C/GC/12), par. 11 \& 19. Zie ook Blaak e.a 2012, p. 232.

${ }^{301}$ General Comment No. 12 (CRC/C/GC/12), par. 9.
} 


\section{Recht op vrije meningsuiting}

Op basis van art. 12 IVRK heeft ieder kind dat in staat is een mening te vormen het recht om te worden gehoord. Dit moet niet worden gezien als een limitatie. Lidstaten zouden moeten uitgaan van de presumptie dat een kind in staat is zijn mening te vormen en te uiten. In dit licht benadrukt het VN-Comité dat onderzoek heeft uitgewezen dat zelfs zeer jonge kinderen die nog niet in staat zijn zich verbaal uit te drukken, een mening kunnen vormen. Aandacht moet dan ook worden besteed aan non-verbale vormen van communicatie, waaronder spel, lichaamstaal, gezichtsuitdrukking en tekenen of kleuren waardoor kinderen uitdrukking kunnen geven aan hun gevoelens en voorkeuren. ${ }^{302}$ Hoewel dit algemene uitgangspunt kan worden onderschreven lijkt het moeilijk voorstelbaar dat zeer jonge kinderen al een inschatting kunnen maken van de strekking, inhoud en gevolgen van bijvoorbeeld een ondertoezichtstelling. Het VN-Comité stelt op dit punt dat het niet noodzakelijk wordt geacht dat kinderen in staat zijn alle details te doorgronden van het besluitvormingsproces waarin zij zijn betrokken. Voldoende is dat zij in staat zijn zich een mening te vormen over de kwestie. ${ }^{303}$ In ieder geval spreekt daaruit een aanmoediging richting lidstaten om ook jonge(re) kinderen zoveel mogelijk te betrekken in het besluitvormingsproces.

Logischerwijs volgt uit het voorgaande dat lidstaten wordt afgeraden specifieke leeftijdsgrenzen te hanteren waardoor het recht om te worden gehoord wordt beperkt. Nederland hanteert wel een leeftijdsgrens voor het horen van minderjarigen in civiele procedures maar het is niet uitgesloten dat minderjarigen onder de grens (van twaalf jaar) worden gehoord. Uiteindelijk is het belangrijkste dat lidstaten zich voldoende inspannen om ook kinderen onder de twaalf jaar te horen, ook al hanteren zij deze leeftijd als grens.

Volgens de tekst van art. 12 lid 1 IVRK moet het kind zijn mening vrijelijk kunnen uiten in alle aangelegenheden die het kind betreffen. Het VN-Comité geeft aan dat een ruime interpretatie van hetgeen aangelegenheden zijn die het kind betreffen wenselijk is. ${ }^{304}$ Vrijelijk betekent in dit verband dat het kind zonder druk van buitenaf moet kunnen beslissen of hij gebruikt wenst te maken van het recht om gehoord te worden. ${ }^{305}$ Daarnaast geeft het woord 'vrijelijk' aan dat het gaat om de mening van het kind en niet om de mening van anderen. Daaruit volgt ook dat moet worden voorkomen dat het kind wordt geconfronteerd met

\footnotetext{
${ }^{302}$ General Comment No. $12(\mathrm{CRC} / \mathrm{C} / \mathrm{GC} / 12)$, par. 20.

${ }^{303}$ General Comment No. 12 (CRC/C/GC/12), par. 21.

${ }^{304}$ General Comment No. 12 (CRC/C/GC/12), par. 27.

305 General Comment No. 12 (CRC/C/GC/12), par. 22.
} 
manipulatie of anderszins onder druk wordt gezet. In de praktijk kan het complex zijn om te bepalen of het kind zijn eigen standpunten verwoordt, of (impliciet) is beïnvloed door de ouders om bepaalde dingen te zeggen. In jeugdbeschermingszaken bestaat er een reële kans dat het kind is beïnvloed of zelfs onder druk is gezet door de ouder(s) om een bepaald standpunt in te nemen. Bijvoorbeeld in zaken waarin de ouders in het kader van een complexe echtscheiding elkaar via het kind proberen zwart te maken of tegen elkaar op te zetten. Het is derhalve noodzakelijk dat degene die het kind hoort hier op beducht is. Het creëren van een omgeving en condities waarin het kind zich gerespecteerd en veilig voelt moet bijdragen aan de mogelijkheid om zijn mening in alle vrijheid te uiten. ${ }^{306}$

\section{Passend belang hechten aan de mening van het kind}

Het horen van de mening van het kind in de zin van art. 12 IVRK behelst meer dan alleen de mogelijkheid bieden om zijn mening te geven. Indien het kind in staat is een mening te vormen dan moet zijn mening serieus worden genomen en worden betrokken in de besluitvorming. De tekst van art. 12 lid 1 IVRK geeft dit duidelijk weer: aan de mening van het kind moet passend belang worden gehecht overeenkomstig zijn of haar leeftijd en rijpheid. De formulering impliceert dat een beoordeling moet worden gemaakt van de capaciteiten van de minderjarige om te bepalen hoeveel waarde aan zijn mening wordt gehecht. De capaciteiten van de minderjarige moet per individueel geval worden beoordeeld op basis van de leeftijd en rijpheid van de minderjarige. Het VN-Comité benadrukt in dit verband dat een beoordeling van de leeftijd alleen niet voldoende is om te bepalen welk belang aan de mening van de minderjarige moet worden gehecht. Hoewel leeftijd een belangrijk element is zijn er andere factoren zoals sociale, cognitieve en emotionele ontwikkeling en de mate van ondersteuning, die de capaciteiten van de minderjarige mede bepalen. ${ }^{307}$ Rijpheid verwijst in dit verband naar het vermogen van de minderjarige om een redelijke inschatting te kunnen maken van de implicaties van de procedure en naar de capaciteit om hier vervolgens op een redelijke en onafhankelijke manier een mening over te vormen. ${ }^{308}$

Doordat de mate waarin de mening van het kind meeweegt moet worden beoordeeld aan de hand van de leeftijd en rijpheid van het kind geeft art. 12 IVRK tevens blijk van een dynamisch kindbeeld. Art. 12 IVRK moet dan ook in nauwe samenhang worden gelezen met art. 5 IVRK waarin staat dat het kind in de uitoefening van zijn rechten vertegenwoordigd

\footnotetext{
${ }^{306}$ General Comment No. 12 (CRC/C/GC/12), par. 23.

${ }^{307}$ General Comment No. 12 (CRC/C/GC/12), par. 29.

${ }^{308}$ General Comment No. 12 (CRC/C/GC/12), par. 30.
} 
wordt door zijn wettelijke vertegenwoordiger op een wijze die aansluit bij de zich ontwikkelende vermogens van het kind (concept of evolving capacities of the child). De notie 'ontwikkelende vermogens van het kind' veronderstelt dat een kind in zijn ontwikkeling naar volwassenheid in toenemende mate zelfstandig, zonder inmenging van buitenaf, zijn of haar rechten kan en mag uitoefenen. ${ }^{309}$ In het licht van het hoorrecht zoals verwoord in art. 12 IVRK impliceert deze notie dat naarmate het kind zich verder ontwikkelt, het horen van de minderjarige in toenemende mate de vorm dient te hebben van gesprek op basis van gelijkwaardigheid, waarbij de mening van de minderjarige een steeds belangrijkere rol zou moeten spelen in het besluitvormingsproces. Het VN-Comité zegt hierover:

'The more the child himself or herself knows, has experienced and understands, the more the parent, legal guardian or other persons legally responsible for the child have to transform direction and guidance into reminders and advice and later to an exchange on an equal footing. This transformation will not take place at a fixed point in a child's development, but will steadily increase as the child is encouraged to contribute her or his views. This requirement is stimulated by article 12 of the Convention, which stipulates that the child's views must be given due weight, whenever the child is capable of forming her or his own views. In other words, as children acquire capacities, so they are entitled to an increasing level of responsibility for the regulation of matters affecting them. ${ }^{310}$

\section{Terugkoppeling beslissing aan de minderjarige}

Leeftijd, rijpheid en de daarmee verbonden notie van de zich ontwikkelende vermogens van de minderjarige zijn belangrijke factoren in de bepaling van de waarde die aan zijn mening moet worden gehecht. Het VN-Comité noemt echter nog een cruciale factor die in ogenschouw genomen moeten worden als het gaat om passend belang hechten aan de mening van de minderjarige. Het is belangrijk dat de minderjarige kennis kan nemen van de beslissing en de mate waarin zijn mening het besluitvormingsproces heeft beïnvloed. De terugkoppeling naar de minderjarige garandeert dat het horen niet slechts wordt gezien als formaliteit, maar dat zijn mening serieus is overwogen.

Een dergelijke terugkoppeling kan mondeling plaatsvinden, bijvoorbeeld in het adviesgesprek na afloop van het beschermingsonderzoek door de Raad voor de Kinderbescherming. ${ }^{311}$ Het

\footnotetext{
${ }^{309}$ Lansdown 2005, p. 4.

${ }^{310}$ General Comment No. 12 (CRC/C/GC/12), par. 84.

${ }^{311}$ Op basis van het Kwaliteitskader 2013 van de RvdK was een adviesgesprek ook het uitgangspunt. In hoofdstuk 8 wordt nader uitgewerkt hoe de Rvdk in de praktijk invulling gaf aan het adviesgesprek tijdens het beschermingsonderzoek.
} 
verdient echter voorkeur de mening van de minderjarige vast onderdeel uit te laten maken van de rapportage naar aanleiding van het beschermingsonderzoek. Niet duidelijk is of altijd een adviesgesprek wordt gehouden door de RvdK met de minderjarige. En ook als wel een adviesgesprek wordt gehouden is niet gegarandeerd dat duidelijk wordt besproken welke rol de mening van de minderjarige heeft gespeeld. Het weergeven van de mening van de minderjarige in de beschermingsrapportage maakt voor iedereen duidelijk hoe hij over het verzoek tot ondertoezichtstelling/uithuisplaatsing denkt. In de eerste plaats is dit belangrijk voor de minderjarige zelf. Het geeft de minderjarige de mogelijkheid direct of op een later moment nog eens rustig de overwegingen van de RvdK en de kinderrechter door te nemen. Daarnaast geeft het de kinderrechter de mogelijkheid om kennis te nemen van de mening van de minderjarige indien hij leeftijd van twaalf jaar nog niet heeft bereikt, ervan uitgaande dat de minderjarige dan niet wordt gehoord in de gerechtelijke procedure.

Hetzelfde geldt in zekere zin voor de terugkoppeling door de kinderrechter. De kinderrechter kan, als de minderjarige wordt gehoord, weliswaar tijdens het kindgesprek duidelijk maken de mening van de minderjarige belangrijk te vinden maar de echte terugkoppeling van de wijze waarop die mening zijn beslissing heeft beïnvloed ontbreekt dan. Door aandacht te besteden aan de waarde die is gehecht aan de mening van de minderjarige in het verzoekschrift en/of de daaropvolgende beschikking van de kinderrechter, wordt de kans vergroot dat zijn mening consequent wordt betrokken in de besluitvorming.

\section{Hoorrecht in procedures}

Het tweede lid van art. 12 IVRK garandeert het recht om te worden gehoord in iedere gerechtelijke en administratieve procedure die het kind betreft, hetzij rechtstreeks, hetzij door tussenkomst van een vertegenwoordiger. Ook hier geldt volgens het VN-Comité dat moet worden uitgegaan van een brede definitie van gerechtelijke procedures die het kind betreffen. Procedures waaraan kan worden gedacht zijn voor bijvoorbeeld procedures inzake een scheiding van kind en ouders, adoptiezaken, juridische procedures die het kind treffen, zaken waarin kinderen slachtoffer zijn geworden van fysieke of geestelijke mishandeling, seksueel misbruik of andere strafbare feiten, zaken betreffende alleenstaande minderjarige asielzoekers of zaken over gezondheidszorg/ jeugdzorg of (sociale) verzekeringen. ${ }^{312} \mathrm{Bij}$ administratieve procedures kan het bijvoorbeeld gaan om beslissingen over het kind inzake medische behandeling, school(keuze), leefomstandigheden of jeugdbescherming. ${ }^{313}$ Het zou daarbij

\footnotetext{
312 General Comment No. 12 (CRC/C/GC/12), par. 32.

${ }^{313}$ General Comment No. 12 (CRC/C/GC/12), par. 32.
} 
geen verschil moeten maken of de procedure is geïnitieerd door het kind of dat het kind wordt getroffen door een procedure die door een ander is geïnitieerd. ${ }^{314}$ Lidstaten worden aangemoedigd om in hun procedurele voorschriften bepalingen op te nemen waarin de beslissingsbevoegde autoriteiten worden verplicht aan te geven welke waarde aan de mening van het kind is gehecht en wat de gevolgen van de procedure zijn voor het kind. Daarnaast moet ook aandacht worden besteed aan de omstandigheden waaronder de minderjarige wordt gehoord. Het recht om te worden gehoord kan niet effectief worden uitgeoefend in een voor de minderjarige intimiderende- of anderszins ongeschikte omgeving. De juridische of administratieve procedure moet daarom zowel toegankelijk als kindvriendelijk zijn. ${ }^{315}$ Voor gerechtelijke procedures betekent dit volgens het VN-Comité ook dat het kind bij voorkeur niet moet worden gehoord op een openbare zitting maar onder vertrouwelijke condities. ${ }^{316}$ Ten aanzien van de zitting zelf geldt dat de minderjarige vooraf bekend zou moeten worden gemaakt met de indeling van de zittingszaal en de identiteit van de aanwezigen. ${ }^{317}$ Door de verschillende aspecten van de procedure voor de minderjarige te verhelderen wordt de kans vergroot dat hij in staat is effectief te participeren.

Tot slot wordt in art. 12 lid 2 IVRK gesteld dat het kind rechtstreeks, of door tussenkomst van een vertegenwoordiger of daarvoor geschikte instelling, op een wijze verenigbaar met de proceduregels van het nationale recht, in de gelegenheid wordt gesteld om te worden gehoord. Het is echter het kind dat, eenmaal besloten gebruik te maken van het recht om te worden gehoord, zou moet beslissen of het direct gehoord wil worden of door tussenkomst van een vertegenwoordiger. Volgens het VN-Comité behoort wel als uitgangspunt te worden genomen, dat het kind de gelegenheid krijgt rechtstreeks te worden gehoord in iedere procedure. ${ }^{318}$ De eventueel gekozen vertegenwoordiger kan bijvoorbeeld een ouder, advocaat of hulpverlener zijn, waarbij men beducht moet zijn op het feit dat in de verschillende procedures het risico bestaat op een belangenstrijd tussen het kind en de meest voor de hand liggende vertegenwoordigers: de ouders. ${ }^{319}$ Het is derhalve noodzakelijk dat de vertegenwoordiger onafhankelijk is, in die zin dat alleen het belang van het kind wordt

\footnotetext{
${ }^{314}$ General Comment No. 12 (CRC/C/GC/12), par. 33.

315 General Comment No. 12 (CRC/C/GC/12), par. 42-43.

316 General Comment No. 12 (CRC/C/GC/12), par. 42-43.

${ }^{317}$ General Comment No. 12 (CRC/C/GC/12), par. 41. Zie voor de invloed van de setting op de mogelijkheden tot participatie van minderjarigen : Rap 2013. Hoewel in het onderzoek de jeugdstrafzitting centraal staat kunnen de genoemde uitgangspunten net zo goed van belang zijn in de jeugdbeschermingsprocedure.

318 General Comment No. 12 (CRC/C/GC/12), par. 35-37.

${ }^{319}$ General Comment No. 12 (CRC/C/GC/12), par. 36.
} 
gediend (en bijvoorbeeld geen instellingsbelang of het belang van de ouders), en dat de visie van het kind op correcte wijze wordt gedeeld met de beslissingsbevoegde persoon of instantie. ${ }^{320}$

\subsubsection{Hoorrecht bij scheiding van kind en ouders: art. 9 IVRK}

Volgens art. 9 IVRK dienen lidstaten te waarborgen dat het kind niet van zijn ouders wordt gescheiden tegen hun wil. Een dergelijke scheiding is alleen toegestaan indien de bevoegde autoriteiten, onder voorbehoud van rechterlijke toetsing en in overeenstemming met het toepasselijke recht en de toepasselijke procedures, beslissen dat deze scheiding noodzakelijk is in het belang van het kind. De zinsnede 'tegen hun wil' verwijst naar de wil van het kind en zijn ouders tezamen of de wil van de ouders afzonderlijk. ${ }^{321}$ Naar mag worden aangenomen omdat het recht van het kind op ouderlijke zorg onlosmakelijk is verbonden met de wil van de ouders. Opvallend genoeg worden in art. 9 lid 1 IVRK expliciet enkele gevallen genoemd waarin een scheiding van kind en ouders noodzakelijk kan zijn, te weten in geval van misbruik of verwaarlozing van het kind door de ouders, of wanneer de ouders gescheiden leven en er een beslissing moet worden genomen ten aanzien van de verblijfplaats van het kind. Niet is echter beoogd lidstaten te sturen middels een opsomming van indicatoren die een scheiding noodzakelijk zouden maken. De genoemde voorbeelden hebben louter een indicatief karakter. ${ }^{322}$ Het gaat derhalve om een scheiding van kind en ouders in breedst mogelijke zin. In de eerste plaats kan worden gedacht aan kinderen die worden geconfronteerd met een (echt)scheiding van de ouders. Evenals het totale aantal echtscheidingen, stijgt ook het aantal echtscheidingen waarbij minderjarige kinderen zijn betrokken. ${ }^{323}$ Daarnaast is scheiding van kind en ouders natuurlijk ook mogelijk als ouders uit elkaar gaan buiten huwelijk, zoals door ontbinding van het geregistreerd partnerschap of in geval samenwonenden uit elkaar gaan. Een andere belangrijke - en voor dit onderzoek meest relevante - categorie is de scheiding van kind en ouders door de plaatsing van het kind in een pleeggezin of instelling, of een scheiding met een definitiever karakter in geval van een ontheffing of ontzetting uit het ouderlijk gezag. Er is geen duidelijk beeld van de gangbare

\footnotetext{
${ }^{320}$ General Comment No. 12 (CRC/C/GC/12), par. 37.

${ }^{321}$ Detrick 1992, p. 168 e.v.

${ }^{322}$ Doek 2006, p. 24.

${ }^{323}$ In 2014 ging het om 19.906 echtscheidingen waar kinderen bij betrokken waren. In 2010 waren dat 18.115 kinderen. In de tussenliggende periode is ieder jaar een lichte stijging waarneembaar: CBS Jeugdmonitor 2014
} 
praktijk in lidstaten waar het gaat om het scheiden van kind en ouders onder art. 9 IVRK gezien de grote verschillen tussen landen. ${ }^{324}$

Op grond van art. 9 lid 2 IVRK dienen alle betrokken partijen, waaronder het kind, de gelegenheid te krijgen aan de betreffende procedure deel te nemen en hun standpunten naar voren te brengen. Art. 9 lid 2 IVRK vertoont daarmee grote overeenkomsten met art. 12 IVRK, maar lijkt specifiek tot uitdrukking te willen brengen dat in procedures waarin een scheiding van kind en ouders aan de orde is, het recht om te worden gehoord extra belangrijk is. Met name in zaken waarin de scheiding van kind en ouders van overheidswege wordt geïnitieerd en er een reële kans bestaat dat ouders en/of kind het niet eens zijn met de voorgestelde maatregel, moet de mening van het kind worden meegewogen.

Het is dus niet zonder reden dat blijkens art. 9 lid 2 IVRK extra nadruk wordt gelegd op het recht om te worden gehoord in deze categorie zaken. In de eerste plaats mag worden verwacht dat indien een scheiding van kind en ouders wordt voorgestaan, beide ouders worden gehoord, ook in die gevallen waarin slechts een van de ouders de feitelijke verzorging en opvoeding van het kind vormgeeft. Ten tweede geldt dat lidstaten wordt aangeraden een zo breed mogelijke interpretatie van 'alle betrokkenen' te hanteren, zodat kan worden gestreefd naar een beslissing in het belang van het kind op basis van zo volledig mogelijke informatie. ${ }^{325}$ Tot slot moet bij de bepaling van de kring van betrokkenen als in art. 9 IVRK in de eerste plaats worden gedacht aan het kind. ${ }^{326}$ Een scheiding van kind en ouders, om wat voor reden dan ook, zal immers altijd inbreuk maken op het recht van het kind om bij zijn ouders op te groeien.

Is een scheiding van kind en ouders eenmaal tot stand gekomen, dan heeft ieder kind recht op persoonlijk contact en omgang met beide ouders, zo blijkt uit art. 9 lid 3 IVRK. Hiermee wordt recht gedaan aan het uitgangspunt zoals is verwoord in art. 18 lid 1 IVRK: lidstaten moeten alles doen wat in hun vermogen ligt om de erkenning te verzekeren van het beginsel dat beide ouders de gezamenlijke verantwoordelijkheid dragen voor de opvoeding en ontwikkeling van het kind. Het recht van het kind om met beide ouders contact te houden na een scheiding gaat niet zover dat bij gebleken nadeel voor het kind, dit recht niet geheel of gedeeltelijk beperkt zou mogen worden. Als uitgangspunt geldt echter dat het in algemene zin in het belang van het kind is contact te houden met beide ouders. Eenzelfde uitgangspunt is

\footnotetext{
${ }^{324}$ Doek 2006, p. 25.

${ }^{325}$ Doek 2006, p. 27.

${ }^{326}$ Doek 2006, p. 27.
} 
zichtbaar in nationale wetgeving. Na ontbinding van het huwelijk zijn ouders verplicht een ouderschapsplan op te stellen en de kinderen hierbij te betrekken (art. 815 lid 2 Rv). Het kind heeft op grond van art. 1: 377a lid $1 \mathrm{BW}$ recht op omgang met beide ouders en degene die in een nauwe persoonlijke betrekking staat. Een beperking of ontzegging van het recht op omgang is alleen mogelijk op grond van de (strikte) ontzeggingsgronden neergelegd in art. 1:377a lid 3 BW.

Tot slot voegt art. 9 lid 4 IVRK daaraan toe dat mocht de beslissing tot scheiding van kind en ouders van overheidswege zijn genomen, de Staat verplicht is op verzoek informatie te verstrekken over de verblijfplaats van de ouder(s), het kind of een ander familielid.

\subsubsection{Hoorrecht minderjarige op grond van het EVRM}

Het EVRM bevat, in tegenstelling tot het IVRK, geen bepaling waarin de minderjarige expliciet het recht om te worden gehoord, wordt toegekend. Het ligt echter voor de hand dat een dergelijk recht ligt besloten in de verdragsrechten in het EVRM, meer specifiek het recht op een eerlijk proces (art. 6 EVRM) en/of het recht op eerbiediging van het privé- familie en gezinsleven (art. 8 EVRM). Het EHRM heeft zich in verschillende zaken uitgesproken over de klacht van de ouders of de wettelijke vertegenwoordigers dat het niet (voldoende) horen van het kind of het niet betrekken van een deskundige teneinde het kind te horen, een schending oplevert van hun rechten onder art. 6 en 8 EVRM. ${ }^{327}$

Daarnaast is in verschillende zaken zichtbaar dat het EHRM de mening van het kind betrekt en waarde toekent bij de eigen overwegingen. ${ }^{328}$ Gesteld kan dus worden dat het hoorrecht van het kind wel degelijk een rol van betekenis speelt binnen de extensieve jurisprudentie van het EHRM. In het vervolg worden voornoemde elementen ten aanzien van het hoorrecht in het licht van het EVRM nader toegelicht.

Daly betuigt dat in diverse argumenten steun kan worden gevonden voor de stelling dat een hoorrecht voor het kind kan worden afgeleid uit de artt. 6 EVRM (eerlijk proces) en/of art. 8 EVRM (eerbiediging van het recht op privé- familie en gezinsleven). ${ }^{329}$ Zo moet het EVRM worden beschouwd als een 'living instrument' hetgeen betekent dat de interpretatie en uitleg

\footnotetext{
${ }^{327}$ EHRM 3 september 2015, appl. nr. 10161/13, (M. \& M. t. Kroatie); EHRM 8 juli 2003, appl.nr. $31871 / 96$ (Sommerfeld t. Duitsland).

${ }^{328}$ EHRM 9 mei 2006, appl. nr. 18249/02, (C. t. Finland)

${ }^{329}$ Daly 2011, The international journal of human rights 2011, vol. 15, issue 3.
} 
van de rechten in de verdrag geen statisch gegeven is. Maatschappelijke ontwikkelingen en/of gewijzigde rechtsopvattingen kunnen leiden tot een andere, in de regel bredere uitleg en toepassing van de rechten zoals geformuleerd in het EVRM. Het expliciete recht van het kind om gehoord te worden is bij uitstek een recht dat bij de totstandkoming en inwerkingtreding van het EVRM nog geen rol van betekenis speelde, maar inmiddels met de erkenning van het kind als rechtssubject zowel in nationale wetgeving als internationale regelgeving stevig is verankerd. Het is derhalve goed denkbaar volgens Daly dat het EHRM middels evolutieve interpretatie het recht van het kind om gehoord te worden afleidt uit de toepasselijke rechten binnen het EVRM. ${ }^{330}$

Een tweede argument kan worden gevonden in de toegenomen verwijzingen naar het IVRK door het EHRM. ${ }^{331}$ Hoewel het EHRM niet altijd expliciteert of en in welke mate het IVRK invloed heeft gehad op zijn beslissingen, is wel duidelijk dat het bij de interpretatie van het EVRM wordt gevoed door het IVRK. ${ }^{332}$ In verschillende zaken heeft het EHRM geoordeeld dat bij een beroep op de ouderlijke rechten onder art. 8 EVRM, gestreefd moet worden naar een eerlijke balans tussen het belang van het kind en dat van zijn ouders. In het streven naar deze eerlijke balans moet bijzondere waarde worden toegekend aan het belang van het kind, als in art. 3 IVRK. ${ }^{333}$ Zoals reeds genoegzaam is gebleken wordt het recht van het kind om te worden gehoord in iedere aangelegenheid die hem betreft op grond van art. 12 IVRK, in overwegende mate geacht bij te dragen aan het handelen in het belang van het kind. Het is in dit licht niet onaannemelijk dat het EHRM onder verwijzing naar art. 12 IVRK komt tot een schending van het recht van het kind om te worden gehoord. ${ }^{334}$

\section{Horen van het kind als onderdeel van de procedurele rechten van de ouder}

In de zaak Sahin t. Duitsland gaat het om een vader die klaagt dat het niet horen van zijn kind in de procedure tot vaststelling van een omgangsregeling een schending oplevert van de procedurele waarborgen die liggen besloten in het recht op eerbiediging van het privé- familie en gezinsleven, ex. art. 8 EVRM. Bij de beoordeling van de vraag of de in casu genomen beslissingen, welke inbreuk maken op het recht op family life, noodzakelijk waren in een democratische samenleving, gaat het EHRM na of de aangevoerde redenen hiervoor

\footnotetext{
${ }^{330}$ Daly 2011, The international journal of human rights 2011, vol. 15, issue 3.

${ }^{331}$ Daly 2011, The international journal of human rights 201, vol. 15, issue 3.

${ }_{32}$ Daly 2011, The international journal of human rights 201, vol. 15, issue 3. Onder verwijzing naar bv. EHRM 26 mei 1994, appl. nr. 16969/90, (Keegan t. Ierland).

${ }^{333}$ EHRM 6 juni 1998, appl.nr. 22430/93, (Bronda t. Italie).

${ }^{334}$ Daly 2011, The international journal of human rights 201, vol. 15, issue 3. Zie voor een analyse van de vraag of, en zo ja hoe en hoevaak het EHRM verwijst naar het IVRK: Pulles 2014, p. 35 e.v.
} 
voldoende en relevant zijn in het licht van art. 8 lid 2 EVRM. ${ }^{335}$ De Kamer van het EHRM stelt vast dat het kind in deze zaak nimmer is gehoord terwijl het in dergelijke zaken van cruciaal belang is om het kind te horen, teneinde vast te stellen welke beslissing het meest tegemoet komt aan het belang van het kind. ${ }^{336}$ Ondanks dat het toentertijd vijfjarige kind door een deskundige is gehoord die tegen het horen door de rechter heeft geadviseerd, heeft de Duitse rechter volgens het EHRM onvoldoende gemotiveerd waarom van het horen van het kind is afgezien. ${ }^{337}$ Daarbij moet worden aangetekend dat het Hof zwaarwegende betekenis toekent aan het feit dat de deskundige in kwestie heeft nagelaten tijdens het gesprek met het kind over haar vader te spreken. ${ }^{338}$ Het EHRM oordeelt dat de vader op grond daarvan onvoldoende is betrokken in de procedure en komt tot een schending van art. 8 EVRM.

Wortmann toont zich kritisch en komt tot de conclusie dat op basis van de redenering van het EHRM in casu nauwelijks beoordelingsruimte wordt gelaten aan de nationale autoriteiten om te beslissen over de noodzaak van het horen van het kind. ${ }^{339}$ Duitsland kan zich niet verenigen met de uitspraak en besluit de zaak voor te leggen aan de Grote Kamer van het EHRM. De Grote Kamer herziet de beslissing en oordeelt dat het te ver gaat om te eisen dat de nationale rechter het kind altijd moet horen op zitting in omgangszaken. ${ }^{340}$ Of dit noodzakelijk is zal afhangen van de omstandigheden van de zaak, waarbij passende aandacht moet worden gegeven aan de leeftijd en rijpheid van het kind. ${ }^{341}$ In dit geval wijst het EHRM erop dat het kind nog zeer jong was ten tijde van de aanvang van de gerechtelijke procedure ( 3 jaar en 10 maanden) en ziet verder geen reden te twijfelen aan de deskundigheid van de expert en de wijze waarop zij haar onderzoek heeft uitgevoerd. De Grote Kamer komt op basis van de dezelfde feiten en omstandigheden dan ook tot een volledig tegengestelde conclusie en ziet geen schending van art. 8 EVRM.

In de enigszins vergelijkbare zaak Sommerfield t. Duitsland wijst het EHRM nadrukkelijk op het belang van het IVRK voor de realisering van de rechten die ieder kind toekomen. ${ }^{342}$ Lidstaten zijn dan ook verplicht om bij de ontwikkeling en toepassing van beleid het belang van het kind voorop te stellen (3 IVRK) en in het licht van deze zaak heeft het kind het recht

\footnotetext{
${ }^{335}$ EHRM 8 juli 2003, appl. nr. 30943/96, (Sahin t. Duitsland).

${ }^{336}$ EHRM 8 juli 2003, appl. nr. 30943/96, (Sahin t. Duitsland), par. 69.

${ }^{337}$ EHRM 8 juli 2003, appl. nr. 30943/96, (Sahin t. Duitsland), par. 69.

${ }^{338}$ EHRM 8 juli 2003, appl. nr. 30943/96, (Sahin t. Duitsland), par. 69.

${ }^{339}$ EHRM 11 oktober 2001, appl. no. 30943/96 (Sahin t. Duitsland).

${ }^{340}$ EHRM 8 juli 2003, appl. nr. 30943/96, (Sahin t. Duitsland), par. 69.

${ }^{341}$ EHRM 8 juli 2003, appl. nr. 30943/96, (Sahin t. Duitsland), par. 69.

${ }^{342}$ EHRM 8 juli 2003, appl. nr. 31871/96, (Sommerfield t. Duitsland).
} 
persoonlijk en direct contact te onderhouden met beide ouders na een scheiding (art. 9 IVRK). ${ }^{343}$ In de zaak Sommerfield gaat het om een dertienjarig meisje dat in de gerechtelijke procedure tot verzoek om vaststelling van een omgangsregeling meerdere malen uitdrukkelijk te kennen heeft gegeven geen omgang met de vader te willen. De Duitse rechter wijst vervolgens het verzoek tot omgang tussen het kind en de vader af. De vader voert een schending aan van de procedurele waarborgen die liggen besloten in art. 8 EVRM aangezien een psychologisch advies duidelijk had moeten maken in hoeverre de mening van het kind is beïnvloed door de andere ouder. ${ }^{344}$ Ook hier herziet de Grote Kamer van het EHRM de uitspraak van de Kamer en stelt in vergelijkbare bewoordingen als in Sahin t. Duitsland dat het niet altijd noodzakelijk is aanvullend deskundigenonderzoek te doen naar de mening van het kind. ${ }^{345}$ Of zoiets noodzakelijk is zal afhangen van de omstandigheden van het geval, mede gelet op de leeftijd en rijpheid van het kind. ${ }^{346}$ In onderhavige zaak benadrukt het EHRM dat het kind op tien- en elfjarige leeftijd al door dezelfde Duitse rechter in persoon was gehoord, waardoor deze zich een goed beeld heeft kunnen vormen van de mening van het kind.

In beide zaken laat het EHRM zien dat het recht om te worden gehoord van het kind - of het recht op aanvullend deskundigenonderzoek teneinde de mening van het kind helder te krijgen - onderdeel uit kan maken van de procedurele rechten waarop een ouder zich kan beroepen onder art. 8 EVRM. Of het niet (afdoende) horen van het kind een schending oplevert van de rechten van de ouder zal blijkens diverse uitspraken afhangen van de omstandigheden van het geval, waarbij passende aandacht moet worden geschonken aan de leeftijd en rijpheid van het kind. De maatstaf die het EHRM hier aanlegt lijkt geïnspireerd, zo niet direct afgeleid van art. 12 IVRK. Door uit te gaan van de omstandigheden van het geval heeft de jurisprudentie op dit punt een sterk casuïstisch karakter hetgeen noopt tot voorzichtigheid bij de interpretatie van zienswijze van het EHRM op dit punt. Zoals Wortmann terecht opmerkt in haar annotatie:

'De verwijzing naar de omstandigheden van het geval, mede in het licht van de leeftijd en rijpheid van het kind, levert echter niet veel soelaas op. De Grote Kamer zegt niet dat een vijfjarig kind niet gehoord behoeft te worden en zegt ook niet dat, als er een vrij recent en adequaat psychologisch rapport is, een nieuw rapport overbodig is. Dat alles

\footnotetext{
${ }^{343}$ EHRM 8 juli 2003, appl. nr. 31871/96, (Sommerfield t. Duitsland), par. 39.

${ }^{344}$ EHRM 8 juli 2003, appl. nr. 31871/96, (Sommerfield t. Duitsland), par. 53.

${ }^{345}$ EHRM 8 juli 2003, appl. nr. 31871/96, (Sommerfield t. Duitsland), par. 53.

${ }^{346}$ EHRM 8 juli 2003, appl. nr. 31871/96, (Sommerfield t. Duitsland), par. 71.
} 
hangt af van de omstandigheden van het geval. Daarbij spelen de leeftijd en rijpheid van het kind een rol., ${ }^{347}$

Dat leidt wel tot de conclusie dat het EHRM nadrukkelijk aansluiting zoekt bij de uitgangspunten zoals geformuleerd in art. 12 IVRK. Voor de Nederlandse rechtspraktijk veronderstelt dit dat het categorisch hanteren van de leeftijd van twaalf jaar en ouder voor het uitnodigen van het kind om te worden gehoord, kritisch moet worden beschouwd in het licht van art. 8 EVRM. ${ }^{348}$

\section{De waarde die het EHRM hecht aan de mening van het kind}

Het EHRM lijkt -direct of indirect- in toenemende mate belang te hechten aan de mening van het kind in zaken die hem betreffen. In de zaak Hokkanen t. Finland ging het om de 'margin of appreciation' van in dit geval de Finse autoriteiten bij de beslissing omtrent een omgangsregeling en de mate waarin de visie van het kind mag meespelen in die beslissing. ${ }^{349}$ Volgens het EHRM komt lidstaten een ruime mate van beoordelingsvrijheid toe bij de bepaling van de wenselijkheid van een omgangsregeling. ${ }^{350}$ Het EHRM concludeert dat de Finse nationale autoriteiten in beginsel beter in staat zijn om het aangedragen bewijsmateriaal te beoordelen en dat zij voorts de grens van beoordelingsvrijheid die hen toekomt niet hebben overschreden. ${ }^{351}$ In het bijzonder wordt daarbij van belang geacht dat het kind al geruime tijd bij de grootouders verbleef, aan grootouders was gehecht en dat een beslissing waarin een omgangsregeling zou worden vastgesteld uitdrukkelijk zou ingaan tegen de wil het kind. ${ }^{352}$ Het EHRM stelt dus niet dat de mening van het kind doorslaggevend moet zijn bij een dergelijke beslissing, maar komt tot de conclusie dat het binnen de beoordelingsvrijheid valt van de nationale autoriteiten om de mening van het kind doorslaggevend te laten zijn bij deze beslissing.

Enkele jaren na de uitspraak in de zaak Hokkanen t. Finland lijkt het EHRM in de zaak Bronda t. Italië explicieter te verwijzen naar het belang dat moet worden gehecht aan de mening van het kind in zaken die hem betreffen. Het EHRM bepaalt in deze zaak dat zwaarwegende betekenis moet worden toegekend aan de mening van het kind bij de beslissing omtrent zijn verblijfplaats. In dit geval gaat het om een ten tijde van de zaak veertienjarig kind

\footnotetext{
${ }^{347}$ EHRM 11 oktober 2001, appl. nr. 30943/96, m.nt. S.Wortmann (Sahin t. Duitsland), onder punt 4.

${ }^{348}$ EHRM 11 oktober 2001, appl. nr. 30943/96, m.nt. S.Wortmann (Sahin t. Duitsland), onder punt 4.

${ }^{349}$ EHRM 23 september 1994, appl. nr. 19823/92, (Hokkanen t. Finland).

${ }^{350}$ EHRM 23 september 1994, appl. nr. 19823/92, (Hokkanen t. Finland), par. 64.

${ }^{351}$ EHRM 23 september 1994, appl. nr. 19823/92, (Hokkanen t. Finland), par. 64.

352 EHRM 23 september 1994, appl. nr. 19823/92, (Hokkanen t. Finland), par. 63.
} 
dat consequent en stellig heeft aangegeven het pleeggezin waarin zij verblijft niet te willen verlaten. ${ }^{353}$ Het EHRM concludeert dat speciale aandacht moet worden geschonken aan het belang van het kind, dat op de leeftijd van veertien jaar duidelijk kenbaar heeft gemaakt dat zijn in het pleeggezin wil blijven en niet zoals verzocht door de grootouders, wil terugkeren naar haar oorspronkelijke verblijfplaats. Op grond daarvan komt het EHRM niet tot een schending van art. 8 EVRM omdat het belang van het kind (wat primair wordt afgeleid uit de mening van het kind, cursief $\mathrm{JH}$ ) in dit geval zwaarder weegt dan het belang van de grootouders. ${ }^{354}$

\subsubsection{Het hoorrecht van minderjarigen op grond van art. $809 \mathrm{Rv}$}

Net als op tal van andere punten vormden de voorstellen van de commissie Wiarda in het rapport 'Jeugdbeschermingsrecht' de basis voor de wettelijke verankering van het hoorrecht voor minderjarigen in burgerrechtelijke zaken. Enige tijd na publicatie van het rapport van de commissie verscheen een wetsvoorstel waarmee werd beoogd de rechtspositie van minderjarigen in zaken die hen direct raakten te versterken middels de introductie van een algemeen geldend hoorrecht. ${ }^{355}$ Voorgesteld werd een algemene bepaling in de wet te doen opnemen die het hoorrecht voor minderjarigen vanaf de leeftijd van twaalf regelde bij alle beslissingen omtrent het gezag en met betrekking tot alle maatregelen van kinderbescherming. ${ }^{356}$ De leeftijd van twaalf jaar werd ook voorgesteld in het rapport van commissie Wiarda hetgeen een bewuste keuze was. Het markeerde volgens de commissie een duidelijke cesuur in het leven van het kind, het overgrote deel van de kinderen sluit op deze leeftijd de lagere schoolperiode af en begint aan een vervolgopleiding waarin een grotere mate van zelfstandigheid en verantwoordelijkheid wordt verwacht. ${ }^{357}$ Daarnaast sloot een leeftijd van twaalf jaar aan bij de grens voor strafrechtelijke verantwoordelijkheid. Uiteindelijk werd bij wet van 2 juni 1982 het hoorrecht voor minderjarigen vastgelegd in art. 902b oud Rv. Bij de herziening van het procesrecht inzake het personen- en familierecht in 1995 werd het op enkele punten gewijzigde hoorrecht neergelegd in art. $809 \mathrm{Rv} .{ }^{358}$ In het vervolg van deze paragraaf worden de belangrijkste regels en ontwikkelingen ten aanzien van het hoorrecht

\footnotetext{
${ }^{353}$ EHRM 6 juni 1998, appl.nr. 22430/93, (Bronda t. Italie).

${ }^{354}$ EHRM 6 juni 1998, appl.nr. 22430/93, (Bronda t. Italie), par. 62.

355 Kamerstukken II 1979/80, 16 127, nr. 1-3.

${ }^{356}$ Kamerstukken II 1979/80, 16 127, nr. 3, p. 5 (MvT).

${ }^{357}$ Aangehaald in Kamerstukken II 1979/80, 16 127, nr. 3, p. 5 (MvT). Voor de toelichting omtrent de voorgestelde leeftijd van twaalf jaar zie Wiarda 1971, p. 63.

${ }^{358}$ Wet van 7 juli 1994, Stb 1994, 570. Inwerkingtreding 1 april 2015.
} 
beschreven voor de periode waar dit deel van het onderzoek op ziet. Hoewel dus wordt teruggekeken naar de toepassing van het hoorrecht op grond van art. $809 \mathrm{Rv}$ in de jaren 2013 en 2014, moet worden opgemerkt dat art. 809 Rv met de wettelijke herziening van het jeugdbeschermingsrecht in 2015 inhoudelijk ongewijzigd is gebleven. De belangrijkste ontwikkelingen ten aanzien van het hoorrecht van minderjarigen voor de periode na 2015 komen aan bod in deel III van het onderzoek.

Het hoorrecht voor minderjarigen in civiele procedures was ook in 2013 en 2014 neergelegd in art. $809 \mathrm{Rv}$. De tekst van art. $809 \mathrm{Rv}$. luidde als volgt: 'in zaken betreffende minderjarigen, uitgezonderd die welke het levensonderhoud van een minderjarige betreffen die de leeftijd van zestien jaren nog niet heeft bereikt, beslist de rechter niet dan na de minderjarige van twaalf jaren of ouder in de gelegenheid te hebben gesteld hem zijn mening kenbaar te maken, tenzij het naar het oordeel van de rechter een zaak van kennelijk ondergeschikt belang betreft. De rechter kan minderjarigen die de leeftijd van twaalf jaren nog niet hebben bereikt, in de gelegenheid stellen hem hun mening kenbaar te maken op een door hem te bepalen wijze. Hetzelfde geldt in zaken betreffende het levensonderhoud van minderjarigen die de leeftijd van zestien jaren nog niet hebben bereikt.'

Minderjarigen van twaalf jaar of ouder moesten in de gelegenheid worden gesteld hun mening kenbaar te maken en minderjarigen onder de leeftijd van twaalf jaar konden in de gelegenheid worden gesteld hun mening kenbaar te maken. Het lijdt geen twijfel dat onder 'zaken betreffende minderjarigen' ook jeugdbeschermingszaken werden begrepen. Art. 809 lid 1 Rv gaf ook direct een uitzondering op het uitgangspunt dat de rechter pas besliste indien de minderjarige van twaalf jaar en ouder in de gelegenheid was gesteld zijn mening kenbaar te maken: indien het een zaak van 'kennelijk ondergeschikt belang' betrof kan dit achterwege blijven. De invulling van dit open begrip werd overgelaten aan de rechtspraktijk hoewel op grond van de wetsgeschiedenis een ruime interpretatie niet aannemelijk was. ${ }^{359}$ Voor de bepaling van het oordeel dat van het oproepen van de minderjarige kon worden afgezien verwees de wetgever naar de gronden die hiervoor golden in oud art. $902 \mathrm{~b} \mathrm{Rv}$, waar tot de inwerkintreding van art. $809 \mathrm{Rv}$ het hoorrecht was neergelegd. Op grond van art. $809 \mathrm{Rv}$ hoefde de rechter ook minderjarigen onder de zestien jaar niet te horen indien het ging om zaken betreffende het levensonderhoud van de minderjarige. Daarnaast gold blijkens art. 809 lid $3 \mathrm{Rv}$ dat indien de gelegenheid waarop de minderjarige zijn mening kenbaar kon maken

\footnotetext{
${ }^{359}$ Chin-A-Fat, in: GS Burgerlijke rechtsvordering, art. $809 \mathrm{Rv}$, aant. 2
} 
niet kon worden afgewacht zonder onmiddellijk en ernstig gevaar voor de minderjarige, de rechter onder meer een beschikking tot voorlopige ondertoezichtstelling eventueel met machtiging uithuisplaatsing kon geven. Wel gold dat de minderjarige in dat geval binnen twee weken in de gelegenheid moest worden gesteld zijn mening kenbaar te maken, anders verloor de beschikking zijn kracht.

In een uitspraak van 1 november 2013 voegde de Hoge Raad nog drie gronden toe op basis waarvan kon worden afgezien van het horen van de minderjarige. ${ }^{360} \mathrm{Op}$ basis van de wetsgeschiedenis werd aangenomen dat van het horen kon worden afgezien als de minderjarige kennelijk niet gehoord wilde worden of de minderjarige wegens een lichamelijke of geestelijke stoornis niet in staat was zijn mening te vormen. ${ }^{361}$ Op basis van buitenlandse regelingen werd daar als derde grond aan toegevoegd de vrees dat het bieden van de gelegenheid om zijn mening kenbaar te maken de gezondheid van de minderjarige zou schaden. ${ }^{362}$ Tegelijkertijd benadrukte de Hoge Raad in deze zaak het belang van het hoorrecht, hetgeen veronderstelt dat niet te snel mag worden aangenomen dat zich één van de gronden voordoet op basis waarvan van het horen kon worden afgezien. In casu was sprake van een minderjarige die geen uitnodiging voor een kindgesprek in hoger beroep had ontvangen omdat Bureau Jeugdzorg een dergelijk gesprek te belastend vond voor de minderjarige. De (veertienjarige) minderjarige werd niet gekend in de beslissing van Bureau Jeugdzorg. Het gerechtshof 's Gravenhage was kritisch over de handelswijze van Bureau Jeugdzorg maar besloot geen nieuwe uitnodiging naar de minderjarige te sturen, kennelijk omdat de mening van de minderjarige niet tot een andere beslissing zou hebben geleid. ${ }^{363} \mathrm{De}$ Hoge Raad oordeelde dat voor zover de beslissing van het gerechtshof op laatstgenoemd standpunt berustte het blijk gaf van een onjuiste rechtsopvatting. Voor zover het besluit was gebaseerd op de drie eerder genoemde gronden op basis waarvan kon worden afgezien van het horen van de minderjarige, was het ontoereikend gemotiveerd. ${ }^{364}$

De rechtbank behoorde de minderjarige van twaalf jaar en ouder een oproep te versturen waarin stond dat de minderjarige de gelegenheid had zijn mening kenbaar te maken. Hieruit volgde ook dat deze mogelijkheid moest worden gezien als hoorrecht en niet als hoorplicht. De minderjarige was vrij om te besluiten van de gelegenheid geen gebruik te maken. Het

\footnotetext{
${ }^{360}$ HR 1 november 2013, ECLI:NL:HR:2013:1084, r.o. 3.3.5., m.nt. S. Wortmann.

${ }^{361}$ HR 1 november 2013, ECLI:NL:HR:2013:1084, r.o. 3.3.5., m.nt. S. Wortmann.

${ }^{362}$ HR 1 november 2013, ECLI:NL:HR:2013:1084, r.o. 3.3.5., m.nt. S. Wortmann.

${ }^{363}$ Gerechtshof's Gravenhage 19 december 2012, ECLI:NL:GHSGR:2012:5085, (niet gepubliceerd).

${ }^{364}$ HR 1 november 2013, ECLI:NL:HR:2013:1084, r.o. 3.3.6., m.nt. S. Wortmann.
} 
horen van de minderjarige gebeurde in de regel op de rechtbank, in een zogenaamd kindgesprek, voorafgaand aan de zitting. Dit was evenwel niet noodzakelijk. De regel dat de rechter de wijze en plaats bepaalde waar de minderjarige zijn mening kenbaar maakte was weliswaar niet neergelegd in art. $809 \mathrm{Rv}$. maar volgde uit oud art. $902 \mathrm{~b}$ lid $3 \mathrm{Rv}$., waarvan het karakter en de inhoud nog steeds relevant werden geacht voor de toepassing van het hoorrecht.

Hetgeen is aangeduid als 'kindgesprek' werd lange tijd omschreven als 'kinderverhoor', een term die lijkt te suggereren dat de rechter primair beoogde informatie van het kind te verkrijgen als fundament voor zijn uitspraak. Groenhuijsen zag hierin een belangrijk verschil met het horen door de Raad voor de Kinderbescherming, dat meer gericht zou zijn op het verhelderen van de ontwikkelingsbedreiging, het kind de kans geven te begrijpen wat er gebeurt en het kind de kans geven om mee te praten. ${ }^{365}$ Dit onderscheid is niet geheel overtuigend. De Raad voor de Kinderbescherming poogt net zo goed als de rechter informatie te vergaren om een beslissing te nemen over de noodzaak van een

jeugdbeschermingsmaatregel. Andersom zal de kinderrechter ook het kind in beginsel de kans willen geven om mee te praten en wenst hij de ontwikkelingsbedreiging ook zo helder mogelijk te krijgen. De vraag is dan ook of met het bieden van de mogelijkheid aan het kind om zijn mening te geven, om beter te begrijpen wat er gebeurt waardoor het kind ook beter in staat wordt gesteld te participeren, niet tevens het belangrijkste doel van het kindgesprek is gegeven. Het is daarbij niet uitgesloten dat het gesprek informatie oplevert die uiteindelijk waardevol is voor de te nemen beslissing.

\section{Het horen van twaalfminners}

Voor minderjarigen onder de leeftijd van twaalf jaar gold dat zij door de rechter in de gelegenheid konden worden gesteld hun mening kenbaar te maken mochten zij hier prijs op stellen. Het lijkt dus de minderjarige zelf, al dan niet via zijn ouders, een advocaat of een andere professional, die de kinderrechter kenbaar moest maken dat hij gehoord wilde worden. De kinderrechter besliste uiteindelijk geheel zelfstandig of hij de minderjarige in de gelegenheid stelde zijn mening kenbaar te maken. De Hoge Raad concludeerde in een uitspraak van 24 januari 2003 dat niet alleen de beslissing over het horen van twaalfminners geheel binnen de discretionaire bevoegdheid van de rechter viel, maar ook dat de beslissing tot het niet horen van de minderjarige niet gemotiveerd hoefde te worden, behoudens

\footnotetext{
${ }^{365}$ Groenhuijsen FJR 2007/101.
} 
bijzondere omstandigheden. ${ }^{366}$ De uitspraak gaf geen verdere aanwijzingen over hetgeen onder bijzondere omstandigheden kon worden verstaan.

In hoeverre twaalfminners voor 2015 van de mogelijkheid gebruik maakten om te worden gehoord, is grotendeels onbekend. ${ }^{367}$ De wijze waarop de regeling van art. $809 \mathrm{Rv}$ was vormgegeven doet echter vermoeden dat minderjarigen onder de twaalf jaar niet of nauwelijks van deze mogelijkheid gebruik maakten, juist omdat zij naar het zich laat aanzien op geen enkele wijze werden gestimuleerd om hun mening kenbaar te maken. Voor twaalfplussers geldt dat mag worden aangenomen dat zij in de regel een oproep ontvingen voor de behandeling van het verzoek. Echter de mate waarin deze groep feitelijk gebruik maakte van het recht om te worden gehoord is ook grotendeels onduidelijk. Zo is weinig tot niets bekend over de mate waarin minderjarigen van twaalf jaar en ouder gebruik maakten van de mogelijkheid om te worden gehoord, welke redenen ten grondslag lagen aan de eventuele weigering van de minderjarige om gehoord te worden of de mate waarin de rechters op basis van de wettelijke gronden afzagen van het horen van de minderjarige.

Gedurende het wetgevingsproces inzake de wet bevordering voortgezet ouderschap en zorgvuldige scheiding in 2006 vroegen de leden van de CDA-fractie zich af waarom een expliciete leeftijdsgrens van twaalf jaar werd gehanteerd nu het ook mogelijk was voor de rechter jongere kinderen te horen. ${ }^{368}$ De minister liet weten de leeftijdsgrens niet te verlagen omdat de regeling op basis van art. $809 \mathrm{Rv}$ voldoende ruimte bood aan de minderjarige om zijn stem te laten horen en daarnaast gold dat het stellen van een leeftijdsgrens altijd iets willekeurigs heeft. ${ }^{369}$ Bewust of onbewust gaf de toenmalige minister daarmee juist een argument voor een individuele beoordeling van ieder kind, zonder hantering van leeftijdsgrenzen. Een individuele beoordeling biedt immers de mogelijkheid te beslissen over het hoorrecht op basis van de capaciteiten van ieder kind afzonderlijk, hetgeen de mate van willekeur die ligt besloten in het stellen van een leeftijdsgrens, zou verkleinen. De minister was echter van mening dat er geen aanleiding was te veronderstellen dat de regeling in art. $809 \mathrm{Rv}$ niet in overstemming zou zijn met art. 12 IVRK, nu dit artikel niet verplicht dat ieder kind door de rechtbank wordt gehoord. ${ }^{370}$ Dat is op zichzelf juist, maar neemt niet weg dat het hanteren van een leeftijdsgrens van twaalf jaar kritisch moet worden bezien in het licht van

\footnotetext{
${ }^{366}$ HR 24 januari 2003, ECLI:NL:PHR:2003:AF0204, m.nt. Sylvia Wortmann..

${ }^{367}$ Doek 2008, p. 36.

${ }^{368}$ Kamerstukken II 2005/06, 30145, nr. 5.

${ }^{369}$ Kamerstukken II 2005/06, 30145, nr. 6.

${ }^{370}$ Kamerstukken II 2005/06, 30145, nr. 6.
} 
art. 12 IVRK. Hoewel op grond van art. 12 IVRK leeftijdsgrenzen niet expliciet verboden zijn, worden lidstaten aangemoedigd om geen leeftijdsgrenzen te stellen voor het horen van minderjarigen. Aan de andere kant moet ook worden opgemerkt dat een individuele beoordeling van het kind er ook toe zou kunnen leiden dat onder aan de streep kinderen minder snel gehoord worden dan in het geval er een leeftijdsgrens is gesteld. Zeker binnen de doelgroep die te maken krijgt met een jeugdbeschermingsmaatregel zijn er kinderen die qua ontwikkelingsniveau ver achter lopen.

Voor de instanties die de minderjarige horen, in dit onderzoek de Raad voor de Kinderbescherming en de kinderrechter, is het van belang de leeftijd en rijpheid van de minderjarige in ogenschouw te nemen, om te bepalen welke waarde aan zijn mening wordt gehecht. Er is immers een groot verschil tussen een thuiswonende twaalfjarige en een zeventienjarige die via een kamertrainingstraject op zichzelf wil gaan wonen. Leeftijd speelt hier wel degelijk een belangrijke rol, maar het gaat net zo goed over de specifieke sociale- en emotionele ontwikkeling van de minderjarige, de band met de ouders en het toekomstperspectief op korte en lange termijn.

Voor de groep jeugdigen die de meerderjarigheidsgrens nadert geldt dat het einde van het gezag in zicht komt en daarmee in beginsel ook de mogelijkheid om de minderjarige een jeugdbeschermingsmaatregel op te leggen. ${ }^{371}$ De mogelijkheden om deze groep ( uitgaande van zestien- en zeventienjarigen) nog te beïnvloeden of te beschermen binnen een gedwongen kader zijn beperkt. Dit zou er toe moeten leiden dat de visie van de minderjarige over zijn toekomst en weg naar zelfstandigheid als uitgangspunt wordt genomen in de besluitvorming. Er is voor de overheid immers nog maar zeer beperkt de tijd om deze groep dwingend bij te sturen. Overigens wordt hier niet betoogd dat passend belang hechten impliceert dat vanzelfsprekend tegemoet wordt gekomen aan de mening van de minderjarige.

\section{Vertrouwelijkheid van het kindgesprek}

Een ander veelbesproken discussiepunt is de vertrouwelijkheid van hetgeen de minderjarige in uitoefening van zijn hoorrecht deelde tijdens het kindgesprek met de kinderrechter. Lange tijd gold op basis van de verschillende procesreglementen van de rechtbanken dat ter zitting aan ouders en belanghebbenden niet te kennen werd gegeven wat het kind had verklaard, tenzij het kind desgevraagd had aangegeven hier geen bezwaar tegen te hebben en het de rechter

\footnotetext{
${ }^{371}$ Op grond van art. 1:233 eindigt minderjarigheid, wettelijke uitzonderingen daargelaten, bij de leeftijd van 18 jaar.
} 
wenselijk voorkwam de informatie te delen. ${ }^{372}$ Een werkwijze die overigens niet werd gevolgd door de verschillende gerechtshoven. ${ }^{373}$ De regeling heeft veel kritiek gekregen omdat het strijdig leek met het recht op een eerlijk proces zoals neergelegd in art. 6 EVRM. In de zaak Moser t. Oostenrijk oordeelde het EHRM dat de ouder voldoende mogelijkheid moet worden geboden om te reageren op de informatie die aan de beslissing van de autoriteiten ten grondslag heeft gelegen. ${ }^{374}$ Daarnaast raakte deze gang van zaken aan het voor het burgerlijk recht fundamentele beginsel van hoor- en wederhoor. Blijkens art. 19 Rv. veronderstelt het beginsel van hoor en wederhoor dat de rechter partijen in de gelegenheid stelt over en weer hun standpunten naar voren te brengen en toe te lichten en zich uit te laten over elkaars standpunten en over alle bescheiden en andere gegevens die in de procedure ter kennis van de rechter zijn gebracht. Daarnaast geldt dat de rechter zijn beslissing alleen op die gegevens van feitelijke aard mag baseren, waarvan partijen de juistheid en volledigheid hebben kunnen nagaan en in proces ter discussie hebben kunnen stellen.

De informatie die de minderjarige deelde tijdens het kindgesprek werd in beginsel niet met de ouders gedeeld, tenzij de minderjarige uitdrukkelijk aangaf hier geen bezwaar tegen te hebben en de rechter vervolgens ook geen bezwaar zag in het delen van de informatie. Ongetwijfeld beoogde deze beschermende opstelling de minderjarige niet in een lastige positie ten opzichte van zijn ouders te brengen. Denk bijvoorbeeld aan de zeer reële situatie in jeugdbeschermingszaken dat de minderjarige de rechter vertelde over de problemen in de thuissituatie. Dit knelde echter met het beginsel van equality of arms, hetgeen betekent dat iedere partij het recht heeft zijn zaak vanuit een gelijk positie als de tegenpartij aan de rechter voor te leggen. Toegang tot de door anderen geleverde informatie en het recht om verweer te voeren was daarvoor onontbeerlijk. Het achterhouden van informatie uit het kindgesprek voor de ouders kon een schending opleveren van art. 6 EVRM (fair trial) en art. 8 EVRM (recht op eerbiediging van privé- familie- en gezinsleven). ${ }^{375}$ In algemene zin kon worden gesteld dat het EVRM maar zeer beperkt ruimte laat aan de rechter om informatie verstrekt door het kind te verzwijgen voor de ouders. ${ }^{376}$ Ook Van Teeffelen concludeerde vanuit juridisch perspectief dat het achterhouden van de informatie uit het kindgesprek voor de ouders complex, zo niet onrechtmatig was, maar voegde daar nog een belangrijk aspect aan toe: hoe deze regeling te

\footnotetext{
372 Zie hierover van Teeffelen EB 2007/41.

${ }^{373}$ Van Teeffelen $E B$ 2007/41.

${ }^{374}$ EHRM 12-09-2006, ECLI:NL:XX:2006:AZ1538 (Moser t. Oostenrijk), par. 72.

375 Zie hierover Bruning FJR 2007/1.

376 Vgl. EHRM 12-09-2006, ECLI:NL:XX:2006:AZ1538 (Moser t. Oostenrijk), par. 72. ; EHRM 17 december 2002, appl. nr. 35731/97 (Venema t. Nederland), par. 96.
} 
beoordelen vanuit menselijk perspectief.? Welk signaal werd hiermee afgegeven aan de minderjarige, die indien de rechter zo besliste, weer met zijn geheim naar huis werd gestuurd $?^{377}$ Groenhuijsen sloot zich daar vanuit gedragswetenschappelijk perspectief bij aan.

Indien de rechter de informatie die het kind verstrekte stilhield, verviel de morele basis om het kind te ondervragen. ${ }^{378}$ Geconcludeerd werd dat het belangrijk is aan het begin van het kindgesprek duidelijk te maken dat de informatie op zitting met ouders wordt gedeeld, zodat het kind hierop kan anticiperen. ${ }^{379}$

Voor de periode 2013 en 2014 vond voornoemd uitgangspunt zijn uitwerking in de toen geldende procesreglementen van de rechtbanken en gerechtshoven. Hierin stond dat de minderjarige alleen werd gehoord en dat van het verhoor geen proces verbaal werd opgemaakt. ${ }^{380}$ Tijdens de mondelinge behandeling van de zaak deelde de kinderrechter vervolgens kort en zakelijk mee wat de minderjarige mondeling dan wel schriftelijk had verklaard. Daarmee werd recht gedaan aan het beginsel van hoor en wederhoor aangezien ouders de kans kregen de informatie te beoordelen, aan te vullen of te betwisten. Het was aan de kinderrechter om richting de minderjarige op een heldere manier te communiceren dat zijn informatie werd gedeeld op zitting. Tegelijkertijd moest het streven zijn de minderjarige in een positie te brengen waarin hij werd gestimuleerd vrijelijk zijn mening te uiten. Het is duidelijk dat er een zekere spanning bestaat tussen deze uitgangspunten.

\subsection{Uitgangspunten voor het dossieronderzoek in jeugdbeschermingszaken}

In dit hoofdstuk is de rechtspositie van de minderjarige (en in mindere mate de rechtspositie van zijn ouders) in de jeugdbeschermingsprocedure op hoofdlijnen geschetst. Het doel hiervan is te bepalen welke positie de minderjarige inneemt in de jeugdbeschermingsprocedure en welke rechten hij kan uitoefenen gedurende het proces.

In de eerste plaats is aandacht besteed aan de wettelijke regeling van gezag. Volgens de wet behoren minderjarigen onder gezag te staan (1:245 BW). De ondertoezichtstelling beperkt het gezag van de ouders in die zin dat zij gehouden zijn de aanwijzingen van de gezinsvoogd op te volgen. Vooral van belang voor dit onderzoek is dat het gezag van de ouders zich ook

\footnotetext{
377 Van Teeffelen $E B$ 2007/41.

${ }^{378}$ Groenhuijsen FJR 2007/101.

${ }^{379}$ Groenhuijsen FJR 2007/101.

${ }^{380}$ Het betreft hier het Procesreglement Civiel Jeugdrecht 2014, art. 7.2, Stcrt. 2014/36 en voor zaken in hoger beroep, het Procesreglement Verzoekschriftprocedures Familiezaken Gerechtshoven 2013, art. 2.4.9; Stcrt. $2013 / 36149$.
} 
uitstrekt tot de vertegenwoordig van de minderjarige in en buiten rechte. De minderjarige kan derhalve niet zelfstandig optreden in de procedure waarin een ondertoezichtstelling wordt verzocht. Op het uitgangspunt van de processuele onbekwaamheid van de minderjarige worden in het jeugdbeschermingsrecht twee belangrijke uitzonderingen gemaakt. In de eerste plaats kan de minderjarige wel diverse verzoeken zelfstandig indienen ten aanzien van de uitvoering van de ondertoezichtstelling. Daarnaast is de minderjarige die de leeftijd van twaalf jaar heeft bereikt, in zaken betreffende een machtiging gesloten jeugdzorg, bekwaam in rechte op te treden. Hetzelfde geldt voor de minderjarige die de leeftijd van twaalf jaar nog niet heeft bereikt maar in staat kan worden geacht tot een redelijke waardering van zijn belangen terzake. Daarnaast krijgt de minderjarige ambtshalve een raadsman toegewezen. Deze uitzondering moet de betrokkenheid van de minderjarige in een procedure die mogelijk leidt tot vrijheidsbeneming garanderen.

Vervolgens is de positie van de minderjarige en zijn ouders als belanghebbenden in de jeugdbeschermingsprocedure uitgewerkt. Voor de minderjarige geldt dat hij als belanghebbende kan worden aangemerkt in de jeugdbeschermingsprocedure. Voorgaande betekent echter niet dat de minderjarige onverkort alle rechten die normaal gesproken aan belanghebbenden toekomen kan uitoefenen. De minderjarige dient zich bijvoorbeeld voor de uitoefening van het recht op inzage en afschrift van de processtukken te wenden tot zijn wettelijke vertegenwoordiger. Ontstaat hier een conflict waardoor de belangen van de minderjarige onvoldoende worden behartigd dan kan verzocht worden om een bijzondere curator.

Vanwege de processuele onbekwaamheid van de minderjarige wordt zijn rechtspositie met name ingevuld door het recht om te worden gehoord. Op grond van art. $809 \mathrm{Rv}$ moet de minderjarige van twaalf jaar en ouder in de gelegenheid worden gesteld om te worden gehoord in de gerechtelijke procedure. Voor minderjarigen onder de twaalf jaar geldt dat zij in de gelegenheid gesteld kunnen worden om te worden gehoord. Vervolgens is de wettelijke regeling van art. $809 \mathrm{Rv}$ afgezet tegen het recht van de minderjarige om te worden gehoord op grond van art. 12 IVRK art. 9 IVRK en art. 8 EVRM. Belangrijke toevoeging blijkens de tekst van art. 12 IVRK is dat de minderjarige niet alleen zijn mening vrijelijk moet kunnen uiten maar dat er passend belang aan zijn mening moet worden gehecht, afhankelijk van zijn leeftijd en rijpheid. Voor de analyse van jeugdbeschermingsdossiers in deel II van dit onderzoek kunnen op basis van voornoemde vereisten de volgende uitgangspunten geformuleerd: 
- De minderjarige heeft het recht om te worden gehoord in alle fasen van het besluitvormingsproces. Tijdens het beschermingsonderzoek moeten in principe alle minderjarigen worden gehoord. In ieder geval is zichtbaar in de beschermingsrapportage van de $\mathrm{RvdK}$ of de minderjarige is gehoord. In de gerechtelijke procedure moet de minderjarige van twaalf jaar en ouder in de gelegenheid worden gesteld om te worden gehoord. Voor minderjarigen onder de twaalf is het wenselijk dat zij worden gestimuleerd om te worden gehoord.

- De minderjarige heeft er recht op dat zijn mening - afhankelijk van zijn leeftijd en rijpheid wordt meegewogen in de besluitvorming. Bij voorkeur geeft het beschermingsrapport van de RvdK informatie over mening van de minderjarige ten aanzien van het verzoek. Hetzelfde geldt voor de beschikking op het verzoek.

- De minderjarige heeft er recht op te worden geïnformeerd over de wijze waarop hij kan participeren en dient te worden geïnformeerd over de beslissing van de RvdK en de kinderrechter. Onderdeel daarvan is ook dat de minderjarige kennis kan nemen van de beslissing en de mate waarin zijn mening het besluitvormingsproces heeft beïnvloed. Deze terugkoppeling kan mondeling plaatsvinden bijvoorbeeld in een adviesgesprek waarin RvdK de minderjarige uitlegt hoe zijn mening heeft meegewogen in de besluitvorming. Voor de kinderrechter is dit lastiger omdat de minderjarige doorgaans na de beslissing niet meer wordt gesproken. De beschikking is om die reden de meest voor de hand liggende plek om aandacht te besteden aan de mening van de minderjarige. 


\section{Gronden en doelstellingen van de jeugdbeschermingsmaatregelen}

\subsection{Inleiding}

De wettelijke bepalingen van de verschillende jeugdbeschermingsmaatregelen waren en zijn neergelegd in Boek 1, Titel 14, Afdeling 4 BW, en geven in algemene zin de vereisten weer waaraan moet zijn voldaan wil een inbreuk op het ouderlijk gezag ter bescherming van de minderjarige gerechtvaardigd zijn. In dit hoofdstuk worden de rechtsgronden en de wettelijke doelstellingen van de jeugdbeschermingsmaatregelen uitgewerkt zoals die golden tot aan de wettelijke herziening van de jeugdbeschermingsmaatregelen op 1 januari 2015. In deel II van dit onderzoek wordt gekeken of, en zo ja hoe de RvdK in het beschermingsrapport en de kinderrechter in de beschikking aandacht besteden aan de wettelijke gronden en de doelstelling van de maatregelen. Het is daarom noodzakelijk eerst een compleet overzicht te geven van de rechtsgronden die van toepassing waren binnen het jeugdbeschermingsrecht in 2013 en 2014. Uiteindelijk zijn de rechtsgronden bepalend voor de vraag wanneer de feiten en omstandigheden zodanig zijn dat een jeugdbeschermingsmaatregel gerechtvaardigd is. Dit hoofdstuk beoogt dan ook de theoretische basis te schetsen op basis waarvan in deel II van het onderzoek de toepassing van het materiële jeugdbeschermingsrecht kan worden geanalyseerd. De nadruk ligt op de maatregelen die centraal staan binnen het dossieronderzoek, te weten de ondertoezichtstelling en de machtiging uithuisplaatsing in het kader van de ondertoezichtstelling. Om de onderlinge verhouding en afstemming tussen de jeugdbeschermingsmaatregelen goed te begrijpen worden alle in 2013/2014 van toepassing zijnde jeugdbeschermingsmaatregelen beschreven. Dit betekent dat ook de gezagsontnemende maatregelen van ontheffing en ontzetting uit het gezag aan bod komen. Hierbij speelt ook mee dat voor een goed begrip van het jeugdbeschermingsrecht na 2015 (deel III van het onderzoek) het noodzakelijk is een volledig overzicht te hebben van de belangrijkste ontwikkelingen binnen- en het functioneren van het materiële jeugdbeschermingsrecht voor die tijd.

In paragraaf 4.2 worden de rechtsgrond van de ondertoezichtstelling en de wettelijke doelstelling van ondertoezichtstelling beschreven. Vervolgens wordt een overzicht gegeven van de regels omtrent de duur, verlenging en beëindiging van de ondertoezichtstelling, evenals een korte toelichting omtrent de regels inzake de voorlopige ondertoezichtstelling. Paragraaf 4.3 kent een vergelijkbare opzet maar dan ten aanzien van de machtiging uithuisplaatsing. Daarna wordt in paragraaf 4.4 aandacht besteed aan de rechtsgrond van de machtiging uithuisplaatsing in een accommodatie voor gesloten jeugdzorg. Tot 1 januari 2015 
waren de vereisten voor een dergelijke machtiging neergelegd in de Wet op de Jeugdzorg. De wettelijke gronden die hiervoor golden worden beschreven aangezien het dossieronderzoek ook zaken bevat waarin een machtiging gesloten jeugdzorg is verzocht door de RvdK. Tot slot worden de gezagsontnemende maatregelen van ontheffing en ontzetting uit het gezag in paragraaf 4.5 op hoofdlijnen behandeld.

\subsection{De ondertoezichtstelling}

De primaire rechtvaardiging voor gedwongen overheidsingrijpen in het gezinsleven moet in beginsel volgen uit de wet zoals uit het legaliteitsbeginsel voortvloeit. De verschillende rechtsgronden van de jeugdbeschermingsmaatregelen behoren de overheid en het gezin voldoende houvast te bieden ten aanzien van de vraag wanneer een inbreuk op het recht op een ongestoord familie- en gezinsleven gerechtvaardigd is. ${ }^{381}$ Zeker waar het gedwongen overheidsingrijpen betreft is een duidelijke legitimatie voor het handelen van de overheid wenselijk. De maatregelen van jeugdbescherming bieden de mogelijkheid een minderjarige bescherming te bieden in die gevallen waarin zijn ontwikkeling wordt bedreigd en andere, minder ingrijpende middelen niet afdoende zijn gebleken om deze ontwikkelingsbedreiging weg te nemen. De bescherming van de minderjarige middels inzet van een jeugdbeschermingsmaatregel heeft als consequentie dat inbreuk wordt gemaakt op het (ouderlijk) gezag.

\subsubsection{Achtergronden en kenmerken van de ondertoezichtstelling}

De ondertoezichtstelling speelde en speelt als maatregel een centrale rol in het systeem van jeugdbescherming. Sinds 1922 is de gezagsbeperkende maatregel van ondertoezichtstelling onderdeel van het Nederlandse jeugdbeschermingsrecht. ${ }^{382}$ De ondertoezichtstelling was het antwoord op het te rigoureus bevonden systeem met alleen de ontheffing en de ontzetting uit het gezag als mogelijkheden. ${ }^{383}$ Sinds zijn introductie heeft de ondertoezichtstelling zich in rap tempo ontwikkeld tot de meest toegepaste maatregel van jeugdbescherming. Cijfers van het Centraal Bureau voor de Statistiek laten zien dat hoewel in de $20^{\mathrm{e}}$ eeuw schommelingen zijn waar te nemen in het aantal minderjarigen dat onder toezicht is gesteld, er toch gesproken

\footnotetext{
${ }^{381}$ Bruning 2001, p. 3.

${ }^{382}$ Wet van 5 juli 1921 houdende invoering van den kinderrechter en van de ondertoezichtstelling van minderjarigen, Stb. 1921, 834. De wet is op 1 november 1922 in werking getreden.

${ }^{383}$ Wet van 5 juli 1921, Stb. 834
} 
kan worden van een relatief stabiel beeld tot midden jaren '90. ${ }^{384}$ Daarna volgt een substantiële stijging van het aantal onder toezicht gestelde minderjarigen met als hoogtepunt de periode tussen 2008 en 2011 waarin meer dan 30.000 minderjarigen op 31 december van het betreffende peiljaar onder toezicht stonden. ${ }^{385}$ Tussen 2011 en 2015 is het aantal ondertoezichtstellingen gestaag gedaald tot ongeveer 25.000 (peildatum 31 december 2014).

Als 'lichtste' maatregel markeert de ondertoezichtstelling de grens tussen het vrijwillig kader en de gedwongen hulpverlening. De ondertoezichtstelling wordt opgelegd aan de minderjarige en behelst verplichte begeleiding van de minderjarige en de gezagsdrager(s) door een gezinsvoogd. ${ }^{386}$ Het onder toezicht stellen van de minderjarige heeft tot gevolg dat het gezag van degene die dit uitoefent wordt beperkt, hetgeen veronderstelt dat de mogelijke inzet van de ondertoezichtstelling direct is gekoppeld aan de situatie dat de betreffende minderjarige onder gezag staat. ${ }^{387}$ Het gaat daarbij om gezag uitgeoefend door de ouders gezamenlijk of door één ouder (art. 1:245 lid 3 BW). De beperking van het gezag moet er toe leiden dat de problemen in de ontwikkeling van de minderjarige binnen de ondertoezichtstelling worden weggenomen. De vraag in hoeveel gevallen dit lukt - en daarmee de vraag of de ondertoezichtstelling een effectieve maatregel is - laat zich om verschillende redenen moeizaam beantwoorden. In de eerste plaats moet voor de beantwoording van deze vraag gekeken worden naar de specifieke interventies die mogelijk ingezet worden binnen het kader van de ondertoezichtstelling. De gezinsvoogd is immers niet zelf degene die zorg verleent en om die reden is het weinig zinvol de ondertoezichtstelling in kader van effectiviteitsonderzoek als interventie op zich te beschouwen. ${ }^{388}$ Daarnaast is het vanuit methodologisch oogpunt bijzonder ingewikkeld te komen tot een onderzoekskader dat voldoet aan de eisen die binnen de sociaal-wetenschappelijke discipline aan effectonderzoek worden gesteld. ${ }^{389}$ Tegelijkertijd is de vraag naar de effectiviteit van de ondertoezichtstelling (en overige jeugdbeschermingsmaatregelen) wel cruciaal voor de rechtvaardiging van gedwongen overheidsingrijpen. De rechtvaardiging voor het feit dat inbreuk wordt gemaakt op het familie- en gezinsleven van de minderjarige en zijn ouders hangt immers voor een deel samen

\footnotetext{
${ }^{384}$ CBS 'Jeugdbescherming en Jeugdreclassering $1^{\mathrm{e}}$ kwartaal 2015 ', p. 6.

${ }^{385}$ Zie voor meer informatie over de mogelijke oorzaken en achtergronden van de stijging van het aantal beschermingsmaatregelen aan het begin van de $21^{\mathrm{e}}$ eeuw: Berends e.a. 2010, p. 25 e.v.

${ }^{386}$ Op grond van art. 1:257 lid $1 \mathrm{BW}$. In het vervolg ten behoeve van de leesbaarheid zoveel mogelijk aangeduid als Bureau Jeugdzorg.

${ }^{387}$ HR 30 april 1928, ECLI:NL:HR:1928:37, m.nt. P. Scholten.

${ }^{388}$ Zie hierover uitgebreid Dekker 2016, p. 204 e.v.

${ }^{389}$ Zie hierover bijvoorbeeld Slot e.a. die om deze reden niet wensen te spreken van onderzoek naar de effectiviteit van de ondertoezichtstelling maar de doelmatigheid van de maatregel. Slot e.a. 2002.
} 
met de verwachting dat de beoogde maatregel voorzienbaar een positieve invloed heeft op de ontwikkeling van het kind. In de praktijk heeft altijd de nodige twijfel bestaan of de ondertoezichtstelling aan deze doelstelling voldoet. ${ }^{390}$

Die twijfel is gevoed door de uitkomsten van verschillende onderzoeken waarin is gekeken of de ondertoezichtstelling leidde tot een verbetering van de situatie voor de minderjarige. Onderzoek van Clemens-Schröner, uitgevoerd in de jaren 1930-1936, liet zien dat slechts in $27,5 \%$ van de gevallen de ondertoezichtstelling als 'geslaagd' kon worden aangemerkt. In de overige gevallen werd geen vooruitgang geboekt of verslechterde de situatie van de minderjarige zelfs. ${ }^{391}$ Het in 2002 gepubliceerde onderzoek van Slot en collega's liet opvallend overeenkomstige resultaten zien. Na bestudering van 103 dossiers van onder toezichtgestelde minderjarigen bleek dat twee jaar na oplegging van de maatregel in slechts $28 \%$ van de gevallen het aantal zorgpunten was afgenomen. In $38 \%$ van de gevallen bleef de situatie gelijk hetgeen volgens de onderzoekers niet per definitie negatief moet worden beoordeeld en in $33 \%$ van de gevallen was de situatie verslechterd. ${ }^{392}$ Sindsdien is gewerkt aan een nieuwe basismethodiek voor gezinsvoogdijinstellingen, de zogenaamde Delta methode. De eerste onderzoeksresultaten lieten zien dat methodisch werken volgens de Delta methode een positief effect had op de duur van de ondertoezichtstelling, de kans op uithuisplaatsing en de duur daarvan. ${ }^{393}$

Het is belangrijk dat de resultaten van voornoemde onderzoeken in het juiste perspectief worden geplaatst. Het is immers niet duidelijk hoe de situatie van de minderjarigen binnen deze onderzoeken eruit had gezien als geen ondertoezichtstelling was opgelegd. Het belangrijkste inzicht dat dan ook aan deze onderzoeken kan worden ontleend is dat de ondertoezichtstelling lang niet voor ieder kind tot een verbetering van de situatie leidt. Het is geen 'wondermiddel' en tegelijkertijd worden er vrijwel nooit vraagtekens gezet bij de inzet van een ondertoezichtstelling indien er sprake is van een ernstige bedreiging van de belangen van de minderjarige. In dit onderzoek wordt gekeken naar de besluitvorming over de noodzaak van een ondertoezichtstelling door de RvdK en de kinderrechter. Op het moment dat zij de beslissing nemen dat een ondertoezichtstelling noodzakelijk is moet de overtuiging aanwezig zijn dat de maatregel positief zal uitpakken voor de minderjarige. Maar of dat uiteindelijk ook zo is hangt van verschillende factoren af, bovenal ook van de

\footnotetext{
390 Zie hierover Slot e.a. 2002, p. 5.

${ }^{391}$ Doek 1972, p. 137.

${ }^{392}$ Slot e.a. 2002, p. 38-40.

${ }^{393}$ Stams e.a 2010, p. 49.
} 
voortvarendheid waarmee de noodzakelijke zorg voor de minderjarige (en zijn ouders) kan worden ingezet. De RvdK en de kinderrechter kunnen hier wel een inschatting van maken op basis van ervaring die zij hebben met de uitvoering van de maatregel, maar daar blijft het ook bij. Aangezien zij op afstand staan van de daadwerkelijke uitvoering van de maatregel is het in zekere zin 'afwachten' hoe de situatie van de minderjarige zich ontwikkelt.

4.2.2 Rechtsgrond ondertoezichtstelling: de ernstige bedreiging van de zedelijke of geestelijke belangen of gezondheid van de minderjarige

In deze paragraaf wordt de rechtsgrond van de ondertoezichtstelling beschreven op basis van het jeugdbeschermingsrecht dat van kracht was in de jaren 2013 en 2014. De rechtsgrond van de ondertoezichtstelling was destijds opgenomen in art. 1:254 lid 1 oud BW en was als volgt geformuleerd:

'Indien een minderjarige zodanig opgroeit de minderjarige dat zijn zedelijke of geestelijke belangen of zijn gezondheid ernstig worden bedreigd, en andere middelen ter afwending van deze bedreiging hebben gefaald of, naar is te voorzien, zullen falen, kan de kinderrechter hem onder toezicht stellen van een stichting als bedoeld in art. 1, onder $f$, van de Wet op de Jeugdzorg'

De rechtsgrond van de ondertoezichtstelling bevatte blijkens voorgaande formulering twee cumulatieve gronden waaraan moest zijn voldaan voor oplegging van de maatregel: een primair pedagogisch oordeel over de zedelijke of geestelijke belangen of gezondheid van de minderjarige en de eis dat vrijwillige hulpverlening moest zijn ingezet, althans nadrukkelijk zijn overwogen. In het vervolg worden de verschillende elementen die terugkwamen in deze twee gronden afzonderlijk besproken.

\section{Indien de minderjarige 'zodanig opgroeit'}

Uit de formulering 'zodanig opgroeit' bleek dat het ging om de opvoedingssituatie van de minderjarige, waardoor hij in zijn ontwikkeling ernstig werd bedreigd. ${ }^{394} \mathrm{Er}$ is bewust voor gekozen om uit te gaan van de opvoedingssituatie van de minderjarige en niet de verantwoordelijkheid ofwel geheel of gedeeltelijk bij ouders of het kind neer te leggen. Dit betekende ook dat van enige verwijtbaarheid aan de zijde van de ouders voor het ontstaan van

\footnotetext{
${ }^{394}$ Van Montfoort 2008 . p. 21.
} 
de ontwikkelingsbedreiging geen sprake hoefde te zijn. ${ }^{395}$ Het uitgangspunt dat niet de 'schuldvraag' maar de feitelijke opvoedssituatie van de minderjarige centraal behoort te staan, neemt niet weg dat de ondertoezichtstelling de verantwoordelijkheid voor de verzorging en opvoeding (art. 1:247 lid 1 BW) van de ouders ten dele inperkt. De vraag is of daarin niet tevens een impliciet oordeel over het opvoedershandelen van de ouders ligt besloten.

De Raad voor de Kinderbescherming leek deze redenering te volgen in zijn advies naar aanleiding van het wetsvoorstel tot herziening van de ondertoezichtstelling in 1995. De RvdK stelde onder meer dat de toen geldende grond van de ondertoezichtstelling (de grond geldend tot de herziening van de ondertoezichtstelling in 1995, cursief $\mathrm{JH}$ ) onvoldoende tot uitdrukking bracht dat de ondertoezichtstelling bedoeld was om te interveniëren in de situatie waarin ouders hun opvoedingsverantwoordelijkheden niet (voldoende) waarmaakten. ${ }^{396}$ Daarbij werd ook verwezen naar de gronden van de ontheffing en ontzetting uit het gezag waarin wel een direct verband viel waar te nemen met het opvoedershandelen van de ouders. Toenmalig staatssecretaris Kosto wees deze suggestie echter van de hand. De noodzaak tot het opleggen van ondertoezichtstelling behoorde in zijn visie niet noodzakelijkerwijs tot de conclusie te leiden dat de ouders de verantwoordelijkheid voor de verzorging en opvoeding van het kind niet hadden waargemaakt. ${ }^{397}$ Dit zou volgens de staatssecretaris geen recht doen aan de complexiteit van het verzorgen en opvoeden van kinderen. Daarnaast werd hiermee de reële mogelijkheid genegeerd dat de ouders geen enkele schuld droegen aan het ontstaan van de situatie die had geleid tot de bedreigde belangen van het kind. ${ }^{398}$

In het wetgevingsproces inzake de herziening van de maatregelen van kinderbescherming in 2008 heeft de wetgever nog eens bevestigd dat de oorzaak van de stagnatie in de ontwikkeling van de minderjarige kon liggen aan de minderjarige zelf en/of de beperkte opvoedcapaciteiten van de ouders. ${ }^{399}$ Hoewel de schuldvraag dus werd vermeden en men tracht uit te gaan van de feitelijke situatie waarin het kind verkeerde, lijkt het niet onwaarschijnlijk dat in een substantieel deel van de gevallen het opvoedershandelen van de ouders direct of indirect van invloed is geweest op het ontstaan van de bedreigde ontwikkeling van de minderjarige. Van Wijk benadrukte in dit verband het belang van het benoemen van het ouderlijk gedrag zonder daar een moreel oordeel aan te voegen. Het is immers voor een deugdelijke motivering van de

\footnotetext{
395 HR 17 juni 1977, ECLI:NL:PHR:1977:AC598.

396 Kamerstukken II 1992/93, 23 003, nr. 3 (MvT), p. 12.

${ }^{397}$ Kamerstukken II 1992/93, 23 003, nr. 3 (MvT), p. 12.

${ }^{398}$ Kamerstukken II 1992/93, 23 003, nr. 3 (MvT), p. 12.

${ }^{399}$ Kamerstukken II 2008/9, 32 015, nr. 3 (MvT), par. 5.2.
} 
noodzaak tot oplegging van een jeugdbeschermingsmaatregel noodzakelijk dat alle bepalende omstandigheden, daaronder ook het ouderlijk handelen begrepen, worden geëxpliciteerd. ${ }^{400}$

Ook de Hoge Raad heeft sinds de introductie van de ondertoezichtstelling in 1922 consequent geoordeeld dat het opleggen van een ondertoezichtstelling geen oordeel omtrent de bekwaamheid van de ouders impliceerde, aangezien ook zonder dat ouders een verwijt kon worden gemaakt, de ontwikkeling van de minderjarige door velerlei oorzaken kon worden bedreigd. ${ }^{401}$

De conclusie dat ouders niet noodzakelijkerwijs hoeven bijgedragen te hebben aan het ontstaan van de ontwikkelingsbedreiging van de minderjarige liet onverlet dat het handelen van de ouders wel buitengewoon relevant was in de beoordeling van de situatie waarin het kind verkeerde. De keuze van de wetgever om niet te spreken van schuld in de zin van schuldig aan het ontstaan of instandhouden van de ontwikkelingsbedreiging van de minderjarige is desondanks begrijpelijk. Zo werd voorkomen dat een moraliserend oordeel werd gevormd ten aanzien van de ouders hetgeen strookte met het uitgangspunt dat op dit punt de overheid zich prudent moest opstellen. ${ }^{402}$ Daarnaast leek het ook een manier om niet bij voorbaat al veel weerstand op te roepen bij de ouders. Als immers expliciet zou worden benoemd dat falend opvoederschap ten grondslag lag aan de ondertoezichtstelling, dan voelden ouders zich terecht ernstig bekritiseerd. Dat terwijl het voor een doelmatige uitvoering van de ondertoezichtstelling wenselijk was dat mensen bereid waren om mee te werken. De empirische vraag hoe vaak het voorkwam dat het ouderlijk handelen op geen enkele wijze verband hield met de ernstige bedreiging van de belangen van de minderjarige wordt beantwoord in het dossieronderzoek in deel II van dit onderzoek.

\section{De ernst van de bedreiging}

Wat werd verstaan onder 'ernstige bedreiging' diende ingevuld te worden aan de hand van het specifieke feiten en omstandigheden van het geval. De formulering 'ernstige bedreiging' gaf een globale indicatie ten aanzien van het moment van ingrijpen. Tot de herziening van de ondertoezichtstelling in 1995 sprak de wet van 'bedreiging met zedelijke of lichamelijke ondergang' ${ }^{403}$ De toen aangepaste formulering 'ernstige bedreiging van de zedelijke of geestelijke belangen of gezondheid', heeft echter niet tot doel gehad enige wijziging aan te

\footnotetext{
400 Van Wijk 1999, p. 69 e.v.

401 Vgl. HR 6 oktober 1967, ECLI:NL:PHR:1967:AB7246; HR 17 juni 1977, NJ 1977, 564.

$402 \mathrm{Zie}$ voor een uitgebreide toelichting op dit punt Weijers 2012, p. 11 e.v. en Weijers 2014, p. 47-48.

${ }^{403}$ Dit criterium is derhalve sinds de wet tot invoering van de ondertoezichtstelling in 1921 niet gewijzigd. Zie voor een uitgebreide analyse van de ontwikkeling van de rechtsgronden, Bruning 2001, p. 177 e.v.
} 
brengen in het moment waarop middels een ondertoezichtstelling kon worden ingegrepen, maar beoogde slechts de grondslag te verduidelijken. ${ }^{404}$ Men mag er dus vanuit gaan dat ook oudere jurisprudentie waarin uitleg werd gegeven over de aard en omvang van de 'bedreiging' in de ontwikkeling van de minderjarige nog steeds relevant is. De jurisprudentie waarin nadere duiding werd gegeven ten aanzien van de mate waarin het kind moest worden bedreigd wil een ondertoezichtstelling gerechtvaardigd zijn, is gezien het casuïstische karakter van de afweging weinig concreet. Hiermee wordt niet bedoeld dat in de rechtspraak geen aandacht is besteed aan de ontwikkelingsproblematiek van de minderjarige. Gedoeld wordt op concrete inzichten ten aanzien van de weging van de ernst van die problematiek, waarmee meer inzicht kan worden verkregen over de vraag in welke gevallen een ondertoezichtstelling is aangewezen.

In de rechtspraak is geoordeeld dat het niet noodzakelijk was dat de minderjarige reeds verwaarloosd werd hetgeen ook logisch is aangezien met de inzet van een jeugdbeschermingsmaatregel juist moest worden getracht (ernstige) schade voor de ontwikkeling van de minderjarige te voorkomen. ${ }^{405}$ De enkele mogelijkheid van schade bij het kind was onvoldoende, maar de schade hoefde nog niet daadwerkelijk te zijn ingetreden. Voldoende was een reële dreiging van de ondergang van het kind. ${ }^{406}$ Het ingrijpende karakter van de ondertoezichtstelling bracht met zich mee dat een bedreiging in de ontwikkeling van de minderjarige, zoals was opgenomen in artikel 1:254 lid 1 oud BW zich slechts voordeed wanneer in de actuele situatie niet mis te verstane aanwijzingen voor die bedreiging aan de dag traden. ${ }^{407}$

Hoewel deze uitgangspunten in algemene zin benadrukten dat de ernst van de situatie overtuigend moest worden aangetoond, was het aan de praktijk gelaten om in iedere zaak afzonderlijk een afweging te maken. De ruim geredigeerde rechtsgrond van de ondertoezichtstelling impliceerde dan ook een grote mate van vrijheid voor de kinderrechter om te bepalen of de toestand waarin het kind verkeerde een ondertoezichtstelling rechtvaardigde. ${ }^{408} \mathrm{Om}$ die afweging te maken was geen vast wegingskader voorhanden op basis waarvan kon worden bepaald wanneer de ontwikkelingsproblemen van de minderjarige ernstig genoeg waren. De onzekerheid die hiermee gepaard ging is ook terug te zien in de

\footnotetext{
${ }^{404}$ Kamerstukken II 1992/93, 23 003, nr. 3 (MvT), p. 32.

${ }^{405}$ HR 30 april 1928, ECLI:NL:HR:1928:37, m.nt. P. Scholten.

${ }^{406}$ HR 20 november 1987, ECLI:NL:HR:1987:AD0060.

${ }^{407}$ HR 20 november 1987, ECLI:NL:HR:1987:AD0060.

${ }^{408}$ Asser/De Boer 1* 2010/844.
} 
parlementaire stukken. De mate waarin het woord 'ernstig' als onderdeel van het criterium 'ernstige bedreiging' meer duidelijkheid verschafte over het moment van ingrijpen door de inzet van een ondertoezichtstelling werd uitgebreid bediscussieerd in het wetgevingsproces tot herziening van de kinderbeschermingsmaatregelen. ${ }^{409}$ Het in 2009 uitgekomen wetsvoorstel bevatte het voorstel om het woord 'ernstig' in de rechtsgrond van de ondertoezichtstelling te schrappen waardoor, zo werd beoogd, de ondertoezichtstelling ook van toepassing kon zijn op kinderen met 'relatief lichte problemen' ${ }^{410}$ In de memorie van toelichting werd slechts gesteld dat de voorgestelde grond ruimer was geformuleerd dan de grond zoals vastgesteld bij wet van 26 april 1995 tot herziening van de maatregel van ondertoezichtstelling. ${ }^{411}$ Wat het verschil tussen een 'ernstige bedreiging van de zedelijke of geestelijke belangen of gezondheid' en het voorgestelde 'onbedreigd opgroeien' voor toepassing van de wettelijke gronden in de praktijk betekende en wat de wetgever verstond onder 'relatief lichte problemen van de minderjarige' werd in eerste instantie echter niet verder toegelicht.

Tijdens de parlementaire behandeling van het wetsvoorstel tot herziening van de kinderbeschermingsmaatregelen in de Tweede Kamer werd vervolgens uitgebreid gediscussieerd over de grondslag van de ondertoezichtstelling en meer specifiek over de mogelijke gevolgen van het wijzigen van een 'ernstige bedreiging van de zedelijke of geestelijke belangen of gezondheid' in het ruimer geformuleerde 'onbedreigd opgroeien' ${ }^{412}$ In algemene zin was het voor de meeste kamerfracties moeilijk een inschatting te maken van de voorgestelde wijziging en vreesde men een verdere toename van het aantal opgelegde jeugdbeschermingsmaatregelen. ${ }^{413}$

Vanuit de wetenschap heeft de discussie over het mogelijke schrappen van het woord 'ernstig' in de rechtsgrond van de ondertoezichtstelling en de gevolgen daarvan voor de toepassing van de maatregel in de praktijk, ook een prominente rol gespeeld, met wisselende conclusies tot gevolg. Vlaardingerbroek onderschreef het belang van de voorgestelde wijziging aangezien hierdoor ook kinderen onder toezicht konden worden gesteld waarover zorgen bestonden maar de ernst van deze zorgen nog niet concreet kon worden aangetoond. ${ }^{414}$ Het feit dat er

\footnotetext{
${ }^{409}$ Kamerstukken II 2010/11, 32 015, nr. 47, nr. 49.

${ }^{410}$ Kamerstukken II 2008/9, 32 015, nr. 3.

411 Wet van 26 april 1995, Stb. 1995, 255.

412 Zie onder meer Kamerstukken II 2010/11, 32 015, nr. 47; Kamerstukken II 2010/11, 32 015, nr. 49.

${ }^{413}$ Zie in dit verband o.a Dibi (Groenlinks) die stelde dat de enorme stijging in het aantal jeugdbeschermingsmaatregelen tussen 2000 en 2009 suggereert dat de toen geldende grond al een zeer lage drempel opwierp voor het ingrijpen in het gezinsleven. Een verdere verruiming werd om principiële en praktische redenen niet wenselijk geacht; Kamerstukken II 2010/11, 32 015, nr. 47, p. 71.

${ }^{414}$ Vlaardingerbroek, FJR 2007/1, p. 2-9.
} 
sprake moest zijn van een ernstige bedreiging zou de toepassingsmogelijkheden van de ondertoezichtstelling in de praktijk onnodig beperken. ${ }^{415}$ Doek toonde zich kritischer en stelde dat de voorgestelde verruiming van de rechtsgrond van de ondertoezichtstelling vroeg om een nadere toelichting van de overheid omtrent het begrip 'onbedreigd opgroeien'. Zonder een duidelijke afbakening zou immers het risico op ongerechtvaardigd overheidsingrijpen in het gezinsleven op de loer liggen. ${ }^{416}$

Ook Slot besprak de voorgestelde wijziging en dan met name ten aanzien van de interpretatie van het woord 'bedreiging'. Hij stelde dat 'bedreiging' zoals neergelegd in de rechtsgrond van de ondertoezichtstelling (art. 1:254 lid 1 oud BW) concreter was dan het tot 1995 geldende 'dreiging met zedelijke of lichamelijke ondergang. ${ }^{417}$ Een bedreiging veronderstelde in zijn visie in de eerste plaats dat bekend is wat er bedreigd wordt en ten tweede waar de bedreiging uit bestaat. In de visie van Slot zaaide de wetgever echter verwarring door aan te geven dat de bedreiging kon voortkomen uit een stagnatie in de ontwikkeling (hetgeen veronderstelde dat de ontwikkelingsschade al was ingetreden) terwijl bedreiging juist ook kon betekenen dat de minderjarige thans nog in blakende gezondheid verkeerde en goed functioneerde maar toch beschermd moest worden. ${ }^{418}$ Deze zienswijze verdient enige nuance in die zin dat de noodzakelijk geachte ernstige bedreiging in de ontwikkeling van de minderjarige tevens suggereerde dat er al duidelijke en concrete aanwijzingen moesten zijn wilde men overgaan tot een onderzoek naar de noodzaak van een ondertoezichtstelling. Het lijkt vrij onwaarschijnlijk dat de minderjarige nog geheel probleemloos functioneerde maar toch een bedreiging in de ontwikkeling werd geconstateerd. In een dergelijke situatie lijkt de noodzaak van gedwongen overheidsingrijpen moeilijk te rechtvaardigen. Het is wel belangrijk om te benadrukken dat 'bedreiging' betekende dat hoewel de mogelijkheid van ontwikkelingsschade voor het kind acuut en reëel moest zijn, de schade nog niet daadwerkelijk hoefde te zijn ingetreden.

De afwegingen in het kader van de ondertoezichtstelling op dit punt vroegen om een juridische vertaalslag. Het oordeel over de ernst van de bedreiging was primair pedagogisch

\footnotetext{
415 Vlaardingerbroek, FJR 2007/1, p. 2-9.

${ }^{416}$ Doek 2008, p. 33. Zijn kritiek sloot aan bij het commentaar van de Raad van State ten aanzien van de voorgestelde verruiming. De Raad van State concludeerde dat niet duidelijk genoeg werd gemaakt wat onder 'lichtere problemen' werd verstaan. Daarnaast werd ernstig getwijfeld of de doelmatigheid van de ondertoezichtstelling een verruiming van het toepassingsbereik van de maatregel kon rechtvaardigen. Zie: Kamerstukken II 2008/9, 32 015, nr. 4.

417 Slot 2008, p. 91.

418 Slot 2008, p. 91.
} 
van aard en diende per geval bepaald te worden. Dit was ook uitdrukkelijk de bedoeling van de wetgever. Het bood de mogelijkheid om in de praktijk flexibel met de wettelijke norm om te gaan, waardoor de ondertoezichtstelling van toepassing kon zijn op uiteenlopende situaties, variërend in ernst en duur. Tegelijkertijd impliceerde het open begrip ‘ernstige bedreiging' het risico van rechtsonzekerheid voor betrokkenen. Men moet dus genoegen nemen met de vaststelling dat in ieder geval beargumenteerd moest worden dat zonder inzet van de ondertoezichtstelling de minderjarige binnen afzienbare tijd, naar alle waarschijnlijkheid, ernstige ontwikkelingsschade op zou lopen. Daarnaast impliceerde het woord 'ernstig' dat het moest gaan om een ontwikkelingsbedreiging die verder ging dan de bedreigingen die iedere minderjarige werd geacht te ervaren in zijn groei naar volwassenheid. Anders gesteld, indien het voorgestelde schrappen van woord 'ernstig' betekende dat ook kinderen met relatief lichte problemen onder toezicht konden worden gesteld, dan past de conclusie dat nu het woord 'ernstig' destijds is behouden, de ondertoezichtstelling alleen in geval van 'relatief ernstige problemen' geëigend is. Dat past ook het beste bij het van oudsher geldende uitgangspunt dat inzet van een jeugdbeschermingsmaatregel heeft te gelden als ultimum remedium.

\section{Zedelijke of geestelijke belangen of gezondheid}

Volgens art. 1:254 lid 1 oud BW moest het gaan om een ernstige bedreiging 'van de zedelijke of geestelijke belangen of gezondheid van de minderjarige'. Het criterium 'zedelijke of geestelijke belangen of gezondheid' werd met de herziening van de ondertoezichtstelling in 1995 in de wet neergelegd. ${ }^{419}$ Toenmalig staatssecretaris Kosto volgde daarmee slechts ten dele het advies op dit punt van de commissie Wiarda, die eerder had voorgesteld de grond te wijzigen in "indien een kind zodanig opgroeit dat voor zijn zedelijke of geestelijke belangen of voor zijn gezondheid ernstig gevaar is te duchten' ${ }^{420}$ De staatssecretaris was van mening dat de typering 'belang' concreter dan 'ontwikkeling' aangaf in welke gevallen een ondertoezichtstelling kon worden uitgesproken. ${ }^{421}$ Hij gaf als toelichting hieromtrent:

'of een ernstige bedreiging van een ontwikkeling van de minderjarige tot ingrijpen van de overheid moet leiden, hangt immers af van welke ontwikkeling bedreigd wordt. Daarentegen is iedere bedreiging van een belang van het kind zorgwekkend. De in het wetsvoorstel gekozen formulering maakt het mogelijk een ondertoezichtstelling uit te spreken indien de ontwikkeling

\footnotetext{
${ }^{419}$ Wet van 26 april 1995, Stb. 1995, 255.

${ }^{420}$ Commissie Wiarda 1971, p. 171.

${ }^{421}$ Kamerstukken II 1992/93 23 003, nr. 3, p. 11.
} 
van de minderjarige zodanig bedreigd wordt, dat dit een bedreiging van zijn belangen

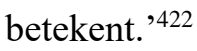

Deze toelichting schiep meer verwarring dan duidelijkheid. Het wekte de suggestie dat 'belang' explicieter aangaf waarin de bedreiging van het kind was gelegen dan 'ontwikkeling' omdat er sprake kon zijn van diverse 'ontwikkelingen' van het kind, waarmee kennelijk werd gedoeld op het onderscheid tussen de lichamelijke, sociaal-emotionele en cognitieve ontwikkeling van het kind. Dat geldt echter evenzeer voor het woord belangen, de wet sprak immers van zedelijke of geestelijke belangen of gezondheid, hetgeen aangaf dat ook diverse belangen van het kind konden worden bedreigd.

De Nederlandse Vereniging voor Rechtspraak deed in het kader van de wettelijke herziening van de ondertoezichtstelling in 1995 het voorstel om de rechtsgrond van de ondertoezichtstelling te wijzigen in 'ernstige bedreiging van de geestelijke of lichamelijke ontwikkeling' ${ }^{423}$ De staatssecretaris reageerde in dit verband expliciet op het ontbreken van de zedelijke belangen van de minderjarige in het gedane voorstel. Hij zei hierover:

'Ik acht handhaving van dit criterium gewenst. Het criterium 'zedelijke belangen' heeft een zelfstandige betekenis die niet altijd gelijk is aan 'geestelijke belangen'. Een ondertoezichtstelling kan bijvoorbeeld noodzakelijk zijn indien een meisje van dertien jaar als prostituée in haar levensonderhoud voorziet. In dat geval zal de bedreiging -afgezien van de aspecten van bedreiging van de gezondheid- veeleer liggen in de bedreiging van haar zedelijke. $^{424}$

Ook tijdens de parlementaire behandeling van voornoemd wetsvoorstel tot herziening van de maatregel van ondertoezichtstelling in 1995 werd uitgebreid gesproken over de interpretatie van het begrip 'zedelijke of geestelijke belangen of gezondheid' ${ }^{425}$ De leden van de fractie van de PvdA vonden dat tenminste verduidelijkt zou moeten worden wat onder zedelijke of geestelijke belangen kon worden verstaan, zodat betrokkenen zich globaal een voorstelling konden maken van de grens tussen opvoedingsvrijheid en overheidsingrijpen. ${ }^{426}$ Ook de VVD-fractieleden vonden de voorgestelde grondslag een verbetering maar hadden ook de nodige kritiek. Zo werd naar hun mening teveel ruimte gelaten voor een subjectieve

\footnotetext{
${ }^{422}$ Kamerstukken II 1992/93 23 003, nr. 3, p. 11.

${ }^{423}$ Kamerstukken II 1992/93 23 003, nr. 3, p. 11.

${ }^{424}$ Kamerstukken II 1992/93 23 003, nr. 3, p. 11.

${ }^{425}$ Zie bv Kamerstukken II 1992/93 23 003, nr. 4, p.11. En voor de reactie van de staatssecretaris: Kamerstukken I1 1993/94 23 003, nr. 5.

${ }^{426}$ Kamerstukken II 1992/93 23 003, nr. 4, p.11.
} 
beoordeling, interpretatieverschillen en/of waarderingsverschillen. Met name ten aanzien van de vraag welke omstandigheden konden leiden tot het oordeel dat de zedelijke of geestelijke belangen of gezondheid van de minderjarige ernstig werden bedreigd wensten zij meer duidelijkheid. ${ }^{427}$ Daar werd aan toegevoegd dat mocht de keuze voor een ruime formulering zijn gebaseerd op de zienswijze dat de grote verscheidenheid aan normen en waarden ten aanzien van de opvoeding het opstellen van breed aanvaarde normen compliceert zo niet onmogelijk maakt, hier sprake was van een schijnargument. Het was immers de professional in de rechtspraktijk (raadsmedewerkers, kinderrechters) die werd geacht invulling te geven aan de wettelijke norm hetgeen tevens een oordeel omtrent het opvoedingsklimaat impliceerde. ${ }^{428}$ De VVD-fractieleden stelden vervolgens de vraag of de wetgever de verantwoordelijkheid hiervoor geheel bij de rechtspraktijk zou moeten neerleggen. Ook de leden van de SGP-fractie vroegen de staatssecretaris om een nadere aanduiding van de termen 'zedelijke belangen' en 'geestelijke belangen' ${ }^{429}$ De staatssecretaris hield echter vast aan de lijn dat invulling van dit criterium primair plaats diende te vinden binnen de rechtspraktijk, mede omdat het feitelijke omstandigheden zijn die maken dat een minderjarige zijn zedelijke of geestelijke belangen wel of niet ernstig worden bedreigd. ${ }^{430}$ Daar werd nog aan toegevoegd dat het bijvoorbeeld kon gaan om een bedreiging van de fysieke gezondheid van een kind maar ook een bedreiging van de immateriële belangen. ${ }^{431}$ Het slotwoord op dit punt was - hoewel teleurstellend voor de Tweede- Kamerfracties - helder: 'het antwoord op de vraag wat zedelijke en geestelijke belangen zijn, wordt in de jurisprudentie gegeven' ${ }^{432}$

\section{Opvoedingsstijl van de ouders}

De jurisprudentie en literatuur hebben inderdaad een aantal algemene gezichtspunten opgeleverd ten aanzien van de vraag wat wel en wat niet behoorde te vallen onder de wettelijke definitie 'een ernstige bedreiging van de zedelijke of geestelijke belangen of gezondheid van de minderjarige'. Er wordt hier niet voor niets gesproken over algemene gezichtspunten. Zichtbaar is dat in de rechtspraak situaties werden benoemd waar de bedreiging van de belangen van de minderjarige niet, of juist wel evident aanwezig was. In het concrete geval moesten echter alle relevante feiten en omstandigheden gewogen worden.

\footnotetext{
${ }^{427}$ Kamerstukken II 1992/93 23 003, nr. 4, p. 12-13.

${ }^{428}$ Kamerstukken II 1992/93 23 003, nr. 4, p. 12-13.

${ }^{429}$ Kamerstukken II 1992/93 23 003, nr. 4, p. 14-15.

${ }^{430}$ Kamerstukken II 1993/94 23 003, nr. 5, p. 33

${ }^{431}$ Kamerstukken II 1993/94 23 003, nr. 5, p. 34.

${ }^{432}$ Kamerstukken II 1993/94 23 003, nr. 5, p. 34.
} 
Duidelijk is in ieder geval dat een ongebruikelijke opvoedingsstijl of afwijkende keuzes van de minderjarige zelf niet per definitie hoefden te leiden tot de conclusie dat de minderjarige ernstig werd bedreigd. Zo bepaalde het gerechtshof 's- Gravenhage in een uitspraak van 13 oktober 2010 dat een opvoedingsstijl waarin onvoldoende structuur en regels werden geboden, zonder dat concreet duidelijk was geworden dat de ontwikkeling van de kinderen ernstig werd bedreigd, niet kon leiden tot een ondertoezichtstelling. ${ }^{433}$ In 2009 moest de Rechtbank Utrecht oordelen over een 14-jarige die met instemming van haar vader solo de wereld rond wilde zeilen. In deze zaak is door de rechtbank secuur gekeken naar alle aspecten van de sociaal-emotionele- en identiteitsontwikkeling, de cognitieve ontwikkeling, de veiligheid op reis en de zogenoemde copingsvaardigheden van de minderjarige. ${ }^{434} \mathrm{De}$ rechtbank ging er hierbij niet vanuit dat een solo-zeilreis op 14-jarige leeftijd per definitie een ernstige bedreiging van de belangen van de minderjarige opleverde. Uiteindelijk leidde dit tot conclusie dat alleen op het punt van de veiligheid van de minderjarige dusdanige zorgen bestonden dat een ondertoezichtstelling gerechtvaardigd was. ${ }^{435}$

Aan de andere kant kon ernstig overgewicht bij de minderjarige ook toen al een reden zijn om een ondertoezichtstelling op te leggen, ook als de ouders zich tot op zekere hoogte hadden ingespannen om het overgewicht aan te pakken. ${ }^{436}$ Ook hier geldt dat veel afhing van de specifieke feiten en omstandigheden van het geval en de beoordeling daarvan door de rechter. In een uitspraak van het gerechtshof Arnhem van 22 maart 2012 ging het om drie minderjarigen met zeer ernstig overgewicht en werd voldoende duidelijk dat de ouders onvoldoende in staat waren om zelfstandig de noodzakelijke stappen te zetten om het overgewicht terug te dringen. ${ }^{437}$ Hoewel hier weinig twijfel zal bestaan over de noodzaak van een ondertoezichtstelling, moet ook opgemerkt worden dat er heel veel kinderen zijn in Nederland met ernstig overgewicht - vaak deels of geheel te wijten aan de leefstijl van het gezin - die geen ondertoezichtstelling opgelegd hebben gekregen.

\footnotetext{
${ }^{433}$ Gerechtshof 's-Gravenhage 13 oktober 2010, ECLI:NL:GHSGR:2010:BP2902. Zie in dit verband ook een uitspraak van het Gerechtshof 's-Gravenhage van 25 oktober 2000 waarin een vader door zijn dochters aansprakelijk werd gesteld vanwege, naar het oordeel van de dochters, ernstige mishandeling en verwaarlozing in de opvoeding. Blijkens de toelichting in deze zaak kwam dit oordeel vooral voort uit het feit dat de dochters te weinig aandacht, liefde en affectie hadden gekregen in de opvoeding. Het hof constateerde dat dit alles onvoldoende was om aan te nemen dat de vader niet had voldaan aan zijn plicht om invulling te geven aan de verzorging en opvoeding van de dochters; Gerechtshof 's-Gravenhage 25 oktober 2000, ECLI:NL:GHSGR:2000:AB0139.

${ }^{434} \mathrm{Rb}$. Utrecht 30 oktober 2009, ECLI:NL:RBUTR:2009:BK1598

${ }^{435} \mathrm{Rb}$. Utrecht 30 oktober 2009, ECLI:NL:RBUTR:2009:BK1598.

436 Gerechtshof Arnhem 22 maart 2012, ECLI:NL:GHARN:2012:BW5429.

${ }^{437}$ Gerechtshof Arnhem 22 maart 2012, ECLI:NL:GHARN:2012:BW5429, r.o. 4.7.
} 
Hoe lastig het is hierin een grens te bepalen liet de zaak zien van een moeder die haar zoon alleen rauw voedsel te eten gaf. In de documentaire 'Rauw' die in 2012 uitkwam was de strijd te zien van een moeder tegen de instanties (RvdK, Bureau Jeugdzorg) die van oordeel waren dat het eten van rauw voedsel leidde tot ondervoeding en gezondheidsrisico's. ${ }^{438}$ Dat oordeel werd ondersteund door een medisch specialist maar de zaak leidde alsnog tot een discussie over de vraag of het problematisch was dat de jongen door zijn dieet, waarschijnlijk, fors achter zou blijven bij de gemiddelde groeicurve voor jongens in Nederland. Uiteindelijk is in de documentaire te zien dat de jongen onder toezicht werd gesteld maar bovenal omdat zijn moeder in strijd handelde met de leerplicht. De vraag of het dieet van de jongen een bedreiging van zijn zedelijke of geestelijke belangen of gezondheid opleverde leek - bewust of onbewust - te worden vermeden.

\section{Conflicten inzake gezag en omgang}

Jaarlijks besluiten een aanzienlijk aantal stellen hun relatie te beëindigen. In de meeste gevallen gaat dit in goed overleg en blijft de schade voor het kind ondanks de ingrijpende aard van de scheiding beperkt. In een klein percentage van de scheidingszaken verloopt het proces zodanig conflictueus dat de scheidingsproblematiek - direct of indirect- ten grondslag ligt aan de ernstige bedreiging van de zedelijke of geestelijke belangen of gezondhie van de minderjarige. Direct, indien conflicten ten aanzien van de verdeling van zorg- en opvoedtaken en de omgangsregeling tussen de ouders zodanig ernstig zijn dat het een bedreiging van de belangen van de minderjarige oplevert. Indirect, indien de scheiding ten grondslag ligt aan tal van veranderingen binnen het gezin, bijvoorbeeld op sociaal-economisch niveau, die uiteindelijk een negatieve uitwerking kunnen hebben op de ontwikkeling van de minderjarige.

Voor dit onderzoek is met name de situatie van belang waarin de RvdK werd gevraagd advies uit te brengen welke verdeling van de taken inzake gezag- en omgang (G\&O) het meeste tegemoet zou komen aan de belangen van het kind. Indien tijdens het G\&O onderzoek bleek dat sprake was van een zodanig conflictueuze situatie dat de minderjarige mogelijk werd bedreigd in zijn belangen, kon het onderzoek van de RvdK worden uitgebreid naar een beschermingsonderzoek. De RvdK kwam dan voor de vraag te staan of de ondertoezichtstelling in het concrete geval het geëigende middel was om conflicten inzake gezag en omgang te verminderen of beëindigen. In de rechtspraak is in algemene zin bepaald dat terughoudend diende te worden omgegaan met een zogenaamde

\footnotetext{
${ }^{438}$ Te raadplegen via www.vpro.nl.
} 
'omgangsondertoezichtstelling'. In een uitspraak van 13 april 2001 overwoog de Hoge Raad ten aanzien van dit vraagstuk:

'Niet uitgesloten is dat het opleggen van de maatregel van ondertoezichtstelling gerechtvaardigd kan zijn wanneer het ontbreken van een omgangsregeling of juist het bestaan ervan, dan wel de conflicten of problemen bij het totstandbrengen of het uitvoeren van een omgangsregeling zodanige belastende conflicten of problemen opleveren voor het kind dat deze, op zichzelf of in combinatie met andere omstandigheden, een ernstige bedreiging opleveren voor zijn zedelijke of geestelijke belangen, en andere middelen ter afwending van deze bedreiging hebben gefaald of, naar te voorzien is, zullen falen. In een dergelijk geval moeten aan de motivering van de toewijzing hoge eisen gesteld worden'. ${ }^{439}$

Deze uitspraak van de Hoge Raad liet zien dat de ondertoezichtstelling in beginsel niet het geschikte middel is om omgang tussen de minderjarige en de ouder af te dwingen.

Aangetoond moest worden dat de conflicten zodanig waren dat bedreiging van de belangen van de minderjarige zich aandiende. Aangenomen mag worden dat die eisen niet anders of hoger waren dan in situaties waarin op grond van andere zorgen een bedreiging van de zedelijke of geestelijke belangen of gezondheid van de minderjarige werd geconstateerd, maar dat de Hoge Raad wilde benadrukken dat ouderproblematiek, zoals bijvoorbeeld een gestagneerde omgangsregeling, niet vanzelfsprekend hoefde te leiden tot een ernstige bedreiging. Blijkens voornoemde toelichting moesten bijkomende belastende conflicten of problemen worden aangetoond om te kunnen voldoen aan de gronden van een ondertoezichtstelling. Daarmee werd evenwel niks gezegd over de aard en ernst van die bijkomende conflicten. De vraag of in het concrete geval een ernstige bedreiging van de zedelijke of geestelijke belangen kon worden aangenomen vereiste dan ook een individuele afweging, waarbij de manier waarop de minderjarige de conflicten ervoer ook een belangrijke rol leek te spelen.

\section{De bedreiging van de belangen van het ongeboren kind}

In beginsel kon de ondertoezichtstelling slechts worden opgelegd aan minderjarigen, waar op basis van art. 1:233 lid $1 \mathrm{BW}$ onder werd verstaan: 'zij die de ouderdom van achttien jaren niet hebben bereikt'. Ook het feit dat oplegging van de ondertoezichtstelling een beperking van het gezag inhield, impliceerde dat de maatregel zich in beginsel richtte tot geboren

\footnotetext{
${ }^{439}$ Hoge Raad 13 april 2001, ECLI:NL:HR:2001:AB1009, r.o. 3.4
} 
kinderen. ${ }^{440}$ Er konden zich echter situaties voordoen waarin het ongeboren kind reeds tijdens de zwangerschap ernstig in zijn ontwikkeling werd bedreigd. Situaties die konden nopen tot ingrijpen voor de geboorte waren een drugs- of alcoholverslaving, een verstandelijke beperking of een psychische stoornis, hoewel bij elk van deze factoren kanttekeningen kunnen worden geplaatst. ${ }^{441}$ Noodzakelijk was in ieder geval dat de concrete situatie tijdens de zwangerschap een groot risico opleverde primair voor de lichamelijke belangen van het kind indien het eenmaal geboren was.

Het ongeboren kind komt in juridische zin echter geen persoonlijkheid toe hetgeen betekent dat het geen zelfstandige drager is van rechten, plichten en rechtsbetrekkingen. ${ }^{442}$ De persoonlijkheid en daarmee het genot van burgerlijke rechten wordt geacht aan te vangen met de geboorte (art. 1:1 lid 1 BW). Zulks doet echter niet af aan de beschermenswaardige positie van het ongeboren kind. Ook op grond van het IVRK is deze zienswijze verdedigbaar. Art. 1 IVRK bepaalt dat onder kind moet worden verstaan 'ieder mens jonger dan 18 jaar'. In de preambule wordt echter nadrukkelijk aangegeven dat het kind op grond van zijn lichamelijke en geestelijke onrijpheid bijzondere bescherming en zorg nodig heeft, met inbegrip van de geëigende wettelijke bescherming, zowel vóór als na zijn geboorte. ${ }^{443}$

De constatering dat het ongeboren kind niet kan worden beschouwd als zelfstandig rechtssubject, heeft als consequentie dat de discussie omtrent prenataal ingrijpen middels een jeugdbeschermingsmaatregel, mede moet worden bezien in het licht van de rechten van de zwangere vrouw.

In beginsel behoort de aanstaande moeder (en de vader) zonder inmenging te kunnen beslissen over de wijze waarop met het nog niet geboren kind wordt omgegaan. Tegelijkertijd verdient het ongeboren kind bescherming en dient het gevrijwaard te blijven van schadelijke invloeden. Het is de plicht van de aanstaande moeder voor het kind te zorgen, een zorg die zich uitstrekt tot voor de geboorte. Op grond van art. 1:247 BW in samenhang met art. 1:2 BW strekt de plicht van de ouder tot verzorging zich uit tot voor de geboorte waarbij in dit verband met name de verantwoordelijkheid voor het lichamelijk welzijn van ongeboren kind

\footnotetext{
${ }^{440}$ Gezag omvat immers het recht en de plicht van de ouder om het minderjarige kind te verzorgen en op te voeden, ex. art. 1:247 BW.

${ }^{441}$ In die zin dat de aanwezigheid van één van de genoemde factoren niet per definitie leidt tot een situatie waarin het kind ernstig in zijn ontwikkeling wordt bedreigd. Ten aanzien van overmatig alcoholgebruik tijdens de zwangerschap is voldoende overtuigend aangetoond dat het schadelijk is voor het ongeboren kind. Zie bv. Meyer-Leu e.a. 2011. Voor de andere factoren kan dit genuanceerder liggen. Zie o.a. over verstandelijk beperkten/gehandicapten met een kinderwens: Davids FJR 2010/5.

${ }_{442}$ Asser/De Boer 1* 2010/21.

${ }^{443}$ Preambule IVRK, p. 2.
} 
(art. 1:247 lid 2 ) relevant is. Indien niet, of niet voldoende aan deze plicht wordt voldaan rust op de overheid een positieve verplichting het kind de bescherming te garanderen die noodzakelijk is.

Ook in de jaren 2013 en 2014 werd algemeen aangenomen dat een ondertoezichtstelling ook voor de geboorte kon worden opgelegd. Op grond van art.1:2 BW jo. art. 1:254 oud BW was het mogelijk een (voorlopige) ondertoezichtstelling voor de geboorte uit te spreken. Art. 1:2 BW stelde 'het kind waarvan de vrouw zwanger is wordt als reeds geboren aangemerkt zo dikwijls zijn belang dit vordert. Komt het dood ter wereld dat wordt het geacht nooit te hebben bestaan.' Voornoemd artikel beoogde niet te fungeren als uitbreiding van het begrip persoonlijkheid tot de ongeboren vrucht, maar creëerde een dubbele fictie ten aanzien van het tijdstip van geboorte. ${ }^{444}$ De dubbele fictie was gelegen in het fingeren van de geboorte tijdens de zwangerschap en het ontkennen van het bestaan indien het kind dood ter wereld kwam. Daarnaast moest overeenkomstig de grond in art. 1:2 BW het belang van het kind de totstandkoming van deze fictieve situatie vorderen. Art. 1:2 BW kende zijn oorsprong in het vermogensrecht, en zag vooral toe op het verkrijgen van de erfenis. De constructie heeft echter zijn weg gevonden naar het civiele jeugdrecht en maakte het mogelijk het ongeboren kind onder toezicht te stellen. Hoewel de wetgever destijds deze situatie voor toepassing van art. 1:2 BW niet voor ogen heeft gehad, bestond en bestaat er consensus over de mogelijkheid om prenataal in te kunnen grijpen middels een ondertoezichtstelling. ${ }^{445}$

Mede gezien het feit dat de ondertoezichtstelling zich moest richten op het kind konden geen wonderen worden verwacht waar het ging om het bijsturen van schadelijk gedrag van de zwangere vrouw of het beperken van schadelijke invloeden vanuit de bredere sociale context. De ondertoezichtstelling als maatregel voor het kind, veronderstelde dat eventueel noodzakelijke geachte hulpverlening ook direct gerelateerd moest zijn aan de ernstige bedreiging van het ongeboren kind. Dit bleek ook uit art. 1:258 lid 1 oud BW waarin stond dat Bureau Jeugdzorg een (dwingende) schriftelijke aanwijzing kon verstrekken die de verzorging en opvoeding van het kind moest betreffen. De gezinsvoogd moest binnen de strekking en het doel van de ondertoezichtstelling proberen de (toekomstige) schade voor het kind te voorkomen. Een schriftelijke aanwijzing inhoudende een verwijzing van een ouder naar een psycholoog werd door de rb. Alkmaar niet toelaatbaar geacht omdat het slechts indirect

\footnotetext{
${ }^{444}$ Asser/De Boer $1 * 2010 / 22$.

${ }^{445}$ Vgl. Vlaardingerbroek in $J P F$ 2012, nr. 82 (23 juni 2012) p. 411-414, Wortmann in NJ 2012, 442 (06 augustus 2012) p. 5011-5015, en Dorhout in FJR 2012/50.
} 
toezag op de opvoeding van het kind in kwestie. ${ }^{446}$ Dat gold eveneens voor een schriftelijke aanwijzing waarin de moeder met gezag werd opgedragen haar medewerking te verlenen aan een persoonlijkheidsonderzoek terwijl direct verband met de verzorging en opvoeding ontbrak. ${ }^{447}$ Indien de ondertoezichtstelling het schadelijke gedrag van de ouder niet kon voorkomen, was de maatregel niet direct nutteloos. Het was ook een manier om de zwangere vrouw te monitoren en bood de mogelijkheid om direct in te grijpen na de geboorte, in ernstige gevallen.

\section{De bedreiging van de zedelijke of geestelijke belangen of gezondheid in de literatuur}

In de literatuur zijn diverse pogingen gedaan om de zorgen die konden leiden tot het oordeel dat de belangen van de minderjarige werden bedreigd te categoriseren. Een verhelderend onderscheid is daarbij de onderverdeling in oudergebonden factoren, kindgebonden factoren, of een combinatie van oudergebonden en kindgebonden factoren. ${ }^{448}$ Voorbeelden van oudergebonden factoren zijn verwaarlozing, mishandeling, misbruik of psychiatrische problemen van ouders. Bij kindgebonden factoren kan gedacht worden aan ongeoorloofd schoolverzuim, het weglopen van huis of ernstig probleemgedrag. ${ }^{449}$ Een dergelijk onderscheid was ook zichtbaar in het onderzoek van Slot e.a. naar de doelmatigheid van de ondertoezichtstelling. ${ }^{450}$ In dat onderzoek werd de onderzoekspopulatie van onder toezichtgestelde minderjarigen gekarakteriseerd aan de hand van zorgpunten op drie domeinen: zorgpunten op kindniveau (deze betreffen het functioneren van het kind zelf; zorgpunten op gezinsniveau (deze betreffen het functioneren van het gezin en de primaire opvoedingsomgeving); en zorgpunten op omgevingsniveau (deze betreffen de interactie van de minderjarige met zijn wijdere omgeving, zoals met zijn vriendengroep). ${ }^{451}$ Ten aanzien van de zorgpunten op kindniveau kon bijvoorbeeld worden gedacht aan medische problematiek, sociaal-emotionele problematiek, agressief en/of antisociaal gedrag en risicovol gedrag c.q. een risicovolle levensstijl. ${ }^{452}$ Zorgpunten op gezinsniveau die werden onderscheiden waren onder andere een conflictueuze relatie tussen de ouders, pedagogische onmacht en psychische problemen bij één of beide ouders/opvoeders. ${ }^{453}$ Ten aanzien van zorgpunten op

\footnotetext{
${ }^{446}$ Rb. Alkmaar 5 september 2007, ECLI:NL:RBALK:2007:BB3871.

${ }^{447}$ Rb. Breda 2 maart 2007, ECLI:NL:RBBRE:2007:BA0701.

448 Van der Linden e.a 2009, p. 127. Overigens is meer differentiatie mogelijk ten aanzien van de categorieën zorgpunten. Vgl: Kalverboer 1996.

449 Van der Linden e.a. 2009, p. 127-128.

450 Slot e.a. 2002.

${ }^{451}$ Slot e.a. 2002, p. 38.

${ }^{452}$ Slot e.a. 2002, p. 111-112.

${ }^{453}$ Slot e.a. 2002, p. 11-112.
} 
omgevingsniveau kon worden gedacht aan gedragsproblemen op school, spijbelgedrag, problemen met vrienden of een risicovolle vrijetijdsbesteding. ${ }^{454}$

Overigens is het voornoemde onderscheid niet absoluut. Men kan evengoed beargumenteren dat gedrags- of motivatieproblemen op school een zorgpunt is op kindniveau. Duidelijk is ook dat er sprake is van wederzijdse beïnvloeding in de relatie tussen het kind en de ouders. De ontwikkeling van kinderen wordt beschouwd als een transactioneel proces. ${ }^{455}$ Vanuit een sociaal-interactionistisch perspectief wordt aangenomen dat de invloed van factoren op gezinsniveau toeneemt naarmate ze dichter bij het kind komen te liggen. ${ }^{456}$ Een verhelderend (en in de pedagogiek gebruikelijk) onderscheid tussen factoren op gezinsniveau is de onderverdeling in proximale, distale, contextuele en globale factoren. ${ }^{457}$ Proximale factoren staan het dichtst bij het kind en zien toe op het opvoedgedrag van ouders en de kwaliteit van de ouder-kind relatie; distale factoren op gezinsniveau betreffen kenmerken van de opvoeder, zoals psychopathologie en persoonlijkheid; contextuele factoren verwijzen naar de hiërarchie en overige relaties in het gezin; tot slot, globale factoren zijn factoren die verwijzen naar de bredere sociale context, bijvoorbeeld de sociaal economische status van het gezin. ${ }^{458}$ Algemeen wordt aangenomen dat voornoemde factoren invloed uitoefenen op de ontwikkeling van het kind via proximale factoren. ${ }^{459}$ Er is sprake van samenhang tussen de verschillende niveaus van factoren op gezinsniveau en wederzijdse beïnvloeding tussen kindkenmerken en gezinskenmerken, meest direct via de ouder-kind relatie. ${ }^{460}$ In het dossieronderzoek in deel II van dit onderzoek wordt het onderscheid tussen zorgen op kindniveau en zorgen op ouderniveau aangehouden om te analyseren op welke wijze door de RvdK invulling wordt gegeven aan de ernstige bedreiging van de zedelijke of geestelijke belangen of gezondheid van de minderjarige.

4.2.3 Rechtsgrond van de ondertoezichtstelling: het (voorzienbaar) falen van andere middelen Met de wettelijke herziening van de ondertoezichtstelling op 26 april 1995 werd een tweede cumulatieve voorwaarde aan de rechtsgrond van de ondertoezichtstelling toegevoegd. Naast de voorwaarde dat de zedelijke of geestelijke belangen of gezondheid van de minderjarige

\footnotetext{
${ }^{454}$ Slot e.a. 2002, p. 11-112.

455 Zie bv. Van Aken e.a. 2007.

${ }^{456}$ Dekovic \& Prinzie 2014, p. 241.

${ }^{457}$ Dekovic \& Prinzie 2014, p. 241.

${ }^{458}$ Dekovic \& Prinzie 2014, p. 241.

${ }^{459}$ Dekovic \& Prinzie 2014, p. 241

${ }^{460}$ Dekovic \& Prinzie 2014, p. 241
} 
ernstig werden bedreigd, gold sindsdien op grond van art. 1:254 lid 1 oud BW, dat andere middelen ter afwending van deze bedreiging moesten hebben gefaald of, naar was te voorzien, zouden falen. Deze toevoeging beoogde het ultimum remedium karakter van de ondertoezichtstelling te benadrukken; een beperking van de ouderlijke rechten kan slechts gerechtvaardigd zijn indien er sprake is van een ernstige situatie die niet op minder ingrijpende wijze kan worden weggenomen. ${ }^{461}$ De wetgever stelde in het kader van de herziening van de ondertoezichtstelling in 1995 dat slechts voor het geval op basis van medewerking en overleg geen, of geen voldoende verbetering kon worden bereikt, de mogelijkheid zou moeten bestaan om zo nodig tegen de wil van de ouders, in te grijpen in het belang van de minderjarige. ${ }^{462}$ Deze toevoeging was eerder bepleit door de commissies Gijsbers en Vliegenthart en sloot aan bij de toen gemaakte onderzoeksafwegingen in het beschermingsonderzoek door de $\mathrm{RvdK} .{ }^{463}$ De omschrijving 'andere middelen hebben gefaald of, naar is te voorzien, zullen falen' veronderstelde met name dat eerst vrijwillige hulpverlening ingezet moest worden om de bedreiging in de ontwikkeling van de minderjarige weg te nemen. ${ }^{464}$ Ook was het blijkens bovenstaande formulering mogelijk dat nog geen vrijwillige hulpverlening was ingezet maar men voorzag dat vrijwillige hulpverlening niet tot het gewenste resultaat zou leiden. In het laatste geval mochten wel hoge eisen worden gesteld aan de specifieke motivering van de verzoekende instantie op dit punt, nu het uitgangspunt was dat ouders eerst op basis van vrijwilligheid de kans moesten krijgen om te werken aan de omstandigheden die hadden geleid tot de bedreigde ontwikkeling van de minderjarige.

De verschillende Tweede Kamerfracties reageerden in algemene zin positief op de voorgestelde toevoeging. De leden van de PvdA-fractie vonden het wenselijk dat in het vervolg zou worden beargumenteerd waarom vrijwillige hulpverlening niet (meer) tot de mogelijkheden behoorde. Wel vroegen zij zich af of niet tevens moest worden gemotiveerd waarom met de ondertoezichtstelling wel de geconstateerde bedreiging kon worden afgewend. ${ }^{465}$ Een interessante gedachte nu de legitimering van het ingrijpen in overwegende mate samenhing met de vraag of in alle redelijkheid een positieve uitwerking van de maatregel was te verwachten. ${ }^{466}$ De leden van de D66-fractie stelden een ander

\footnotetext{
${ }^{461}$ Kamerstukken II 1992/93 23 003, nr. 3, p. 11.

462 Kamerstukken II 1992/93 23 003, nr. 3, p. 11.

${ }^{463}$ Zie over de totstandkoming van deze grond in de wet uitvoerig: Bruning 2001, p. 132 e.v.

${ }^{464}$ Kamerstukken II 1992/93 23 003, nr. 3, p. 11.

${ }^{465}$ Kamerstukken II 1992/93 23 003, nr. 4, p.11.

${ }^{466}$ Zie bv. Gerechtshof Amsterdam 23 juni 1970, ECLI:NL:GHAMS:1970:AC5037.
} 
noemenswaardig punt aan de orde: liet de toevoeging dat vrijwillige hulpverlening voorzienbaar moest falen niet teveel ruimte voor een subjectieve interpretatie? ${ }^{467}$ Er zou in die situatie immers worden gevraagd om een verwachting uit te spreken die niet altijd gebaseerd was op eerdere hulpverlening aan de minderjarige en zijn ouders. De staatssecretaris erkende dat het uitspreken van een verwachting zoals besloten lag in voorgestelde rechtsgrond, betekent dat nooit met zekerheid kon worden vastgesteld of de hulpverlening ook daadwerkelijk geen effect zou sorteren. Het was echter niet zo dat de verzoeker zonder nadere toelichting mocht veronderstellen dat vrijwillige hulpverlening niet zou helpen. Het moest gaan om een gerechtvaardigde verwachting, gebaseerd op feiten die het oordeel konden dragen. ${ }^{468}$ De staatssecretaris zag hier met name een belangrijke taak weggelegd voor de kinderrechter die bij uitstek ervaring heeft met het waarderen van vage begrippen en kritisch moest beoordelen de verwachting omtrent het falen van de vrijwillige hulpverlening 'redelijk' was. $^{469}$

Met de toevoeging dat andere middelen moeten hebben gefaald, of naar is te voorzien, zullen falen, is in 1995 een heldere grondslag in de wet opgenomen die het mogelijk maakte de grens tussen het vrijwillig kader en het gedwongen kader, in concrete gevallen scherp af te bakenen. Er mag worden aangenomen dat met de omschrijving 'andere middelen' primair werd gedoeld op hulpverlening in het vrijwillig kader. Het was evenwel niet noodzakelijk de feitelijke invulling tot verschillende vormen van hulpverlening te beperken. In ieder geval veronderstelde deze voorwaarde in de wet dat de RvdK of andere verzoekers in het verzoekschrift moesten aangeven welke andere middelen tevergeefs waren aangewend om de bedreiging weg te nemen, dan wel op grond van welke feiten en omstandigheden kon worden aangenomen dat de inzet van andere middelen niet tot gewenste resultaat zou leiden. ${ }^{470}$ In het dossieronderzoek in deel II van het onderzoek wordt gekeken of de RvdK invulling gaf aan de wettelijke grond en welke oorzaken werden genoemd die ten grondslag lagen aan het (voorzienbare) falen van andere middelen.

\subsubsection{De wettelijke doelstelling van de ondertoezichtstelling}

Met de introductie van de ondertoezichtstelling in 1922 werd voorzien in een nieuwe, minder ingrijpende jeugdbeschermingsmaatregel, naast de reeds bestaande ontheffing en ontzetting

\footnotetext{
${ }^{467}$ Kamerstukken II 1992/93 23 003, nr. 4, p.14.

${ }^{468}$ Kamerstukken II 1993/94 23 003, nr. 5, p. 35

${ }^{469}$ Kamerstukken II 1993/94 23 003, nr. 5, p. 35.

${ }^{470}$ Kamerstukken II 1992/93 23 003, nr. 3, p. 11.
} 
uit het gezag. Sinds de introductie van de jeugdbeschermingswetgeving in Nederland in 1905 kende het systeem een alles of niets karakter. Een ontheffing of ontzetting uit het gezag had tot gevolg dat de minderjarige van zijn ouders werd gescheiden en residentieel werd geplaatst. Vanuit de praktijk kwam kritiek op de rigiditeit en verstrekkende gevolgen van het systeem na invoering van de Kinderwetten. Tussen allerlei vormen van preventief ingrijpen zonder wettelijke basis en gezagsontneming diende een maatregel te komen die nadrukkelijk beoogde de ouderlijke macht te handhaven, en waar mogelijk te versterken. De ondertoezichtstelling moest derhalve voorkomen dat bij gezinsproblemen die zich qua ernst (nog) niet leenden voor een gezagsontneming, de hulpverlening geheel buiten zicht van de voogdijraad en de rechter bleef. ${ }^{471}$ De ondertoezichtstelling kende ten tijde van de invoering dan ook expliciet als doelstelling het terugdringen van aantal ontheffingen en ontzettingen door tijdig hulp te bieden aan het gezin. Binnen de ondertoezichtstelling werd en wordt beoogd de oorzaak van de problemen ten aanzien van de minderjarige weg te nemen waardoor het vervolg van de opvoeding zonder gezinsvoogd verder vorm kan worden gegeven. ${ }^{472}$ In de hierop volgende decennia is bovengenoemde doelstelling echter steeds verder naar de achtergrond verdwenen omdat veel minderjarigen die onder toezicht werde gesteld tevens voor langere tijd uit huis werden geplaatst. ${ }^{473}$

Met de wetswijziging van 1995 beoogde de wetgever de primaire doelstelling van de ondertoezichtstelling te voorzien van een duidelijke wettelijke grondslag zonder de aard van de maatregel of de inhoudelijke doelstelling te wijzigen. Het primaire doel van de ondertoezichtstelling was het wegnemen van de geconstateerde ontwikkelingsbedreiging door het bieden van hulp en steun aan kind en ouder. ${ }^{474}$ Welke hulp en steun geboden moest worden hing af van de concrete omstandigheden van het geval. Zo kon de gezinsvoogdijinstelling mede leiding geven aan de opvoeding van de minderjarige maar konden de inspanningen ook gericht zijn op het coördineren van de noodzakelijke hulpverlening. ${ }^{475}$ In de jaren 2013 en 2014 gaf art. 1:257 lid 1 oud BW aan dat de ondertoezichtstelling gericht moest zijn op het houden van toezicht op de minderjarige en het bieden van hulp en steun aan de minderjarige en de met gezag belaste ouder teneinde de bedreiging in de zedelijke of geestelijke belangen of de gezondheid van de minderjarige af te wenden. Het houden van

\footnotetext{
${ }^{471}$ Kamerstukken II 1919/20, 409, nr. 3 (MvT).

472 Bruning 2001, p.85.

${ }^{473}$ Bruning 2001, p. 199.

${ }^{474}$ Kamerstukken II 1992/93 23 003, nr. 3, p. 12.

${ }^{475}$ Kamerstukken II 1992/93 23 003, nr. 3, p. 12.
} 
toezicht richtte zich op de minderjarige hetgeen aansloot bij de aard van de ondertoezichtstelling zoals neergelegd in art. 1:254 lid 1 oud BW. Het waren niet de ouders, die primair voorwerp waren van toezicht en zorg. Dit betekende niet dat de hulp en steun niet aan de ouders zou kunnen worden geboden, maar mocht hier sprake van zijn dan diende er een duidelijke koppeling te zijn met de ernstige bedreiging van de minderjarige. ${ }^{476}$ Het bieden van hulp en steun aan de minderjarige en zijn ouders was niet vrijblijvend, maar hield een verplichting in voor Bureau Jeugdzorg.

\section{Behoud van ouderlijke verantwoordelijkheid}

Op grond van art. 1:257 lid 2 oud BW was de ondertoezichtstelling er tevens op gericht de met gezag belaste ouder de verantwoordelijkheid voor de verzorging en opvoeding zoveel mogelijk te doen behouden. Deze doelstelling werd expliciet in de wet opgenomen met de wettelijke herziening van de ondertoezichtstelling in 1995. In de memorie van toelichting bij het wetsvoorstel werd hierover opgemerkt:

'Ik acht het wenselijk het algemene uitgangspunt zoals geformuleerd in artikel 257, tweede lid, in de wet op te nemen omdat ik het van groot belang vind dat aan de ouders hulp geboden wordt bij het verzorgen en opvoeden van hun kinderen en dat voorkomen wordt, dat ouders de ondertoezichtstelling ervaren als het overnemen van deze opvoeding en verzorging door instanties en het buitenspel zetten van hen als ouders. Het geeft uitdrukking aan het in onze samenleving als fundamenteel geldende beginsel, dat de verantwoordelijkheid voor de verzorging en opvoeding van minderjarigen in beginsel berust bij de ouders' ${ }^{477}$

Over het algemeen reageerden de verschillende Kamerfracties zeer positief op het voorstel om bij het expliciteren van de doelstelling van de ondertoezichtstelling in de wet, ook het uitgangspunt op te nemen dat ouders binnen een lopende ondertoezichtstelling de eerstverantwoordelijken zouden zijn voor de verzorging en opvoeding van de minderjarige. ${ }^{478}$

\section{Bevorderen gezinsband}

Overeenkomstig de grond in art. 1:257 lid 4 oud BW werd Bureau Jeugdzorg opgedragen om binnen de ondertoezichtstelling de gezinsband tussen de met gezag belaste ouder en de minderjarige te bevorderen. Dit betekende ook dat de gezinsvoogdij-instelling in geval de minderjarige uit huis werd geplaatst in het kader van de ondertoezichtstelling, aandacht moest besteden aan het verbeteren van de opvoedsituatie van de minderjarige, zodat de

\footnotetext{
${ }^{476}$ Asser/de Boer $1 * 2010 / 852$.

477 Kamerstukken II 1992/93 23 003, nr. 3.

${ }^{478}$ Kamerstukken II 1992/93 23 003, nr. 4.
} 
uithuisplaatsing kon worden opgeheven. ${ }^{479}$ Tijdens de parlementaire behandeling van het wetsvoorstel tot herziening van de ondertoezichtstelling (1995) werden wel vragen gesteld over de verhouding tussen de verschillende doelstellingen, specifiek de doelstelling in art. 1:257 lid 3 oud BW (de ondertoezichtstelling gericht op zelfstandigheid minderjarige) en art. 1:257 lid 4 oud BW (het bevorderen van de gezinsband). De leden van de D66-fractie vroegen zich af of het bevorderen van de gezinsband als doelstelling ook van toepassing zou zijn op de situatie waarin ten aanzien van de minderjarige werd gestreefd naar zelfstandigheid. ${ }^{480}$

In deze gevallen was doorgaans sprake van minderjarigen die de grens van meerderjarigheid naderden en die al geruime tijd niet meer in het oorspronkelijke gezin verbleven, waardoor van een gezinsband niet of nauwelijks sprake was. Aanvullend stelden de leden van de GPVfractie de vraag of hiermee niet het risico zou worden gecreëerd dat een oordeel over de ouder-kind relatie teveel in handen kwam van de gezinsvoogdij-instelling, hetgeen er ook toe zou kunnen leiden dat er een verschil van inzicht ontstond over de wenselijkheid van het bevorderen van de gezinsband. ${ }^{481}$ De staatssecretaris stelde in een reactie dat de betreffende fracties kennelijk veronderstelden dat de voorgestelde tekst van art. 1:257 oud BW ruimte liet voor tegenstrijdige doelstellingen. Dat is evenwel niet de bedoeling. De centrale opdracht van de ondertoezichtstelling zou worden neergelegd in art. 1:257 lid 1 oud BW (toezicht op de minderjarige en hulp en steun aan de minderjarige en ouders teneinde de bedreiging weg te nemen). De overige leden van art. 1:257 oud BW verschaften de criteria die invulling konden geven aan de hulp en steun. Ten aanzien van het bevorderen van de gezinsband als doelstelling stelde de staatssecretaris dat ook in die gevallen waarin de ondertoezichtstelling zich primair richtte op het vergroten van de zelfstandigheid van de minderjarige, het hulpverleningsplan in ieder geval niet mocht leiden tot het vergroten van de kloof tussen minderjarige en ouder. ${ }^{482}$ Het bevorderen van de gezinsband bleef dus een nastrevenswaardig doel ook al bood de actuele gezinssituatie niet direct aanknopingspunten om daarin te investeren.

\section{Zelfstandigheid}

De leden 1, 2 en 4 van art. 1:257 oud BW waren gericht op herstel van de normale opvoedingssituatie en het investeren in de ouder-kind relatie. Zoals gesteld week art. 1:257 lid 3 oud BW af van deze uitgangspunten. Indien het leeftijds- en ontwikkelingsniveau van de

\footnotetext{
${ }^{479}$ Kamerstukken II 1992/93 23 003, nr. 3, p. 34.

${ }^{480}$ Kamerstukken II 1992/93 23 003, nr. 4.

${ }^{481}$ Kamerstukken II 1992/93 23 003, nr. 4.

${ }^{482}$ Kamerstukken II 1993/94 23 003, nr. 5.
} 
minderjarige en diens bekwaamheid en behoefte zelfstandig te handelen en zijn leven naar eigen inzicht in te richten daartoe noodzaakten, moest de hulp en steun, meer dan op het vergroten van de mogelijkheden van de ouders om hun kind te verzorgen en op te voeden, gericht zijn op het vergroten van de zelfstandigheid van de minderjarige. Hierbij kon met name worden gedacht aan jeugdigen die nog net minderjarig waren en die, om wat voor reden dan ook, geen contact meer wensten te hebben met hun ouders. In deze gevallen kon de hulp en steun binnen de ondertoezichtstelling erop gericht zijn de minderjarige te begeleiden naar zelfstandigheid. In de memorie van toelichting bij het wetsvoorstel tot herziening van de ondertoezichtstelling 1995 werd gewezen op jeugdigen die dak- of thuisloos waren, verslaafd waren geraakt en/of in de prostitutie terecht waren gekomen. ${ }^{483}$ Voor deze groep gold dat zij zich reeds los hadden gemaakt van het ouderlijk gezag waardoor eventuele aanwijzingen van de gezinsvoogd gericht op de gezagsrelatie tussen kind en ouder weinig zinvol zouden zijn. Hoewel in het concept-wetsvoorstel nog een leeftijdsgrens van 16 jaar voor deze specifieke groep werd gehanteerd, is uiteindelijk uitgegaan van de gedachte dat in iedere zaak casuïstisch zou moeten worden bepaald of het ontwikkelingsniveau, de behoefte en bekwaamheid van de minderjarige aanleiding gaven om de ontwikkeling naar zelfstandigheid als doel centraal te stellen. ${ }^{484}$

Verschillende Tweede Kamerfracties reageerden kritisch op het voorstel. Gewezen werd op de open formulering van het criterium 'leeftijds- en ontwikkelingsniveau van de minderjarige en diens bekwaamheid en behoefte zelfstandig te handelen', hetgeen de mogelijkheid open zou laten dat een (te) grote groep minderjarigen hiervoor in aanmerking kwam. ${ }^{485}$ Dit kon bijvoorbeeld betekenen dat bij iedere 12-jarige die onder toezicht werd gesteld de afweging gemaakt moest worden of hij redelijkerwijs in staat kon worden geacht zijn leven naar eigen inzicht vorm te geven. ${ }^{486}$ De staatssecretaris meende echter dat deze wijziging een verduidelijking zou opleveren voor de toepassing van de ondertoezichtstelling in de praktijk. Zo bleek dat sommige gezinsvoogden ten onrechte in de veronderstelling verkeerden dat het bevorderen van de zelfstandigheid van de minderjarige niet aansloot bij de doelstelling van de ondertoezichtstelling in het geval de ouders aandrongen op een terugkeer naar huis. ${ }^{487}$ De voorgestelde regeling moest eventuele twijfel op dit punt wegnemen. Wel werd ter nuancering ingebracht dat in het geval de specifieke situatie van de minderjarige zou noodzaken een weg

\footnotetext{
${ }^{483}$ Kamerstukken II 1992/93 23 003, nr. 3.

${ }^{484}$ Kamerstukken II 1992/93 23 003, nr. 3.

485 Kamerstukken II 1992/93 23 003, nr. 4.

${ }^{486}$ Kamerstukken II 1993/94 23 003, nr. 5.

${ }^{487}$ Kamerstukken II 1993/94 23 003, nr. 5.
} 
naar zelfstandigheid in te slaan,de hulp en steun meer, maar niet exclusief gericht moest zijn op het vergroten van deze zelfstandigheid. ${ }^{488}$ Hierdoor moest worden voorkomen dat er een tegenstelling zou onstaan tussen de doelstellingen genoemd in art. 1:257 oud BW.

\subsubsection{Het vertalen van de wettelijke doelstelling van de ondertoezichtstelling in concrete} werkdoelen

Het uitgangspunt op grond van art. 1:257 oud BW was duidelijk, de ondertoezichtstelling was primair gericht op hulp en steun aan het kind en de ouders en het bevorderen van de gezinsband, maar in bepaalde specifieke gevallen kon de focus verschuiven naar het vergroten van de zelfstandigheid van de minderjarige. Heldere wettelijke doelstellingen kunnen een rol spelen bij de rechtvaardiging van de op te leggen maatregel, zo betoogde Bruning in haar dissertatie in $2001 .{ }^{489}$ Het opleggen of instandhouden van de maatregel werd gerechtvaardigd doordat in het specifieke geval de voor betrokkenen kenbare doelstellingen van de maatregel nog niet waren behaald. Dit lijkt een argument ontleend aan het rechtszekerheidsbeginsel: de regels waar burgers aan zijn gebonden, en de gevolgen van deze regels dienen voor eenieder, kenbaar, duidelijk en ondubbelzinnig te zijn. ${ }^{490}$ De betrokkenen zouden dus tenminste uit de wettelijke doelstelling moeten kunnen afleiden met welk perspectief de hulpverlening werd ingezet.

Voor de ondertoezichtstelling betekende dit dat de minderjarige en zijn ouders er vanuit mochten gaan dat de maatregel gericht was op een verbetering van de opvoedsituatie van de minderjarige. Om dit te bereiken was het noodzakelijk dat binnen het kader van de wettelijke (algemene) doelstelling op grond van art. 1:257 oud BW concrete (werk)doelen werden gesteld die moesten worden behaald om de geconstateerde ontwikkelingsbedreiging weg te nemen. Ten aanzien van het stellen van concrete doelen voor de uitvoering van de ondertoezichtstelling zijn meerdere malen tekortkomingen gesignaleerd. Zo concludeerde Mertens in 1996 dat de doelen van de ondertoezichtstelling niet altijd helder werden geformuleerd. ${ }^{491}$ Zo liepen korte- en de lange termijn doelen vaak in elkaar over en werden doelen en middelen door elkaar gehaald. ${ }^{492}$ Tot een vergelijkbare conclusie kwamen Slot en collega's enkele jaren later op basis van uitgebreid dossieronderzoek. De doelen die werden terugvonden in de hulpverleningsdossiers bleken zeer algemeen geformuleerd, waarbij doelen

\footnotetext{
${ }^{488}$ Kamerstukken II 1993/94 23 003, nr. 5.

${ }^{489}$ Bruning 2001, p. 4.

${ }^{490}$ Zie hierover Vranken 1997, p. 4.

${ }^{491}$ Mertens 1996, p. 62.

${ }^{492}$ Mertens 1996, p. 62.
} 
en middelen regelmatig door elkaar werden gehaald. ${ }^{493}$ Ook werd ter discussie gesteld of doelen gericht op de ouders wenselijk waren in het licht van de hoofddoelstelling van de ondertoezichtstelling. De ondertoezichtstelling moest er uiteindelijk toe leiden dat de bedreiging van de zedelijke of geestelijke belangen of gezondheid van de minderjarige werd weggenomen. Als de doelen dan alleen waren gericht op de ouder dan bestond de mogelijkheid dat deze doelen waren behaald zonder dat de ernstige bedreiging van de minderjarige was weggenomen. ${ }^{494}$ Daarnaast was er sprake van een dusdanig geringe specificiteit van de gestelde doelen dat het niet mogelijk bleek de doelmatigheid van de ondertoezichtstelling te onderzoeken op basis van de verschuiving in doelen gedurende de maatregel. Geadviseerd werd om in de uitvoering van de ondertoezichtstelling toetsbare doelen te stellen, bij voorkeur zo geformuleerd dat duidelijk zou worden wat de gewenste ontwikkelingsuitkomsten zouden zijn voor de minderjarige. ${ }^{495}$

Het belang van het stellen van concrete doelen is recentelijker ook naar voren gekomen tijdens de parlementaire behandeling van de Wet herziening kinderbeschermingsmaatregelen. Het eerste voorontwerp van wet bevatte de verplichting voor de kinderrechter om de doelen die met de ondertoezichtstelling worden nagestreefd in de beschikking op te nemen. De doelen moesten aangedragen worden in het verzoekschrift, dus in beginsel door de RvdK. ${ }^{496}$ Uiteindelijk heeft dit voorstel het niet gehaald na kritiek van verschillende organisaties. De kinderrechter zou deze manier te veel invloed uit kunnen oefenen op uitvoering van de maatregel. Wel benadrukten alle adviserende organisaties het belang te zien van concreet geformuleerde doelen nu hierdoor inzichtelijk kon worden gemaakt aan welke problemen de minderjarige en zijn ouders moesten werken. ${ }^{497}$

Het stellen van doelen in het kader van de ondertoezichtstelling is vooral onderzocht bij de gezinsvoogdij-instellingen die uitvoering geven aan de maatregel van ondertoezichtstelling. Het voorgaande doet de vraag rijzen wat ten aanzien van het stellen van doelen mag worden verwacht van de RvdK, als verzoeker van de ondertoezichtstelling. Enerzijds is voldoende aannemelijk gemaakt dat het stellen van concrete doelen belangrijk is in ieder fase van het proces, dus ook in het rapport ter onderbouwing van het verzoek tot ondertoezichtstelling door de RvdK. Daarnaast is in hoofdstuk 2 al besproken dat het stellen van doelen een

\footnotetext{
${ }^{493}$ Slot e.a. 2002 , p. $23-26$.

${ }^{494}$ Slot e.a. 2002, p. 16.

495 Slot e.a. 2002, p. 15.

496 Zie hierover Bruning \& Kok 2008, p 5.; De Ruyter \& Bij1 2008, p. 111 e.v.

${ }^{497}$ Kamerstukken II 2008/09 32 015, nr. 3., p. 3.
} 
belangrijke plek heeft gekregen in het rapportageformat beschermingszaken van de RvdK. Anderzijds is de RvdK wellicht geneigd nog niet te concreet invulling geven aan de concrete doelen zodat de gezinsvoogdij-instellingen de ruimte hebben om (samen met ouders) tot een plan van aanpak te komen. Het belang van het stellen van concrete doelen, juist ook op het moment dat de ondertoezichtstelling nog niet is aangevangen, weegt uiteindelijk zwaarder. De ondertoezichtstelling is een hulpverleningsmaatregel met een verplichtend karakter. Een belangrijk kenmerk van hulpverlening is dat (vaak in een hulpverleningsplan) duidelijk wordt gemaakt welke doelen worden nagestreefd. Daarnaast kan hiermee worden benadrukt dat de ondertoezichtstelling een tijdelijk en eindig karakter heeft. Het belangrijkste doel van de ondertoezichtstelling is uiteindelijk een zodanige situatie creeëren dat de maatregel kan worden opgeheven. ${ }^{498}$ Tot slot, en waarschijnlijk meest cruciaal, voor de rechtvaardiging van de ondertoezichtstelling is het noodzakelijk dat de minderjarige en zijn ouders zo precies mogelijk krijgen te weten welke redenenen hebben geleid tot de overheidsbemoeienis en wat er moet worden bereikt om de maatregel te laten eindigen. ${ }^{499}$

Aangezien de RvdK de aangewezen instantie is om aan de hand van zorgpunten de bedreiging in de ontwikkeling van de minderjarige te concretiseren, lijkt het ook zeer wel mogelijk om de gevonden bedreigingen om te zetten in gewenste ontwikkelingsuitkomsten. In het dossieronderzoek in deel II van dit onderzoek zal dan ook worden gekeken of de RvdK een hulpverleningsperspectief schetst en aangeeft welke doelen moeten worden behaald binnen de ondertoezichtstelling.

\subsubsection{Duur, verlenging en beëindiging van de ondertoezichtstelling}

Binnen de jeugdbeschermingswetgeving in de jaren 2013 en 2014 was opgenomen dat de kinderrechter de duur van de ondertoezichtstelling bepaalde op ten hoogste een jaar (art. 1:256 lid 1 oud BW). Wanneer met een kortere duur kon worden volstaan dan behoorde de kinderrechter de termijn van de ondertoezichtstelling op minder dan een jaar te bepalen, bijvoorbeeld wanneer het een zeer jong kind betrof, voor wie spoedig duidelijk moest worden welke rol de ouders in de nabije toekomst konden vervullen. Er waren echter meerdere redenen die er toe konden leiden dat niet werd gekozen voor de wettelijke maximumtermijn van een jaar, bijvoorbeeld wanneer de onderbouwing van het verzoek mager was maar wel noodzaak werd gezien om in te grijpen vanwege de ernst van de problematiek. ${ }^{500}$ Ook kon

\footnotetext{
${ }^{498}$ Zie hierover uitgebreider: De Ruyter \& Bij1 2008, p. 113.

${ }^{499}$ De Ruyter \& Bijl 2008, p. 114.

${ }^{500}$ Zie Rb. 's-Gravenhage 11 maart 2013, ECLI:NL:RBDHA:2013:BZ7295.
} 
worden gedacht aan een lopende ondertoezichtstelling waarbinnen ondanks toezeggingen van de gezinsvoogdij-instelling de noodzakelijke hulpverlening niet, of onvoldoende was geboden. In zo'n geval kon een korte verlenging ook dienen als signaal naar Bureau Jeugdzorg om vaart te zetten achter het organiseren van de hulpverlening. ${ }^{501}$ In de praktijk bleken dit echter uitzonderingen. In het overgrote deel van de zaken werd de ondertoezichtstelling voor een jaar opgelegd.

De kinderrechter kon de duur van de ondertoezichtstelling telkens voor ten hoogste een jaar verlengen op verzoek van de stichting, bedoeld in art.1, onder $\mathrm{f}$, van de Wet op de jeugdzorg, een ouder, een ander die de minderjarige als behorende tot zijn gezin verzorgde en opvoedde, de RvdK of het openbaar ministerie (art. 1: 256 lid 2 oud BW). De ondertoezichtstelling mocht alleen worden verlengd indien de gronden van de ondertoezichtstelling (art. 1: 254 oud BW) ten tijde van de beoordeling van het verlengingsverzoek nog steeds aanwezig waren. Er behoorde dus geen ruimte te zijn voor verlenging zonder dat nog steeds sprake was van een ernstige ontwikkelingsbedreiging van de minderjarige en andere middelen op dat moment niet afdoende waren om de geconstateerde bedreiging af te wenden. Deze beoordeling kon gecompliceerd zijn indien de minderjarige tevens in het kader van de ondertoezichtstelling uit huis was geplaatst en zich goed ontwikkelde. Een beoordeling van de feitelijke situatie waarin de minderjarige op dat moment verkeerde zou dan kunnen leiden tot het oordeel dat de ontwikkelingsbedreiging was weggenomen als gevolg van de eerder genomen maatregel van kinderbescherming, hetgeen een verlenging van de maatregel onwenselijk maakte. ${ }^{502}$ Wilde de toetsing omtrent het nog steeds aanwezig zijn van de gronden van een ondertoezichtstelling een zinvolle betekenis hebben dan diende de beoordeling van de kinderrechter uit te gaan van de vraag of bij het uitblijven van een verlenging van de ondertoezichtstelling de minderjarige wederom zodanig zou opgroeien dat hij in zijn zedelijke of geestelijke belangen of ontwikkeling ernstig wordt bedreigd, en andere middelen ter afwending van deze bedreiging hebben gefaald of, naar is te voorzien, zullen falen. ${ }^{503}$ Hieruit volgde dat een beoordeling omtrent de bedreigde ontwikkeling van de minderjarige altijd diende te worden bepaald ten opzichte van de ouder(s) met gezag. Dit sloot ook het beste aan bij de aard van de ondertoezichtstelling als gezagsbeperkende maatregel.

\footnotetext{
${ }^{501}$ Zie hierover: Odink 2013, p. 82.

${ }^{502}$ HR 7 september 2007, ECLI:NL:PHR:2007:BA3034, r.o. 3.4 (conclusie A-G Langemeier).

${ }^{503}$ HR 7 september 2007, ECLI:NL:PHR:2007:BA3034, r.o. 3.4 (conclusie A-G Langemeier).
} 
In de regel werd een verzoek tot verlenging van de ondertoezichtstelling ingediend door de stichting, bedoeld in art. 1, onder f, Wet op de jeugdzorg, die tevens was belast met de uitvoering van de ondertoezichtstelling (Bureau Jeugdzorg). Indien Bureau Jeugdzorg echter besloot niet over te gaan tot een verzoek tot verlenging van de ondertoezichtstelling dan diende hiervan zo spoedig mogelijk en onder overlegging van een verslag van het verloop van de ondertoezichtstelling mededeling aan de RvdK te worden gedaan (art. 1:256 lid 3 oud BW). Op basis van de rapportage die ten grondslag lag aan het besluit om de ondertoezichtstelling of uithuisplaatsing niet te verlengen controleerde de RvdK of de gronden niet meer aanwezig waren en of de veiligheid van het kind voldoende was gewaarborgd. Mocht de RvdK tot een andersluidend oordeel komen omtrent de noodzaak tot verlenging van de ondertoezichtstelling dan kon hij de rechter vragen de ondertoezichtstelling nog enige tijd door te laten lopen. Deze zogenoemde toetsende taak van de RvdK is met de wetswijziging van 1995 in de wet opgenomen teneinde een vorm van externe controle in te voeren nu niet meer de kinderrechter maar de gezinsvoogdijinstelling verantwoordelijk was geworden voor de uitvoering van de ondertoezichtstelling. ${ }^{504}$ Beëindiging (de wet sprak van opheffing) van de ondertoezichtstelling kon worden verzocht door de met gezag belaste ouder, de minderjarige van twaalf jaar of ouder en het Bureau Jeugdzorg indien werd gemeend dat de gronden voor de maatregel niet langer aanwezig waren (art. 1:256 lid 4 oud $\mathrm{BW})$.

\subsubsection{Voorlopige ondertoezichtstelling}

Niet in alle gevallen kon het onderzoek naar de noodzaak van een ondertoezichtstelling worden afgewacht. Indien het dringend en onverwijld noodzakelijk was dan kon de kinderrechter hangende het onderzoek, de minderjarige voorlopig onder toezicht stellen voor ten hoogste drie maanden (art. 1:255 oud BW). De voorlopige ondertoezichtstelling had en heeft dan ook tot doel om te onderzoeken of een definitieve ondertoezichtstelling noodzakelijk is. Gezien het spoedeisende karakter van de maatregel kon de voorlopige ondertoezichtstelling ook opgelegd worden zonder voorafgaand verhoor, al was het wel noodzakelijk dat de behandeling niet kon worden afgewacht in verband met onmiddellijk en ernstig gevaar voor de minderjarige. Op grond van art. 800 lid 3 Rv. en art. 809 lid 3 Rv.

\footnotetext{
504 Zie voor een verdere toelichting omtrent de noodzaak van deze externe controle: Kamerstukken II 1993/94, 23 003, nr. 5, p. 11. Overigens is er sinds de invoering van de toetsende taak van de Raad aanhoudende kritiek op de wijze waarop invulling wordt gegeven aan deze taak. Zie Kamerstukken II 2009/10, 31 839, nr. 58. Zie ook Bruning, FJR 2010/58.
} 
diende de minderjarige (van 12 jaar en ouder) binnen twee weken in de gelegenheid gesteld te worden om te worden gehoord. Was dit niet het geval dan verviel de beschikking waar de voorlopige maatregel op was gebaseerd.

$\mathrm{Nu}$ in de praktijk de voorlopige ondertoezichtstelling veelal werd en wordt gecombineerd met een spoedmachtiging tot uithuisplaatsing is het uitgangspunt dat uiterste terughoudendheid is geboden gezien de ingrijpende aard van de maatregel. De uithuisplaatsing in het kader van een voorlopige ondertoezichtstelling heeft eveneens een tijdelijk karakter. ${ }^{505}$ De beperkte wettelijke vereisten op grond van art. 1: 255 oud BW, die zich overigens goed lieten rechtvaardigen door de noodzaak in bepaalde gevallen acuut te kunnen handelen, noopten wel tot terughoudendheid in de toepassing. Een dergelijke beslissing diende in beginsel slechts te worden genomen op basis van een zorgvuldige afweging van alle feiten en omstandigheden, waarbij alle betrokkenen in de gelegenheid werden gesteld hun mening kenbaar te maken. Het kon evenwel noodzakelijk zijn deze beslissing te nemen zonder hoor en wederhoor, bijvoorbeeld bij concrete vrees voor vlucht indien de ouders en/of minderjarige kennis nemen van het verzoek. Dit gold als uitzondering aangezien op op basis van beperkte informatie een zeer ingrijpende en voor betrokkenen vaak onverwachte maatregel werd getroffen. De positie van ouders was extra kwetsbaar gezien de beperkte mate van rechtsbeschermings die ouders/ kind hadden in de procedure omtrent een voorlopige ondertoezichtstelling. 506

\subsection{De uithuisplaatsing}

Met de introductie van de ondertoezichtstelling in 1922 werd zoals gesteld voorzien een in maatregel die tijdelijk inbreuk maakte op het ouderlijk gezag teneinde een scheiding van kind en ouder door gezagsontneming te voorkomen. ${ }^{507}$ Desondanks leidde de invoering van de ondertoezichtstelling vanaf het begin tot veelvuldige scheidingen van kind en ouder door een plaatsing buiten het gezin. Een van de oorzaken was de koppeling van het tuchtrecht aan de ondertoezichtstelling. De kinderrechter kreeg hierdoor de mogelijkheid om kinderen die onder toezicht waren gesteld ter correctie buiten het gezin te plaatsen 'indien zij bijzondere tucht

\footnotetext{
505 De Hoge Raad concludeerde in dezen dat noch de wet 5 juli 1921, Stb. 834, houdende invoering van de ondertoezichtstelling van minderjarigen, noch de wet van 20 juli 1955, Stb. 323, waarbij de mogelijkheid van uithuisplaatsing tijdens de ondertoezichtstelling werd geregeld, aanwijzingen gaven die wezen op de onmogelijkheid van een machtiging uithuisplaatsing in het kader van een voorlopige ondertoezichtstelling; HR 31 mei 1963, NJ 1966, 337.

506 Op grond van art. 807 onder a Rv staat tegen de beslissing tot voorlopige ondertoezichtstelling.geen hoger beroep open, doch slechts cassatie in belang der wet.

${ }^{507}$ Wet van 5 juli 1921 houdende invoering van den kinderrechter en van de ondertoezichtstelling van minderjarigen, Stb. 1921, 834. De wet is uteindelijk op 1 november 1922 in werking getreden.
} 
behoefden' ${ }^{508}$ Echter, ook buiten de wettelijk geregelde plaatsing ter observatie of tucht, werd de ondertoezichtstelling vanaf de invoering veelvuldig gecombineerd met een uithuisplaatsing. ${ }^{509}$ De uithuisplaatsing kon plaatsvinden na uitspraak van de kinderrechter maar ook op aanwijzing van de gezinsvoogd, dus zonder rechterlijke tussenkomst. Na kritiek vanuit de rechtspraktijk werd uiteindelijk besloten om de regeling omtrent de uithuisplaatsing in het kader van een ondertoezichtstelling te verduidelijken. Na enkele aanpassingen in $1947^{510}$ vond in 1956 een aanzienlijke wijziging plaats ten aanzien van de uithuisplaatsing. Gezien het ontbreken van duidelijke wettelijke criteria en de onduidelijke koppeling tussen de ondertoezichtstelling en uithuisplaatsing werd aanvullende wetgeving noodzakelijk bevonden. De uithuisplaatsing kreeg voor het eerst een eigen rechtsgrond en kon worden toegepast 'indien noodzakelijk in het belang van de verzorging en opvoeding'. ${ }^{511}$ Sindsdien is de rechtsgrond van de uithuisplaatsing ongewijzigd gebleven.

De uithuisplaatsing leidt ertoe dat de minderjarige buiten het gezin van de ouder met gezag wordt geplaatst. Daarbij moest in de jaren 2013 en 2014 onderscheid gemaakt worden tussen de uithuisplaatsing op vrijwillige basis en de uithuisplaatsing met machtiging van de kinderrechter. Op grond van art. 1:258 lid 3 oud BW konden de ouders beslissen tot uithuisplaatsing indien er geen bezwaar bestond aan de zijde van Bureau Jeugdzorg. Ouders dienden in dit verband Bureau Jeugdzorg te verzoeken een indicatiebesluit af te geven waaraan de aanspraak op 'zorg' - hetgeen in dit verband ook slechts het verblijf buiten het gezin kon betreffen (art. 4 Uitvoeringsbesluit Wet op de Jeugdzorg) - kon worden ontleend. Als overige voorwaarde gold dat de minderjarige van 12 jaar en ouder, en de ouders dienden in te stemmen met de uithuisplaatsing. Stemde de minderjarige niet in met de door de ouder geïnitieerde uithuisplaatsing dan moest de procedure tot het verkrijgen van een rechterlijke machtiging worden gevolgd. Het feit dat vrijwillig moest worden ingestemd met de uithuisplaatsing maakte ook dat de ouders en/of het kind op ieder desgewenst moment konden besluiten de uithuisplaatsing te beëindigen. De uithuisplaatsing op initiatief van de ouder met gezag, zonder bezwaar van Bureau Jeugdzorg, moet scherp onderscheiden worden van de uithuisplaatsing op initiatief van Bureau Jeugdzorg met instemming van de ouder met gezag.

\footnotetext{
508 Asser/De Boer 1*. 2010/855.

${ }^{509}$ Delfos \& Doek 1982, p. 97. ; Bruning 2001, p. 102.

${ }^{510}$ Wet van 10 juli 1947, Stb. H232

${ }^{511}$ Bij Wet van 20 juli 1955, Stb. 323. De rechtsgrond van de uithuisplaatsing was te vinden in art. 263 lid 1 oud BW.
} 
In het laatstgenoemde geval was de uithuisplaatsing uitsluitend toegestaan krachtens een op grond van art. 1:261 BW verleende machtiging. ${ }^{512}$

De uithuisplaatsing is een middel binnen de ondertoezichtstelling dat kan worden ingezet indien de belangen van de minderjarige in de thuissituatie niet voldoende kunnen worden gewaarborgd en heeft niet te gelden als zelfstandige maatregel. Incidenteel is gepleit om de uithuisplaatsing als zelfstandige maatregel aan te merken. Bij de wettelijke herziening van de ondertoezichtstelling in 1995 heeft de wetgever aangegeven de noodzaak hiervan niet in te zien. $^{513}$

\section{Het indicatiebesluit}

Indien niet vrijwillig werd ingestemd met een uithuisplaatsing gedurende dag en nacht - of de instemming volgde op initiatief van Bureau Jeugdzorg - dan was een machtiging van de kinderrechter op grond van art. 1:261 lid 1 oud BW vereist. De machtiging van de kinderrechter, diende ter effectuering van het indicatiebesluit in het geval de uithuisplaatsing betrekking had op het verlenen van zorg zoals bedoeld in art. 5 lid $2 \mathrm{Wjz}$. Het indicatiebesluit vestigde de aanspraak op de benodigde zorg en de daarmee samenhangende financiering van de zorg. Daarnaast beoogde het indicatiebesluit bij te dragen aan de onderbouwing van de noodzaak om een scheiding van kind en ouders te bewerkstelligen. ${ }^{514}$ Het besluit kon worden gekwalificeerd als een besluit in de zin van 1:3 Algemene wet bestuursrecht (Awb) en diende derhalve aan de zorgvuldigheidseisen te voldoen die op basis van de Awb aan besluitvorming ten grondslag dienen te liggen. De inhoudelijke eisen die gesteld moesten worden aan het indicatiebesluit waren terug te vinden in art. 6 lid $1 \mathrm{Wjz}$ : het indicatiebesluit moest een beschrijving van de problemen of dreigende problemen bevatten; de ernst en mogelijke oorzaken daarvan; een beschrijving van de benodigde zorg en het met die zorg beoogde doel; de termijn waarbinnen de aanspraak op zorg ten gelding moest zijn gebracht en een advies wie de zorg het beste kon verlenen en coördineren.

Binnen de grenzen van de verleende machtiging tot uithuisplaatsing bepaalde het Bureau Jeugdzorg de verblijfplaats van de minderjarige, waarbij tevens in het indicatiebesluit vermeld diende te worden op wat voor soort verblijf de minderjarige was aangewezen. Op grond van art. 4 lid 1 Uitvoeringsbesluit Wet op de Jeugdzorg omvatte het verblijf van de minderjarige pleegzorg of verblijf in een accommodatie van een zorgaanbieder. Een indicatiebesluit was

\footnotetext{
${ }^{512}$ HR 13 november 1998, ECLI:NL:HR:1998:ZC2774, r.o. 1.3.2.

${ }^{513}$ Kamerstukken II 1993/94 23 003, nr. 5, p. 13.

514 Bakker \& Bentem 2012.
} 
niet noodzakelijk indien de uithuisplaatsing geen betrekking had op geïndiceerde zorg als in art. 5 lid 2 onder a,b WJZ, waarbij kon worden gedacht aan een plaatsing bij de andere ouder met gezag. De Hoge Raad heeft in een uitspraak van 14 oktober 2011 bevestigd dat geen rechtsregel zich verzet tegen een machtiging uithuisplaatsing bij de ouder met gezag waar de minderjarige niet zijn hoofdverblijfplaats heeft. ${ }^{515}$ Wel diende het verzoekschrift in dat geval op grond van art. 1:261 lid 2 oud BW te vermelden voor welke verblijfplaats de machtiging werd gevraagd. Vroom-Cramer stelde mede op basis van deze uitspraak vast dat niet snel sprake was van 'niet-geïndiceerde zorg' en veelal een indicatiebesluit noodzakelijk was. ${ }^{516} \mathrm{De}$ vermoedelijk belangrijkste categorie zaken waarin dit gebeurde was een plaatsing binnen het netwerk van de minderjarige. In de jurisprudentie was zichtbaar dat het ontbreken van een indicatiebesluit dat voldeed aan de wettelijke vereisten niet altijd noodzakelijk werd bevonden indien werd gekozen voor een plaatsing in een netwerkpleeggezin. ${ }^{517}$ Onduidelijk is echter of de rechters met het oog op de specifieke feiten en omstandigheden van deze zaak de netwerkplaatsing hebben toegewezen, en daarbij bewust de wettelijke vereisten minder strikt hebben toegepast.

\subsubsection{Rechtsgrond van de machtiging tot uithuisplaatsing}

Uitgangspunt is dat de minderjarige gedurende de ondertoezichtstelling thuis blijft wonen en door ondersteuning van het gezin wordt getracht de geconstateerde ontwikkelingsbedreiging weg te nemen. Het bleek echter lang niet altijd mogelijk om de belangen van het kind binnen de toepasselijke gezinscontext te waarborgen. In die gevallen bood de wet de mogelijkheid de minderjarige in het kader van de ondertoezichtstelling dag en nacht uit huis te plaatsen. In de jaren 2013 en 2014 was de rechtsgrond van de machtiging uithuisplaatsing neergelegd in art. 1:261 lid 1 oud BW. Op grond van dit artikel kon de kinderrechter een machtiging verlenen 'indien het noodzakelijk in het belang van de verzorging en opvoeding van de minderjarige of tot onderzoek van diens geestelijke of lichamelijk gesteldheid'. Het noodzakelijkheidsvereiste benadrukt het ultimum remedium karakter van de maatregel. Dit betekent dat de verzoekende instantie bescheiden zal moeten overleggen aan de kinderrechter waaruit voldoende duidelijk de noodzaak tot uithuisplaatsing blijkt. Het ultimum remedium-criterium met betrekking tot de uithuisplaatsing hangt samen met de ernstige inbreuk die wordt gemaakt op het recht van ouders en kind op respect voor hun privé- familie- en gezinsleven zoals verwoord in art. 8 lid

\footnotetext{
${ }^{515}$ HR 14 oktober 2011, ECLI:NL:HR:2011:BR5151, m.nt. S.F.M. Wortmann

${ }^{516}$ Vroom Cramer FJR 2014/6.

517 Zie bv. Gerechtshof Amsterdam 11 maart 2014, ECLI:NL:GHAMS:2014:1504.
} 
1 EVRM. Het betekent ook dat redelijkerwijs enig positief effect van de maatregel te verwachten moet zijn en dat deze in de gegeven omstandigheden niet slechts wenselijk, maar noodzakelijk is met het oog op het herstel van de gezinsband en het wegnemen van de ontwikkelingsbedreiging. ${ }^{518}$ Daarnaast zal moeten worden aangegeven welke doelen met de uithuisplaatsing worden beoogd zodat de kinderrechter kan beoordelen of die doelen inderdaad niet zonder uithuisplaatsing bereikt kunnen worden. ${ }^{519}$

In de rechtsgrond werd expliciet verwezen naar het belang van de minderjarige. Met andere woorden, de maatregel moest noodzakelijk zijn in het belang zijn van de opvoeding en verzorging van de minderjarige en het moest noodzakelijk zijn dat deze verzorging buiten het gezin plaatsvond. Hoewel het noodzakelijkheidsvereiste zoals neergelegd in de rechtsgrond van de uithuisplaatsing een subsidiariteitstoets impliceerde, gaf de wet geen nadere indicaties hoe de noodzaak moest worden aangetoond. In het verleden is met name in de literatuur nadrukkelijk gepleit voor een verdere concretisering van de rechtsgrond van de uithuisplaatsing. ${ }^{520}$ De wetgever heeft in het wetgevingsproces inzake de Wet herziening kinderbeschermingsmaatregelen bevestigd dat voor een beperking van het gezag, de noodzaak van deze beperking moet worden aangetoond. ${ }^{521}$ Ook in art. 9 IVRK is het uitgangspunt neergelegd dat een kind niet van zijn ouders wordt gescheiden tenzij na zorgvuldig onderzoek en slechts indien is voldaan aan de wettelijke vereisten, de noodzaak van een scheiding kan worden aangetoond.

Net als ten aanzien van de ondertoezichtstelling is het lastig een volledig overzicht te geven van de feiten en omstandigheden die konden leiden tot het oordeel dat een uithuisplaatsing noodzakelijk was. Aangenomen mag worden dat de factoren die invulling gaven aan de open norm 'ernstige bedreiging van de zedelijke of geestelijke belangen of gezondheid' in het kader van de ondertoezichtstelling hier van overeenkomstige toepassing waren, met die toevoeging dat specifiek de thuissituatie een uithuisplaatsing noodzaakte. De uithuisplaatsing lijkt daarom meer samen te hangen met het begrip 'veiligheid' anders dan puur de gestagneerde of bedreigde ontwikkeling van de minderjarige. Evenals bij de ondertoezichtstelling geldt ook hier dat het ontstaan van een onveilige thuissituatie niet per definitie hoeft voort te komen uit een doen of nalaten van de ouders, hoewel hier doorgaans wel sprake van zal zijn.Verdere gezichtspunten ten aanzien van de noodzakelijkheid op basis

\footnotetext{
${ }^{518}$ Asser/De Boer $1 * 2010 / 856$.

${ }^{519}$ Zie over het stellen van doelen en de effectiviteit van de uithuisplaatsing: Bartelink e.a. 2013.

${ }^{520} \mathrm{Zie}$ in dit verband zeer uitgesproken: Koens 1994, p.37.

${ }^{521}$ Kamerstukken II 2008/09 32 015, nr. 3.
} 
van de nationale wetgeving zijn niet voorhanden. Dat is opvallend gezien het grote verschil tussen een 'kale' ondertoezichtstelling en een ondertoezichtstelling gecombineerd met een machtiging uithuisplaatsing. Voor veel betrokken ouders is het feit dat het kind elders wordt geplaatst moeilijk te accepteren. Een diepgaande rechtvaardiging van de beslissing tot uithuisplaatsing mag dan ook worden verwacht van de RvdK, (Bureau Jeugdzorg) en de kinderrechter.

\subsubsection{De noodzaak tot uithuisplaatsing in het licht van art. 8 EVRM}

Het recht van ouders en kinderen op familie- en gezinsleven met elkaar onder 8 EVRM betekent dat hoge eisen gesteld moeten worden aan een scheiding van kind en ouders. De zeer uitgebreide en gedetailleerde jurisprudentie van het EHRM inzake de bepaling van de noodzakelijkheid van een uithuisplaatsing geeft in dit verband houvast. Het EHRM heeft consequent geoordeeld dat vraag of de inbreuk op het familie- en gezinsleven kan worden gerechtvaardigd (op grond van art. 8 lid 2 EVRM) het beste kan worden beantwoord door de lidstaten zelf. ${ }^{522}$ De lidstaten zijn het beste in staat de feiten van de zaak te beoordelen waardoor het EHRM zich op dit vlak terughoudend opstelt. Deze discretionaire bevoegdheid wordt geacht groter te zijn als met spoed ingegrepen moet worden in het gezin. ${ }^{523}$ Zo stelde het EHRM in de zaak Venema t. Nederland:

\footnotetext{
'The Court recalls that its role is not to substitute itself for the domestic authorities in the exercise of their responsibilities in the field of the compulsory taking of children into public care, but rather to review under the Convention the decisions that those authorities have taken in the exercise of their power of appreciation. The margin of appreciation so to be accorded to the competent national authorities will vary in the light of the nature of the issues and the seriousness of the interests at stake. While national authorities enjoy a wide margin of appreciation in assessing the necessity of taking a child into care, in particular where an emergency situation arises, the Court must still be satisfied in the circumstances of the case that there existed circumstances justifying such a measure. ${ }^{524}$
}

Ondanks de beoordelingsruimte die lidstaten toekomt toetst het EHRM wel of de redenen die zijn aangedragen relevant en voldoende zijn om een inbreuk op het recht op familie- en gezinsleven te rechtvaardigen. ${ }^{525}$ Zo bespreekt het EHRM in diverse zaken de ernst van de

\footnotetext{
${ }^{522}$ Zie bv. EHRM 27 november 1992, appl. nr. 13 441/87, (Olsson t. Zweden 2); EHRM 23 september 1994, appl. nr. 19823/92, (Hokkanen t. Finland).

${ }^{523}$ Zie hierover Forder 2008, p. 47.

${ }^{524}$ EHRM 17 december 2002, appl. nr. 35731/97, (Venema t. Nederland), par. 90.

${ }^{525}$ Zie bv. EHRM 7 augustus 1996, appl. nr. 17383/90 (Johansen t. Noorwegen).
} 
situatie als aanleiding voor de uithuisplaatsing. ${ }^{526}$ Het EHRM is extra kritisch in zaken waarin niet aantoonbaar sprake is geweest van mishandeling, misbruik of andere ernstige vormen van verwaarlozing. ${ }^{527}$ Juist in deze zaken is volgens het EHRM overtuigend bewijs noodzakelijk om tot een scheiding van kind en ouders te komen. ${ }^{528}$ Daarnaast weegt het EHRM mee of de veronderstelde problemen ten aanzien van de kinderen verholpen hadden kunnen worden door adequaat ingrijpen van overheid. Zo werd in Saviny t. Oekraine een schending van art. 8 EVRM aangenomen omdat de problemen van de kinderen grotendeels voortkwamen uit de problematische financiële situatie van de ouders. ${ }^{529}$ Problemen die anders dan het plaatsen van de kinderen elders opgelost hadden kunnen worden door sociaal-maatschappelijke ondersteuning van overheidswege. Een onderbouwing waaruit blijkt dat het kind elders vermoedelijk beter toekomt aan zijn ontwikkelingstaken is op zichzelf onvoldoende om een uithuisplaatsing te rechtvaardigen. 530

\section{De noodzaak alternatieven te overwegen voor de uithuisplaatsing}

Het EHRM heeft in diverse uitspraken laten zien zeer kritisch te toetsen of de autoriteiten voldoende diepgaand en zorgvuldig hebben overwogen of er alternatieven voorhanden waren om de uithuisplaatsing te voorkomen. Zo bepaalde het EHRM in de zaak K. en T. t. Finland dat onderdeel van een zorgvuldige afweging over de uithuisplaatsing is dat aandacht wordt besteed aan de mogelijkheid van (minder ingrijpende) alternatieven. ${ }^{531}$ In de zaak Haase t. Duitsland expliciteert het EHRM voornoemde eis waar het gaat om een scheiding van kind en ouder direct na de geboorte. Zo stelt het EHRM dat alleen in zeer uitzonderlijke gevallen een scheiding van kind en ouder in deze situatie de toets van art. 8 EVRM kan doorstaan. ${ }^{532}$ Vervolgens wordt daar aan toegevoegd dat een dergelijk ingrijpende actie alleen gerechtvaardigd kan zijn als de autoriteiten hebben getracht door middel van minder ingrijpende alternatieven de uithuisplaatsing van het kind te voorkomen. ${ }^{533}$

Hoe hoog het EHRM de lat legt in dit verband blijkt ook uit de zaak Moser t. Oostenrijk. ${ }^{534}$ Van de autoriteiten mogen de grootst mogelijke inspanningen worden verwacht waar het gaat

\footnotetext{
${ }^{526}$ Zie bv. EHRM 26 oktober 2006, appl. nr. 23848/04 (Wallova \& Walla t. Tsjechie); EHRM 26 februari 2002, appl. nr. 46544/99 (Kutzner t. Duitsland); EHRM 8 april 2004, appl.nr 11057/02 (Haase t. Duitsland).

${ }^{527}$ EHRM 26 oktober 2006, appl. nr. 23848/04, (Wallova \& Walla t. Tsjechie).

${ }^{528}$ Zie in dit verband ook EHRM 26 februari 2002, appl. nr. 46544/99 (Kutzner t. Duitsland); par. 72.

${ }^{529}$ EHRM 18 december 2008, appl. nr. 39948/06, (Saviny t. Oekranie), par. 56-58.

${ }^{530}$ EHRM 12 juli 2002, appl.no. 25702/94 (K. \& T. t. Finland).

${ }^{531}$ EHRM 27 april 2000, appl. nr. 25702/94, (K. \& T. t. Finland), par. 166.

${ }^{532}$ EHRM 8 april 2004, appl.nr 11057/02 (Haase t. Duitsland), par. 102.

${ }^{533}$ EHRM 8 april 2004, appl.nr 11057/02 (Haase t. Duitsland), par. 101.

${ }^{534}$ EHRM 29 september 2006, appl. nr. 12643/02 (Moser t. Oostenrijk).
} 
om het onderzoek naar alternatieve middelen om een uithuisplaatsing te voorkomen. In deze zaak verblijft een moeder illegaal in Oostenrijk. Direct na de geboorte van haar kind wordt het kind uit huis geplaatst, aangezien het ontbreken van een verblijfsvergunning het welzijn van haar kind in gevaar zou brengen. ${ }^{535}$ Vervolgens wordt de moeder uit de ouderlijke macht ontzet en de zoon wordt bij een pleeggezin ondergebracht. Het EHRM stelt vast dat anders dan in de meeste zaken, hier geen sprake is van een ouder die opvoedkundig tekort schiet of op andere wijze schade aan het kind heeft toegebracht. ${ }^{536}$ Juist daarom is deugdelijk onderzoek naar alternatieven voor een uithuisplaatsing zo belangrijk. Zo wordt gesteld:

'In the Court's view, a case like the present one called for a particularly careful examination of possible alternatives to taking the second applicant into public care. The Government argued in essence that the courts examined alternative measures and dismissed them as not being practicable. Moreover, they alleged that the first applicant herself failed to co-operate. The applicants, for their part, maintained that no alternatives whatsoever were proposed or assessed by the authorities. ${ }^{537}$

Uiteindelijk gaat het EHRM niet mee in de klacht van moeder dat geen alternatieven zijn overwogen door de Oostenrijke autoriteiten om een scheiding van kind en ouder te voorkomen. De autoriteiten hadden echter meer kunnen en moeten doen om moeder en kind bij elkaar te houden. ${ }^{538}$ Dit wordt als extra ernstig aangemerkt door het EHRM vanwege het feit dat na de spoedmaatregel direct na de geboorte van het kind, onvoldoende stappen zijn gezet om het contact tussen moeder en kind te behouden. ${ }^{539}$

De jurisprudentie van EHRM biedt zoals is gebleken duidelijke aanknopingspunten waar het gaat om de beoordeling van de noodzaak van een uithuisplaatsing. Deze aanknopingspunten zijn van belang voor de analyse van zaken in deel II van dit onderzoek. Gekeken zal worden op welke wijze de RvdK en de kinderrechter de noodzaak tot uithuisplaatsing onderbouwen in het beschermingsrapport en de beschikking. Zoals eerder besproken moet de toetsing van de noodzaak van de voorgestelde uithuisplaatsing in de eerste plaats uit de rechtsgrond van de uithuisplaatsing volgen (art. 1:261 lid 1 oud BW). Het is echter ook duidelijk dat de rechtsgrond verder geen indicaties gaf hoe deze noodzaak moest worden aangetoond. Op

\footnotetext{
${ }^{535}$ EHRM 21 september 2006, appl. nr. 12643/02 (Moser t. Oostenrijk), par. 10.

${ }^{536}$ EHRM 21 september 2006, appl. nr. 12643/02 (Moser t. Oostenrijk), par. 68.

${ }^{537}$ EHRM 21 september 2006, appl. nr. 12643/02 (Moser t. Oostenrijk), par. 69.

${ }^{538}$ EHRM 21 september 2006, appl. nr. 12643/02 (Moser t. Oostenrijk), par. 70.

${ }^{539}$ EHRM 21 september 2006, appl. nr. 12643/02 (Moser t. Oostenrijk), par. 71..
} 
grond van het proportionaliteits- en subsidiariteitsbeginsel zoals zichtbaar is geworden in het rechtspraak van het EHRM is een verdere concretisering wel mogelijk.

In de eerste plaats kan hieruit worden afgeleid dat in de besluitvorming moet worden beargumenteerd welke alternatieven zijn overwogen om de uithuisplaatsing te voorkomen. Mocht een uithuisplaatsing toch noodzakelijk worden bevonden dan is het belangrijk dat wordt gekeken of dit op de voor de minderjarige minst ingrijpende wijze kan worden vormgegeven. Concreet betekent dit dat een vervangende gezinssituatie de voorkeur geniet boven een residentiële plaatsing. Zeker de laatste jaren geldt als uitgangspunt dat in eerste instantie wordt gekeken of het kind binnen het eigen netwerk van het gezin kan verblijven, waarbij primair moet worden gedacht aan verblijf bij familie of binnen de naaste kennissenkring. ${ }^{540}$ Mocht plaatsing binnen het netwerk niet in het belang van de minderjarige zijn dan wordt gekozen voor bestandspleegzorg hetgeen betekent dat de pleegzorgaanbieder op basis van een pleegcontract een geschikte plek voor de minderjarige zoekt. Ook deze vorm van plaatsing kent verschillende varianten waarbij in dit verband met name het verschil tussen een crisisplaatsing, een plaatsing met hulpverleningsperspectief en een plaatsing met opvoedingsperspectief relevant is. Indien plaatsing binnen een vervangende gezinssituatie niet mogelijk of wenselijk is, kan de minderjarige ook in een residentiële voorziening worden geplaatst. ${ }^{541}$ De beginselen van proportionaliteit en subsidiariteit vragen in dezen dat voor iedere uithuisplaatsing wordt beargumenteerd of de beslissing tot- en uitvoering van de uithuisplaatsing in redelijke verhouding staat tot het na te streven en doel en daarnaast, dat wordt beargumenteerd waarom niet kan worden volstaan met een andere, minder ingrijpende middelen.

\subsubsection{Doelstelling van de uithuisplaatsing}

Het Burgerlijk Wetboek kende en kent geen afzonderlijke wettelijke bepaling waarin de doelstelling van de uithuisplaatsing is neergelegd. Aangenomen mag worden dat voor de uithuisplaatsing als middel om het ontwikkelingsbelang van de minderjarige te waarborgen, in grote lijnen dezelfde doelstellingen golden als ten aanzien van de ondertoezichtstelling. Dit betekent dat naar oud recht voor de uithuisplaatsing gold dat op grond van art. 1:257 oud BW moest worden getracht de ontwikkelingsbedreiging van de minderjarige weg te nemen en de

\footnotetext{
${ }^{540}$ In bredere zin wordt deze tendens in beleid en praktijk geduid onder de noemer 'eigen kracht', zie bv. Kamerstukken II 2013/14, 33 684, nr. 3 (MvT), p. 14.

${ }^{541} \mathrm{Zie}$ in dit verband art. 4 lid 1 Uitvoeringsbesluit Wet op de Jeugdzorg
} 
ouders zoveel mogelijk de verantwoordelijkheid voor de verzorging en opvoeding te doen laten behouden. Door de plaatsing van de minderjarige buiten het gezin ontstond echter wel een wezenlijk andere situatie nu de eindverantwoordelijkheid voor de bepaling van verblijfplaats, dagelijkse verzorging en opvoeding en vragen omtrent het opvoedperspectief van de minderjarige, de ouders niet meer toekwam. In de praktijk was niet altijd duidelijk in hoeverre binnen de lopende uithuisplaatsing werd gestreefd naar gezinshereniging door het verbeteren van de thuissituatie/ ouderlijke competenties. Van Wijk zag onderscheiden naar doelstelling drie vormen van uithuisplaatsing voorkomen die gefaseerd in elkaar konden overlopen. In de eerste plaats de ondertoezichtstelling met uithuisplaatsing met als primaire doelstelling een terugkeer naar de gezagsdragende ouder; ten tweede een uithuisplaatsing met ongespecificeerd doel; en ten derde de uithuisplaatsing met als doel langdurig verblijf buiten het oorspronkelijke gezin. ${ }^{542}$

Zeker bij jonge kinderen geldt met het oog op het belang van hechting aan de opvoeder(s) het kind niet te lang in onzekerheid kan blijven over de vraag waar hij opgroeit. De tijdelijke aard van de ondertoezichtstelling en uithuisplaatsing dient het belang van het kind bij stabiliteit en continuïteit in de opvoeding, zoals verwoord in art. 20 lid 3 IVRK. Ontbreekt echter het terugkeerperspectief van de minderjarige naar huis en vervalt dus de primaire doelstelling van de ondertoezichtstelling met uithuisplaatsing, dan volgde in de praktijk van voor 2015 niet noodzakelijkerwijs gezagsontneming middels een verderstrekkende maatregel. Al geruime tijd werd kritiek geleverd op de vaak jarenlange verlengingen van de ondertoezichtstelling met uithuisplaatsing terwijl het opvoedperspectief van de minderjarige in het pleeggezin lag. ${ }^{543}$ De wetsherziening van de ondertoezichtstelling in 1995 opende echter de deur naar een nog frequentere toepassing van langdurige uithuisplaatsingen. Tot aan de herziening van de ondertoezichtstelling in 1995 was de duur van de uithuisplaatsing in het kader van de ondertoezichtstelling beperkt tot twee jaar, behoudens enkele uitzonderingen. ${ }^{544}$ Deze zogenaamde tweejaarstermijn werd in de praktijk als te rigide ervaren. ${ }^{545}$ De Nederlandse Vereniging voor Rechtspraak zag echter door afschaffing van de tweejaarstermijn het uitgangspunt dat de minderjarige zo spoedig mogelijk duidelijkheid dient te krijgen over zijn opvoedperspectief - in het licht van de noodzakelijke hechting van het kind aan een opvoeder

\footnotetext{
${ }^{542}$ Van Wijk 1999, p. 246 e.v.

${ }^{543}$ Meest uitgebreid en concreet is Bruning die in haar dissertatie voorstelt om binnen lopende uithuisplaatsingen een duidelijker (wettelijk) onderscheid te maken tussen de uithuisplaatsing met als doel gezinshereniging en de uithuisplaatsing met als doel waarborgen van de vervangende gezinssituatie: Bruning 2001, p. 462.

${ }^{544}$ Op grond van art. 1:263 (oud) BW.

${ }^{545}$ Kamerstukken II 1992/93, 23 003, nr.3 (MvT), p. 18.
} 
- in gevaar komen. ${ }^{546}$ Daarbij werd tevens gerefereerd aan de vigerende praktijk inzake jonge kinderen die niet zelden langdurig uit huis werden geplaatst zonder definitieve zekerheid omtrent hun opvoedperspectief. De staatssecretaris was bereid te kijken naar de samenhang tussen de ondertoezichtstelling en ontheffing maar meende dat ontheffing als vanzelfsprekende stap na twee jaar uithuisplaatsing geen recht zou doen aan de ontheffing als meest vergaande maatregel van kinderbescherming. ${ }^{547}$ De afschaffing van de tweejaarstermijn had echter wel tot gevolg dat er geen juridische belemmeringen meer waren om de uithuisplaatsing jaar in jaar uit te verlengen.

\subsubsection{De doelstelling van de uithuisplaatsing in het licht van art. 8 EVRM}

Ook waar het gaat om de doelstelling van de uithuisplaatsing speelt de rechtspraak van het EHRM met betrekking tot art. 8 EVRM een belangrijke rol. Het EHRM heeft in diverse zaken geoordeeld dat de autoriteiten onder art. 8 EVRM in beginsel de plicht hebben maatregelen te nemen die zijn gericht op hereniging van kind en ouders. Het EHRM benadrukt dat een jeugdbeschermingsmaatregel inhoudende een uithuisplaatsing een tijdelijke maatregel is die zodra de omstandigheden het toelaten moet worden beeindigd. ${ }^{548}$ Op de overheid rust dan ook de verplichting om maatregelen te nemen met als doel hereniging van kind en ouder. ${ }^{549}$ In de zaak Olsson t. Zweden benoemt het EHRM dit specifiek ten aanzien van een maatregel die geen definitief karakter heeft. Zo wordt gesteld:

'the Court would first observe that there appears to have been no question of the children's being adopted. The care decision should therefore have been regarded as a temporary measure, to be discontinued as soon as circumstances permitted, and any measures of implementation should have been consistent with the ultimate aim of reuniting the Olsson family. ${ }^{550}$

In de zaak Eriksson t. Zweden wordt het doel van hereniging van het gezin ook expliciet benoemd door het EHRM, waarbij met name wordt gewezen op de stappen die gezet moeten worden in de uitvoering van de maatregel. ${ }^{551}$

\footnotetext{
${ }^{546}$ Kamerstukken II 1992/93, 23 003, nr. 3 (MvT), p. 18.

${ }^{547}$ Kamerstukken II 1992/93, 23 003, nr. 3 (MvT), p. 18.

${ }^{548}$ Zie EHRM 22 juni 1989, appl. nr. 11373/85 (Eriksson tegen Zweden).

${ }^{549}$ Zie bv. EHRM 10 juli 2002, appl. nr. 46544/99 (Kutzner tegen Duitsland), par. 76.

${ }^{550}$ EHRM 24 maart 1988, appl. nr. 10465/83 (Olsson / Zweden nr. 1).

${ }^{551}$ EHRM 27 november 1992, appl. nr. 13441/87 (Olsson/Zweden nr. 2), par. 90.
} 
In latere uitspraken heeft het EHRM daaraan toegevoegd dat naarmate de uithuisplaatsing voortduurt en de minderjarige hecht in het pleeggezin, het recht op continuïteit van de opvoedingssituatie onder omstandigheden voorrang moet krijgen boven het recht op hereniging van kind en ouder. ${ }^{552}$ Het doel van hereniging van het gezin staat dus niet in alle omstandigheden voorop maar heeft te gelden als 'guiding principle' . In iedere zaak afzonderlijk zal moeten worden geoordeeld of hereniging in het concrete geval in het belang van het kind is. ${ }^{553}$ In de zaak K. \& T. t. Finland wijst het EHRM in dit verband op de situatie waarin kinderen al geruime tijd uit huis zijn geplaatst (en mogelijk zijn ingegroeid in een vervangende gezinsomgeving). In dit geval kan het belang van het kind om niet te worden geconfronteerd met een veranderende gezinsomgeving voorrang krijgen boven het recht van de ouders om herenigd te worden met hun kind. ${ }^{554}$ Waar in de eerdere uitspraken van het EHRM zichtbaar is dat eenzijdig wordt gewezen op het belang van hereniging, is later meer nuance aangebracht ten aanzien van dit standpunt.

In dit dossieronderzoek in deel II van dit onderzoek staat het verzoek tot ondertoezichtstelling met machtiging uithuisplaatsing door de Rvdk centraal. Bij de start van een jeugdbeschermingstraject is (in de regel) nog geen sprake van kinderen die zijn ingegroeid in een pleeggezin, waardoor mag worden verwacht dat het streven naar gezinshereniging in beginsel ten grondslag ligt aan iedere uithuisplaatsing verzocht door de RvdK. Indien de geconstateerde problematiek noopt tot een verblijf buiten het gezin dan behoort de basisveronderstelling te zijn ouders door middel van intensieve ondersteuning in ieder geval de reële kans wordt geboden de verantwoordelijkheid voor de verzorging en opvoeding weer zelfstandig vorm te geven. Dit sluit ook het beste aan bij de aard van de ondertoezichtstelling en uithuisplaatsing als tijdelijke maatregelen.

\subsubsection{Duur, verlenging en beëindiging van de machtiging uithuisplaatsing}

De duur van de machtiging uithuisplaatsing werd in 2013 en 2014 door de kinderrechter bepaald op ten hoogste een jaar (art. 1:262 lid 1 oud BW). Deze termijn kon steeds met een jaar worden verlengd op verzoek van Bureau Jeugdzorg of de Raad voor de Kinderbescherming, op grond van art. 1:262 lid 2 oud BW. Naarmate de uithuisplaatsing voortduurde zou steeds nadrukkelijker de vraag aan de orde moeten komen of er een reële

\footnotetext{
${ }^{552}$ Zie EHRM 24 september 2012, appl. nr. 35141/06 (Levin tegen Zweden), par. 65.

${ }^{553}$ EHRM 12 juli 2001, appl. nr. 25702/94 (K. en T. t. Finland), par. 178 e.v.

${ }^{554}$ EHRM 12 juli 2001, appl. nr. $25702 / 94$ (K. en T. t. Finland), par. 178 e.v.
} 
kans bestond op een terugkeer van de minderjarige naar huis, en zo niet, welke maatregel dan het meest tegemoet zou komen aan het belang van de minderjarige. Twee opties liggen in een dergelijk geval voor de hand: bij duurzame instemming en medewerking van de ouders met gezag kon de pleegzorgplaatsing in het vrijwillig kader worden voortgezet. Bestonden er twijfels over de duurzame bereidheid van de ouder het kind in het pleeggezin op te laten groeien dan was gezagsontneming middels ontheffing de meest voor de hand liggende optie. De gezagsontneming had tot gevolg dat het ontstane gezagsvacuüm moest worden opgeheven door toewijzing van de voogdij aan een instelling of aan de pleegouders. Het voordeel van toewijzing van de voogdij aan de pleegouders was dat de verantwoordelijkheid voor de verzorging en opvoeding in handen zou komen van de feitelijke opvoeders.

Indien Bureau Jeugdzorg besloot de machtiging uithuisplaatsing niet te verlengen, of te beëindigingen, dan deed zij hiervan zo spoedig mogelijk melding en onder overlegging van een verslag van de uithuisplaatsing mededeling aan de Raad voor de Kinderbescherming (resp. art. 1: 262 lid 2 oud BW en art. 1:263 lid 1 oud BW. De Raad voor de Kinderbescherming behoorde vervolgens te toetsen of de beslissing van Bureau Jeugdzorg tot niet verlenging c.q. beëindiging van de uithuisplaatsing in het belang van het kind was. De toetsende taak is voortgekomen uit de gevoelde noodzaak om een onafhankelijke toets uit te voeren op voornoemde besluiten van Bureau Jeugdzorg, ingegeven door het verdwijnen van de leidende rol van de kinderrechter met de herziening van de ondertoezichtstelling in $1995 .{ }^{555}$ De RvdK diende te oordelen over de vraag of er inderdaad geen gronden meer bestonden voor een verdere verlenging van de ondertoezichtstelling met uithuisplaatsing. Kwam de RvdK tot het oordeel dat die gronden nog aanwezig waren dan kon hij op grond van art. 1:254 lid 5 oud BW gebruikmaken van zijn rekestrerende bevoegdheid en verzoeken de stichting te vervangen door een zodanige stichting in een andere provincie. In $2005 \mathrm{kwam}$ de Inspectie Jeugdzorg naar aanleiding van onderzoek in de Savanna-zaak ${ }^{556}$ tot het vernietigende oordeel dat de RvdK landelijk gezien geen structurele uitvoering gaf aan zijn toetsende taak. Latere evaluaties van de toetsende taak van de RvdK lieten verbeteringen zien. 557

\footnotetext{
${ }^{555}$ De kinderrechter werd lijdelijk en de verantwoordelijkheid voor de uitvoering van de ondertoezichtstelling kwam in handen van de gezinsvoogdij-instelling; De staatssecretaris liet zich na kritiek van diverse fracties overtuigen de externe controle op de uitvoering te versterken middels de toetsende taak van de Raad voor de Kinderbescherming; Kamerstukken II 1993/94, 23 003, nr. 5, p. 11.

${ }^{556}$ Inspectie Jeugdzorg, Onderzoek naar de kwaliteit van het hulpverleningsproces aan S., maart 2005.

${ }^{557}$ Kamerstukken II 2009/10, 31 839, nr. 58.
} 


\subsection{De machtiging uithuisplaatsing in een accommodatie voor gesloten jeugdzorg}

Reeds sinds de invoering van de Kinderwetten in 1905 was het mogelijk minderjarigen jeugdigen op civielrechtelijke titel gesloten te plaatsen, in de regel tezamen met minderjarigen die op strafrechtelijke titel werden geplaatst. ${ }^{558}$ Jeugdigen die destijds in het kader van een jeugdbeschermingsmaatregel gesloten uit huis waren geplaatst werden in beginsel geplaatst in een particulier opvoedingsgesticht en in geval van ernstige gedragsproblemen, een rijksinrichting. ${ }^{559}$ Deze zogenaamde samenplaatsing van jeugdigen op civielrechtelijke titel en strafrechtelijke titel heeft stand gehouden tot begin van de $21^{\mathrm{e}}$ eeuw. Bij behandeling van de Beginselenwet justitiële jeugdinrichtingen (Bjj), de wet die zeer uitgebreid en gedetailleerd de rechtspositie van minderjarigen die op strafrechtelijke titel waren geplaatst moest regelen, werd de samenplaatsing nadrukkelijk aan de orde gesteld. ${ }^{560}$ In 2000 was de toenmalige minister van Justitie nog van mening dat samenplaatsing geen onwenselijke situaties opleverde. Enkele jaren later werd toch besloten civielrechtelijke jeugdigen en strafrechtelijke jeugdigen van elkaar te scheiden na alarmerende berichten vanuit de praktijk en de aanbeveling van het Comité voor de Rechten van het Kind om samenplaatsing van 'OTSkinderen en delinquenten' te voorkomen. ${ }^{561}$ Opname van jeugdigen met ernstige gedragsproblemen in justitiële jeugdinrichtingen werd niet gezien als passend ondanks de pedagogische doelstelling die op basis van art. 2 lid 2 Bjj aan ieder verblijf in een justitiële jeugdinrichting ten grondslag lag.

Met invoering van de Wet gesloten jeugdzorg in 2008 als onderdeel van de Wet op de jeugdzorg werd de scheiding geformaliseerd en ontstonden tevens accommodaties voor gesloten jeugdzorg. ${ }^{562}$ Binnen deze accommodaties moest worden voorzien in een passend aanbod voor jeugdigen met ernstige opvoed- en opgroeiproblemen veelal gecombineerd met bijkomende problematiek, die tot dan middels een machtiging op civielrechtelijke titel in Justitiële Jeugdinrichtingen terecht waren gekomen. ${ }^{563}$ Vanaf het allereerste conceptwetsvoorstel gesloten jeugdzorg zijn zorgen geuit over de rechtspositie van jeugdigen in gesloten jeugdzorginstellingen, op basis van de Wet op de Jeugdzorg, die mager oogde ten

\footnotetext{
${ }^{558}$ Zie hierover uitgebreid: Uit Beijerse FJR 2016/9.

${ }^{559}$ Uit Beijerse FJR 2016/9.

${ }^{560}$ Kamerstukken II 2001/02 26016, nr. 19.

${ }^{561}$ Zie voor meer achtergrondinformatie: Goderie e.a. 2004.

562 Wet van 20 december 2007, houdende wijziging van de Wet op de jeugdzorg met betrekking tot jeugdzorg waarop aanspraak bestaat ingevolge de wet in gesloten setting (gesloten jeugdzorg), Stb. 2007/578.

${ }^{563}$ Kamerstukken II 2005/6, 30 664, nr.3 (MvT), p. 1.
} 
opzichte van de rechtpositie van jeugdigen onder de Bjj. ${ }^{564} \mathrm{Om}$ een dekkend aanbod van zowel jeugdzorginstellingen als Justitiële Jeugdinrichtingen te garanderen vond zowel de capaciteitsuitbreiding binnen de jeugdzorg als overheveling vanuit de justitiële jeugdinrichtingen plaats. De Wet gesloten jeugdzorg bewerkstelligde dat jeugdigen niet meer werden samengeplaatst hoewel uitgangspunten voor de toepassing van gesloten jeugdzorg cq. jeugddetentie- en aard van het verblijf op hoofpunten overeenkomen (en overlap tussen de populaties gangbaar is).

Gesloten jeugdzorg moest worden beschouwd als de meest intensieve en vergaande vorm van jeugdzorg nu de rechten en vrijheden van de minderjarige met het verblijf ernstig konden worden ingeperkt. In de eerste plaats behelsde de machtiging een verplichting van de jeugdige in of rondom de accommodatie te verblijven tenzij toestemming werd gegeven om het terrein te verlaten. Daarnaast konden intern andere maatregelen worden toegepast die de vrijheid van de jeugdige verder beperkten zoals verplichte deelname aan een behandeling, en verdere dwang- en controlemaatregelen.

De plaatsing van een jeugdige in een accommodatie voor gesloten jeugdzorg vereiste een specifieke machtiging op grond van art. 1:261 lid 5 oud BW. De formele en materiële vereisten die golden voor opname en verblijf in de gesloten jeugdzorg waren geregeld in de artikelen 29a - 29y Wet op de Jeugdzorg. In de eerste plaats kon de kinderrechter slechts een machtiging gesloten jeugdzorg verlenen ten aanzien van een jeugdige die de leeftijd van 18 jaar nog niet had bereikt indien: de jeugdige onder toezicht was gesteld (art. 29b lid 2 onder a Wjz), de voogdij over de jeugdige berustte bij een stichting (art. $29 \mathrm{~b}$ lid 2 onder b Wjz) of, degene anders dan de voogd, die het gezag over hem uitoefende, met de opneming en het verblijf instemde (art. 29b lid 2 onder c Wjz). Met name dit laatste element heeft voor nogal wat discussie gezorgd omdat het impliceerde dat een automatische koppeling met de ondertoezichtstelling ontbrak. In de conceptfase van het wetsvoorstel gesloten jeugdzorg hebben verscheidene adviesorganisaties zich uitgesproken tegen het voorstel om de koppeling tussen de ondertoezichtstelling en de machtiging gesloten jeugdzorg los te laten, primair omdat de situatie waarin de minderjarige zich bevindt veelal niet los kan worden gezien van de opvoedsituatie. ${ }^{565}$ De wetgever zag echter in de eisen van subsidiariteit en proportionaliteit een belangrijk argument om ook een machtiging gesloten jeugdzorg mogelijk te maken met slechts instemming van de ouder met gezag. Ingrijpen met dwang zou alleen mogelijk moeten

\footnotetext{
${ }^{564}$ Zie voor een nadere uitwerking: Liefaard, FJR 2006/96 en Bruning \& Liefaard, NJB 2006/59.

${ }^{565}$ Kamerstukken II 2005/6, 30 664, nr.3 (MvT), p. 10.
} 
zijn als op vrijwillige basis geen mogelijkheden meer voorhanden waren. Als de ouders instemden hoefde er geen inbreuk te worden gemaakt op het ouderlijk gezag als in art. 1: 247 lid 1 oud BW. ${ }^{566}$ Deze zienswijze van de wetgever destijds laat zich lastig begrijpen nu gezag het recht en de plicht van de ouder omvat om de minderjarige te verzorgen en op te voeden. Een machtiging gesloten jeugdzorg - met of zonder de koppeling aan de ondertoezichtstelling - maakte het feitelijk onmogelijk voor de ouder de dagelijkse verzorging en opvoeding vorm te geven. In deze visie leek het gezag zich te beperken tot de beslissing wel of niet in te stemmen met de gesloten plaatsing. Ondanks voornoemde kritische geluiden werd de mogelijkheid om de jeugdige tegen zijn zin op te nemen in de gesloten jeugdzorg, met instemming van de ouders, opgenomen in art. 29b lid 2 onder c Wjz.

\section{Vrijheidsbeneming van minderjarigen in verdragsrechtelijk perspectief}

Het toepassen van vrijheidsbenemende maatregelen ten aanzien van minderjarigen - ook indien de grondslag wordt gevonden in het bieden van zorg en hulpverlening - is aan banden gelegd via (inter)nationale wet- en regelgeving. Bescherming van de persoonlijk vrijheid van eenieder is onder meer neergelegd in art. $15 \mathrm{Gw}$, waarin staat dat vrijheidsbeneming alleen is toegestaan op basis van een wettelijke grondslag. Daarnaast geldt op basis van art. 5 lid 1 EVRM dat eenieder recht heeft op vrijheid en veiligheid van zijn persoon. Deze vrijheid mag alleen worden ingeperkt overeenkomstig de wettelijke voorschriften en in nader genoemde gevallen, waaronder detentie met een opvoedkundige doelstelling, ex. art. 5 lid 1 sub d EVRM. Dat betekent in dit verband dat minderjarigen die worden geplaatst in een instelling voor gesloten jeugdzorg een programma moet worden geboden ten behoeve van de opvoeding. ${ }^{567}$ Daarnaast geldt op grond van art. 37 aanhef onder b IVRK dat Staten dienen te waarborgen dat geen enkel kind op onwettige of willekeurige wijze van zijn vrijheid wordt beroofd. Vrijheidsbeneming mag slechts worden gehanteerd als uiterste maatregel (last resort) en voor de kortst mogelijke passende duur (shortest appropriate period of time). Hieruit volgt dat de toepassing van vrijheidsbeneming van minderjarigen middels een gesloten machtiging vraagt om een duidelijke wettelijke grondslag. Nationale wetgeving dient zo precies mogelijk aan te geven onder welke voorwaarden de minderjarige in zijn vrijheid kan worden beperkt. ${ }^{568}$ De kortst mogelijke passende duur veronderstelt dat voor iedere

\footnotetext{
${ }^{566}$ Kamerstukken II 2005/6, 30 664, nr. 3 (MvT), p. 10.

${ }^{567}$ Kamerstukken II 2005/6, 30 664, nr. 3 (MvT), p. 6.

${ }^{568}$ Zie hierover uitvoerig Liefaard 2008, p. 188.
} 
jeugdigde afweging wordt gemaakt welke periode passend en noodzakelijk is om zijn ontwikkelingsbelangen veilig te stellen.

\subsubsection{Rechtsgrond machtiging gesloten jeugdzorg}

De wettelijke vereisten op basis waarvan een machtiging gesloten jeugdzorg kon worden verleend waren tot 1 januari 2015 opgenomen in art. 29b lid $3 \mathrm{Wjz}$. Een machtiging gesloten jeugdzorg kon slechts worden verleend indien naar het oordeel van de kinderrechter de jeugdige ernstige opgroei- of opvoedingsproblemen had die zijn ontwikkeling naar volwassenheid ernstig belemmerden en die maakten dat de opneming en het verblijf noodzakelijk waren om te voorkomen dat de jeugdige zich aan de zorg die hij nodig had zou onttrekken of daaraan door anderen zou worden onttrokken. Een duidelijk stringentere rechtsgrond ten opzichte van de reguliere uithuisplaatsing hetgeen zijn rechtvaardiging vond in het ingrijpende karakter van de gesloten plaatsing. Het feit dat het moest gaan om jeugdigen die 'ernstige opgroei- of opvoedingsproblemen hadden die de ontwikkeling naar volwassenheid ernstig belemmerden' benadrukte dat de maatregel zich richtte op jeugdigen met vaak ernstige, meervoudige ontwikkelingsproblemen. De wetgever omschreef dit als volgt:

'Anders gezegd, er zijn jeugdigen met ernstige gedragsproblemen welke problemen noodzaken tot verblijf gedurende dag en nacht in een voorziening waar hen jeugdzorg in de vorm van behandeling en opvoeding wordt geboden. Een groot aantal van deze jeugdigen heeft een aanpak nodig waarbij zij in hun bewegingsvrijheid kunnen worden beperkt en gedwongen kunnen worden, mee te werken aan een behandeling. Ook zijn voor deze jeugdigen controlemaatregelen nodig. ${ }^{569}$

Het kon daarbij enerzijds gaan om jeugdigen die problemen voor anderen veroorzaakten, zoals onveiligheid in de thuissituatie, maar ook jeugdigen die ernstige problemen ervoeren door kwalijke invloeden van buitenaf. ${ }^{570}$ Voorbeelden waren jeugdigen met agressieregulatieproblemen of jeugdigen die in het criminele circuit terecht dreigden te komen, al dan niet met bijkomende alcohol- en drugsproblematiek. Ook kon het gaan om jeugdigen die makkelijk te beïnvloeden waren en daardoor in bescherming genomen moesten worden, bijvoorbeeld meisjes die onder invloed van een loverboy stonden. ${ }^{571}$

\footnotetext{
${ }^{569}$ Kamerstukken II 2005/6, 30 664, nr.3 (MvT), p. 1.

${ }^{570}$ Kamerstukken II 2005/6, 30 664, nr.3 (MvT), p. 10.

${ }^{571}$ Kamerstukken II 2005/6, 30 664, nr.3 (MvT), p. 20 \& 27.
} 
Het tweede deel van de rechtsgrond van de machtiging gesloten jeugdzorg zoals opgenomen in de Wet op de Jeugdzorg richtte zich op het feit dat de minderjarige (mede in het licht van de problematiek) zich zou onttrekken of zou worden onttrokken aan de noodzakelijke zorg. De wetgever veronderstelde dat bij deze doelgroep de kans reeël was dat zij weigerden mee te werken aan iedere vorm van hulpverlening.

'Gesloten jeugdhulp is een zeer zware en intensieve vorm van gespecialiseerde jeugdhulp waarbij de vrijheden van de jeugdige kunnen worden ingeperkt, om te voorkomen dat jeugdige zich onttrekt of onttrokken wordt aan de hulp die hij nodig heeft. Gesloten jeugdhulp heeft als doel jeugdigen met ernstige gedragsproblemen te behandelen en een dusdanige gedragsverandering te bewerkstelligen dat deze jeugdigen weer kunnen participeren in de maatschappij. De jeugdige wordt daartoe opgenomen in een gesloten accommodatie. ${ }^{572}$

Het subsidiariteitsbeginsel vereiste in dezen dat geen andere mogelijkheid bestond dan vrijheidsbeneming om de jeugdige tegen zichzelf of zijn omgeving te beschermen. De wetgever benadrukte dat zeker ten aanzien van de groep jeugdigen waarbij het risico bestond dat zij door anderen werden onttrokken aan de zorg, niet te snel aan een gesloten plaatsing mocht worden gedacht. ${ }^{573}$ Als negatieve beïnvloeding van buitenaf kon worden voorkomen met vrijwillige hulpverlening, bijvoorbeeld in voorzieningen lijkend op een blijf-van-mijnlijf-huis dan werd gesloten opvang niet noodzakelijk gevonden.

\subsubsection{Overige wettelijke vereisten}

Naast de aangescherpte rechtsgrond voor een machtiging gesloten jeugdzorg waren met het oog op de ingrijpende aard van de maatregel nog enkele aanvullende vereisten gesteld. Op grond van art. 29b lid $4 \mathrm{Wjz}$ kon een machtiging slechts worden verleend indien Bureau Jeugdzorg een indicatiebesluit nam dat strekte tot verblijf niet zijnde een verblijf bij een pleegouder en voorts verklaarde dat was voldaan aan de wettelijke vereisten voor opneming op basis van art. $29 \mathrm{~b}$ lid $3 \mathrm{Wjz}$. Deze verklaring behoefde vervolgens instemming van een gedragswetenschapper die de jeugdige kort voor zijn beoordeling in eigen persoon had onderzocht (art. 29b lid $5 \mathrm{Wjz}$ ). De gedragswetenschapper, aangewezen bij nadere regeling, behoorde te toetsen of de geslotenheid inderdaad noodzakelijk was. ${ }^{574}$ De wetgever heeft geen specifieke termijn willen verbinden aan van het vereiste dat de jeugdige 'kort tevoren' moest

\footnotetext{
${ }^{572}$ Kamerstukken II 2012/13, 33 684, nr.3 (MvT), p. 54.

${ }^{573}$ Kamerstukken II 2005/6, 30 664, nr.3 (MvT), p. 10.

${ }^{574}$ Kamerstukken II 2005/6, 30 664, nr.3 (MvT), p. 20.
} 
worden onderzocht, maar het belang van de actualiteitswaarde van het advies werd benadrukt. ${ }^{575}$

Vanaf de introductie van de gesloten jeugdzorg in de Wet op de Jeugdzorg zijn verschillende kritische kanttekeningen geplaatst met name ten aanzien van de positie van de gedragswetenschapper en de inhoud van de door hem afgegeven instemmingsverklaring. In de eerste plaats bleek na inwerkingtreding van de Wet gesloten jeugdzorg dat niet duidelijk was of de gedragswetenschapper zelf een verklaring moest opstellen of slechts zijn instemming diende te verlenen aan de verklaring van Bureau Jeugdzorg omtrent de noodzaak tot gesloten plaatsing. Het laatste was volgens de minister het geval. ${ }^{576}$ Daarnaast maake het in beginsel niet uit waar de gedragswetenschapper werkzaam was zolang hij maar behoorde tot een van de categorieën zoals aangewezen in de Regeling aanwijzing gedragswetenschappers gesloten jeugdzorg. ${ }^{577}$ Het was dus zeer wel mogelijk dat de gedragswetenschapper die de instemmingsverklaring opstelde in dienst was van Bureau Jeugdzorg zelf of in sommige gevallen van een gesloten jeugdzorginstelling of justitiële jeugdinrichting. Met name ten aanzien van dit laatste element hebben Bruning en Liefaard kritiek geuit omdat in dat geval de verklaring mogelijk afkomstig was van de instelling die de jeugdige vervolgens zelf opnam. ${ }^{578}$

Daarnaast konden ook vraagtekens worden gezet bij de instemmingsverklaring afgegeven door een gedragswetenschapper werkzaam bij Bureau Jeugdzorg. In feite beoordeelde de gedragswetenschapper in zo'n geval het oordeel van een collega dat een gesloten verblijf noodzakelijk was. Het gerechtshof 's-Gravenhage vond dat op zichzelf echter onvoldoende om de objectiviteit van het oordeel in twijfel te trekken. ${ }^{579}$ De Hoge Raad oordeelde in een uitspraak van 22 oktober 2010 dat een instemmingsverklaring afgegeven door een gedragswetenschapper die dezelfde minderjarige al eerder had onderzocht, niet betekende dat het onderzoek onvoldoende objectief was uitgevoerd. ${ }^{580}$ De Hoge Raad heeft in een uitspraak van 18 april 2014 zich nogmaals uitgelaten over de instemmingsverklaring van de gedragswetenschapper. Art. 29b lid $5 \mathrm{Wjz}$ noch enige andere bepaling uit de Wjz verzette zich tegen een instemmingsverklaring afgegeven door een gedragswetenschapper in dienst van Bureau Jeugdzorg. ${ }^{581}$ Wel konden ‘bijkomende omstandigheden' aanleiding geven de

\footnotetext{
${ }^{575}$ Kamerstukken II 2005/6, 30 664, nr.3 (MvT), p. 20-21.

${ }^{576}$ Kamerstukken II 2007/8 30 644, nr. 27.

577 Regeling aanwijzing gedragswetenschappers gesloten jeugdzorg, Stcrt. 2007, nr. 248.

${ }^{578}$ Bruning \& Liefaard 2009, FJR 2009/42.

${ }^{579}$ Gerechtshof 's-Gravenhage 6 augustus 2008, ECLI:NL:GHSGR:2008:BE9979.

${ }^{580}$ HR 22 oktober 2010, ECLI:HR:2010:BO1245.

${ }^{581}$ HR 18 april 2014, ECLI:NL:HR:2014:951, r.o. 3.5.2.
} 
onafhankelijkheid van de verklaring in twijfel te trekken. ${ }^{582}$ De Hoge Raad liet echter na deze toevoeging verder te concretiseren.

Inhoudelijk heeft de wetgever ook nagelaten nadere vereisten te stellen aan de instemmingsverklaring door de gedragswetenschapper waardoor onduidelijk was hoe diepgaand het onderzoek behoorde te zijn. In de jurisprudentie is enige duiding gegeven aan de inhoudelijke eisen die mochten worden gesteld aan de instemmingsverklaring. Zo mocht van de gedragswetenschapper worden verwacht dat hij zelfstandig en onafhankelijk een oordeel velde over de noodzaak van plaatsing in een gesloten setting. De verklaring behoorde daarnaast inhoudelijk een toegevoegde waarde te hebben ten opzichte van de verklaring van Bureau Jeugdzorg dat een dergelijke plaatsing noodzakelijk was. ${ }^{583}$ De rechtbank Zwolle voegde daar aan toe dat de verklaring deugdelijk en controleerbaar moest zijn gemotiveerd, dat de gedragswetenschapper niet betrokken mocht zijn bij het opstellen van het inleidende verzoekschrift en indicatiebesluit en dat er sprake moest zijn van zekere distantie ten aanzien van de behandeling van de minderjarige. ${ }^{584}$

Het was volgens de Hoge Raad echter niet noodzakelijk dat de gedragswetenschapper in zijn instemmingsverklaring gemotiveerd inging op de informatie die de minderjarige (schriftelijk) aan hem verstrekte. ${ }^{585}$ Geoordeeld werd dat art. 12 IVRK geen steun bood voor de opvatting dat de gedragswetenschapper gehouden was om rekening te houden met de door de minderjarige aangeboden informatie. Daarmee koos de Hoge Raad voor een beperkte opvatting van het hoorrecht zoals in art. 12 IVRK en de uitleg die daaraan wordt gegeven in General Comment 12. ${ }^{586}$ Naast het recht van de minderjarige om vrijelijk zijn mening te uiten ten aanzien van iedere beslissing die hem betreft, veronderstelt art. 12 IVRK immers dat aan deze mening 'passend belang' wordt gehecht overeenkomstig de leeftijd en rijpheid van de minderjarige. Dit standpunt laat zich extra gelden ten aanzien van de instemmingsverklaring van de gedragswetenschapper. In het onderzoek staan namelijk de minderjarige, zijn gevoelens, persoonlijke problematiek en de verhouding tot vrijheidsbeneming centraal.

\footnotetext{
${ }^{582}$ HR 18 april 2014, ECLI:NL:HR:2014:951, r.o. 3.5.4.

${ }^{583} \mathrm{Rb}$. Maastricht 2 juni 2010, ECLI:NL:RBMAA:2010:BM7024.

${ }^{584}$ Rb. Zwolle 8 december 2008, ECLI:NL:RBZLY:2008:BG8871.

${ }^{585}$ HR 18 april 2014, ECLI:NL:HR:2014:951.

${ }^{586}$ General Comment 12 (CRC/C/GC/12).
} 


\subsection{Gezagsontneming}

In deze paragraaf wordt op hoofdlijnen aandacht besteed aan de mogelijkheden tot beeindiging van het gezag zoals die bestonden in de jaren 2013 en 2014. Kennis over de specifieke verhouding tussen de gezagsbeperkende maatregelen (ondertoezichtstelling/uithuisplaatsing) en gezagsbeeindigende maatregelen (ontheffing/ontzetting) in deze periode is noodzakelijk voor een goed begrip van de wijzigingen die op 1 januari 2015 met de Wet herziening kinderbeschermingsmaatregelen zijn doorgevoerd.

Lang voordat de ondertoezichtstelling als gezagsbeperkende maatregel zijn intrede deed bestond al de mogelijkheid om in te grijpen in de ouderlijke macht ter bescherming van de minderjarige. Met de inwerkintreding van de Burgerlijke Kinderwet in 1905 werden de gedwongen ontheffing en ontzetting uit wat toen nog de ouderlijke macht heette bij wet ingevoerd. Beide maatregelen leidden tot beëindiging van de ouderlijke macht op grond van het oordeel dat het gezin in kwestie ongeschikt was als opvoedingsomgeving en maakten dat het kind elders werd ondergebracht. ${ }^{587}$ Hoewel sindsdien diverse wetswijzigingen ten aanzien van de ontheffing en ontzetting hebben plaatsgevonden, zijn de rechtsgronden in materieel opzicht nauwelijks gewijzigd. Bij de wetswijziging in 1995 werd de term 'ouderlijke macht' vervangen door 'ouderlijk gezag. ${ }^{588}$ Dit betrof meer dan alleen een redactionele wijziging omdat het impliceerde dat de bepalingen inzake de ontheffing en ontzetting van toepassing zouden zijn op alle gevallen waarin de ouder alleen, of de ouders gezamenlijk het gezag uitoefenden.

Zowel de ontheffing als de ontzetting uit het gezag had tot gevolg dat de ouder het gezag werd ontnomen. In geval de ouders gezamenlijk het gezag uitoefenden, werd na ontheffing of ontzetting van een van hen, het gezag voortaan door de andere ouder uitgeoefend Was er echter sprake van eenhoofdig gezag dan kan de ouder zonder gezag de rechtbank te allen tijde verzoeken met het gezag belast te worden. Een dergelijk verzoek behoorde slechts te worden afgewezen indien er gegronde vrees bestond dat bij inwilliging de belangen van de kinderen zouden worden verwaarloosd (art. 1:274 lid 2 oud BW). Werden beide ouders uit het gezag ontheven of ontzet, of voerde de andere ouder niet voortaan alleen het gezag over de minderjarigen dan behoorde het verzoek tot ontheffing en ontzetting gepaard te gaan met een

\footnotetext{
${ }^{587}$ Bruning 2001, p. 7.

${ }^{588}$ Stb. 1995, 255.
} 
voogdijopdracht (art. 1:275 lid $1 \mathrm{BW}$ ). Minderjarigen behoren immers op grond van art. 1:245 lid $1 \mathrm{BW}$ onder gezag te staan.

\subsubsection{Ontheffing uit het gezag}

De ontheffing werd van oudsher beschouwd als 'zachter' middel dan de ontzetting, in die zin dat het onterende karakter van de ontzetting niet kenmerkend was voor de ontheffing. ${ }^{589}$ Niet centraal stond het wangedrag van de ouder maar de ongeschiktheid of onmacht de rechten en plichten die voortkomen uit het ouderlijk gezag te vervullen. Op grond van art. 1:266 oud BW kon een ouder ontheven worden indien hij ongeschikt of onmachtig was zijn plicht inzake het gezag (art. 1:245 lid 1 BW) te vervullen en het belang van het kind zich niet tegen de maatregel verzette. De formulering van art. 1:266 lid 1 oud BW impliceerde een zekere discretionaire bevoegdheid voor de rechtbank om te bepalen of voldaan was aan de gronden voor ontheffing uit het gezag.

Er was een principieel verschil tussen ongeschiktheid en onmacht in dezen hoewel in de praktijk een duidelijk onderscheid niet altijd was te maken. Ongeschikt was diegene, die de gave tot opvoeding miste en daardoor tekort schoot in zijn opvoedingsplicht jegens de kinderen, onmacht wees op een situatie waarin de ouder in zijn algemeenheid wel geschikt moest worden geacht, maar door omstandigheden niet in staat bleek de verantwoordelijkheid voor de verzorging en opvoeding te dragen. ${ }^{590}$ De onmacht of ongeschiktheid van de ouder hoefde zich niet in algemene zin te manifesteren. Het kon ook gaan om de onmacht of ongeschiktheid om een specifiek kind te verzorgen en op te voeden waarbij de onmacht of ongeschiktheid samenhing met de bijzondere eigenschappen van het kind, of met de bijzondere omstandigheden waarin het kind zich bevond ten tijde van het nemen van de beslissing. ${ }^{591}$ Lange tijd kon volgens vaste rechtspraak van de Hoge Raad geen ontheffing worden uitgesproken op basis onmacht of ongeschiktheid van de ouder indien de betrokken ouder blijk gaf van de duurzame bereidheid om het kind in een pleeggezin te laten opgroeien. ${ }^{592}$ In een uitspraak van 4 april 2008 heeft de Hoge Raad dit standpunt verregaand genuanceerd. In het belang van het kind bij stabiliteit en continuïteit in de opvoeding werd voornoemde zienswijze in zoverre heroverwogen dat de duurzame bereidheid weliswaar in de

\footnotetext{
${ }^{589}$ Delfos \& Doek 1974, p. 414.

${ }^{590}$ De Vries en van Tricht 1905, p. 36.

${ }^{591}$ De Vries en van Tricht 1905, p. 347

${ }^{592}$ HR 25 april 1997, NJ 1997/596, m.nt. J. de Boer.
} 
beoordeling moest worden betrokken maar niet zonder meer in de weg stond aan een gedwongen ontheffing. ${ }^{593}$

Naast de onmacht of ongeschiktheid van de ouder gold als voorwaarde dat het belang van het kind zich niet tegen de ontheffing mocht verzetten. Het belang van het kind behoorde het doorslaggevende criterium te zijn ten aanzien van het besluit tot ontheffing, hoewel de rechtsgrond zich primair richtte op het rechtsgevolg voor de ouder. Dit betekende ook dat een ontheffing achterwege diende te blijven in die gevallen waarin geen voorzienbaar positieve uitwerking van de maatregel was te verwachten voor het kind, ook al kon de ouder in kwestie worden aangemerkt als ongeschikt of onmachtig.

In beginsel kon een ontheffing niet worden uitgesproken indien de ouder zich hiertegen verzette (art. 1:268 lid 1 oud BW). Dit uitgangspunt kwam voort vanuit de gedachte dat het oordeel omtrent de belangen van het kind in de eerste plaats de ouders zou toekomen. Bij invoering van de Kinderwetten werd gesteld dat het overheidsingrijpen te ver zou gaan indien het natuurlijke recht der ouders de verantwoordelijkheid voor het kind te dragen zou worden aangetast op grond van een vermeend beter inzicht van anderen. Bij wet van 10 juni 1947 werd echter tegemoet gekomen aan de gevoelde behoefte in de praktijk om onder bepaalde voorwaarden tot een gedwongen ontheffing te komen. ${ }^{594}$ In de periode voor 2015 waren deze uitzonderingsmogelijkheden opgenomen in art. 1:268 lid 2 oud BW. Op grond van art. 1:268 lid 2 oud BW kon de ontheffing ondanks verzet van de ouder toch worden uitgesproken: indien na een ondertoezichtstelling van tenminste zes maanden, of een machtiging uithuisplaatsing van meer dan een jaar en zes maanden gegronde vrees bestond, dat deze maatregel - door ongeschiktheid of onmacht van een ouder om zijn plicht tot verzorging en opvoeding te vervullen - onvoldoende was om de dreiging als bedoeld in art. 1:254 lid 1 oud BW af te wenden (1:268 lid 2 sub a oud BW); indien zonder de ontheffing van de ene ouder, de ontzetting van de andere ouder de kinderen niet aan diens invloed zou onttrekken (1:268 lid $2 \mathrm{sub}$ b oud BW); indien de geestvermogens van de ouder zodanig waren gestoord, dat hij niet in staat was zijn wil te bepalen of de betekenis van zijn verklaring te begrijpen (1:268 lid 2 sub c oud BW); indien na een verzorging en opvoeding met instemming van de ouder anders dan uit hoofde van een ondertoezichtstelling of een plaatsing onder voorlopige voogdij - van tenminste een jaar in een ander gezin dan het ouderlijke, een voortzetting daarvan

\footnotetext{
${ }^{593}$ HR 4 april 2008, ECLI:NL:HR:2008:BC5726.

${ }^{594}$ Stb. 1947, 232.
} 
noodzakelijk was en van terugkeer naar de ouder ernstig nadeel voor het kind moest worden gevreesd (1:268 lid 2 sub d oud BW).

\subsubsection{Ontzetting uit het gezag}

De ontzetting kon worden beschouwd als meest ingrijpende maatregel van jeugdbescherming. De ontzetting berustte, anders dan de ontheffing, op moedwillig plichtsverzuim of onwaardigheid de taak als verzorger en opvoeder te vervullen en had daarmee primair een onterend karakter. Meest pregnante uiting van dit gegeven was dat art. $90 \mathrm{Gw}$ tot aan de Grondwetswijziging in 1983 vermeldde dat degenen die uit de ouderlijke macht of voogdij waren ontzet, uitgesloten waren van het actieve en passieve kiesrecht. ${ }^{595}$ Hoewel ontzetting hierna niet meer kon leiden tot uitsluiting van het kiesrecht, was voor toepassing van deze maatregel nog steeds verwijtbaar gedrag van de ouder noodzakelijk. Het infamerende karakter van de ontzetting kwam tot uiting in de gronden voor oplegging van de maatregel zoals die golden onder oude wetgeving. Op grond van art 1:269 lid 1 oud BW kon de rechtbank een of beide ouders uit het ouderlijk gezag ontzetten indien dit in het belang van het kind/de kinderen noodzakelijk was. Dit maakt duidelijk dat de ontzetting niet ten aanzien van alle kinderen hoefde te gelden. Naast dat de ontzetting in het belang van het kind moest zijn, moest bewezen worden dat was voldaan een of meerdere gronden waarin het verwijt jegens de ouder was gelegen.

In de eerste plaats ging het om 'misbruik van het gezag of grove verwaarlozing van de verzorging en opvoeding van een of meer kinderen' (art. 1:269 lid 1 sub a oud BW). Misbruik van gezag verwees naar schending van de plichten die voortkwamen uit de verantwoordelijkheid voor de verzorging en opvoeding door een doen van de ouder. ${ }^{596}$ Grove verwaarlozing verwees naar een nalaten van de ouder zijn plicht te vervullen. Het feit dat het moet gaan om grove verwaarlozing gaf aan dat het een ernstige situatie moest betreffen, waarbij het kind niet de nodige zorg ontving. ${ }^{597}$ Ook hier heeft de wetgever destijds ruimte gelaten aan de jeugdbeschermingsautoriteiten en de kinderrechter om aan de hand van de specifieke feiten en omstandigheden van het geval te bepalen of sprake was van grove verwaarlozing. De formulering van art. 1:269 oud BW impliceerde dat zowel ten aanzien van misbruik van gezag als grove verwaarlozing, verwijtbaarheid aan de zijde van de ouder noodzakelijk was, hetgeen ook betekende dat een wilsonbekwame ouder niet voor ontzetting

\footnotetext{
595 Zie voor een verdere toelichting hieromtrent: Rood- de Boer 1983, p. 87 e.v.

${ }^{596}$ Bruning, Liefaard \& Vlaardingerbroek 2014, p. 465.

${ }^{597}$ Delfos \& Doek 1974.
} 
in aanmerking zou moeten komen. Een ontzetting kon - naast het algemene uitgangspunt dat het belang van het kind de ontzetting noodzakelijk maakte - ook uitgesproken worden op grond van slecht levensgedrag van de ouder, ex. art. 1:269 lid 1 sub b oud BW. Het noodzakelijke slechte levensgedrag mocht zich niet beperken tot algemeen afkeurenswaardig gedrag, maar moest het kind schade berokkenen. Dat maakte deze grond ook van gering belang omdat slecht levensgedrag niet zelden kon leiden tot het oordeel dat er sprake was van grove verwaarlozing als in art. 1:269 lid $1 \mathrm{sub}$ a oud BW of overlapte met de concreter geformuleerde gronden in art. 1:269 lid 1 sub c-e oud BW. Hetgeen onder slecht levensgedrag moet worden verstaan kon niet in algemene zin worden bepaald en diende te worden afgeleid aan de hand van geldende maatschappelijke opvattingen. ${ }^{598}$

Artikel 1:269 lid 1 sub c oud BW somde vervolgens een aantal zeer specifieke strafbare feiten op die konden leiden tot ontzetting, te weten een onherroepelijke veroordeling: wegens opzettelijke deelneming aan enig misdrijf met een onder gezag staande minderjarige (art. 1:269 lid 1 sub c onder 1 oud BW); wegens het plegen tegen de minderjarige van een der misdrijven omschreven in de titels XIII - XV en XVIII - XX van het tweede boek van het Wetboek van Strafrecht (art. 1:269 lid 1 sub c onder 2 oud BW); tot een vrijheidsstraf van twee jaar of langer (art. 1:269 lid 1 sub c onder 3 oud BW). De genoemde gronden waren ondanks de concrete formulering van gering belang in de rechtspraktijk. Een veroordeling op basis van een der genoemde gronden betekende immers in vrijwel alle gevallen dat ook kon worden gesproken van misbruik van gezag, grove verwaarlozing of slecht levensgedrag van de ouder.

Voorts kon op basis van art. 1:269 lid 1 sub d oud BW het in ernstige mate veronachtzamen van de aanwijzingen van Bureau Jeugdzorg, of belemmering van een uithuisplaatsing als in art. 1:261 oud BW, een grond vormen voor ontzetting. Het is duidelijk dat onder belemmering van de uithuisplaatsing niet werd verstaan het op legitieme wijze inroepen van de rechtsmiddelen die ouders toekwamen in het kader van de uithuisplaatsing. ${ }^{599}$ De grond was met name preventief bedoeld en moest als stimulans dienen voor het welslagen van de ondertoezichtstelling (en uithuisplaatsing). ${ }^{600}$ Voorbeelden waarin deze grond zich kon aandienen waren gevallen waarin de ouder een effectieve uitvoering van de

\footnotetext{
${ }^{598}$ De Toepassing der Kinderwetten IV, p. 112

${ }^{599}$ Zoals de mogelijkheden te verzoeken tot verkorting van de duur van ondertoezichtstelling, het intrekken van een schriftelijke aanwijzing of beeindiging van de maatregel. Deze aanvullende grond is in 1995 opgenomen in de wet; Wet van 26 april 1995, Stb. 1995, 255.

${ }^{600}$ Zie Delfos-Doek 1974, p. 133.
} 
ondertoezichtstelling ernstig tegenwerkte of in geval van een uithuisplaatsing, het kind onvindbaar maakte om de plaatsing te verhinderen. ${ }^{601}$ Tot slot kon een ontzetting worden uitgesproken indien er gegronde vrees bestond voor verwaarlozing van de belangen van het kind, doordat de ouder het kind terugeiste of terugnam van anderen, die diens verzorging en opvoeding op zich hadden genomen (art. 1:269 lid 1 sub e oud BW. In de praktijk betekende dit vereiste een versterking van de positie van de pleegouders nu het kind niet zomaar teruggenomen kon worden door de ouder indien gegronde vrees bestond voor verwaarlozing bij terugkeer.

\subsection{Tussenconclusie}

In dit hoofdstuk heeft een uitgebreide beschrijving plaatsgevonden van het materiële jeugdbeschermingsrecht geldend in de jaren 2013 en 2014. Met name ten aanzien van de ondertoezichtstelling en machtiging uithuisplaatsing is op basis van oude wetgeving gekeken welke uitgangspunten in de praktijk werden gehanteerd om de beoordeling over de noodzaak van een maatregel te maken. Duidelijk is geworden dat de wetgever de nodige ruimte heeft gelaten aan de praktijk om in ieder geval afzonderlijk de noodzaak van een ondertoezichtstelling en machtiging uithuisplaatsing te bepalen. De rechtsgronden van de ondertoezichtstelling en machtiging uithuisplaatsing waren beiden (deels) te typeren als open normen hetgeen de praktijk de noodzakelijk geachte flexibiliteit bood in de besluitvorming.

De bespreking van de wettelijke gronden en de doelstelling van de ondertoezichtststelling en machtiging uithuisplaatsing heeft verschillende gezichtspunten opgeleverd voor het dossieronderzoek in deel II van dit onderzoek. Ten aanzien van de ondertoezichtstelling geldt dat de RvdK en de kinderrechter, teneinde invulling te geven aan de wettelijke grond 'een ernstige bedreiging van de zedelijke of geestelijke belangen of gezondheid van de minderjarige' concrete feiten en omstandigheden moesten aandragen waaruit de ernst van de bedreiging kon worden afgeleid. Daarnaast moest zowel in het beschermingsrapport als in de beschikking worden aangegeven waarom andere middelen (vrijwillige hulpverlening) niet voldoende waren om de bedreiging van de belangen van de minderjarige weg te nemen. Vervolgens is benadrukt dat de RvdK binnen het kader van de wettelijke doelstelling van de ondertoezichtstelling, concrete doelen moest stellen voor de beoogde uitvoering van de ondertoezichtstelling. Idealiter waren die doelen zo geformuleerd dat de duidelijk zou worden wat de gewenste ontwikkelingsuitkomst was voor de minderjarige.

\footnotetext{
${ }^{601}$ Rb. Leeuwarden 18 mei 2011, ECLI:NL:RBLEE:2011:BR2117.
} 
Ten aanzien van de uithuisplaatsing is geconcludeerd dat weinig concrete vereisten in nationale wetgeving waren opgenomen om de noodzaak van een uithuisplaatsing te bepalen. De wet gaf geen verdere indicatie hoe die noodzaak aan te tonen en het Burgerlijk Wetboek bevatte geen afzonderlijke doelstelling voor de uithuisplaatsing. Een concretere toetsing is wel mogelijk op grond van de vereisten die konden worden ontleend aan art. 8 EVRM. Zo heeft het EHRM geoordeeld dat de noodzaak van een scheiding van kind en ouders slechts kon worden aangetoond als alle mogelijke alternatieven om een uithuisplaatsing te voorkomen, waren overwogen. Daarnaast geldt, zeker indien het om een eerste uithuisplaatsing gaat, dat de uitvoering van de maatregel in het teken moet staan van de hereniging van kind en ouders.

Tot slot zijn met het oog op het dossieronderzoek de wettelijke vereisten van de machtiging gesloten jeugdzorg beschreven. Aangezien een gesloten plaatsing een maatregel met een vrijheidsbenemend karakter is zijn verschillende kinder- en mensenrechtelijke bepalingen van toepassing die de minderjarige beschermen tegen onwettige en willekeurige opsluiting (art. 5 EVRM en art. 37b IVRK). Uitgangspunt is dat een gesloten plaatsing een ultimum remedium is, hetgeen betekent dat vrijheidsbeneming de enige mogelijkheid moet zijn om de belangen van de minderjarige veilig te stellen. Op grond van de Wet op de Jeugdzorg moest daarom worden aangetoond dat sprake was ernstige opgroei- en/of opvoedproblemen die de ontwikkeling ernstig belemmerden en een risico op onttrekking aan de noodzakelijke zorg. Daarnaast behoefde de gesloten plaatsing instemming van een gekwalificeerde gedragswetenschapper die de minderjarige kort van tevoren had onderzocht. In deel II van dit onderzoek wordt gekeken of, en zo ja hoe, deze wettelijke vereisten terugkwamen in de besluitvorming van de RvdK en de kinderrechter. 


\section{Deel II Dossieronderzoek naar de rechtvaardiging van jeugdbescherming in de praktijk (2013 - 2014)}

\section{Opzet en uitvoering dossieronderzoek en kenmerken onderzoekspopulatie}

\subsection{Inleiding}

In het eerste deel van dit onderzoek is het juridisch kader geschetst aan de hand waarvan de rechtvaardiging voor de (gewenste) inzet van een ondertoezichtstelling en uithuisplaatsing kan worden geanalyseerd. De analyse in dit deel van het onderzoek is gericht op de (schriftelijke) besluitvorming door de RvdK en de kinderrechter zoals deze heeft plaatsgevonden in de jaren 2013 en 2014. Als uitgangspunt is daarbij gehanteerd dat een diepgaande rechtvaardiging in de eerste plaats vraagt om een besluitvormingsproces door de RvdK en de kinderrechter waarin de wettelijke gronden en doelstellingen, mede in het licht van de uitgangspunten op grond van de besproken kinder- en mensenrechtenbepalingen, correct worden toegepast en geïnterpreteerd. Ten tweede dient het feitenonderzoek zoals uitgevoerd door de RvdK voldoende zorgvuldig te worden uitgevoerd waarbij de wettelijke regels van bewijsrecht in civiele zaken en interne kwaliteitscriteria leidend zijn. Ten derde is het voor de rechtvaardiging van de jeugdbeschermingsmaatregel noodzakelijk dat de minderjarige en zijn ouders in de procedure tijdens het beschermingsonderzoek en in de gerechtelijke procedure in staat worden gesteld op een effectieve manier te participeren. De nadruk is daarbij gelegd op het recht van de minderjarige om te worden gehoord in alle fasen van het besluitvormingsproces en de aanvullende eis op grond van art. 12 IVRK dat de (mening van de) minderjarige moet worden betrokken in de besluitvorming. De uitgangspunten ten aanzien van het materiële- en formele jeugdbeschermingsrecht die golden in de jaren 2013 en 2014 zijn ontleend aan de parlementaire geschiedenis, de wet(tekst), toepasselijk verdragsrecht, rechtspraak en relevante literatuur.

Voordat de inhoudelijke resultaten van het dossieronderzoek kunnen worden beschreven is het noodzaak eerst te verantwoorden hoe het dossieronderzoek is opgezet, uitgevoerd en op welke wijze de data voor het onderzoek zijn verkregen. In paragraaf 5.2 vindt de methodologische verantwoording plaats. Daarnaast is het noodzakelijk aandacht te besteden aan de belangrijkste (achtergrond) kenmerken van zaken die zijn geanalyseerd, om zo - voor 
zover mogelijk - te bepalen in hoeverre de steekproef representatief is voor de onderzoekspopulatie van de RvdK in beschermingszaken. In het dossieronderzoek zijn 200 zaken geanalyseerd waarin door de RvdK in de jaren 2013 en 2014 een verzoek tot ondertoezichtstelling aan de kinderrechter is voorgelegd. In 100 van de 200 zaken is het verzoek tot ondertoezichtstelling gecombineerd met een verzoek machtiging uithuisplaatsing. In paragraaf 5.3 wordt onder meer toegelicht hoe regionale verdeling eruit ziet van de zaken die deel uitmaken van de steekproef. Zo kan worden gekeken of bepaalde regio's wellicht zijn onder- of oververtegenwoordigd in de steekproef hetgeen van invloed kan zijn op de resultaten. Daarnaast wordt gekeken hoe de zaken zijn verdeeld binnen de steekproef (ondertoezichtstelling- reguliere uithuisplaatsing - gesloten plaatsing) en wordt aandacht besteed aan het feit dat in deel van de zaken een spoedmaatregel aan het definitieve verzoek is vooraf gegaan.

Vervolgens wordt in paragraaf 5.4 een overzicht gegeven van verschillende algemene kenmerken van de minderjarigen en ouders die worden geconfronteerd met het verzoek tot ondertoezichtstelling/machtiging uithuisplaatsing. Zo wordt onder meer aandacht besteed aan de spreiding in leeftijd van de minderjarigen binnen de steekproef aangezien de leeftijd belangrijke consequenties kan hebben voor de aard van het beschermingsonderzoek, de procedurele rechten die de minderjarige kan uitoefenen en de doelen die met de noodzakelijke geachte maatregel worden nagestreefd. Ook wordt de verdeling in sekse van de minderjarigen binnen de steekproef toegelicht en vergeleken met de hierover bekende gegevens ten aanzien van de landelijke ondertoezichtstellingspopulatie. Tot slot is het ook belangrijk om een aantal factoren ten aanzien van de gezinssituatie en bredere opvoedingsomgeving binnen de steekproef te beschrijven. Omdat de ondertoezichtstelling in veel gevallen gericht zal zijn op het doorvoeren van verbeteringen in de opvoedingssituatie wordt eerst besproken hoe de feitelijke opvoedingssituatie van de mindejarigen binnen de steekproef eruit ziet. Daarnaast richt de ondertoezichtstelling zich op de verantwoordelijkheden van de ouders in het kader van de gezagsuitoefening, waardoor het relevant is te bespreken hoe het gezag is verdeeld binnen de gezinnen die deel uitmaken van de steekproef.

\subsection{Opzet en uitvoering dossieronderzoek}

Het dossieronderzoek in dit deel van het onderzoek bevat een analyse van het door de RvdK opgestelde beschermingsrapport ter onderbouwing van het verzoek tot ondertoezichtstelling met of zonder machtiging uithuisplaatsing in de jaren 2013 en 2014 en de daaropvolgende 
beschikking van de kinderrechter. Het betreft derhalve een systematische analyse van voornoemde schriftelijke documenten met als doel inzichtelijk te maken hoe de rechtvaardiging voor de inzet van maatregel in juridisch opzicht was vormgegeven. Het onderzoek kan als empirisch worden aangemerkt omdat inhoudelijk zal worden gekeken naar de toepassing van het recht in de rechtspraktijk en aan de hand van de onderzoeksgegeven zal worden gereflecteerd op effecten van het recht. ${ }^{602}$ Binnen traditioneel juridisch onderzoek ligt de focus doorgaans op normatieve vragen, gericht op de meest wenselijke vormgeving en uitleg van rechtsregels. ${ }^{603}$ Vaak wordt daarbij uitgegaan van al dan niet impliciete aannames ten aanzien van het functioneren van het recht, de rechtssubjecten en het effect van regelgeving. Deze assumpties worden meestal niet op correctheid onderzocht. ${ }^{604}$ Ook in het familierecht is het verre van ongebruikelijk dat wijzigingen in wetgeving en beleid worden gebaseerd op basis veronderstellingen die niet zijn getoetst in wetenschappelijk onderzoek. ${ }^{605}$ Zo kunnen een aantal tekortkomingen ontstaan die in meer of mindere mate ook opgaan voor het jeugdbeschermingsrecht, zoals een gebrek aan feitelijke kennis over de effectiviteit van rechtsregels, de procedure en een gebrek aan inzicht over de specifieke kenmerken en gedragen van de rechtssubjecten. Empirisch onderzoek op dit terrein kan leiden tot meer kennis over welke regels een betere toepassing genereren, welke regels beter te handhaven zijn door overheden en welke procedures voor welke soorten geschillen het meest effectief zijn. ${ }^{606}$ Effectiviteit in het kader van dit onderzoek verwijst dus niet naar de uitvoering van de maatregel. Is een diepgaande rechtvaardiging door de RvdK en de kinderrechter mogelijk waarbij een balans moet worden gevonden tussen het belang van de bescherming van de minderjarige en het recht van de minderjarige en zijn ouders op familie- en gezinsleven.

\subsubsection{Dataverzameling}

De RvdK heeft ten behoeve het dossieronderzoek toegang gegeven tot de dossiers op basis waarvan een verzoek tot ondertoezichtstelling/machtiging uithuisplaatsing is verzocht. Als voorwaarden heeft de RvdK hiervoor gesteld dat de resultaten worden geanonimiseerd en eventuele onderzoeksresultaten gebaseerd op casuïstiek tijdig voor publicatie ter inzage aan de RvdK worden voorgelegd. Sinds enkele jaren worden alle onderzoeken door de RvdK digitaal verwerkt en gearchiveerd in het programma Kinderbescherming Bedrijfsprocessen

\footnotetext{
${ }^{602}$ Zie Vranken \& Van Dijck, WPNR 2011/142, p. 1105 e.v.

${ }^{603}$ Van Boom 2013, p. 7 - 84.

${ }^{604}$ Zie hierover Vranken 2014, p.

${ }^{605}$ Antokolskaia 2013, p. 172 e.v.

${ }^{606}$ Vgl. Stolker 2002; Vranken 2014.
} 
Systeem (hierna KBPS). Aan het begin van het onderzoek is gestart met een verkennende pilot op de raadslocatie Den Haag waar 10 fysieke jeugdbeschermingsdossiers zijn geanalyseerd op bruikbaarheid. De dossiers bleken inhoudelijk voldoende compleet om een inhoudsanalyse te maken waarin wordt gekeken naar de de toepassing van de wettelijke gronden en doelstellingen, het feitenonderzoek en de rechtspositie van de minderjarige en zijn ouders. Vanwege het feit dat de benodigde dossiers digitaal verkregen konden worden is in overleg met de RvdK besloten het dossieronderzoek in zijn geheel uit te voeren vanuit het ministerie van Justitie en Veiligheid, waar de Landelijke staforganisatie van de Raad voor de Kinderbescherming is gevestigd. De RvdK heeft geen inspraak gehad ten aanzien van de opzet en uitvoering van het onderzoek.

\section{Steekproef}

Voor de steekproef is gestreefd naar een analyse van zo recent mogelijk afgeronde beschermingsonderzoeken. Op het moment dat het analysekader gereed was kon worden gestart met het dossieronderzoek zijn 2013 en 2014 aangemerkt als peiljaren voor de steekproef. De keuze is gemaakt om uit deze jaren 200 jeugdbeschermingzaken te analyseren, waarvan 100 onderzoeken hebben geleid tot een verzoek tot ondertoezichtstelling en 100 onderzoeken tot een verzoek tot ondertoezichtstelling en machtiging uithuisplaatsing.

De selectie van zaken heeft plaatsgevonden aan de hand van lijsten verstrekt door de RvdK van afgeronde beschermingsonderzoeken waaruit een rekest ondertoezichtstelling of een rekest ondertoezichtstelling met machtiging uithuisplaatsing is voortgekomen. Er heeft in zoverre selectie plaatsgevonden dat de lijst over 2013 alleen verzoeken tot ondertoezichtstelling zonder machtiging uithuisplaatsing bevat en de lijst over 2014 alleen verzoeken tot ondertoezichtstelling met machtiging uithuisplaatsing. Dat wil zeggen de onderzoekspopulatie betreft alle, in KBPS geregistreerde, door de Raad voor de Kinderbescherming afgeronde beschermingsonderzoeken die hebben geleid tot een rekest ondertoezichtstelling en rekest ondertoezichtstelling met machtiging uithuisplaatsing in de jaren 2013 en 2014. In zowel 2013 als 2014 heeft de RvdK jaarlijks tussen de 15.000 en 20.000 beschermingsonderzoeken uitgevoerd. ${ }^{607}$ Naar schatting wordt in ongeveer driekwart van de uitgevoerde beschermingsonderzoeken een rekest ingediend. ${ }^{608}$ Aangezien deze studie

\footnotetext{
${ }^{607}$ Dit aantal kan niet nader worden gespecificeerd aangezien de gegevens uit een grafiek zijn afgeleid. De extacte aantallen zijn niet weergegeven in de instroomanalyse van de RvdK. Zie Instroomanalyse 2016 RvdK. ${ }^{608}$ Ook hier geldt dat niet preciezer kan worden aangegeven hoe groot de rekestratio is. Intern onderzoek van de Raad voor de Kinderbescherming op dit punt laat zien dat in 2012 en 2013 in een kleine 30\% van de beschermingsonderzoeken het besluit luidt dat geen jeugdbeschermingsmaatregel wordt gevraagd.
} 
primair toeziet op de juridische onderbouwing van het besluit wel een ondertoezichtstelling/machtiging uithuisplaatsing te verzoeken maken de zaken waarin is besloten geen maatregel te verzoeken door de RvdK geen onderdeel uit van de onderzoekspopulatie.

De Excel-bestanden met de rekesten waaruit de steekproef is getrokken zijn geordend op datum van afronding van het beschermingsonderzoek, een factor die geen invloed heeft op het soort zaken dat wordt geselecteerd. De zaken in Excel waren alleen te identificeren aan de hand van een zogenoemd kindzaaknummer. Via de ASELECT functie in Excel (de toevalsgenerator) zijn 200 willekeurige nummers geselecteerd die verwezen naar een kindzaaknummer en daarmee een beschermingsonderzoek.nHet kindzaaknummer correspondeert met de naam van de minderjarige op wie het beschermingsonderzoek door de RvdK betrekking heeft. Het is evenwel niet uitzonderlijk dat de RvdK voor of tijdens het onderzoek naar de minderjarige ambtshalve besluit het onderzoek uit te breiden naar overige kinderen in het gezin. Onder één en hetzelfde kindzaaknummer kunnen dus een rapportage en verzoek tot jeugdbeschermingsmaatregel ten aanzien van meerdere kinderen worden gevonden. In de zaken waarin dit het geval bleek is besloten alleen het kind waarnaar het kindzaaknummer direct naar verwijst mee te nemen in de analyse. Uiteindelijk is dus het beschermingsrapport ter onderbouwing van een verzoek tot ondertoezichtstelling met of zonder uithuisplaatsing en de daaropvolgende beschikking ten aanzien van 200 minderjarigen geanalyseerd. In enkele gevallen bleek na het invoeren van het kindzaaknummer uit de steekproef dat niet de benodigde documenten aanwezig waren om de analyse uit voeren. Dat wil zeggen, het raadsrapport beschermingszaken was niet digitaal gearchiveerd, de daaropvolgende beschikking was niet digitaal gearchiveerd, of beide documenten konden niet worden geraadpleegd. Indien het raadsrapport beschermingszaken en/of de beschikking ontbrak is in Microsoft Excel een nieuw willekeurig nummer gegenereerd leidend naar een nieuw rekest tot ondertoezichtstelling/machtiging uithuisplaatsing. Dit was noodzakelijk aangezien de analyse zich richt op het beschermingsrapport leidend tot een verzoek en de beschikking op het verzoek.

De beschikking door de kinderrechter op het verzoek tot ondertoezichtstelling/machtiging uithuisplaatsing is tevens geraadpleegd via KBPS. Zoals gesteld is de Raad voor de Kinderbescherming in alle van de 200 geanalyseerde zaken als verzoeker opgetreden. Op grond van art. 805 lid $1 \mathrm{Rv}$ verstrekt of verzendt de griffier onverwijld een afschrift van de beschikking aan de verzoeker, de verschenen belanghebbenden en niet verschenen 
belanghebbenden aan wie een afschrift van het verzoekschrift is verzonden. Het ontvangen afschrift van de beschikking wordt door de RvdK digitaal gearchiveerd onder het betreffende kindzaaknummer. Aan de hand van het kindzaaknummer dat in de steekproef naar voren is gekomen is het derhalve mogelijk gebleken zowel de beschermingsrapportage als de beschikking die is gevolgd op het verzoek te raadplegen. De Raad voor de Rechtspraak heeft toestemming gegeven voor het includeren van een analyse van de rechterlijke beslissing en de motivering daarvan in de beschikking, op voorwaarde dat de uitspraken volledig worden geanonimiseerd.

\subsection{Representativiteit}

In dit onderzoek wordt beoogd zicht krijgen op de rechtvaardiging van het besluit een ondertoezichtstelling en machtiging uithuisplaatsing te verzoeken (en eventueel op te leggen) door de wijze te analyseren waarop relevante (inter)nationale wet- regelgeving door de RvdK en de kinderrechter is toegepast. Het streven is daarbij de steekproef een representatieve afspiegeling te laten zijn van zaken waarin de RvdK in 2013 en 2014 een maatregel heeft verzocht. In het vervolg van deze paragraaf worden diverse aspecten besproken die van invloed kunnen zijn op de representativiteit van de steekproef. Daarbij moet worden opgemerkt dat niet met nauwkeurigheid is te zeggen hoe de steekproef zich verhoudt tot de tot de totale onderzoekspopulatie van de RvdK in beschermingszaken omdat concrete gegevens over de zaakkenmerken en de onderzoekspopulatie beperkt beschikbaar zijn.

\subsubsection{Landelijke spreiding zaken}

Er is op voorhand geen selectie van regio's gemaakt hetgeen heeft geleid tot de verwachting dat de regio's waarbinnen de grote steden liggen (Amsterdam, Rotterdam, Den Haag, Utrecht), in verhouding tot de overige regio's sterker zijn vertegenwoordigd in de steekproef. Het is aannemelijk dat instroom in deze regio's ook hoger ligt dan in de kleinere regio's. Wel bestond de hoop dat de steekproef ook voldoende zaken op zou leveren uit regio's buiten de Randstad aangezien het dossieronderzoek anders vooral een beeld zou geven van de besluitvorming in grootstedelijke gebieden. Overigens is onvoldoende duidelijk of er zoiets bestaat als 'grootstedelijke problematiek' en zo ja, welke specifieke kenmerken dan kunnen worden toegeschreven aan de problematiek van minderjarigen en gezinnen in de grote steden. ${ }^{609}$ De 200 zaken die deel uitmaken van de steekproef zijn uitgesplitst aan de hand van

\footnotetext{
${ }^{609}$ Zie hierover Slot e.a. 2002, p. 30.
} 
het Organisatiebesluit raad voor de kinderbescherming 2006 (hierna: Organisatiebesluit), aangezien dit besluit in 2013 en 2014 de regionale indeling van de RvdK bepaalde. ${ }^{610}$

Volgens art. 2 lid 1 Organisatiebesluit behoorde de RvdK een landelijk bureau te hebben was zij werkzaam in dertien regio's waarbinnen een of meerdere locaties de wettelijke taken en bevoegdheden uitvoerden. Art. 2 lid 2 Organisatiebesluit gaf weer hoe de specifieke verdeling in regio's en locaties eruit zag. Ten behoeve van de minderjarigen die binnen een arrondissement hetzij hun woonplaats of laatste woonplaats, hetzij hun werkelijk verblijf hebben, treden op voor de RvdK de in dat arrondissement aanwezige werkeenheden van de RvdK, zo volgt uit art. 1:239 lid 2 BW. Hoewel de terminologie tussen het Organisatiebesluit en voornoemd wetsartikel enigszins verschilde mag er van worden uitgegaan dat met 'werkeenheid' en 'locatie' hetzelfde werd bedoeld. Het is op basis van het voorgaande aannemelijk dat de verdeling naar regio's op basis van de steekproef ook een representatief beeld geeft van de woonplaats, dan wel feitelijke verblijfplaats van de minderjarigen die deel uitmaken van de steekproef.. In tabel 1 zijn de 200 zaken die deel uitmaken van de steekproef uitgesplitst naar regio.

\footnotetext{
${ }^{610}$ Hierna is aangenomen Besluit van 15 mei 2015, houdende vaststelling van de zetel en de organisatie van de raad voor de kinderbescherming (Organisatiebesluit raad voor de kinderbescherming 2015); Stb. 2015, 183. Op grond van art. 6 Organisatiebesluit raad voor de kinderbescherming 2015 treedt het besluit in werking met terugwerkende kracht tot 1 januari 2013. Hoewel het dossieronderzoek is gestart en afgerond na deze datum is besloten de regionale indeling op grond van het Organisatiebesluit 2006 te hanteren omdat de vermelding van de regio's in de dossiers hierop is afgestemd. Hoewel er enkele verschillen zijn in de regionale indeling op grond van het Organisatiebesluit 2015 maakt het voor het doel van het overzicht in dit onderzoek, te weten een beeld geven van de landelijke spreiding, geen wezenlijk verschil.
} 
Tabel 1: Landelijke spreiding

$\begin{array}{lcc}\text { regio } & \text { aantal zaken } & \text { percentage } \\ \text { Friesland en Flevoland } & 12 & 6 \% \\ \text { Groningen en Drenthe } & 12 & 6 \% \\ \text { Overijssel } & 16 & 8 \% \\ \text { Gelderland } & 14 & 7 \% \\ \text { Utrecht } & 12 & 6 \% \\ \text { Amsterdam/ Gooi en Vechtstreek } & 21 & 10,5 \% \\ \text { Noord-Holland } & 11 & 5,5 \% \\ \text { Haaglanden } & 22 & 11 \% \\ \text { Rotterdam-Rijnmond } & 22 & 11 \% \\ \text { Zuid-Holland Zuid en Zeeland } & 14 & 7 \% \\ \text { Oost-Brabant } & 12 & 6 \% \\ \text { Midden- en West-Brabant } & 10 & 5 \% \\ \text { Limburg } & 22 & 11 \% \\ \text { Totaal } & 200 & \\ & & \end{array}$

De gegevens in Tabel 1 laten zien dat uit alle dertien regio's van de RvdK zaken terugkomen binnen de steekproef. Hoewel niet kan worden vastgesteld in hoeverre de regionale verdeling van zaken binnen de steekproef aansluit bij de totale regionale instroom van de RvdK, vallen een aantal zaken in algemene zin op. Overeenkomstig de verwachting is zichtbaar dat gekeken naar de regio's afzonderlijk het aantal zaken afkomstig uit de regio's Amsterdam/ Gooi en Vechtstreek, Haaglanden en Rotterdam-Rijnmond het grootst is. Een logische verklaring hiervoor is dat in deze regio's vermoedelijk ook meer zaken instromen en worden behandeld door de regiokantoren van de RvdK. Enigszins opvallend is het forse aantal zaken 
afkomstig uit de regio Limburg, met de locaties Maastricht en Roermond, hoewel landelijke cijfers laten zien dat minderjarigen uit de regio Limburg in verhouding vaker met een jeugdbeschermingsmaatregel worden geconfronteerd. ${ }^{611}$

\subsubsection{Soort maatregel}

Zoals eerder is aangegeven beperkt het dossieronderzoek zich tot het verzoek tot ondertoezichtstelling en machtiging uithuisplaatsing ingediend door de RvdK. Het gaat in totaal om 200 zaken waarin een ondertoezichtstelling is verzocht door de RvdK. In alle gevallen gaat het om nieuw geinitieerde maatregelen. Het verzoek tot verlenging van de ondertoezichtstelling/machtiging uithuisplaatsing werd in de regel ingediend door Bureau Jeugdzorg en viel daarom buiten het bestek van dit onderzoek. Dit onderzoek richt zich op de rechtvaardiging van de inzet van een ondertoezichtstelling/ machtiging uithuisplaatsing verzocht door de Raad voor de Kinderbescherming, hetgeen bijna altijd nieuwe verzoeken zijn. Dit betekent evenwel niet dat de minderjarigen die deel uitmaken van de steekproef per definitie niet eerder met een ondertoezichtstelling of machtiging uithuisplaatsing zijn geconfronteerd. Indien de ondertoezichtstelling in een eerder stadium was opgeheven (art. 1:256 lid 4 oud BW) of de machtiging uithuisplaatsing was beëindigd (art. 1: 263 lid 1 oud BW) dan wel was ingetrokken door de kinderrechter (art. 1:263 lid 4 oud BW), werd in geval van nieuwe zorgen over de minderjarige een nieuw raadsonderzoek gedaan waarin logischerwijs wel gebruik kon worden gemaakt van de informatie verkregen uit de eerdere maatregel. Omdat in deze gevallen de procedure en inhoudelijke afwegingen van het raadsonderzoek niet afweken van een raadsonderzoek in zaken waar geen eerdere maatregel was opgelegd, zijn deze zaken meegenomen in de analyse.

In de steekproef die ten grondslag ligt aan de analyse zijn twee situaties te onderscheiden waarin het onderzoek van de RvdK leidde tot een verzoek ondertoezichtstelling en machtiging uithuisplaatsing. In de eerste plaats kwam het voor dat de RvdK tijdens het reguliere beschermingsonderzoek tot de conclusie kwam dat een uithuisplaatsing noodzakelijk was in het belang van de verzorging en opvoeding van de minderjarige. In een behoorlijk aantal gevallen was het echter zo dat de RvdK een verzoek tot ondertoezichtstelling indiende waarbij tevens werd verzocht alvast een voorlopige ondertoezichtstelling doorgaans gecombineerd met een spoedmachtiging uithuisplaatsing uit te spreken, omdat dit dringend en onverwijld noodzakelijk was (art. 1:254 lid 1 jo art. 1:255 oud BW). Ook was het mogelijk dat het

${ }^{611}$ CBS 2015, p. 12. 
reguliere beschermingsonderzoek reeds was gestart maar dat zich tijdens het onderzoek omstandigheden voordeden die acuut ingrijpen middels een voorlopige ondertoezichtstelling gecombineerd met machtiging uithuisplaatsing noodzakelijk maakte.

Er heeft geen verdere selectie plaatsgevonden ten aanzien van de melder of het voortraject waardoor zichtbaar is dat binnen de 100 zaken in de steekproef waar een verzoek tot machtiging uithuisplaatsing is ingediend door de RvdK, regelmatig een voorlopige ondertoezichtstelling met spoedmachtiging uithuisplaatsing aan het definitieve verzoek is voorafgegaan. In de meeste gevallen besloot de RvdK indien na overleg bleek dat er inderdaad sprake was van een acute noodsituatie, mondeling een verzoek tot ondertoezichtstelling en machtiging uithuisplaatsing in te dienen, waarbij tevens werd verzocht de ondertoezichtstelling en machtiging uithuisplaatsing voorlopig uit te spreken hangende het onderzoek, op grond van art. 1:255 oud BW. Doorgaans betrof het een telefonisch verzoek aan de kinderrechter waarna binnen enkele dagen het schriftelijke verzoek tot voorlopige ondertoezichtstelling met de beschikbare informatie ter onderbouwing werd ingediend. Het doorgaans acute karakter en de ernst van de situatie in dit soort gevallen heeft gevolgen gehad voor de inhoudelijke besluitvorming. Bij verzoeken tot machtiging uithuisplaatsing indien reeds een ondertoezichtstelling loopt is immers lang niet altijd sprake van acute en ernstige onveiligheid voor de minderjarige. Voor het onderzoek naar de noodzaak van een definitieve maatregel door de RvdK heeft het ook consequenties indien het onderzoek plaatsvindt tijdens een lopende spoedmaatregel. De minderjarige verblijft immers (in de regel) niet meer thuis, maar op een tijdelijke plek in een pleeggezin, gezinshuis of instelling.

Uiteindelijk bleek de maximale periode van drie maanden die kon gelden voor de voorlopige ondertoezichtstelling - en die overigens ook vrijwel altijd werd verzocht - ruim voldoende voor de RvdK om deugdelijk onderzoek te doen naar de noodzaak van handhaving van het definitieve verzoek tot ondertoezichtstelling en machtiging uithuisplaatsing. Zo is in het dossieronderzoek te zien dat de RvdK over het algemeen om en nabij de twee maanden nodig had na het uitspreken van de voorlopige ondertoezichtstelling om tot een handhavingsverzoek van de definitieve maatregel te komen. ${ }^{612}$ De dossieranalyse heeft zich alleen gericht op het deel van de besluitvorming waarin de noodzaak van een definitieve maatregel is onderzocht.

\footnotetext{
${ }^{612}$ Het is, zoals eerder aangegeven niet noodzakelijk dat de Raad het verzoek handhaaft, maar in dit onderzoek zijn alleen zaken geselecteerd waarin de procedure heeft geleid tot een verzoek ondertoezichtstelling met of zonder machtiging uithuisplaatsing.
} 
In 82 van de 100 zaken waarin een verzoek tot ondertoezichtstelling/machtiging uithuisplaatsing is gedaan betrof het een verzoek om een machtiging pleegzorg of verblijf in een accommodatie van een zorgaanbieder, niet zijnde gesloten jeugdzorg. In 18 van de 100 zaken bleek het te gaan om een rekest (verzoek) machtiging uithuisplaatsing op grond van art. 29b Wet op de Jeugdzorg (machtiging gesloten jeugdzorg).

\subsection{Achtergrondkenmerken kind en opvoedingsomgeving}

\subsubsection{Leeftijd minderjarigen}

De leeftijd van de minderjarigen binnen de steekproef is in het licht van het verzoek tot ondertoezichtstelling en machtiging uithuisplaatsing om meerdere redenen relevant. In de eerste plaats is het aannemelijk dat de aard van de problematiek (en daarmee mogelijk ook de ernst van de bedreiging) verandert naarmate de minderjarige ouder wordt. Eerder onderzoek naar de kenmerken van de ondertoezichtstellingspopulatie heeft laten zien dat het aantal zorgpunten op kind- gezin- en omgevingsniveau significant toeneemt naarmate de minderjarige ouder wordt, ook wijzigt de verhouding tussen de zorgpunten op de verschillende niveaus. ${ }^{613} \mathrm{Zo}$ is te zien dat bij minderjarigen in de leeftijd tussen $0-6$ jaar er in verhouding nog weinig sprake is van zorgpunten op kindniveau en is de problematiek veelal te herleiden naar factoren op gezinsniveau. ${ }^{614}$

In het verlengde daarvan veronderstelt dit ook dat de specifieke doelstellingen die met een ondertoezichtstelling en uithuisplaatsing worden nagestreefd gerelateerd zijn aan de gevonden zorgpunten op kind- gezin- en omgevingsniveau. Verwacht mag worden dat bij jongere kinderen - in verhouding tot oudere kinderen - de nadruk van de hulpverlening meer zal liggen op het bieden van concrete hulp en steun binnen het gezin of opvoedingsomgeving, omdat de kans groter is dat de ontwikkelingsbedreiging van de minderjarige voortkomt uit factoren op gezinsniveau. Naarmate de minderjarige ouder wordt ligt het in de lijn der verwachting dat de ook steeds nadrukkelijker doelen op kindniveau worden gesteld. Zo kan het leeftijds- en ontwikkelingsniveau van de minderjarige en diens bekwaamheid en behoefte zelfstandig te handelen en zijn leven naar eigen inzicht in te richten ertoe noodzaken, dat de ondertoezichtstelling zich bovenal richt op het vergroten van de zelfstandigheid van de minderjarige. Hoewel geen specifiek leeftijdscriterium hieraan is verbonden is het

\footnotetext{
613 Slot e.a. 2002 , p. $38-39$.

${ }^{614}$ Slot e.a. 2002 , p. $38-39$.
} 
aannemelijk dat het vooral zal gaan om minderjarigen in de laatste fase voor de overgang naar (wettelijke) meerderjarigheid.

De leeftijd van de minderjarigen die deel uitmaken van de steekproef is bepaald op de datum van de afronding van het rapport beschermingszaken, dat wil zeggen de officiële datum van afronding die is vermeld in het beschermingsrapport. In bijna alle gevallen volgt de beschikking van de kinderrechter binnen enkele weken na afronding van de rapportage (en indiening van het verzoek) dus de leeftijd van de minderjarige ten tijde van de (mogelijke) oplegging van de ondertoezichtstelling/uithuisplaatsing zal nauwelijks afwijken van de leeftijd ten tijde van de afronding van de rapportage.

De onderzoeksgroep van 200 minderjarigen is onderverdeeld in verschillende leeftijdscategorieën: aantal ongeboren kinderen; aantal kinderen in de leeftijd van 0 tot 6 jaar; aantal kinderen in de leeftijd van 6 tot 12 jaar; aantal kinderen in de leeftijd van 12 tot 18 jaar. Het aantal ongeboren kinderen binnen de steekproef is apart gescoord omdat de besluitvorming over de noodzaak van een ondertoezichtstelling, hoewel aan dezelfde wettelijke gronden moet zijn voldaan, hier een wezenlijk ander karakter heeft. De drie leeftijdscategorieën voor de geboren kinderen ( 0-6 jaar; 6-12 jaar; 12-18 jaar) zijn niet willekeurig gekozen. In de eerste plaats biedt het de mogelijkheid om de populatie op te splitsen in drie gelijke categorieën van ieder 6 levensjaren en daarnaast is de leeftijd van 12 jaar een cruciale leeftijd voor de minderjarigen binnen het civiele jeugdrecht, aangezien de minderjarige vanaf deze leeftijd een aantal processuele bevoegdheden krijgt toegekend in de besluitvormingsprocedure. Door de gekozen onderverdeling is derhalve zichtbaar hoe groot het aandeel minderjarigen is die als belanghebbende gebruik hebben kunnen maken van ruimere processuele bevoegdheden. Daaronder valt ook het recht om te worden gehoord in de gerechtelijke procedure. In Tabel 2 is de specifieke onderverdeling in leeftijdscategorieën weergegeven. 


\section{Tabel 2: Leeftijdsverdeling}

Leeftijd

\author{
Ongeboren \\ $0-6$ jaar \\ $6-12$ jaar \\ $12-18$ jaar \\ Waarvan 16-17 jarigen
}

Totaal
Aantal minderjarigen

9

36

46

109

39

200
$19,5 \%$

\section{Percentage}

\section{$4,5 \%$}

$18 \%$

$23 \%$

$54,5 \%$

$100 \%$

In 9 van de 200 zaken die deel uitmaken van de steekproef gaat het blijkens de gegevens in Tabel 2 om een verzoek tot ondertoezichtstelling ten aanzien van een ongeboren kind. Verder valt op dat de groep 12 tot 18 jarigen is oververtegenwoordigd binnen de steekproef. Maar liefst 109 van de 200 minderjarigen is in de leeftijd tussen de 12 en 18 jaar (54,5\%) en van deze 109 minderjarigen binnen de leeftijdscategorie zijn 39 minderjarigen 16 of 17 jaar (19,5\% van de totale steekproef). Deze percentages sluiten echter in grote lijnen wel aan bij de leeftijdsverdeling van minderjarigen die is gevonden in eerder onderzoek. In het onderzoek van de Savornin Lohman in 2000 e.a. werden cijfers aangehaald afkomstig van het ministerie van Justitie over de leeftijdsopbouw van minderjarigen die een onder toezicht stonden in 1996 en 1997. Uit de cijfers over 1996 bleek dat de groep minderjarigen in de leeftijdsklasse van 12 $\mathrm{t} / \mathrm{m} 15$ jaar met $35 \%$ de grootste groep vormde binnen de ondertoezichtstellingspopulatie. ${ }^{615}$ In 1997 betrof dit de groep $13 \mathrm{t} / \mathrm{m} 16$ jarigen met een aandeel van $40 \%$.

\subsubsection{Sekseverdeling}

Eerder onderzoek heeft uitgewezen dat binnen de populatie van minderjarigen die onder toezicht zijn gesteld er sprake is van een lichte oververtegenwoordiging van jongens. Zo laat

\footnotetext{
${ }^{615}$ De Savornin Lohman e.a. 2000, p. 48.
} 
dossieronderzoek van Mertens naar de kinderbeschermingspopulatie tussen 1980 en 1990 een vrij constante verdeling zien van 55\% jongens en $45 \%$ meisjes. ${ }^{616}$ Een vergelijkbare verdeling is te zien in het onderzoek van de Savornin Lohman e.a uit 2000 waarin de wettelijke herziening van de ondertoezichtstelling in 1995 werd geëvalueerd. Op basis van cijfers over de jaren 1994 tot 1998 is een gemiddelde verdeling zien te van 55\% jongens en $45 \%$ meisjes. ${ }^{617}$ Ook in het onderzoek van Slot e.a enkele jaren later, onder andere naar de doelmatigheid van de ondertoezichtstelling, bevatte de onderzoeksgroep bestaande uit ondertoezichtstellingspupillen uit drie jeugdzorgregio's net iets meer jongens dan meisjes. ${ }^{618}$ Tot slot, en meest recent, de landelijke cijfers van het Centraal Bureau voor de Statistiek (hierna: CBS) bevestigen het beeld uit voorgaande onderzoeken dat iets meer jongens dan meisjes onder toezicht werden gesteld. ${ }^{619}$

In de steekproef die aan de basis ligt van dit dossieronderzoek is een vergelijkbare verdeling tussen jongens en meisjes gevonden. Van de 200 geanalyseerde dossiers bleek het in 107 gevallen om een jongen te gaan $(53,5 \%)$, in 90 gevallen ging het om een meisje (45\%) en in 3 gevallen was het geslacht nog niet bekend (1,5\%). In de 3 gevallen waarin het geslacht nog niet bekend was, ging het om ongeboren kinderen waarbij tijdens het beschermingsonderzoek door de RvdK nog geen duidelijkheid was verkregen omtrent het geslacht, althans waar het rapport beschermingszaken nog geen informatie bevatte over het geslacht van het ongeboren kind.

\subsubsection{Opvoedingssituatie minderjarigen}

De opvoedingsomgeving van de minderjarige is een relevante factor in het besluitvormingsproces omtrent de ondertoezichtstelling en machtiging uithuisplaatsing. De rechtsgrond van de ondertoezichtstelling onder oude wetgeving ging uit van een direct verband tussen de opvoedingsomgeving en de geconstateerde ernstige bedreiging van de zedelijke of geestelijke belangen of gezondheid van de minderjarige. ${ }^{620}$ Het feit dat de ondertoezichtstelling wordt opgelegd aan de minderjarige en de minderjarige onder gezag staat, maakt dat de ouder-kind relatie doorgaans een belangrijk onderdeel vormt van het onderzoek naar de noodzaak van gedwongen overheidsingrijpen in het familie- en gezinsleven. Een aantal kenmerken ten aanzien van die ouder-kind relatie en in bredere zin

\footnotetext{
${ }^{616}$ Mertens 1993, p. 21.

${ }^{617}$ De Savornin Lohman e.a. 2000, p. 48.

${ }^{618}$ Slot e.a. 2002.

${ }^{619}$ CBS 2015, p. 11.

${ }^{620} \mathrm{Vgl}$. paragraaf 4.2.2.
} 
ten aanzien van de opvoedingsomgeving van de minderjarigen binnen het onderzoek, wordt in het vervolg nader toegelicht.

In dit onderzoek is gekeken hoe de feitelijke opvoedingssituatie van de minderjarige is vormgegeven bij aanvang van het beschermingsonderzoek. De volgende categorieën ten aanzien van de bepaling van de hoofdverblijfplaats zijn daarbij aangehouden: moeder alleenstaand; vader alleenstaand; beide ouders; één van de ouders samenwonend met partner/stiefouder; extern verblijf. Eerder onderzoek heeft uitgewezen dat bij aanvang van een ondertoezichtstelling relatief veel minderjarigen opgroeien in een éénoudergezin. ${ }^{621} \mathrm{De}$ verwachting is dat indien sprake is van een éénoudergezin de minderjarige in de meeste gevallen zijn hoofdverblijfplaats heeft bij de moeder. ${ }^{622}$ De opvoedingssituatie moeder/vader alleenstaand is gescoord indien bij de ouder waar de minderjarige zijn hoofdverblijfplaats heeft er geen stabiele tweede opvoedfiguur aanwezig is. Dit laat onverlet dat de andere ouder mogelijk enige vorm van contact en omgang met de minderjarige heeft. De opvoedingssituatie ouder + partner is gelet op het bovenstaande gescoord indien uit de gegevens in het raadsrapport blijkt dat de partner als mede-opvoeder van de minderjarige fungeert. In veel zaken gaan de ouders na scheiding of beëindiging van de relatie (een) nieuwe relatie(s) aan, maar slechts indien sprake is van duurzaam opvoederschap van de zijde van de nieuwe partner dan is de opvoedingssituatie geschaard onder de categorie 'ouder + partner. De categorie extern verblijf is niet nader gespecificeerd maar in de meeste gevallen gaat het om minderjarigen die op vrijwillige basis in een (netwerk)pleeggezin verblijven of residentieel verblijven. In enkele gevallen gaat het om oudere minderjarigen die verblijven in een vorm van begeleid wonen zoals kamertraining, waar wordt toegewerkt naar zelfstandig wonen.

In dit onderzoek is uitgegaan van de beschrijving van de gezinssamenstelling aan de start van beschermingsonderzoek, zoals weergegeven in het rapport door de Raad voor de Kinderbescherming. Al snel bleek echter dat een strikte hantering van het criterium 'bij aanvang van het beschermingsonderzoek' tot een vertekenend beeld zou kunnen leiden. Dat heeft te maken met het feit dat van de 200 geanalyseerde zaken het in 100 zaken gaat om een verzoek tot ondertoezichtstelling gecombineerd met een verzoek machtiging uithuisplaatsing. Niet zelden is aan een dergelijk verzoek een verzoek tot voorlopige ondertoezichtstelling en

\footnotetext{
${ }^{621}$ Slot e.a 2002, p. 33. In het onderzoek komt naar voren dat maar liefst $39 \%$ van de minderjarigen bij aanvang van de ondertoezichtstelling opgroeit in een eenoudergezin. Slechts $17 \%$ van de minderjarigen verblijft op dat moment bij beide ouders.

${ }^{622}$ De meeste eenoudergezinnen ontstaan door scheiding van de ouders. In veruit de meeste gevallen heeft de minderjarige na de scheiding zijn hoofdverblijfplaats bij de moeder, hoewel het aantal minderjarigen dat bij de vader verblijft toeneemt. Vgl. CBS 2013; CBS 2014.
} 
spoedmachtiging uithuisplaatsing voorafgegaan. De minderjarige verblijft in zo $\mathrm{n}$ geval al elders (bv. in een pleeggezin, gezinshuis of in sommige gevallen residentieel) bij aanvang van het reguliere beschermingsonderzoek. In deze zaken is gekeken naar de opvoedingssituatie van de minderjarige op het moment dat het verzoek tot voorlopige ondertoezichtstelling met spoedmachtiging is gedaan. Verbleef de minderjarige op dat moment thuis dan is de zaak niet gescoord onder extern verblijf omdat het beeld daardoor zou kunnen ontstaan dat veel minderjarigen al elders opgroeien op het moment dat de RvdK betrokken raakte.

Indien de minderjarige bij aanvang van het beschermingsonderzoek op vrijwillige basis al geruime tijd uit huis was geplaatst, dan is de zaak wel gescoord onder extern verblijf

Tabel 3: Opvoedingssituatie

Plek waar de minderjarige opgroeit

Moeder alleenstaand
Vader alleenstaand
Beide ouders
Ouder + partner
Extern verblijf

Totaal

\section{Aantal}

90

21

39

17

33

200

\section{Percentage}

$45 \%$

$10,5 \%$

$19,5 \%$

$8,5 \%$

$16,5 \%$

$100 \%$

Op basis van de gegevens in Tabel 3 moet worden geconcludeerd dat van de 200 minderjarigen die deel uitmaken van de steekproef het merendeel opgroeit in een éénoudergezin. Cijfers van het CBS over kenmerken van de opvoedingssituatie van alle minderjarigen in Nederland laten zien dat het aantal minderjarigen dat opgroeit in een éénoudergezin de afgelopen jaren is toegenomen van $11 \%$ in 1999 tot $15 \%$ in $2014 .{ }^{623}$ Daarnaast geldt dat het percentage minderjarigen dat opgroeit in een éénoudergezin toeneemt naarmate de leeftijd vordert. In dit onderzoek waarin minderjarigen centraal staan die worden geconfronteerd met een ondertoezichtstelling en machtiging uithuisplaatsing ligt het

${ }^{623}$ CBS Landelijke Jeugdmonitor 2013, p. 27. 
percentage van minderjarigen dat opgroeit in een eenoudergezin aanmerkelijk hoger. Geheel verrassend is deze uitkomst echter niet. Het zijn immers de feitelijke omstandigheden waaronder de minderjarige opgroeit die leiden tot het oordeel dat er sprake is van een ernstige bedreiging van de zedelijke of geestelijke belangen of gezondheid. Scheidingsproblematiek, en in bredere zin problematiek die samenhangt met het beëindigen van een relatie, kan direct of indirect bijdragen aan de bedreiging van de minderjarige. Daarnaast is het ook mogelijk dat de moeder nooit een relatie heeft gehad met de biologische vader en er geen duidelijkheid bestaat over de vraag wie de vader van de minderjarige is.

Uit de steekproef blijkt ook dat in het geval de minderjarige opgroeit in een eenoudergezin dit in het overgrote deel van de gevallen bij de moeder is. Een eenoudergezin ontstaat vaak door echtscheiding en bekend is dat de minderjarige in het overgrote deel van de gevallen zijn hoofdverblijfplaats na echtscheiding bij de moeder heeft. ${ }^{624}$ Het feit dat de minderjarige doorgaans zijn hoofdverblijfplaats heeft bij de moeder laat onverlet dat in de meeste zaken wel sprake is van contact en omgang met de vader. Desondanks ontstaat wel een zorgelijk beeld indien verder inhoudelijk wordt gekeken naar de positie van de alleenstaande moeders (en in mindere mate vaders) in dit onderzoek. In veel zaken is namelijk te zien dat allerlei bijkomende factoren het voor de toch al kwetsbare alleenstaande ouder complex maken om het kind te kunnen bieden wat noodzakelijk is om een ernstige ontwikkelingsbedreiging te vermijden. Eerder onderzoek laat zien dat kinderen in eenoudergezinnen meer risico lopen problemen in hun ontwikkeling te ervaren. Dit kan bijvoorbeeld te maken hebben met de slechte financiële positie van de alleenstaande ouder of andere problemen die zijn voortgekomen uit de scheiding. ${ }^{625}$ Het kind kan meer probleemgedrag gaan vertonen hetgeen zijn weerslag kan hebben op de communicatie tussen kind en ouder. ${ }^{626}$ Hoewel deze problemen zich net zo goed voor kunnen doen in een tweeoudergezin is in het dossieronderzoek gebleken dat het raadsonderzoek zich vaak richtte op alleenstaande moeders, met problemen op diverse levensgebieden en die maar beperkt steun ondervonden van een andere opvoeder of het bredere sociale netwerk. Enkele voorbeelden uit het dossieronderzoek kunnen dit beeld verhelderen:

'Moeder heeft eenhoofdig het gezag over de jongens, maar wordt belemmerd in haar opvoedmogelijkheden door complexe persoonlijke problematiek (eigen belaste

\footnotetext{
${ }^{624}$ CBS Landelijke Jeugdmonitor 2013, p. 27. Desondanks constateert het CBS wel een forse toename van het aantal minderjarigen dat alleen bij de vader woont.

${ }^{625}$ De Roos e.a 2011; Colpin e.a 2000; Van der Heide 2010.

${ }^{626}$ Vgl. Van Dorselaer e.a 2010; De Roos e.a 2011; Zeijl e.a 2005.
} 
voorgeschiedenis, geen afgeronde opleiding, jonge leeftijd aanvang moederschap, Bipolaire II stoornis, persoonlijkheidsstoornis NAO, financiële problemen, huisvestingsproblemen).'

'De bedreiging van de minderjarige bestaat uit een instabiele en kwetsbare opvoedingssituatie door de ziekte van de moeder die alleen zorg draagt voor de opvoeding en de impact daarvan op het gezin. Moeder is niet meer in staat om haar ouderrol op adequate wijze in te vullen en geeft aan het niet meer alleen te kunnen. Vader heeft geen gezag en maakt geen deel uit van de opvoedingssituatie.'

'Met betrekking tot de opvoedersfactoren van moeder zijn er zorgen. Moeder heeft een verminderde draagkracht en kan mede daardoor onvoorspelbaar en emotioneel reageren richting hulpverleners en haar kinderen. Moeder heeft last van stemmingswisselingen. Er is ADHD bij moeder gediagnosticeerd. Ze geeft zelf aan dat ze mogelijk in een depressie begint te raken, ze slaapt slecht en ervaart veel stress. Moeder is vaak ziek, waarbij het niet altijd duidelijk is wat ze heeft. Moeder is bang terug te vallen in haar eetstoornis. Moeder heeft geen sociaal netwerk waarop ze kan terug vallen. Ze heeft geen goed contact met de vaders van haar kinderen.'

Wat verder opvalt kijkend naar de feitelijke opvoedingssituatie is dat toch een behoorlijk aantal minderjarigen bij de (alleenstaande) vader verblijft. Deze uitkomst moet mede worden begrepen in het licht van de vele (echt)scheidingen binnen de gezinnen die deel uitmaken van de steekproef, een punt waar later in het onderzoek nog op wordt teruggekomen. Uit eerder dossieronderzoek naar de ondertoezichtstelling is in ieder geval bekend dat een aanzienlijk deel van de ouders die zijn betrokken bij een ondertoezichtstelling een scheiding achter de rug hebben gehad. ${ }^{627}$ In sommige gevallen wordt in goed onderling overleg tussen ouders en minderjarige besloten dat de minderjarige na de (echt)scheiding, of na enige tijd, bij de vader verblijft. In dit onderzoek (en andere onderzoeken) is echter zichtbaar dat door de met de (echt)scheiding gepaard gaande strijd het bepalen van de hoofdverblijfplaats - en allerlei anderen afwegingen omtrent contact, omgang, verzorging en opvoeding van de minderjarige minder harmonieus verloopt. De onderlinge strijd tussen de ouders kan er dan toe leiden dat de ouders het belang van de andere ouder en/of minderjarige uit het oog verliezen, een situatie die thans veelal wordt getypeerd als 'vechtscheiding'. ${ }^{628}$ De strijd kan zich daarbij ook richten op de hoofdverblijfplaats van de minderjarige hetgeen tot gevolg kan hebben dat de

\footnotetext{
${ }^{627}$ In het onderzoek van Komen naar ondertoezichtstellingsdossiers wordt een scheidingspercentage van $76 \%$ gevonden. Komen 1999.

${ }^{628}$ Zie bv. over de rol van de overheid bij complexe echtscheidingsproblematiek: De Kinderombudsman 2014.
} 
minderjarige meerdere keren wisselt van hoofdverblijfplaats. Duidelijk is dat deze strijd in bepaalde gevallen dusdanige vormen aan kan nemen dat de conclusie gerechtvaardigd is dat de minderjarige in zijn zedelijke of geestelijke belangen of gezondheid ernstig wordt bedreigd.

\subsubsection{Uitoefening van het gezag}

Zoals reeds is gebleken horen minderjarigen op grond van art. 1:245 BW onder gezag te staan. De oplegging van een ondertoezichtstelling eventueel gecombineerd met een machtiging uithuisplaatsing vormt een beperking van het recht de opvoeding en verzorging geheel naar eigen inzicht vorm te geven. De wijze waarop het gezag is geregeld is derhalve belangrijk in het licht van de beoordeling van de noodzaak tot oplegging van een jeugdbeschermingsmaatregel. In het onderzoek is onderscheid gemaakt tussen gezamenlijk gezag en eenhoofdig gezag. De minderjarige staat onder gezamenlijk gezag vanaf de geboorte indien beide juridische ouders met elkaar zijn gehuwd of een geregistreerd partnerschap hebben. Indien het huwelijk eindigt na scheiding dan is het uitgangspunt dat de ouders die gezamenlijk het gezag hebben, dit gezag gezamenlijk blijven uitoefenen (art. 1:251 lid $2 \mathrm{BW}$ ). De rechter kan echter op verzoek bepalen dat het gezag aan een ouder toekomt indien er een onaanvaardbaar risico is dat het kind klem of verloren zou raken tussen de ouders en niet te verwachten is dat hierin binnen afzienbare tijd voldoende verbetering zou komen of de wijziging van de gezag anderszins in het belang van het kind noodzakelijk is (art. 1: 251a leden 1 \& 2 BW). Ook de ouders die niet elkaar zijn gehuwd of een geregistreerd partnerschap zijn aangegaan kunnen gezamenlijk gezag uitoefenen over het kind indien dit op beider verzoek in het gezagsregister wordt aangetekend. Tot slot moet voor de volledigheid worden opgemerkt dat het gezag ook gezamenlijk kan worden uitgeoefend door een ouder en een ander dan de ouder die een nauwe persoonlijke betrekking tot het kind staat, op gezamenlijk verzoek aan de rechtbank (art. 1: 253t BW). 


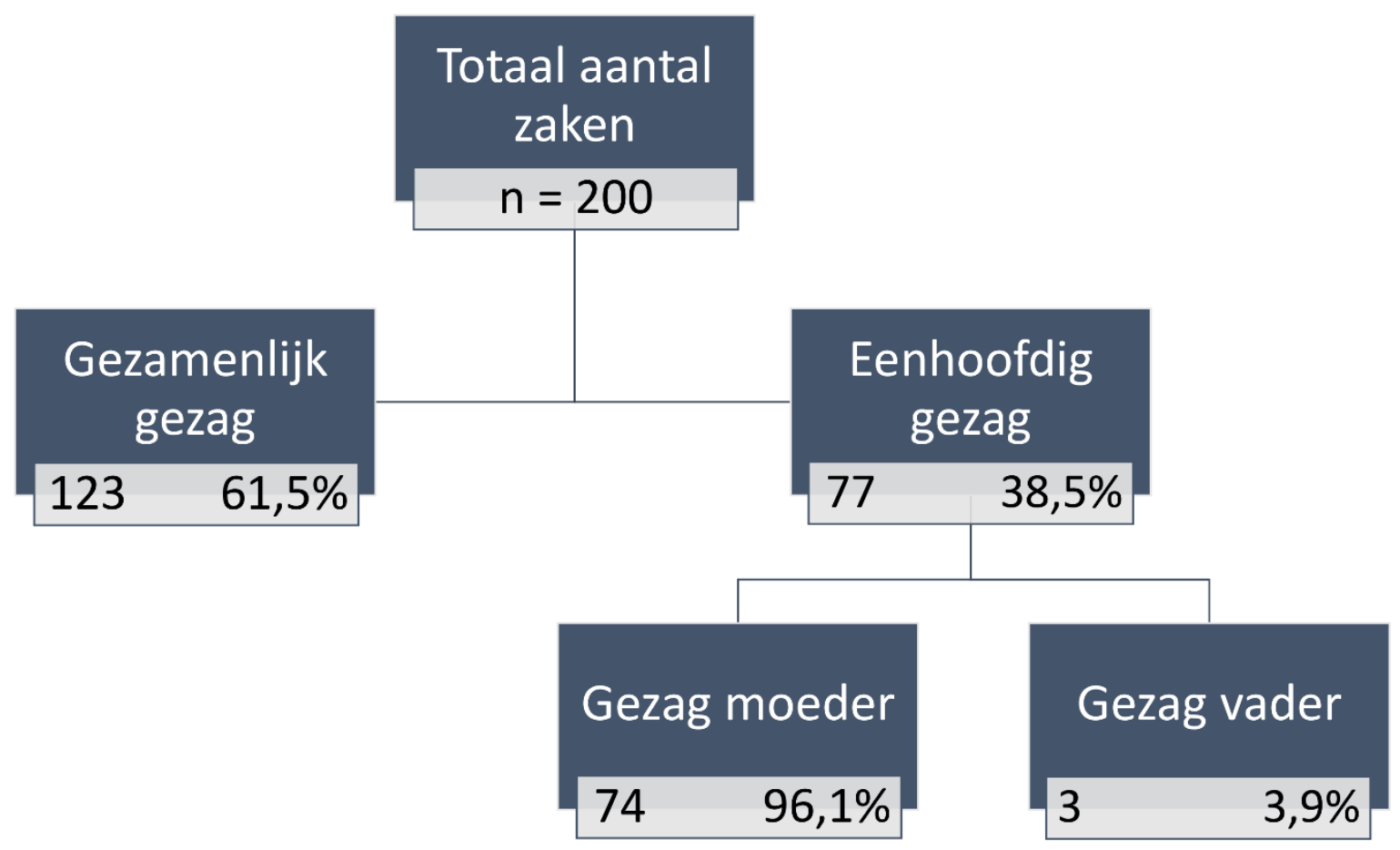

Figuur 1. De verdeling in gezag

In 77 van de 200 zaken is sprake van eenhoofdig gezag (38,5\%). In slechts 3 van de 77 zaken waarin sprake is van eenhoofdig gezag, komt het gezag toe aan de vader. Bijvoorbeeld is zichtbaar in twee van de zaken dan de ouders na echtscheiding enige tijd gezamenlijk het gezag over de minderjarige hebben uitgeoefend, maar dat het gezamenlijk gezag op den duur door de rechtbank is beeindigd en alleen aan de vader is toegewezen. In een andere zaak berust het gezag bij de vader omdat de moeder van de minderjarige is overleden. Echter, zoals is af te leiden uit bovenstaande gegevens zijn dit uitzonderingssituaties. In bijna alle zaken in het dossieronderzoek komt het gezag, indien eenhoofdig, toe aan de moeder. Er zijn tal van redenen waarom het gezag in behoorlijk wat zaken alleen bij de moeder berust, waarbij het niet zo hoeft te zijn dat de ouders niet meer samenleven. Bijvoorbeeld is zichtbaar dat de biologische vader de minderjarige niet heeft erkend of wel heeft erkend maar vervolgens geen verzoek is ingediend om gezamenlijk met het gezag te worden belast.

Dit betekent vanzelfsprekend dat in 123 van de 200 zaken $(61,5 \%)$ er sprake is van gezamenlijk gezag. Het gezamenlijk gezag kan worden uitgeoefend door de (juridische) ouders die samen de minderjarige verzorgen en opvoeden maar evengoed is mogelijk dat de 
ouders niet (meer) samenleven maar toch gezamenlijk het gezag over de minderjarige hebben. Het uitgangspunt op grond van art. 1:251 lid $2 \mathrm{BW}$ is immers dat het gezamenlijk ouderlijk gezag voortduurt na scheiding. De situatie waarin sprake is van gezamenlijk gezag veronderstelt dat beide ouders belangrijke beslissingen inzake de verzorging en opvoeding gezamenlijk nemen, of tenminste dat beide gezagshouders overleggen over belangrijke beslissingen. De ondertoezichtstelling, als maatregel die een beperking van het gezag inhoudt zal zich dan ook in eerste instantie richten op de belangrijkste beslissingen inzake de verzorging en opvoeding van de minderjarige. In het geval dat de ouders gescheiden leven maar wel gezamenlijk gezag hebben over de minderjarige zal de gezinsvoogd met beide gezagshouders sturing moet geven aan de verzorging en opvoeding hoewel in de praktijk grote verschillen mogelijk zijn in de mate waarin beide ouders met gezag worden betrokken bij de hulpverlening.

\subsubsection{Etnische achtergrond minderjarigen}

In het onderzoek is gekeken naar de etnische achtergrond van de minderjarigen binnen de steekproef. Bepaalde houdingen en praktijken die voortkomen uit culturele e/of religieuze overtuigingen kunnen spanning opleveren ten aanzien van het vraagstuk naar de noodzaak van gedwongen overheidsingrijpen in het gezinsleven. De etnische achtergrond van de minderjarigen binnen de steekproef is daarom een factor van belang. Deze gegevens dienen echter wel met de nodige voorzichtigheid te worden geïnterpreteerd.

Dilemma's met betrekking tot sociaal-culterele gebruiken die mogelijk een bedreigende situatie opleveren voor minderjarigen doen zich geenszins exclusief voor binnen groepen die deel uitmaken van etnische minderheidsgroepen. Denk bijvoorbeeld aan de noch immer actuele discussie of het ouders vrij zou moeten staan om met een beroep op de vrijheid van godsdienst en levensovertuiging de vaccinatie van hun kind te weigeren. ${ }^{629}$ Er zijn echter wel factoren die samenhangen of kunnen samenhangen met de etnische achtergrond van iemand die relevant zijn voor jeugdbeschermingzaken. Zo is bijvoorbeeld bekend dat het geboortecijfer onder jonge meisjes van Surinaamse, Antiliaanse en Arubaanse komaf veel hoger dan ligt dan het geboortecijfer onder autochtone Nederlandse meisjes. ${ }^{630}$ De RvdK kan in actie kan komen als er sprake is van een jonge tienermoeder die wettelijk gezien nog niet

\footnotetext{
${ }^{629}$ Zie hierover de kamerbrief van staatssecretaris Blokhuis waarin de problemen rond vaccineren worden geduid en plannen worden gepresenteerd met als doel de vaccinatiegraad te verhogen: Kamerstukken II 2018/19 32793, nr. 338.

${ }^{630}$ Zie CBS StatLine, Geboorte; leeftijd moeder. Te raadplegen via: https://www.cbs.nl/nlnl/nieuws/2016/14/steeds-minder-tienermoeders.
} 
het gezag mag dragen over haar kind. ${ }^{631}$ Ook heeft de RvdK aangegeven dat er meer kans op schade is voor minderjarigen in een gemeente die meer gescheiden ouders, eenoudergezinnen en tienermoeders telt. Daarnaast kan ten aanzien van religie worden gedacht aan ernstige conflicten tussen de minderjarige en zijn ouders omdat de wijze waarop de minderjarige zijn leven vormgeeft botst met de culturele en religieuze normen en waarden die gebruikelijk zijn binnen de betreffende cuturele of religieuze stroming. Zo kan worden gedacht aan minderjarigen met een islamitische achtergrond die naar het oordeel van de ouders zich niet gedraagt conform de normen en waarden vanuit de culturele achtergrond van het gezin. Bijvoorbeeld op het gebied van relaties of middelengebruik. Ook kan het zo zijn dat de ouders van de minderjarige uit een land komen waar fysieke bestraffing in de opvoeding niet expliciet bij wet is verboden. ${ }^{632}$

Onderzoek van Mertens naar de jeugdbeschermingspopulatie in de jaren 1982- 1989 liet zien dat het aandeel allochtone kinderen geleidelijk is gestegen van ruim 10\% in 1982 tot iets boven de $20 \%$ in $1989 .{ }^{633}$ In het onderzoek van Slot e.a. uit 2002 waarin dossieronderzoek heeft plaatsgevonden ten aanzien van minderjarigen bij wie na de herziening van de ondertoezichtstelling in 1995 een ondertoezichtstelling is uitgesproken bleek maar liefst bij $62 \%$ van minderjarigen tenminste één van de ouders niet in Nederland geboren. ${ }^{634} \mathrm{In}$ laatstgenoemd onderzoek is echter het merendeel van de dossiers afkomstig uit de regio Rotterdam en Amsterdam, steden waar het aandeel gezinnen waarvan tenminste een ouder niet in Nederland is geboren ook aanzienlijk hoger ligt. Meer recentere cijfers van het CBS laten zien dat het percentage niet-westerse allochtonen in de jeugdbescherming $25 \%$ bedraagt, hetgeen betekent dat niet-westerse allochtonen zijn oververtegenwoordigd in de jeugdbescherming. ${ }^{635}$

In dit onderzoek is gekeken naar de etnische achtergrond van de gezinnen waarbij onderscheid is gemaakt tussen westerse allochtonen, niet-westerse allochtonen en autochtonen overeenkomstig de definitie die het CBS in deze periode hanteert voor de verschillende groepen. Volgens het CBS is de definitie van het begrip allochtoon 'een persoon van wie

\footnotetext{
${ }^{631}$ Zie bv. Dagblad van het Noorden 1 april 2011.

${ }^{632}$ Zie het overzichtsrapport van the Global Initiative to End All Corporal Punishment of Children 2011.

${ }^{633}$ Mertens 1993, p. 25.

${ }^{634}$ Slot e.a. 2002, p. 31.

${ }^{635}$ Onder 'jeugdbescherming' rekent het CBS hier (voorlopige) voogdijmaatregelen en (voorlopige) ondertoezichtstelling. Wordt echter naar de ondertoezichtstelling afzonderlijk gekeken dan blijft het percentage niet-westerse allochtonen nagenoeg ongewijzigd; CBS 2015, p.11.
} 
tenminste een ouder in het buitenland is geboren'. ${ }^{636}$ Een verder onderscheid wordt gemaakt tussen personen die zelf in het buitenland zijn geboren (eerste generatie) en personen die zelf in Nederland zijn geboren maar waarvan tenminste een van de ouders in het buitenland is geboren (tweede generatie). In deze studie zal het in bijna alle gevallen gaan om minderjarigen die zelf in Nederland zijn geboren. Daarnaast wordt de onderverdeling gehanteerd in niet-westerse allochtonen en Westerse allochtonen. Niet-Westerse allochtonen zijn overeenkomstig de definitie van het CBS personen met als herkomstgroepering een van de landen in Afrika, Latijns-Amerika, en Azië (exclusief Indonesië en Japan) of Turkije, waarbij, zoals gesteld, het in dit onderzoek vooral gaat om minderjarigen waarvan een of beide ouders in een van deze landen is geboren. Een Westerse allochtoon kent als herkomstgroepering een van de landen in Europa (uitgezonderd Turkije), Noord-Amerika, Oceanië, Indonesië of Japan.

In de steekproef is achterhaald waar de minderjarige en zijn ouders zijn geboren. Niet in alle gevallen bleek het mogelijk deze informatie uit het raadsrapport beschermingszaken te halen. Indien de noodzakelijke informatie ontbrak zijn via KBPS, het digitale documentatiesysteem van de Raad voor de Kinderbescherming, overige documenten geraadpleegd om het geboorteland van de minderjarige en zijn ouders te achterhalen, zoals de uittreksels geboorteen gezagsregister en/of de beschikking. Uiteindelijk is het zo gelukt de benodigde informatie te verkrijgen. In de steekproef komt naar voren dat 37 zaken sprake is van een minderjarige die valt onder de CBS-definitie van niet-westerse allochtoon. Op de totale steekproef van 200 zaken is dat een percentage van $18,5 \%$ hetgeen onder het percentage niet-westerse allochtonen in de jeugdbescherming ligt in vergelijking met de landelijke cijfers van het CBS. In 10 van de 200 zaken is er sprake van een minderjarige die kan worden aangemerkt als Westerse allochtoon (5\% van de onderzoekspopulatie) en in 153 van de 200 zaken (76,5\%) sprake is van een minderjarige van wie beide ouders in Nederland zijn geboren.

${ }^{636} \mathrm{CBS} 2015$. 


\section{Dossieronderzoek naar de rechtvaardiging van de ondertoezichtstelling door de RvdK en de kinderrechter}

\subsection{Inleiding}

In de hoofdstukken $2-4$ van dit onderzoek zijn de belangrijkste uitgangspunten op basis van (inter)nationale wet- en regelgeving geschetst voor de rechtvaardiging van de ondertoezichtstelling in de jeugdbeschermingspraktijk. In dit hoofdstuk vindt analyse plaats van de 200 zaken in het dossieronderzoek waarin in de jaren 2013 en 2014 een verzoek tot ondertoezichtstelling is ingediend door de RvdK. Het dossieronderzoek moet duidelijkheid geven over de wijze waarop in de praktijk invulling is gegeven aan de toen geldende gronden van de ondertoezichtstelling en tevens wordt aandacht geschonken aan wijze waarop de doelen die met de maatregel werden nagestreefd, concreet werden ingevuld. In het eerste deel van het hoofdstuk wordt de onderbouwing van het verzoek tot ondertoezichtstelling door de RvdK geanalyseerd, gevolgd door de schriftelijke onderbouwing in de beschikking door de kinderrechter.

De analyse vangt in paragraaf 6.2 aan met een overzicht van de wijze waarop de RvdK omging met de eerste grond voor oplegging van de ondertoezichtstelling op grond van art. 1:254 lid 1 oud BW: de ernstige bedreiging van de zedelijke of geestelijke belangen of gezondheid van de minderjarige. In deel I van het onderzoek is beschreven dat de open formulering van dit deel van de rechtsgrond van de ondertoezichtstelling het risico met zich meebracht dat op basis van vage zorgen een ondertoezichtstelling zou worden gevraagd. Het was immers niet precies te bepalen hoe ernstig en concreet de zorgen moesten zijn om te voldoen aan de wet op dit punt. Cruciaal is daarom dat de RvdK een concreet overzicht geeft van de zorgen op kindniveau en op het niveau van de opvoedingsomgeving en dat wordt beargumenteerd wat deze zorgen betekenen voor de belangen van de minderjarige.

Vervolgens wordt geanalyseerd hoe het tweede deel van de rechtsgrond van de ondertoezichtstelling invulling kreeg in het beschermingsrapport van de RvdK. Het tweede deel van de rechtsgrond als in art. 1:254 lid 1 oud BW veronderstelde dat eerst andere middelen moesten worden ingezet, althans nadrukkelijk worden overwogen, voor een ondertoezichtstelling gerechtvaardigd kon zijn. De wet op dit punt gaf aan dat de noodzaak van een ondertoezichtstelling moest blijken uit het feit dat op vrijwillige basis onvoldoende resultaat was behaald. Met de beantwoording van de vraag of andere middelen hebben gefaald, of naar is te voorzien, falen, bestond daarom de mogelijkheid om expliciet de 
rechtmatigheid van de ondertoezichtstelling te toetsen, hetgeen ook mocht worden verwacht van de verzoeker en de beslisser.

In paragraaf 6.3 is gekeken naar een aantal elementen met betrekking tot de doelstelling van de ondertoezichtstelling. Voor de analyse is als uitgangspunt gehanteerd dat de RvdK binnen het kader van de wettelijke doelstelling van de ondertoezichtstelling concrete doelen moest stellen op basis waarvan voor de betrokkenen inzichtelijk zou worden waaraan moest zijn voldaan om de geconstateerde ontwikkelingsbedreiging zodanig te verminderen dat de ondertoezichtstelling kon worden opgeheven. In de 200 geanalyseerde zaken is gekeken of de RvdK in de beschermingsrapportage doelen stelde ten aanzien van de minderjarige. Vervolgens is de vraag beantwoord of tevens een indicatie werd gegeven van wat nodig was om de gestelde doelen te bereiken. Tot slot is geanalyseerd of de RvdK ook aandacht besteedde aan de haalbaarheid van de gestelde doelen en daarmee de kans van slagen van de ondertoezichtstelling.

In paragraaf 6.4 wordt verslag gedaan van de analyse van de beschikking van de kinderrechter op het verzoek tot ondertoezichtstelling. De motiveringsplicht voor de rechter kon worden afgeleid uit art. $30 \mathrm{Rv}$ en volgde tevens uit het recht op een eerlijk proces op grond van art. 6 EVRM. Het belang van een inhoudelijk motivering liet zich in de eerste plaats rechtvaardigen doordat de kinderrechter hiermee invulling zou geven aan de (deels) vage gronden in de wet en daarmee voor betrokkenen duidelijk kon maken welke feiten en omstandigheden een ondertoezichtstelling rechtvaardigden. Als uitgangspunt voor de analyse is daarom gehanteerd dat een gedegen inhoudelijke motivering veronderstelde dat de kinderrechter tenminste inhoudelijk een koppeling maakte tussen de feiten van de zaak en de twee cumulatieve gronden voor oplegging van de ondertoezichtstelling (art. 1:254 lid 1 oud BW). Concreet betekent dit dat in iedere beschikking afzonderlijk de bedreiging van de zedelijke of geestelijke belangen of gezondheid van de minderjarige zou moeten worden geconcretiseerd en dat moest worden beargumenteerd waarom andere middelen hadden gefaald, of naar was te voorzien, zouden falen

\subsection{Verzoek tot ondertoezichtstelling: wettelijke gronden}

\subsubsection{Ernstige bedreiging van de zedelijke of geestelijke belangen of gezondheid}

De beantwoording van de vraag of een minderjarige in het concrete geval ernstig in zijn zedelijke of geestelijke belangen of gezondheid werd bedreigd was een primair pedagogische afweging die in de visie van de wetgever grotendeels invulling behoorde te krijgen in de 
praktijk. De analyse laat zien hoe in de praktijk (voor zover het de besluitvorming door de RvdK betrof) invulling werd gegeven aan dit deel van de rechtsgrond van de ondertoezichtstelling. Onderzocht is of de RvdK in jaren 2013 en 2014 tot een gedegen, op de casus toegespitste onderbouwing kwam van de geconstateerde bedreiging van de minderjarige. Onder een gedegen, op de casus toegespitste onderbouwing van voornoemd wettelijk criterium wordt in dit onderzoek verstaan: een invulling waarbij op basis van de in het onderzoek verzamelde informatie een weging plaatsvond van de zorgen op kind- en gezinsniveau én beantwoording van de vraag wat de geconstateerde zorgpunten betekenden voor de ontwikkeling van het kind.

De analyse ten aanzien van de vraag of de RvdK concreet invulling gaf aan de vraag of de minderjarige ernstig in zijn zedelijke of geestelijke belangen of gezondheid werd bedreigd viel om hierop een antwoord te kunnen formuleren uiteen in drie deelvragen: (1) werden concrete zorgpunten op kindniveau en/of op het niveau van de opvoedingsomgeving aangedragen ter invulling van de ernstige ontwikkelingsbedreiging; (2) welke zorgpunten werden aangedragen op kindniveau en op het niveau van de opvoedingsomgeving en (3) werd beargumenteerd wat de geconstateerde zorgen betekenden voor de ontwikkeling van de minderjarige?

\section{Het benoemen van zorgpunten}

In de analyse zijn zorgpunten alleen gescoord indien in het beschermingsrapport duidelijk melding werd gemaakt van ontwikkelingsachterstanden, probleemgedragingen, stoornissen of bijvoorbeeld bedreigingen vanuit de opvoedingsomgeving. Ten aanzien van de eerste vraag laat de analyse zien dat in 199 van de 200 verzoeken tot ondertoezichtstelling door de RvdK zorgpunten werden aangedragen op kindniveau en/of op het niveau van de opvoedingsomgeving $(99,5 \%)$.

De wijze waarop het rapportageformat van de RvdK in beschermingszaken was vormgegeven maakte het niet waarschijnlijk dat zonder uitgebreide inhoudelijke toelichting werd volstaan met de conclusie dat er sprake was van een ernstige bedreiging van de zedelijke of geestelijke belangen of gezondheid. Na het horen van de minderjarige en zijn ouders en mogelijke informanten beoordeelde de RvdK de informatie om te komen tot een afweging van de onderzoeksvragen in het beschermingsrapport, die volgens een vaste structuur werden beantwoord. Aangezien concreet werd gevraagd naar de zorgpunten (en sterke punten) op kindniveau en het niveau van de opvoedingsomgeving lag het niet voor de hand dat hieraan 
voorbij werd gegaan. In de zaak waarin geen concrete zorgpunten werden beschreven door de RvdK werd het rapportageformat dan ook niet gevolgd

In 166 van de 199 zaken $(83,4 \%)$ waarin concrete zorgpunten werden benoemd ging het om zorgpunten op kindniveau en op het niveau van de opvoedingsomgeving. In 29 van de 199 zaken $(14,6 \%)$ waarin zorgpunten werden benoemd, werden alleen zorgpunten op het niveau van de opvoedingsomgeving gevonden. Voor een belangrijk deel ging het dan om zaken waarin het onderzoek zich moest richten op een ongeboren, of nog zeer jong kind. Het totaal aantal zaken waarin zorgpunten op het niveau van de opvoedingsomgeving werden gevonden komt daarmee op 195 van de 199 (98\%). Dit maakt duidelijk dat de situatie waarin ten aanzien van het opvoedershandelen van ouders geen zorgen zijn gebleken, nauwelijks voorkomt.

In 4 van de 199 zaken (2\%) waarin zorgpunten werden benoemd, ging het alleen om zorgen op kindniveau. Dit betrof dus de situatie waarin de RvdK geen zorgen heeft vast kunnen stellen ten aanzien van het functioneren van de ouders. Zo constateerde de RvdK in één van deze zaken:

'Ouders komen zeer betrokken en liefdevol over richting de minderjarige. De RvdK heeft minimale zorgen omtrent de opvoedingsomgeving. Ouders lijken ondanks het feit dat zij niet langer bij elkaar wonen goed contact en goede communicatie te hebben omtrent de minderjarige.'

Op basis van deze gegevens is duidelijk dat de bedreiging van de zedelijke of geestelijke belangen of gezondheid van de minderjarige vrijwel altijd ten dele of geheel werd toegeschreven aan het functioneren van de ouders. Zoals besproken in deel 1 van het onderzoek hanteerde de wetgever als uitgangspunt dat oplegging van de maatregel van ondertoezichtstelling niet noodzakelijkerwijs tot de conclusie zou moeten leiden dat ouders hun verantwoordelijkheid voor de verzorging en opvoeding van het kind niet hadden waargemaakt. ${ }^{637}$ De consequentie van een ondertoezichtstelling was echter dat een deel van de verantwoordelijkheid voor de verzorging en opvoeding als in art. 1:247 BW in handen kwam van de gezinsvoogd. Dat geeft al aan dat het niet waarschijnlijk is dat ouders in pedagogisch opzicht op geen enkele wijze hebben bijgedragen aan het ontstaan en instandhouden van de bedreiging van de minderjarige.

${ }^{637}$ Kamerstukken II 1992/93, 23 003, nr. 3 (MvT), p. 12. 


\section{Aard van de problematiek}

In het voorgaande is gebleken dat de RvdK in vrijwel alle zaken binnen de steekproef zorgpunten beschreef op kindniveau en/of op het niveau van de opvoedingsomgeving. Vervolgens is in het dossieronderzoek aandacht besteed aan de vraag welke zorgpunten op kindniveau en welke zorgpunten ten aanzien van de opvoedingsomgeving werden geconstateerd door de RvdK, ter invulling van de ernstige bedreiging van de zedelijke of geestelijke belangen of gezondheid van de minderjarige. Door de problematiek uit te splitsen is het mogelijk om te kijken of er bepaalde categorieen zorgpunten zijn op kind- en/of ouderniveau waarbij het lastiger was om de vertaling van zorgen naar de bedreiging van de belangen of gezondheid van de minderjarige te maken.

\section{Zorgpunten kindniveau}

De onderzoeksafwegingen in het beschermingsrapport van de Raad voor de Kinderbescherming begonnen met de vraag: 'Wat zijn de zorgpunten en sterke punten in de ontwikkeling van de minderjarige en wat heeft hij naast basale zorg en veiligheid nodig?' In het onderzoek is voor de zaken waarin een ondertoezichtstelling is verzocht gekeken welke zorgpunten hier op kindniveau door de Raad voor de Kinderbescherming werden genoemd. Impliciete of terloops genoemde zorgen in het beschermingsrapport die niet terugkwamen bij de onderzoeksafwegingen zijn niet meegenomen in de analyse. Zoals gesteld zijn er 166 zaken gevonden waar zorgpunten op kind- en ouderniveau werden gesignaleerd. In 4 van zaken werden alleen zorgen op kindniveau gevonden. Dit brengt het totaal aantal zaken waarin zorgen worden gemeld ten aanzien van het functioneren van de minderjarige op 170. In het vervolg wordt een overzicht gegeven van de gevonden zorgpunten op kindniveau.

Verstandelijke beperking: dit item is alleen gescoord indien naast de conclusie dat er sprake is van een verstandelijke beperking een duidelijk vastgestelde IQ-score werd genoemd. In veel overige zaken werd wel gerefereerd aan de verstandelijke vermogens van de minderjarige maar bleef het vaak vaag in hoeverre dat een rol speelde bij de problematiek van de minderjarige. In 23 van de 170 zaken (13,5\%) waarin zorgpunten op kindniveau werden genoemd was een verstandelijke beperking vastgesteld. De enkele aanwezigheid van een verstandelijke beperking levert nog geen ernstige ontwikkelingsbedreiging op, althans geen ontwikkelingsbedreiging waar binnen een ondertoezichtstelling invloed op kan worden 
uitgeoefend. Toch werd het wel geregeld genoemd onder zorgpunten op kindniveau door de RvdK. Wel werd dan meestal de koppeling gemaakt tussen de verstandelijke beperking en het ontstaan van allerlei andere problemen.Voorbeelden zijn impulsief en/of onmachtig gedrag van de minderjarige thuis of op school, uitval op school of een geringe weerstand tegen de invloed van antisociale leeftijdsgenoten.

Aanwezigheid stoornis: indien het rapport melding maakte van een duidelijke diagnose met daarbij vermeld wie wanneer die diagnose heeft gesteld. In 35 van de 170 zaken (20,6\%) waarin zorgpunten op kindniveau werden beschreven is een stoornis vastgesteld bij de minderjarige.

Lichamelijke problematiek: gescoord indien duidelijke zorgen werden benoemd ten aanzien van de lichamelijke gezondheid van de minderjarige. In 22 van de 170 zaken (12,9\%) constateerde de RvdK zorgen ten aanzien van de lichamelijke ontwikkeling van de minderjarige. Het ging om zeer uiteenlopende lichamelijke problemen die in veel gevallen ook samenhingen met sociaal-emotionele problematiek. Bijvoorbeeld minderjarigen die vanwege angst en onzekerheid slaapproblemen of eetproblemen ervoeren hetgeen leidde tot ernstig onder/overgewicht.

Internaliserende (gedrags)problematiek: problematiek waar het kind in de basis zelf last van heeft zoals angstproblematiek, suïcidale gedachten, parentificatie, depressieve gevoelens en/of psychosomatische klachten, sociaal angstig of andersoortig sociaal problematisch gedrag zoals ernstige teruggetrokkenheid, somber gedrag of schuldgevoelens/loyaliteitsproblemen. In 97 van de 170 zaken $(57,1 \%)$ werd door de RvdK internaliserende gedragsproblematiek van de minderjarige als zorgpunt genoemd.

Externaliserende (gedrags)problematiek: problematiek waar primair de omgeving last van heeft zoals, agressief of normoverschrijdend gedrag, onrustig of hyperactief gedrag, aandachten concentratieproblemen, prikkelbaar gedrag, antisociaal gedrag niet zijnde delinquent gedrag. In 74 van de 170 zaken (43,5\%) waarin zorgen op kindniveau werden gevonden werd externaliserende gedragsproblematiek van de minderjarige als zorgpunt benoemd.

Seksueel grensoverschrijdend/risicovol gedrag: gescoord indien het seksuele gedrag van de minderjarige expliciet als problematisch werd aangemerkt bijvoorbeeld: het vertonen van risicovol, niet leeftijdsadequaat seksueel gedrag zoals onbeschermde seksuele contacten, seksueel wervend gedrag, wisselende contacten op jeugdige leeftijd of seksuele contacten 
tegen betaling. In 19 van de 170 zaken $(11,2 \%)$ betrof de zorg op kindniveau seksueel grensoverschrijdend/risicovol gedrag van de minderjarige.

Verslaving/middelenmisbruik: problematisch alcohol- drugsgebruik, gokverslaving of gameverslaving. In 13 van de 170 zaken $(7,6 \%)$ constateerde de RvdK problematisch middelengebruik bij de minderjarige. In bijna alle gevallen ging het om minderjarigen die overmatig blowden.

Delinquent gedrag: apart gescoord indien sprake was van verdenking van/veroordeling wegens het plegen van strafbare feiten. In 19 van de 170 zaken $(11,2 \%)$ werd door de RvdK het (mogelijke) delinquente gedrag van de minderjarige als zorgpunt op kindniveau genoemd.

Schoolverzuim/problematische schoolgang: dit item is apart gescoord indien de schoolgang/ het schoolverzuim van de minderjarige als zorgpunt werd benoemd. Er is daarbij geen onderscheid gemaakt tussen absoluut verzuim (het niet ingeschreven staan bij een onderwijsinstelling) en relatief verzuim (de minderjarige staat wel ingeschreven maar is zonder geldige reden (langdurig) afwezig). Onder problematische schoolgang zijn zaken gescoord waarin de RvdK als zorg constateerde dat de minderjarige binnen korte tijd ver terugviel in niveau. In 55 van de 170 zaken $(32,4 \%)$ werd door de RvdK (ernstig) schoolverzuim en/of een problematische schoolgang geconstateerd. Het is daarbij opvallend dat in het onderzoek meerdere zaken zijn gevonden waar de minderjarige op het moment van het onderzoek door de RvdK al jarenlang geen onderwijs meer volgde. Een situatie verwacht mocht worden dat eerder zou zijn ingegrepen door een leerplichtambtenaar.

Ingrijpende levensgebeurtenissen: primair traumagerelateerde problematiek. Hoewel dit niet direct toeziet op persoonskenmerken of gedrag van de minderjarige werden ingrijpende levensgebeurtenissen indien meegemaakt door de RvdK genoemd onder zorgpunten op kindniveau. Het kon dan bijvoorbeeld gaan om het overlijden van een naaste, het veelvuldig moeten verhuizen of wisselen van gezinsomgeving, slachtoffer of getuige zijn van mishandeling, huiselijk geweld, seksueel misbruik of verwaarlozing, waardoor de minderjarige in een kwetsbare positie verkeerde. In 38 van de 170 zaken $(22,4 \%)$ werden ingrijpende levensgebeurtenissen expliciet door de RvdK benoemd als zorg ten aanzien van de minderjarige.

\section{Zorgpunten opvoedingsomgeving}

Zoals gesteld werd in het beschermingsrapport opgesteld door de RvdK een duidelijk onderscheid gemaakt tussen zorgpunten op kindniveau en zorgpunten in de 
opvoedingsomgeving. De tweede onderzoeksvraag in het rapport van de RvdK zag dan ook toe op de opvoedingsomgeving en luidde: 'wat zijn de zorgpunten en sterke punten in de opvoedingsomgeving / -context en in hoeverre komt deze tegemoet aan wat de minderjarige nodig heeft?' Van de 199 zaken waarin zorgpunten werden benoemd, kwamen in 195 zaken (doorgaans meerdere) zorgpunten terug op het niveau van de opvoedingsomgeving.

Verstandelijke beperking: dit item is alleen gescoord indien naast de conclusie dat er sprake was van een verstandelijke beperking een duidelijke IQ-score werd genoemd. Ouders met een verstandelijke beperking zijn doorgaans kwetsbaar en zij kunnen snel overbelast raken. In 24 van de 195 zaken (12,3\%) waarin zorgpunten op ouderniveau werden genoemd ging het om een verstandelijke beperking.

Aanwezigheid stoornis: dit item is alleen gescoord indien een duidelijke diagnose werd gesteld. In veel zaken werd wel problematiek waargenomen ten aanzien van de ouder die zou kunnen passen bij een stoornis maar was geen diagnose gesteld op basis van een gedegen en gedocumenteerd (persoonlijkheids)onderzoek. In 33 van de 195 zaken (16,9\%) waarin zorgpunten op ouderniveau werden genoemd ging het om een stoornis.

Internaliserende (gedrags)problematiek: primair naar binnen toe gerichte problematiek zoals angstproblematiek, suïcidale gedachten, depressiviteit en/of psychosomatische klachten, sociaal angstig of andersoortig sociaal problematisch gedrag zoals ernstige teruggetrokkenheid. In 38 van de 195 zaken (19,5\%) werd internaliserende problematiek geconstateerd ten aanzien van de ouder(s).

Externaliserende (gedrags)problematiek: naar buiten toe gerichte problematiek zoals, agressief of normoverschrijdend gedrag, onrustig of hyperactief gedrag, aandacht- en concentratieproblemen, prikkelbaar gedrag, antisociaal gedrag niet zijnde delinquent gedrag. In dit geval kan het ook gaan om schreeuwen/schelden tegen de kinderen of hulpverleners. In 41 van de 195 zaken (21\%) was waar het ging om de zorgen op ouderniveau sprake van externaliserende problematiek bij de ouder(s).

Delinquent gedrag: apart gescoord indien sprake was van verdenking van/veroordeling wegens het plegen van strafbare feiten. In 12 van de 195 zaken (6,2\%) constateerde de RvdK dat de ouder(s) werden verdacht van/waren veroordeeld wegens het plegen van strafbare feiten. 
Verslavingsproblematiek/middelenmisbruik: bijvoorbeeld problematisch alcoholdrugsgebruik of een gokverslaving. In 34 van de 195 zaken (17,4\%) zag de RvdK het middelengebruik of een andersoortige verslaving als een zorg op het niveau van de opvoedingsomgeving.

Pedagogische onmacht: gescoord indien het rapport melding maakte van ouders die een inadequate of niet bij de leeftijd of het ontwikkelingsniveau van het kind passende opvoedingsstijl hanteerden. Dit kon gaan om een (affectief) verwaarlozende, autoritaire of permissieve opvoedingsstijl. In 119 van de 195 zaken (61\%) waarin zorgen op het niveau op het niveau van de opvoedingsomgeving werden gemeld werd door de RvdK vastgesteld dat ouders pedagogisch onmachtig waren. Dit was het totaal aantal zaken waarin pedagogische onmacht werd genoemd. Als wordt gekeken naar zaken waarin pedagogische onmacht als enige zorgpunt werd genoemd ten aanzien van de ouders blijft een percentage van $21 \%$ over. (41 van de 195 zaken)

Huiselijk geweld: dit item is apart gescoord indien het rapport melding maakte van lichamelijke of seksuele geweldpleging tussen de ouders/verzorgers, belaging en bedreiging (al dan niet door middel van, of gepaard gaand met, beschadiging van goederen in en om het huis). In 49 van de 195 zaken $(25,1 \%)$ constateerde de RvdK dat sprake was van huiselijk geweld.

Mishandeling: alleen fysieke kindermishandeling is gescoord. Hieronder wordt verstaan: alle vormen van lichamelijk geweld tegen het kind. Er is geen onderscheid gemaakt ten aanzien van de ernst van het geweld. In 24 van de 195 zaken (12,3\%) constateerde de RvdK dat sprake was van fysieke kindermishandeling.

Seksueel misbruik: apart gescoord indien sprake is van seksuele aanrakingen of handelingen die een volwassene een kind opdringt. Dit varieert van begluurd worden of moeten toezien bij seksuele handelingen van de volwassene tot betasting en verkrachting. In 2 van de 195 zaken (1\%) was volgens de RvdK sprake geweest van seksueel misbruik van de minderjarige.

Financiële problematiek/huisvestingsproblematiek: gescoord indien de financiële problematiek zodanig ernstig is dat de verzorging en opvoeding van de minderjarige in gevaar komt en/of indien sprake is van problemen rond de huisvesting. Gedacht kan worden aan niet passende huisvesting of het voortdurend wisselen van woning of het hebben van grote schulden. In 51 van de 195 zaken (26,2\%) constateerde de RvdK ernstige financiële problemen en/of huisvestingsproblematiek. 
Scheidingsproblematiek: dit item is alleen gescoord indien de scheidingsproblematiek van dien aard is dat de RvdK constateerde dat de minderjarige hierdoor ernstig in zijn ontwikkeling werd bedreigd. In 60 van de 195 zaken (30,8\%) was de geconstateerde scheidingsproblematiek zodanig dat het volgens de RvdK direct bijdroeg aan het ontstaan of in stand houden van de ernstige ontwikkelingsbedreiging van de minderjarige.

\section{3) Bedreiging van de zedelijke of geestelijke belangen of gezondheid van de minderjarige} Vervolgens is gekeken of de RvdK in het beschermingsrapport aandacht besteedde aan de vraag wat de zorgpunten betekenden of bij een dreiging van schade, konden betekenen, voor de ontwikkeling van de minderjarige. Deze derde stap is cruciaal aangezien zorgen op kinden of ouderniveau niet per definitie hoeven te leiden tot een ernstige bedreiging in de ontwikkeling van de minderjarige. Om deze reden eindigde het raadsrapport in beschermingszaken met de vraag 'of er sprake is van een zodanig bedreigde ontwikkeling van de minderjarige dat een kinderbeschermingsmaatregel noodzakelijk is? Hier werd beoogd een korte samenvatting te geven van de geconstateerde zorgpunten waarna een duidelijke koppeling moest worden gemaakt met de ontwikkeling van de minderjarige.

Uit het dossieronderzoek komt naar voren dat de RvdK in 191 van de 200 zaken waarin een ondertoezichtstelling is verzocht $(95,5 \%)$ expliciet antwoord gaf op de vraag waarom de geconstateerde zorgen een ernstige bedreiging van de zedelijke of geestelijke belangen of gezondheid van de minderjarige opleverden. De noodzakelijk tussen zorgen en ontwikkeling werd door de RvdK in vrijwel iedere zaak gemaakt. Als meer in detail wordt gekeken naar de zaken waarin de zorgpunten vaag bleven of de koppeling met de ontwikkelingsbedreiging niet expliciet werd gemaakt dan worden een aantal aandachtspunten zichtbaar.

Ten aanzien van de zaken waarin niet duidelijk werd beargumenteerd wat de gevonden zorgpunten betekenden voor de ontwikkeling van de minderjarige ( 9 van de 200 zaken, $4,5 \%$ ), valt ten eerste op dat een inhoudelijk antwoord op de vraag of er sprake was van een ernstige bedreiging, ontbrak of zeer summier was. Zo bleek in een enkele zaak te worden volstaan met de conclusie dat er een ernstige ontwikkelingsbedreiging was geconstateerd zonder nadere concretisering. De bedreiging van de belangen van de minderjarige kon dan (soms) indirect wel worden afgeleid door de zorgpunten te analyseren, maar het is belangrijk dit expliciet te maken. 
Verder valt op dat in bijna alle zaken waarin de koppeling tussen de zorgen en de bedreiging van de zedelijke of geestelijke belangen of gezondheid van de minderjarige niet werd gemaakt, alleen zorgpunten werden gevonden op het niveau van de opvoedingsomgeving. Het is voorstelbaar dat eenvoudiger is te beargumenteren waarom de belangen van de minderjarige ernstig wordt bedreigd in zaken waarin op kindniveau ook zorgen worden geconstateerd. De bedreiging kan dan immers heel duidelijk worden gekoppeld aan het problematische functioneren van de minderjarige zelf. Maar juist in de zaken waarin de zorgen exclusief op het niveau van de opvoedingsomgeving liggen is het noodzakelijk te anticiperen op de risico's voor de ontwikkeling van de minderjarige.

Het is daarom vermoedelijk ook onbewust dat de uitleg van de RvdK in dit soort zaken zich soms beperkte tot de rol van de ouders. Bijvoorbeeld bij het verzoek tot ondertoezichtstelling van ongeboren of net geboren kinderen. Bij deze groep is het lastig, zo niet onmogelijk, om uitspraken te doen over het functioneren van de minderjarige zelf. Maar wel zou moeten worden beargumenteerd waarom de ontwikkeling van de ongeboren vrucht al tijdens de zwangerschap wordt bedreigd en kan door de RvdK worden geanticipeerd op de situatie kort na de geboorte. In enkele zaken werd echter onevenredig veel aandacht besteed aan het vermeende disfunctioneren van de ouder en lijken de gevolgen voor de ontwikkeling van het kind uit beeld te verdwijnen.

Een categorie zaken waarin het eveneens lastig bleek te zijn om de (acuut dreigende) ontwikkelingsschade voor de minderjarige aan te tonen, betrof de zaken waarin scheidingsproblematiek centraal stond. Uit het dossieronderzoek komt naar voren dat scheidingsproblematiek in 30,8\% van de zaken werd genoemd als oorzaak, of een van de oorzaken van de geconstateerde bedreiging van de minderjarige. Nadere analyse van deze zaken laat zien dat het doorgaans voor de RvdK geen enkel probleem was aan te tonen dat het gedrag van ouders problematisch was. Helder krijgen dat hierdoor ook ontwikkelingsschade dreigde voor de minderjarige bleek een veel grotere opgave. In de beschermingsrapporten werd dan gesteld dat de minderjarige thans nog goed functioneert maar dat wetenschappelijk onderzoek heeft uitgewezen dat een conflictueuze scheiding op latere leeftijd tot tal van problemen kan leiden bij de minderjarige die hiermee wordt geconfronteerd. Een ander frequent ingebracht argument door de RvdK was dat het ontbreken van omgang met de andere ouder een bedreiging in de sociaal-emotionele ontwikkeling van de minderjarige opleverde. Voor beide argumenten geldt dat het risico ontstaat dat onvoldoende duidelijk wordt waarom bezien vanuit de belangen van de minderjarige een ondertoezichtstelling gerechtvaardigd is. 
Zo lijkt een onderbouwing waarin wordt verwezen naar de mogelijkheid dat er op latere leeftijd problemen kunnen ontstaan voor de minderjarige niet te voldoen aan de eis dat de bedreiging ernstig moet zijn en schade voor de minderjarige zich ieder moment kan aandienen. Ook ten aanzien van het ontbreken van omgang met de andere ouder geldt dat dit onder omstandigheden een ernstige bedreiging van de belangen van de minderjarige op kan leveren. Vanzelfsprekend is dit echter niet. De Hoge Raad heeft consequent bevestigd dat in zaken waarin conflicten omtrent gezag en omgang centraal staan, hoge eisen moeten worden gesteld aan de onderbouwing van de ernstige bedreiging van de zedelijke of geestelijke belangen of gezondheid van de minderjarige. Alleen het stagneren van een omgangsregeling lijkt onvoldoende. Er moet sprake zijn van bijkomende belastende conflicten of problemen om te kunnen voldoen aan de gronden van een ondertoezichtstelling. Een ander oordeel zou ook conflicteren met de beoogde uitvoering van de ondertoezichtstelling. De uitvoering van de maatregel behoort zich primair te richten op de minderjarige, maar als de ondertoezichtstelling alleen beoogt de omgangsregeling te herstellen, dan staat het (problematische) gedrag van ouders centraal.

\section{Het gebruik van vakjargon in de beschermingsrapportage}

Een ander punt van aandacht als wordt gekeken naar de wijze waarop de zorgpunten op ouderniveau door de RvdK werden beschreven was het veelvuldige gebruik van containerbegrippen en standaardzinnen die soms frequent werden herhaald. Het gebruiken van standaardzinnen en vakjargon is op zichzelf niet direct problematisch, hoewel het belang van helder en begrijpelijk taalgebruik niet voldoende kan worden benadrukt. De uitdaging voor de raadsonderzoeker is steeds weer aan de hand van concrete gedragingen of uitlatingen duidelijk te maken hoe tot een bepaalde kwalificatie is gekomen. Anders blijft de onderbouwing vaag. Zo zijn veelgebruikte zinsneden als ‘ouders zijn handelingsverlegen’ of 'ouders komen onvoldoende tegemoet aan het ontwikkelingsbelang van de minderjarige' weinigzeggend zonder nadere concretisering.

In dit verband sprong de veelgebruikte de term 'pedagogische onmacht' van de ouders het meest in het oog. Uit het dossieronderzoek volgt dat de RvdK in liefst 119 van de 195 zaken $(61 \%)$ waarin zorgpunten op ouderniveau werden gevonden, pedagogische onmacht als zorgpunt benoemde. In 41 van de 119 zaken waarin pedagogische onmacht als zorgpunt werd genoemd, was dit zelfs op ouderniveau de enige gemelde zorg. Dat is op zichzelf geen verrassende uitkomst aangezien de pedagogische capaciteiten van de ouders direct van invloed zijn op de ontwikkeling van de minderjarige. Het is alleen wel noodzakelijk dat aan 
de hand van een concrete omschrijving duidelijk wordt gemaakt waaruit is afgeleid dat de ouders in opvoedkundig opzicht onmachtig zijn. Anders bestaat het risico dat pedagogische onmacht als een soort restcategorie gaat fungeren voor zaken waarin wel zorgen zijn ten aanzien van de minderjarige maar niet voldoende concreet kan worden vastgesteld welke rol de ouders daarin hebben gespeeld. Er zijn beschermingsrapporten waarin uitvoerig werd beschreven waaruit blijkt dat ouders op pedagogisch vlak onmachtig waren, maar toch ook zaken waarin dit begrip niet of nauwelijks nadere invulling kreeg.

De analyse ten aanzien van de wijze waarop invulling werd gegeven door de RvdK aan de grond 'ernstige bedreiging van de zedelijke of geestelijke belangen of gezondheid van de minderjarige' heeft een aantal gezichtspunten opgeleverd. In de eerste plaats moet worden vastgesteld dat de RvdK in 2013 en 2014 in het overgrote deel van de geanalyseerde zaken zorgpunten benoemde en duidelijk aangaf wat de zorgen betekenden voor de ontwikkeling van de minderjarige. De in deel I van dit onderzoek beschreven zorg dat gezien de open formulering van de rechtsgrond van de ondertoezichtstelling mogelijk kon worden volstaan met een vage of weinig diepgaande omschrijving van de bedreiging is binnen de onderzochte zaken grotendeels onterecht gebleken. Wel heeft het dossieronderzoek laten zien dat het mogelijk is bepaalde situaties te identificeren waarin het risico groter is dat de zorgen onvoldoende concreet worden onderbouwd of waar niet voldoende duidelijk wordt gemaakt wat de zorgen betekenen voor de belangen van de minderjarige.

\subsection{2 (Voorzienbaar) falen van andere middelen}

In deel I van het onderzoek zijn de belangrijkste uitgangspunten beschreven met betrekking tot wijze waarop de rechtsgrond van de ondertoezichtstelling onder oude wetgeving moest worden geinterpreteerd en toegepast. De tweede cumulatieve voorwaarde voor oplegging van een ondertoezichtstelling op grond van art. 1:254 oud lid $1 \mathrm{BW}$, luidde dat andere middelen ter afwending van de ontwikkelingsbedreiging van de minderjarige moesten hebben gefaald, of naar was te voorzien, zouden falen. Dit vereiste gaf uitdrukking aan het subsidiariteitsbeginsel ten aanzien van gedwongen overheidsingrijpen in het gezinsleven. Slechts indien binnen het vrijwillig kader de ontwikkelingsbedreiging van de minderjarige niet, of onvoldoende werd weggenomen, dan kon een dwangmaatregel gerechtvaardigd zijn.

Van de RvdK als verzoeker mocht tenminste worden verwacht dat nadrukkelijk aandacht zou worden besteed aan de vraag of vrijwillige hulpverlening was ingezet of overwogen en wat 
het resultaat hiervan was. Dit is geanalyseerd door te kijken hoe de RvdK in het beschermingsrapport met het thema 'hulpverlening' omging. Bij de onderzoeksafwegingen in het beschermingsrapport was een vraag specifiek gericht op het thema hulpverlening: 'welke hulp is nodig en wat zijn de mogelijkheden om de noodzakelijke hulpverlening te accepteren en benutten?' Voornoemde vraag bevatte verschillende elementen, waarbij op het oog niet concreet werd gevraagd naar het resultaat van de eerder ingezette hulpverlening. De vraag veronderstelde dat eerst een globaal hulpverleningsperspectief zou worden geschetst. Vervolgens moest worden beargumenteerd in hoeverre ouders en kind bereid zich bereid toonden medewerking te verlenen aan de noodzakelijk geachte hulpverlening en tot slot moest worden beargumenteerd in hoeverre ouders en kind ook in staat zouden zijn de mogelijkheden tot hulpverlening te benutten. In de analyse is voor de 200 zaken die deel uitmaken van de steekproef gekeken of de RvdK, ondanks dat niet expliciet werd gevraagd naar het falen van hulpverlening, tot een inhoudelijke toetsing kwam van deze grond en zo ja, op welke wijze hieraan invulling werd gegeven. Daarbij is gekeken in welke zaken duidelijk was dat vrijwillige hulpverlening had gefaald (op basis van eerdere resultaten) en in welke zaken voorzien werd dat vrijwillige hulpverlening zou falen. Vervolgens is gekeken welke rol het wel of niet accepteren van de noodzakelijke hulpverlening door de minderjarige en zijn ouders speelde in het oordeel over het resultaat van de eerder ingezette of overwogen middelen in het vrijwillig kader. In Figuur 1 worden de gevonden resultaten weergegeven, gevolgd door de analyse van deze resultaten. 


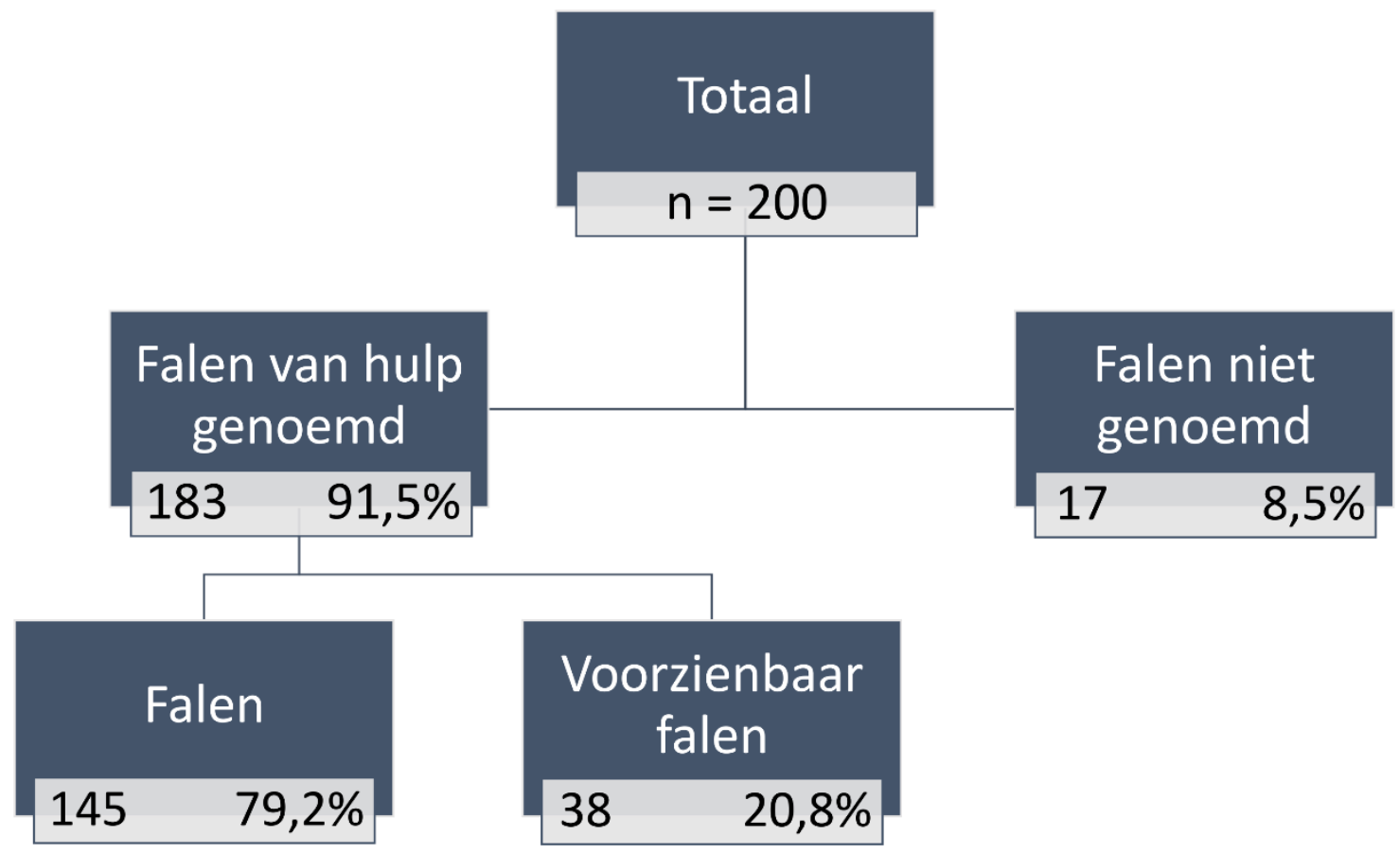

Figuur 1. De onderbouwing van het falen van hulpverlening door de RvdK

De analyse laat zien dat in 183 van de 200 zaken (91,5\%) waarin een verzoek tot ondertoezichtstelling is gedaan aandacht werd besteed aan de vraag of andere middelen hadden gefaald, of naar was te voorzien, zouden falen. De RvdK maakte in de meeste gevallen een afweging omtrent de noodzaak van gedwongen overheidsingrijpen in het gezinsleven door inzet van een ondertoezichtstelling. Dat niet in alle zaken binnen de steekproef werd beargumenteerd waarom vrijwillige hulpverlening geen optie meer was lijkt vooral samen te hangen met de manier waarop in het beschermingsrapport werd gevraagd dit deel van de rechtsgrond van de ondertoezichtstelling te onderbouwen. De focus leek op basis van de vraagstelling vooral te liggen op de huidige en toekomstige situatie en de mogelijkheden van kind en ouders. Een belangrijke vraag, nu de bereidheid en de capaciteiten om gebruik te maken van de noodzakelijke hulpverlening cruciaal is voor het (toekomstige) resultaat van de eventueel op te leggen maatregel. Er werd echter niet expliciet gevraagd terug te kijken en te beargumenteren welke opties in het vrijwillig kader waren overwogen of ingezet met welk resultaat. Op basis van enkele voorbeelden uit het dossieronderzoek wordt dit verschil verder verduidelijkt. De eerste twee voorbeelden komen uit zaken waarin wel nadrukkelijk aandacht was voor het resultaat van de eerder ingezette hulpverlening in het vrijwillig kader: 


\section{Voorbeeld 1}

'Binnen het vrijwillig kader zijn verschillende pogingen gedaan om ervoor te zorgen dat de situatie zo min mogelijk belastend is voor de minderjarige. Het hulpverleningsproces stagneert echter doordat moeder en stiefvader het samen met de hulpverlening niet eens worden over wat in het belang van de minderjarige is. Een extra gezagskader zal ervoor zorgen dat er in het belang van de minderjarige wordt gehandeld, ongeacht of moeder en stiefvader hiermee instemmen of niet.'

\section{Voorbeeld 2}

'De Raad voor de Kinderbescherming is van mening dat een ondertoezichtstelling noodzakelijk is om noodzakelijk geachte hulpverlening te garanderen en veiligheid te creëren in de opvoedingssituatie van de minderjarige. De bedreiging kan niet op een andere manier worden weggenomen omdat de ontwikkelingsbedreiging van de minderjarige, ondanks hulp in vrijwillig kader, niet is afgewend. Ouders staan niet open voor de noodzakelijk geachte hulp van betrokken hulpverleningsinstelling, ondanks dat ouders tijdens het vorige raadsonderzoek lieten weten mee te willen en zullen werken aan hulpverlening. De Raad ziet dit als een groot zorgpunt. Hierdoor is hulp in vrijwillig kader ontoereikend gebleken.'

In de zaken waarin de Raad niet expliciet aandacht besteedde aan het (voorzienbare) falen van vrijwillige hulpverlening (17 van de 200 zaken, 8,5\%), was incidenteel zichtbaar dat helemaal geen inhoudelijke toelichting werd gegeven omtrent het falen van andere middelen. Maar meestal werd (binnen deze 17 zaken) wel aandacht besteed aan het thema hulpverlening, alleen dan alleen gericht op wat nu en in toekomst nodig zou zijn voor de minderjarige. In die gevallen werd in de beantwoording geen aandacht besteed aan het resultaat van de eerder ingezette hulpverlening, zoals op basis van art. 1:254 lid 1 oud BW mocht worden verwacht. Het volgende voorbeeld uit het dossieronderzoek geeft dit weer:

\section{Voorbeeld 1}

'De RvdK is van mening dat er niet vrijblijvende en gestructureerde hulp dient te komen en een ondertoezichtstelling wordt daarvoor een passende maatregel gevonden. Verder zal de thans geboden hulp gecontinueerd worden en is er de mogelijkheid voor scheidingsbemiddeling. Om te voorkomen dat er straks te veel hulpverleners bij ouders over de vloer komen en zij door de bomen het bos niet meer zien, zullen al deze vormen van hulp daarom wel op elkaar afgestemd moeten worden.'

\section{Het (voorzienbaar) falen van de vrijwillige hulpverlening}

In Figuur 1 is te zien dat de RvdK in 145 van de 183 zaken $(79,2 \%)$ constateerde dat 
vrijwillige hulpverlening had gefaald. In de regel werd het falen van de eerder ingezette hulpverlening uitgebreid gedocumenteerd in de beschermingsrapportage, en bestond er ook nauwelijks twijfel dat het voor de minderjarige gewenste resultaat niet was behaald. In 38 van de 183 zaken (20,8\%) werd door de RvdK beargumenteerd dat vrijwillige hulpverlening naar was te voorzien zou falen. Daarbij kwamen twee situaties terug in de geanalyseerde zaken. Ten eerste kwam het een enkele keer voor dat nog geen hulpverlening was ingezet voor de minderjarige. Gedacht kan worden aan de situatie waarin de hulpverlening in het vrijwillig kader geen enkele ingang bij het gezin had kunnen krijgen. Ten tweede kwam het voor dat reeds een hulpverleningstraject in het vrijwillig kader was opgestart waarvan het resultaat nog grotendeels onduidelijk was maar waar de RvdK om uiteenlopende redenen van dacht dat het op termijn onvoldoende zou zijn voor de minderjarige.

Deze 38 zaken waarin de RvdK voorzag dat vrijwillige hulpverlening zou falen, hebben met elkaar gemeen dat ten aanzien van de minderjarige nog niet met zekerheid was vast te stellen dat vrijwillige hulpverlening niet het gewenste effect zou sorteren. De RvdK was daar wel van overtuigd anders zou geen verzoek tot ondertoezichtstelling zijn ingediend. Wel is duidelijk dat in deze zaken extra kritisch moet worden gekeken naar hoe waarschijnlijk het is dat vrijwillige hulpverlening onvoldoende is. Gaat het bijvoorbeeld om de situatie waarin ervaring met andere kinderen binnen het gezin is opgedaan binnen de hulpverlening dan kan waarschijnlijk wel aannemelijk worden gemaakt waarom het gedwongen kader noodzakelijk is. Minder zeker is de situatie waarin wel vrijwillige hulpverlening is opgestart, nog geen duidelijkheid is over het resultaat, maar de RvdK toch wenst op te schalen naar een ondertoezichtstelling.

De rol die acceptatie speelde bij de afweging over het falen van de hulpverlening Zoals gesteld werd in het beschermingsrapport concreet gevraagd naar de mate waarin de minderjarige en zijn ouders de noodzakelijke hulp accepteerden. Het niet of onvoldoende accepteren van de vrijwillige hulpverlening kon de oorzaak zijn van het falen van de vrijwillige hulpverlening, maar dit was niet noodzakelijkerwijs het geval. Het kon immers ook zo zijn dat de minderjarige en zijn ouders wel goed meewerkten, maar de bedreiging van de zedelijke of geestelijke belangen of gezondheid van de minderjarige niet voldoende was weggenomen. In de analyse is gekeken in hoeveel zaken de RvdK aangaf dat de vrijwillige hulpverlening voldoende werd geaccepteerd door de minderjarige en zijn ouders maar toch een ondertoezichtstelling noodzakelijk was. Uitkomst is dat in 71 van de 200 zaken $(35,5 \%)$ 
werd gesteld door de RvdK dat er voldoende bereidheid was om mee te werken aan de zijde van de minderjarige en zijn ouders, maar toch een ondertoezichtstelling was aangewezen. In de overige zaken (129) was er ofwel geen sprake van acceptatie door de betrokkenen, of werd geen aandacht besteed aan de vraag of de vrijwillige hulpverlening voldoende werd geaccepteerd. De belangrijkste reden die werd aangedragen ter onderbouwing van de noodzaak van een ondertoezichtstelling ondanks de medewerking van betrokkenen was dat de problematiek van het gezin het vrijwillig kader ontsteeg. Bijvoorbeeld omdat door een veelvoud aan problemen sturing en regie in de vorm van een onafhankelijke gezinsvoogd noodzakelijk was. De relevantie van de bevindingen ten aanzien van de mate waarin de minderjarige en zijn ouders de vrijwillige hulpverlening accepteerden wordt verder uitgewerkt in deel IIII van onderzoek, gericht op het jeugdbeschermingsrecht na 2015.

\subsection{Verzoek tot ondertoezichtstelling: doelstelling}

In deel I van het onderzoek is de wettelijke doelstelling van de ondertoezichtstelling beschreven die toepassing was op jeugdbeschermingszaken in 2013 en 2014. De wettelijke doelstelling van de ondertoezichtstelling was neergelegd in art. 1:257 oud BW. Als primaire doelstelling van de ondertoezichtstelling gold het bieden van hulp en steun aan de minderjarige en zijn ouders teneinde de geconstateerde ontwikkelingsbedreiging bij de minderjarige weg te nemen. Daarnaast gold op grond van art. 1:257 lid 2 oud BW dat de ondertoezichtstelling erop gericht moest zijn de met gezag belaste ouder de verantwoordelijkheid voor de verzorging en opvoeding zoveel mogelijk te doen laten behouden en diende de gezinsvoogdij-instelling de gezinsband tussen kind en ouder te bevorderen. De wettelijke doelstelling van art. 1:257 oud BW gaf in algemene zin weer waar de ondertoezichtstelling zich op zou moeten richten. Voor de analyse is als uitgangspunt gehanteerd dat het voor de rechtvaardiging van de ondertoezichtstelling noodzakelijk is dat binnen de grenzen van de wettelijke doelstelling in iedere zaak afzonderlijk concrete, toetsbare doelen worden gesteld. Richting de betrokkenen (ouders, kind) vindt de rechtvaardiging dan plaats doordat duidelijk wordt gemaakt wat de gewenste ontwikkelingsuitkomsten zijn voor de minderjarige en welke stappen gezet moeten worden om hier te komen. 


\subsubsection{Doelen van de ondertoezichtstelling}

In deel I van het onderzoek is besproken dat het stellen van doelen een belangrijke plek heeft gekregen in het rapportageformat beschermingszaken van de RvdK. Aangezien de RvdK de aangewezen instantie is om aan de hand van zorgpunten de bedreiging in de ontwikkeling van de minderjarige te concretiseren, lijkt het ook zeer wel mogelijk om de gevonden bedreigingen om te zetten in gewenste ontwikkelingsuitkomsten

In het dossieronderzoek is er niet voor gekozen de mate van concreetheid van de gestelde doelen door de RvdK te scoren volgens vooraf vastgestelde criteria, zoals wel is gedaan in eerder onderzoek. ${ }^{638}$ De variatie in vorm en concreetheid van de gestelde doelen bleek zodanig groot dat het niet mogelijk was heldere criteria te formuleren op basis waarvan de mate van concreetheid kon worden gescoord. In de analyse is in de eerste plaats gekeken of de RvdK in de 200 zaken zaken waarin een ondertoezichtstelling is verzocht doelen heeft gesteld die binnen de maatregel moesten worden behaald om de geconstateerde ontwikkelingsbedreiging weg te nemen. Daarnaast worden enkele algemene bevindingen gedeeld over de vorm en inhoud van de gestelde doelen in de beschermingsrapporten. Tot slot is gekeken of de RvdK ook aangaf hoe de gestelde doelen moesten worden behaald. Met andere woorden, of een globaal hulpverleningsperspectief werd geschetst.

\section{Het stellen van doelen door de RdvK}

In het rapportageformat beschermingszaken van de RvdK werd expliciet gevraagd naar de doelen die binnen de verzochte ondertoezichtstelling zouden moeten worden behaald: welke doelen moeten behaald worden om de ontwikkelingsperspectieven van de minderjarige veilig te stellen? Omdat in het rapportageformat werd gevraagd doelen te stellen lijkt het onwaarschijnlijk dat hieraan voorbij zou worden gegaan in het beschermingsrapport. De analyse laat zien dat de RvdK in 185 van de 200 geanalyseerde zaken (92,5\%) doelen heeft opgenomen.

Over de wijze waarop de doelen werden geformuleerd in de beschermingsrapporten kunnen wel een aantal algemene opmerkingen worden gemaakt. De analyse laat zien dat de doelen die werden gesteld vaak zeer algemeen waren geformuleerd, waarbij lang niet altijd duidelijk werd wat de gewenste ontwikkelingsuitkomst was voor de minderjarige. Waar de RvdK veel aandacht besteedde aan het concretiseren van de zorgpunten om zo de ontwikkelingsbedreiging te verhelderen, daar leken de gestelde doelen veel vaker

\footnotetext{
${ }^{638}$ Slot e.a. 2002.
} 
'standaarddoelen' te zijn die niet gekoppeld waren aan de concrete bedreiging van de belangen van de minderjarige. Een drietal zaken is daarbij in het bijzonder opgevallen.

\section{1)Geen concrete doelen}

Omdat niet volgens vaste criteria de concreetheid van de gestelde doelen is gemeten moeten de bevindingen op dit punt met de nodige voorzichtigheid worden geïnterpreteerd. Het onderzoek heeft geleid tot enige zorg over de vaagheid van tenminste een deel van de doelen zoals deze waren opgenomen in de beschermingsrapporten. Daarbij wordt niet gesuggereerd dat het beschermingsrapport al een complete lijst met specifieke werkdoelen zou moeten bevatten. De onderzoeksperiode voor de RvdK was daarvoor te kort waardoor nog geen compleet beeld van de gezinssituatie kon worden gegeven en er diende ruimte te worden gelaten voor Bureau Jeugdzorg om met het gezin tot een plan van aanpak te komen. Op een bepaald punt kunnen doelen echter zo weinig concreet geformuleerd zijn dat de inhoudelijke waarde van het stellen van die doelen verdwijnt. In eerder onderzoek is al aangegeven dat in iedere zaak als doel kan worden gesteld het bieden van hulp en steun teneinde de ontwikkelingsbedreiging van de minderjarige weg te nemen. ${ }^{639}$ Het doel is zonder meer relevant maar het is voor geen van de betrokkenen (kind, ouders, gezinsvoogd) duidelijk waaraan gewerkt moet worden binnen de ondertoezichtstelling. Voor de minderjarige en zijn ouders is er dan sprake van een gebrek aan rechtszekerheid, waardoor ook het risico ontstaat dat de maatregel op basis van de vage doelstellingen (vele malen) wordt verlengd. In de beschermingsrapporten kwamen dit soort vage doelstellingen regelmatig voor. Een aantal voorbeelden uit het dossieronderzoek kan verduidelijken wat wordt verstaan onder vage doelstellingen:

De ontwikkelingsbedreiging van de minderjarige is gestopt

De minderjarige zit goed in zijn vel

De minderjarige heeft positieve contacten

De minderjarige komt toe aan zijn ontwikkelingstaken

Het inzicht van ouders is vergroot

De minderjarige functioneert thuis goed

Ouders nemen hun verantwoordelijkheid als opvoeder

De minderjarige heeft goed contact met de ouders

${ }^{639}$ Geparafraseerd de wettelijke doelstelling van de ondertoezichtstelling op grond van art. 1:257 oud BW. Vgl. Slot e.a. 2002. 


\section{2) Negatief geformuleerde doelen}

In een ideale situatie geven de doelen die door de RvdK worden gesteld het verschil weer tussen de ernstig bedreigde ontwikkeling en de gewenste ontwikkelingsuitkomst voor de minderjarige. Het stellen van doelen in termen van gewenste ontwikkelingsuitkomsten is essentieel omdat zo duidelijkheid wordt verschaft ten aanzien van de vraag wanneer de bedreiging in de ontwikkeling voldoende is afgewend. ${ }^{640}$ In de beschermingsrapporten is dit echter lang niet altijd het geval. Zichtbaar is dat doelen negatief werden geformuleerd, dus gericht op het verbieden van probleemgedrag of het opheffen van een bepaalde situatie, in plaats van een positieve formulering gericht op de gewenste uitkomst voor de minderjarige. Als dit niet gebeurt geven de doelen onvoldoende duidelijk aan waarin het verschil zit tussen een bedreigde ontwikkeling en een adequaat verlopende ontwikkeling. Enkele voorbeelden uit het dossieronderzoek hiervan zijn:

\section{De minderjarige stopt met blowen}

De minderjarige vertoont geen gedragsproblemen meer

Ouders belasten de minderjarige niet met volwassenproblematiek

De minderjarige stopt met spijbelen

Er spelen geen praktische problemen in het gezin

Er spelen geen relatieproblemen tussen ouders

Verder is zichtbaar dat doelen en middelen door elkaar werden gehaald. In het rapportageformat dat werd gebruikt bij beschermingszaken werd consequent onderscheid gemaakt tussen doelen ('welke doelen moeten worden behaald om de ontwikkelingsperspectieven van de minderjarige veilig te stellen'?) en middelen ('welke hulp is nodig?'). In de uitwerking van deze vragen lopen doelen en middelen echter door elkaar. Daarbij is tevens zichtbaar dat onder de vraag welke doelen moesten worden behaald doelen zijn geformuleerd die waren gericht op de uitvoering van de ondertoezichtstelling door de gezinsvoogd. Het is de vraag of de RvdK hier bewust de keuze maakte om doelen te stellen voor de minderjarige, zijn ouders en de gezinsvoogd of dat men onbewust enige invloed wilde uitoefenen op de uitvoering van de maatregel. Bijvoorbeeld door het advies op te nemen dat bepaalde onderzoeken bij de minderjarige moesten worden verricht. Ongeacht de uitkomst

\footnotetext{
${ }^{640}$ Vgl. Slot e.a. 2002 en voor een verdere uitwerking hiervan: PI Research \& Van Montfoort 2009.
} 
van voornoemde vraag lijkt het meer voor de hand te liggen om doelen die zich uitsluitend richten op de gezinsvoogd, meer specifiek de inzet of coördinatie van hulpverlening, onder middelen te scharen. Onderstaand enkele voorbeelden van doelen die gericht leken te zijn op de uitvoering van de ondertoezichtstelling door de gezinsvoogd:

\section{Er wordt een persoonlijkheidsonderzoek bij de minderjarige afgenomen}

Minderjarige en ouders ontvangen hulpverlening

Er komt zicht op de opvoedingsvaardigheden van ouders

Er wordt zicht gehouden op de opvoedingsvaardigheden van ouders in combinatie met hun verslavingsproblematiek.

Bij moeder wordt een urinetest afgenomen

\section{3) Doelen gericht op een optimale ontwikkelingsuitkomst}

Ten derde werden in enkele gevallen doelen gesteld die niet passend leken binnen de context van gedwongen overheidsingrijpen in het gezinsleven. De ondertoezichtstelling, als uiterste middel moet gericht zijn op de ontwikkelingsbedreiging van de minderjarige en beoogt dus een punt te bereiken waarop kan worden gezegd dat de bedreiging is afgewend. Het is verleidelijk, maar onwenselijk om een stap verder te gaan en doelen te formuleren waarin vergaande inhoudelijke eisen worden gesteld aan de opvoedingsomgeving, en het functioneren van de minderjarige binnen die opvoedingsomgeving. Het formuleren van doelen in termen van gewenste ontwikkelingsuitkomsten leidt daarmee onherroepelijk tot de vraag hoe ver men binnen het kader van de gedwongen hulpverlening zou moeten gaan als het gaat om de vraag wat een gewenste ontwikkelingsuitkomst is voor de minderjarige. Een concreet voorbeeld kan dit verduidelijken. In diverse beschermingsrapporten was zichtbaar dat de minderjarige - om wat voor reden dan ook - langdurig niet naar school ging en zich daarmee onttrok aan de leerplicht. Zichtbaar was dat de RvdK en de kinderrechter scherp waren op deze situatie en het belang van een goede schoolgang in het beschermingsrapport en de beschikking benadrukten voor de ontwikkeling van de minderjarige. De vraag is hoe ver daarin kan worden gegaan. In verschillende beschermingsrapporten is zichtbaar dat de RvdK bij de doelen een concreet opleidingsniveau benoemde waaraan de minderjarige zou moeten voldoen. Ook al was de minderjarige wellicht in staat om een bepaald niveau aan te kunnen, het is de vraag of daar een taak ligt binnen het gedwongen kader van de ondertoezichtstelling. Het geldt immers voor veel meer minderjarigen dat zij om wat voor reden dan ook onderwijs volgen op een lager niveau dan zij in potentie aankunnen. Het voorbeeld maakt duidelijk dat 
in iedere zaak afzonderlijk zal moeten worden bepaald wat als ondergrens heeft te gelden voor de ontwikkeling van de minderjarige.

\subsubsection{Hulpverleningsperspectief}

Vervolgens is gekeken of de RvdK een globaal perspectief schetste van hetgeen nodig was aan hulpverlening om de bedreiging van de zedelijke of geestelijke belangen of gezondheid van de minderjarige weg te nemen. Niet zonder reden is gekeken of een 'globaal' hulpverleningsplan werd opgenomen in de rapportage. Dit sluit aan bij de visie van de wetgever dat voor of bij aanvang van de ondertoezichtstelling het eerste hulpverleningsplan in de regel beperkt is en dat het op de weg van de gezinsvoogdij-instelling ligt om het hulpverleningsplan met het gezin verder vorm te geven. ${ }^{641}$ Desondanks kan een indicatie van hetgeen op hulpverleningsgebied noodzakelijk is een doelmatige uitvoering van de maatregel bevorderen. Uit de analyse blijkt dat in 187 van de 200 zaken $(93,5 \%)$ een globaal hulpverleningsperspectief werd geschetst door de RvdK. Zoals eerder aangegeven werd in rapportageformat in beschermingszaken ook nadrukkelijk gevraagd een indicatie te geven van de hulp die nodig was om de geconstateerde ontwikkelingsbedreiging weg te nemen. Het resultaat laat zien de RvdK in het overgrote deel van de geanalyseerde zaken hieraan voldeed.

\subsection{Beschikking op het verzoek tot ondertoezichtstelling}

In hoofdstuk 2 zijn de inhoudelijke eisen die op basis van de wet aan de motivering van beschikkingen mogen worden gesteld besproken. Overeenkomstig de eisen die gelden voor vonnissen (art. 287 lid $1 \mathrm{Rv}$ jo. art. $230 \mathrm{Rv}$ ) moet de beschikking zodanig zijn gemotiveerd dat inzicht wordt geboden in de aan de beslissing ten grondslag liggende gedachtegang, om de beslissing voor partijen en derden controleerbaar en aanvaardbaar te maken. Inhoudelijk wordt de omvang van de motiveringsplicht van de rechter bepaald door hetgeen door partijen is aangedragen. Is er geen sprake van verweer dan kan de rechter volstaan met een minder diepgaande motivering in vergelijking met een procedure op tegenspraak. Ook van toepassing is de algemene motiveringsplicht voor vonnissen, arresten en beschikkingen, ex art. $30 \mathrm{Rv}$, waaruit volgt dat dezen de gronden moeten inhouden waarop zij rusten, tenzij anders uit de wet voortvloeit. De motiveringsplicht ligt tevens besloten in de vereisten die gelden voor een recht op een eerlijk proces op grond van art. 6 EVRM.

\footnotetext{
${ }^{641}$ Kamerstukken 11 1993/94, 23 003, nr.5, p. 29.
} 
In deel I van het onderzoek is belang van de rechterlijke motivering in jeugdbeschermingszaken benadrukt. De inzet van een ondertoezichtstelling betekent een inbreuk op de vrijheid van de ouders met gezag om de opvoeding en verzorging naar eigen inzicht vorm te geven. De verstrekkende gevolgen hiervan rechtvaardigen daarom dat de kinderrechter tenminste de gronden zoals opgenomen in de wet inhoudelijk toetst. In de eerste plaats zou gemotiveerd moeten worden welke feiten en omstandigheden hebben geleid tot het oordeel dat de minderjarige ernstig in zijn ontwikkeling wordt bedreigd en waarom vrijwillige hulpverlening niet meer haalbaar is. In hoofdstuk 2 is besproken dat vanuit verschillende hoeken is geconcludeerd dat lang niet altijd sprake was van diepgaande motivering van de beslissing tot ondertoezichtstelling en/of uithuisplaatsing. In jeugdbeschermingszaken werd nog vaak volstaan met een standaardmotivering. De beschikking bevatte dan een opsomming van de wettelijke gronden die golden voor oplegging van de maatregel, zonder dat aandacht werd besteed aan de specifieke feiten en omstandigheden van het geval. In het dossieronderzoek is voor de 200 beschikkingen die deel uitmaken van de steekproef gekeken hoe de motivering van de kinderrechter op het verzoek tot ondertoezichtstelling is vormgegeven. In de eerste plaats wordt beschreven welke beslissing de kinderrechter heeft genomen. Dit kan inzicht geven in de redenen die ten grondslag liggen aan de beslissing om het verzoek toe- of af te wijzen of aan te houden. Vervolgens wordt beschreven of de kinderrechter in de beschikking aandacht besteedde aan de twee cumulatieve gronden voor oplegging van de ondertoezichtstelling.

\subsubsection{Beslissing van de kinderrechter}

In de eerste plaats is voor alle 200 zaken gekeken welke beslissing de kinderrechter nam op het verzoek tot ondertoezichtstelling. De heersende gedachte is dat het overgrote deel van de verzoeken tot ondertoezichtstelling worden toegewezen door de kinderrechter. Toch zijn harde cijfers over de beslissing van de kinderechter in jeugdbeschermingszaken niet of nauwelijks voorhanden. In dit onderzoek wordt het beeld bevestigd dat - in ieder geval in de jaren 2013 en 2014 - het verzoek tot ondertoezichtstelling ingediend door de RvdK doorgaans werd toegewezen. Van de 200 zaken binnen de steekproef waarin in een verzoek tot ondertoezichtstelling door de RvdK werd ingediend, werd het verzoek 183 keer in zijn geheel toegewezen (91,5\% van de gevallen). In 9 van de 200 zaken (4,5\%) werd het verzoek tot ondertoezichtstelling afgewezen. In alle 9 zaken waarin het verzoek werd afgewezen, volgde dit oordeel op grond van het feit dat onvoldoende vast was komen te staan dat andere 
middelen hadden gefaald, of naar was te voorzien, zouden falen. Dit bevestigt het beeld dat de kinderrechter op basis van dit deel van de rechtsgrond van de ondertoezichtstelling veel concreter de rechtmatigheid van de maatregel kon beoordelen, dan op basis van het oordeel over de ernstige bedreiging van de belangen van de minderjarige.

In 5 van de 200 zaken $(2,5 \%)$ werd het verzoek gedeeltelijk toegewezen en voor het overige aangehouden. In deze zaken is zichtbaar dat (positieve) ontwikkelingen ertoe hebben geleid dat de kinderrechter een eerder toetsingsmoment wilde inbouwen om te kijken of de ondertoezichtstelling nog noodzakelijk was. In 3 van de 200 zaken $(1,5 \%)$ werd het verzoek voor kortere duur dan verzocht toegewezen.

6.4.2 Onderbouwing ernstige bedreiging van de zedelijke of geestelijke belangen of gezondheid van de minderjarige door de kinderrechter

In de analyse is de vraag gesteld of de beschikking op het verzoek tot ondertoezichtstelling een inhoudelijke, op de casus toegespitste motivering bevatte. De analyse valt uiteen in twee delen. In de eerste plaats is gekeken of in de beschikking op het verzoek tot ondertoezichtstelling aandacht werd besteed aan de concrete bedreiging van de zedelijke of geestelijke belangen of gezondheid van de minderjarige, zoals vereist was op grond van art. 1:254 lid 1 oud BW. Dit vroeg om een afweging waarin de bedreiging concreet werd gemaakt en derhalve feiten en omstandigheden werden aangehaald die hebben geleid tot het oordeel dat sprake was van een ernstige bedreiging, of in het geval van een afwijzing van het verzoek, het ontbreken van een bedreiging.

Uitkomst is dat in 135 van 200 geanalyseerde beschikkingen (67,5\%) concreet invulling werd gegeven aan de feiten en omstandigheden die hadden geleid tot het oordeel dat sprake was van (het ontbreken van) een ernstige bedreiging van de zedelijke of geestelijke belangen en gezondheid van de minderjarige. In 65 van de 200 zaken (32,5\%) werd alleen het wettelijk criterium zoals genoemd in art. 1:254 lid 1 oud BW (ernstige bedreiging van de zedelijke of geestelijke belangen of gezondheid) genoemd zonder nadere toelichting. Ter nuancering dient daarbij te worden opgemerkt dat in 59 van de 65 zaken waarin geen aandacht werd besteed aan de concrete bedreiging in de ontwikkeling van de minderjarige, geen verweer werd gevoerd tegen het verzoek tot ondertoezichtstelling. 
6.4.3 Onderbouwing (voorzienbaar) falen van andere middelen door de kinderrechter

De analyse laat zien dat de tweede cumulatieve grond voor oplegging van de ondertoezichtstelling (het falen of voorzienbaar falen van andere middelen) beduidend minder vaak inhoudelijk werd getoetst door de kinderrechter, dan de toets met betrekking tot de ernstige bedreiging van de belangen van de minderjarige. Slechts in 69 van de 200 geanalyseerde beschikkingen $(34,5 \%)$ werd inhoudelijk de noodzaak van een ondertoezichtstelling onderbouwd door aandacht te besteden aan de pogingen tot hulpverlening die in het vrijwillig kader waren ondernomen. $\mathrm{Nu}$ is het niet uitgesloten dat de hulpverleningsgeschiedenis wel werd meegenomen in de besluitvorming maar niet de noodzaak werd gezien dit ook inhoudelijk uit te werken in de beschikking. Beide gronden behoren echter aandacht te krijgen in de beoordeling door de kinderrechter. In tegenstelling tot het oordeel over de ernstige bedreiging van de zedelijke of geestelijke belangen of gezondheid bood dit deel van de rechtsgrond de mogelijkheid om tot een concrete rechtmatigheidstoets te komen.

\subsection{Tussenconclusie}

Het dossieronderzoek naar de rechtvaardiging van de ondertoezichtstelling door de RvdK en de kinderrechter in de jaren 2013 en 2014 heeft diverse punten aan het licht gebracht. Als op hoofdlijnen een vergelijking wordt gemaakt tussen de onderbouwing door de RvdK en de onderbouwing door de kinderrechter dan valt op dat de RvdK in meer zaken dan de kinderrechter aandacht besteedde aan de wettelijke gronden van de ondertoezichtstelling op grond van art. 1:254 lid 1 oud BW. Enerzijds is dit begrijpelijk, aangezien de RvdK in het beschermingsrapport veel meer ruimte heeft om inhoudelijk in te gaan op alle aspecten die relevant voor de afweging over de ondertoezichtstelling. Een beschikking bevat doorgaans de kernoverwegingen van de rechter en de uiteindelijke beslissing. Aan de andere kant is gesteld dat voor de rechtvaardiging van de ondertoezichtstelling door de kinderrechter in ieder geval een koppeling gemaakt dient te worden tussen de feiten en omstandigheden van de casus en de twee cumulatieve gronden voor de maatregel. Blijkens de analyse gebeurde dat in 2013 en 2014 nog onvoldoende.

Worden de resultaten van het dossieronderzoek bezien vanuit de toepassing van de wettelijke gronden dan is duidelijk dat zowel de RvdK in het beschermingsrapport als de kinderrechter in de beschikking vaker aandacht besteedden aan het vereiste dat sprake moest zijn van een 'ernstige bedreiging van de zedelijke of geestelijke belangen of gezondheid van de minderjarige' dan aan het vereiste dat 'andere middelen hadden gefaald, of naar was te 
voorzien, zouden falen. Dat moet worden beschouwd als een gemiste kans. Beide gronden zagen op een ander deel van de rechtvaardiging van de ondertoezichtstelling. De bedreiging van de zedelijke of geestelijke belangen van de minderjarige vroeg om een pedagogisch- of in uitzonderingsgevallen om een medisch oordeel. Aangenomen mag worden binnen de RvdK in beginsel meer expertise in huis was om dit oordeel inhoudelijk te onderbouwen, aangezien standaard een gedragsdeskundige bij het onderzoek was betrokken. De kinderrechter moest in beginsel af kunnen gaan op dit oordeel van de RvdK. De tweede cumulatieve grond (het voorzienbaar falen van andere middelen) was inhoudelijk meer juridisch, althans concreter en objectiever te toetsen, zowel voor de RvdK als de kinderrechter. Het dossieronderzoek heeft laten zien dat de toetsing van deze grond achterbleef, bovenal in de beschikking op het verzoek tot ondertoezichtstelling. Hierdoor werd onvoldoende aangetoond waarom het vrijwillig kader geen optie meer was en daarmee schoot de rechtvaardiging van de ondertoezichtstelling op dit punt te kort. 


\section{Dossieronderzoek naar de rechtvaardiging van de uithuisplaatsing door de RvdK en de kinderrechter}

\subsection{Inleiding}

Een uithuisplaatsing van de minderjarige conflicteert met het belangrijke uitgangspunt in het personen- en familierecht dat de minderjarige bij zijn ouders behoort op te groeien. De ouders met gezag dragen op grond van art. 1:247 BW de primaire verantwoordelijkheid voor de verzorging en opvoeding van de minderjarige. Slechts indien binnen de thuissituatie de geconstateerde ontwikkelingsbedreiging van de minderjarige niet of onvoldoende kan worden weggenomen dan kan een (tijdelijke) scheiding van kind en ouder gerechtvaardigd zijn.

Het feit dat de noodzaak van een scheiding van kind en ouders moet blijken betekent dat voldoende aannemelijk moet worden gemaakt waarom de geconstateerde ontwikkelingsbedreiging niet binnen de thuissituatie kan worden weggenomen. De professional die moet beslissen over een uithuisplaatsing wordt geacht een afweging te maken tussen wat de minderjarige nodig heeft (ontwikkelingsbehoefte) en wat in de thuissituatie kan worden geboden (opvoedcapaciteiten ouders). In deze afweging moet ook nadrukkelijk worden gekeken of - al dan niet met ondersteuning van het sociale netwerk - er nog mogelijkheden bestaan om de scheiding van kind en ouders te voorkomen

In dit hoofdstuk wordt verslag gedaan van de wijze waarop de RvdK en de kinderrechter in de besluitvorming over de uithuisplaatsing invulling gaven aan de vereisten die konden worden ontleend aan (inter)nationale wet- en regelgeving. In deel I van dit onderzoek zijn de belangrijkste uitgangspunten en specifieke vereisten ter beoordeling van de noodzaak van een uithuisplaatsing beschreven zoals die golden in 2013 en 2014. In de eerste plaats moest dan worden gedacht aan de wettelijke gronden voor oplegging van een uithuisplaatsing op basis van nationale wetgeving. Er is echter ook geconstateerd dat de vereisten op grond van nationale wetgeving weinig concreet waren. Op grond van art. 1:261 lid 1 oud BW moest de noodzaak van een uithuisplaatsing worden aangetoond, maar de wetgever heeft niet nader gespecificeerd waaruit die noodzaak moet blijken. Daarnaast ontbrak een wettelijke doelstelling voor de uithuisplaatsing in het Burgerlijk Wetboek. Omdat duidelijke indicaties voor de rechtvaardiging van de uithuisplaatsing op basis van nationale wetgeving ontbraken is aandacht besteed aan de rechtspraak van het EHRM die in een groot aantal uitspraken heeft geoordeeld over de verenigbaarheid van een uithuisplaatsing met het in art. 8 lid 1 EVRM neergelegde recht op familie- en gezinsleven. Het EHRM heeft onder meer gesteld dat van 
een uithuisplaatsing redelijkerwijs enig positief effect te verwachten moet zijn en dat deze scheiding van kind en ouders niet slechts wenselijk, maar noodzakelijk is voor het wegnemen van de ontwikkelingsbedreiging. Deze noodzaak kan slechts overtuigend worden aangetoond indien de autoriteiten laten zien dat alternatieven om de uithuisplaatsing te voorkomen zijn ingezet of in ieder geval nadrukkelijk zijn overwogen. Daarnaast heeft het EHRM benadrukt dat een uithuisplaatsing een tijdelijke maatregel is die zodra de omstandigheden het toelaten moet worden beeindigd. Op de autoriteiten rust de verplichting om maatregelen te nemen met als doel hereniging van kind en ouder, hetgeen ook veronderstelt dat in de besluitvorming over een uithuisplaatsing de mogelijkheden tot hereniging worden onderzocht.

Deze uitgangspunten vormen de basis voor het analysekader op basis waarvan 100 zaken zijn geanalyseerd waarin de RvdK een uithuisplaatsing heeft verzocht. Deze 100 zaken maken deel uit van de totale steekproef van 200 zaken. Zoals in het vorige hoofdstuk beschreven gaat het om 200 zaken waarin door de RvdK een ondertoezichtstelling is verzocht. In 100 van de 200 zaken wordt het verzoek tot ondertoezichtstelling gecombineerd met een verzoek machtiging uithuisplaatsing. De toepassing van de wettelijke vereisten voor de uithuisplaatsing is in deze 100 zaken afzonderlijk (van de vereisten voor een ondertoezichtstelling) geanalyseerd. Omdat een machtiging tot uithuisplaatsing onder oude wetgeving strekte ter effectuering van een indicatiebesluit waarin de aanspraak op zorg voor de minderjarige werd geregeld, wordt in paragraaf 7.2 eerst de analyse van de wijze waarop in de praktijk met het indicatiebesluit werd omgegaan, uitgewerkt.

Vervolgens wordt in paragraaf 7.2 geanalyseerd hoe de RvdK invulling gaf aan het noodzakelijkheidsvereiste voor oplegging van de uithuisplaatsing. De analyse start met een overzicht van enkele algemene bevindingen ten aanzien van de onderbouwing van het verzoek tot machtiging uithuisplaatsing zoals dat door de RvdK werd vormgegeven. Vervolgens is gekeken of de $\mathrm{RvdK}$ beargumenteerde waarom alternatieve, minder ingrijpende maatregelen in het specifieke geval onvoldoende waren om de belangen van de minderjarige veilig te stellen

In paragraaf 7.3 wordt geanalyseerd of, en zo ja hoe het doel dat met de uithuisplaatsing werd nagestreefd terugkwam in de besluitvorming. In het dossieronderzoek is voor de 100 zaken waarin de RvdK concludeerde dat een uithuisplaatsing noodzakelijk was, gekeken of aandacht werd besteed aan de kans op hereniging van kind en ouders, en daarmee het perspectief van de minderjarige na plaatsing. 
In paragraaf 7.4 wordt de beschikking op het verzoek machtiging uithuisplaatsing geanalyseerd. In paragraaf 7.4.1. wordt gekeken welke beslissing de beslissing de kinderrechter heeft genomen op het verzoek. Vervolgens wordt in paragraaf 7.4.2. voor de zaken waarin een beschikking op het verzoek machtiging uithuisplaatsing werd uitgesproken, gekeken of de kinderrechter aandacht besteedde aan de noodzaak - of in geval van een afwijzing van het verzoek, het ontbreken van de noodzaak - van een verblijf buiten het gezin. In paragraaf 7.5 wordt aandacht besteed aan het verzoek tot machtiging uithuisplaatsing in een instelling voor gesloten jeugdzorg. In de analyse van de gronden die in de wet waren neergelegd voor een uithuisplaatsing is onderscheid gemaakt tussen een 'regulier' verzoek machtiging uithuisplaatsing op grond van art. 1:261 oud BW en een verzoek machtiging gesloten jeugdzorg (art. 29b Wjz). Van de 100 geanalyseerde zaken gaat het in 82 zaken om een verzoek pleegzorg of residentieel, niet zijnde een gesloten plaatsing en in 18 zaken om een verzoek machtiging gesloten jeugdzorg. Hoewel het om een klein aantal zaken gaat binnen de steekproef zijn deze zaken wel meegenomen en geanalyseerd aan de hand van de aanvullende wettelijke vereisten in de Wet op de Jeugdzorg en op basis van toepasselijk verdragsrecht ten aanzien van vrijheidsbeneming van minderjarigen.

\subsection{Verzoek tot machtiging uithuisplaatsing: wettelijke vereisten}

\subsubsection{Het indicatiebesluit}

In beginsel gold dat voor ieder verzoek tot machtiging uithuisplaatsing de verzoekende instantie een indicatiebesluit diende te overleggen aan de kinderrechter. ${ }^{642}$ Art. 1:261 lid 2 oud BW stelde een indicatiebesluit verplicht indien de uithuisplaatsing zorg als in art. 5 lid $2 \mathrm{Wjz}$ met zich meebracht. De de term 'zorg' verwees naar het verlenen van jeugdzorg zoals was genoemd in art. 5 lid 2 sub a Wjz.

In het dossieronderzoek is in de eerste plaats gekeken in hoeveel van de 100 zaken waarin een machtiging utihuisplaatsing werd verzocht, een indicatiebesluit noodzakelijk was omdat aanspraak werd gemaakt op geindiceerde zorg. In 94 van de 100 zaken was hiervan sprake. In 6 van de 100 zaken betrof het een plaatsing bij de andere ouder met of zonder gezag.

Overeenkomstig de wettelijke vereisten werd in deze zaken benoemd dat een indicatiebesluit niet noodzakelijk was, maar werd wel de verblijfplaats waarvoor de machtiging werd

\footnotetext{
${ }^{642}$ Kamerstukken II 2006/06, 30 644, nr.3 (MvT).
} 
gevraagd, genoemd. In Figuur 1 is zichtbaar wat voor soort plaatsing werd verzocht door de RvdK in de 100 zaken binnen de steekproef.

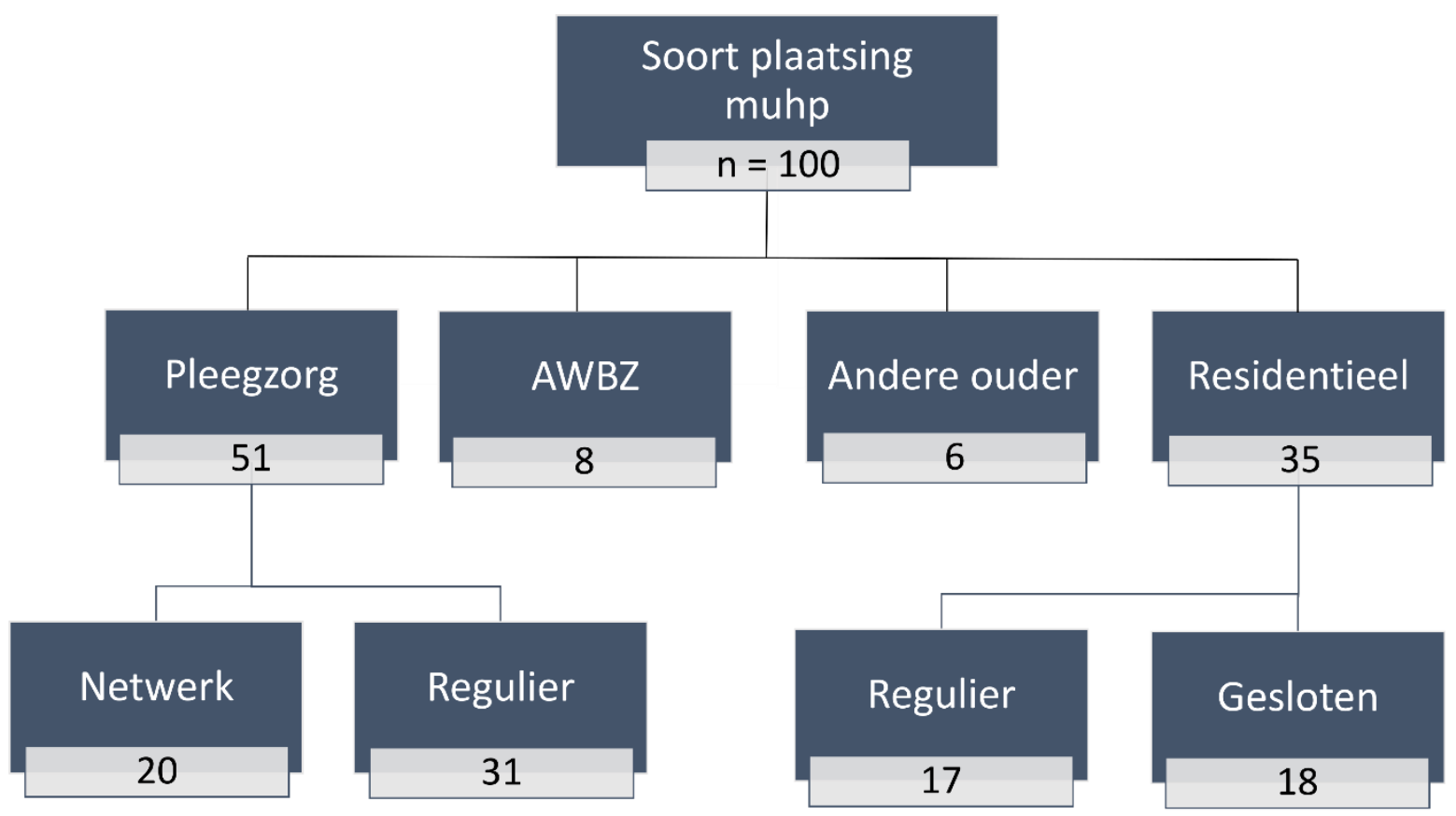

\section{Figuur 1. Soort plaatsing verzocht door de RvdK}

Van de 94 zaken waarin een indicatiebesluit vereist was ging het in 8 zaken om een AWBZplaatsing waarvoor een indicatiestelling van het CIZ (Centrum Indicatiestellingen Zorg) noodzakelijk was. In 51 zaken ging het om een pleegzorgplaatsing, waarvan het in 20 zaken een plaatsing ' netwerkpleegzorg' betrof. In 35 zaken ging het om een plaatsing in een accommodatie van een zorgaanbieder, te onderscheiden in een reguliere residentiele plaatsing (17 zaken) en een plaatsing in de gesloten jeugdzorg (18 zaken). Echter lang niet in alle zaken waarin een indicatiebesluit noodzakelijk was, is in de dossiers ook een indicatiebesluit aangetroffen. In 57 van de 94 zaken $(60,6 \%)$ waarin een indicatiebesluit noodzakelijk was, is in het registratiesysteem van de RvdK ook daadwerkelijk een indicatiebesluit gevonden. In 37 van de 94 zaken is het daarom niet mogelijk gebleken het indicatiebesluit te analyseren.

Voor het ontbreken van het indicatiebesluit in zoveel zaken kunnen een aantal mogelijke oorzaken worden aangedragen. In de eerste plaats kwam het voor dat blijkens de beschikking op het verzoek tot machtiging uithuisplaatsing wel een indicatiebesluit was ingediend, maar deze om wat voor reden dan ook niet was gearchiveerd in het registratiesysteem van de RvdK. Ten tweede zijn er verschillende zaken waarin zowel in het beschermingssrapport als in de beschikking met geen woord werd gerept over het indicatiebesluit terwijl op basis van het 
verzoek mocht worden aangenomen dat er sprake van was van geïndiceerde zorg. Tot slot is zichtbaar dat een indicatiebesluit niet noodzakelijk werd geacht omdat een netwerkplaatsing werd verzocht. In de onderzochte zaken waarin hier sprake van was werd echter wisselend geoordeeld over de vraag of bij een plaatsing binnen het netwerk wel of geen indicatiebesluit was vereist. Zoals gesteld ging het in 20 zaken om een verzoek tot plaatsing van de minderjarige binnen het netwerk. In 8 van de 20 zaken waarin een netwerkplaatsing werd verzocht, werd een indicatiebesluit overlegd (en leek ook niet ter discussie te staan dat een indicatiebesluit noodzakelijk was). In 12 van de 20 zaken werd echter geen indicatiebesluit overlegd omdat zulks niet nodig zou zijn bij een netwerkplaatsing. In de meeste gevallen werd deze zienswijze expliciet benoemd in het raadsrapport.

\section{Inhoudelijke vereisten}

Het indicatiebesluit vestigde de aanspraak op de benodigde zorg en de daarmee samenhangende financiering van zorg. Daarnaast beoogde het indicatiebesluit bij te dragen aan de onderbouwing van de noodzaak om een scheiding van kind en ouders te bewerkstelligen. ${ }^{643}$ De inhoudelijke eisen die gesteld werden aan het indicatiebesluit waren terug te vinden in art. 6 lid $1 \mathrm{Wjz}$ : het moest een beschrijving van de problemen of dreigende problemen bevatten; de ernst en mogelijke oorzaken daarvan; een beschrijving van de benodigde zorg en het met die zorg beoogde doel; de termijn waarbinnen de aanspraak op zorg ten gelding moest zijn gebracht en een advies wie de zorg het beste kon verlenen en coördineren.

In het dossieronderzoek is voor de 57 zaken waarin een indicatiebesluit is aangetroffen, gekeken of werd voldaan aan de inhoudelijke vereisten op grond van art. $6 \mathrm{Wjz}$. De analyse laat zien dat in 53 van de 57 geanalyseerde indicatiebesluiten (92,9\%) een globale omschrijving werd gegeven van de aard en ernst van de problematiek van de minderjarige Hoewel in het dossieronderzoek is gebleken dat de Bureaus Jeugdzorg geen vast format hanteerden voor het indicatiebesluit, werd in een groot deel van de zaken aandacht besteed aan de problematiek van de minderjarige. Hetzelfde kan gezegd worden voor de beschrijving van de zorg die nodig was voor de minderjarige. In 55 van 57 geanalyseerde indicatiebesluiten (96,5\%) werd een (globaal) overzicht gegeven van de geïndiceerde zorg. Het opnemen van de met de noodzakelijke geachte zorg na te streven doelen gebeurde in iets mindere mate. In 51 van de $57(89,5 \%)$ zaken zijn doelen opgenomen in het indicatiebesluit.

\footnotetext{
${ }^{643}$ Bakker \& Bentem 2012.
} 
De verzilveringstermijn voor de aanspraak op zorg werd in 55 van de 57 (96,5\%) indicatiebesluiten weergegeven. Tot slot, een advies wie het beste met de (coördinatie van) zorg kon worden belast werd in 54 van de 57 (94,7\%) geanalyseerde indicatiebesluiten geïncludeerd.

Het indicatiebesluit betrof de formele vaststelling dat een cliënt was aangewezen op geïndiceerde zorg en beoogde bij te dragen aan de onderbouwing van de noodzaak van een uithuisplaatsing. Met name ten aanzien van laatstgenoemd element is niet duidelijk geworden op welke wijze het indicatiebesluit zou moeten bijdragen aan de besluitvorming over de uithuisplaatsing. Het weergeven van de geconstateerde problematiek van de minderjarige en het schetsen van een hulpverleningsperspectief met doelen die moesten worden behaald gebeurde ook in het beschermingsrapport van de RvdK en dan vaak veel concreter en uitgebreider. Wat dan als functie overbleef was het regelen van de toegang tot de geïndiceerde zorg (en de financiering daarvan). In het dossieronderzoek is ook niet zichtbaar geworden dat kinderrechters inhoudelijke tekortkomingen in het indicatiebesluit sanctioneerden. Het ontbreken van een overzicht van de problematiek van de minderjarige in het indicatiebesluit is nergens binnen de steekproef door de kinderrechter als problematisch aangemerkt en heeft niet geleid tot afwijzing van het verzoek machtiging uithuisplaatsing.

7.2.2 Onderbouwing van het verzoek tot machtiging uithuisplaatsing - algemene bevindingen Indien de RvdK op een zeker moment tot de conclusie kwam dat een uithuisplaatsing van de minderjarige mogelijk noodzakelijk was dan werd in het beschermingsrapport een aanvullende vraag opgenomen specifiek gericht op de uithuisplaatsing. Zoals besproken bevatte het standaard rapportageformat van de RvdK een overzicht van de zorg-en sterke punten op kindniveau en op het niveau van de opvoedingsomgeving; een overzicht van de doelen die werden nagestreefd; een overzicht van het hulpverleningsperspectief en de vraag in hoeverre de noodzakelijke hulpverlening werd geaccepteerd en benut; en tot slot de conclusie waarin de vraag werd beantwoord of er sprake was van een zodanige ontwikkelingsbedreiging dat een kinderbeschermingsmaatregel noodzakelijk was. Indien de noodzaak van een uithuisplaatsing aan het licht kwam werd daar de vraag aan toegevoegd of een uithuisplaatsing noodzakelijk was, hetgeen qua formulering vrijwel overeenkwam met de rechtsgrond van de uithuisplaatsing zoals neergelegd in art. 1:261 lid 1 oud BW. Het kwam ook voor dat geen aparte vraag werd toegevoegd aan het rapportageformat en de noodzaak tot 
uithuisplaatsing werd besproken bij de bredere afweging over de vraag of er sprake was van een ernstige bedreiging van de zedelijke of geestelijke belangen of gezondheid van de minderjarige.

In veruit de meeste zaken werd echter wel expliciet de vraag gesteld of een uithuisplaatsing noodzakelijk was. De kans dat helemaal niets werd gezegd in de beschermingsrapportage over de noodzaak van een uithuisplaatsing werd daarmee aanzienlijk verkleind. De inhoudelijke onderbouwing van de noodzaak tot uithuisplaatsing door de RvdK was echter te vaak summier. Hierdoor werd onvoldoende inhoudelijke onderbouwing gegeven ten aanzien van de feiten en omstandigheden die hadden geleid tot het oordeel dat een scheiding van kind en ouders noodzakelijk was. Een aantal voorbeelden uit het dossieronderzoek kan verduidelijken wat wordt bedoeld met een korte en inhoudelijk magere onderbouwing:

\section{Voorbeeld 1}

'De RvdK is van mening dat een gezinsvoogd de veiligheid van de kinderen moet blijven waarborgen, waarbij vooralsnog een plaatsing in een pleeggezin voor de kinderen noodzakelijk is.'

\section{Voorbeeld 2}

'Het (tot op heden vrijwillige) verblijf binnen de opvang staat onder druk doordat moeder zich er niet mee kan verenigen. De uithuisplaatsing dient derhalve geformaliseerd te worden'.

\section{Voorbeeld 3}

'Om de verblijfplek van de minderjarige bij vader op korte termijn te bestendigen is de RvdK van mening dat een machtiging uithuisplaatsing op het adres van vader nodig is.'.

Het gebrek aan onderbouwing met betrekking tot de uithuisplaatsing is om meerdere redenen opvallend. In de eerste plaats is er een groot verschil als de vergelijking wordt gemaakt met de wijze waarop de noodzaak van de ondertoezichtstelling werd onderbouwd door de RvdK. Hiermee wordt niet gesteld dat alle elementen die reeds in het kader van het verzoek tot ondertoezichtststelling al werden beschreven nogmaals aan bod zouden moeten komen. Zo kan goed onderbouwd verzoek tot ondertoezichtstelling voldoende aannemelijk maken dat er sprake is van een zorgelijke situatie omtrent de minderjarige en ook meer duidelijkheid verschaffen over de hulpverlening die reeds is ingezet. De overweging of daarbij ook een uithuisplaatsing moet worden ingezet is echter een zelfstandige afweging, waarbij een aantal 
afwegingen moet worden gemaakt die wezenlijk anders zijn dan bij de ondertoezichtstelling. Ten tweede en samenhangend met het eerste punt, het lijkt voor de hand te liggen dat naarmate de maatregel dieper ingrijpt in het gezinsleven van de minderjarige en zijn ouders, ook concreter en uitgebreider wordt gemotiveerd waarom de inbreuk gerechtvaardigd is. Eerder is al aangegeven dat juist de mogelijkheid dat de minderjarige uit huis wordt geplaatst een schrikbeeld is voor veel ouders. Het in enkele zinnen aangeven dat de minderjarige uit huis moet worden geplaatst zonder dat verder inzicht wordt geboden in de beweegredenen van de RvdK, moet onbevredigend zijn (geweest) voor de betrokkenen. Het is de vraag of het gebrek aan concrete wettelijke vereisten hierin een rol heeft gespeeld. De grond zoals opgenomen in art. 1:161 lid $1 \mathrm{BW}$ stimuleerde niet tot een inhoudelijk diepgaande afweging. Tegelijkertijd is zichtbaar dat sommige raadsonderzoekers wel uitgebreid beschreven waarom de noodzaak van een uithuisplaatsing aanwezig was.

\subsubsection{Het onderzoek naar minder ingrijpende alternatieven ter voorkoming van de uithuisplaatsing}

Voor de analyse is op grond van art. 1:261 lid 1 oud BW en met name art. 8 EVRM als uitgangspunt gesteld dat de RvdK in de besluitvorming alternatieven zou moeten overwegen ter voorkoming van een uithuisplaatsing. Daarnaast is gesteld dat de RvdK indien werd besloten dat een uithuisplaatsing noodzakelijk was, moest onderzoeken of op de minst ingrijpende wijze uitvoering kon worden gegeven aan de uithuisplaatsing. Dit kon bijvoorbeeld blijken uit het feit dat de RvdK aandacht besteedde aan de mogelijkheid om een scheiding van kind en ouder te voorkomen door plaatsing in een moeder-kind huis. Werd een uithuisplaatsing toch noodzakelijk bevonden dan verdiende een vervangende gezinsomgeving de voorkeur, indien mogelijk binnen het netwerk van het gezin. Werd gekozen voor een neutraal pleeggezin dan is gekeken of het rapport aangaf of een plaatsing binnen het netwerk is onderzocht. Werd gekozen voor een residentiële plaatsing dan is geanalyseerd of werd beargumenteerd waarom een plaatsing in het pleeggezin niet in het belang van het kind werd geacht. In totaal zijn 82 van de 100 zaken waarin een machtiging uithuisplaatsing pleegzorg of residentieel is verzocht op dit punt geanalyseerd. De 18 zaken binnen de steekproef waarin een verzoek machtiging gesloten jeugdzorg werd ingediend zijn gezien de aanvullende wettelijke vereisten op grond van de Wet op de Jeugdzorg en toepasselijk verdragsrecht apart geanalyseerd in paragraaf 7.5. 
De analyse laat zien dat de RvdK in 49 van de 82 zaken (59,8\%) waarin een machtiging uithuisplaatsing werd verzocht, aandacht besteedde aan alternatieve, minder ingrijpende mogelijkheden ter voorkoming van de uithuisplaatsing. In sommige zaken zaken gebeurde dat zeer uitvoering en werden mogelijke alternatieven inhoudelijk diepgaand geanalyseerd, zoals blijkt uit de volgende twee voorbeelden:

\section{Voorbeeld 1}

'De bedreiging voor de minderjarige hangt samen met de ernstige persoonlijke problematiek van moeder. Het is voor de Raad voor de Kinderbescherming op dit moment onverantwoord moeder zelfstandig de zorg te laten dragen voor de minderjarige. Een

moederskindtraject/plaatsing is voorlopig niet meer aan de orde, gezien de drugsverslaving van moeder. Binnen korte tijd wordt onderzocht of een plaatsing bij tante tot de mogelijkheden behoort.'

\section{Voorbeeld 2}

'Na specialistische observatie, schoolgang en ambulante hulp is geconcludeerd dat de minderjarige het meeste zal kunnen profiteren van hulp binnen een 24uurs behandelvoorziening, buiten de opvoedingsomgeving bij ouders. De Raad vindt ouders argumenten dat er nooit eerder een lichtere vorm van hulp is ingezet dan in een 24uurs behandelvoorziening en dat een ambulant kader eerst een kans verdient begrijpelijk. Ambulante hulp is echter ingezet maar bleek onvoldoende om de ontwikkelingsachterstand te verkleinen. Ondanks dat de Raad zich realiseert dat een uithuisplaatsing zeer ingrijpend zal zijn voor zowel de minderjarige als ouders verwacht de Raad het meeste effect van hulp in residentieel kader in plaats van intensieve vormen van hulp thuis.'

Logischerwijs volgt hieruit dat in 33 van de 82 zaken (40,2\%) waarin een machtiging uithuisplaatsing werd verzocht geen aandacht werd besteed aan minder ingrijpende alternatieven voor de verzochte uithuisplaatsing. Ervan uitgaande dat de vraag waarom minder ingrijpende alternatieven niet in aanmerking komen op grond van art. 8 EVRM nadrukkelijk in de besluitvorming moest worden betrokken, is dat een zorgelijke uitkomst. Nadere analyse van deze zaken laat wel zien dat er grote verschillen waren met betrekking tot de onderbouwing van het verzoek tot uithuisplaatsing.

Minst positief zijn de zaken waarin helemaal niets werd gezegd over de specifieke machtiging die werd verzocht, laat staan dat aandacht werd besteed aan de vraag of alternatieven mogelijk waren. In het beschermingsrapport werd dan volstaan met de mededeling dat een 
uithuisplaatsing noodzakelijk was, zonder nadere toelichting. De gevraagde machtiging (pleegzorg, residentieel) was dan zonder toelichting op het verzoekschrift terug te vinden.

Er zijn ook zaken waarin in het beschermingsrapport in ieder geval wel de gevraagde machtiging specifiek werd genoemd, maar verder geen onderbouwing werd gegeven voor de keuze van de soort machtiging. Uit het beschermingsrapport waarin de problematiek van de minderjarige was beschreven was dan soms wel terug te vinden waarom een bepaalde machtiging het meeste in het belang van het kind was, ook al ontbrak een specifieke toelichting hieromtrent. Tot slot zijn er zaken waarin niet werd besproken waarom minder ingrijpende alternatieven niet mogelijk waren maar wel de specifieke machtiging werd genoemd én een korte toelichting werd gegeven over de mogelijkheden (tot zorg) binnen die machtiging. Om een voorbeeld te geven uit een van de dossiers:

\section{Voorbeeld 1}

'de $\mathrm{RvdK}$ is van mening dat plaatsing in een voorziening van een zorgaanbieder noodzakelijk is. Binnen de plaatsing kan de minderjarige leren zichzelf staande te houden voordat zij eventueel wordt teruggeplaatst. Daarnaast kan meer duidelijkheid komen over de motivatie van de minderjarige om naar huis terug te willen.'

In dit voorbeeld verzocht de RvdK een residentiële plaatsing en werd tevens een indicatie gegeven ten aanzien van de stappen die binnen deze plaatsing ondernomen moesten worden. Alleen niet is op te maken uit deze toelichting waarom het voor het bereiken van de genoemde doelen noodzakelijk was dat de minderjarige in een residentiele instelling verbleef. Uiteraard geeft laatsgenoemde onderbouwing wel veel meer inzicht in de beweegredenen voor de gevraagde uithuisplaatsing dan de zaken waarin slechts werd volstaan met de mededeling dat een uithuisplaatsing noodzakelijk was. Uiteindelijk ontbrak dus in bijna de helft van de geanalyseerde zaken een inhoudelijke onderbouwing van de RvdK waarin op schrift expliciet werd verantwoord welke alternatieven waren overwogen voor de uithuisplaatsing. Zoals gesteld kan een zaak waarin dit onvoldoende wordt onderbouwd naar alle waarschijnlijkheid de toets van art. 8 EVRM niet doorstaan. In dit licht kan de vraag worden gesteld of het in dezen voldoende is de RvdK nadrukkelijk te wijzen op de uitgangspunten die kunnen worden ontleend art. 8 EVRM, of dat aanscherping van de rechtsgrond van de uithuisplaatsing in het Burgerlijk Wetboek is aangewezen. In deel III van dit onderzoek wordt deze vraag nader uitgewerkt. 


\subsection{Verzoek machtiging uithuisplaatsing: doelstelling}

De uithuisplaatsing als middel binnen de ondertoezichtstelling heeft tot doel de bedreiging van de zedelijke of geestelijke belangen of gezondheid van de minderjarige binnen de duur van de maatregel weg te nemen en de ouders daarbij zoveel mogelijk de verantwoordelijkheid voor de verzorging en opvoeding te doen laten behouden. De focus op het behoud van ouderlijke verantwoordelijkheid impliceert ook dat de ondertoezichtstelling - ook indien deze wordt gecombineerd met een machtiging uithuisplaatsing - gericht is op het creëren van een situatie waarin de ouders weer voor de minderjarige kunnen zorgen in de thuissituatie. In deel I van het onderzoek is laten zien dat de autoriteiten op grond van art. 8 EVRM in het kader van een uithuisplaatsing in beginsel de plicht hebben maatregelen te nemen die zijn gericht op de hereniging van kind en ouders. Dit betekent niet dat in alle omstandigheden dit doel ook voorop staat. Het doel van hereniging van het gezin heeft te gelden als 'guiding principle' maar moet altijd worden bezien in het licht van de vraag of hereniging in het concrete geval in het belang van het kind is.

\subsubsection{Doel van hereniging van het gezin}

De 100 zaken binnen de steekproef waarin door de RvdK een machtiging uithuisplaatsing werd verzocht, zijn allen zaken waarin een nieuwe ondertoezichstelling met machtiging uithuisplaatsing werd verzocht, al dan niet vooraf gegaan door een voorlopige ondertoezichtstelling. Dit betekent dat de kinderen waarover de RvdK moest beslissen nog thuis verbleven of pas kortstondig in het kader van de voorlopige maatregel uit huis waren geplaatst. Er mag derhalve vanuit worden gegaan dat de RvdK in de onderbouwing aandacht schonk aan de mogelijkheden de situatie voor de minderjarige zodanig te verbeteren dat hij kon terugkeren naar huis.

De dossieranalyse laat zien dat de RvdK in 68 van de 100 zaken (68\%) waarin een machtiging uithuisplaatsing werd verzocht aandacht besteedde aan de mogelijkheden tot hereniging en daarmee het opvoedperspectief van de minderjarige. Dit betekent niet dat in al deze zaken de vraag of ouders op termijn weer in de thuissituatie voor de minderjarige zouden kunnen zorgen ook definitief werd beantwoord. In veel zaken is zichtbaar dat de RvdK een indicatie gaf van de stappen die in de uitvoering van de uithuisplaatsing moesten worden ondernomen om meer helderheid te krijgen over het opvoedperspectief van de minderjarige. Een logische uitkomst nu ten tijde van het beschermingsonderzoek lang niet altijd voldoende informatie voorhanden is om met enige zekerheid een uitspraak te kunnen doen over het opvoedperspectief van de minderjarige. Dat het, ook in zaken waarin het perspectief nog niet 
volledig is uitgekristalliseerd, goed mogelijk is heldere doelen te verschaffen ten aanzien van de gevraagde uithuisplaatsing laat het volgende voorbeeld uit het dossieronderzoek zien:

\section{Voorbeeld 1}

'De minderjarige heeft baat bij een orthopedagogisch opvoedingsklimaat waar zij tegemoet gekomen wordt in haar hulpvragen op cognitief en sociaal-emotioneel niveau. Ouders kunnen dit momenteel niet bieden omdat zij in de verslavingszorg verblijven. Ouders hebben aangegeven, na hun opname, weer zelf de zorg voor de minderjarige op zich te willen nemen. De RvdK is van mening dat de gezinsvoogd de voortgang van het behandeltraject van ouders moeten volgen. Op de langere termijn is de voorwaarde voor een terugplaatsing van de minderjarige bij ouders dat zij volledig abstinent zijn, zij mee blijven werken aan de hulpverlening en intensieve pedagogische ondersteuning accepteren. De RvdK is van mening dat er een prioriteit moet liggen ten aanzien van het creëren van een thuissituatie bij ouders met dezelfde stabiliteit, structuur en regelmaat als de minderjarige binnen een orthopedagogisch opvoedingsklimaat ervaart. Of een dergelijke opvoedingsomgeving in de toekomst haalbaar is en aansluit bij de specifieke opvoedingsvraag van haar, is ter beoordeling van de gezinsvoogd.'

In 32 van de 100 zaken (32\%) in het dossieronderzoek waarin een machtiging uithuisplaatsing is verzocht werd geen aandacht besteed aan de mogelijkheden tot hereniging van kind en ouders. De focus in het beschermingsrapport was dan veelal gericht op de problematiek in de thuissituatie en niet zozeer op het perspectief na plaatsing. Dat is zonde, omdat juist een helder stappenplan van hetgeen moest gebeuren na uithuisplaatsing, gecombineerd met inschatting van de verandermogelijkheden van (primair) de ouders, zou bij kunnen dragen aan een doelmatige uitvoering van de maatregel.

\subsection{Beschikking op het verzoek tot machtiging uithuisplaatsing}

In deze paragraaf wordt verslag gedaan van de analyse van de beschikking op het verzoek tot machtiging uithuisplaatsing. De analyse beperkt zich tot hetgeen schriftelijk was uitgewerkt in de beschikking, hetgeen logischerwijs veel beknopter was dan de informatie in het beschermingsrapport. De analyse heeft zich gezien de beperkte inhoudelijke informatie in de beschikkingen dan ook beperkt tot twee elementen. In de eerste plaats is gekeken welke beslissing de kinderrechter heeft genomen op het verzoek machtiging uithuisplaatsing, en in het verlengde daarvan, welke redenen ten grondslag lagen aan de keuze om het verzoek toe- 
of af te wijzen of aan te houden. Daarnaast is gekeken of de kinderrechter inhoudelijk de noodzaak van een scheiding van kind en ouders onderbouwde.

\subsubsection{Beslissing van de kinderrechter}

Voor de 82 zaken waarin de RvdK een machtiging uithuisplaatsing (niet zijnde een verzoek machtiging gesloten jeugdzorg) heeft verzocht is gekeken hoe de kinderrechter besliste op het verzoek. De beslissing van de rechter op dit punt is onafhankelijk geanalyseerd van het besluit op het verzoek tot ondertoezichtstelling. Het is immers goed mogelijk dat de rechter ten aanzien van het verzoek tot machtiging uithuisplaatsing tot een ander besluit komt dan ten aanzien van het verzoek tot ondertoezichtstelling. Het algemene beeld dat verzoeken tot een jeugdbeschermingsmaatregel in het overgrote deel van de gevallen werden toegewezen, is ook terug te zien in de analyse. In 66 van de 82 zaken (80,5\%) waarin de RvdK een machtiging uithuisplaatsing verzocht werd het verzoek door de kinderrechter in zijn geheel toegewezen. In slechts 3 van de 82 zaken $(3,7 \%)$ werd het verzoek machtiging uithuisplaatsing afgewezen. In 2 van de 3 zaken waarin het verzoek door de kinderrechter werd afgewezen hadden de ouders na het uitspreken van een voorlopige ondertoezichtstelling met spoedmachtiging, stappen gezet om de opvoedingssituatie te verbeteren. Anders dan de RvdK kwam de kinderrechter in deze zaken tot de conclusie dat de noodzaak tot uithuisplaatsing daarmee was komen te vervallen. De derde afwijzing betrof een zaak waarin de moeder bereid was (duurzaam) in te stemmen met plaatsing van de minderjarige binnen het netwerk. De kinderrechter zag daarom geen noodzaak voor een machtiging en gaf aan dat de uithuisplaatsing in het vrijwillig kader kan worden voortgezet.

In 1 van de 82 zaken $(1,2 \%)$ werd het verzoek machtiging uithuisplaatsing in zijn geheel aangehouden. De kinderrechter kwam tot de conclusie dat er sprake was van een zorgelijke situatie rond de minderjarige maar dat de mogelijkheid tot gezinsopname van moeder en kind nog onvoldoende was onderzocht. Moeder had eenmaal een aanbod tot gezinsopname geweigerd vanwege negatieve ervaringen met de hulpverleningsinstelling die de opname zou moeten gaan uitvoeren. Alternatieve mogelijkheden voor de gezinsopname die moeder zelf had aangedragen werden door Bureau Jeugdzorg afgewezen. De kinderrechter stelde dat deze alternatieven hadden moeten worden overwogen voordat moeder en kind van elkaar gescheiden werden door een plaatsing in een behandelinstelling. Bureau Jeugdzorg kreeg de 
opdracht om de mogelijkheid van een gezinsopname diepgaand te onderzoeken in de maanden dat het verzoek werd aangehouden.

In 9 van de 82 zaken (11\%) werd het verzoek machtiging uithuisplaatsing gedeeltelijk toegewezen en voor het overige aangehouden. Zichtbaar is dat de kinderrechter in deze zaken het verzoek aanhield om een vinger aan de pols te houden. Soms omdat het onderzoek van de RvdK onvoldoende informatie had opgeleverd, bijvoorbeeld ten aanzien van de veranderingsmogelijkheden van de ouders met gezag of juist ten aanzien van het perspectief van de plaatsing. Zo bleek de minderjarige in een aantal zaken in een crisispleeggezin of bij de andere ouder te verblijven zonder dat duidelijk was hoelang de minderjarige daar kon verblijven en hoe een eventuele vervolgplek eruit moest gaan zien. Gedeeltelijke aanhouding van het verzoek geeft de kinderrechter dan de mogelijkheid het verloop van de plaatsing tot dat moment en het toekomstperspectief van de minderjarige te beoordelen. De beschikking bevatte in deze gevallen ook een duidelijke opdracht voor de RvdK of Bureau Jeugdzorg. Bijvoorbeeld ten aanzien van de RvdK om bij behandeling van het aangehouden deel van het verzoek nadrukkelijk de uitkomsten van een nog af te ronden $\mathrm{G} \& \mathrm{O}$ onderzoek te betrekken.

In 3 van de 82 zaken $(3,7 \%)$ werd het verzoek machtiging uithuisplaatsing gedeeltelijk toegewezen en werd het meer of anders verzochte afgewezen. Ook hier is zichtbaar dat het perspectief van de minderjarige nog onvoldoende duidelijk was maar kennelijk gaven de omstandigheden geen aanleiding om het verzoek deels aan te houden.

\subsubsection{Onderbouwing van de noodzaak van een plaatsing buiten het gezin}

In de analyse is vervolgens gekeken of de beschikking op het verzoek tot machtiging uithuisplaatsing een inhoudelijke, op de casus toegespitste motivering bevatte. Als uitgangspunt is daarbij gehanteerd dat de kinderrechter gezien de ernst van de inbreuk op het familie- en gezinsleven van kind en ouders niet zou mogen volstaan met een standaardmotivering. Onder een standaardmotivering wordt verstaan een letterlijke weergave van de rechtsgrond van de uithuisplaatsing zoals was opgenomen in art. 1:261 lid 1 oud. BW. Van de kinderrechter mag worden verwacht dat tenminste feiten en omstandigheden worden aangehaald ten aanzien van de problematiek van de minderjarige en/of de mogelijkheid van alternatieven ter voorkoming van de uithuisplaatsing. Hoewel de wet niet expliciet verplichtte tot een inhoudelijke onderbouwing van de kinderrechter op dit punt, is in de rechtspraak en 
literatuur het standpunt verdedigd dat een standaardmotivering in de beschikking niet aanvaardbaar is.

De analyse laat zien dat in 64 van de 82 beschikkingen (78\%) die deel uitmaken van steekproef de noodzaak tot uithuisplaatsing - of in geval van afwijzing/aanhouding van het verzoek, het ontbreken van de noodzaak - werd onderbouwd aan de hand van de concrete feiten en omstandigheden van het geval. In 18 van de 82 beschikkingen (22\%) op het verzoek tot machtiging uithuisplaatsing werd volstaan met een standaardmotvering waarin alleen de rechtsgrond van art. 1:261 lid 1 oud BW) werd herhaald. Ondanks het feit dat ook hier in een deel van de zaken geen verweer werd gevoerd tegen verzoek, is het zorgelijk dat ruim 1/5 van de onderzochte zaken geen inhoudelijke motivering door de kinderrechter werd gegeven ten aanzien van de noodzaak tot uithuisplaatsing.

\subsection{Het verzoek machtiging gesloten jeugdzorg: wettelijke vereisten}

De machtiging tot opneming in een accommodatie voor gesloten jeugdzorg was de meest vergaande vorm van residentiële zorg aan minderjarigen in de jaren 2013 en 2014. Voor een uithuisplaatsing in de gesloten jeugdzorg was een specifieke machtiging vereist (art. 1:261 lid 5 oud BW jo. art. 29b Wjz. Toepassing van gesloten jeugdzorg betrof een vorm van vrijheidsbeneming van minderjarigen. Consequentie daarvan was dat aanvullende rechtswaarborgen golden om onwettige en willekeurige vrijheidsbeneming van de minderjarige te voorkomen. Bezien vanuit de positie van de minderjarige was een belangrijk verschil met de 'reguliere' jeugdbeschermingsprocedure dat de minderjarige van 12 jaar en ouder bekwaam werd geacht om in rechte op te treden (art. 29a lid 2 Wjz). Hetzelfde gold voor de minderjarige onder de 12 jaar die in staat kan worden geacht tot een redelijke waardering van zijn belangen terzake. Daarnaast kreeg de minderjarige ambtshalve een raadsman toegewezen.

Uitgangspunt is dat iedere vorm van vrijheidsbeneming van minderjarigen, gesloten jeugdzorg daaronder begrepen, slechts mag worden toegepast als ultimum remedium (art. 5 EVRM, art. 9 IVRK) en indien toegepast slechts voor de kortst mogelijke duur (art. 37b IVRK). Deze uitgangspunten kwam ook tot uiting in de rechtsgrond voor een gesloten machtiging in art. 29b lid $3 \mathrm{Wjz}$ : de kinderrechter moest van oordeel zijn dat de jeugdige ernstige opgroei- of opvoedingsproblemen had die zijn ontwikkeling naar volwassenheid ernstige belemmerden en die maakten dat de opneming en het verblijf noodzakelijk waren om 
te voorkomen dat de jeugdige zich aan de zorg die hij nodig had zou onttrekken of daaraan door anderen zou worden onttrokken. De Wet op de Jeugdzorg bevatte daarmee feitelijk twee criteria om de noodzaak van een gesloten plaatsing te beoordelen. Een inhoudelijk primair pedagogisch georiënteerd oordeel over de opgroei- en opvoedproblematiek van de minderjarige en een oordeel over het risico op onttrekking aan de noodzakelijke zorg. Daarnaast was vereist dat door Bureau Jeugdzorg een indicatiebesluit werd overlegd met een instemmingsverklaring van een gedragswetenschapper die de minderjarige kort daarvoor had onderzocht. In het dossieronderzoek is voor de 18 zaken binnen de steekproef waarin de RvdK een gesloten plaatsing verzocht gekeken of, en zo ja hoe deze wettelijke vereisten werden toegepast. Eerst wordt aandacht besteed aan de instemmingsverklaring van de gedragswetenschapper en vervolgens wordt uitgewerkt hoe de wettelijke gronden op basis van de Wet op de Jeugdzorg door de RvdK en de kinderrechter werden toegepast.

\subsubsection{Instemmingsverklaring van gedragswetenschapper}

In deel I van het onderzoek zijn de eisen geschetst die konden worden gesteld aan de instemmingsverklaring van de gedragswetenschapper voor een gesloten plaatsing. Inhoudelijk werd in de wet niet nader gespecificeerd welke inhoudelijke eisen konden worden gesteld aan de instemmingsverklaring. De uitgangspunten voor de analyse zijn daarom primair ontleend aan de vereisten die in de rechtspraak zijn geformuleerd. Hieruit is naar voren gekomen dat de gedragswetenschapper op basis van eigen onderzoek tot de conclusie moest komen dat een gesloten plaatsing noodzakelijk was in het belang van de minderjarige. De gedragswetenschapper diende de minderjarige in persoon en kort voor het verzoek te hebben onderzocht. Inhoudelijk moest in ieder geval de toegevoegde waarde van de instemmingsverklaring blijken ten opzichte van de verklaring van Bureau Jeugdzorg dat een gesloten plaatsing noodzakelijk was.

\section{Persoonlijk gesprek}

Het onderzoek dat door de gedragswetenschapper werd verricht kon worden onderverdeeld in twee delen: het dossieronderzoek en een persoonlijk gesprek met de minderjarige. Het was de bedoeling dat de gedragswetenschapper informatie uit het dossier (het raadsdossier maar eventueel ook andere bronnen), interpreteerde en tot een hypothese kwam die de basis vormde voor het gesprek met de minderjarige. Uiteindelijk moest het onderzoek leiden tot een antwoord op de vraag of gesloten jeugdzorg noodzakelijk was om het gewenste resultaat te behalen en zo ja, wat de kortst mogelijke periode was waarbinnen (naar verwachting) dit resultaat kon worden behaald. 
In de analyse is gekeken of de gedragswetenschapper een persoonlijk gesprek hield met de minderjarige. Alleen in zeer uitzonderlijke situaties kon worden volstaan met een verklaring op basis van alleen het dossier. ${ }^{644}$ Bijvoorbeeld in het geval het feitelijk onmogelijk was de minderjarige te spreken, maar ook dan moest blijken dat de gedragswetenschapper de nodige inspanningen had verricht om een gesprek tot stand te brengen. De dossieranalyse laat zien dat in 17 van de 18 zaken $(94,4 \%)$ een persoonlijk gesprek met de minderjarige werd gehouden in het kader van de benodigde instemmingsverklaring voor een gesloten plaatsing. In 1 zaak was een gesprek met de minderjarige feitelijk onmogelijk omdat de verblijfplaats van de minderjarige tijdens het onderzoek niet bekend was. Tijdens dit onderzoek was door de gedragswetenschapper zonder resultaat geprobeerd de verblijfplaats van de minderjarige te achterhalen.

\section{Actualiteit van het onderzoek}

Vervolgens is in het dossieronderzoek is gekeken in hoeverre in de praktijk werd voldaan aan de eis dat de minderjarige 'kort tevoren' moest worden onderzocht. Hier waren in de wet geen concrete termijnen voor gesteld maar als uitgangspunt gold volgens de wetgever dat de actualiteitswaarde van het onderzoek hoog moest zijn. In de literatuur is betoogd dat tussen het afgeven van de instemmingsverklaring en de beoordeling van het verzoek niet meer dan een maand zou mogen zitten.

Voor de 17 zaken in het dossieronderzoek waarin de gedragswetenschapper een gesprek met de minderjarige hield is gekeken naar de totale periode tussen het gesprek en de behandeling van het verzoek op zitting. Er is gekozen voor het gesprek met de minderjarige als startpunt omdat in het gesprek de informatie uit het dossieronderzoek aan bod komt. Als eindpunt is gekozen voor de zittingsdatum aangezien de kinderrechter wordt geacht tijdens de behandeling van het verzoek ook de actualiteitswaarde van de verklaring te beoordelen. De datum van ondertekening van de instemmingsverklaring zelf is niet geregistreerd maar uit het dossieronderzoek blijkt dit doorgaans de dag van het gesprek of enkele dagen later zijn.

Uit de analyse blijkt dat in de regel het onderzoek van de gedragswetenschapper actueel was. In 14 van de 17 zaken zat tussen het gesprek met de minderjarige en de zitting 27 dagen of minder. Gemiddeld ging het in deze 14 zaken om 13 dagen. In 3 van de 17 zaken zat echter beduidend meer tijd tussen het gesprek met de minderjarige en de zitting, respectievelijk 86 , 80 en 78 dagen. In alledrie de gevallen werd de instemmingsverklaring die was verleend op

${ }^{644}$ Zie Hoge Raad 31 mei 2013, ECLI:NL:HR:2013:BZ5422. 
grond van een voorlopige machtiging (art. 29c lid $4 \mathrm{Wjz}$ ) ook gebruikt bij de behandeling van het definitieve verzoek tot ondertoezichtstelling en de gesloten machtiging. Het is de vraag of dit een juiste gang van zaken was aangezien de verklaring in dit geval alleen was bedoeld voor spoedsituaties en zoals blijkt uit de dossieranalyse, er maanden konden verstrijken voordat een definitief verzoek werd ingediend.

\section{De inhoud van de instemmingsverklaring}

De ingrijpende aard van een gesloten plaatsing maakte dat aan het onderzoek van de gedragswetenschapper de nodige eisen inhoudelijke mochten worden gesteld. Opdat de instemmingsverklaring een waarborg was tegen willekeurige vrijheidsbeneming moest inhoudelijk sprake zijn van een voldoende diepgaand onderzoek, hetgeen betekende dat verifieerbare feiten en omstandigheden werden aangedragen en conclusies werden onderbouwd. De gedragswetenschapper zou zich niet mogen beperken tot het herhalen van de wettelijke gronden en de verklaring moest inhoudelijk van toegevoegde waarde zijn ten opzichte van het indicatiebesluit en/of verzoekschrift.

Wat betreft de inhoud van de instemmingsverklaring vallen verschillende dingen op in de analyse. In de eerste plaats leek er in de praktijk geen vast rapportageformat te worden gehanteerd, hoewel bepaalde elementen wel consequent terugkwamen in de onderbouwing. De instemmingsverklaring begon in de regel met een voorgedrukte tekst waarin stond dat Bureau Jeugdzorg verklaarde dat was voldaan aan de gronden voor oplegging van een machtiging gesloten jeugdzorg, gevolgd door de tekst dat op basis van het dossier en het gesprek met de minderjarige de gedragswetenschapper zijn instemming verleende. De wijze waarop dit was vormgegeven wekte niet direct de indruk van een onafhankelijk en onbevooroordeeld onderzoek naar de noodzaak van een gesloten plaatsing. Aangezien het om een klein aantal geanalyseerde zaken gaat moeten de bevindingen op dit punt met de nodige voorzichtigheid worden geïnterpreteerd. Het leek op basis van het zojuist geschetste format echter niet waarschijnlijk dat het oordeel van de gedragswetenschapper ook zou kunnen luiden dat niet werd ingestemd met een gesloten plaatsing. Eerder ontstaat het beeld van een gedragswetenschapper die alleen nog maar hoefde te tekenen bij het kruisje. Dit beeld is wellicht onterecht, aangezien een onafhankelijk oordeel impliceert dat de gedragswetenschapper ook kon weigeren zijn instemming te verlenen. Maar het maakt wel nieuwsgierig of het überhaupt voorkwam dat de gedragswetenschapper zijn of haar instemming weigerde. 
Wat in positieve zin is opgevallen aan de instemmingsverklaringen is de uitgebreide aandacht voor de visie van de minderjarige. Omdat het gesprek met de minderjarige een cruciaal onderdeel was van het onderzoek van de gedragswetenschapper, bevatte de verklaring doorgaans veel informatie over hoe het kind zelf aankeek tegen de geconstateerde problematiek en de noodzaak van een eventuele gesloten plaatsing.

7.5.2 Ernstige opgroei/opvoedingsproblemen die de ontwikkeling naar volwassenheid ernstig belemmeren

Het feit dat slechts een gesloten machtiging kon worden verleend indien sprake was van ernstige opgroei- of opvoedingsproblemen die de ontwikkeling naar volwassenheid ernstige belemmerden impliceerde dat er sprake moest zijn van ernstige problematiek. Hoewel de wetgever enkele voorbeelden ter indicatie heeft gegeven van de gevallen die in aanmerking konden komen voor een gesloten machtiging, betrof het hier nog steeds open norm die invulling moest krijgen aan de hand van de concrete feiten en omstandigheden van het geval.

Zoals gesteld bevinden zich in het dossieronderzoek 18 zaken waarin de RvdK een machtiging gesloten jeugdzorg verzocht op grond van art. 29b lid $3 \mathrm{Wjz}$. Analyse van de aangedragen problematiek in deze zaken brengt een aantal zaken aan het licht. In de eerste plaats ging het in alle 18 zaken om minderjarigen van 13 jaar of ouder (de gemiddelde leeftijd is om en nabij de 15 jaar). Dit is goed verklaarbaar vanuit het feit dat men eerst zal trachten de geconstateerde ontwikkelingsbedreiging met minder ingrijpende middelen weg te nemen. Het feit dat gesloten jeugdzorg vrijheidsbeneming en de mogelijkheid van toepassing van dwangmaatregelen met zich meebracht maakte het in beginsel geen bevorderlijke opvoedingsomgeving voor zeer jonge kinderen.

Daarnaast is zichtbaar dat in alle zaken waarin de RvdK een machtiging gesloten jeugdzorg verzocht in het beschermingsrapport werd onderbouwd waar de ernstige opgroei- en/of opvoedingsproblemen uit bestonden. Duidelijk is ook dat er bij deze minderjarigen sprake was van complexe, meervoudige problematiek op kindniveau. In 8 van de 18 zaken $(44,4 \%)$ van de zaken in het dossieronderzoek was er sprake van verslaving/problematisch middelenmisbruik bij de minderjarige. In 9 van de 18 zaken (50\%) waren een of meerdere stoornissen gediagnostiseerd bij de minderjarige. In 15 van de 18 zaken $(83,3 \%)$ was sprake van (ernstige) externaliserende gedragsproblematiek en in 12 van de 18 zaken $(66,7 \%)$ was bij de minderjarige een verstandelijke beperking vastgesteld. 


\subsubsection{Risico op onttrekking aan de noodzakelijke zorg}

De aanwezigheid van ernstige, meervoudige problematiek bij de minderjarige alleen leverde op zichzelf onvoldoende grond op om een machtiging gesloten jeugdzorg te rechtvaardigen. Op grond van art. 29b lid $3 \mathrm{Wjz}$ gold daarnaast als voorwaarde dat opneming en verblijf noodzakelijk moesten zijn om te voorkomen dat de jeugdige zich aan de zorg onttrok of door anderen aan zou worden onttrokken. De wetgever heeft in het wetgevingstraject tot invoering van de Jeugdwet nog eens bevestigd dat er sprake moet zijn van onttrekkingsgevaar: Door deze toevoeging werdeen vrij hoge drempel opgeworpen voor toepassing van gesloten jeugdzorg in verband met de inperking van de persoonlijke vrijheid van de minderjarige, beschermd in art. 12 Gw., art. 5 EVRM en art. 37b IVRK. Was het niet aannemelijk dat de jeugdige zich onttrok aan de noodzakelijke zorg, of daaraan zou worden onttrokken, dan verviel de grondslag voor gesloten jeugdzorg. De wetgever heeft daarmee een grond in de wet neergelegd waarmee concreet de rechtmatigheid van een gesloten plaatsing kon worden beoordeeld.

In het dossieronderzoek is gekeken of de RvdK consequent aandacht besteedde aan voornoemd wettelijk vereiste. Als maatstaf is hiervoor gehanteerd dat duidelijk uit de argumentatie moest blijken dat het gesloten plaatsen noodzakelijk was om de minderjarige de noodzakelijke hulp te verschaffen, bijvoorbeeld in het geval de minderjarige voortdurend weglieo of consequent hulpverlening weigerde terwijl er ernstige zorgen zijn. Een strikte toets door de RvdK van het onttrekkingsgevaar laat zich rechtvaardigen door de beperking van de vrijheid van de minderjarige die werd beoogd.

Uitkomst is dat de RvdK in 9 van de 18 zaken (50\%) expliciet inging op het risico dat de jeugdige zich onttrok of zou worden onttrokken aan de noodzakelijke hulpverlening. In de overige 9 zaken werd de noodzaak tot vrijheidsbeneming niet inhoudelijk onderbouwd. In zijn algemeenheid valt - net als ten aanzien van het reguliere verzoek machtiging uithuisplaatsingook hier op dat de onderbouwing van de noodzaak van een gesloten plaatsing weinig diepgaand was. Meer specifiek is zichtbaar dat de focus in het beschermingsrapport vrijwel geheel lag op de complexe problematiek van de minderjarige. Een mogelijke verklaring hiervoor zou kunnen zijn dat in het rapportageformat geen onderscheid werd gemaakt tussen een 'regulier' verzoek tot machtiging uithuisplaatsing en een verzoek tot gesloten plaatsing. De aanvullende wettelijke vereisten op grond van de Wet op de Jeugdzorg waren niet 
geïntegreerd in de vraagstelling in het beschermingsrapport. Sterker nog, de vraag of een uithuisplaatsing noodzakelijk was, maakte in verschillende zaken geen onderdeel uit van de onderzoeksvragen. Uiteindelijk werd dan alleen aandacht besteed aan de problematische ontwikkeling van de minderjarige. Om een gesloten plaatsing te rechtvaardigen is dat echter niet onvoldoende. Meer nog dan de grond 'ernstige opgroei- of opvoedingsproblemen van de minderjarige', moest de noodzaak van de geslotenheid van de opname blijken uit het feit de zorg anders niet geleverd zou kunnen worden in verband met het risico op onttrekking daaraan. Was immers alleen sprake van ernstige opgroei- en opvoedingsproblemen dan zou de minderjarige in beginsel ook kunnen worden ambulant kunnen worden behandeld of worden opgenomen in een residentiële instelling zonder gesloten karakter.

\subsection{Beschikking op het verzoek machtiging gesloten jeugdzorg}

In de analyse is gekeken naar de motivering in de beschikking op het verzoek tot plaatsing in een accommodatie voor gesloten jeugdzorg, ex. art. 29b lid 1 Wjz. Evenals bij de 82 zaken waarin de kinderrechter besliste op een regulier verzoek machtiging uithuisplaatsing is voor de 18 zaken waarin een gesloten machtiging werd verzocht, gekeken naar de beslissing van de kinderrechter en de vraag of de wettelijke gronden inhoudelijk invulling kregen ter onderbouwing van de beslissing.

\subsubsection{Beslissing van de kinderrechter}

Wat betreft de beslissing van de kinderrechter is zichtbaar dat de machtiging voor plaatsing in accommodatie voor gesloten jeugdzorg in 15 van de 18 zaken $(83,3 \%)$ werd verleend. In 2 van de 18 zaken $(11,1 \%)$ werd de gesloten machtiging voor een kortere duur toegewezen dan verzocht. Het ging hier om minderjarigen die in de korte periode dat zij in het kader van een voorlopige ondertoezichtstelling gesloten waren geplaatst een positieve ontwikkeling door hadden gemaakt. De kinderrechter zag daarin reden om de machtiging gesloten jeugdzorg voor 6 maanden in plaats van het verzochte jaar toe te wijzen, gezien de ingrijpende aard van de maatregel. In 1 zaak werd om dezelfde reden het verzoek toegewezen voor 3 maanden in plaats van de gevraagde 6 maanden en voor het overige deel aangehouden.

\subsubsection{Ernstige opgroei- en opvoedingsproblemen die de ontwikkeling ernstig belemmeren}

Vervolgens is voor de 18 beschikkingen op het verzoek machtiging gesloten jeugdzorg gekeken of de kinderrechter de gronden zoals opgenomen in art. 29b lid $3 \mathrm{Wjz}$ betrok bij zijn 
beslissing. In de eerste plaats gaat het dan om de vraag of aandacht werd besteed aan het vereiste dat de minderjarige ernstige opgroei- en opvoedingsproblemen had die de ontwikkeling naar volwassenheid ernstig belemmerden. Het onderzoek laat zien dat in de meeste gevallen door de kinderrechter uitgebreid aandacht werd besteed aan de problematiek van de minderjarige. In 16 van de 18 beschikkingen $(88,9 \%)$ werd een op de casus toegepitste motivering gegeven. In 2 van de 18 zaken $(11,1 \%)$ volstond de kinderrechter met het herhalen van de wettelijke grond als in $29 \mathrm{~b}$ lid $3 \mathrm{Wjz}$ en werden de ontwikkelingsproblemen niet nader toegelicht.

\subsubsection{Risico op onttrekking aan de noodzakelijke zorg}

Ten aanzien van het vereiste dat de minderjarige zich onttrok of aan de noodzakelijke zorg werd onttrokken is het beeld veel wisselender. In 8 van de 18 zaken $(44,4 \%)$ werd inhoudelijk toegelicht door de kinderrechter waarom het risico op onttrekking aan zorg een gesloten plaatsing noodzakelijk maakte. In de overige 10 van de 18 zaken $(55,6 \%)$ gebeurde dit niet. De verklaring die is gegeven voor het gebrek aan aandacht in de rapportages van de RvdK voor het risico op onttrekking aan de noodzakelijke zorg lijkt ook hier op te gaan. De focus lag primair op de ernst van de problematiek op basis waarvan een gesloten plaatsing noodzakelijk zou zijn. Complexe problematiek alleen is echter onvoldoende om tot een gesloten plaatsing te komen. Daarnaast is zichtbaar dat in de beschikkingen meer werd ingegaan op de functioneren van de minderjarige binnen de gesloten jeugdzorg waar hij in het kader van de voorlopige ondertoezichtstelling verbleef. Dat kan een rol spelen bij de vraag of de gesloten plaatsing op het moment van het definitieve verzoek nog noodzakelijk is maar als onderbouwing voor het onttrekkingsrisico is het als onderbouwing te beperkt. De minderjarige was dan immers al gesloten geplaatst (en kan dus nergens heen) terwijl met name moest blijken waarom het gedrag van de minderjarige buiten de gesloten inrichting zodanig was dat vrijheidsbeneming ter bescherming van zijn belangen noodzakelijk was.

\subsection{Tussenconclusie}

In dit hoofdstuk zijn de resultaten besproken van het dossieronderzoek naar de rechtvaardiging van de uithuisplaatsing. In de eerste plaats is het indicatiebesluit geanalyseerd, nu het indicatiebesluit in beginsel noodzakelijk was voor de toekenning van een machtiging uithuisplaatsing. Er zijn echter in de dossiers maar weinig indicatiebesluiten. Deels lijkt dat een kwestie van onzorgvuldige archivering en deels zijn inhoudelijke redenen 
hiervoor aan te dragen. Zo is het zichtbaar dat door raadsonderzoekers wisselend werd geoordeeld over de vraag of een indicatiebesluit noodzakelijk was bij een netwerkplaatsing.

De belangrijkste bevinding op basis van de analyse van de beschermingsrapporten en beschikkingen is echter dat de onderbouwing ten aanzien van de uithuisplaatsing weinig omvangrijk en diepgaand was, zeker in vergelijking met de onderbouwing van de ondertoezichtstelling. Dat geldt in het bijzonder voor de onderbouwing van de noodzaak van een scheiding van kind en ouders. Het dossieronderzoek laat zien dat in minder dan de helft van geanalyseerde zaken aandacht werd besteed aan de vraag waarom alternatieve, minder ingrijpende middelen niet mogelijk waren. Hiermee kwam een belangrijk uitgangspunt op grond van het in art. 8 EVRM neergelegde recht op familie- en gezinsleven onvoldoende terug in de besluitvorming. Hetzelfde gold voor het door het EHRM geformuleerde herenigingsbeginsel. Op grond van art. 8 EVRM gold als uitgangspunt dat de uithuisplaatsing in het teken moest staan van de hereniging van kind en ouders. In het onderzoek is benadrukt dat het voor de rechtvaardiging van de uithuisplaatsing noodzaklijk was dat ook de RvdK al in een vroeg stadium hier aandacht aan besteedde, zodat duidelijk werd voor kind en ouders welke doelen moesten worden behaald om dit te bewerkstelligen. De analyse van dossiers heeft laten zien dat in iets meer dan de helft van de zaken door de RvdK aandacht werd besteed aan de kans op hereniging en daarmee het perspectief van de minderjarige indien hij uit huis werd geplaatst. Mogelijk heeft dit te maken met het feit dat de uithuisplaatsing niet als zelfstandige maatregel wordt beschouwd maar als middel binnen de ondertoezichtstelling. Maar een uitgebreidere onderbouwing is gezien de ernstige inbreuk op de rechten van het kind en ouders gerechtvaardigd. Ten aanzien van het verzoek machtiging gesloten jeugdzorg valt met name op dat slechts in de helft van de beschermingsrapporten het risico op onttrekking van de minderjarige aan de noodzakelijke zorg werd onderbouwd. Voor de beschikking op het verzoek machtiging gesloten jeugdzorg gold hetzelfde. 


\section{Dossieronderzoek naar de zorgvuldigheid van het feitenonderzoek en de rechtspositie van de minderjarige en zijn ouders}

\subsection{Inleiding}

In de twee voorgaande hoofdstukken is gekeken naar de toepassing van het materiële jeugdbeschermingsrecht door de RvdK en de kinderrechter. Voor een zo volledig mogelijk antwoord op de vraag of in de praktijk voldoende rechtvaardiging werd geboden voor de inzet van een ondertoezichtstelling en uithuisplaatsing is echter besloten breder te kijken dan alleen naar de wijze waarop het materiële jeugdbeschermingsrecht werd toegepast. Een correcte interpretatie en toepassing van de gronden en doelstellingen verliest immers voor een deel zijn waarde indien de informatie op basis waarvan de juridische toets plaatsvindt onvolledig of incorrect is. Daarnaast is gesteld dat de vraag hoe de rechtvaardiging van ondertoezichtstelling en uithuisplaatsing wordt vormgegeven niet los kan worden gezien van de mate waarin recht wordt gedaan aan de (rechts)positie van de minderjarige en zijn ouders in de jeugdbeschermingsprocedure.

In dit hoofdstuk wordt verslag gedaan van de analyse van verschillende aspecten die samenhangen met de zorgvuldigheid waarmee het beschermingsonderzoek door de RvdK werd uitgevoerd en rechtspositie van de minderjarige en zijn ouders tijdens de jeugdbeschermingsprocedure. In het eerste deel van het onderzoek is laten zien dat de zorgvuldigheid van het feitenonderzoek en de wijze waarop de minderjarige en zijn ouders konden participeren in het besluitvormingsproces, twee elementen waren waar door betrokkenen forse kritiek op werd geleverd. Het gaat dan met name om het verwijt dat de RvdK (en de overige ketenpartners) niet aan waarheidsvinding deden waarmee werd bedoeld dat de verzoeken niet voldoende werden gebaseerd op feitelijke informatie en er geen duidelijk onderscheid werd gemaakt tussen feiten en meningen.

Het is echter grotendeels onduidelijk of deze kritiek terecht was aangezien het feitenonderzoek door de RvdK niet eerder concreet is onderzocht en ten aanzien van de rechtspositie van de minderjarige doorgaans alleen naar de gerechtelijke procedure wordt gekeken. In deel I van het onderzoek zijn de belangrijkste uitgangspunten, procedurele regels en formele (inhoudelijke) kwaliteitscriteria voor het feitenonderzoek is jeugdbeschermingszaken geschetst. Deze elementen vormen de basis voor de analyse van de 200 zaken binnen de steekproef waarin een verzoek tot ondertoezichtstelling met of zonder 
uithuisplaatsing is gedaan. In paragraaf 8.2 worden de resultaten besproken van het dossieronderzoek naar de wijze waarop de RvdK omging met verschillende zorgvuldigheidsaspecten ten aanzien van de verwerking en interpretatie van de informatie uit het onderzoek. Het juridisch kader hiervoor vormden de regels van bewijsrecht in civiele procedures en specifiek ten aanzien van het beschermingsonderzoek, de interne regels die de RvdK hanteerde voor de uitvoering van het feitenonderzoek.

In paragraaf 8.3 staat de rechtspositie van de minderjarige (en in mindere mate zijn ouders) tijdens het beschermingsonderzoek centraal. Het recht van de minderjarige om te worden gehoord en voldoende te worden betrokken bij de besluitvorming geldt in alle fasen van proces. Het beschermingsonderzoek door de RvdK lijkt bij uitstek geschikt om de minderjarige - afhankelijk van zijn leeftijd en ontwikkelingsniveau - effectief te laten participeren. Voor de ouders geldt dat zij er recht op hebben informatie aan te leveren voor het onderzoek en de kans moeten krijgen om te reageren op de besluitvorming. In de 200 zaken waarin de RvdK een ondertoezichtstelling heeft verzocht is onder meer gekeken of ouders en kind werden gehoord, of de mogelijkheid werd geboden te reageren op de rapportage en of de visie van kind en ouders ten aanzien van het verzoek duidelijk naar voren kwam in het besluitvormingsproces

Tot slot wordt in paragraaf 8.4 aandacht besteed aan de wijze waarop de minderjarige kon participeren in de gerechtelijke procedure. De informatie voor de analyse is afkomstig uit de beschikking op het verzoek tot ondertoezichtstelling en uithuisplaatsing. Die informatie beperkt zich tot de vraag of de minderjarige is gehoord overeenkomstig de wettelijke vereisten en in sommige gevallen, tot een weergave van de mening van de minderjarige in de beschikking bij de inhoudelijke afwegingen van de kinderrechter. Om die reden is in de analyse gekeken of de minderjarigen binnen de steekproef door de kinderrechter werden gehoord en welke rol leeftijd hierbij speelde. Daarnaast wordt geanalyseerd of de kinderrechter in de beschikking op het verzoek de mening van de minderjarige betrok bij zijn overwegingen.

\subsection{Het feitenonderzoek door de RvdK}

De analyse van het feitenonderzoek omvat de 200 zaken waarin de RvdK in 2013 en 2014 een verzoek tot ondertoezichtstelling met of zonder machtiging uithuisplaatsing aan de kinderrechter heeft voorgelegd. De analyse richt zich op de feitenvaststelling binnen het 
beschermingsonderzoek door de RvdK. De beschikking op het verzoek is waar het gaat om de feitenvaststelling niet geanalyseerd. Een analyse zoals die is uitgevoerd ten aanzien van het beschermingsonderzoek is voor de beschikking niet mogelijk gebleken. In het beschermingsrapport wordt - als het goed is - een duidelijk onderscheid gemaakt tussen de verzamelde informatie uit bronnen en de interpretatie daarvan door de RvdK. Ook de kinderrechter interpreteert en beoordeelt de informatie die is ingebracht door de partijen maar die weging vindt doorgaans niet (expliciet) plaats in de beschikking plaats. De beschikkingen binnen de steekproef leverden hierdoor te weinig informatie op met betrekking tot de juistheid van de ingebrachte informatie om tot een inhoudelijke analyse te komen.

In deel I van het onderzoek is op hoofdlijnen het wettelijk kader van bewijsrecht in civiele zaken geschetst. Daarbij is de nadruk gelegd op de waarheidsplicht voor partijen (dus ook de RvdK) in art. $21 \mathrm{Rv}$. op basis waarvan de voor de beslissing van de belang zijnde feiten volledig en waarheid moeten worden aangevoerd. Hieruit kan als algemeen gezichtspunt worden afgeleid dat het feitenonderzoek zorgvuldig moet worden uitgevoerd maar het geeft verder geen indicatie welke specifieke eisen daarvoor kunnen worden gesteld. De belangrijkste uitgangspunten voor de analyse zijn derhalve ontleend aan de eisen die de RvdK in het interne Kwaliteitskader stelde voor een zorgvuldige uitvoering van het feitenonderzoek. Enerzijds ging het dan om formele zorgvuldigheidshandelingen van de RvdK teneinde de juistheid en actualiteit van de onderzoeksgegevens voor zover mogelijk te garanderen. Anderzijds ging het om de inhoudelijke interpretatie van de verzamelde onderzoeksgegevens door de RvdK. Zo bevatte het Kwaliteitskader 2013 van de RvdK de eis dat besluitvorming in de rapportage werd onderbouwd, waarbij feiten, visies van betrokkenen en de interpretatie van deze informatie door de RvdK duidelijk moest worden gescheiden.

\subsubsection{Accorderen en dateren van de ingebrachte informatie}

In deel I van het onderzoek zijn verschillende zorgvuldigheidseisen besproken die eraan moesten bijdragen dat de informatie in het beschermingsrapport correct en actueel was. Als belangrijke kwaliteitswaarborg gold onder meer dat de informatie die door de ouders, de minderjarige en informanten tijdens het beschermingsonderzoek werd aangedragen werd geaccordeerd en gedateerd. Volgens het Kwaliteitskader 2013 van de RvdK moest de formulering van informatie die werd ingebracht door informanten, goedkeuring hebben van de betreffende informant. Het accorderen van de informatie was belangrijk omdat hiermee in 
ieder geval werd bevestigd dat (externe) informanten akkoord waren met de informatie die zij tijdens het onderzoek hadden verstrekt. Zo kon worden voorkomen dat de RvdK informatie uit overige bronnen foutief verwerkte en weergaf in de onderbouwing van het verzoek tot ondertoezichtstelling en uithuisplaatsing. Door ook de datum te vermelden van het moment waarop de informatie werd verkregen kon worden voorkomen dat informatie terugkwam zonder dat duidelijk was van wie deze informatie oorspronkelijk afkomstig was en wanneer de informatie was verkregen.

Het dossieronderzoek laat zien dat de RvdK in 194 van de 200 geanalyseerde zaken (97\%) expliciet in het rapport vermeldde dat de informatie zoals weergegeven door de betreffende informant was geaccordeerd. Het rapportageformat dat werd gehanteerd in beschermingszaken was zo ingericht dat na de weergave van de informatie die werd verstrekt door informanten, direct werd vermeld of de informatie ook was geaccordeerd. Slechts in enkele beschermingsrapporten was zichtbaar dat de informant pas wenste te accorderen nadat het gespreksverslag (gedeeltelijk) was aangepast, omdat de weergave van het gesprek door de RvdK onjuist of onvoldoende genuanceerd was.

Logischerwijs volgt hieruit dat de accordering van de ingebrachte informatie door informanten slechts in 6 van de 200 geanalyseerde zaken (3\%) ontbrak. Het is niet voor alle 6 de zaken duidelijk welke oorzaak aan de basis ligt van het ontbreken van de accordering. Het meest duidelijk is een zaak waarin geen informanten werden geraadpleegd. De RvdK had kort voor deze zaak een beschermingsonderzoek ten aanzien van dezelfde minderjarige uitgevoerd een een ondertoezichtstelling verzocht. Het verzoek was afgewezen. Het nieuwe verzoek tot ondertoezichtstelling was daarom gebaseerd op het eerder gebruikte en nog actuele beschermingsrapport. In 3 van de 6 zaken had het beschermingsonderzoek een spoedeisend karakter hetgeen kan verklaren waarom de accordering ontbrak. De RvdK verzocht in deze zaken de ondertoezichtstelling uit te spreken voor een periode van een jaar en deze maatregel met onmiddellijke ingang voorlopig uit te spreken voor de duur van drie maanden. In feite maakte het verzoek tot voorlopige ondertoezichtstelling dan deel uit van het 'reguliere' verzoek tot ondertoezichtstelling. Door het spoedeisende karakter ontbreken bepaalde noodzakelijke elementen in deze rapporten waaronder de accordering van de informatie door betrokkenen en informanten. In de overige (2) zaken is geen voor de hand liggende verklaring gevonden voor het ontbreken van de accordering.

Het tweede element waarnaar is gekeken is of de datum waarop de informatie werd verkregen van de informanten in het beschermingsrapport werd vermeld. Het vermelden van de datum 
geeft in ieder geval duidelijkheid ten aanzien van het moment waarop informatie door informanten is ingebracht. De analyse laat zien dat de RvdK in 195 van de 200 geanalyseerde zaken $(97,5 \%)$ de datum in het rapport vermeldde waarop de informatie van de betreffende informant werd verkregen. Op enkele uitzonderingen na werd de datum van het gesprek direct bij de uitwerking van het gespreksverslag weergegeven. In de 5 zaken waarin niet alle gesprekken van een datum waren voorzien, lijkt het te gaan om slordigheden. Zo is 2 van de 5 zaken zichtbaar dat een deel van de gesprekken wel van een datum is voorzien, maar een of enkele gesprekken lijken te zijn vergeten.

\subsubsection{Het onderscheid tussen feiten en meningen in de beschermingsrapportage}

In deel I van het onderzoek is de discussie over het feitenonderzoek in jeugdbeschermingszaken geschetst. Hieruit is naar voren gekomen dat de kern van de discussie ging over de vraag of in de rapportages een duidelijk onderscheid tussen feiten en meningen werd gemaakt. Er is ook vastgesteld dat in deze discussie niet of nauwelijks aandacht is besteed aan de noodzakelijke vraag die daaraan vooraf hoorde te gaan: wanneer is sprake van feitelijke (objectief verifieerbare) informatie en wanneer is er sprake van een mening/visie van een betrokkene of informant? Om een analyse van de informatieverwerking en beoordeling door de RvdK van de ingebrachte informatie mogelijk te maken is het noodzakelijk gebleken de informatie te categoriseren waarbij een onderscheid is gemaakt tussen informatie die als feitelijk kan worden beschouwd en informatie die als vermoeden of mening moet worden aangemerkt.

Voor het dossieronderzoek zijn de volgende uitgangspunten geformuleerd: informatie is als feitelijk aangemerkt indien de informatie was gebaseerd op objectieve gegevens (documentatie zoals een persoonlijkheidsonderzoek, een duidelijke vastgestelde diagnose, een proces-verbaal opgemaakt door de politie, behandelgegevens bijvoorbeeld uitslagen van urinecontrole bij verslavingsproblematiek). Daarnaast is informatie als feitelijk aangemerkt als de RvdK door eigen waarneming een bepaalde situatie heeft vast kunnen stellen (bijvoorbeeld drankmisbruik van ouders tijdens een huisbezoek) of wanneer vermoedens of zorgen tijdens het onderzoek door alle betrokkenen worden bevestigd zonder dat er direct zwart op wit bewijs van is (bijvoorbeeld in de situatie waarin door de minderjarige fysieke kindermishandeling wordt gemeld en ouders toegeven zich hier schuldig aan te hebben gemaakt). Overige informatie is als mening/visie van de betrokkenen en informanten aangemerkt. Nergens in wet- en regelgeving noch in bredere discussie is een duidelijke indicatie gegeven van de wijze waarop het onderscheid tussen feiten en meningen kan worden 
gemaakt, hetgeen ontegenzeggelijk te maken heeft met de complexiteit van de vaststelling en interpretatie van feiten in de juridische besluitvorming. De geschetste indeling is gekozen om een systematische analyse van gegevens mogelijk te maken, maar een andere indeling is niet uitgesloten. Daarnaast moet worden opgemerkt dat hanteren van een indeling zoals hiervoor beschreven interpretatie vergt van de door de RvdK ingebrachte onderzoeksgegevens, door de onderzoeker die de gegevens analyseert. Het onderzoek op dit punt beoogt in de eerste plaats zichtbaar te maken hoe lastig het is alle informatie in het beschermingsrapport op een juiste manier te wegen. Meer of minder concrete zorgen, vermoedens en feiten staan door elkaar in de beschermingsrapportages. Tegelijkertijd moet het streven zijn om de beslissing een ondertoezichtstelling te verzoeken zoveel mogelijk gebaseerd te laten zijn op feitelijke informatie. Als uitgangspunt is dan ook gehanteerd dat in de beschermingsrapportage van de RvdK moet worden gestreefd naar het objectiveren en concretiseren van de verzamelde informatie, maar dat visie van betrokkenen evengoed van belang is. Ten aanzien van het streven naar objectivering van informatie is het belangrijk dat de aan het verzoek ten grondslag liggende stellingen - die vatbaar zijn voor objectivering - middels toetsbare feiten en omstandigheden worden onderbouwd. Indien er sprake is van een visie of een vermoeden waaruit blijkt dat er zorgen bestaan over de minderjarige dan kan dit evengoed van belang zijn voor de afweging over de noodzaak van een maatregel, mits de zorgen concreet worden gemaakt en als ook als zorgen herkenbaar zijn.

In alle 200 zaken binnen de steekproef is in drie stappen gekeken naar de interpretatie van de onderzoeksgegevens door de $\mathrm{RvdK}$. Ten eerste is systematisch gekeken welke informatie op basis van het onderzoek werd verkregen. Welke zorgen op kindniveau en het niveau van de opvoedingsomgeving werden geconstateerd. Ten tweede is gekeken of die informatie feitelijk van aard was of moest worden bestempeld als de visie van een betrokkene of informant. Ten derde is gekeken hoe de RvdK de verzamelde informatie interpreteerde bij de onderzoeksafwegingen. Werd de informatie weergegeven als vaststaand feit of als de visie van betrokkenen en was de weergave in overeenstemming met de aard van de verzamelde informatie.

Uit het dossieronderzoek blijkt dat de RvdK in 185 van de 200 zaken $(92,5 \%)$ de informatie werd ingebracht door informanten en overige informatie die in het onderzoek werd verzameld 
correct weergaf bij de afweging van de onderzoeksvragen. Dit betekent dat zowel de vastgestelde feiten als zorgen en vermoedens ook als zodanig door de RvdK werden benoemd. In 15 van de 200 zaken (7,5\%) was de interpretatie van de onderzoeksgegevens door de RvdK niet geheel, maar vaak wel voor het grootste deel correct. Nadere analyse van deze 15 zaken laat zien dat het in de meeste zaken ging om vermoedens of zorgen die door de RvdK te stellig en daarmee als feitelijk werden gepresenteerd. In het vervolg worden twee voorbeelden aangehaald uit het dossieronderzoek waarin zichtbaar is dat de RvdK informatie te stellig weergaf. ${ }^{645}$ Er wordt steeds onderscheid gemaakt tussen de informatie uit de melding, de informatie uit het onderzoek van de RvdK en de interpretatie van de onderzoeksgegevens door de RvdK. De twee volgende voorbeelden mogen dit verduidelijken.

Voorbeeld 1

\section{Melding}

Bureau Jeugdzorg meldt zorgen over een zwangere vrouw. Zij is volgens Bureau Jeugdzorg verstandelijk gehandicapt en moeder heeft een vriend die haar vermoedelijk mishandelt.

\section{Informatie uit onderzoek}

Het onderzoek van de RvdK levert de volgende informatie op ten aanzien van de mishandeling: moeder en haar vriend ontkennen ten stelligste dat er sprake is geweest van huiselijk geweld. De politie heeft moeder een keer gezien na een melding maar geen signalen van mishandeling geconstateerd. De betrokken hulpverleenster geeft als informant aan dat er signalen zijn van mishandeling maar licht dit verder niet toe. Oma moederszijde geeft als informant aan een keer een blauw oog bij moeder te hebben gezien.

\section{Interpretatie van onderzoeksgegevens door de RvdK}

De RvdK geeft bij de onderzoeksafwegingen het volgende aan: 'gebleken is dat moeder wordt mishandeld door vader. De mishandeling van moeder vormt bovendien een fysieke bedreiging voor de ontwikkeling van de ongeboren baby. Moeder stelt zich bloot aan mishandeling en brengt zo het leven van de ongeboren baby in gevaar.'

\footnotetext{
${ }^{645}$ De voorbeelden zijn door de onderzoeker ingekort en geparafraseerd omwille van de leesbaarheid. Inhoudelijk zijn er geen aanpassingen gedaan. De voorbeelden geven geen totaalbeeld van het onderzoek maar laten op een concreet punt zien hoe de informatie niet correct werd geïnterpreteerd.
} 


\section{Melding}

Bureau Jeugdzorg meldt bij de RvdK zorgen over twee meisjes van 11 en 13 jaar. Ouders liggen in een vechtscheiding en er zijn vermoedens van huiselijk geweld.

\section{Informatie uit onderzoek}

Het onderzoek geeft het volgende beeld: moeder verklaart mishandeld te zijn door vader. Vader ontkent en stelt bedreigd te zijn door moeder. Beide meisjes hebben een goede band met beide ouders. Zij geven aan dat er ruzies waren thuis, ouders hard schreeuwden tegen elkaar, maar zeggen niks over huiselijk geweld. Bureau Jeugdzorg is betrokken geraakt bij het gezin na een zorgmelding van de politie over conflicten in de thuissituatie. Meer informatie dan dat het ging om hevige conflicten waar de kinderen getuige van waren levert de informatie van de politie niet op.

\section{Interpretatie van de onderzoeksgegevens door de RvdK}

Bij de onderzoeksafwegingen concludeert de RvdK het volgende: 'de grootste zorg van de RvdK is de voortdurende strijd tussen ouders. Binnen deze strijd is er sprake van zeer heftige ruzies met hevig verbaal geweld. Het is ook voorgekomen dat er fysiek geweld is geweest tussen ouders en er is diverse malen politie bij betrokken geweest.'

In zowel voorbeeld 1 als voorbeeld 2 gaat het om vermoedens van huiselijk geweld. De realiteit (binnen de zaken in de steekproef) is dat deze vermoedens soms, maar meestal niet bevestigd konden worden. Huiselijk geweld in de thuissituatie speelt zich doorgaans af achter de voordeur en in de geanalyseerde zaken komt het zelden voor dat er overtuigend bewijs is van het geweld.

In de situatie zoals terugkomend in de voorbeelden lijkt dat ook niet nodig om toch te kunnen spreken van een voor de minderjarige zorgelijke situatie. Ook de zorg dat er mogelijk sprake is geweest van huiselijk geweld had kunnen leiden tot de conclusie dat de minderjarige ernstig werd bedreigd in zijn ontwikkeling. Blijkens de analyse ging de RvdK hier in het overgrote deel van de zaken voldoende zorgvuldig mee om en waren zorgen of vermoedens ook als zodanig herkenbaar in het beschermingsrapport. In enkele zaken was de RvdK te stellig zoals 
blijkt uit de analyse en de aangehaalde voorbeelden. Deze uitkomst kan zowel positief als negatief benaderd worden. Positief is dat de wijze waarop de RvdK informatie interpreteerde in het overgrote deel van de zaken op orde was. Het idee dat helemaal niet aan waarheidsvinding werd gedaan en feiten en meningen voortdurend door elkaar werden gehaald moet op basis van deze bevindingen sterk worden genuanceerd. Aan de andere kant moet worden vastgesteld dat iedere onjuiste interpretatie van gegevens door de RvdK - hoe subtiel ook - grote gevolgen kan hebben voor de betrokkenen gezinnen. De conclusie dat sprake is geweest van huiselijk geweld staat zwart op wit in de rapportage en wordt vermoedelijk overgenomen door de instantie die uitvoering geeft aan de ondertoezichtstelling. Als de uitvoerder vervolgens start vanuit het uitgangspunt dat er huiselijk geweld heeft plaatsgevonden en dit ook als zodanig opneemt in de rapportages, dan is dit beeld voor de ouder vrijwel onmogelijk te kantelen.

Het onjuist interpreteren van de onderzoeksgegevens bestond niet alleen uit het door elkaar halen van feiten en meningen/vermoedens. In 3 zaken binnen de steekproef is zichtbaar dat onvoldoende zorgvuldig werd omgegaan met het al dan niet aanwezig zijn van een officiele diagnose van een stoornis. Zo is zichtbaar dat bij een moeder werd gesproken over een verstandelijke beperking maar ontbrak iedere informatie over de hoogte van haar IQ en het onderzoek waar de verstandelijke beperking werd vastgesteld. In een andere zaak benoemde de RvdK dat een moeder op haar $13^{\mathrm{e}}$ uit huis was geplaatst hetgeen traumatisch voor haar was geweest. Er wordt gesproken over een persoonlijkheidsonderzoek waarin toendertijd een posttraumatische stress stoornis is vastgesteld maar iedere informatie over het persoonlijkheidonderzoek ontbreekt. Als dit persoonlijkheidsonderzoek al heeft plaatsgevonden moet het sterk verouderd zijn en had de RvdK bij de zorgen die nu gelden ten aanzien van de minderjarige niet zomaar de stoornis van moeder mogen benoemen. In de derde zaak werd door informanten benoemd dat een moeder grote moeite had met het verwerken van informatie. De RvdK geeft vervolgens aan bij de onderzoeksafwegingen dat er bij moeder sprake is van een informatieverwerkingsstoornis. Uit de onderzoeksgegevens is echter niet op te maken dat ook daadwerkelijk een stoornis is vastgesteld.

Bovenstaande bevindingen maken duidelijk dat de RvdK in 2013 en 2014 niet in alle zaken de informatie die in het beschermingsonderzoek naar voren kwam juist interpreteerde of afdoende onderbouwde. Maar de analyse heeft ook aangetoond hoe complex dat is. De informatie die terugkomt in de beschermingsrapporten kan deels feitelijk zijn maar bestaat vaak ook uit verschillende meer of minder concrete zorgen of signalen. Afhankelijk van hoe 
duidelijk die zorgen in het onderzoek worden bevestigd, kan de RvdK stelliger of minder stellig zijn in zijn argumentatie. Het is buitengewoon moeilijk, zo laten de aangehaalde voorbeelden uit het dossieronderzoek ook zien, om van alle informatie afzonderlijk te bepalen in hoeverre er overtuigend bewijs is en de RvdK iets als een feit kan presenteren, of waar onvoldoende zekerheid is en de informatie beter als zorg voortkomend uit de visie of vermoedens van informanten en/of betrokkenen kan worden gepresenteerd. Ten aanzien van ieder stukje informatie vereist dit dat indringend wordt nagedacht over de waarde van de verkregen informatie. Wie heeft wat naar voren gebracht? Wordt hetgeen naar wordt gebracht ondersteund door andere verklaringen of ander bewijs en wat betekent dat voor de afwegingen in het beschermingsonderzoek. Het feit dat dit moeilijke afwegingen zijn, die het raadsonderzoek mogelijk ook verder compliceren, betekent niet dat een minder zorgvuldige weging van de informatie in de rapportages aanvaardbaar is. Het is daarom de vraag of de manier waarop naar bewijs werd gekeken door de RvdK voldoende is voor de rechtvaardiging die noodzakelijk is voor gedwongen overheidsingrijpen. In deel III van het onderzoek gericht op de toepassing van het jeugdbeschermingsrecht na 2015 wordt verder gereflecteerd op deze vraag, waarbij ook recente ontwikkelingen worden meegenomen.

\subsection{De rechtspositie van de minderjarige en zijn ouders tijdens het beschermingsonderzoek}

In deze paragraaf wordt de rechtspositie van kind en ouders tijdens het beschermingsonderzoek op een aantal punten geanalyseerd. Het is van het grootste belang dat ouders en minderjarigen zorgvuldig worden geïnformeerd over de besluitvorming in de jeugdbeschermingsprocedure. Zonder deze informatievoorziening wordt het voor de minderjarige en zijn ouders moeilijk om in te schatten wat de betrokkenheid van de verschillende organisaties betekent en welke mogelijkheden zij hebben om hun zienswijze in de procedure naar voren te brengen. In deel I van het onderzoek zijn op basis van nationale wet- en regelgeving en toepasselijk verdragsrecht de volgende uitgangspunten geformuleerd voor de analyse van dossiers:

De minderjarige heeft er ongeacht zijn leeftijd recht om te worden gehoord in alle fasen van het besluitvormingsproces (art. 12 IVRK). De RvdK hoort in principe alle kinderen tijdens het beschermingsonderzoek (Kwaliteitskader 2013) en motiveert anders waarom het horen achterwege is gebleven. In de gerechtelijke procedure moet de minderjarige van twaalf jaar en ouder in de gelegenheid worden gesteld om te worden gehoord (art. $809 \mathrm{Rv}$ ). Voor de 
minderjarige onder de twaalf is het wenselijk dat hij wordt gestimuleerd om te worden gehoord (art. 12 IVRK). Daarnaast heeft de minderjarige er recht op dat zijn mening afhankelijk van zijn leeftijd en ontwikkelingsniveau - wordt meegewogen in de besluitvorming. Bij voorkeur geeft het beschermingsrapport van de RvdK informatie over mening van de minderjarige ten aanzien van het verzoek. Hetzelfde geldt voor de beschikking op het verzoek (art. 12 IVRK). Tot slot heeft de minderjarige er recht op te worden geïnformeerd over de wijze waarop hij kan participeren en dient hij te worden geïnformeerd over de beslissing van de RvdK en de kinderrechter (art. 12 IVRK, art. 9 lid 2 IVRK). Onderdeel daarvan is ook dat de minderjarige kennis kan nemen van de beslissing en de mate waarin zijn mening het besluitvormingsproces heeft beïnvloed. Het heeft de voorkeur dat deze terugkoppeling ook altijd schriftelijk plaatsvindt (in het beschermingsrapport en de beschikking).

\subsubsection{Het horen van de minderjarige en zijn ouders tijdens het beschermingsonderzoek}

Het dossieronderzoek bevat een analyse van de wijze waarop het hoorrecht van de minderjarige tijdens het beschermingsonderzoek werd vormgegeven. In de 200 zaken die deel uitmaken van de steekproef is gekeken of de RvdK de regels voor het horen en informeren van minderjarigen zoals neergelegd in het eigen Kwaliteitskader 2013 naleefde. Op grond van het Kwaliteitskader had als uitgangspunt te gelden dat met alle minderjarigen een gesprek met de raadsonderzoeker plaatsvond Mocht het niet mogelijk zijn gebleken de minderjarige te spreken binnen het onderzoek, dan diende de minderjarige tenminste door de raadsonderzoeker te worden geobserveerd. Bleek ook dit niet mogelijk dan moest in het beschermingsrapport gemotiveerd worden weergegeven waarom het horen/observeren binnen het onderzoek niet had plaatsgevonden.

Uitkomst is dat de RvdK in 146 van de 200 zaken (73\%) volgens het beschermingsrapport de minderjarige tijdens het beschermingsonderzoek heeft gehoord. In 144 van de 146 zaken waarin de minderjarige is gehoord, gebeurde dit door middel van een persoonlijk gesprek. In 2 van de 146 zaken bleek het vanwege praktische redenen niet mogelijk de minderjarige persoonlijk te spreken en heeft het gesprek telefonisch plaatsgevonden.

In 29 van de 200 zaken (14,5\%) is met zekerheid vast te stellen dat de minderjarige niet werd gehoord tijdens het beschermingsonderzoek omdat dit in het beschermingsrapport expliciet werd weergegeven. Het gaat in 10 van de 29 zaken om een onderzoek naar de noodzaak van 
een maatregel over ongeboren kinderen. Logischerwijs bestaat er geen mogelijkheid om ongeboren kinderen te horen of observeren. In 15 van de 29 zaken waarin het kind niet werd gehoord ging het om zeer jonge kinderen en heeft om die reden een observatie van het kind plaatsgevonden. Doorgaans werd het kind geobserveerd voor, tijdens en/of na het gesprek met de ouders. In 1 van de 29 zaken waarin de minderjarige niet werd gehoord is dit te wijten aan de ouders die geen toestemming gaven om met de minderjarige te spreken. Voorts kwam de RvdK in 3 van de 29 zaken na een belangenafweging tot de conclusie dat het beter was de minderjarige niet te horen, aangezien het horen als te belastend werd beschouwd voor de minderjarige. In de eerste zaak vanwege de heftige scheidingsproblematiek van ouders, in de tweede zaak in verband met ingrijpende levensgebeurtenissen in het leven van de minderjarige en in de derde zaak vanwege het feit dat al veel instanties bij het gezin waren betrokken.

Dit betekent dat in 25 van de 200 geanalyseerde zaken (12,5\%) uit het beschermingsrapport niet is op te maken of de minderjarige werd gehoord. Het lijkt onwaarschijnlijk dat het horen in deze zaken wel heeft plaatsgevonden, aangezien het beschermingsrapport dan informatie zou hebben bevat over de standpunten van de minderjarige. Deze gang van zaken is niet in lijn met de eisen voor het horen/observeren van kinderen tijdens het beschermingssonderzoek op basis van het toen geldende Kwaliteitskader 2013 van de RvdK. Er dienen zich een aantal mogelijke verklaringen aan voor het ontbreken van een toelichting over het horen van de minderjarige tijdens het beschermingsonderzoek. In een aantal zaken ging het om zeer jonge kinderen die nog niet gehoord konden worden en waarbij observeren wellicht niet veel toegevoegde waarde had. Dan nog zou in het beschermingsrapport gemotiveerd moeten worden waarom het horen dan wel observeren achterwege is gebleven. Ook is zichtbaar dat kinderen soms in het kader van een voorlopige ondertoezichtstelling en spoedmachtiging in een pleeggezin verbleven en ervoor werd gekozen alleen de pleegouder te raadplegen over het functioneren van de minderjarige. Kennelijk vanuit de gedachte dat de minderjarige zo kort na de uithuisplaatsing niet verder moest worden belast. De vraag is of niet te snel tot deze conclusie werd gekomen. Het gesprek kan immers ook een hoop onzekerheid over de procedure en de mogelijke uitkomsten wegnemen bij de minderjarige.

Tot slot, in een aantal zaken is zichtbaar dat de RvdK een spoedonderzoek deed, maar op basis daarvan een ondertoezichtstelling/machtiging uithuisplaatsing voor een jaar werd verzocht (waarvan met onmiddellijke ingang de voorlopige ondertoezichtstelling voor 3 maanden). Dit leidde ertoe dat veel van de normale elementen die hoorden bij een regulier 
beschermingsonderzoek niet werden uitgevoerd. $\mathrm{Nu}$ werd in deze beschermingsrapporten vermeld dat het horen niet plaats kon vinden vanwege tijdgebrek. Maar niet duidelijk is waarom niet de keuze is gemaakt om een voorlopige ondertoezichtstelling met spoedmachtiging te verzoeken en de periode van (doorgaans) drie maanden waarin de voorlopige maatregel liep, te benutten om een volledig beschermingsonderzoek uit te voeren. In de analyse is ook gekeken in hoeveel van de 200 zaken tenminste één ouder met het gezag over de minderjarige door de RvdK werd gehoord. Uitkomst is dat dit gebeurde in 193 van de 200 zaken (96,5\%). In 7 zaken werd de ouder niet gehoord maar werd in het beschermingsrapport wel een plausibele verklaring hiervoor gegeven. Bijvoorbeeld omdat de ouder onvindbaar was, pertinent weigerde mee te werken aan het beschermingsonderzoek of omdat de ouder was opgenomen en geestelijk en/of fysiek niet in staat was om te worden gehoord.

\subsubsection{Inzage in de conceptrapportage voor de minderjarige en zijn ouders}

Het beschermingsonderzoek van de RvdK moest uiteindelijk leiden tot een conceptrapportage waarin het besluit van de RvdK werd toegelicht. Het besluit moest vervolgens ook persoonlijk met de minderjarige en zijn ouders worden besproken in een adviesgesprek. In de eerste plaats is in de analyse opgevallen dat er wisselend werd omgegaan door de RvdK met het toezenden van de conceptrapportage en de afstemming met het adviesgesprek. De conceptrapportage werd ofwel voor het adviesgesprek verzonden, of ter inzage aan de ouders meegegeven tijdens het adviesgesprek. In beide gevallen gold dat ouders en/of de minderjarige vijf werkdagen hadden om mondeling of schriftelijk op de conceptrapportage te reageren. Het verschil is echter dat als de conceptrapportage voor het adviesgesprek werd verzonden de ouders en/of minderjarige de mogelijkheid hadden om kennis te nemen van de onderzoeksbevindingen van de RvdK. De kans lijkt dan groter dan de minderjarige/zijn ouders tijdens het adviesgesprek op basis van alle informatie een onderbouwd standpunt konden innemen. Indien de conceptrapportage tijdens het adviesgesprek werd verstrekt dan werden de betrokkenen in zekere zin 'overvallen' door het besluit van de RvdK en leek het moeilijker voor betrokkenen om direct een adequate reactie te geven. Een eventuele reactie op de conceptrapportage werd dan soms schriftelijk of telefonisch nagezonden door de ouders en/of minderjarige.

De analyse van dossiers laat zien dat de ouders vrijwel altijd inzage kregen in de conceptrapportage. In 189 van de 200 zaken (94,5\%) werd het conceptrapport ofwel naar de 
betrokkenen opgestuurd of tijdens het adviesgesprek overhandigd. In 6 van de 200 zaken (3\%) werd in de rapportage geen nadere informatie gegeven over de vraag of de ouders en minderjarige inzage kregen in de conceptrapportage. In 5 van de 200 zaken $(2,5 \%)$ vermeldde het rapport dat geen inzage was gegeven vanwege het spoedeisende karakter van de zaak. Voor de minderjarige was het afhankelijk van zijn leeftijd of inzage werd gegeven in de (volledige) conceptrapportage. De minderjarige van 16 en ouder ontving net als de ouders de conceptrapportage. De minderjarige onder de 12 jaar was voor de informatie uit het conceptrapport afhankelijk van zijn ouders. Was de minderjarige tussen de 12 en 16 jaar dan ontving hij minimaal 'zijn gedeelte' van de rapportage. Dit betrof in de regel niet meer dan een zakelijke weergave van het gesprek dat tijdens het beschermingsonderzoek met de minderjarige had plaatsgevonden over zijn ontwikkeling, de opvoedingsomgeving en de hulpverlening. De keuze om minderjarigen tussen de 12 en 16 jaar slechts een heel klein deel van de rapportage te verstrekken leek te zijn ingegeven door voorzichtigheid. De minderjarige kon immers in de complete rapportage worden geconfronteerd met ingrijpende informatie waarbij ook het risico zou ontstaan dat de verhouding tussen ouder en kind op scherp kwam te staan. Toch lijkt deze gang van zaken zich slecht te verhouden met het uitgangspunt zoals opgenomen in art. 12 IVRK en art. 9 lid 2 IVRK dat de minderjarige moet worden geinformeerd en zoveel mogelijk deel moet kunnen nemen aan de procedure. Het zogenoemde 'kinddeel' van de rapportage gaf de minderjarige geen enkel inzicht in de besluitvorming en de rol die zijn mening daarin had gespeeld. Hierdoor was het voor de minderjarige ook moeilijk, zo niet onmogelijk om een serieuze, inhoudelijke reactie op het verzoek tot ondertoezichtstelling te geven.

\subsubsection{Adviesgesprek met de minderjarige en zijn ouders}

Blijkens het Kwaliteitskader 2013 van de RvdK werd ieder onderzoek afgesloten met een gesprek met de ouders en minderjarige waarin het raadsbesluit werd toegelicht. Het belang van dit gesprek was evident. Voor minderjarigen onder de twaalf jaar was dit de enige mogelijkheid om geïnformeerd te worden over het besluit door de betrokken autoriteiten. Voor twaalf- tot zestienjarigen gold feitelijk hetzelfde gezien het summiere gespreksverslag dat zij ontvingen. Zestien- en zeventienjarigen ontvingen wel de gehele rapportage maar ook dan was het adviesgesprek een cruciaal moment om de participatie van de minderjarige in de procedure vorm te geven. 
In de analyse is gekeken of een adviesgesprek heeft plaatsgevonden met de ouders en de minderjarige na afloop van het onderzoek. De raadsrapportage werd afgesloten met het onderdeel 'reactie op verzoek en rapport'. Indien een adviesgesprek had plaatsgevonden dan vermeldde de RvdK op deze plek de reactie van de ouders en de minderjarige. Vermeldde het rapport dat alleen de ouders waren gesproken dan is er vanuit gegaan dat de minderjarige niet werd gesproken. Vermeldde het rapport dat geen adviesgesprek had plaatsgevonden dan is gekeken welke redenen daaraan te grondslag lagen. Indien helemaal geen melding werd gemaakt van een adviesgesprek lijkt het aannemelijk dat geen adviesgesprek heeft plaatsgevonden.

De analyse laat zien dat in 160 van de 200 zaken (80\%) een persoonlijk dan wel telefonisch adviesgesprek met tenminste een van de ouders werd gehouden. In 6 van de 200 zaken (3\%) heeft de RvdK zonder succes getracht een adviesgesprek met de ouders te organiseren. In nog eens 6 van de 200 zaken (3\%) is geen adviesgesprek gehouden met de ouders vanwege het spoedeisende karakter van de zaak. In 28 van de 200 zaken (14\%) is geen informatie in het beschermingsrapport opgenomen over een mogelijk adviesgesprek. Het adviesgesprek werd niet genoemd in de rapportage en er was ook geen inhoudelijke reactie van de ouders waaruit kon worden afgeleid dat een dergelijk gesprek had plaatsgevonden. Zoals eerder gesteld lijkt het onwaarschijnlijk dat in deze gevallen wel een gesprek heeft plaatsgevonden maar de RvdK om wat voor reden dan ook hier geen melding van makkte in de beschermingsrapportage. Helemaal uit te sluiten is dat echter niet.

Voor wat betreft het adviesgesprek met de minderjarige is het belangrijk te bespreken vanaf welke leeftijd dit gesprek als wenselijk/noodzakelijk werd gezien door de RvdK. Zo is zichtbaar in de analyse dat in 56 van de 200 zaken (28\%) in de rapportage melding werd gemaakt van een adviesgesprek met de minderjarige. In alle 56 zaken waren dit kinderen van twaalf jaar en ouder. Overigens was de toelichting omtrent de inhoud van het adviesgesprek en de reactie van de minderjarige in de regel zeer summier. De toelichting beperkte zich veelal tot de vaststelling dat het advies met de minderjarige was besproken. Soms werd in enkele zinnen nog kort weergegeven hoe de minderjarige aankeek tegen het advies/verzoek.

In de overige zaken (144 van de 200) is het deels zeker dat geen adviesgesprek met de minderjarige werd gehouden en deels onduidelijk omdat de rapportage geen enkele informatie bevatte over het adviesgesprek met de minderjarige. In 14 zaken is met zekerheid vast te stellen dat geen adviesgesprek is gehouden aangezien de rapportage vermeldde dat de minderjarige was uitgenodigd, maar hij een adviesgesprek had afgewezen. Hier zitten ook 
enkele zaken tussen waarin de minderjarige wel was uitgenodigd maar het onduidelijk was waar hij verbleef waardoor het gesprek geen doorgang kon vinden.

In 130 zaken (65\% van het totaal) bevatte de beschermingsrapportage geen informatie over een eventueel adviesgesprek met de minderjarige. In een groot deel van deze zaken lijkt het niet waarschijnlijk dat een adviesgesprek werd gehouden met de minderjarige omdat het beschermingsrapport dit anders zou hebben vermeld. In het Kwaliteitskader 2013 van de RvdK werden geen leeftijdsgrenzen genoemd maar in de praktijk leken die wel tot op zekere hoogte worden gehanteerd. Tot op zekere hoogte want de in 130 zaken waarin in het rapport niks werd vermeld over een adviesgesprek ging het deels om twaalf-minners en deels om twaalfplussers. Het ligt niet voor de hand dat de RvdK met alle kinderen een adviesgesprek houdt, zeker ten aanzien van de allerjongsten lijkt dit weinig zinvol. De uitkomst van de analyse doet echter twijfelen of kinderen net onder de twaalf en boven de twaalf wel standaard werden uitgenodigd voor een adviesgesprek door de RvdK. In ieder geval werd er in een ruime meerderheid van de geanalyseerde zaken niks over het adviesgesprek met de minderjarige vermeld in de rapportage waardoor ook onduidelijk is gebleven hoe de minderjarige tegen het verzoek aankeek.

\subsection{De rechtspositie van de minderjarige en zijn ouders tijdens de gerechtelijke procedure}

Voor dit deel van het dossieronderzoek is gekeken naar een aantal aspecten die onderdeel uitmaken van de rechtspositie van de minderjarige (en in mindere mate de ouders) tijdens de procedure bij de kinderrechter. Omdat de minderjarige in familierechtelijke procedures in beginsel procesonbekwaam is, krijgt zijn rechtspositie primair vorm door de uitoefening van het hoorrecht. Gekeken is hoe de vereisten ten aanzien van het hoorrecht van minderjarigen op grond van art. $809 \mathrm{Rv}$ en art. 12 IVRK in de praktijk werden ingevuld. Een belangrijke beperking van dit onderzoek is dat de informatie die is verkregen afkomstig is uit de (schriftelijke) beschikking op het verzoek tot ondertoezichtstelling/uithuisplaatsing. De vraag of de minderjarige werd gehoord en welke rol zijn mening speelde in de besluitvorming wordt beantwoord aan de hand van de informatie die in de beschikkingen is opgenomen. Omdat een beschikking qua inhoud beperkter is dan het proces-verbaal van de zitting en het ook niet uit te sluiten is dat niet altijd correct in de beschikking is weergegeven hoe de zitting precies is verlopen, moeten de bevindingen met de nodige voorzichtigheid worden geïnterpreteerd. Het is bijvoorbeeld zeer wel mogelijk dat de kinderrechter in het kindgesprek voorafgaand aan de 
zitting de minderjarige uitgebreid informeerde over de rol die zijn mening in de besluitvorming speelde maar dat de beschikking hier geen informatie over bevatte.

\subsubsection{Het horen van de minderjarige}

In de eerste plaats is voor de 200 zaken waarin een ondertoezichtstelling werd verzocht door de RvdK gekeken of de minderjarige overeenkomstig de vereisten van art. $809 \mathrm{Rv}$. in de gelegenheid werd gesteld om te worden gehoord. In de analyse is eerst gekeken of het in de zaak ging een minderjarige jonger dan twaalf jaar of twaalf jaar en ouder ten tijde van de zitting. Op grond van art. $809 \mathrm{Rv}$. kon de minderjarig jonger dan twaalf in de gelegenheid worden gesteld zijn mening kenbaar te maken op een door hem gekozen wijze. In de analyse is zichtbaar dat het 91 van de 200 zaken ging om een minderjarigen in de leeftijd tot twaalf jaar. In geen van de 91 zaken waarin het een minderjarige onder de twaalf jaar betrof, geeft de beschikking blijk van het feit dat het kind werd gehoord. Ook hier moet worden opgemerkt dat het voor een deel om zeer jonge of zelfs ongeboren kinderen ging waarbij horen respectievelijk weinig zinvol en feitelijk onmogelijk was. Voor de groep kinderen die de leeftijd van twaalf jaar naderden is het echter minder evident dat zij geen gebruik konden en wilden maken van het recht om te worden gehoord. Het dossieronderzoek geeft aanleiding te veronderstellen de groep twaalfminners in 2013 en 2014 niet actief werd uitgenodigd om zijn mening te geven in de gerechtelijke procedure. In het licht van art. 12 IVRK zou dat wel wenselijk zijn, aangezien voor minderjarigen onder de twaalf jaar de mogelijkheid dat zij gehoord wilden worden, feitelijk categorisch werd genegeerd.

Het dossieronderzoek bevat 109 zaken waarin de minderjarige twaalf jaar of ouder is op het moment van de zitting en hij daarom op grond van art. $809 \mathrm{Rv}$ in de gelegenheid moest worden gesteld om te worden gehoord. In 87 van de 109 zaken $(79,8 \%)$ werd de minderjarige blijkens de beschikking ook daadwerkelijk gehoord. In de meeste zaken werd in de beschikking expliciet aangegeven of de minderjarige was verschenen en gehoord. In enkele zaken vermeldde de beschikking alleen dat de minderjarige was verschenen. In de analyse is er vanuit gegaan dat deze minderjarigen werden gehoord, aangezien het onwaarschijnlijk is dat de minderjarige wel op de zitting verscheen, maar niet werd gehoord.

In 19 van de 109 zaken werd de minderjarige in gelegenheid gesteld om zijn mening kenbaar te maken maar maakte hij de keuze hier geen gebruik van te maken. De rechtbank voldeed daarmee aan zijn plicht op grond van art. $809 \mathrm{Rv}$. om de gelegenheid te bieden aan de minderjarige om te worden gehoord. In de overige 3 zaken bevatte de beschikking geen informatie over de vraag of de minderjarige was uitgenodigd, verschenen en gehoord. Het 
lijkt niet aannemelijk dat de minderjarigen in deze 3 zaken geen uitnodiging hebben ontvangen aangezien het standaard werkwijze is van de rechtbank minderjarigen van twaalf jaar en ouder hiervoor uit te nodigen, maar dit kan niet met zekerheid worden vastgesteld.

\subsubsection{De mening van de minderjarige in de beschikking}

De uitgangspunten op grond van art. 12 IVRK beperken zich niet tot het faciliteren van het hoorrecht van de minderjarige. Het uitgangspunt dat 'passend belang' moet worden gehecht aan de mening van de minderjarige impliceert dat de minderjarige wordt geïnformeerd over de rol die zijn mening in de besluitvorming heeft gespeeld en over de uitkomst van het proces. Het informeren van de minderjarige over de uitkomst van de procedure kan op verschillende manieren. De kinderrechter kan tijdens het kindgesprek aangeven of, en zo ja hoe de mening van de minderjarige meespeelt in zijn beoordeling en wellicht anticiperen op de uitkomst van het proces. Het is echter niet heel waarschijnlijk dat de kinderrechter na zijn uitspraak terugkoppelt aan de minderjarige wat met zijn mening is gedaan. Het opnemen van de mening van de minderjarige in de beschikking biedt daarom de mogelijkheid inzichtelijk te maken of, en zo ja hoe de mening van de minderjarige is meegewogen. Op deze manier kan de kinderrechter overeenkomstig art. 12 IVRK laten zien 'passend belang' te hechten aan de mening van de minderjarige.

In de analyse is voor de 200 zaken waarin een ondertoezichtstelling met of zonder uithuisplaatsing door de RvdK werd verzocht gekeken of de mening van de minderjarige door de kinderrechter bij zijn beoordeling in de beschikking werd betrokken. Uitkomst is dat de kinderrechter in 22 van de 200 geanalyseerde beschikkingen (11\%) expliciet aandacht besteedde aan de rol die mening van de minderjarige bij zijn beslissing heeft gespeeld. Nadere analyse van de beschikkingen waarin de mening van de minderjarige werd weergegeven laat zien dat het vaak hiermee wordt bijgedragen aan inhoudelijk goed onderbouwde beslissing zonder dat het direct ten koste hoeft te gaan van de kwaliteit van juridische argumentatie. Dat geldt in het bijzonder voor zaken waarin de rechter anders besloot dan de wens van de minderjarige. De beschikking biedt de mogelijkheid om de minderjarige van twaalf jaar en ouder inzicht te geven in de reden waarom zijn mening niet is gevolgd. Een aantal fraaie voorbeelden uit het dossieronderzoek laat zien op welke manier de mening van de minderjarige terug kwam in de beschikkingen:

\section{Voorbeeld 1}

'Ten aanzien van de machtiging uithuisplaatsing overweegt de kinderrechter dat de 
minderjarige gebaat is bij kamertraining waarbij zij intensieve begeleiding kan ontvangen en kan toewerken naar zelfstandigheid. De minderjarige heeft te kennen gegeven graag weer bij moeder te willen wonen en moeder stemt hiermee in. De kinderrechter twijfelt aan de standvastigheid van het standpunt van de minderjarige en moeder. Gebleken is dat zowel de minderjarige als moeder de laatste tijd wisselend zijn geweest in hun uitspraken. Daarnaast is sprake geweest van escalaties in de thuissituatie. De kinderrechter denkt dat de minderjarige thans is gebaat bij rust en stabiliteit.'

\section{Voorbeeld 2}

'Weliswaar stelt de minderjarige nu te willen meewerken aan de hulpverlening om zodoende een uithuisplaatsing te voorkomen, maar het is de kinderrechter gebleken dat hij in het verleden vaker een dergelijke belofte heeft gedaan, zonder deze belofte waar te maken. De minderjarige laat blijken niet gemotiveerd te zijn tot hulpverlening en erkent zijn problematische drugsgebruik niet. Naar het oordeel van de kinderrechter is de enige mogelijkheid de minderjarige tegen zichzelf in bescherming te nemen door hem weg te halen uit zijn omgeving en hem het drugsgebruik onmogelijk te maken.'

Het opnemen van de mening van de minderjarige in de beschikking is in het licht van de vereisten die voortvloeien uit art. 12 IVRK en in zekere zin ook art. 9 lid 2 IVRK, verheugend te noemen. De mening van de minderjarige moet serieus worden betrokken in de besluitvorming. Een cruciaal onderdeel hiervan is zoals besproken dat aan het kind wordt gecommuniceerd of, en zo ja op welke manier, zijn mening het besluitvormingsproces heeft beïnvloed. Door het includeren van de mening van de minderjarige in de beschikking laat de kinderrechter duidelijk blijken belang te hechten aan diens mening. Het is belangrijk te benadrukken dat er ook zaken zijn waarin de kinderrechter doelbewust de mening van de minderjarige buiten de beschikking laat om hem niet onnodig te belasten of te schaden. De visie van de minderjarige immers via de beschikking ook zichtbaar voor de ouders hetgeen de minderjarige in een kwetsbare en onwenselijke positie kan brengen. Gedacht kan worden aan jeugdbeschermingszaken waarin ook sprake is van conflicten inzake gezag en omgang. Het kind kan in dit geval klem zitten tussen de ouders en ingezet worden door de ouders om het geschil in hun voordeel te beslechten. 


\subsection{Tussenconclusie}

In dit hoofdstuk is gekeken naar de feitenvaststelling in het besluitvormingsproces en de rechtspositie van de minderjarige en zijn ouders tijdens het beschermingsonderzoek en in de gerechtelijke procedure. Hierdoor kan een zo compleet mogelijk beeld worden gegeven ten aanzien van de vraag hoe in de praktijk rechtvaardiging werd geboden voor de inzet van een ondertoezichtstelling/machtiging uithuisplaatsing. Ten aanzien van de feitenvaststelling door de $\mathrm{RvdK}$ is gekeken naar een aantal formele vereisten en naar de wijze waarop de informatie inhoudelijk werd verwerkt en geïnterpreteerd. Analyse van de 200 zaken die deel uitmaken van de steekproef laat zien dat de RvdK in vrijwel alle zaken de informatie verkregen van informanten accordeerde en voorzag van een datum. Hoewel dit geen garantie bood dat alle informatie ook correct was, is het een belangrijke kwaliteitswaarborg, aangezien hiermee kan worden voorkomen dat onjuiste en/of gedateerde informatie in de besluitvorming wordt meegenomen.

Vervolgens is in de analyse gekeken naar de wijze waarop de RvdK informatie interpreteerde en meer specifiek of hierbij een duidelijk onderscheid werd gemaakt tussen feiten en meningen. Hiervoor was het noodzakelijk om te komen tot een aantal criteria op basis waarvan informatie kon worden ingedeeld in feitelijke informatie en vermoedens of zorgen die niet met zekerheid konden worden bevestigd. Het komen tot deze criteria en het analyseren van de rapporten op deze wijze is een bijzonder complex proces gebleken. Het beschermingsrapport van de RvdK een mix is van informatie, soms heel concreet maar soms ook vaag. Dit maakt de informatie echter niet direct minder relevant voor de beoordeling van de noodzaak van een jeugdbeschermingsmaatregel. Het gaat er uiteindelijk om, zoals ook het Kwaliteitskader 2013 van de RvdK vermeldde dat feiten en meningen/vermoedens van elkaar zijn gescheiden en dat duidelijk is wat de RvdK met deze informatie doet. De analyse heeft laten zien dat de $\operatorname{RvdK}$ in $(92,5 \%)$ van de zaken de informatie op een juiste manier interpreteerde, waarmee wordt bedoeld dat informatie niet stelliger werd geïnterpreteerd dan op basis van de informatie in rapport toelaatbaar was. Slechts in een klein deel van de zaken werd informatie niet geheel juist geïnterpreteerd door de RvdK. Dat is op zichzelf een hoopgevend resultaat gezien het feit dat de RvdK in het rapport geen zichtbaar onderscheid maakte tussen feitelijke (harde gegevens) en niet-feitelijke informatie (zachte gegevens). Het hing derhalve primair van de interpretatie van de betreffende raadsonderzoeker af of juist werd ingeschat hoe stevig de conclusies konden zijn op basis de verzamelde informatie. $\mathrm{Nu}$ is al aangegeven hoe lastig dit onderscheid is te maken en het is wellicht ook niet werkbaar voor 
raadsonderzoekers om steeds in de rapporten dit onderscheid aan te geven. Maar dit onderzoek zou wel aanleiding kunnen zijn voor de RvdK om concreter na te denken over de wijze waarop de waardering van informatie systematischer plaats kan vinden. Puur waar het gaat om de waardering van informatie zou wellicht nadrukkelijker gekeken kunnen worden naar publiekrechtelijk georiënteerde rechtsgebieden (zoals het strafrecht), waar het tot de kern van het besluitvormingsproces behoort om het aangedragen bewijs te waarderen. Voor de uiteindelijke uitkomst van die waardering is dit niet zinvol omdat de bewijsstandaard niet gelijk is. In het jeugdbeschermingsrecht hoeft niet wettig en overtuigend aangetoond te worden dat een concreet handelen of nalaten zich heeft voorgedaan

Tot slot is gekeken naar de positie van de minderjarige en de ouders waarbij de nadruk lag op de invulling van het hoorrecht van de minderjarige en de wijze waarop hij werd geïnformeerd over de besluitvorming. Wat betreft het horen van de minderjarige zijn zowel tijdens het beschermingsonderzoek door de RvdK als in de gerechtelijke procedure aandachtspunten gesignaleerd. Zo is in een (klein) deel van de geanalyseerde zaken niet duidelijk of de minderjarige is gehoord door de RvdK, terwijl het beschermingsrapport hier informatie over zou moeten bevatten. Wat betreft het horen in de gerechtelijke procedure is de belangrijkste bevinding dat van de 91 minderjarigen onder de twaalf jaar binnen de steekproef, geen enkele minderjarige is gehoord door de kinderrechter. Dit bevestigt het beeld uit eerder onderzoek en uit de praktijk dat minderjarigen onder de twaalf jaar maar zeer incidenteel werden gehoord. De grootste tekortkomingen zijn echter zichtbaar geworden op het vlak van het betrekken van de (mening van de) minderjarige in de besluitvorming. In veel van de geanalyseerde beschermingsonderzoeken was het onduidelijk of een adviesgesprek met de minderjarige werd gehouden en daardoor ook onduidelijk hoe de minderjarige tegen het verzoek aankeek. Daarnaast is zichtbaar de kinderrechters nog maar beperkt gebruik maakten van de mogelijkheid om de mening van de minderjarige te betrekken bij de inhoudelijke overwegingen in de beschikking. 


\section{Conclusies dossieronderzoek naar de rechtvaardiging van jeugdbescherming in de jaren $2013-2014$}

\subsection{Inleiding}

De rechtvaardiging in algemene zin voor de inzet van een jeugdbeschermingsmaatregel kan worden gevonden in de noodzaak de minderjarige te beschermen tegen invloeden die schadelijk zijn of kunnen zijn voor zijn belangen. Deze taak komt primair toe aan de ouders die de verantwoordelijkheid dragen voor de verzorging en opvoeding van de minderjarige. Indien de ouders er niet in slagen om de minderjarige de noodzakelijke zorg en bescherming te bieden, rust op de overheid de verplichting om - rekening houdend met de rechten en plichten van de ouders - de minderjarige te verzekeren van de bescherming en zorg die noodzakelijk is voor zijn welzijn (art. 3 lid 2 IVRK). In eerste instantie moet worden getracht vrijwillig, in samenwerking met het gezin, de belangen van de minderjarige veilig te stellen. Het met dwang ingrijpen in de gezinssituatie heeft te gelden als ultimum remedium. Slechts indien op basis van vrijwilligheid de ernstige bedreiging van de belangen van de minderjarige niet weg kan worden genomen, dan kan de inzet van een ondertoezichtstelling en uithuisplaatsing gerechtvaardigd zijn.

Door de inzet van een jeugdbeschermingsmaatregel wordt inbreuk gemaakt op het familie- en gezinsleven van de minderjarige en zijn ouders. Deze inbreuk vraagt om rechtvaardiging aan de zijde van de overheid in juridisch opzicht. In dit deel van het onderzoek is gekeken naar de juridische rechtvaardiging door de RvdK in het beschermingsrapport en de kinderrechter in de beschikking. Het begrip 'juridische rechtvaardiging' is nader ingekleurd door onderscheid te maken tussen drie met elkaar samenhangende componenten die cruciaal zijn in de besluitvorming over de noodzaak van een ondertoezichtstelling en uithuisplaatsing. In de eerste plaats is gekeken naar de vraag wanneer en met welk doel ingegrepen kan worden in het gezinsleven van de minderjarige en zijn ouders. Dit kan worden afgeleid uit de wettelijke gronden en doelstellingen zoals opgenomen in Boek 1 Burgerlijk Wetboek, toepasselijk verdragsrecht, waarbij voor dit onderzoek met name art. 8 EVRM (het recht op familie- en gezinsleven) en relevante bepalingen uit het IVRK van belang zijn, en de uitwerking van deze vereisten in het interne Kwaliteitskader van de RvdK. Ten tweede is vastgesteld dat de zorgvuldigheid waarmee het feitenonderzoek wordt uitgevoerd een essentieel element is voor de rechtvaardiging van een jeugdbeschermingsmaatregel. Het op een zorgvuldige manier verzamelen, selecteren en interpreteren van de informatie in het beschermingsonderzoek moet 
eraan bijdragen dat de beslissing een maatregel te verzoeken wordt genomen op basis van een navolgbare en correcte weergave van de onderzoeksgegevens. De zorgvuldigheid waarmee het feitenonderzoek wordt uitgevoerd wordt in belangrijke mate bepaald door de wettelijke regels van bewijsrecht in civiele zaken en interne kwaliteitscriteria voor zorgvuldig onderzoek van de RvdK. Ten derde kan de vraag hoe de rechtvaardiging van jeugdbeschermingsmaatregelen in de praktijk is vormgegeven niet los worden gezien van de mate waarin recht wordt gedaan aan de (rechts)positie van de minderjarige en zijn ouders in de procedure bij de RvdK en in de gerechtelijke procedure. De rechtspositie van de minderjarige tijdens het beschermingsonderzoek en in de gerechtelijke procedure behoort primair invulling te krijgen door de uitoefening van het hoorrecht en de eis op basis van verdragsrecht dat de (mening van de) minderjarige voldoende moet worden betrokken in de besluitvorming.

In deel I van het onderzoek zijn de belangrijkste uitgangspunten en concrete eisen beschreven die in 2013 en 2014 golden voor de juridische rechtvaardiging van de ondertoezichtstelling en uithuisplaatsing. Deze uitgangspunten op basis van wet- en regelgeving en verdragsrecht vormen de basis voor het analysekader dat is gebruikt in deel II van het onderzoek. In het tweede deel van het onderzoek heeft een systematische analyse van dossiers van de RvdK plaatsgevonden, waarin de RvdK een verzoek tot ondertoezichtstelling met of zonder machtiging uithuisplaatsing heeft ingediend. De aselecte steekproef voor het dossieronderzoek omvat 200 zaken waarin ten aanzien van een minderjarige een ondertoezichtstelling is verzocht. In 100 van de 200 zaken gaat het om een verzoek ondertoezichtstelling gecombineerd met een verzoek tot machtiging uithuisplaatsing. De analyse heeft zich beperkt tot de schriftelijke onderbouwing door de RvdK en de kinderrechter, hetgeen betekent het door de RvdK opgestelde rapport beschermingszaken en de beschikking van de kinderrechter op het verzoek. Het onderzoek richt zich op dossiers van de RvdK uit 2013 en 2014 met als belangrijke consequentie dat het analysekader en de analyse zelf is uitgevoerd aan de hand van de regels die van toepassing waren op jeugdbeschermingszaken tot aan de wettelijke herziening van het jeugdbeschermingsrecht op 1 januari 2015. De delen I en II van het onderzoek kunnen daarom getypeerd worden als een terugblik, waarmee inzichtelijk wordt gemaakt hoe de rechtvaardiging van jeugdbescherming in de betreffende periode vorm kreeg.

In het vervolg van de conclusie worden de bevindingen van de delen I en II van het onderzoek per onderdeel uitgewerkt. In paragraaf 9.2 worden de conclusies ten aanzien van de 
rechtvaardiging van de ondertoezichtstelling beschreven. In paragraaf 9.3 worden de conclusies uitgewerkt ten aanzien van de rechtvaardiging van de uithuisplaatsing. In paragraaf 9.4 worden de resultaten besproken van de analyse van zaken waarin een machtiging gesloten jeugdzorg werd verzocht. In paragraaf 9.5 wordt gereflecteerd op de bevindingen met betrekking tot de zorgvuldigheid van het feitenonderzoek door de RvdK. Vervolgens worden in paragraaf 9.6 de belangrijkste uitkomsten besproken van de analyse waar het gaat om de rechtspositie van de minderjarige en zijn ouders. Het deel van het onderzoek gericht op het jeugdbeschermingsrecht in de jaren 2013 en 2014 wordt afgesloten in paragraaf 9.7, waarin de belangrijkste knel- en aandachtspunten met met betrekking tot de rechtvaardiging van jeugdbescherming voor deze periode op hoofdlijnen worden benoemd.

\subsection{Rechtvaardiging van de ondertoezichtstelling}

Om de vraag te beantwoorden of de rechtvaardiging van de ondertoezichtstelling zoals vormgegeven door de RvdK en de kinderrechter in overeenstemming was met de toen geldende regels op grond van (inter)nationale wet- en regelgeving, zijn de belangrijkste uitgangspunten die konden worden ontleend aan de rechtsgrond van de ondertoezichtstelling en de wettelijke doelstelling beschreven. De conclusies ten aanzien van de wijze waarop de gronden werden toegepast en de wettelijke doelstelling inhoudelijk invulling kreeg worden in het vervolg toegelicht.

\section{Toetsing gronden ondertoezichtstelling door de RvdK}

Gestart is met de eerste cumulatieve grond voor oplegging van de ondertoezichtstelling op grond van art. 1:254 lid 1 oud BW: het vereiste dat de minderjarige 'zodanig opgroeit dat hij ernstig in zijn zedelijke of geestelijke belangen of gezondheid wordt bedreigd'. Aangezien de rechtsgrond van de ondertoezichtstelling op dit punt een open formulering kende moest invulling van hetgeen onder een 'ernstige bedreiging van de zedelijke of geestelijke belangen of gezondheid van de minderjarige' werd verstaan worden ingevuld door de RvdK en de kinderrechter aan de hand van de feiten en omstandigheden van het geval. Om te voorkomen dat bedreiging van de minderjarige onvoldoende concreet zou worden onderbouwd door de RvdK, moesten verschillende stappen worden gezet in de besluitvorming. In ieder geval diende de RvdK een concrete beschrijving te geven van de zorgen op kindniveau en het niveau van de opvoedingsomgeving en moest worden beargumenteerd waarom deze zorgen gelet op de belangen van de minderjarige direct ingrijpen noodzakelijk maakte. 
Ernstige bedreiging van de zedelijke of geestelijke belangen of gezondheid van de minderjarige

De analyse van dossiers heeft laten zien dat het beschrijven van de zorgen in het gezin door de RvdK tot de kern van ieder beschermingsonderzoek hoorde. Een substantieel deel van de beschermingsrapportage werd ingevuld met het beschrijven van de zorgen, waarbij het onderscheid tussen zorgen op kindniveau en zorgen op het niveau van de opvoedingsomgeving consequent werd aangehouden. In vrijwel alle geanalyseerde zaken (199 van de 200 - 99,5\%) werd door de RvdK een overzicht gegeven van de zorgpunten op kindniveau en/of op het niveau van de opvoedingsomgeving. In de enige zaak waarin dit niet gebeurde werd afgeweken van het rapportageformat op basis waarvan de raadsonderzoeker de zorgpunten behoorde te beschrijven.

Vervolgens is geanalyseerd welke zorgpunten op kind- en ouderniveau door de RvdK werden geconstateerd in de 200 zaken binnen de steekproef. De vraag welke zorgen werden gevonden door de RvdK is belangrijk omdat op basis hiervan inhoudelijk invulling werd gegeven aan de ernstige bedreiging van de zedelijke of geestelijke belangen of gezondheid van de minderjarige. Een overzicht van deze zorgen geeft tevens de mogelijkheid om te onderzoeken of er situaties waren waarin het lastiger was voor de RvdK om concreet en overtuigend aan te tonen dat de zorgen een ernstige bedreiging van de belangen van de minderjarige tot gevolg hadden. De analyse van dossiers heeft laten zien dat in een groot deel van de zaken (166 van de 200 - 83\%) zowel zorgpunten op kindniveau als op het niveau van de opvoedingsomgeving werden gevonden. Dit is een logische uitkomst nu het functioneren van de ouders in de regel invloed heeft op het functioneren van de minderjarige, en andersom.

Het zijn echter juist de zaken waarin alleen zorgpunten op kindniveau of alleen zorgpunten op ouderniveau werden beschreven die om extra aandacht vragen. In de eerste plaats is zichtbaar dat het vrijwel nooit voorkwam dat de zorgen puur aan de minderjarige werden toegeschreven. In de steekproef zijn maar 4 zaken gevonden (2\% van het totaal) aangetroffen waarin de RvdK heeft geconcludeerd dat ten aanzien van het functioneren van de ouders op pedagogisch vlak geen zorgen konden worden vastgesteld. De wetgever heeft de principiële keuze gemaakt in de rechtsgrond van de ondertoezichtstelling te verwijzen naar de opvoedingsomgeving in algemene zin en niet specifiek naar het functioneren van de ouders met gezag. Belangrijkste argument voor deze keuze was dat de mogelijkheid open gelaten moest worden dat ouders op geen enkele wijze door hun handelen of nalaten hadden bijgedragen aan het ontstaan of in standhouden van de ernstige bedreiging. De dossieranalyse 
laat zien dat dit niet was uitgesloten, maar wel zeer uitzonderlijk was. Vrijwel altijd werden een of meerdere zorgen ten aanzien van de ouders gevonden, hetgeen ook logisch lijkt nu de ondertoezichtstelling een deel van de verantwoordelijkheid voor de verzorging en opvoeding bij de ouders wegneemt. De situatie waarin geen zorgen werden gemeld ten aanzien van het functioneren van de minderjarige, maar alleen op ouderniveau kwam vaker voor in de steekproef (29 van de 199 zaken waarin zorgpunten werden genoemd - 14,6\%).

De laatste stap die gezet moest worden door de RvdK was de vertaling van zorgpunten naar de bedreiging van de zedelijke of geestelijke belangen of gezondheid van de minderjarige. Ook als zorgen werden geconstateerd moest nog steeds worden aangetoond dat die zorgen ook zodanig waren dat er een bedreiging van de belangen van de minderjarige aanwezig was. Uit de analyse is naar voren gekomen dat de RvdK in 191 van de 200 zaken (95,5\%) expliciet antwoord gaf op de vraag waarom de geconstateerde zorgen een ernstige bedreiging van de zedelijke of geestelijke belangen of gezondheid van de minderjarige opleverden. Opvallend is in vrijwel alle zaken waarin de bedreiging niet of onvoldoende concreet werd benoemd, alleen zorgpunten werden gevonden op het niveau van de opvoedingsomgeving. Het is voorstelbaar dat eenvoudiger is te beargumenteren waarom er een bedreiging is als de minderjarige ook aantoonbaar problematisch functioneert. Juist in de zaken waarin de zorgpunten exclusief op het niveau van de opvoedingsomgeving worden gevonden zou de RvdK extra kritisch moeten kijken of er wel sprake is van een acute en reeële bedreiging van de minderjarige. In verschillende zaken lijkt dit onvoldoende te gebeuren. Met name is daarbij opgevallen dat in zaken waar scheidingsproblematiek speelde soms door de RvdK werd gewezen op problemen in het functioneren van de minderjarige, voortkomend uit de scheidingsproblematiek, die op latere leeftijd zouden kunnen gaan spelen. Dat lijkt, als er geen sprake is van bijkomende problematiek, onvoldoende om tot een reeële bedreiging van de belangen van de minderjarige te komen.

\section{Het (voorzienbaar) falen van andere middelen}

De tweede cumulatieve grond voor oplegging van een ondertoezichtstelling op grond van art. 1:254 lid 1 oud BW bood de mogelijkheid om de rechtmatigheid van de maatregel concreet te toetsen. Voor de analyse is als uitgangspunt gehanteerd dat in iedere zaak door de RvdK moest worden aangetoond dat andere middelen nadrukkelijk waren overwogen of geen/onvoldoende resultaat hadden opgeleverd, om de noodzaak van een ondertoezichtstelling aan te kunnen tonen. De rechtvaardiging van de ondertoezichtstelling 
was dan gelegen in het feit dat overtuigend kon worden aangetoond dat de middelen in het vrijwillig kader waren uitgeput.

De analyse heeft laten zien dat de RvdK in 183 van de 200 geanalyseerde zaken (91,5\%) expliciet aandacht besteedde aan het resultaat van de eerder ingezette hulpverlening. Hoewel dit deel van de rechtsgrond dus in het overgrote deel van geanalyseerde zaken wel inhoudelijk werd ingevuld, blijft de beoordeling van de RvdK iets achter bij de onderbouwing van de bedreiging. Er moest aantoonbaar zijn voldaan aan beide gronden voor de ondertoezichtstelling zoals opgenomen in art. 1:254 lid 1 oud BW. Daarnaast was veel concreter en objectiever vast te stellen of vrijwillige hulp was ingezet of overwogen, dan de vaststelling ten aanzien van de ernstige bedreiging van de zedelijke of geestelijke belangen of gezondheid van de minderjarige. Een mogelijke verklaring voor het ontbreken van een inhoudelijke toelichting van de RvdK is dat soms teveel werd gefocust op de problematiek van de minderjarige ten tijde van het raadsonderzoek en de middelen die na het uitspreken van de ondertoezichtstelling nodig zouden zijn. Hierdoor werd er, kort gezegd, soms onvoldoende teruggekeken naar het resultaat van de vrijwillige hulp tot op dat moment.

\section{Toetsing gronden ondertoezichtstelling door de kinderrechter}

In het onderzoek is de vraag gesteld wat qua motivering in de beschikking minimaal mocht worden verwacht van de kinderrechter. De motiveringsplicht van de rechter in civiele zaken volgde uit art. 30 Rv. en art. 6 EVRM en was volgens de Hoge Raad een cruciaal onderdeel van een behoorlijke rechtspleging. Dit betekende niet per definitie dat op basis van voornoemde vereisten iedere zaak uitgebreid inhoudelijk moest worden gemotiveerd. De wet verbood niet expliciet het gebruik van standaardmotiveringen door de kinderrechter. In jeugdbeschermingszaken is heel lang het beeld geweest dat werd volstaan met standaardmotiveringen in de beschikking, hetgeen betekende dat de wettelijke gronden werden herhaald zonder inhoudelijke koppeling aan de feiten en omstandigheden van de zaak. Als uitgangspunt voor het dossieronderzoek is gehanteerd dat voor een gedegen rechtvaardiging van de ondertoezichtstelling de kinderrechter tenminste inhoudelijk zou moeten aangeven waar de bedreiging van de belangen van de minderjarige uit bestond en waarom andere middelen (vrijwillige hulpverlening) onvoldoende waren om de belangen van de minderjarige veilig te stellen. Beide elementen zijn afzonderlijk van elkaar geanalyseerd. Ten aanzien van de eerste grond heeft de analyse van beschikkingen laten zien dat in 135 van de 200 zaken $(67,5 \%)$ de bedreiging van de zedelijke of geestelijke belangen of gezondheid van de minderjarige concreet werd uitgewerkt. In de overige 65 zaken werd ten aanzien van 
de bedreiging alleen de rechtsgrond van de ondertoezichtstelling als in art. 1:254 lid 1 oud BW herhaald. In een groot deel van zaken waarin door de kinderrechter werd gewerkt met een standaardmotivering werd geen verweer gevoerd tegen het verzoek tot ondertoezichtstelling. Dit laat echter onverlet dat het beschrijven van de concrete zorgen ten aanzien van de minderjarige in de beschikking belangrijk is, ook als de betrokkenen instemmen met het verzoek.

Ten aanzien van de tweede grond heeft de analyse laat zien dat het falen of voorzienbaar falen van andere middelen beduidend minder vaak inhoudelijk werd getoetst door de kinderrechter, dan de toets met betrekking tot de ernstige bedreiging van de belangen van de minderjarige. Slechts in 69 van de 200 geanalyseerde beschikkingen (34,5\%) werd inhoudelijk de noodzaak van een ondertoezichtstelling onderbouwd door aandacht te besteden aan de pogingen tot hulpverlening die in het vrijwillig kader waren ondernomen. Voor de rechtvaardiging van de ondertoezichtstelling was een inhoudelijk argumentatie op dit punt belangrijk, juist omdat de noodzaak van de maatregel concreet getoetst kon worden. De analyse van dossiers laat dit ook zien als wordt gekeken naar de zaken waarin de kinderrechter het verzoek tot ondertoezichtstelling afwees. In 9 van de 200 zaken (4,5\%) kwam de kinderrechter tot een afwijzing van het verzoek en in alle 9 zaken op basis van de conclusie dat niet overtuigend was aangetoond dat andere middelen hadden gefaald, of naar was te voorzien, zouden falen. Hiermee is aangetoond dat de tweede cumulatieve grond zoals opgenomen in art. 1:254 lid 1 oud BW een belangrijke rol speelde bij de vraag of een ondertoezichtstelling was aangewezen. Het ligt voor de hand dat de kinderrechters voorzichtiger waren met hun oordeel over de ernstige bedreiging van de zedelijke of geestelijke belangen of gezondheid van de minderjarige. Ten eerste omdat het een open norm betrof (dus het ontbrak de kinderrechter grotendeels aan objectieve criteria om te bepalen of was voldaan aan deze grond). En ten tweede omdat het oordeel over belangen van de minderjarige primair een pedagogisch oordeel was, waardoor mag worden aangenomen dat de kinderrechter zich op dit punt terughoudender opstelde en zijn oordeel primair baseerde op het standpunt van de RvdK hierover. Het oordeel over het resultaat van eerder ingezette vrijwillige hulpverlening was concreter te maken en kon daarom het gebrek aan houvast ten aanzien het oordeel over de belangen van de minderjarige deels 'compenseren'. Het dossieronderzoek heeft laten zien dat dit onvoldoende gebeurde. 
Het stellen van doelen voor de ondertoezichtstelling

In de jaren 2013 en 2014 gaf art. 1:257 lid 1 oud BW aan dat de ondertoezichtstelling gericht moest zijn op het houden van toezicht op de minderjarige en het bieden van hulp en steun aan de minderjarige en de met gezag belaste ouder teneinde de bedreiging in de zedelijke of geestelijke belangen of de gezondheid van de minderjarige af te wenden. Het houden van toezicht en het bieden van hulp en steun was primair gericht op de minderjarige hetgeen ook veronderstelde dat alle doelen die gesteld werden in het kader van de ondertoezichtstelling uiteindelijk in het teken moesten staan van het hoofddoel van de maatregel: het wegnemen van de ernstige bedreiging. Voor de analyse is als uitgangspunt gehanteerd dat de RvdK binnen het kader van de zojuist geschetste wettelijke doelstelling van de ondertoezichtstelling, moest komen tot concrete doelen die binnen de maatregel moesten worden behaald. Voor de rechtvaardiging van de ondertoezichtstelling was dit van belang aangezien het de betrokkenen meer zekerheid zou bieden ten aanzien van de vraag hoe de bedreiging kon worden weggenomen en met welk perspectief de hulpverlening werd ingezet. Bovendien werd door het stellen van een hulpverleningsperspectief de kans op een doelmatige uitvoering van de ondertoezichtstelling vergroot. In het rapportageformat van de RvdK voor het onderzoek in beschermingszaken was de vraag opgenomen welke doelen moesten worden behaald om de ontwikkelingsperspectieven van de minderjarige veilig te stellen.

De analyse van de wijze waarop in het beschermingsrapport doelen werden gesteld door de RvdK heeft laten zien dat in het overgrote deel van de geanalyseerde zaken doelen werden gesteld. In 185 van de 200 zaken (92,5\%) was tenminste één doel opgenomen, maar in de regel ging het om een behoorlijke lijst met doelen voor de uitvoering van de ondertoezichtstelling. In algemene zin zijn daarbij wel een aantal dingen opgevallen ten aanzien van de inhoud van de gestelde doelen. In de eerste plaats is zichtbaar dat de doelen vaak zeer algemeen werden geformuleerd, een uitkomst die aansluit bij de bevindingen ten aanzien van het stellen van doelen voor de ondertoezichtstelling in eerder onderzoek. ${ }^{646}$ Doelen als 'de minderjarige zit lekker in zijn vel', 'ouders moeten hun verantwoordelijkheid nemen' of zelfs 'de ontwikkelingsbedreiging wordt weggenomen', kwamen geregeld terug in de beschermingsrapporten. Verder is opgevallen dat de geformuleerde doelen soms gericht waren op het verbieden van bepaald gedrag of het opheffen van een onwenselijke situatie. In een ideale situatie geven de geformuleerde doelen het verschil weer tussen een ernstig bedreigde ontwikkeling en een adequaat verlopende ontwikkeling. Echter, in plaats van

\footnotetext{
${ }^{646}$ Slot e.a. 2002.
} 
doelen gericht op de gewenste ontwikkelingsuitkomst ging het vaak om dingen die de ouders en minderjarige niet meer zouden moeten doen, zoals stoppen met spijbelen of het staken van de echtscheidingsstrijd. Het risico hiervan is dat een doel wel zou worden behaald maar de bedreiging niet is weggenomen omdat het doel niet duidelijk aangeeft wat nodig is voor hiervoor. In het verlengde daarvan is zichtbaar in de analyse dat doelen en middelen (mogelijk onbedoeld) door elkaar heen liepen in de rapportage. Het ging dan om doelen als 'er moet hulpverlening ingezet worden', zonder dat het beoogde resultaat daarvan werd weergegeven.

In eerder onderzoek is primair gekeken naar het stellen van doelen in de uitvoering van de maatregel van ondertoezichtstelling. In dit onderzoek is benadrukt dat het stellen van concrete doelen ook belangrijk is in het onderzoek van de RvdK, in de fase waarin er (nog) geen maatregel is. Een lijst met vage, niet-toetsbare doelen levert voor de minderjarige en zijn ouders een situatie op waarin onvoldoende duidelijk is waaraan moet worden gewerkt om de ernstige bedreiging weg te nemen. De analyse van dossiers onderzoek heeft laten zien dat het de RvdK wel vrij consequent lukte aan de hand van zorgpunten te laten zien waaruit de ernstige bedreiging van de belangen van de minderjarige bestond. Het zou dan ook mogelijk moeten zijn een betere verbinding te leggen tussen de bedreiging en de gewenste ontwikkelingsuitkomst.

\subsection{Rechtvaardiging van de uithuisplaatsing}

Een van de meest ingrijpende middelen om de belangen van de minderjarige te beschermen is het verlenen van een machtiging uithuisplaatsing. Onder oude wetgeving kon de minderjarige dag en nacht uit huis worden geplaatst indien dit noodzakelijk was in het belang van de verzorging en opvoeding van de minderjarige, of tot onderzoek naar diens geestelijke of lichamelijke gesteldheid (art. 1:261 lid 1 oud BW). Waar het ging om de scheiding van kind en ouders speelden de vereisten op basis van toepasselijk verdragsrecht ook toen al een belangrijke rol in de besluitvorming. Deze vereisten konden in zekere zin het gebrek aan concrete criteria op basis van nationale wetgeving compenseren. Zo werd in de wet niet nader gespecificeerd hoe de noodzaak van een uithuisplaatsing moest worden aangetoond en ontbrak een wettelijke doelstelling in het Burgerlijk Wetboek voor de uithuisplaatsing. Op basis van het art. 8 EVRM neergelegde recht op familie- en gezinsleven zijn voor de analyse een aantal aanvullende uitgangspunten geformuleerd die essentieel zijn voor de rechtvaardiging van de uithuisplaatsing. Het EHRM heeft onder meer gesteld dat van een uithuisplaatsing enig positief effect te verwachten moet zijn en dat een scheiding van kind en ouders niet slechts wenselijk, maar noodzakelijk is voor het wegnemen van de 
ontwikkelingsbedreiging. Deze noodzaak kan slechts overtuigend worden aangetoond indien de autoriteiten laten zien dat alternatieven om de uithuisplaatsing te voorkomen zijn ingezet of in ieder geval nadrukkelijk zijn overwogen. Met betrekking tot de doelstelling heeft het EHRM benadrukt dat een uithuisplaatsing een tijdelijke maatregel is die zodra de omstandigheden het toelaten moet worden beëindigd. Op de autoriteiten rust de verplichting om maatregelen te nemen met als doel hereniging van kind en ouder, hetgeen ook veronderstelt dat in de besluitvorming over een uithuisplaatsing wordt geanticipeerd op de stappen die genomen moeten worden voor een terugkeer van de minderjarige naar de ouders.

In de analyse is gekeken of deze uitgangspunten in de besluitvorming van de RvdK en de kinderrechter terugkwamen. Daarnaast is gestart met een analyse van het indicatiebesluit als noodzakelijke voorwaarde voor de toekenning van een machtiging uithuisplaatsing. In totaal zijn 100 zaken geanalyseerd waar naast het verzoek tot ondertoezichtstelling een machtiging uithuisplaatsing werd verzocht door de RvdK. In 82 van de 100 zaken ging het om een reguliere machtiging uithuisplaatsing op grond van art. 1:261 oud BW in een pleeggezin of residentiële instelling. In 18 van de 100 zaken ging het om een verzoek machtiging uithuisplaatsing in een accommodatie voor gesloten jeugdzorg. De wijze waarop door de RvdK en de kinderrechter werd omgegaan met de aanvullende wettelijke vereisten voor een gesloten plaatsing is apart geanalyseerd.

\section{Het indicatiebesluit}

In de analyse is eerst gekeken of een indicatiebesluit werd overlegd door de RvdK. Het indicatiebesluit betrof de formele vaststelling dat een cliënt was aangewezen op geïndiceerde zorg en beoogde daarnaast bij te dragen aan de motivering van de noodzaak van een uithuisplaatsing. De RvdK moest als verzoeker van een machtiging uithuisplaatsing overleggen op grond van art. 1:261 lid 2 oud BW indien sprake was van geïndiceerde zorg. Daarvan was in dit onderzoek sprake in 94 van de 100 geanalyseerde zaken. In 6 van de 100 zaken ging het om een plaatsing bij de andere ouder met of zonder gezag en werd alleen de gewenste verblijfplaats in de machtiging vermeld. De analyse van de indicatiebesluiten is lastig gebleken omdat van de 94 zaken waarin een indicatiebesluit noodzakelijk was, er slechts 57 zijn gevonden in het registratiesysteem van de RvdK. Voor het ontbreken van een indicatiebesluit in de overige (37) zaken kunnen verschillende redenen worden aangedragen. In de eerste plaats is in de beschikking zichtbaar dat wel een indicatiebesluit werd ingediend maar deze niet was terug te vinden in het registratiesysteem. Daarnaast ontbrak soms een indicatiebesluit omdat er sprake was van een netwerkplaatsing bij een ander dan de ouder met 
gezag. Het dossieronderzoek laat zien dat hier wisselend mee werd omgegaan door de RvdK. In sommige gevallen werd expliciet aangegeven dat voor plaatsing binnen het netwerk geen indicatiebesluit was vereist. In andere zaken werd voor een vergelijkbare plaatsing, bijvoorbeeld bij een oma of tante, wel gewoon een indicatiebesluit bij het verzoek machtiging uithuisplaatsing gevoegd.

Vervolgens is gekeken of de indicatiebesluiten die wel werden aangetroffen voldeden aan de inhoudelijke eisen die werden gesteld voor een indicatiebesluit op grond van art. 6 lid $1 \mathrm{Wjz}$. Het indicatiebesluit moest een beschrijving bevatten van de problematiek; de ernst en mogelijke oorzaken daarvan; een beschrijving van de benodigde zorg en het beoogde doel; de termijn waarbinnen de aanspraak op zorg moest zijn verzilverd en advies over de coördinatie en uitvoering van de zorg. Het dossieronderzoek laat zien dat de indicatiebesluiten die zijn geraadpleegd in vrijwel alle gevallen voldeden aan voornoemde wettelijke vereisten.

De vraag die naar aanleiding van de analyse is gesteld, is wat inhoudelijk de toevoegde waarde van het indicatiebesluit inhoudelijk was. Het weergeven van de geconstateerde problematiek van de minderjarige en het schetsen van een hulpverleningsperspectief met de doelen die moesten worden behaald gebeurde ook in het beschermingsrapport van de RvdK en dan vaak veel concreter en uitgebreider. De belangrijkste functie leek daarom het regelen van de toegang tot de geïndiceerde zorg (en de financiering daarvan). Maar hiervoor was het verkrijgen en opstellen van een indicatiebesluit wel een een tijdrovend administratief proces. Van een waarborgfunctie tegen ongerechtvaardigde inbreuk op de rechten van de minderjarige en zijn ouders is in dit onderzoek niet gebleken, aangezien inhoudelijk geen afwegingen werden gemaakt die aanvullend waren ten opzichte van de besluitvorming in het beschermingsrapport van de RvdK.

\section{De toetsing van de noodzaak tot uithuisplaatsing door de RvdK}

Zoals besproken gold in algemene zin dat een scheiding van kind en ouders door een uithuisplaatsing slechts was toegestaan als overtuigend werd aangetoond dat minder ingrijpende alternatieven niet (meer) mogelijk waren. Voor de rechtvaardiging van de uithuisplaatsing was het noodzakelijk dat de RvdK als verzoeker een uitgebreide en concrete onderbouwing gaf ten aanzien van de gevraagde machtiging, waarbij nadrukkelijk aandacht werd besteed aan minder ingrijpende alternatieven om de uithuisplaatsing te voorkomen. 
De analyse heeft geleid tot de conclusie dat van een diepgaande onderbouwing door de RvdK van de noodzaak tot uithuisplaatsing, zoals vereist was op grond van art. 1:261 oud BW en art. 8 EVRM, geen sprake was. In het beschermingsrapport was een groot aantal onderzoeksvragen gesteld die gericht waren op de ondertoezichtstelling. De aandacht voor de verzochte machtiging uithuisplaatsing stak daar schril bij af. De analyse heeft uitgewezen dat in veel zaken werd volstaan met enkele korte zinnen waarin stond dat het beter was voor de minderjarige om elders te worden geplaatst.

Dit gebrek aan onderbouwing is ook concreet zichtbaar geworden als wordt gekeken naar de vraag of de RvdK aandacht besteedde aan de alternatieven ter voorkoming van de uithuisplaatsing. In 40,2\% van de geanalyseerde zaken werd geen aandacht besteed aan de vraag waarom niet kon worden volstaan met minder ingrijpende alternatieven. Wel zijn duidelijke verschillen zichtbaar als wordt gekeken naar de inhoudelijke onderbouwing. Dat varieerde van het zonder inhoudelijke toelichting noemen dat een machtiging uithuisplaatsing werd verzocht tot het specifiek uitwerken waarom een bepaalde machtiging werd gevraagd. In het laatste geval was soms indirect nog wel af te leiden waarom minder ingrijpende alternatieven niet mogelijk waren.

Het is de vraag waarom de motivering in de beschermingsrapporten ten aanzien van de noodzaak van een machtiging uithuisplaatsing op dit punt zo summier was. Wellicht hangt het samen met het feit dat de machtiging uithuisplaatsing als middel werd ingezet binnen de ondertoezichtstelling en niet als zelfstandige maatregel werd beschouwd. Dit kon er mogelijk toe leiden dat de afweging omtrent de uithuisplaatsing slechts werd gezien als onderdeel van de bredere besluitvorming inzake de ondertoezichtstelling. In beginsel is dat juist, maar het aantonen van de noodzaak tot uithuisplaatsing betreft een zelfstandige afweging. Een machtiging uithuisplaatsing heeft immers een wezenlijk ander karakter dan de ondertoezichtstelling. Het maakt ook duidelijk dat de vereisten die op grond van art. 8 EVRM konden worden gesteld aan de onderbouwing van de noodzaak van een uithuisplaatsing, onvoldoende werden geïntegreerd in de afwegingen in de beschermingsrapportage.

\section{Het doel van hereniging van het gezin}

De 100 zaken binnen de steekproef waarin door de RvdK een machtiging uithuisplaatsing werd verzocht, zijn allen zaken waarin een nieuwe ondertoezichtstelling met machtiging uithuisplaatsing werd verzocht, al dan niet vooraf gegaan door een voorlopige ondertoezichtstelling. Dit betekent dat de minderjarigen waarover de RvdK moest beslissen nog thuis verbleven of pas kortstondig in het kader van de voorlopige maatregel uit huis 
waren geplaatst. Er mag derhalve vanuit worden gegaan dat de RvdK in de onderbouwing aandacht schonk aan de mogelijkheden de situatie voor de minderjarige zodanig te verbeteren dat hij kon terugkeren naar huis. In het licht van art. 8 EVRM was het wenselijk dat aandacht werd besteed aan de impact van de uithuisplaatsing zelf en de mogelijkheden tot hereniging van kind en ouders.

De analyse van dossiers heeft laten zien dat de RvdK in 68 van de 100 zaken (68\%) waarin een machtiging uithuisplaatsing werd verzocht aandacht besteedde aan de mogelijkheid van hereniging en daarmee het opvoedperspectief van de minderjarige. Dit betekent niet dat in al deze zaken de vraag of ouders op termijn weer in de thuissituatie voor de minderjarige zouden kunnen zorgen ook definitief werd beantwoord. In het merendeel van de zaken gaf de RvdK een indicatie van de stappen die in de uitvoering van de uithuisplaatsing moesten worden ondernomen. Het is gezien de impact van een uithuisplaatsing zonde dat niet in meer zaken door de RvdK aandacht werd besteed aan het perspectief van de minderjarige na plaatsing. Een mogelijke verklaring hiervoor is dat de RvdK in dit stadium van het besluitvormingsproces nog meende onvoldoende informatie te hebben om een verwachting uit te spreken ten aanzien van het opvoedperspectief van de minderjarige. Het dossieronderzoek laat echter zien dat het de onderbouwing van het verzoek tot machtiging uithuisplaatsing sterk ten goede kwam indien wel aandacht werd besteed aan het opvoedperspectief van de minderjarige.

Een uithuisplaatsing betekent in veel gevallen dat de minderjarige tegen zijn wil wordt gescheiden van zijn ouders waardoor de uithuisplaatsing op zichzelf vaak al een traumatische gebeurtenis is. Daarnaast wordt de minderjarige op een plek geplaatst waarvan in ieder geval aannemelijk gemaakt zal moeten worden dat het in zijn belang is daar een bepaalde periode te blijven. Als niet wordt geanticipeerd op het perspectief van de plaatsing en de mogelijkheid van een terugkeer naar huis blijft het voor betrokkenen onduidelijk hoe het door de overheid gewenste alternatief voor een verblijf thuis vorm moet krijgen. De uithuisplaatsing wordt dan als oplossing aangedragen voor de problemen thuis, zonder dat duidelijk wordt welke doelen moeten worden behaald om een terugkeer in de thuissituatie mogelijk te maken.

\section{Toetsing van de noodzaak tot uithuisplaatsing door de kinderrechter}

Het zojuist geschetste beeld wordt grotendeels bevestigd als wordt gekeken naar de 82 beschikkingen op het verzoek tot machtiging uithuisplaatsing. Omdat binnen dit onderzoek de 
RvdK een gecombineerd verzoek tot ondertoezichtstelling/machtiging uithuisplaatsing indiende, was de motivering van de kinderrechter in de beschikking vaak ook gericht op het gecombineerde verzoek. In de analyse is gekeken of de kinderrechter afzonderlijk inging op de noodzaak van een machtiging uithuisplaatsing. De toepassing van de gronden door de kinderrechter in de 18 zaken waarin een gesloten plaatsing werd verzocht is afzonderlijk geanalyseerd.

Gezien de ernst van de inbreuk op het familie- en gezinsleven van de minderjarige en zijn ouders is daarbij als uitgangspunt gehanteerd dat niet zou mogen worden volstaan met een standaardmotivering ten aanzien van de uithuisplaatsing. Hoewel dit geen expliciet vereiste was op grond van de wet, werd in de rechtspraak wel aangenomen dat een standaardmotivering op het verzoek machtiging uithuisplaatsing geen recht deed aan de ernst van de inbreuk op het recht op familie- en gezinsleven van de minderjarige en zijn ouders . Een standaardmotivering betekende hier dat alleen onder vermelding van de wettelijke grond als in art. 1:261 lid 1 oud BW werd geconcludeerd dat de noodzaak - of het ontbreken van de noodzaak - van een uithuisplaatsing aanwezig was.

De analyse heeft laten zien dat de beslissing op het verzoek tot machtiging uithuisplaatsing in 64 van de 82 zaken (78\%) een inhoudelijke motivering bevatte. In 18 van de 82 zaken (22\%) werd volstaan met een standaardmotivering op het verzoek tot machtiging uithuisplaatsing. Net als ten aanzien van het verzoek tot ondertoezichtstelling geldt ook hier dat er zaken tussen zaten waarin geen verweer werd gevoerd. In het onderzoek is geconcludeerd dat ook als geen verweer wordt gevoerd de kinderrechter nog steeds zou moeten beargumenteren waarom een scheiding van kind en ouders noodzakelijk is. Daarin speelt ook mee dat het onderzoek heeft uitgewezen dat de RvdK, vergeleken met het verzoek tot ondertoezichtstelling, veel vaker volstond met een korte motivering. Als de kinderrechter vervolgens in de beschikking geen inhoudelijke motivering geeft voor de beslissing dan is de onderbouwing van de noodzaak tot uithuisplaatsing over het hele besluitvormingsproces bezien te mager.

\subsection{Rechtvaardiging van de machtiging gesloten jeugdzorg}

Een machtiging tot opneming in een accommodatie voor gesloten jeugdzorg was de meest vergaande vorm van uithuisplaatsing voor de minderjarige. Een gesloten plaatsing op grond van de Wet op de Jeugdzorg had een vrijheidsbenemend karakter en kon alleen worden door het feit dat de minderjarige op andere, minder ingrijpende manieren niet de noodzakelijke 
zorg kon ontvangen. Op grond van art. 37b IVRK gold ook toen dat een gesloten plaatsing slechts als uiterste maatregel en dan voor de kortst mogelijke duur mocht worden ingezet. In de Wet op de Jeugdzorg waren verschillende aanvullende rechtswaarborgen opgenomen om de minderjarige te beschermen tegen ongerechtvaardigde vormen van vrijheidsbeperking. Een specifieke machtiging was op grond van art. 1:261 lid 5 BW jo. art. 29b WJZ. vereist. In de steekproef kwamen 18 zaken terug waarin de RvdK een machtiging gesloten jeugdzorg verzocht. In de analyse is gekeken hoe de wettelijke vereisten voor een gesloten plaatsing werden toegepast.

\section{De instemmingsverklaring van een gekwalificeerde gedragswetenschapper}

Naast de aangescherpte gronden in de Wet op de Jeugdzorg voor het verlenen van een machtiging gesloten jeugdzorg gold dat Bureau Jeugdzorg een besluit moest nemen als in art. 6 lid $1 \mathrm{Wjz}$. Het besluit voor residentieel verblijf moest een verklaring bevatten dat was voldaan aan de gronden voor een gesloten machtiging. Op grond van art. 29b lid $5 \mathrm{Wjz}$ behoefde de verklaring van Bureau Jeugdzorg de instemming van een gekwalificeerde gedragswetenschapper die de minderjarige kort tevoren had onderzocht. De instemmingsverklaring beoogde een belangrijke functie te vervullen bij de beoordeling van de noodzaak van vrijheidsbeneming van de minderjarige. Voor de analyse zijn een aantal uitgangspunten geformuleerd ten aanzien van de inhoudelijke eisen voor de instemmingsverklaring die primair in de rechtspraak tot stand waren gekomen Zo moest de gedragswetenschapper zelfstandig en onafhankelijk een oordeel vormen over de noodzaak van een gesloten plaatsing. Onafhankelijk betekende in dit verband dat de gedragswetenschapper op zekere afstand stond van de behandeling van de minderjarige, hoewel in de rechtspraak werd geaccepteerd dat de gedragswetenschapper in dienst was bij de organisatie die uitvoering gaf of zou gaan geven aan de jeugdbeschermingsmaatregel (zoals Bureau Jeugdzorg). Zelfstandig veronderstelde dat de gedragswetenschapper zijn eigen onderzoek uitvoerde dat inhoudelijk van toegevoegde waarde was ten opzichte van het besluit van Bureau Jeugdzorg dat een gesloten plaatsing noodzakelijk was.

In het dossieronderzoek is gekeken naar voornoemde vereisten voor de instemmingsverklaring. In alle 18 zaken waarin de RvdK een machtiging gesloten jeugdzorg verzocht werd de noodzakelijke instemmingsverklaring van een gekwalificeerde gedragswetenschapper verstrekt. Vervolgens is gekeken naar het vereiste dat de 'minderjarige in persoon kort tevoren' moest worden onderzocht door de gedragswetenschapper. In het dossieronderzoek is gekeken hoeveel tijd er tussen het onderzoek van de 
gedragswetenschapper en de behandeling van het verzoek op zitting zat. Uitkomst is dat er gemiddeld 13 dagen tussen het onderzoek van de gedragswetenschapper en de behandeling van het verzoek op zitting zat. Aangenomen mag worden dat hiermee werd voldaan aan het vereiste dat de minderjarige 'kort tevoren' moest worden onderzocht. Het gemiddelde van 13 dagen is gebaseerd op 15 van de 18 zaken. Drie zaken worden hier apart genoemd omdat zij de uitkomst op dit punt sterk zouden vertekenen. Hier is op basis van art. 29c lid $4 \mathrm{Wjz}$ een instemmingsverklaring afgegeven. Dit betreft de instemmingsverklaring voor een voorlopige machtiging gesloten jeugdzorg. De destijds afgegeven instemmingsverklaring werd in deze drie zaken vervolgens ook gebruikt voor het definitieve verzoek maanden later. De gemiddelde duur tussen de instemmingsverklaring en de behandeling op zitting van het verzoek over deze drie zaken was 81 dagen. In 17 van de 18 zaken verleende de gedragswetenschapper zijn instemming na een persoonlijk gesprek met de minderjarige. In 1 zaak was een persoonlijk gesprek niet mogelijk omdat de minderjarige uit de instelling waar hij verbleef was weggelopen en sindsdien spoorloos was. De instemming werd in dit geval op basis van het dossier verleend.

Of de instemmingsverklaringen die terugkwamen in het dossieronderzoek inhoudelijk kunnen worden beschouwd als een zelfstandig en onafhankelijk oordeel over de noodzaak van een gesloten plaatsing is lastig te beoordelen. Het beperkte aantal geanalyseerde instemmingsverklaringen noopt tot terughoudendheid in de conclusies. Wat in algemene zin is opgevallen is dat de instemmingsverklaringen, zoals de naam al zegt, gericht leken op het verlenen van instemming. De instemmingsverklaring begon in de regel met een voorgedrukte tekst waarin stond dat Bureau Jeugdzorg verklaarde dat was voldaan aan de gronden voor oplegging van een machtiging gesloten jeugdzorg gevolgd door de tekst dat op basis van het dossier en het gesprek met de minderjarige de gedragswetenschapper zijn instemming verleende. De analyse heeft niet uitgewezen of hier ook kon staan dat de instemming niet werd verleend, aangezien in alle 18 zaken de instemming wel werd verleend. De wijze waarop dit was vormgegeven in de instemmingsverklaringen wekte in ieder geval niet de indruk dat het niet verlenen van de instemming een aannemelijke uitkomst was.

In positieve zin is opgevallen dat het weergave van het gesprek met de minderjarige veel informatie gaf over de gemoedstoestand van het minderjarige in het algemeen, en specifiek over de mening van de minderjarige ten aanzien van de gesloten plaatsing. De gedragswetenschapper besprak systematisch de zorgen die in de rapportage werden vermeld en gaf de minderjarige de gelegenheid zijn eigen mening te geven over deze zorgen. 
Daarnaast werd expliciet besproken hoe de minderjarige aankeek tegen een gesloten plaatsing. Ondanks het feit dat de minderjarigen vrijwel zonder uitzondering zeer afwijzend stonden tegen het gesloten geplaatst worden, werden zij op deze manier wel nadrukkelijk betrokken bij de besluitvorming. Opvallend genoeg leidde dit ertoe dat het relatief korte gespreksverslag van de gedragswetenschapper vaak meer informatie gaf over de visie van de minderjarige ten aanzien van de gewenste machtiging dan het uitgebreide beschermingsrapport van de RvdK.

\section{Toetsing gronden gesloten plaatsing door de RvdK}

Voor een machtiging gesloten jeugdzorg golden (aangescherpte) gronden die niet terug waren te vinden in het Burgerlijk Wetboek maar in de Wet op de Jeugdzorg. Op grond van art. 29b lid $3 \mathrm{Wjz}$ kon een machtiging worden verleend indien sprake was van ernstige opgroei- en opvoedingsproblemen die de ontwikkeling van de minderjarige naar volwassenheid ernstig belemmerden en het verblijf moest noodzakelijk zijn om te voorkomen dat de minderjarige zich zou onttrekken of zou worden onttrokken aan de noodzakelijke zorg. De eerste grond vereiste een primair pedagogisch oordeel over de ernst van de problematiek, de tweede grond vereiste dat werd aangetoond dat deze problematiek alleen in een gesloten plaatsing (voorzienbaar) zou kunnen worden verholpen. In de analyse is gekeken of, en zo ja hoe door de RvdK invulling werd gegeven aan deze gronden.

\section{Ernstige opgroei- en opvoedingsproblemen}

Uit de analyse is gebleken dat alle 18 minderjarigen voor wie een gesloten machtiging werd verzocht 13 jaar of ouder waren. Dit is niet verwonderlijk aangezien zeer ernstige ontwikkelingsproblemen zich vaak pas op latere leeftijd manifesteren. Verder laat de analyse zien dat de gesloten machtiging op grond van de Wet op de Jeugdzorg inderdaad voorbehouden leek te zijn voor de groep minderjarigen met meervoudige, complexe problematiek. In alle 18 zaken gaf de RvdK een concrete beschrijving van de zorgen die hebben geleid tot het oordeel dat sprake was ernstige opgroei- en opvoedingsproblemen die de ontwikkeling naar volwassenheid ernstig belemmerden. Bijna de helft van de minderjarigen (8 van de $18-44 \%$ ) kampte met verslavingsproblematiek. In 15 van de 18 zaken (83\%) was sprake van ernstige externaliserende gedragsproblematiek en bij 12 van de 18 minderjarigen $(66,6 \%)$ was een verstandelijke beperking vastgesteld.

\section{Onttrekkingsrisico}

Ernstige problematiek op basis waarvan de ontwikkeling naar volwassenheid ernstig werd 
belemmerd was zoals gesteld niet voldoende om tot een gesloten machtiging te komen. Een gesloten machtiging kon slechts rechtmatig zijn indien het verblijf noodzakelijk was om te voorkomen dat de jeugdige zich onttrok, of aan de noodzakelijke zorg werd onttrokken. Er moest geen andere mogelijkheid open staan om de minderjarige te beschermen tegen zichzelf en/of zijn omgeving dan door middel van een vrijheidsbeperking maatregel. De Wet op de Jeugdzorg bevatte hiermee een concreet toetsbare norm, waaruit duidelijk het ultimum remedium karakter van de maatregel bleek. Het is dan ook teleurstellend dat de analyse heeft laten zien dat de RvdK slechts in 9 van de 18 zaken (50\%) in de beschermingsrapportage beargumenteerde in hoeverre de minderjarige zich onttrok of werd onttrokken aan de noodzakelijke zorg. Nadere analyse van deze zaken laat zien dat de onderbouwing van de noodzaak tot gesloten plaatsing zich primair richtte op de ernstige ontwikkelingsproblematiek van de minderjarige.

\section{Toetsing gronden gesloten plaatsing door de kinderrechter}

De analyse van de 18 beschikkingen op het verzoek machtiging gesloten jeugdzorg heeft laten zien dat net als de RvdK, de kinderrechter vaker aandacht besteedde aan de problematiek van de minderjarige dan het risico op onttrekking aan de noodzakelijke zorg. In 16 van de 18 beschikkingen $(88,9 \%)$ werd een op de casus toegespitste motivering gegeven, waarin de opgroei- en opvoedingsproblemen van de minderjarige werden geconcretiseerd. In 2 van de 18 zaken $(11,1 \%)$ volstond de kinderrechter met het herhalen van de wettelijke grond als in 29b lid $3 \mathrm{Wjz}$ en werden de ontwikkelingsproblemen niet nader toegelicht.

Het risico op onttrekking aan de noodzakelijke zorg werd veel minder consequent getoetst in de geanalyseerde beschikkingen. In 8 van de 18 zaken $(44,4 \%)$ werd inhoudelijk toegelicht door de kinderrechter waarom het risico op onttrekking aan de zorg een gesloten plaatsing noodzakelijk maakte. De verklaring die is gegeven voor het gebrek aan aandacht in de rapportages van de RvdK voor het risico op onttrekking aan zorg lijkt ook hier op te gaan. De focus lag primair op de ernst van de problematiek op basis waarvan een gesloten plaatsing noodzakelijk zou zijn. Zoals aangegeven zou complexe problematiek alleen onvoldoende moeten zijn om tot een gesloten plaatsing te komen. Daarnaast is zichtbaar dat in de beschikkingen meer werd ingegaan op het functioneren van de minderjarige binnen de gesloten jeugdzorg waar hij in het kader van de voorlopige ondertoezichtstelling verbleef. Dat kan een rol spelen bij de vraag of de gesloten plaatsing op het moment van het definitieve verzoek nog noodzakelijk is maar dit hoeft niet. Zichtbaar is dat de vraag of er nog steeds een reëel risico was op onttrekking aan de noodzakelijke niet expliciet werd beantwoord. 
Het risico op onttrekking aan zorg betekende dat er geen andere mogelijkheid mocht zijn om de minderjarige de zorg te bieden die nodig was dan binnen het gesloten karakter van de gesloten jeugdzorg. De Wet op de Jeugdzorg gaf daarmee uitdrukking aan het belangrijke uitgangspunt op grond van art. 5 EVRM en art. 37b IVRK dat vrijheidsbeneming een uiterst middel is. Blijkens de analyse werd dit uitgangspunt niet systematisch meegewogen door de RvdK en de kinderrechter in de onderzochte zaken.

\subsection{Zorgvuldigheid van het feitenonderzoek}

Voor het dossieronderzoek is de keuze gemaakt de analyse niet geheel te beperken tot de wijze waarop het materiële jeugdbeschermingsrecht werd toegepast. Door ook te kijken naar de wijze waarop de RvdK de feitenvaststelling binnen het onderzoek vormgaf ontstaat een completer beeld van de rechtvaardiging die in de praktijk werd gegeven door de RvdK voor de gewenste inzet van een ondertoezichtstelling en uithuisplaatsing. Om een analyse van het feitenonderzoek mogelijk te maken zijn eerst de belangrijkste uitgangspunten, procedurele regels en formele (inhoudelijke) kwaliteitscriteria voor het feitenonderzoek is jeugdbeschermingszaken geschetst. Op basis van art. $21 \mathrm{Rv}$. moest de RvdK als verzoeker de voor de beslissing van de belang zijnde feiten volledig en waarheid aanvoeren. Hieruit is als algemeen gezichtspunt afgeleid dat het feitenonderzoek zorgvuldig moest worden uitgevoerd maar het gaf verder geen indicatie welke specifieke eisen daarvoor konden worden gesteld. De belangrijkste uitgangspunten voor de analyse zijn derhalve ontleend aan de eisen die de RvdK in het interne Kwaliteitskader 2013 stelde voor een zorgvuldige uitvoering van het feitenonderzoek. Enerzijds ging het dan om formele zorgvuldigheidshandelingen van de RvdK teneinde de juistheid en actualiteit van de onderzoeksgegevens voor zover mogelijk te garanderen. Anderzijds ging het om de inhoudelijke interpretatie van de verzamelde onderzoeksgegevens door de RvdK. Zo bevatte het Kwaliteitskader 2013 van de RvdK de eis dat besluitvorming in de rapportage werd onderbouwd, waarbij feiten, visies van betrokkenen en de interpretatie van deze informatie door de RvdK duidelijk moest worden gescheiden Voor de analyse is als uitgangspunt gehanteerd dat in rapportages van de RvdK moest worden gestreefd naar het objectiveren en concretiseren van de verzamelde informatie. Daarnaast gold dat de visie van betrokkenen een cruciaal onderdeel is in het proces van informatieverzameling. Het belangrijkste is dat op alle plekken in de rapportage duidelijk was wie de informatie had verstrekt en of de verstrekte informatie was aan te merken als feitelijk of als de visie van een betrokkene. Twee elementen zijn in dit licht geanalyseerd in het 
dossieronderzoek. In de eerste plaats of de ingebrachte informatie door de betrokkenen en informanten die voor het beschermingsonderzoek werden geraadpleegd, was geaccordeerd en voorzien van een datum. En ten tweede, of door de RvdK bij de verwerking van

onderzoeksgegevens een duidelijk onderscheid werd gemaakt tussen feiten en meningen en de interpretatie van die gegevens door de RvdK.

\section{Accorderen en dateren van onderzoeksgegevens}

In het dossieronderzoek is voor de 200 zaken waarin een ondertoezichtstelling met of zonder uithuisplaatsing werd verzocht gekeken naar de informatieverwerking door de RvdK. Hoewel het laten accorderen en dateren van de ingebrachte informatie niet de juistheid van de ingebrachte informatie garandeerde, kon het toch worden beschouwd als een kwaliteitswaarborg. In ieder geval werd hiermee vastgesteld dat alle betrokkenen akkoord waren met de wijze waarop de RvdK door de hun ingebrachte informatie heeft weergegeven. De analys heeft laten zien dat in 194 van de 200 zaken (97\%) de informatie door de betrokkenen werd geaccordeerd. In enkele zaken is zichtbaar dat betrokkenen pas akkoord wilden gaan met de ingebrachte informatie indien enkele elementen werden aangepast. De RvdK voldeed aan dit verzoek in de geanalyseerde zaken. De zaken waarin de informatie niet was geaccordeerd waren voor het grootste deel zaken met een spoedeisend karakter. In spoedzaken wordt vaak acuut gehandeld op basis van nog beperkte informatie.

Vervolgens is gekeken of in de beschermingsrapportage van de RvdK de datum werd vermeld waarop de informatie door de informanten, ouders en minderjarige werd ingebracht. Het vermelden van de datum waarop de informatie werd verkregen droeg bij aan het voorkomen knip- en plakwerk uit oudere rapportages, hetgeen een belangrijk kritiekpunt was van betrokkenen. Het vormt alleen een garantie dat de weergave van de informatie die door de informanten werd ingebracht, in hun ogen correct was. Het onderzoek kan geen antwoord geven op de vraag of de informatie ook daadwerkelijk actueel en correct was, aangezien dan het feitenonderzoek in alle zaken over gedaan zou moeten worden. Uit de analyse is gebleken dat de RvdK in 195 van de 200 zaken (97,5\%) de datum vermeldde waarop de informatie bij alle betrokkenen werd verkregen. Net als ten aanzien van het accorderen van informatie lijkt het in de enkele zaak waarin de datum ontbrak te gaan om slordigheden, mogelijk vanwege de spoed waarmee het onderzoek werd uitgevoerd.

\section{Het onderscheid tussen feiten en meningen in de beschermingsrapportage}

In het vervolg van het dossieronderzoek is inhoudelijk gekeken naar de manier waarop de tijdens het onderzoek verzamelde informatie is verzameld en geïnterpreteerd door de RvdK. 
Een cruciaal element in dit verband is dat er een duidelijk onderscheid moest worden gemaakt tussen feiten en meningen in de rapportage. Het door elkaar lopen van feiten en meningen in de rapportages van de RvdK en Bureau Jeugdzorg was een van de belangrijkste kritiekpunten van betrokkenen. De RvdK had zoals gesteld in zijn eigen Kwaliteitskader 2013 de eis opgenomen dat in rapportages een duidelijk onderscheid moest worden gemaakt tussen feiten en visies van betrokkenen enerzijds, en de interpretatie van die gegevens door de RvdK anderzijds. De onderzoeksgegevens die zijn verzameld op basis van de gesprekken met informanten en betrokkenen werden in het eerste deel van het beschermingsrapport weergegeven. De interpretatie van deze gegevens door de RvdK vond plaats in het tweede deel van het beschermingsrapport bij de onderzoeksafwegingen.

Een aantal belangrijke uitgangspunten zijn hieruit gedestilleerd. In de eerste plaats moest bij de weergave van de informatie door betrokkenen en informanten duidelijk zijn of het ging om feitelijke, dus objectief toetsbare informatie of informatie die kon worden bestempeld als een mening/visie of vermoeden. Vervolgens moest de ingebrachte informatie op correcte wijze geduid worden door de RvdK in het beschermingsrapport. Het correct duiden betekende in dit verband dat als informatie als feitelijk werd bestempeld ook duidelijk moest zijn op basis van welke onderzoeksgegevens tot deze conclusie werd gekomen. Hetzelfde gold voor het correct weergeven van de vermoedens of zorgen van betrokkenen bij de onderzoeksafwegingen van de RvdK.

In de analyse is in drie stappen gekeken naar de informatieverwerking door de RvdK: het uitgangspunt vormde de informatie zoals door alle betrokkenen was ingebracht tijdens het onderzoek. Deze informatie is ingedeeld in feitelijke informatie en de visie van betrokkenen. Informatie is als feitelijk aangemerkt indien de informatie was gebaseerd op objectieve gegevens (documentatie); de RvdK zelf een bepaalde situatie vast kon stellen (bijvoorbeeld drankmisbruik van ouders tijdens een huisbezoek) of wanneer vermoedens of zorgen tijdens het onderzoek door alle betrokkenen werden bevestigd zonder dat er direct zwart op wit bewijs van was (bijvoorbeeld ouders geven toe de minderjarige fysiek te hebben gestraft). Aangezien tijdens een beschermingsonderzoek een grote hoeveelheid informatie werd ingebracht en het duiden van die informatie bijzonder complex was voor de RvdK zijn alleen zaken waarin de interpretatie van de onderzoeksgegevens evident niet correct was gescoord onder 'informatie niet correct verwerkt'.

De analyse van dossiers heeft laten zien dat de informatie zoals ingebracht tijdens het beschermingsonderzoek in 185 van de 200 zaken (92,5\%) volledig correct werd verwekt. In 
15 van 200 zaken (7,5\%) was niet alle informatie - maar vaak wel het grootste deel van de informatie - correct verwerkt. In deze 15 zaken ging het voornamelijk om vermoedens geuit door informanten en/of betrokkenen die door de RvdK bij de onderzoeksafwegingen te stellig werden gepresenteerd. Zo is bijvoorbeeld dat in enkele zaken het vermoeden bestond dat er sprake was van huiselijk geweld. In het beschermingsrapport is dit vermoeden afkomstig van betrokkenen wel als zodanig weergegeven, maar bij de onderzoeksafwegingen stelde de RvdK dat er sprake was geweest van huiselijk geweld. Ook kwam het in drie verschillende zaken voor dat een diagnose werd aangehaald door de RvdK zonder dat uit de onderzoeksgegevens duidelijk werd wie en wanneer de diagnose had gesteld.

Naar aanleiding van de analyse is geconcludeerd dat het correct interpreteren van de informatie die door betrokkenen is ingebracht een ingewikkeld proces is dat met de uiterste zorgvuldigheid dient te gebeuren. In de beschermingsrapporten kwam vaak heel veel informatie terug, soms heel concreet en soms heel erg vaag. Tussen evident objectief vast te stellen informatie (zoals een duidelijk gedocumenteerde diagnose) en evident subjectieve informatie (zoals een vaag vermoeden van een leerkracht) zat veel informatie waarvan het maar de vraag was of het als feitelijk kon worden aangemerkt. Voor de analyse is op basis van de genoemde criteria dit onderscheid gemaakt. De waarde van de onderzoeksresultaten op dit punt beperken zich daarom niet alleen tot de vraag in hoeveel gevallen het zorgvuldig genoeg was en in hoeveel gevallen niet. In bredere zin beoogt het dossieronderzoek een eerste aanzet te vormen voor de ketenpartners om nadrukkelijker na te gaan denken over de waarde van de informatie die tijdens het onderzoek wordt verzameld. Alle informatie, concreet of vaag, feitelijk of niet feitelijk, werd gebundeld in de beschermingsrapportage van de RvdK, waarmee het risico werd vergroot dat feiten en vermoedens door elkaar liepen. Dat dit in het overgrote deel van de geanalyseerde zaken niet gebeurde geeft aan dat raadsonderzoekers in veel gevallen in staat zijn gebleken de informatie op een juiste manier te interpreteren.

Voor de analyse van het feitenonderzoek zijn een aantal criteria geformuleerd om de informatie in de beschermingsrapporten in te delen. Of deze indeling optimaal is kan worden bediscussieerd en als nuancering moet daaraan worden toegevoegd dat een andere indeling mogelijk ook zou hebben geleid tot een andere uitkomst. Maar in ieder geval is op deze manier anders, systematischer, gekeken naar de informatie die terugkwam in de beschermingsrapporten. Niet slechts het verzamelen van informatie maar steeds een aantal aanvullende vragen stellen: waar kwam de informatie vandaan? Om wat voor soort informatie ging het? Met hoeveelheid zekerheid kon worden vastgesteld dat de gemelde zorgen ten 
aanzien van de minderjarige ook daadwerkelijk aanwezig waren en wat betekende dit voor de vraag of de minderjarige ernstig in zedelijke of geestelijke belangen of gezondheid werd bedreigd? Het lijkt, zonder grote veranderingen in wet- en regelgeving mogelijk, duidelijker aan te geven in de beschermingsrapporten wat als feitelijk wordt beschouwd en wat als (meer) subjectieve informatie en welke rol de interpretatie van gegevens voor de raadsonderzoeker heeft gespeeld.

\subsection{De rechtspositie van de minderjarige (en ouders) in de jeugdbeschermingsprocedure}

Het laatste deel van de analyse van dossiers is gericht op de rechtspositie van de minderjarige (en in mindere mate zijn ouders) tijdens het beschermingsonderzoek en in de gerechtelijke procedure. Op basis van nationale wet- en regelgeving en toepasselijk verdragsrecht zijn de belangrijkste uitgangspunten geformuleerd die van toepassing waren op de rechtspositie van de minderjarige,

Aangezien de minderjarige processueel onbekwaam is in de procedure tot oplegging van de ondertoezichtstelling, en hij als belanghebbende voor informatie grotendeels afhankelijk is van zijn ouders, heeft de nadruk gelegen op het recht om te worden gehoord. De minderjarige heeft er ongeacht zijn leeftijd recht om te worden gehoord in alle fasen van het besluitvormingsproces (art. 12 IVRK). De RvdK behoorde in principe alle kinderen tijdens het beschermingsonderzoek (Kwaliteitskader 2013) te horen ongeacht de leeftijd en moest ander aangeven waarom het horen niet had kunnen plaatsvinden. In de gerechtelijke procedure moest de minderjarige van twaalf jaar en ouder in de gelegenheid worden gesteld om te worden gehoord (art. $809 \mathrm{Rv).} \mathrm{Voor} \mathrm{de} \mathrm{minderjarige} \mathrm{onder} \mathrm{de} \mathrm{twaalf} \mathrm{zou} \mathrm{het} \mathrm{in} \mathrm{het} \mathrm{licht}$ van art. 12 IVRK in ieder geval wenselijk zijn als hij werd gestimuleerd zijn mening te geven ten aanzien van het verzoek tot ondertoezichtstelling en uithuisplaatsing. Daarnaast had de minderjarige er recht op dat zijn mening - afhankelijk van zijn leeftijd en ontwikkelingsniveau - werd meegewogen in de besluitvorming. Bij voorkeur werd de mening van de minderjarige ten aanzien van het verzoek weergegeven in het beschermingsrapport. Hetzelfde gold voor de beschikking op het verzoek (art. 12 IVRK). Tot slot had de minderjarige er recht op te worden geïnformeerd over de wijze waarop hij kan participeren en dient te worden geïnformeerd over de beslissing van de RvdK en de kinderrechter (art. 12 IVRK, art. 9 lid 2 IVRK). Onderdeel daarvan was ook dat de minderjarige kennis kon nemen van de beslissing en de mate waarin zijn mening het besluitvormingsproces had beïnvloed, bij voorkeur schriftelijk (in het beschermingsrapport en de beschikking). 
Het horen van de minderjarige tijdens het beschermingsonderzoek

In de eerste plaats is gekeken of de RvdK voldeed aan de eis in het Kwaliteitskader 2013 dat met iedere minderjarige (in beginsel) een persoonlijk gesprek werd gevoerd. De analyse heeft laten zien dat de minderjarige in 146 van de 200 zaken (73\%) werd gehoord tijdens het beschermingsonderzoek. Van de 54 zaken waarin de minderjarige niet werd gehoord was er in 29 zaken een goede verklaring voor. Zo ging het voor een deel om onderzoek naar ongeboren kinderen en waren sommige kinderen nog te jong waardoor de RvdK het kind alleen observeerde. In de beschermingsrapportage werd dan wel overeenkomstig de eisen in het Kwaliteitskader 2013 aangegeven waarom het horen van de minderjarige achterwege was gebleven. Ook kwam het voor dat ouders geen toestemming gaven voor het horen van de minderjarige.

In 25 van de 200 zaken $(12,5 \%)$ bevatte het beschermingsrapport geen toelichting over het horen van de minderjarige. Nadere analyse van deze zaken heeft een aantal mogelijke verklaringen opgeleverd. Ten eerste was het mogelijk zo dat de RvdK de minderjarige te jong vond om te worden gehoord maar dit niet expliciet benoemde in de rapportage. Ook kwam het voor dat de minderjarige in het kader van een voorlopige ondertoezichtstelling in een pleeggezin verbleef en de RvdK alleen de pleegouders sprak over de minderjarige. Mogelijk om de minderjarige niet verder te belasten. Tot slot werd de minderjarige in een aantal zaken kennelijk niet gehoord vanwege het spoedeisende karakter van de zaak.

Op basis hiervan is geconcludeerd dat voornoemde verklaringen het achterwege laten van het horen kunnen rechtvaardigen, maar dat de RvdK in iedere zaak zou moeten aangeven waarom het wel of niet had plaatsgevonden. Hiermee legt de RvdK ook verantwoording door te laten zien welke inspanningen zijn geleverd om de minderjarige te spreken. Dat is belangrijk omdat het beschermingsrapport bij uitstek de plek is om uitgebreid aandacht te besteden aan de mening van de minderjarige.

\section{Inzage in de conceptrapportage voor de minderjarige en zijn ouders}

Het beschermingsonderzoek van de RvdK leidde tot een conceptrapportage waarin de beslissing een ondertoezichtstelling/uithuisplaatsing te verzoeken schriftelijk werd toegelicht. Daarnaast moest het besluit mondeling worden toegelicht in een adviesgesprek. Wat betreft de conceptrapportage en de afstemming met het adviesgesprek is in de analyse opgevallen dat er sprake was van een wisselende aanpak van de RvdK bij het verstrekken van de conceptrapportage. De conceptrapportage werd of voor het adviesgesprek aan de ouders (en minderjarige) toegezonden of tijdens het adviesgesprek ter inzage overhandigd. In beide 
gevallen gold een inzagetermijn van vijf werkdagen om een reactie te geven op de conceptrapportage. Werd de conceptrapportage voor het adviesgesprek verzonden dan gaf dat de betrokkenen de mogelijkheid tijdens het gesprek inhoudelijk op de onderzoeksbevindingen van de RvdK in te gaan. Dit is een stuk lastiger als de betrokkenen pas tijdens het gesprek met de bevindingen van de RvdK werden geconfronteerd. Het is tijdens het onderzoek niet duidelijk geworden waarom hier wisselend mee werd omgegaan door de RvdK. Bezien vanuit de positie van de ouders en minderjarige lijkt de optie om de rapportage voor het gesprek toe te zenden betere mogelijkheden te bieden om effectief te participeren. De ouders en minderjarige hebben dan tijd gehad om de informatie en het besluit te beoordelen en kunnen in het gesprek beter inhoudelijk reageren.

$\mathrm{Na}$ deze meer algemene observatie is in de analyse gekeken in hoeveel zaken de ouders inzage hebben gekregen in het conceptrapportage. Uitkomst is dat de ouders in 189 van de 200 zaken $(94,5 \%)$ het conceptrapport kregen opgestuurd of tijdens het adviesgesprek kregen overhandigd. In 5 van de 200 (2,5\%) zaken was inzage niet mogelijk gezien het spoedeisende karakter van de zaak en in 6 van de 200 zaken (3\%) was geen informatie over de mogelijkheid tot inzage in de rapportage opgenomen.

Voor de minderjarige leken de mogelijkheden tot inzage af te hangen van zijn leeftijd. In de eerste plaats ontving de minderjarige slechts het gehele rapport indien hij 16 jaar of ouder was. Tussen de 12 en 16 jaar ontving de minderjarige 'zijn kinddeel'. Dit deel betrof niet meer dan een zakelijke uitwerking van het gesprek dat de raadsonderzoeker met de minderjarige hield tijdens het raadsonderzoek. In het onderzoek is kritisch geoordeeld over deze gang van zaken. Het heeft er alle schijn van dat de RvdK de minderjarige op deze leeftijd nog niet wilde confronteren met de mogelijk ingrijpende informatie in de rapportage. Het zorgde er echter ook voor dat de minderjarige schriftelijk geen inzicht werd geboden in de besluitvorming en de rol die zijn mening daarin had gespeeld. Zo bevatte het kinddeel nooit enige informatie over afwegingen van de RvdK om wel of geen ondertoezichtstelling te verzoeken. Een serieuze, inhoudelijke reactie op het verzoek door de minderjarige werd hierdoor ernstig bemoeilijkt. Tot slot lijkt deze gang van zaken zich ook moeilijk te verhouden met het hoorrecht van de minderjarige in de gerechtelijke procedure. Op grond van art. $809 \mathrm{Rv}$ werd iedere minderjarige van 12 jaar en ouder in gelegenheid gesteld om te worden gehoord door de kinderrechter. De kans was daarom groot dat de minderjarige vanaf 12 jaar in de gerechtelijke procedure alsnog met informatie uit het beschermingsrapport en de consequenties van de maatregel werd geconfronteerd. 


\section{Adviesgesprek met de minderjarige en zijn ouders}

Volgens het Kwaliteitskader 2013 van de RvdK moest ieder onderzoek met een adviesgesprek worden afgesloten. Op basis van het dossieronderzoek is het niet waarschijnlijk dat dit ook altijd gebeurde. In 160 van de 200 geanalyseerde zaken (80\%) werd een persoonlijk dan wel telefonisch adviesgesprek gevoerd met de ouders volgens de beschermingsrapportage. In 12 van de 40 zaken was er een logische verklaring voor het feit dat geen adviesgesprek is gehouden. Zo kwam het voor dat de RvdK wel een adviesgesprek heeft proberen te organiseren maar de ouders hier niet ingingen. In 28 van de 200 geanalyseerde zaken (14\%) vermeldde het rapport niets over een adviesgesprek. Het lijkt niet heel waarschijnlijk dat in deze gevallen wel een adviesgesprek is gehouden maar met zekerheid is dat niet vast te stellen.

Voor wat betreft het adviesgesprek met de minderjarige leek de leeftijd van de minderjarige een belangrijke rol te spelen voor de vraag of hij werd uitgenodigd. Het Kwaliteitskader 2013 van de RvdK koppelde geen leeftijdsgrens aan het adviesgesprek maar in de praktijk bleek deze wel te worden gehanteerd. De analyse heeft laten zien dat in 56 van de 200 zaken (28\%) in de rapportage melding werd gemaakt van een adviesgesprek met de minderjarige. In alle gevallen waren dit kinderen van twaalf jaar en ouder. In 14 van de 200 zaken (7\%) was de minderjarige wel uitgenodigd maar vermeldde de beschermingsrapportage dat de minderjarige een adviesgesprek had afgewezen. Dat laat nog 130 van de 200 zaken (65\%) over waarin de beschermingsrapportage geen informatie bevatte over een adviesgesprek met de minderjarige. Voor een deel ging het dan om minderjarigen van 12 jaar en ouder waarvan mocht worden verwacht dat de RvdK ze los van de ouders zou spreken over de voorgenomen beslissing.

Als wordt gekeken naar de rechtspositie van de minderjarige en zijn ouders tijdens het beschermingsonderzoek dan kunnen grofweg twee elementen worden onderscheiden: het horen van de minderjarige en ouders tijdens het beschermingsonderzoek en het informeren van de minderjarige en ouders over de uitkomst van het onderzoek. Met name ten aanzien van het tweede element heeft het dossieronderzoek enkele tekortkomingen aan het licht gebracht. De mening van de minderjarige en zijn ouders was lang niet altijd duidelijk weergegeven in het beschermingsrapport. Gebeurde dit wel dan werd dit vaak zeer kort weergegeven helemaal aan het einde van de rapportage. Terwijl de visie van betrokkenen ten aanzien van het verzoek van de RvdK belangrijk genoeg is om integraal onderdeel uit te maken van de onderzoeksafwegingen. 


\section{Rechtspositie van minderjarige in de gerechtelijke procedure}

Het dossieronderzoek is afgesloten met een analyse van de rechtspositie van de minderjarige tijdens de procedure voor de kinderrechter. Aangezien hier niet de nadruk van het onderzoek lag, en alleen informatie uit de beschikking voorhanden was, is de keuze gemaakt primair te focussen op een analyse van de wijze waarop het hoorrecht van de minderjarige vorm kreeg tijdens de gerechtelijke procedure. Meer specifiek is gekeken hoe de wettelijke vereisten voor het horen van minderjarigen op grond van $809 \mathrm{Rv}$. en art. 12 IVRK in de praktijk werden ingevuld.

\section{Het horen van de minderjarige door de kinderrechter}

Op grond van art. 809 Rv. kon de minderjarige die nog niet de leeftijd van twaalf jaar nog niet had bereikt in de gelegenheid worden gesteld om te worden gehoord. De formulering van de wet op dit punt oogde daarmee weinig uitnodigend voor minderjarigen onder de 12 jaar om gebruik te maken van het hoorrecht. Het is in dit licht geen verrassing dat de analyse van beschikkingen heeft uitgewezen dat minderjarigen onder de twaalf niet of nauwelijks werden gehoord. In 91 van de 200 zaken ging het om een minderjarige die de leeftijd van 12 jaar nog niet had bereikt. Geen van deze minderjarigen is volgens de beschikking door de rechter gehoord over het verzoek tot ondertoezichtstelling/machtiging uithuisplaatsing.

Voor een deel is dat goed verklaarbaar aangezien het ging om zeer jonge kinderen. Voor de groep minderjarigen die de leeftijd van 12 jaar naderde is het echter voorstelbaar dat sommigen na enige aanmoediging wellicht bereid waren geweest om hun mening te geven. In 2013 en 2014, de peiljaren voor de steekproef, leek deze aanmoediging van overheidswege niet aanwezig. Het onderzoek heeft geen aanwijzingen opgeleverd dat de RvdK minderjarigen onder de leeftijd van 12 jaar actief informeerde over de mogelijkheid om te worden gehoord in de gerechtelijke procedure. En ook vanuit de rechtspraak werden minderjarigen onder de twaalf jaar voor zover bekend niet actief benaderd om te worden gehoord.

Voor minderjarigen die twaalf jaar en ouder waren binnen de steekproef was het beeld vanzelfsprekend heel anders. In de steekproef ging het in 109 zaken om minderjarigen die twaalf jaar of ouder waren. Hier gold op de grond van art. $809 \mathrm{Rv}$. de wettelijke verplichting om de minderjarige in de gelegenheid te stellen om te worden gehoord. In 87 van de 109 zaken is in de beschikking aangegeven dat de minderjarige overeenkomstig de wettelijke vereisten werd gehoord. In 19 van de 109 zaken vermeldde de beschikking dat de minderjarige in gelegenheid was gesteld om te worden gehoord maar werd door de minderjarige besloten hier geen gebruik van te maken. In 3 van de 109 zaken is in de 
beschikking geen informatie terug te vinden over de vraag of de minderjarige in de gelegenheid werd gesteld om te worden gehoord.

\section{De mening van de minderjarige in de beschikking}

Vervolgens is gekeken of de mening van de minderjarige ook in de beschikking was opgenomen. Uitgangspunt is dat de minderjarige niet onnodig wordt belast of geschaad hetgeen een belangrijke overweging kon zijn voor de rechter om de mening van de minderjarige niet weer te geven in de beschikking. Daar staat tegenover dat het opnemen van de mening van de minderjarige in de beschikking kon bijdragen aan het informeren van de minderjarige over de besluitvorming. Op grond van art. 12 IVRK moest de minderjarige zijn mening vrijelijk kunnen uiten over beslissingen die hem aangingen en moest aan de mening van de minderjarige passend belang worden gehecht overeenkomstig de leeftijd en rijpheid van de minderjarige. Door het opnemen van de mening van de minderjarige in de beschikking kon de rechter laten zien de mening van de minderjarige serieus te nemen. Daarnaast was het een goede manier om aan de minderjarige te communiceren of, en zo ja op welke manier, zijn mening een rol had gespeeld in de besluitvorming. De analyse van dossiers heeft laten zien dat de kinderrechter in 22 van de 200 geanalyseerde beschikkingen (11\%) expliciet aandacht besteedde aan de mening van de minderjarige.

Het onderzoek heeft diverse fraaie voorbeelden opgeleverd van zaken waarin de kinderrechter uitgebreid inging op de rol die mening van de minderjarige in zijn beslissing had gespeeld. In het bijzonder kan gewezen op het belang van het meewegen van de mening van de minderjarige in zaken waarin de kinderrechter anders besliste dan de minderjarige wenste. De beschikking kan dan het aangewezen medium zijn om de minderjarige te informeren over de rol die zijn mening heeft gespeeld, aangezien de kinderrechter in de regel na het kindgesprek geen contact meer had met de minderjarige.

De uitkomsten van het dossieronderzoek op dit punt laten zien dat in 2013 en 2014 nog beperkt van de mogelijkheid gebruik werd gemaakt om de mening van het kind op te nemen in de beschikking. In het onderzoek is niet betoogd dat dit altijd kan of wenselijk is. De kinderrechter zal altijd moeten afwegen of het belang de mening van de minderjarige serieus te betrekken in de besluitvorming, in het concrete geval niet leidt tot een voor de minderjarige nadelige situatie. Een balans vinden dus tussen de bescherming van de minderjarige en in de ruimst mogelijk mate invulling geven aan het recht om effectief te participeren. 


\subsection{Afsluitende conclusies deel I \& deel II}

In het eerste deel van deze conclusie is in detail besproken op welke wijze de rechtvaardiging van de ondertoezichtstelling en uithuisplaatsing in 2013 en 2014 werd vormgegeven door de RvdK en kinderrechter. Dat is gedaan door te kijken hoe door de RvdK in het beschermingsrapport en door de kinderrechter in de beschikking invulling werd gegeven aan de wettelijke gronden en doelen van de maatregel, hoe door de RvdK het feitenonderzoek werd uitgevoerd en hoe de rechtspositie van de minderjarige en zijn ouders eruit zag in de jeugdbeschermingsprocedure. Als iets verder wordt uitgezoomd dan kan worden geconcludeerd dat de kans dat de concrete rechtvaardiging door de RvdK en kinderrechter in een individuele zaak door een kritieke ondergrens heen zakte gering was. In 2013 en 2014 waren de waarborgen op grond van (inter)nationale wet- en regelgeving al voldoende geïntegreerd in het afwegingskader van de RvdK en de kinderrechter. Dit leidde ertoe dat vrijwel ieder geanalyseerd beschermingsrapport blijk gaf van inhoudelijke afwegingen waarin pedagogische inzichten en het juridisch perspectief samenkwamen. Tegelijkertijd zijn zowel ten aanzien van de toepassing van het materiële jeugdbeschermingsrecht, de uitvoering van het feitenonderzoek en de rechtspositie van de minderjarige en ouders, knel- en/of aandachtspunten gesignaleerd. Deels gaat het dan om cruciale vereisten op grond van (inter)nationale wet- en regelgeving die niet voldoende terugkwamen in de beschermingsrapporten en beschikkingen; en deels omdat de wijze waarop (inter)nationale wet- en regelgeving werd toegepast in de beschermingsrapporten en beschikkingen voor verbetering vatbaar was. De knel- of aandachtspunten op hoofdlijnen voor de jaren 2013 en 2014 worden hieronder kort beschreven. In de afsluiting van deel III van het onderzoek gericht op de toepassing van het jeugdbeschermingsrecht na 2015, wordt gekeken in hoeverre de geconstateerde knel- en aandachtspunten zijn verminderd of weggenomen.

\section{1) Onvoldoende aandacht voor de toetsing van de noodzaak van de ondertoezichtstelling en uithuisplaatsing}

De afweging of een jeugdbeschermingsmaatregel in juridisch opzicht noodzakelijk is bestaat uit twee kernelementen. Een primair pedagogisch oordeel over de ontwikkeling van de minderjarige en de onderbouwing ten aanzien van noodzaak om met dwang in te grijpen in het familie- en gezinsleven van de minderjarige en zijn ouders. Het dossieronderzoek heeft laten zien dat de toetsing van de noodzaak van overheidsdwang door de RvdK en de kinderrechter achterbleef bij de inhoudelijke onderbouwing van de ontwikkelingsbedreiging van de minderjarige. Ten aanzien van de ondertoezichtstelling is gebleken dat zowel de RvdK 
als de kinderrechter het (voorzienbare) falen van andere middelen veel minder vaak inhoudelijk uitwerkten dan de zorgen die die hebben geleid tot het oordeel dat sprake was van een ernstige bedreiging van de zedelijke of geestelijke belangen of gezondheid van de minderjarige. Voor de uithuisplaatsing niet zijnde een gesloten plaatsing moest de noodzaak (onder meer) blijken uit het feit dat niet kon worden volstaan met minder ingrijpende alternatieven. Ook hier was zichtbaar dat de argumentatie vooral gericht was op de ontwikkelingsproblematiek van de minderjarige en niet consequent werd aangegeven waarom alternatieven voor een uithuisplaatsing niet voldoende waren. Hoewel maar een klein aantal zaken is geanalyseerd waarin een machtiging gesloten jeugdzorg werd verzocht sluiten de resultaten van het onderzoek wel aan bij voornoemde bevindingen. De RvdK besteedde in alle zaken waarin een gesloten plaatsing werd verzocht aandacht aan de ernstige opgroei- en opvoedproblemen van de minderjarige. Maar de tweede grond voor een gesloten plaatsing het risico op onttrekking aan de noodzakelijke zorg - werd in slechts de helft van de onderzochte zaken inhoudelijk getoetst door de $\mathrm{RvdK}$ en de kinderrechter. In het onderzoek is steeds het belang benadrukt om ook consequent te toetsen waarom vrijwillige hulpverlening of in ieder geval minder ingrijpende alternatieven onvoldoende zijn om de ontwikkelingsbelangen van de minderjarige veilig te stellen.

\section{2) Te weinig diepgang in afweging omtrent een uithuisplaatsing}

Een uithuisplaatsing kan als middel worden ingezet binnen de ondertoezichtstelling om de ontwikkelingsbelangen (en vaak de veiligheid) van de minderjarige te garanderen. Het is voor de betrokken minderjarige en zjn ouders buitengewoon ingrijpend hetgeen wel blijkt uit het feit dat het verweer zich doorgaans richt tegen de uithuisplaatsing en niet zozeer de ondertoezichtstelling. De rechtsgrond van de machtiging uithuisplaatsing (art. 1:261 oud BW), zo is geconstateerd, gaf echter weinig sturing ten aanzien van de vraag hoe de noodzaak van een scheiding van de minderjarige en zijn ouders moest worden aangetoond. Die sturing kon wel worden gevonden in de vereisten die gelden voor een scheiding van kind en ouder op grond van art. 8 EVRM en art. 9 IVRK). Op basis van de analyse van zaken is geconcludeerd dat deze vereisten onvoldoende werden betrokken in de besluitvorming van de RvdK en de kinderrechter. De inhoudelijke afweging over de noodzaak van een uithuisplaatsing was zeker ten opzichte van de afwegingen in het kader van de ondertoezichtstelling - vaak opvallend summier. In het beschermingsrapport werd door de raadsonderzoeker doorgaans alleen kort antwoord gegeven op de vraag of een uithuisplaatsing in het belang was van de 
verzorging en opvoeding van de minderjarige. En ook in de beschikking was lang niet altijd sprake van een uitgebreide motivering ten aanzien van de noodzaak tot uithuisplaatsing. Dit heeft geleid tot de conclusie op tenminste twee punten de onderbouwing van de noodzaak tot uithuisplaatsing tekort schoot. Ten eerste werd in de besluitvorming onvoldoende aandacht besteed aan de mogelijkheid om met minder ingrijpende alternatieven een uithuisplaatsing te voorkomen. Daaronder ook begrepen dat als werd besloten een uithuisplaatsing te verzoeken er in ieder geval gekeken zou moeten worden of een plaatsing binnen het netwerk, in een gezinsvervangende omgeving tot de mogelijkheden behoorde. En ten tweede een gebrek aan aandacht voor het doel dat met de uithuisplaatsing werd nagestreefd en daarmee een inschatting van het opvoedperspectief van de minderjarige.

\section{3) Geen duidelijk afwegingskader voor het feitenonderzoek in jeugdbeschermingszaken}

In het onderzoek is ruim aandacht besteed aan de discussie over de rol van waarheidsvinding in jeugdbeschermingszaken. De focus heeft daarbij gelegen op de zorgvuldigheid van het feitenonderzoek zoals uitgevoerd door de RvdK in 2013 en 2014. Belangrijkste bevinding is dat de RvdK in het overgrote deel van de geanalyseerde zaken de ingebrachte informatie correct verwerkte in de beschermingsrapportage. In de zaken waarin dit niet gebeurde was meestal sprake van mening/visie van een betrokkene of informant die te stellig (feitelijk) werd verwoord door de RvdK. Deze conclusie had niet getrokken kunnen worden zonder een afwegingskader op basis waarvan de informatieverwerking door de RvdK kon worden geanalyseerd. Met andere woorden, binnen het onderzoek zijn een aantal criteria geformuleerd om te bepalen welke informatie als feitelijk kon worden beschouwd en welke informatie als mening van de betrokkenen. De wet- en regelgeving die in 2013 en 2014 op jeugdbeschermingszaken van toepassing was gaf geen nadere indicaties over interpretatie van gegevens tijdens het feitenonderzoek. En ook in de bredere discussie over waarheidsvinding werd niet of nauwelijks aandacht besteed aan het inhoudelijke onderscheid tussen feiten en meningen. Zonder verheldering van dit onderscheid kan het feitenonderzoek in jeugdbeschermingszaken niet verbeterd worden.

4) Onvoldoende aandacht voor de (mening van de) minderjarige in het besluitvormingsproces Het dossieronderzoek heeft laten zien dat het horen van de minderjarige door de RvdK en de kinderrechter en het betrekken van de minderjarige in de besluitvorming, in de jaren 2013 en 
2014 niet optimaal verliep. Zo bleek dat de RvdK in het beschermingsrapport nog niet altijd standaard aangaf of de minderjarige was gesproken, terwijl dit volgens het eigen Kwaliteitskader wel had gemoeten. Daarnaast is duidelijk geworden dat de informatieverstrekking aan de minderjarige over de besluitvorming door de $\mathrm{RvdK}$ voor verbetering vatbaar was. Zo kreeg de minderjarige in de regel pas vanaf 16 jaar inzage in de conceptrapportage van de RvdK en was in veel gevallen onduidelijk of het voorgenomen verzoek met de minderjarige was besproken en welke reactie hij hierop had gegeven. Ten aanzien van het horen van de minderjarige door de kinderrechter is gebleken dat de leeftijd van twaalf in de praktijk fungeerde als een harde grens. Onder de twaalf jaar konden minderjarigen in de gelegenheid worden gesteld om te worden gehoord, maar het dossieronderzoek heeft laten zien dat dit niet of nauwelijks voorkwam. Het feit dat het kon, betekende in de praktijk dat de minderjarige zelf het initiatief moest nemen om te worden gehoord. Boven de twaalf jaar werd de minderjarige wel in de gelegenheid gesteld om te worden gehoord en een groot deel van de minderjarigen (binnen de steekproef) maakte hiervan gebruik. Tot slot is geconcludeerd dat kinderrechters beperkt van de mogelijkheid gebruik maakten om de mening van de minderjarige expliciet weer te geven bij de overwegingen in de beschikking. Op grond van art. 12 IVRK moet de minderjarige zijn mening vrijelijk kunnen uiten over beslissingen die hem aangaan en moet aan de mening van de minderjarige passend belang worden gehecht overeenkomstig de leeftijd en rijpheid van de minderjarige. Door het opnemen van de mening van de minderjarige in de beschikking kan de kinderrechter laten zien de mening van de minderjarige serieus te nemen. Daarnaast is het een goede manier om aan de minderjarige te communiceren of, en zo ja op welke manier, zijn mening een rol heeft gespeeld in de besluitvorming. 


\section{Deel III Bevindingen en reflecties op de jeugdbeschermingspraktijk vanaf 2015}

\section{De rechtvaardiging van jeugdbescherming vanaf 1 januari 2015}

\subsection{Inleiding}

Op de in deel I en II van deze studie onderzochte vraagstukken hebben de ontwikkelingen in het recht sinds 2013 en 2014 niet stilgestaan. Het materiële jeugdbeschermingsrecht is op 1 januari 2015 ingrijpend gewijzigd met inwerkingtreding van de Wet herziening kinderbeschermingsmaatregelen. ${ }^{647}$ De Wet herziening kinderbeschermingsmaatregelen moet zorgen voor een effectiever en efficiënter systeem van jeugdbescherming. Dit moet worden bereikt door een betere onderlinge afstemming van de maatregelen; een duidelijkere scheiding tussen vrijwillige hulpverlening en het gedwongen kader en meer aandacht voor de (rechts)positie van het kind in de besluitvorming. ${ }^{648}$ Eveneens op 1 januari 2015 zijn substantiële aanpassingen gedaan in het systeem jeugdhulp en jeugdbescherming door de inwerkingtreding van de Jeugdwet. ${ }^{649}$ De Jeugdwet beoogt door meer in te zetten op preventie en het tijdig bieden van de juiste hulp op maat, te komen tot een efficiënter en beter functionerend systeem van jeugdhulp. ${ }^{650}$ Ook op andere voor dit onderzoek belangrijke thema's kunnen voor de periode na 2013/2014 belangrijke ontwikkelingen worden gesignaleerd. Zo heeft de wetgever getracht het feitenonderzoek in jeugdbeschermingszaken verder te normeren en hebben zowel de Jeugdwet als de Wet herziening kinderbeschermingsmaatregelen voor aanpassingen in de rechtspositie van de minderjarige en zijn ouders gezorgd.

Deze ingrijpende wetswijzigingen zijn midden in de onderzoeksperiode van dit onderzoek doorgevoerd. Dit heeft de nodige consequenties gehad voor de opzet, uitvoering en de waarde van de uitkomsten van dit onderzoek. De wijzigingen in de jeugdbeschermingswetgeving

\footnotetext{
${ }^{647}$ Wet van 12 maart 2014 tot wijziging van Boek 1 van het Burgerlijk Wetboek, het Wetboek van Burgerlijke Rechtsvordering, de Wet op de jeugdzorg en de Pleegkinderenwet in verband met herziening van de maatregelen van kinderbescherming, Stb. 2014, 130.

${ }^{648}$ Kamerstukken II 2008/9, 32 015, nr. 3 (MvT).

${ }^{649}$ Wet van 1 maart 2014 inzake regels over de gemeentelijke verantwoordelijkheid voor preventie, ondersteuning, hulp en zorg aan jeugdigen en ouders bij opgroei- en opvoedingsproblemen, psychische problemen en stoornissen (Jeugdwet), Stb. 2014, 105.

${ }^{650}$ Kamerstukken II 2012/13, 33684, nr. 3. Zie ook De Boer \& Bruning FJR 2018/46.
} 
hebben uiteraard tot doel om de bescherming van kinderen in Nederland te verbeteren. Het is dus mogelijk - maar niet vanzelfsprekend - dat de knelpunten die zijn geconstateerd in dit onderzoek voor de jaren 2013 en 2014, deels zijn ondervangen door wijzigingen in wetgeving en beleid. Er is daarom voor gekozen een deel III aan dit onderzoek toe te voegen waarin in verschillende stappen wordt gekeken naar de ontwikkelingen op het terrein van de jeugdbescherming sinds begin 2015.

In de eerste plaats worden de belangrijkste wijzigingen op het gebied van het materiële en formele jeugdbeschermingsrecht beschreven. Het gaat dan primair om wijzigingen die zijn doorgevoerd met de Wet herziening kinderbeschermingsmaatregelen en de Jeugdwet, waarbij alleen de elementen terugkomen die direct in het verlengde liggen van hetgeen is behandeld in deel I en deel II van het onderzoek. Vervolgens wordt aan de hand van de resultaten van het dossieronderzoek over de jaren 2013 en 2014 gereflecteerd op de belangrijkste wijzigingen in wetgeving en beleid. Wat betekenen de specifieke wijzigingen voor de resultaten ten aanzien van de gronden en doelstellingen van de maatregelen, het feitenonderzoek en de rechtspositie van kind en ouders.

Tot slot worden enkele actuele onderzoeken besproken waarin wordt gekeken naar de toepassing van het jeugdbeschermingsrecht sinds 2015. Bovenal moet dan worden gedacht aan de tussenevaluatie van de Wet herziening kinderbeschermingsmaatregelen die in augustus 2018 is uitgekomen. ${ }^{651}$ In samenwerking met het Verwey-Jonker Instituut heeft deze auteur (voor deze tussenevaluatie) gekeken in hoeverre de resultaten van de gewijzigde jeugdbeschermingswetgeving zich ontwikkelen in de richting van de met de wet nagestreefde doelen. Primair gaat het om de toepassing van de gewijzigde gronden van de ondertoezichtstelling en de nieuw geïntroduceerde gezagsbeëindigende maatregel. Ook de Jeugdwet is inmiddels geëvalueerd. ${ }^{652}$ Belangrijke elementen voor dit onderzoek uit deze evaluatie worden op hoofdlijnen beschreven, aangezien de manier waarop het systeem van jeugdhulp is georganiseerd en functioneert van invloed is op de vraag wanneer, op welke manier en onder welke voorwaarden een jeugdbeschermingsmaatregel kan worden opgelegd.

Paragraaf 2 van dit hoofdstuk vangt aan met een kort overzicht van de belangrijkste achtergronden en kenmerken van de gewijzigde jeugdbescherming. Hierna volgt het hoofdstuk de structuur van het dossieronderzoek zoals uitgewerkt in deel II van het

\footnotetext{
${ }^{651}$ Lunnemann, Huijer e.a. 2018.

${ }^{652}$ Friele e.a. 2018.
} 
onderzoek. Eerst wordt in paragraaf 10.3 uitgebreid aandacht besteed aan de wijzigingen ten aanzien van de ondertoezichtstelling. Vervolgens worden in paragraaf 10.4 de belangrijkste wijzingen besproken die toezien op de besluitvorming in uithuisplaatsingszaken. In paragraaf 10.5 staat de gezagsbeëindigende maatregel centraal. Gezagsbeëindiging heeft in deel I en deel II van dit onderzoek geen belangrijke rol gespeeld. Voor de toepassing van het jeugdbeschermingsrecht na 2015 is het echter noodzakelijk hier uitgebreid op in te gaan, nu de maatregel van ondertoezichtstelling en de gezagsbeëindigende maatregel sindsdien in direct verband met elkaar staan. Aan de hand van de wettelijke gronden wordt gekeken naar de afweging tussen gezagsbeperking en gezagsbeëindiging zoals die in de praktijk sinds 2015 wordt gemaakt. Hierna wordt de voortdurende discussie over de zorgvuldigheid van het feitenonderzoek geschetst. Paragraaf 10.6 vangt aan met een kort overzicht van de belangrijkste punten die terugkomen in de maatschappelijke en politieke discussie. Vervolgens worden relevante ontwikkelingen op het gebied van wetgeving, rechtspraak en beleid besproken. Tot slot wordt in paragraaf 10.7 aandacht besteed aan de rechtspositie van de minderjarige en zijn ouders in de voor het onderzoek relevante deel van de jeugdbeschermingsprocedure.

\subsection{De Wet herziening kinderbeschermingsmaatregelen en de Jeugdwet: achtergronden en uitgangspunten}

Het is niet zonder reden dat in dit onderzoek een 'knip' in de tijd is gemaakt op 1 januari 2015. Op deze datum traden de Wet herziening kinderbeschermingsmaatregelen en de Jeugdwet gelijktijdig in werking. De invloed van deze omvangrijke wetswijzigingen op de besluitvorming binnen het systeem van jeugdbescherming is groot. Hoewel beide wetten de datum van inwerkingtreding delen, zijn de verschillen als wordt gekeken naar de totstandkomingsgeschiedenis en uitgangspunten die aan de wijzigingen ten grondslag hebben gelegen aanzienlijk. In het vervolg wordt een globaal overzicht gegeven van de totstandkoming- en belangrijke uitgangspunten van beide wetten, te beginnen met de Wet herziening kinderbeschermingsmaatregelen.

De Wet herziening kinderbeschermingsmaatregelen - achtergronden

Het materiële jeugdbeschermingsrecht is gerekend vanaf 2015 voor het laatst ingrijpend gewijzigd met de wettelijke herziening van de ondertoezichtstelling in 1995. De Wet herziening kinderbeschermingsmaatregelen kende dus een behoorlijk lange aanlooptijd, zeker 
gezien het feit dat al vrij kort na 1995 de kritiek op het functioneren van het systeem van jeugdbescherming toenam. Zo liet de in 2000 uitgekomen evaluatie van de jeugdbeschermingswetgeving zien dat de belangrijkste doelstelling van de herziening, het verbeteren en verduidelijken van de rechtswaarborgen voor belanghebbenden, niet was behaald. ${ }^{653}$ Een gesignaleerd knelpunt, dat later een belangrijke rol zou spelen bij de aanpassing van het maatregelenpakket, betrof het onduidelijke onderscheid tussen de ondertoezichtstelling en de ontheffing uit het gezag. ${ }^{654}$ Specifiek ging het dan om minderjarigen die in het kader van een ondertoezichtstelling op jonge leeftijd in een pleeggezin waren geplaatst. Hoe langer de plaatsing in het pleeggezin duurde, hoe groter de kans dat de doelstelling van de ondertoezichtstelling uit beeld raakte. Het verlengen van de ondertoezichtstelling waarbij werd gestreefd naar behoud van ouderlijke verantwoordelijkheid strookte niet met de praktijk waarin de pleegouders deze verantwoordelijkheid feitelijk droegen. Beëindiging van het gezag door middel van ontheffing zou hier meer voor de hand liggen, maar dat werd in de praktijk veelal als een te ingrijpende stap gezien. Onder meer Bruning vroeg in haar in 2001 uitgekomen dissertatie uitgebreid aandacht voor de onduidelijke verhouding tussen de ondertoezichtstelling en gezagsontneming. ${ }^{655} \mathrm{Zij}$ concludeerde dat de maatregelen duidelijk van elkaar te onderscheiden doelen zouden moeten nastreven om tot een gerechtvaardigde inbreuk op het familie- en gezinsleven van kind en ouders te kunnen komen. ${ }^{656}$

Niet lang hierna werd in opdracht van het ministerie van Justitie een werkgroep gestart die moest adviseren over de herziening van de jeugdbeschermingsmaatregelen. ${ }^{657}$ Het advies van deze werkgroep (Kinderen eerst!) kwam uit in 2006 en bestond uit drie hoofdonderwerpen: aanpassingen van de gronden van de jeugdbeschermingsmaatregelen, de verantwoording over de uitvoering van de ondertoezichtstelling en voogdij en de rechtspositie van belanghebbenden. Als belangrijk uitgangspunt werd geformuleerd dat de ontwikkeling van de minderjarige centraal moest staan in de overweging of een maatregel noodzakelijk was en zo ja, welke maatregel het beste aansloot bij het ontwikkelingsbelang van de minderjarige. ${ }^{658}$ Het advies vormde voor een belangrijk deel de basis voor het voorontwerp van wet en uiteindelijk

\footnotetext{
${ }^{653}$ De Savornin Lohman e.a. 2000, p. 105 e.v.

${ }^{654}$ De Savornin Lohman e.a. 2000, p. 34.

${ }^{655}$ Bruning 2001, p. 307.

${ }^{656}$ Bruning 2001, p. 147.

${ }^{657}$ Zie hierover Bruning \& Kok 2008, p. 3-4.

${ }^{658}$ Bruning \& Kok 2008, p. 4.
} 
voor het in 2008 uitgekomen wetsvoorstel. ${ }^{659}$ Uitgangspunt van de voorgestelde wetswijziging was om op grond van het IVRK het recht van het kind op een gezonde en evenwichtige ontwikkeling en groei naar zelfstandigheid voorop te stellen. ${ }^{660}$ De manier om dit doel te bereiken was volgens de wetgever sneller en zwaarder ingrijpen. Het wetsvoorstel gaf blijk van een veranderende balans tussen de van oudsher terughoudende opstelling van de overheid bij gezinsinterventie en het streven naar actiever en sneller ingrijpen met als doel een voorspoedige ontwikkeling van het kind beter te waarborgen. ${ }^{661}$ Zo werd wijziging van de rechtsgrond van de ondertoezichtstelling beoogd, teneinde de maatregel ook in te kunnen zetten bij lichtere opvoed- en opgroeiproblemen. ${ }^{662}$ De Raad van State toonde zich erg kritisch over de voorgestelde verruiming van de mogelijkheden om gedwongen in te grijpen in het gezinsleven. ${ }^{663}$ Zo werd geconcludeerd dat eerst de doeltreffendheid van maatregelen zou moeten toenemen voordat aan een verruiming van de mogelijkheden tot ondertoezichtstelling en gezagsbeëindiging kon worden gedacht. ${ }^{664}$

Ook tijdens de parlementaire behandeling werd hevig gedebatteerd over de voorgestelde verruiming van de jeugdbeschermingsmaatregelen, waarbij de discussie zich vrijwel geheel richtte op de ondertoezichtstelling. ${ }^{665}$ De behandeling in de Tweede Kamer was eenzijdig en rommelig te noemen, ook omdat via amendering nog verschillende ingrijpende wijzigingen werden doorgevoerd. ${ }^{666}$ Opvallend was dat het doel om sneller in te grijpen middels dwangmaatregelen gedurende het wetgevingsproces steeds verder naar de achtergrond verdween, mede onder invloed van ontwikkelingen in de praktijk die toezagen op preventief ingrijpen. Door vroegtijdig te investeren in de mogelijkheden van het kind, zijn ouders en sociale omgeving, moesten jeugdbeschermingsmaatregelen worden voorkomen. ${ }^{667}$

Uiteindelijk kan worden geconcludeerd dat bij inwerkingtreding van de wet op 1 januari 2015, het streven naar sneller ingrijpen niet is verdwenen maar wel minder prominent terugkomt in de gewijzigde wettelijke bepalingen.

\section{De Wet herziening kinderbeschermingsmaatregelen - uitgangspunten}

De Wet herziening kinderbeschermingsmaatregelen kent als centraal uitgangspunt dat het

\footnotetext{
${ }^{659}$ Kamerstukken II 2008/9, 32 015, nr. 2.

${ }^{660}$ Kamerstukken II 2008/9, 32 015, nr. 3.

${ }^{661}$ Bruning AA 2011/779.

${ }^{662}$ Kamerstukken II 2008/9, 32 015, nr. 2.

${ }^{663}$ Kamerstukken II 2008/9, 32 015, nr. 4.

${ }^{664}$ Kamerstukken II 2008/9, 32 015, nr. 4.

${ }^{665}$ Zie Handelingen II 2010/11, 32 015, nrs. 47 \& 49.

${ }^{666} \mathrm{Vgl}$ Forder 2012, p. 71 e.v. ;Weijers 2012, p. 28.

${ }^{667}$ Zie voor een verdere analyse: Huijer FJR 2015/8.
} 
ontwikkelingsperspectief van de minderjarige leidend moet zijn voor de vorm, duur en uitvoering van de gedwongen hulpverlening. ${ }^{668}$ Een meer kindgerichte formulering van gronden van de jeugdbeschermingsmaatregelen moet zorgen voor een betere aansluiting tussen gezagsbeperking en gezagsbeëindiging waardoor het eenvoudiger wordt een maatregel te kiezen die het meest aansluit bij de omstandigheden waaronder de minderjarige opgroeit. ${ }^{669}$ Om dit te bereiken is de rechtsgrond van de ondertoezichtstelling ingrijpend aangepast. Daarnaast is door aanpassing van de gronden een duidelijke koppeling gemaakt tussen de ondertoezichtstelling en de nieuw geïntroduceerde maatregel van gezagsbeëindiging. Voorts zijn een aantal subdoelen opgesteld die samenhangen of mede invulling geven aan de centrale doelstelling van de Wet herziening kinderbeschermingsmaatregelen. Zo wordt het waarborgen van de stabiliteit en continuïteit in de opvoedingssituatie van de minderjarige als een van de speerpunten van de nieuwe wetgeving aangemerkt. Dit veronderstelt dat de minderjarige zo min mogelijk wordt geconfronteerd met wisselende opvoedsituaties en dat bij voorkeur degene die de minderjarige feitelijk verzorgt en opvoedt ook in juridisch opzicht de verantwoordelijkheid draagt voor de verzorging en opvoeding. ${ }^{670}$ Hieraan ligt de gedachte ten grondslag dat stabiliteit en continuïteit in de opvoedsituatie een noodzakelijke voorwaarde is voor een adequate ontwikkeling van de minderjarige. ${ }^{671}$

Een volgend subdoel hangt hier sterk mee samen. Getracht moet worden om onnodige verlengingen van de ondertoezichtstelling zoveel mogelijk te voorkomen. De ondertoezichtstelling is een tijdelijke maatregel gericht op de ondersteuning van het gezin en het behoud van ouderlijke verantwoordelijkheid (art. 1:262 BW). Op het moment dat deze doelstelling in de praktijk niet meer actief wordt nagestreefd, moet worden gekeken of gezagsbeëindiging in het belang van de minderjarige is. ${ }^{672}$ Een volgend subdoel is het vergroten van de transparantie en doelgerichtheid tijdens de uitvoering van de ondertoezichtstelling. Dit moet onder meer worden bereikt door in elke fase van de besluitvorming duidelijk aan te geven hoe de concrete bedreiging in de ontwikkeling van de minderjarige eruit ziet. Daarnaast heeft de gezinsvoogd (nu jeugdbeschermer genoemd) een aantal extra bevoegdheden gekregen in de uitvoering van de maatregelen. ${ }^{673}$ Tot slot is

\footnotetext{
${ }^{668}$ Kamerstukken II 2008/9, 32 015, nr. 3 (MvT)

${ }^{669}$ Kamerstukken II 2008/9, 32 015, nr. 3 (MvT)

${ }^{670}$ Kamerstukken II 2008/9, 32 015, nr. 3 (MvT), par. 5.2.

${ }^{671}$ Zie Kalverboer \& Zijlstra 2006.

${ }^{672}$ Kamerstukken II 2008/9, 32 015, nr. 3 (MvT), par. 5.2.

${ }^{673} \mathrm{Om}$ de ondertoezichtstelling doelgerichter te maken heeft de jeugdbeschermer een aantal bevoegdheden gekregen, onder meer het toekennen van deelgezag bij een uithuisplaatsing, het verzoeken tot vaststelling veen
} 
beoogd om meer duidelijkheid aan te brengen in de hiërarchie die geldt voor het indienen van een verzoek tot jeugdbeschermingsmaatregel. Om deze doelen te bereiken zijn een groot aantal wettelijke bepalingen uit Boek 1 Burgerlijk Wetboek gewijzigd, alsook enkele bepalingen in aanverwante wet- en regelgeving. De concrete wijzigingen ten aanzien van het maatregelenpakket komen in het vervolg van het hoofdstuk aan bod.

\section{De Jeugdwet - achtergronden}

Zoals eerder in het onderzoek is beschreven hebben de wetswijzigingen op het terrein van jeugdzorg elkaar in de achterliggende decennia in hoog tempo opgevolgd. De in 2005 ingevoerde Wet op de Jeugdzorg bleek niet de oplossing voor de diverse knelpunten in het systeem van zorg aan jeugdigen, zo bleek onder meer uit de tussenevaluatie die uitkwam in 2009. ${ }^{674}$ Zo wees de evaluatie uit dat financiële prikkels binnen het systeem dure gespecialiseerde zorg in de hand werkten; de samenwerking tussen hulpverleningsinstanties te wensen overliet en er onnodig werd gemedicaliseerd, hetgeen leidde tot oplopende zorgkosten. ${ }^{675}$ Kort hierna werd in 2010 in het Regeerakkoord een ingrijpende wijziging van het jeugdstelsel aangekondigd, met als belangrijkste doelstelling een verschuiving van zware zorg naar lichtere vormen van ondersteuning. ${ }^{676}$ Een omslag in denken en werken werd nodig geacht. Meer uitgaan van de eigen kracht van gezinnen, minder snel medicaliseren en een betere samenwerking rond gezinnen. ${ }^{677}$ Het jeugdstelsel moest eenvoudiger, effectiever en efficiënter worden. Effectiever en efficiënter betekende in dit verband ook goedkoper, aangezien de introductie van de Jeugdwet gepaard ging met forse bezuinigingen op de jeugdhulp. ${ }^{678} \mathrm{Om}$ de doelen van de Jeugdwet te bereiken werd het noodzakelijk bevonden de verantwoordelijkheid voor de jeugdhulp te decentraliseren naar gemeentelijk niveau.

Het hoge tempo van het wetgevingsproces van de Jeugdwet, leidde tot scherpe kritiek. QuikSchuijt die als lid van de Eerste Kamer moest oordelen over de Jeugdwet bestempelde de krappe tijd voor de behandeling van het wetsvoorstel als 'een nachtmerrie' en 'een Eerste Kamer onwaardig' ${ }^{679}$ Ook op andere fronten was er forse kritiek op de wijzigingen die met Jeugdwet werden beoogd. Onder andere vanuit de jeugd-GGZ kwam forse kritiek op de

\footnotetext{
omgangsregeling en het verzoeken tot bekrachtiging van de schriftelijke aanwijzing. Daarnaast mag informatie worden opgevraagd bij derden zonder toestemming van ouders.

674 Baecke e.a 2009.

${ }^{675}$ Baecke e.a 2009, p. 151 e.v.

${ }^{676}$ Kamerstukken II 2010/11 32 417, nr. 15.

${ }^{677}$ Kamerstukken II 2012/13 33 684, nr. 3, p. 2 e.v. (MvT).

${ }^{678}$ Zie hierover Bruning \& De Boer FJR 2018/46.

${ }^{679}$ Quik-Schuijt FJR 2015/51.
} 
transitie van de zorg naar gemeentelijk niveau. ${ }^{680}$ Dit alles heeft er niet aan de in weg gestaan dat anderhalf jaar na de publicatie van het voorstel van wet, de Jeugdwet op 1 januari 2015 volledig in werking is getreden. ${ }^{681}$

\section{De Jeugdwet - uitgangspunten}

De Jeugdwet plaatst de verantwoordelijkheid voor alle vormen van jeugdhulp bij gemeenten. Het gaat dan primair om de toeleiding tot de toekenning van alle vormen van jeugdhulp, een taak die voorheen aan de Bureaus Jeugdzorg was toebedeeld. ${ }^{62}$ Gemeenten hebben in de uitvoering van die taak grote vrijheid gekregen om zelf te bepalen hoe de toegang is geregeld en hoe lokaal het hulpverleningsaanbod wordt ingevuld. Een belangrijke consequentie hiervan is dat er tussen gemeenten grote verschillen zijn ontstaan, hetgeen in de eerste plaats de minderjarige en zijn ouders treft. Gemeenten zijn verantwoordelijk jeugdhulpvoorzieningen te treffen voor jeugdigen die hun woonplaats hebben in die betreffende gemeente. De bepaling van de woonplaats van de minderjarige vindt nu nog volgens art. 1.1 Jeugdwet jo. art. 1:12 lid $1 \mathrm{BW}$ plaats door te kijken naar de woonplaats van de ouder met gezag. ${ }^{683}$ De gemeente waar de minderjarige zijn woonplaats heeft een jeugdhulpplicht op grond van art. 2.6 Jeugdwet. Dit betekent dat de gemeente verantwoordelijk is voor de toeleiding naar- maar ook voor een dekkend aanbod van- kwalitatief goede zorg. De centrale toegang tot jeugdhulp is veelal in handen van sociale wijkteams, die samenwerken met Veilig Thuis (voorheen AMK), de RvdL, politie en de gecertificeerde instellingen (GI). ${ }^{684}$ De gecertificeerde instellingen hebben de Bureaus Jeugdzorg vervangen en zijn nu verantwoordelijk voor de uitvoering van de jeugdbeschermings- en jeugdreclasseringsmaatregelen (art. 3.2 Jeugdwet).

Met de ingrijpende wijzigingen in het systeem van jeugdhulp in Nederland wordt een aantal doelen ('transformatiedoelen') nagestreefd. Het eerste transformatiedoel gaat over preventie, uitgaan van eigen mogelijkheden en eerder de juist hulp op maat, waardoor de inzet van dure

\footnotetext{
${ }^{680}$ Zie hierover uitgebreid: Dorenberg FJR 2014/62.

${ }^{681}$ Het voorstel van wet kwam uit op 1 juli 2013: Kamerstukken II 2013/14, 33 684, nr 2. Wet van 1 maart 2014 inzake regels over de gemeentelijke verantwoordelijkheid voor preventie, ondersteuning, hulp en zorg aan jeugdigen en ouders bij opgroei- en opvoedingsproblemen, psychische problemen en stoornissen (Jeugdwet), $($ Stb 2014,105$)$

682 Zie hierover Bruning \& De Boer FJR 2018/46.

${ }^{683} \mathrm{Op}$ het woonplaatsbeginsel zoals opgenomen in de Jeugdwet is veel kritiek gekomen. Het zou in de praktijk soms het tijdig bieden van de juiste jeugdhulp in de weg staan. Vgl: Transitie Autoriteit Jeugd 2017b, p. 8. Zie ook Oosterbaan, Van Huizen \& Den Outer 2016; Friele e.a 2018, p. 51. Op het moment van schrijven is een wetsvoorstel aanhanging waarin het woonplaatsbeginsel wordt gewijzigd. Kamerstukken II 2018-2019, 35 219, nr. 3 (Wet wijziging woonplaatsbeginsel). Mocht de wet worden aangenomen dan wordt de woonplaats van de minderjarige bepaald door te kijken waar hij zijn woonadres heeft volgens de Basisregistratie Personen.

${ }^{684}$ Friele e.a. 2018, p. 49.
} 
gespecialiseerde hulp kan worden verminderd. ${ }^{685}$ Daarbij is het uitgangspunt dat preventie en de juiste hulp op maat, een verergering van de problematiek kan voorkomen, waardoor minder langdurige en intensieve hulp (in gedwongen kader) nodig is. Het tweede transformatiedoel gaat over meer samenhang binnen jeugdhulp aan jeugdigen en gezinnen door betere samenwerking en innovaties in ondersteuning, hulp en zorg aan jeugdigen en gezinnen. Het derde en laatste transformatiedoel betreft meer ruimte voor professionals om de juiste hulp te bieden door vermindering van regeldruk. Gemeenten hebben voorts de verplichting hun beleid af te stemmen met het onderwijs. Uitgangspunt bij dit alles is dat de verantwoordelijkheid voor het gezond en veilig opgroeien van jeugdigen allereerst bij de ouders en de jeugdige zelf ligt. ${ }^{686}$

\subsection{De rechtvaardiging van de ondertoezichtstelling}

Na inwerkingtreding van de Wet Herziening kinderbeschermingsmaatregelen telt de rechtsgrond van de ondertoezichtstelling drie cumulatieve voorwaarden waaraan moet zijn voldaan voor oplegging van de maatregel. Op grond van art. 1:255 lid $1 \mathrm{BW}$ kan de kinderrechter een minderjarige onder toezicht stellen van een gecertificeerde instelling indien: de minderjarige zodanig opgroeit dat hij in zijn ontwikkeling ernstig wordt bedreigd; de zorg die in verband met het wegnemen van de bedreiging noodzakelijk is voor de minderjarige of voor zijn ouders of de ouder die het gezag uitoefenen door dezen niet of onvoldoende wordt geaccepteerd; en de verwachting gerechtvaardigd is dat de ouders of de ouder die het gezag uitoefenen binnen een gelet op de persoon en ontwikkeling van de minderjarige aanvaardbaar te achten termijn, de verantwoordelijkheid voor de verzorging en opvoeding, bedoeld in art. 1:247 lid $2 \mathrm{BW}$, in staat zijn te dragen.

De eerste gewijzigde voorwaarde (ernstige ontwikkelingsbedreiging in plaats van ernstige bedreiging van de zedelijke of geestelijke belangen of gezondheid, cursief $\mathrm{JH}$ ) beoogt geen verandering aan te brengen ten aanzien van het moment van ingrijpen. Het betreft hier slechts een tekstuele aanpassing die aansluit bij de reeds gehanteerde terminologie in beschermingsonderzoeken. Zo werd in de beschermingsrapporten in de jaren 2013 en 2014 vrijwel altijd al consequent gesproken over 'ontwikkelingsbedreiging' en niet over 'bedreiging van de zedelijke of geestelijke belangen of gezondheid'. Toch verdient deze

\footnotetext{
${ }^{685}$ Kamerstukken II 2012/13 33 684, nr. 3 (MvT), p. 2 e.v.

${ }^{686}$ Kamerstukken II 2012/13 33 684, nr. 3 (MvT), p. 2 e.v.
} 
wijziging uitgebreid de aandacht. In de eerste plaats omdat de vraag wat onder 'een ernstige ontwikkelingsbedreiging' moet worden verstaan een substantieel deel van de parlementaire behandeling van het wetsvoorstel tot herziening van de kinderbeschermingsmaatregelen in beslag heeft genomen. ${ }^{687}$ Dat geldt, opvallend genoeg, in veel mindere mate voor de overige twee vereisten in de rechtsgrond van de ondertoezichtstelling. ${ }^{688}$ De tweede voorwaarde 'het niet of onvoldoende accepteren van de noodzakelijke zorg' is strikter geformuleerd dan het oude 'falen van hulpverlening' hetgeen gevolgen kan hebben voor de toepassing van de ondertoezichtstelling. De derde voorwaarde 'de aanvaardbare termijn' is nieuw geïntroduceerd en voegt een totaal nieuwe dimensie toe aan de besluitvorming over de ondertoezichtstelling. Er moet immers sprake zijn van een gerechtvaardigde verwachting dat ouders binnen een aanvaardbare termijn de verantwoordelijkheid voor de verzorging en opvoeding in staat zijn te dragen. Is die verwachting niet gerechtvaardigd dan zou volgens de wettelijke systematiek gezagsbeëindiging moeten worden overwogen. De gevolgen voor de besluitvorming hiervan zijn aanzienlijk. Waar voorheen de ondertoezichtstelling centraal stond en gezagsontneming slechts een marginale rol speelde, zijn beide maatregelen nu nauw met elkaar verbonden. In de volgende paragrafen worden de drie cumulatieve vereisten voor de ondertoezichtstelling zoals thans opgenomen in art. 1:255 lid $1 \mathrm{BW}$ uitgebreid besproken.

\subsubsection{De ernstige ontwikkelingsbedreiging}

Tijdens de parlementaire behandeling van het wetsvoorstel tot herziening van de kinderbeschermingsmaatregelen in de Tweede Kamer is uitgebreid gediscussieerd over de grondslag van de ondertoezichtstelling op dit punt. Die discussie kwam voort uit de wens van de wetgever om het wettelijke vereiste 'ernstige bedreiging van de zedelijke of geestelijke belangen of gezondheid' te wijzigen in het ruimer geformuleerde 'onbedreigd opgroeien'. 689 In algemene zin leken de meeste kamerfracties zich moeilijk een inschatting te kunnen maken van de voorgestelde wijziging en vreesde men een verdere toename van het aantal jeugdbeschermingsmaatregelen. ${ }^{60}$ Het was aan toenmalig staatssecretaris Teeven om middels concrete voorbeelden meer duidelijkheid te verschaffen ten aanzien van de juridische duiding van het onderscheid tussen een bedreigde ontwikkeling en een ernstige bedreigde

\footnotetext{
${ }^{687}$ Vgl. Kamerstukken II 2010/11, 32 015, nr. 47; Kamerstukken II 2010/11, 32 015, nr. 49.

${ }^{688}$ Opvallend omdat deze wijzigingen wel direct consequenties hebben gehad voor de vraag wanneer een ondertoezichtstelling is aangewezen. Zie de inhoudelijke toelichting in de paragrafen 10.3.2 en 10.3.3.

${ }^{689}$ Zie onder meer Kamerstukken II 2010/11, 32 015, nr. 47; Kamerstukken II 2010/11, 32 015, nr. 49.

${ }^{690}$ Kamerstukken II 2010/11, 32 015, nr. 47, p. 71.
} 
ontwikkeling. Dat bleek een onmogelijke opgave. De besproken casuïstiek leidde geenszins tot een verhelderend antwoord op de vraag welke gevallen in de toekomst wel onder de wettelijke norm van de ondertoezichtstelling kunnen worden geschaard indien een 'slechts' bedreiging in de ontwikkeling van de minderjarige voldoende is ${ }^{691}$ Door te suggereren dat met enkele voorbeelden voornoemd onderscheid kon worden verduidelijkt werd voorbij gegaan aan het feit dat het wettelijke vereiste 'ernstige ontwikkelingsbedreiging' een open norm is. De invulling hiervan in de praktijk wordt casuïstisch benaderd en vraagt om een primair pedagogisch georiënteerd oordeel van de professional.

Kamerlid Kooijman (SP) merkte tijdens de parlementaire behandeling op dat professionals ook niet anders zouden gaan oordelen door het enkele schrappen van het woord 'ernstig' in de rechtsgrond. ${ }^{692}$ Dit standpunt verdient enige nuance. Een verruiming van de wettelijke gronden betekent natuurlijk wel dat in de praktijk eerder tot een ondertoezichtstelling kan worden besloten. De destijds voorgestelde wijziging zou de drempel voor ingrijpen verlagen, maar gaf nauwelijks houvast waar het ging om de afweging in individuele gevallen.

Uiteindelijk werd besloten om het woord 'ernstig' als onderdeel van 'ernstige ontwikkelingsbedreiging' als eerste cumulatieve voorwaarde is de rechtsgrond van de ondertoezichtstelling te behouden. ${ }^{693}$ Men mag er dus vanuit gaan dat het wettelijke vereiste zoals nu opgenomen in art. 1:255 lid $1 \mathrm{BW}$, niet leidt tot eerder of anders ingrijpen. De uitgangspunten op basis van de oude wetgeving en jurisprudentie ten aanzien het wettelijk criterium 'ernstige bedreiging van de zedelijke of geestelijke belangen of gezondheid' blijven derhalve relevant voor de beoordeling van de noodzaak tot ondertoezichtstelling. Dat geldt ook voor de bevindingen in deel II van dit onderzoek waarin op basis van dossiers uit 2013 en 2014 is gekeken naar de invulling van dit deel van de rechtsgrond door de RvdK en de kinderrechter.

\section{Relevantie dossieronderzoek voor de grond 'ernstige ontwikkelingsbedreiging'}

De analyse van de wijze waarop door de RvdK en de kinderrechter invulling werd gegeven aan de ernstige ontwikkelingsbedreiging van de minderjarige heeft een aantal belangrijke

\footnotetext{
${ }^{691}$ Handelingen II 2010/11, 32 015, nr. 47.

${ }^{692}$ Handelingen II 2010/11, 32 015, nr. 49.

${ }^{693}$ Hetgeen wel tot gevolg heeft gehad dat via amendering een nieuwe, lichtere maatregel van opgroeiondersteuning werd geïntroduceerd, waardoor het alsnog mogelijk moest worden kinderen met relatief lichte opgroeiproblemen een dwangmaatregel op te leggen; Kamerstukken II 2010/11, 32015, nr. 40 (amendement Dijsselbloem en Van Toorenburg). Bij behandeling van de Jeugdwet in de Tweede Kamer werd echter besloten ook de maatregel van opgroeiondersteuning te laten vervallen nu deze ongewenst en onnodig was geworden; Kamerstukken II 2013/14, 33 684, nr. 99 (Amendement Bisschop).
} 
elementen opgeleverd. Zo is er op gewezen dat in zaken waarin geen zorgpunten op kindniveau werden gevonden extra kritisch zou moeten worden gekeken of er wel sprake was van een ernstige ontwikkelingsbedreiging. Het was ogenschijnlijk makkelijker te beargumenteren dat er sprake was van een ernstige ontwikkelingsbedreiging indien de problemen zich nadrukkelijk manifesteerden op kindniveau. Maar ook als alleen zorgen werden gemeld op het niveau van de opvoedingsomgeving moest de koppeling met de ontwikkeling van de minderjarige worden gemaakt. Daarnaast is gewezen op het risico dat in de rapportages en beschikkingen gebruik werd gemaakt van containerbegrippen zoals 'pedagogische onmacht' en 'handelingsverlegenheid' zonder dat concreet werd gemaakt wat hier onder wordt verstaan. Deze aandachtspunten lijken nog steeds relevant. De grond 'ernstige ontwikkelingsbedreiging' laat nog steeds evenveel ruimte aan de praktijk om zelfstandig een afweging te maken. De keuze voor flexibilteit ter bescherming van de minderjarige heeft als keerzijde rechtsonzekerheid voor de betrokkenen.

De toepassing van de grond 'ernstige ontwikkelingsbedreiging' sinds 2015

In de afsluiting van deel II van dit onderzoek is duidelijk geworden dat het gecompliceerd is om meer inzicht te geven in de factoren die kunnen leiden tot het oordeel dat sprake is van een ernstige ontwikkelingsbedreiging van de minderjarige. Er zijn er talloze factoren binnen de gezinssituatie (op kind en/of ouderniveau) die kunnen leiden tot dreigende schade voor de ontwikkeling van de minderjarige. Zelfs een uitvoerig overzicht van de aard en omvang van de problemen in de gezinssituatie zoals beschreven in dit onderzoek geeft slechts en indicatie hoe 'ernstig' een situatie moet zijn om een ondertoezichtstelling te rechtvaardigen. Enerzijds laat dit zien dat afzonderlijk beschouwd de wettelijke grond 'ernstige ontwikkelingsbedreiging' daarmee onvoldoende houvast biedt om tot een concrete rechtvaardiging van de inzet van een ondertoezichtstelling te komen. Aan de andere kant is binnen dit onderzoek niet gebleken dat op grote schaal werd volstaan met een oppervlakkige omschrijving van de zorgen die hebben geleid tot de ernstige ontwikkelingsbedreiging. Bovendien heeft het gebruik van de open norm 'ernstige ontwikkelingsbedreiging' ook een evident voordeel. Het geeft de praktijk de nodige discretionaire beoordelingsruimte om tot een weging van de krachten en zorgen in het gezin te komen. De uitvoeringspraktijk heeft daarmee de mogelijkheid gekregen in te spelen op maatschappelijke veranderingen en nieuwe inzichten over de ontwikkeling van kinderen.

Gezien de geschetste discussie in de Tweede Kamer over de invulling van de grond 'ernstige ontwikkelingsbedreiging' is duidelijk dat de onzekerheid niet is weggenomen. Wil men die 
onzekerheid wegnemen dan is het noodzakelijk ook de potentiële voor- en nadelen van mogelijke alternatieven te bespreken. Voor veel voorstellen die tot nu toe zijn gedaan geldt dat op geen enkele wijze meer duidelijkheid wordt verschaft ten aanzien van de vraag wanneer de situatie ernstig genoeg is om een ondertoezichtstelling in te zetten. Vaak gaat het dan om aanpassingen in de formulering waardoor hoogstens kan worden gesteld dat het geboden alternatief iets scherper of ruimer is geformuleerd dan 'ernstige ontwikkelingsbedreiging'. In zijn algemeenheid kan dat wel een aanwijzing zijn voor de praktijk om strikter of ruimer te toetsen. Op casusniveau is het probleem daarmee echter niet opgelost; voor betrokkenen blijft goeddeels onduidelijk waar precies de grens ligt voor gedwongen overheidsingrijpen. Hetzelfde gaat op voor het eerder gedane voorstel om tussen het kader van vrijwillige hulpverlening en de ondertoezichtstelling een lichtere jeugdbeschermingsmaatregel te positioneren. ${ }^{694}$ Voor de praktijk betekent dit een extra afweging die vermoedelijk alleen maar tot meer onzekerheid over de toepassing van de gronden zou leiden.

Een ander alternatief zou een verdere concretisering in de wet zijn van factoren die kunnen leiden tot een ernstige ontwikkelingsbedreiging. Een limitatieve opsomming van die factoren zou zonder meer leiden tot meer rechtszekerheid, maar lijkt om meerdere redenen geen voor de hand liggend alternatief. Bovenal lijkt het ondoenlijk om tot een werkbare afbakening te komen van de factoren die door de RvdK en de kinderrechter zouden moeten worden gewogen in de besluitvorming. De winst op het gebied van rechtszekerheid leidt in een dergelijk geval automatisch tot verlies van flexibiliteit. Voorzienbaar is dat vrijwel direct problemen ontstaan omdat de specifieke gezinssituatie niet direct aansluit bij de factoren in de wet. Naast dat het de professional in de praktijk ernstig beperkt in zijn beoordelingsvrijheid, dreigen ook hier eindeloze discussies over de afbakening van die factoren. Daarnaast zou een dergelijk 'afvinklijstje' geen recht doen aan de complexiteit van de afweging in de praktijk. De professional zal immers nog steeds tot een weging van die factoren komen.

\subsubsection{Het niet of onvoldoende accepteren van de noodzakelijke zorg}

De tweede wijziging in de rechtsgrond van de ondertoezichtstelling zorgt ervoor dat het (voorzienbare) falen van hulpverlening (art. 1:254 lid 1 oud BW) is vervangen door het

${ }^{694}$ Zie: Kamerstukken II 2010/11, 32015, nr. 40 (amendement Dijsselbloem en Van Toorenburg). 
wettelijk vereiste 'het niet of onvoldoende accepteren van de noodzakelijke zorg'. In zekere zin kwam deze wijziging als een verrassing aangezien in de praktijk, voor zover bekend, geen knelpunten werden gesignaleerd in de toepassing van de grond ' het voorzienbaar falen van andere middelen'. De evaluatie van de herziene OTS-wetgeving in 2000 bracht diverse knelpunten aan het licht, maar niet ten aanzien van dit punt. ${ }^{695}$ Integendeel, zowel de Bureaus Jeugdzorg, de RvdK en kinderrechters gaven in algemene zin aan het als een belangrijke en werkbare grond voor de ondertoezichtstelling te zien. ${ }^{696}$ In het verdere verloop van het wetgevingstraject heeft de voorgestelde wijziging maar weinig aandacht gekregen, vermoedelijk omdat vrijwel alle aandacht uitging naar de wens om het toepassingsbereik van de ondertoezichtstelling te verruimen. ${ }^{697}$ Forder besprak naar aanleiding van het voorstel van wet in 2007 de voorgestelde grond 'acceptatie van zorg' en toonde zich kritisch. De keuze voor acceptatie als onderscheidend criterium voor de afweging tussen vrijwillige hulpverlening en het gedwongen kader, leek te impliceren dat alleen 'lastige' ouders voor een beschermingsmaatregel in aanmerking zouden komen. ${ }^{698}$ Dat was volgens haar op zichzelf onvoldoende om een beschermingsmaatregel te rechtvaardigen en bovendien moest worden gewaakt voor een weigerachtige houding van ouders die door de autoriteiten in de hand was gewerkt. $^{699}$

Tijdens de parlementaire behandeling van het wetsvoorstel tot herziening van de kinderbeschermingsmaatregelen was enige aandacht voor dit deel van de rechtsgrond van de ondertoezichtstelling. SP-Kamerlid Kooijman noemde tijdens de parlementaire behandeling van het wetsvoorstel deze wijziging 'een juridisch schoonheidsfoutje met mogelijk grote gevolgen'. ${ }^{700} \mathrm{Zij}$ wees op de situatie waarin ouders op zitting door de kinderrechter zouden worden gevraagd mee te werken aan vrijwillige hulpverlening. Ook indien in het verleden was gebleken dat ouders niet voldoende hadden meegewerkt, zou de kinderrechter in een dergelijk geval het verzoek tot ondertoezichtstelling moeten afwijzen. ${ }^{701}$ Toenmalig staatssecretaris Teeven liet in een reactie echter weten geen grote gevolgen voor de beslissing tot ondertoezichtstelling te verwachten. ${ }^{702}$ Deze zienswijze van de staatssecretaris was in lijn

\footnotetext{
${ }^{695}$ De Savornin Lohman e.a 2000, p. 25 e.v.

${ }^{696}$ De Savornin Lohman e.a 2000, p. 67.

${ }^{697}$ Zie hierover Huijer FJR 2015/8.

${ }^{698}$ Forder 2008, p. 53-54.

${ }^{699}$ Forder 2008, p. 53-54.

${ }^{700}$ Kamerstukken II 2010/11 32 015, nr. 47, p. 63.

${ }^{701}$ Kamerstukken II 2010/11 32 015, nr. 47, p. 63.

${ }^{702}$ Kamerstukken II 2010/11 32 015, nr. 49, p. 58.
} 
met het in 2010 uitgekomen onderzoeksrapport van de DSP-groep. ${ }^{703}$ Het rapport van de DSP-groep richtte zich op twee belangrijke vragen die gingen over de acceptatie van kind en ouders. In de eerste plaats, in hoeveel gevallen toonden kind en ouders zich bereid om de hulpverlening te accepteren, maar werd in die periode toch een ondertoezichtstelling opgelegd? En in het verlengde daarvan, welke redenen lagen ten grondslag aan de afweging om ondanks de bereidheid van de betrokkenen over te gaan tot een ondertoezichtstelling? Het antwoord op de eerste vraag betrof een grove schatting op basis van enkele interviews met medewerkers van Bureau Jeugdzorg en de RvdK. Conclusie was dat het bij een eerste ondertoezichtstelling zeer zelden voorkwam. ${ }^{704} \mathrm{Bij}$ lopende ondertoezichtstellingen werd de situatie waarin de hulp werd geaccepteerd maar toch een verlenging werd verzocht, een stuk vaker herkend. ${ }^{705}$ De redenen die werden genoemd om dit geval toch een (verlenging van de) ondertoezichtstelling te verzoeken waren de ernst en aard van de problematiek en een tegenvallend resultaat van de hulpverlening in het vrijwillig kader. ${ }^{706}$ In het verdere verloop van de parlementaire behandeling is dit onderdeel van de rechtsgrond van de ondertoezichtstelling niet meer ter discussie gesteld.

Volgens het huidige art. 1:255 lid 1 onder a BW geldt het niet of onvoldoende accepteren van de noodzakelijke zorg als één van de drie cumulatieve vereisten voor de ondertoezichtstelling. Het doel van deze wijziging is, zoals aangegeven, een verduidelijking van de grens tussen vrijwillige hulpverlening en het gedwongen kader van de ondertoezichtstelling. Het betekent ook dat de ouders en het kind die een zekere bereidheid tot medewerking tonen geen ondertoezichtstelling meer opgelegd kunnen krijgen, althans als een strikte interpretatie van het begrip 'acceptatie' wordt gehanteerd. Daarnaast heeft de wetgever aangegeven dat kind en ouders niet vanzelfsprekend akkoord hoeven te gaan met de voorgestelde hulpverlening, bijvoorbeeld als er sprake is van een second best hulpverleningsaanbod. ${ }^{707}$ Wordt bijvoorbeeld vanwege wachtlijstproblematiek een zorgaanbod gedaan waarin de link met de ontwikkelingsbedreiging van het kind ontbreekt dan mogen kind en ouders het zorgaanbod

\footnotetext{
${ }^{703}$ Buysse, Broeders \& Hilhorst 2010, p. 57.

${ }^{704}$ Buysse, Broeders \& Hilhorst 2010, p. 21.

705 Buysse, Broeders \& Hilhorst 2010, p. 39 e.v.

706 Buysse, Broeders \& Hilhorst 2010, p. 39 e.v.

${ }^{707}$ Niet geheel duidelijk is wat de gevolgen voor de praktijk zijn van deze toevoeging door de wetgever. Het veronderstelt immers dat ouder of kind de discussie aan kunnen gaan met de GI over de voorgestelde hulpverlening.
} 
gemotiveerd afwijzen, zonder direct voor een ondertoezichtstelling in aanmerking te komen. ${ }^{708}$

Relevantie dossieronderzoek voor de gewijzigde grond 'het niet of onvoldoende accepteren van de noodzakelijke zorg'

Het dossieronderzoek in deel II van dit onderzoek bood de mogelijkheid om in de dossiers uit 2013 en 2014 te kijken hoe de RvdK oordeelde over de mate waarin de noodzakelijke hulp door kind en ouders werd geaccepteerd. Door te kijken hoe voor 2015 met het begrip 'acceptatie' door de RvdK werd omgegaan, kan de toepassing na 2015 beter worden begrepen. Concreet is gekeken in hoeveel zaken de RvdK tot de conclusie kwam dat ouders en kind de noodzakelijke zorg accepteerden maar toch een ondertoezichtstelling werd verzocht. Het dossieronderzoek in deel II van dit onderzoek heeft laten zien dat in 71 van de 200 zaken $(35,5 \%)$ expliciet werd gesteld dat er voldoende bereidheid was om mee te werken aan de zijde van de minderjarige en zijn ouders, maar werd toch een ondertoezichtstelling verzocht door de RvdK. Daarmee is laten zien dat het percentage ouders (en minderjarigen) dat bereid was de noodzakelijke hulp te accepteren vermoedelijk veel hoger lag dan verwacht, hetgeen zorgelijk is. Het zou immers betekenen dat in meer dan 1/3 van de zaken waarin de RvdK een ondertoezichtstelling nodig vond in 2013 en 2014, na de inwerkintreding van de Wet herziening kinderbeschermingsmaatregelen geen ondertoezichtstelling meer zou kunnen worden verzocht. In het vervolg van deze paragraaf wordt gekeken of in de toepassing sinds 2015 inderdaad problemen zijn ontstaan.

De toepassing van de grond 'het niet of onvoldoende accepteren van de noodzakelijke zorg' sinds 2015

$\mathrm{Nu}$ de Wet herziening kinderbeschermingsmaatregelen al enkele jaren van kracht is kan op basis van onderzoek en analyse van rechtspraak meer worden gezegd over de invulling van de grond 'het niet of onvoldoende accepteren van noodzakelijke zorg' in de rechtsgrond van de ondertoezichtstelling. In de tussenevaluatie van de Wet herziening kinderbeschermingsmaatregelen wordt uitgebreid aandacht besteed aan deze wijziging. ${ }^{709}$ Een eerste belangrijke bevinding gaat niet over de inhoud van het begrip 'acceptatie', maar ziet op de vraag of de RvdK en kinderrechters dit deel van de rechtsgrond van de ondertoezichtstelling expliciet toetsen. De tussenevaluatie laat zien dat de RvdK in 97\% van de geanalyseerde beschermingsrapporten en de kinderrechter in $45 \%$ van de geanalyseerde

\footnotetext{
${ }^{708}$ Kamerstukken II 2008/9, 32 015, nr. 3 (MvT).

${ }^{709}$ Lunneman, Huijer e.a. 2018.
} 
beschikkingen aandacht besteden aan de vraag of de noodzakelijke hulp zorg, of onvoldoende wordt geaccepteerd. ${ }^{710}$ Wat dus gold voor het (voorzienbaar) falen van andere middelen onder oude wetgeving, geldt nu ook voor het niet, of onvoldoende accepteren van de noodzakelijke zorg: met name in de beschikkingen wordt dit deel van de rechtsgrond van de ondertoezichtstelling nog niet standaard uitgewerkt.

Daarnaast is in de tussenevaluatie van de Wet herziening kinderbeschermingsmaatregelen op basis van dossieronderzoek en interviews met professionals gekeken, of meer duidelijkheid is te krijgen over de uitleg van begrip 'acceptatie' in de praktijk. De tussenevaluatie laat zien dat de RvdK in ruim $30 \%$ van de zaken waarin aandacht wordt besteed aan de vraag of de noodzakelijke hulpverlening wordt geaccepteerd, concludeert dat ouders en kind duurzame bereidheid tonen om mee te werken. ${ }^{711}$ In al deze zaken wordt een verzoek ondertoezichtstelling ingediend en toegewezen door de kinderrechter. Deze uitkomst is vergelijkbaar met de uitkomst van het dossieronderzoek in deel II van dit onderzoek gericht op de wetgeving van voor 2015. Ook hier was zichtbaar dat er in ruim $30 \%$ van de geanalyseerde zaken sprake was acceptatie aan de zijde van de minderjarige en ouders.

Het verzoeken van een ondertoezichtstelling terwijl er bereidheid is aan de zijde van de ouders en minderjarige lijkt te conflicteren met de wettelijke uitgangspunten. Veel blijkt echter af te hangen van de manier waarop het begrip 'acceptatie' wordt geïnterpreteerd. In de praktijk worden verschillende definities van acceptatie gehanteerd. ${ }^{712}$ Primair gaat het om de vraag of het voldoende is dat betrokkenen de intentie hebben om de hulp te accepteren of dat uit hun handelen ook moet blijken dat de hulp daadwerkelijk wordt geaccepteerd én effect heeft.

In ieder geval laten de interviews en focusgroepen met professionals in de tussenevaluatie zien dat het begrip 'acceptatie van hulpverlening' niet heel strikt wordt opgevat. ${ }^{713}$ Zo wordt herkend dat er een groep ouders (en minderjarigen) zijn die wel hun medewerking verlenen maar om uiteenlopende redenen zonder de sturing van het gedwongen kader terugvallen in oude patronen. Ook wordt aangegeven dat ouders en kinderen soms voldoende bereid zijn de hulp te accepteren maar er geen passend hulpverleningsaanbod is in de betreffende gemeente. ${ }^{714}$ In deze gevallen zo geven de meeste professionals aan ligt de focus op de

\footnotetext{
${ }^{710}$ Lunneman, Huijer e.a. 2018, p. 20.

${ }^{711}$ Lunneman, Huijer e.a. 2018, p. 20.

${ }^{712}$ Lunneman, Huijer e.a. 2018, p. 20 e.v.

${ }^{713}$ Lunneman, Huijer e.a. 2018, p. 23.

${ }^{714}$ Lunneman, Huijer e.a. 2018, p. 23 e.v.
} 
ontwikkelingsbedreiging van de minderjarige. De vraag of de hulp wordt geaccepteerd wordt minder belangrijk gevonden en de interpretatie van het begrip is wisselend. Zo zijn er rechters die aangeven een strikte lijn te volgen (bij acceptatie geen ondertoezichtstelling) maar geven verschillende rechters aan primair nog steeds te kijken naar het resultaat van de geboden hulpverlening, zoals onder de oude wetgeving pleegde te gebeuren. ${ }^{715} \mathrm{Nu}$ moet gezegd worden dat er genoeg zaken zijn waarin de interpretatie van het begrip 'acceptatie' geen problemen oplevert, omdat volkomen duidelijk is of ouders wel of niet meewerken. Maar de wisselende interpretatie is toch zorgelijk. Voor betrokkenen is immers niet altijd duidelijk wat hun mag worden verwacht op dit vlak, hetgeen de kans op conflicten met de hulpverlening vergroot.

De onduidelijkheid over de wijze waarop de grond 'het niet of onvoldoende accepteren van de noodzakelijke zorg' heeft geleid tot een uitspraak van de Hoge Raad op 16 februari $2018 .{ }^{716}$ In deze zaak wordt in cassatie aangevoerd (door een moeder van meerdere minderjarigen die onder toezicht zijn gesteld) dat het gerechtshof is uitgegaan van een onjuiste rechtsopvatting van de wettelijke vereisten voor de ondertoezichtstelling. Volgens de klacht in cassatie heeft het gerechtshof de nadruk op het (onvoldoende) effect van de vrijwillige hulp gelegd, althans op het niet bereiken van de gestelde doelen. Het gerechtshof zou daarbij hebben verzuimd vast te stellen of voldaan was aan het vereiste dat de noodzakelijke zorg niet of onvoldoende door de moeder werd geaccepteerd. ${ }^{717}$ De Hoge Raad oordeelt dat de enkele bereidverklaring van de ouder om hulp te accepteren, onvoldoende is om een ondertoezichtstelling tegen te houden. Hij stelt daarbij:

'Het in art. 1:255 lid 1, aanhef en onder a, BW opgenomen vereiste dat de noodzakelijke zorg "niet of onvoldoende wordt geaccepteerd" ziet niet slechts op de bereidheid die zorg te accepteren, maar mede op het (in voldoende mate) daadwerkelijk accepteren en benutten van die zorg. Indien de ouder die het gezag uitoefent, onvoldoende in staat is de noodzakelijke zorg daadwerkelijk te benutten, staat derhalve de omstandigheid dat hij of zij zich wel bereid heeft verklaard tot acceptatie van die zorg niet in de weg aan ondertoezichtstelling van de minderjarige' ${ }^{718}$

De Hoge Raad verwerpt aldus het beroep in cassatie. De argumentatie van het gerechtshof dat de moeder van goede wil is maar dat zij niet in staat blijkt de in het vrijwillig kader aangeboden hulp zodanig te accepteren en uit te voeren dat dit het gewenste effect heeft,

\footnotetext{
${ }^{715}$ Lunneman, Huijer e.a. 2018, p. 23 e.v.

${ }^{716}$ Hoge Raad 16 februari 2018, ECLI:NL:HR:2018:218.

${ }^{717}$ Hoge Raad 16 februari 2018, ECLI:NL:HR:2018:218, r.o 3.3.1.

${ }^{718}$ Hoge Raad 16 februari 2018, ECLI:NL:HR:2018:218, r.o 3.3.1
} 
wordt door de Hoge Raad geaccepteerd. ${ }^{719}$ Hij volgt daarin A-G Langemeijer in zijn conclusie en stelt vast dat de enkele bereidverklaring van de ouder om de noodzakelijke hulp te accepteren onvoldoende is om een ondertoezichtstelling tegen te houden. De noodzakelijke hulp moet zodanig worden geaccepteerd en benut dat het gewenste effect wordt bereikt. ${ }^{720}$

De zienswijze van de Hoge Raad lijkt daarmee aan te sluiten bij de manier waarop de meeste van de geïnterviewde professionals in de tussenevaluatie van de Wet herziening kinderbeschermingsmaatregelen aangeven het begrip 'acceptatie' te interpreteren. Een zeer ruime interpretatie, waarin in feite drie inhoudelijke stappen worden gezet: ten eerste de bereidheid van de ouders en minderjarige om in te stemmen met vrijwillige hulpverlening. De intentie om mee te werken is een absolute bodemeis om te kunnen spreken van acceptatie van hulpverlening. Ten tweede de eis daar ook naar te handelen. Het is terecht dat de Hoge Raad concludeert dat onder het begrip acceptatie tevens valt het in voldoende mate daadwerkelijk accepteren en benutten van de hulpverlening. In de praktijk komt het nogal eens voor dat ouders ja zeggen en nee doen. Het zou knellen als in deze gevallen geen ondertoezichtstelling meer kan worden opgelegd omdat niet voldaan is aan het acceptatiecriterium. Toch is hier voorzichtigheid geboden. In de eerste plaats zal scherp in de gaten moeten worden gehouden welke redenen ten grondslag liggen aan het onvoldoende benutten van de noodzakelijk geachte hulpverlening. Als dat puur een kwestie is van onvoldoende medewerking van de ouders en/of minderjarige dan is een ondertoezichtstelling te rechtvaardigen. Maar in het systeem van jeugdhulp na 2015 is het geen uitzondering dat de noodzakelijke zorg niet, of niet tijdig beschikbaar is. ${ }^{721}$ In dat geval lijkt het niet juist de betrokkenen het zwaar aan te rekenen indien de vrijwillige hulpverlening onvoldoende van de grond is gekomen. Daarnaast is er binnen de jeugdbescherming een behoorlijke groep ouders die wel graag willen maar om uiteenlopende redenen niet in staat blijken de aangeboden hulpverlening daadwerkelijk te benutten. Te denken valt aan ouders met een licht-verstandelijke beperking die overal aan mee wensen te werken, maar problemen ervaren om zonder de sturing van het gedwongen kader te handelen naar de aanwijzingen van de hulpverlening. Dat lijkt ook het geval in de zojuist besproken uitspraak van de Hoge Raad. Er wordt immers expliciet benoemd dat de moeder van de minderjarigen jaar in jaar uit bereid is geweest tot aanvaarding van de vrijwillige hulpverlening. ${ }^{722}$ De door de Hoge Raad geaccepteerde conclusie dat in deze zaak

\footnotetext{
${ }^{719}$ Hoge Raad 16 februari 2018, ECLI:NL:HR:2018:218, r.o. 3.3.4.

${ }^{720}$.Hoge Raad 16 februari 2018, ECLI:NL:PHR:2017:1329 (Conclusie A-G Langemeijer).

${ }^{721}$ Zie de evaluatie van de Jeugdwet: Friele e.a. 2018.

${ }^{722}$ Gerechtshof Arnhem-Leeuwarden 23 mei 2017, ECLI:NL:GHARL:2017:4425, r.o. 5.6
} 
gesteld kan worden dat de noodzakelijke hulpverlening door de moeder niet of onvoldoende wordt geaccepteerd voelt dan ook op zijn minst ongemakkelijk.

De derde stap die terugkomt in de uitspraak van de Hoge Raad verwijst naar het resultaat van de eerder ingezette, vrijwillige hulpverlening. De Hoge Raad stemt in met het oordeel van het gerechtshof in hoger beroep dat de noodzakelijke hulp zodanig moet worden geaccepteerd en benut dat het gewenste effect wordt bereikt. ${ }^{723}$ Acceptatie in die opvatting lijkt neer te komen op de beoordeling zoals die onder oude wetgeving moest worden gemaakt, namelijk de vraag of vrijwillige hulpverlening heeft gefaald, of voorzienbaar zal falen. Eerder is al geconcludeerd dat het niet aannemelijk is dat de wetgever het begrip 'acceptatie' zo ver heeft willen oprekken. ${ }^{724}$ Toch wordt dat in de praktijk nodig gevonden om een ondertoezichtstelling te kunnen verzoeken, zo blijkt ook uit de tussenevaluatie van de Wet herziening kinderbeschermingsmaatregelen. ${ }^{725}$

Een ander punt is dat de vraag of de hulp niet of onvoldoende wordt geaccepteerd veel lastiger te beantwoorden is dan het oordeel op grond van oude wetgeving over het falen van hulpverlening. Niet in de laatste plaats omdat ouders (en de minderjarige) zich ook heel wisselend kunnen opstellen. Soms is een patroon zichtbaar waarin ouders enkele maanden goed meewerken om daarna abrupt of juist heel geleidelijk de hulpverlening buiten de deur houden. Of ouders wensen wel in te stemmen met hulpverlening voor de minderjarige maar vinden hulpverlening voor zichzelf niet noodzakelijk. Het kan vrij lastig zijn dan aan te tonen dat de hulp niet of onvoldoende wordt geaccepteerd. Rechters bevestigen dit in de tussenevaluatie en zien meer strijd in de rechtszaal over de vraag of de noodzakelijke hulp wel of niet voldoende wordt geaccepteerd. ${ }^{726}$ De oude grond 'het (voorzienbare) falen van hulpverlening' bood de mogelijkheid een objectieve afweging te maken van het resultaat van de eerdere hulpverlening. Daarbij hoefde minder de nadruk te liggen op de veronderstelde oorzaken van het falen, ook als duidelijk was dat de bedreiging van de minderjarige in stand werd gehouden omdat de bereidheid aan de zijde van de ouders ontbrak.

\footnotetext{
${ }^{723}$ Hoge Raad 16 februari 2018, ECLI:NL:HR:2018:218, r.o. 3.3.4.

${ }^{724}$ Zie de annotatie van Huijer \& Weijers, PFR-Updates.nl 2018-0050.

${ }^{725}$ Lunnemann, Huijer e.a. 2018, p. 24.

${ }^{726}$ Lunnemann, Huijer e.a. 2018, p. 24.
} 


\subsubsection{De aanvaardbare termijn}

Het derde cumulatieve vereiste in art. 1:255 lid 1 onder b BW is met de Wet herziening kinderbeschermingsmaatregelen nieuw opgenomen in de rechtsgrond van de ondertoezichtstelling. Naast de twee andere vereisten moet de verwachting gerechtvaardigd zijn dat de ouder(s) met gezag binnen een gelet op de persoon en ontwikkeling van de minderjarige aanvaardbaar te achten termijn, de verantwoordelijkheid voor de verzorging en opvoeding in staat zijn te dragen. In de praktijk doorgaans omschreven als 'de aanvaardbare termijn' of 'het aanvaardbare termijn criterium'. In deze paragraaf wordt kort aandacht besteed aan de totstandkoming van de aanvaardbare termijn en worden de belangrijke uitgangspunten op basis van de wet benoemd.

Zoals eerder aangegeven werd in de dissertatie van Bruning aandacht gevraagd voor de scheve verhouding tussen de ondertoezichtstelling en gezagsontneming. ${ }^{727}$ Van oudsher werd de ondertoezichtstelling gezien als tijdelijke maatregel die gericht was op het wegnemen van de geconstateerde ontwikkelingsbedreiging en versterken van de gezinsband teneinde gezagsontneming te voorkomen. ${ }^{728}$ In de jeugdbeschermingspraktijk voor de wetswijziging van 2015 was de ondertoezichtstelling echter verworden tot een containermaatregel. Niet alleen geschikt bevonden voor kortdurend ingrijpen in een problematische opvoedsituatie, maar ook voor trajecten die zich uitstrekten over vele jaren. Meer specifiek ging het dan om ondertoezichtstellingen met machtiging uithuisplaatsing die vele malen werden verlengd, ook wanneer het perspectief van de minderjarige niet meer bij de ouders met gezag lag. De ouders met gezag mochten op basis van de wettelijke doelstelling van de ondertoezichtstelling en machtiging uithuisplaatsing verwachten dat nog steeds werd gewerkt aan een terugkeer van het kind naar huis. Dat idee werd zo mogelijk nog versterkt door het feit dat de ouders met gezag in beginsel nog steeds belangrijke beslissingen inzake de verzorging en opvoeding van de minderjarige namen. Voor de minderjarige werd deze situatie als potentieel schadelijk voor zijn ontwikkeling aangemerkt, gezien de onzekerheid die hij kon ervaren over de vraag waar hij mocht opgroeien of loyaliteitsproblemen ten aanzien van de ouders en pleegouders. Zeker waar het jonge kinderen betreft is in het belang van opbouwen van een gehechtheidsrelatie met de opvoeder een stabiele opvoedrelatie, waarin de opvoeder duurzaam emotioneel beschikbaar is, noodzakelijk. ${ }^{729}$ Frequente wisselingen in de opvoedsituatie of onzekerheid

\footnotetext{
${ }^{727}$ Bruning 2001.

${ }^{728} \mathrm{Zie}$ voor een verdere analyse over de totstandkoming (van de doelstelling) van de ondertoezichtstelling Doek 1972; Bruning 2001, p 84.

729 Van IJzendoorn 2008.
} 
omtrent de hechtingspersoon kunnen de ontwikkeling van de minderjarige schaden. ${ }^{730} \mathrm{Om}$ de minderjarige eerder duidelijkheid te kunnen verschaffen over zijn opvoedperspectief werd het noodzakelijk geacht het onderscheid tussen gezagsbeperking en gezagsbeëindiging te verhelderen.

Met de Wet herziening kinderbeschermingsmaatregelen is het aanvaardbare-termijn criterium aan de rechtsgrond van de ondertoezichtstelling toegevoegd. In het huidige jeugdbeschermingsrecht fungeren de ondertoezichtstelling en de maatregel van gezagsbeëindiging als spiegelbepalingen. Wordt een kind ernstig in zijn ontwikkeling bedreigd en is een uithuisplaatsing noodzakelijk in het belang van de verzorging en opvoeding dan staan twee cruciale vragen centraal die samenhangen met de aanvaardbare termijn: wat is voor dit kind, in deze specifieke context een aanvaardbare termijn om in onzekerheid te blijven over de vraag waar hij opgroeit en daarnaast, is de verwachting gerechtvaardigd dat de ouder(s) binnen die termijn in staat zijn de verantwoordelijkheid voor de verzorging en opvoeding te dragen $?^{731}$

De vraag wat voor een kind een aanvaardbare termijn is, betreft een primair pedagogische afweging waarin naast leeftijd, factoren als persoonlijke kenmerken, de draagkracht van het kind en specifieke opvoedingssituatie moet worden meegewogen. Leeftijd wordt door de wetgever expliciet aangemerkt als belangrijke factor bij het bepalen van de aanvaardbare termijn. Hoe jonger het kind is, hoe korter de aanvaardbare termijn doorgaans zal zijn. ${ }^{732}$ De tweede vraag vormt uiteindelijk de grondslag om het onderscheid tussen gezagsbeperking en gezagsbeeindiging te maken. Is de verwachting gerechtvaardigd dat ouders binnen een aanvaardbare termijn het kind weer kunnen opvoeden, of is nog niet met zekerheid te zeggen of de verwachting gerechtvaardigd is, dan is een ondertoezichtstelling (met uithuisplaatsing) de aangewezen maatregel. Is de verwachting evenwel niet gerechtvaardigd dan moet - veel eerder dan nu het geval is - tot gezagsbeëindiging worden overgegaan.

\section{De toepassing van de aanvaardbare termijn in het kader van een ondertoezichtstelling}

De introductie van het aanvaardbare termijn criterium heeft zonder twijfel ingrijpende gevolgen gehad voor het materiële jeugdbeschermingsrecht. Er is een grote verscheidenheid

\footnotetext{
${ }^{730}$ Juffer 2010, p. 22.

${ }^{731}$ Artt. 1:255 BW en 1:266 BW, Zie voor een toelichting omtrent de verhouding tussen de ondertoezichtstelling en gezagsbeëindiging: Kamerstukken II 2010/11, 32 015, nr. 3 (MvT). Vgl. voor een verdere toelichting op het functioneren van de jeugdbeschermingssytematiek: Huijer FJR 2015/8. , Kok FJR 2017/36; Wortmann FJR 2019/61; Aalders FJR 2018/63; Satink FJR 2018/24; Kramer FJR 2018/28; Bruning AA 5/20.

${ }^{732}$ Kamerstukken II 2008/9, 32 015, nr. 3 (MvT), par. 5.2.
} 
aan factoren die een rol speelt bij de bepaling van een aanvaardbare termijn, het uitspreken van een verwachting over het opvoedperspectief van de minderjarige en uiteindelijk de beslissing welke maatregel zijn belang het beste dient. Een groot deel van die afwegingen wordt besproken in de paragrafen 10.4 en 10.5 waar de machtiging uithuisplaatsing en de gezagsbeëindigende maatregel centraal staan. In het vervolg van deze paragraaf wordt gefocust op een element dat zeker kort na introductie van de nieuwe jeugdbeschermingswetgeving voor de nodige discussie heeft gezorgd: welke rol speelt de aanvaardbare termijn als alleen een ondertoezichtstelling wordt opgelegd?

De wetgever heeft de keuze gemaakt de aanvaardbare termijn expliciet te koppelen aan de ondertoezichtstelling. De aanvaardbare termijn is immers als derde cumulatieve voorwaarde in de rechtsgrond van de ondertoezichtstelling (art. 1:255 lid 1 onder b BW) opgenomen. Dit suggereert dat de inhoudelijke invulling van de aanvaardbare termijn ook plaats moet vinden binnen de context van de ondertoezichtstelling. De definitie van de aanvaardbare termijn in de memorie van toelichting wijst echter een andere kant op. De aanvaardbare termijn wordt omschreven als 'de periode van onzekerheid over de vraag in welk gezin hij zal opgroeien, die het kind kan overbruggen zonder verdergaand ernstige schade voor zijn ontwikkeling op te lopen'. ${ }^{733}$ De aanvaardbare termijn en de daaraan verbonden afweging omtrent het opvoedperspectief van de minderjarige vereist blijkens deze omschrijving dat het opvoedperspectief onzeker is. Dat is alleen het geval als de minderjarige in het kader van een ondertoezichtstelling uit huis is geplaatst. Als alleen een ondertoezichtstelling wordt opgelegd behouden de ouders het gezag, zijn zij aldus verantwoordelijk voor de verzorging en opvoeding en verblijft de minderjarige (in de regel) thuis. Het is niet ondenkbaar dat op een zeker moment het opvoedpersperspectief van de minderjarige onzeker wordt, maar zonder dat de minderjarige uit huis wordt geplaatst speelt die afweging nog niet expliciet. De wetgever heeft dit ook zo benoemd:

Indien een kind bij zijn ouders woont en er geen noodzaak is tot uithuisplaatsing is per definitie aan het tweede vereiste (aanvaardbare termijn) voldaan omdat de ouders in deze situatie hun kind verzorgen en opvoeden. Een ondertoezichtstelling kan in die gevallen blijven doorlopen totdat het kind meerderjarig wordt'. ${ }^{734}$

Dit lijkt een heldere toelichting, ware het niet dat onduidelijk blijft welke rol de aanvaardbare termijn dan moet spelen bij een ondertoezichtstelling zonder uithuisplaatsing. ${ }^{735}$ Is het

\footnotetext{
${ }^{733}$ Kamerstukken II 2009/10, 32 015, nr. 3 (MvT), toelichting onder art. 1:255 BW.

${ }^{734}$ Kamerstukken II 2009/10, 32 015, nr. 3 (MvT), toelichting onder art. 1:255 BW.

${ }^{735}$ In de praktijk vaak aangeduid met de term 'kale ondertoezichtstelling'.
} 
voldoende om onder verwijzing naar voornoemde toelichting van de wetgever te volstaan met de conclusie dat is voldaan aan de aanvaardbare termijn? Hiermee zou de inhoudelijke waarde van deze wettelijke grond bij een kale ondertoezichtstelling tot vrijwel nul reduceren. Er is immers per definitie aan voldaan als de minderjarige thuis blijft wonen. Of is het de bedoeling dat wel een termijn wordt gesteld, zonder dat daar de consequenties aan worden verbonden die voor de hand liggen op basis van de wettelijke systematiek? Die consequenties betekenen namelijk dat gezagsbeëindiging zou moeten worden overwogen, hetgeen volstrekt niet voor de hand ligt als de minderjarige thuis bij zijn ouders woont. Verder complicerend bij laatstgenoemde optie is dat de RvdK ook nog aan de hand van de geconstateerde ontwikkelingsbedreiging de duur van de ondertoezichtstelling moet bepalen. Dat vereist het stellen van een termijn waarbij de vraag centraal staat hoeveel tijd voorzienbaar nodig is om de ontwikkelingsbedreiging van de minderjarige weg te nemen. Het ligt gegeven de wettekst van art. 1:255 lid $1 \mathrm{BW}$ en de toelichting van de wetgever hieromtrent, niet voor de hand de aanvaardbare termijn hiervoor te gebruiken. De afweging hoeveel tijd nodig is om de ontwikkelingsbedreiging weg te nemen is immers niet gelijk te stellen met de afweging waar het opvoedperspectief van de minderjarige ligt.

In de tussenevaluatie van de Wet herziening kinderbeschermingsmaatregelen komt naar voren dat raadsonderzoekers er in de praktijk bij een ondertoezichtstelling vanuit gaan dat per definitie is voldaan aan de aanvaardbare termijn. ${ }^{736}$ Het stellen van een aanvaardbare termijn zonder machtiging uithuisplaatsing blijft dus achterwege, zo mag worden aangenomen. Moet de ondertoezichtstelling volgens de RvdK gecombineerd worden met een machtiging uithuisplaatsing dan wordt een aanvaardbare termijn gesteld en gekeken of ouders binnen die termijn weer de verantwoordelijkheid voor de verzorging en opvoeding kunnen dragen. ${ }^{737}$ Ook in de rechtspraak is deze zienswijze aangenomen. Het gerechtshof Arnhem Leeuwarden heeft in een uitspraak van 12 september 2017 vastgesteld dat de aanvaardbare termijn direct aanvangt na het moment van uithuisplaatsing. ${ }^{738}$ Dat lijkt gezien de hiervoor besproken uitgangspunten op basis van de visie van de wetgever een correcte beslissing. Het later in laten gaan van de aanvaardbare termijn is niet wenselijk omdat de onzekerheid over het opvoedperspectief vanaf de eerste dag na uithuisplaatsing al kan ontstaan. Eerder dan het moment van uithuisplaatsing lijkt evenmin correct aangezien de onzekerheid over het opvoedperspectief dan niet speelt. Uiteraard is het wel zo dat eerder geboden hulpverlening,

\footnotetext{
${ }^{736}$ Lunnemann, Huijer e.a 2018, p. 28.

${ }^{737}$ Lunnemann, Huijer e.a 2018, p. 28.

${ }^{738}$ Gerechtshof Arnhem-Leeuwarden 12 september 2017, ECLI:NL:GHARL:2017:8172.
} 
daaronder ook een eventueel eerder opgelegde ondertoezichtstelling, kan meespelen bij de bepaling van de duur van de aanvaardbare termijn. Het voorgaande laat wel de vraag open waarom de aanvaardbare termijn niet is neergelegd in de rechtsgrond van de machtiging uithuisplaatsing, aangezien het duidelijk is dat de afweging daar inhoudelijk thuishoort.

\subsubsection{Doelstelling van de ondertoezichtstelling}

Met de Wet herziening kinderbeschermingsmaatregelen is ook de wettelijke doelstelling van de ondertoezichtstelling op details aangepast. Huidig art. 1:262 BW stelt dat de Gecertificeerde Instelling (GI) toezicht houdt op de minderjarige en zorgt dat aan de minderjarige en de met gezag belaste ouders of ouder hulp en steun wordt geboden opdat de concrete bedreigingen in de ontwikkeling van de minderjarige, binnen de duur van de ondertoezichtstelling worden weggenomen. Hoewel de grond nagenoeg identiek oogt ten opzichte van de voormalige doelstelling die was neergelegd in art. 1:257 oud BW, zit er een klein doch belangrijk verschil in. In de situatie voor 2015 lag de nadruk op het bieden van hulp en steun met als doel de ontwikkelingsbedreiging weg te nemen. In die formulering heeft de grond het karakter van een inspanningsverplichting. Art. 1: $262 \mathrm{BW}$ is dwingender geformuleerd (de GI zorgt dat de ontwikkelingsbedreiging binnen de duur van de ondertoezichtstelling wordt weggenomen) en heeft daarom meer het karakter van een resultaatverplichting. Het is niet geheel duidelijk of dit ook de bedoeling is van de wetgever $\mathrm{nu}$ in de memorie van toelichting wordt gesteld dat het wetsvoorstel niets wijzigt aan het doel van de uitvoering van de ondertoezichtstelling. Nog steeds moet intensief in het gezin worden geïnvesteerd om het pedagogisch gezag te versterken waardoor ouders in staat worden gesteld de verantwoordelijkheid voor de verzorging en opvoeding weer volledig te dragen. ${ }^{739}$ Het is goed mogelijk dat de nieuwe verhouding tussen de maatregelen in het jeugdbeschermingskader, heeft geleid tot het dwingender formuleren van de wettelijke doelstelling. De zojuist besproken tijdelijkheid van de ondertoezichtstelling die in het nieuwe systeem besloten ligt, rechtvaardigt een uitvoering waarin alles in het werk is gesteld om ouders weer zonder dwangmaatregel de verantwoordelijkheid te geven voor de verzorging en opvoeding van de minderjarige.

\footnotetext{
${ }^{739}$ Kamerstukken II 2010/11, 32 015, nr. 3 (MvT), par. 5.2.
} 


\section{Relevantie dossieronderzoek voor het stellen van doelen in het kader van de}

ondertoezichtstelling

Het belang van het stellen van concrete doelen die moeten worden behaald om de ernstige ontwikkelingsbedreiging van de minderjarige weg te nemen, lijkt na invoering van de Wet herziening kinderbeschermingsmaatregelen te zijn toegenomen. Indien het niet waarschijnlijk is dat binnen de duur van de ondertoezichtstelling de ontwikkelingsbedreiging van de minderjarige kan worden weggenomen dan volgt onder huidige wetgeving veel eerder de stap richting gezagsbeëindiging. In het dossieronderzoek in deel II van dit onderzoek is aandacht besteed aan het stellen van doelen door de RvdK in het beschermingsrapport. Het dossieronderzoek heeft laten zien dat in 2013 en 2014 door de RvdK vrijwel altijd doelen werden gesteld maar dat de doelen inhoudelijk soms weinig houvast gaven voor de uitvoering van de maatregel. Het is niet duidelijk in hoeverre de doelen in beschermingsrapporten sindsdien concreter worden uitgewerkt.

Voor de situatie na 2015 lijkt het belangrijk(er) dat nadrukkelijk aandacht wordt besteed aan de haalbaarheid van de gestelde doelen. Dat heeft in de eerste plaats te maken met de wettelijke doelstelling van de ondertoezichtstelling die zoals gesteld dwingender is geformuleerd. Het moet in het verzoek tot ondertoezichtstelling aannemelijk gemaakt kunnen worden dat de ernstige ontwikkelingsbedreiging binnen de duur van de ondertoezichtstelling wordt weggenomen. Daarmee samenhangt dat de aanvaardbare termijn ook noodzaakt dat de haalbaarheid van de doelen worden besproken. De aanvaardbare termijn dwingt de verzoeker van de ondertoezichtstelling om te anticiperen op het perspectief van de minderjarige in de toekomst. Naar mag worden aangenomen betekent dat ook meer aandacht voor de vraag of binnen de gewenste ondertoezichtstelling kan worden voldaan aan het doel om de ernstige ontwikkelingsbedreiging binnen de duur van de maatregel weg te nemen. Als op voorhand niet aannemelijk is dat middels een ondertoezichtstelling ook daadwerkelijk de situatie voldoende kan worden verbeterd, dan moet in ieder geval de mogelijkheid van directe beëindiging van het gezag worden overwogen.

\subsubsection{Tussenconclusie}

In het eerste deel van dit hoofdstuk zijn de belangrijkste wijzigingen sinds 2015 ten aanzien van de ondertoezichtstelling beschreven. De rechtsgrond van de ondertoezichtstelling is met de Wet herziening kinderbeschermingsmaatregelen op diverse punten gewijzigd. Op grond 
van art. 1:255 lid $1 \mathrm{BW}$ kan de kinderrechter een minderjarige onder toezicht stellen van een gecertificeerde instelling indien: de minderjarige zodanig opgroeit dat hij in zijn ontwikkeling ernstig wordt bedreigd; de zorg die in verband met het wegnemen van de bedreiging noodzakelijk is voor de minderjarige of voor zijn ouders of de ouder die het gezag uitoefenen door dezen niet of onvoldoende wordt geaccepteerd; en de verwachting gerechtvaardigd is dat de ouders of de ouder die het gezag uitoefenen binnen een gelet op de persoon en ontwikkeling van de minderjarige aanvaardbaar te achten termijn, de verantwoordelijkheid voor de verzorging en opvoeding, bedoeld in art. 1:247 lid 2 BW, in staat zijn te dragen. Gekeken is voor zover mogelijk hoe deze gronden worden geïnterpreteerd en toegepast in de praktijk sinds en wat deze toepassing betekent voor de resultaten die in deel II van dit onderzoek zijn gevonden ten aanzien van de toepassing van de gronden in de jaren 2013 en 2014.

In de eerste plaats is duidelijk dat de huidige grond 'ernstige bedreiging in de ontwikkeling van de minderjarige' geen verandering beoogt te bewerkstelligen ten aanzien van het moment van ingrijpen middels een ondertoezichtstelling. De grond laat nog evenveel ruimte aan de praktijk om zelfstandig een afweging te maken, als op basis van de oude grond 'ernstige bedreiging van de zedelijke of geestelijke belangen of gezondheid'. Hiermee blijft het risico aanwezig dat in de besluitvorming de zorgen omtrent de minderjarige onvoldoende concreet worden gemaakt. Het gebruik van de open norm 'ernstige ontwikkelingsbedreiging' heeft echter ook een evident voordeel. In de praktijk is grote behoefte aan flexibiliteit rond de afweging over de ontwikkeling van de minderjarige, gezien de grote variatie in aard en ernst van de problemen die worden geconstateerd. Zichtbaar is dan ook dat veel van de alternatieven die in de loop der tijd zijn aangedragen een variant zijn op de open geformuleerde grond zoals nu wordt gehanteerd. Sporadisch is gepleit voor een nadere concretisering in de vorm van een (limitatieve) opsomming van factoren in de wet die kunnen leiden tot het oordeel dat de ontwikkeling van de minderjarige wordt bedreigd. De mogelijkheden om in iedere afzonderlijke zaak aan afweging te maken op grond van alle feiten en omstandigheden zouden hierdoor onnodig worden beperkt.

Alles overziend kan de rechtsgrond van de ondertoezichtstelling op dit punt het beste ongewijzigd blijven. Wel moet worden getracht de onzekerheid die voortkomt uit het gebruik van deze open norm te verkleinen. In de eerste plaats kan dat door partijen in het besluitvormingsproces te verplichten in de rapportages of beschikkingen de concrete bedreiging in de ontwikkeling van de minderjarige te benoemen. De Wet herziening 
kinderbeschermingsmaatregelen heeft hier voor belangrijke verbeteringen gezorgd. Daarnaast kan worden getracht situaties te identificeren waarin het risico groter is dat de ontwikkelingsbedreiging niet concreet wordt onderbouwd. Bijvoorbeeld de situatie zoals in dit onderzoek naar voren is gekomen waarin geen zorgen worden gevonden ten aanzien van het functioneren van de minderjarige. In de werkprocessen van de ketenpartners zou deze kennis kunnen leiden tot verfijning in de besluitvorming door dit soort gevallen te herkennen en vervolgens extra kritisch te zijn ten aanzien van de onderbouwing.

De tweede wijziging in de rechtsgrond van de ondertoezichtstelling heeft ervoor gezorgd dat het (voorzienbare) falen van hulpverlening (art. 1:254 lid 1 oud BW) is vervangen door het wettelijk vereiste 'het niet of onvoldoende accepteren van de noodzakelijke zorg' (art. 1:255 lid 1 onder a BW). Op basis hiervan zou kunnen worden aangenomen dat niet meer het resultaat maar de acceptatie van de eerder ingezette of overwogen hulpverlening bepaalt of voldaan is aan deze grond. De wijziging van de rechtsgrond van de ondertoezichtstelling heeft een duidelijk doel: door de resultaatgerichte grond te vervangen voor 'het niet of onvoldoende accepteren van de noodzakelijke zorg' moet de grens tussen vrijwillige hulpverlening en het gedwongen kader van de ondertoezichtstelling worden verhelderd.

Op basis van de nu beschikbare onderzoeksgegevens en kennis over de toepassing in de praktijk kan ernstig worden betwijfeld of dit doel kan worden behaald. Het lijkt erop dat de wetgever is uitgegaan van de veronderstelling dat een ondertoezichtstelling alleen bestemd is voor de groep ouders (en minderjarigen) die nergens aan willen meewerken. Zowel het dossieronderzoek in deel II van deze studie als de tussenevaluatie van de Wet herziening kinderbeschermingsmaatregelen hebben laten zien dat dit niet het geval was en is. In beide onderzoeken ligt het percentage ouders dat wel meewerkt maar waarin toch een ondertoezichtstelling noodzakelijk wordt gevonden rond de 30\%. Dat in de praktijk desondanks geen grote knelpunten worden ervaren lijkt vooral samen te hangen met het oprekken van het begrip acceptatie door de RvdK, GI en kinderrechters. Dat dit nodig wordt gevonden is een indicatie dat de huidige grond 'het niet of onvoldoende accepteren van de noodzakelijke zorg' niet het juiste criterium is om de noodzaak van een ondertoezichtstelling te beoordelen. Daarnaast is het niet zo dat in alle gevallen het begrip 'acceptatie' zo ruim wordt opgevat. De tussenevaluatie laat zien dat er ook professionals zijn die wel een strikte interpretatie kiezen. Een wisselende opvatting over de invulling van het begrip acceptatie leidt tot meer rechtsonzekerheid voor de betrokkenen. Tot slot is het ook aannemelijk dat de vraag of de noodzakelijke zorg wel of niet voldoende wordt geaccepteerd leidt tot 
interpretatieverschillen en discussie in de rechtszaal. In het licht van het voorgaande verdient het overweging om het oude resultaatgerichte begrip zoals was opgenomen in art.1:254 oud BW, 'het (voorzienbaar) falen van hulpverlening', weer als tweede grond voor de ondertoezichtstelling in de wet op te nemen.

De derde wijziging in de rechtsgrond van de ondertoezichtstelling is de toevoeging van het aanvaardbare-termijn criterium (art. 1:255 lid 1 onder b BW). In het huidige jeugdbeschermingsrecht fungeren de ondertoezichtstelling en de maatregel van gezagsbeëindiging als spiegelbepalingen. Wordt een kind ernstig in zijn ontwikkeling bedreigd en is een uithuisplaatsing noodzakelijk in het belang van de verzorging en opvoeding dan staan twee cruciale vragen centraal die samenhangen met de aanvaardbare termijn: wat is voor dit kind, in deze specifieke context een aanvaardbare termijn om in onzekerheid te blijven over de vraag waar hij opgroeit en daarnaast, is de verwachting gerechtvaardigd dat de ouder(s) binnen die termijn in staat zijn de verantwoordelijkheid voor de verzorging en opvoeding te dragen? De aanvaardbare termijn dwingt om het opvoedperspectief van de minderjarige te betrekken in de besluitvorming. Die afweging speelt echter pas indien de minderjarige in het kader van een ondertoezichtstelling uit huis wordt geplaatst. In dit deel van het hoofdstuk is daarom gekeken wat de rol van de aanvaardbare termijn is of zou moeten zijn in 'kale' ondertoezichtstellingszaken. Het antwoord op die vraag is dat de aanvaardbare termijn in zaken waarin alleen een ondertoezichtstelling wordt verzocht inhoudelijk weinig lijkt toe te voegen aan de besluitvorming over de noodzaak van een ondertoezichtstelling. Raadsonderzoekers geven aan er vanuit te gaan dat bij een kale ondertoezichtstelling per definitie is voldaan aan de aanvaardbare termijn omdat het opvoedperspectief (nog) niet ter discussie staat. Ook in de rechtspraak is aangenomen dat inhoudelijk pas een termijn wordt gesteld als een uithuisplaatsing wordt uitgesproken. Het roept de vraag op of gezien de aanvaardbare termijn inhoudelijk vorm krijgt in het kader van een uithuisplaatsing, dit niet ook in de jeugdbeschermingswetgeving tot uitdrukking moet worden gebracht.

\subsection{Rechtvaardiging van de uithuisplaatsing}

De ingrijpende wijzigingen die zijn doorgevoerd met Wet herziening kinderbeschermingsmaatregelen en de Jeugdwet, lijken zich niet te richten op de uithuisplaatsing. Als alleen wordt gekeken naar de rechtsgrond van de reguliere machtiging uithuisplaatsing in het Burgerlijk Wetboek en de rechtsgrond van de gesloten machtiging in 
de Jeugdwet, dan lijkt er op het eerste gezicht in 2015 weinig aangepast. In het vervolg van deze paragraaf zal worden aangetoond dat ondanks de geringe wijzingen in de wet, de inhoudelijke besluitvorming over de uithuisplaatsing na 2015 wel degelijk ingrijpend is veranderd.

De rechtsgrond van de machtiging uithuisplaatsing is met de Wet herziening kinderbeschermingsmaatregelen inhoudelijk niet gewijzigd. Op grond van art. 1:265b lid 1 BW geldt dat de kinderrechter een machtiging uithuisplaatsing kan verlenen 'indien dit noodzakelijk is in het belang van de verzorging en opvoeding van de minderjarige of tot onderzoek van diens geestelijke of lichamelijke gesteldheid'. Het noodzakelijkheidsvereiste zoals volgt uit art. 1:265b BW betekent dat de verzoeker zal moeten aantonen dat andere middelen dan een uithuisplaatsing niet afdoende zijn om het ontwikkelingsbelang van de minderjarige veilig te stellen. Daarnaast zal moet worden beargumenteerd welk doel met de uithuisplaatsing wordt beoogd zodat duidelijk wordt waarom die doelen niet zonder uithuisplaatsing bereikt kunnen worden. ${ }^{740}$

De rechtsgrond van de machtiging gesloten jeugdzorg (art. 29b Wet op de Jeugdzorg) is nu neergelegd in art. 6.1.2 Jeugdwet. De rechtsgrond is met inwerkingtreding van de Jeugdwet op 1 januari 2015 slechts op details gewijzigd. Een gesloten machtiging kon op grond van de Wet op de Jeugdzorg worden verleend indien de jeugdige ernstige opgroei- en opvoedproblemen had die zijn ontwikkeling naar volwassenheid ernstig belemmerden en opneming noodzakelijk was om te voorkomen dat de jeugdige zich aan de zorg die hij nodig heeft zou onttrekken of daaraan door anderen zou worden onttrokken. Op grond van art 6.1.2 Jeugdwet geldt nu dat jeugdhulp noodzakelijk moet zijn in verband met ernstige opgroei- of opvoedingsproblemen die de ontwikkeling van de jeugdige naar volwassenheid ernstig belemmeren en de opneming en het verblijf noodzakelijk moeten zijn om te voorkomen dat de jeugdige zich aan deze jeugdhulp onttrekt of daaraan door anderen wordt onttrokken. Uit het voorgaande blijkt dat de term 'jeugdzorg', zoals op alle plekken in de Jeugdwet, is vervangen door de term 'jeugdhulp'. Inhoudelijk valt op dat in art. 6.1.2 Jeugdwet het woord noodzakelijk tweemaal voorkomt: de noodzaak van jeugdhulp in verband met ernstige ontwikkelingsproblematiek van de jeugdige en de noodzaak om residentieel (gesloten) opgenomen te worden. Hiermee wordt duidelijker aangegeven dat de noodzaak op beide voornoemde aspecten moet toezien voordat een machtiging gesloten jeugdhulp

\footnotetext{
${ }^{740}$ Bruning, in: GS Personen- en familierecht, art. 1:265b BW, aant. 2.1.
} 
gerechtvaardigd kan zijn. ${ }^{741}$ In het vervolg van deze paragraaf staat de inhoudelijke toepassing van de machtiging uithuisplaatsing op grond van art. 1:265b BW centraal.

\subsubsection{Het verleningsbesluit na inwerkingtreding van de Jeugdwet}

In de periode voor de wetswijzigingen van 2015 speelde het indicatiebesluit een belangrijke rol bij de oplegging van een machtiging uithuisplaatsing. Het indicatiebesluit vestigde de aanspraak op de benodigde zorg en had de functie van (extra) waarborg bij de afweging of een uithuisplaatsing gerechtvaardigd was. Met inwerkingtreding van de Jeugdwet op 1 januari 2015 is het indicatiebesluit vervangen door het verleningsbesluit. Een machtiging uithuisplaatsing kan onder de nieuwe wetgeving slechts worden verleend indien het college van de gemeente waar de minderjarige zijn woonplaats heeft, of de GI die de ondertoezichtstelling of voogdij uitvoert, aangeeft dat een voorziening op het gebied van jeugdhulp nodig is. ${ }^{742}$ Indien de RvdK of het Openbaar Ministerie een machtiging uithuisplaatsing verzoekt dan dienen zij in beginsel op grond van art. 1:265b BW een verleningsbesluit van het college van $\mathrm{B} \& \mathrm{~W}$ te overleggen. Een verleningsbesluit kan echter achterwege blijven indien het belang van het kind dit vergt (art. 1:265b lid 3 BW). Gedacht kan worden aan de situatie waarin het college van $B \& W$ niet tijdig een besluit neemt of er een meningsverschil bestaat tussen de RvdK en gemeente. ${ }^{743}$ In een uitspraak van 13 januari 2016 heeft het gerechtshof 's-Gravenhage zijn instemming verleend aan een zogenaamd 'blanco verleningsbesluit'. ${ }^{744}$ Het verleningsbesluit in deze zaak was ondertekend door de gemandateerde van het college van B\&W die zich conformeerde aan het oordeel van de RvdK. Verder werd slechts aangegeven dat een uithuisplaatsing niet lijkt uit te sluiten zonder dat een beschrijving van de plaats werd genoemd. Volgens het hof volgt noch uit de wettelijke bepalingen, noch uit de wetsgeschiedenis de eis dat het besluit een beschrijving bevat van de plaats waarvoor de machtiging wordt verzocht. ${ }^{745}$

Wordt het verzoek tot machtiging uithuisplaatsing gedaan door de GI dan vindt de onderbouwing van het verzoek plaats aan de hand van het verzoekschrift en plan van aanpak. Een verlengingsbesluit van de het college van B\&W blijft dan achterwege aangezien de GI op grond van art. 3.5 lid 1 Jeugdwet zelf bepaalt of, en zo ja welke vorm van jeugdhulp is aangewezen. De verleningsbeslissing die de GI in zo'n geval zelf neemt, dient wel een

\footnotetext{
${ }^{741}$ De Jong-de Kruijff 2019, p. 216.

742 Artikel 2.3 lid 1 Jw en specifiek voor de machtiging gesloten jeugdhulp, art. 6.1.2. lid 5 Jw.

${ }^{743}$ Kamerstukken II 2013/14, 33983, nr. 3 (MvT), p. 4.

${ }^{744}$ Gerechtshof Den Haag 13 januari 2016, ECLI:NL:GHDHA:2016:40.

745 Gerechtshof Den Haag 13 januari 2016, ECLI:NL:GHDHA:2016:40, r.o. 10.
} 
beschrijving van de plaats waartoe de machtiging strekt te bevatten. ${ }^{746}$ Deze visie van de wetgever in ogenschouw nemend lijkt het vreemd om -zoals het hof Den Haag heeft gedaan in bovenstaande uitspraak - een verleningsbesluit zonder aanduiding van de plaats te accepteren.

In vergelijking met de inhoudelijke eisen die op grond van art. 6 lid $1 \mathrm{Wjz}$ golden voor het indicatiebesluit, zijn de eisen voor het verleningsbesluit mager te noemen. Wel geldt dat op het verleningsbesluit de Algemene wet bestuursrecht (hierna: Awb) van toepassing is. De eerste evaluatie van de Jeugdwet laat echter zien dat de wijze waarop het verleningsbesluit wordt toegepast in de praktijk soms afwijkt van de wettelijke vereisten op grond van de Awb. Zo blijken in de praktijk gemeenten de individuele jeugdhulpvoorziening niet altijd in een (schriftelijke) beschikking neer te leggen. ${ }^{747}$ Verder laat de evaluatie van de Jeugdwet zien dat er discussie is over de relevantie van de verplichting voor de RvdK een verleningsbesluit van de gemeente bij te voegen indien in het kader van een ondertoezichtstelling een uithuisplaatsing wordt verzocht. ${ }^{748}$ De verleningsbesluiten van gemeente laten soms lang op zich wachten en het komt ook voor dat in het verleningsbesluit uitsluitend wordt vermeld dat de gemeente zich conformeert aan de door de RvdK noodzakelijk geachte hulpverlening. ${ }^{749}$ In die vorm oogt het verleningsbesluit meer als een extra administratieve hobbel en wordt niet of nauwelijks meer bijgedragen aan de onderbouwing van de noodzaak van een uithuisplaatsing. Daarnaast blijkt het zoals eerder genoemd voor de rechter mogelijk om het verleningsbesluit te omzeilen als het belang van het kind daarom vraagt (art. 1:265b lid 3 BW). In de evaluatie van de Jeugdwet wordt uiteindelijk geconcludeerd dat het verleningsbesluit is verworden tot een middel om de gemeentelijke regie te garanderen. ${ }^{750}$ Van de waarborgfunctie die uitging of behoorde uit te gaan van het indicatiebesluit is bij het verleningsbesluit weinig over. Dat is opvallend omdat de overige wettelijke vereisten voor de machtiging uithuisplaatsing met invoering van de Wet herziening kinderbeschermingsmaatregelen en de Jeugdwet niet zijn aangescherpt. Het is de vraag of dit gevolgen heeft voor de onderbouwing van de noodzaak van een ingrijpend middel als de uithuisplaatsing.

\footnotetext{
${ }^{746}$ Kamerstukken II 2013/14, 33983, nr. 3 (MvT), p. 10.

${ }^{747}$ Monitor Transitie Jeugd 2015, p. 3;

${ }^{748}$ Friele e.a 2018, p. 50.

${ }^{749}$ Friele e.a 2018, p. 50.

${ }^{750}$ Friele e.a. 2018 , p. 52.
} 
10.4.2. De onderbouwing van de noodzaak tot uithuisplaatsing

Het dossieronderzoek in deel II van dit onderzoek heeft ten aanzien van de onderbouwing van het verzoek tot machtiging uithuisplaatsing in de jaren 2013 en 2014 diverse punten aan het licht gebracht. Grofweg is daarbij onderscheid gemaakt tussen twee noodzakelijke elementen die in de onderbouwing van het verzoek- en de beslissing tot uithuisplaatsing terug zouden moeten komen. In de eerste plaats de vraag in hoeverre in de onderbouwing aandacht is besteed aan de mogelijkheid om alternatieve, minder ingrijpende middelen in te zetten teneinde een uithuisplaatsing te voorkomen. Een eis die is te herleiden tot het noodzakelijkheidsvereiste zoals volgt uit nationale wetgeving, art. 8 EVRM en art. 9 IVRK. Ten tweede is geanalyseerd in hoeverre aandacht is besteed aan het doel dat met de verzochte uithuisplaatsing wordt nagestreefd en daarmee het perspectief van de minderjarige. Voor beide elementen wordt in vervolg van deze paragraaf gekeken in hoeverre de resultaten van het dossieronderzoek naar de besluitvorming in 2013 en 2014 nog steeds relevant zijn voor periode na inwerkingtreding van de Wet herziening kinderbeschermingsmaatregelen en de Jeugdwet.

Het onderzoek naar minder ingrijpende alternatieven ter voorkoming van de uithuisplaatsing Het dossieronderzoek heeft geleid tot diverse kritische conclusies met betrekking tot de onderbouwing van de noodzaak van een uithuisplaatsing door de RvdK en de kinderrechter. Zo is gebleken dat in de jaren 2013 en 2014 een diepgaande inhoudelijke onderbouwing van de feiten en omstandigheden die hebben geleid tot het oordeel dat een scheiding van kind en ouders noodzakelijk was, lang niet altijd plaatsvond. De open geformuleerde rechtsgrond van de machtiging uithuisplaatsing zoals deze was opgenomen in art. 1:261 lid 1 oud BW, stimuleerde niet tot een gedetailleerde en diepgaande onderbouwing van de noodzaak tot uithuisplaatsing. Weliswaar kon een uithuisplaatsing worden opgelegd indien dit 'noodzakelijk' was in het belang van de verzorging en opvoeding van de minderjarige, maar de rechtsgrond gaf maar zeer weinig sturing ten aanzien van de vraag hoe die noodzaak inhoudelijk moest worden aangetoond. Daarbij is geconcludeerd dat de gedetailleerderde vereisten die konden worden ontleend aan art. 8 EVRM kennelijk onvoldoende waren geïntegreerd in de besluitvorming. Meer specifiek is naar voren gekomen dat de RvdK in iets minder dan $60 \%$ van de onderzochte zaken expliciet beargumenteerde waarom minder ingrijpende alternatieven niet voldoende waren om het ontwikkelingsbelang van de minderjarige veilig te stellen. Daarnaast is gebleken dat in de beschikkingen op het verzoek tot machtiging uithuisplaatsing nog te vaak werd volstaan met een standaardmotivering. 
Er zijn geen directe aanwijzingen dat de onderbouwing van de noodzaak van een uithuisplaatsing (door te kijken naar alternatieven ter voorkoming van de scheiding) na de wetswijzigingen van 2015 substantieel is verbeterd. De rechtsgrond van de uithuisplaatsing is slechts vernummerd (thans art. 1:265b BW) en inhoudelijk ongewijzigd gebleven. De wijzingen in de nationale wetgeving met betrekking tot de ondertoezichtstelling (en gezagsbeëindiging) hebben de besluitvorming in jeugdbeschermingszaken ingrijpend beïnvloed. Het noodzakelijkheidsvereiste in de rechtsgrond van de uithuisplaatsing is echter niet verder aangescherpt of geconcretiseerd. De tussenevaluatie van de Wet herziening kinderbeschermingsmaatregelen heeft geen nadere informatie opgeleverd ten aanzien van de wijze waarop het noodzakelijkheidsvereiste in de rechtsgrond van de uithuisplaatsing in de praktijk wordt toegepast. De nadruk heeft in de tussenevaluatie gelegen op de gewijzigde elementen in de jeugdbeschermingswetgeving, hetgeen een mogelijke verklaring is waarom de rechtsgrond van de uithuisplaatsing buiten beschouwing is gebleven. Aangezien in de wet geen aanvullende eisen zijn gesteld ten aanzien van de noodzaak alternatieven te onderzoeken ter voorkoming van de uithuisplaatsing, lijkt het niet heel waarschijnlijk dat de RvdK de besluitvorming ten aanzien van de uithuisplaatsing op dit punt ingrijpend heeft gewijzigd.

\subsubsection{Het doel van hereniging van het gezin na uithuisplaatsing}

Het dossieronderzoek in deel II van dit onderzoek was ook gericht op de vraag of de RvdK bij het verzoek tot uithuisplaatsing aandacht besteedde aan het opvoedperspectief van de minderjarige. In de periode waar het dossieronderzoek op heeft toegezien (2013 en 2014) volgde deze eis niet expliciet uit nationale wetgeving. De wettelijke doelstelling van een uithuisplaatsing was niet te herleiden uit de rechtsgrond van de uithuisplaatsing (art. 1:261 oud BW) en het Burgerlijk Wetboek kende en kent geen afzonderlijke wettelijke doelstelling voor de uithuisplaatsing. In de rechtspraak van het EHRM waarin een beroep wordt gedaan op eerbiediging van het recht op privé- familie en gezinsleven, ex. art. 8 EVRM, komt de doelstelling van de uithuisplaatsing wel expliciet naar voren. De uithuisplaatsing behoort een tijdelijke maatregel te zijn die qua besluit en uitvoering consistent moet zijn met het doel van hereniging van het gezin. Dat geldt in het bijzonder voor zaken waarin de RvdK een eerste verzoek tot ondertoezichtstelling met machtiging uithuisplaatsing heeft ingediend. In het dossieronderzoek is gekeken of de $\mathrm{RvdK}$ aandacht besteedde aan het doel van hereniging van het gezin en daarmee ook anticipeert op het opvoedperspectief van de minderjarige. Het dossieronderzoek heeft geleid tot de conclusie dat mede in het licht van art. 8 EVRM meer 
aandacht besteed zou kunnen worden aan het perspectief van de minderjarige nadat de uithuisplaatsing heeft plaatsgevonden. In de beschermingsrapporten uit 2013 en 2014 lag de focus soms nog teveel op de problematische situatie thuis en werd het ontwikkelingsperspectief van de minderjarige na plaatsing minder concreet besproken.

Met inwerkingtreding van de Wet herziening kinderbeschermingsmaatregelen op 1 januari 2015 is het aannemelijk dat het opvoedperspectief van de minderjarige veel vaker en nadrukkelijker wordt betrokken in de besluitvorming over uithuisplaatsingen. Indien de RvdK onder de wetgeving sinds 2015 een ondertoezichtstelling met machtiging uithuisplaatsing verzoekt moet op grond van art. 1:255 lid 1 onder b BW de verwachting gerechtvaardigd zijn dat de ouder(s) met gezag binnen een gelet op de persoon en ontwikkeling van de minderjarige aanvaardbaar te achten termijn, in staat zijn de verzorging en opvoeding te dragen. Is de verwachting niet gerechtvaardigd dat de ouders binnen een aanvaardbare termijn de verantwoordelijkheid voor de verzorging en opvoeding kunnen dragen dan is gezagsbeëindiging het uitgangspunt.

De aanvaardbare termijn dwingt de verzoeker al in een vroeg stadium aandacht te besteden aan het opvoedperspectief van de minderjarige. Dit betekent ten eerste dat afhankelijk van de persoon van de minderjarige wordt gekeken naar de periode van onzekerheid die aanvaardbaar is. De vraag hoelang een minderjarige in onzekerheid kan verblijven dient casuïstisch te worden vastgesteld aan de hand van factoren als leeftijd, ontwikkelingsniveau, karaktereigenschappen, draagkracht, de gehechtheid aan alternatieve opvoeders en de vraag of er sprake is geweest van ingrijpende levensgebeurtenissen. ${ }^{751} \mathrm{Na}$ de bepaling van een specifieke termijn die voor de minderjarige als 'aanvaardbaar' kan worden beschouwd moet een verwachting worden uitgesproken ten aanzien van de vraag of de ouders binnen de gestelde termijn de minderjarige weer kunnen verzorgen en opvoeden.

De tussenevaluatie van de Wet herziening kinderbeschermingsmaatregelen bevestigt het vermoeden dat de RvdK sinds 2015 nadrukkelijker het opvoedperspectief van de minderjarige betrekt bij de afweging over een uithuisplaatsing. Op basis van (kleinschalig) dossieronderzoek wordt vastgesteld dat de RvdK in $86 \%$ van de zaken waarin een ondertoezichtstelling met machtiging uithuisplaatsing wordt verzocht een concrete termijn wordt gesteld en een verwachting wordt uitgesproken over mogelijkheden tot hereniging van

\footnotetext{
${ }^{751}$ Voor een uitgebreide analyse van de inhoudelijke invulling van het aanvaardbare termijn criterium zie Huijer\& Weijers, FJR 2016/40.
} 
kind en ouders. Interessant is dat de RvdK ook in diverse zaken waarin de verwachting niet gerechtvaardigd is dat ouders binnen een aanvaardbare termijn de verzorging en opvoeding weer op zich kunnen nemen een ondertoezichtstelling met machtiging uithuisplaatsing verzoekt. ${ }^{752}$ Op basis van de wettelijke systematiek ligt in dit geval een verzoek tot gezagsbeëindiging voor de hand, maar de RvdK is hiertoe niet verplicht. Op basis van de wet hebben de RvdK als verzoeker en de kinderrechter als beslisser de discretionaire bevoegdheid om in het belang van het kind anders te beslissen dan op grond van de wettelijke uitgangspunten voor de hand zou hebben gelegen. De vraag of de verwachting gerechtvaardigd is dat ouders binnen een aanvaardbare termijn weer de verzorging en opvoeding kunnen dragen is dus leidend, maar niet allesbeslissend voor de afweging tussen gezagsbeperking en gezagsbeëindiging. De tussenevaluatie laat zien dat RvdK de discretionaire bevoegdheid die hem toekomt kennelijk durft te benutten, in die gevallen waarin gezagsbeëindiging als een te vergaande stap wordt aangemerkt.

\subsubsection{Tussenconclusie}

In dit deel van het hoofdstuk zijn twee elementen besproken die samenhangen met de rechtvaardiging van de uithuisplaatsing. In de eerste plaats de noodzaak aandacht te besteden aan alternatieve, minder ingrijpende middelen ter voorkoming van een uithuisplaatsing. En ten tweede, de noodzaak aandacht te besteden aan het opvoedperspectief van de minderjarige en daarmee de mogelijkheden tot hereniging van kind en ouders. Beide elementen zijn duidelijk terug te zien in de rechtspraak van het EHRM, waarin wordt geoordeeld over rechtvaardiging van een uithuisplaatsing in het licht van het recht op familie- en gezinsleven (art. 8 EVRM).

Het dossieronderzoek gericht op de jaren 2013 en 2014 heeft laten zien dat beide elementen onvoldoende werden betrokken in de besluitvorming van de RvdK over de noodzaak van uithuisplaatsing. Na 2015 zijn er duidelijke verbeteringen doorgevoerd in de besluitvorming over de uithuisplaatsing maar het verder concretiseren hoe de 'noodzaak' moet worden aangetoond lijkt nog steeds belangrijk. Om dit bereiken ligt het voor de hand het noodzakelijkheidsvereiste zoals thans opgenomen in art. 1:265b BW nader te concretiseren. De rechtsgrond in het Burgerlijk Wetboek zou beter tot uitdrukking moeten brengen dat de noodzaak tot uithuisplaatsing primair moet blijken uit het feit andere minder ingrijpende

\footnotetext{
${ }^{752}$ Lunnemann, Huijer e.a. 2018, p. 24.
} 
alternatieven zijn overwogen en onvoldoende zijn. Concreet betekent dit dat de verzoeker niet alleen moet afwegen of een uithuisplaatsing kan worden voorkomen, maar ook als wordt besloten een verzoek tot uithuisplaatsing in te dienen, dat wordt gestreefd naar de minst ingrijpende oplossing.

De introductie van de aanvaardbare termijn heeft er aldus voor gezorgd dat het opvoedperspectief van de minderjarige een centrale positie heeft gekregen in de afweging tussen gezagsbeperking en gezagsbeëindiging. Dat is een positieve ontwikkeling met het oog op de herenigingsdoelstelling die op grond van art. 8 EVRM ten grondslagen behoort te liggen aan de uithuisplaatsing. Daarnaast wordt hiermee (meer) recht gedaan aan het belang van het kind bij stabiliteit en continuïteit in de opvoedsituatie (art. 20 lid 3 IVRK). Hiermee is tegemoet gekomen aan een van de kritiekpunten die in het dossieronderzoek in deel II van het onderzoek aan het licht is gekomen, namelijk de beperkte aandacht voor perspectief van de minderjarige na uithuisplaatsing in de beschermingsrapporten van de RvdK.

\subsection{Rechtvaardiging van de beëindiging van het gezag}

Zeker bij jonge kinderen geldt met het oog op het belang van hechting aan de opvoeder(s) dat het kind niet te lang in onzekerheid kan blijven over de vraag waar hij opgroeit. De tijdelijke aard van de ondertoezichtstelling en uithuisplaatsing dient het belang van het kind bij stabiliteit en continuïteit in de opvoeding, zoals verwoord in art. 20 lid 3 IVRK. Dit uitgangspunt is niet nieuw maar binnen het systeem van jeugdbescherming van voor 2015 kon hier onvoldoende rekening mee worden gehouden. Ontbrak na uithuisplaatsing het terugkeerperspectief van de minderjarige naar huis, dan volgde in de praktijk niet noodzakelijkerwijs gezagsontneming middels een verderstrekkende maatregel. Al geruime tijd werd kritiek geleverd op de vaak jarenlange verlengingen van de ondertoezichtstelling met uithuisplaatsing terwijl het opvoedperspectief van de minderjarige in het pleeggezin lag. ${ }^{753}$ De wetsherziening van de ondertoezichtstelling in 1995 opende echter de deur naar een nog frequentere toepassing van langdurige uithuisplaatsingen. Tot aan de herziening van de ondertoezichtstelling in 1995 was de duur van de uithuisplaatsing in het kader van de ondertoezichtstelling beperkt tot twee jaar, behoudens enkele uitzonderingen. ${ }^{754}$ Deze zogenaamde tweejaarstermijn werd in de praktijk als te rigide ervaren en is met de wettelijke

\footnotetext{
${ }^{753}$ Zie ook Bruning 2001, p. 462.

${ }^{754}$ Op grond van art. 1:263 oud BW.
} 
herziening van 1995 geschrapt. ${ }^{755}$ Hoewel het opheffen van de tweejaarstermijn er toe leidde dat geen juridische noodgrepen meer nodig waren in die gevallen waarin na twee jaar een verdere verlenging van de uithuisplaatsing als meest wenselijke mogelijkheid werd gezien, bleef de verhouding tussen gezagsbeperking en gezagsbeëindiging vaag. Juridisch gezien waren er geen obstakels om de ondertoezichtstelling met uithuisplaatsing te verlengen tot aan meerderjarigheid. Of het kind daar ook het meest mee was gediend, viel sterk te betwijfelen. Indien het kind al jarenlang duurzaam wordt opgevoed in het pleeggezin ligt het feitelijke opvoederschap bij de pleegouders terwijl belangrijke beslissingen inzake de verzorging en opvoeding van de minderjarige, voortvloeiend uit het ouderlijk gezag (art. 1:245 lid 4 BW), toestemming vereisen van de ouder. Voor de minderjarige kan een dergelijke situatie tot onzekerheid leiden over de vraag wie als primaire opvoeder moet worden gezien, en zeker in geval de ouder met gezag nog 'trekt' aan de minderjarige, tot loyaliteitsproblemen. De jaarlijkse gang naar de rechter voor het verzoek tot verlenging van de maatregelen kan daarnaast belastend zijn voor de minderjarige en de gevoelens van onzekerheid versterken. De ouders mogen op basis van de wettelijke doelstelling van de ondertoezichtstelling en uithuisplaatsing verwachten dat wordt gewerkt aan het verbeteren van hun pedagogische capaciteiten, het versterken van de gezinsband en specifiek ten aanzien van de uithuisplaatsing, aan een hereniging van het gezin. Niet in alle gevallen zal dit leiden tot ouders die nog strijden voor de terugkeer van de minderjarige, maar ook in geval van duurzame instemming met de plaatsing, wordt de minderjarige geacht onzekerheid te ervaren, die schadelijk is voor zijn ontwikkeling. ${ }^{756}$

Met de Wet herziening kinderbeschermingsmaatregelen is besloten het wettelijke jeugdbeschermingskader zo in te richten dat de onzekerheid van de minderjarige ten aanzien van de vraag waar hij opgroeit kan worden verkleind. Om dit te bereiken zijn de rechtsgronden van de ondertoezichtstelling en gezagsbeëindigende maatregel gekoppeld aan elkaar. De aanvaardbare termijn zorgt er inhoudelijk voor dat het ontwikkelings- en opvoedperspectief van een minderjarige die ernstig in zijn ontwikkeling wordt bedreigd, het onderscheidende criterium is voor de keuze tussen gezagsbeperking (ondertoezichtstelling/uithuisplaatsing) en gezagsbeëindiging.

\footnotetext{
${ }^{755}$ Kamerstukken II 1992/93, 23 003, nr.3 (MvT), p.18.

${ }^{756}$ Kamerstukken II 2008/9, 32 015, nr.3 (MvT), par. 5.2.
} 
10.5.1 De toepassing van de gezagsbeëindigende maatregel - uitgangspunten

De maatregelen van ontheffing en ontzetting uit het gezag werden op 1 januari 2015 geschrapt en vervangen door één gezagsbeëindigende maatregel. Op grond van art. 1:266 lid 1 BW geldt dat de rechtbank het gezag van een ouder kan beëindigen indien een minderjarige zodanig opgroeit dat hij in zijn ontwikkeling ernstig wordt bedreigd, en de ouder niet de verantwoordelijkheid voor de verzorging en opvoeding, bedoeld in artikel 247, tweede lid, in staat is te dragen binnen een voor de persoon en de ontwikkeling van de minderjarige aanvaardbaar te achten termijn. Op grond van art. 1:266 lid sub BW kan tevens het gezag worden beëindigd indien de ouder het gezag misbruikt. Het doel van gezagsbeëindiging is de minderjarige zekerheid bieden over zijn opvoedperspectief. Dit betekent ook dat waar mogelijk moet worden gestreefd om na beëindiging van het gezag van de ouder, de voogdij toe te wijzen aan de pleegouders. Op die manier kan feitelijk opvoederschap (door de pleegouders) en de juridische bevoegdheid om beslissing te nemen over de verzorging en opvoeding van de minderjarige (gezag in de vorm van voogdij), samenvallen. ${ }^{757} \mathrm{Om}$ de afweging te maken of een gezagsbeëindigende maatregel is aangewezen heeft de wetgever nog enkele uitgangspunten verstrekt:

- Wanneer een kind in een pleeggezin is geplaatst, moet het zich daar, indien mogelijk, volledig en harmonieus kunnen ontwikkelen. Met het oog hierop, in het bijzonder wanneer het op zeer jeugdige leeftijd in een perspectief biedend pleeggezin is geplaatst, dient duidelijkheid te bestaan over het opvoedings- en ontwikkelingsperspectief van het kind.

- Als thuisplaatsing niet meer tot de mogelijkheden behoort, blijft bij een jaarlijkse verlenging van de maatregel van ondertoezichtstelling en uithuisplaatsing onzekerheid over het opvoedingsperspectief voortduren. Verlenging over een reeks van jaren is daarbij in beginsel geen juiste maatregel.

- In die gevallen dient aan het belang van het kind bij continuïteit van de opvoedingssituatie en een ongestoord hechtingsproces zwaarwegende betekenis te worden toegekend.

\footnotetext{
${ }^{757}$ Kamerstukken II 2008/9, 32 015, nr.3 (MvT).
} 
- De enkele bereidheid van de ouder met gezag zich niet te verzetten tegen de uithuisplaatsing van het kind mag niet doorslaggevend zijn bij toewijzing van het verzoek tot beëindiging van het gezag. ${ }^{758}$

Daarnaast geldt als belangrijk uitgangspunt dat gezien de ernstige inbreuk op het familie- en gezinsleven van kind en ouder (art. 8 EVRM) in beginsel eerst moet worden getracht het ontwikkelingsperspectief van de minderjarige veilig te stellen met een lichtere maatregel. In de meeste gevallen zal daarom een ondertoezichtstelling vooraf gaan aan de maatregel van gezagsbeëindiging. Noodzakelijk is dit evenwel niet. De Wet herziening kinderbeschermingsmaatregelen heeft het mogelijk gemaakt om zonder voorafgaande maatregel het gezag te beëindigen. Volgens de wetgever moet hierbij worden gedacht aan ouders met ernstige en langdurige verslavingsproblematiek of psychische problematiek waarbij de ervaring met overige kinderen heeft geleerd dat de ouders niet in staat zijn de noodzakelijke, basale opvoedcapaciteiten zich eigen te maken. ${ }^{759}$ In dergelijke gevallen is met voldoende zekerheid vast te stellen dat het opvoedperspectief van het kind elders ligt, terwijl een ondertoezichtstelling zich zou moeten richten op herstel van de oorspronkelijke opvoedsituatie. In het vervolg van deze paragraaf wordt gekeken naar de toepassing van de gezagsbeëindigende maatregel in de praktijk aan de hand van de uitgangspunten die de wetgever heeft verstrekt. Op basis van de tussenevaluatie van de Wet herziening kinderbeschermingsmaatregelen en relevante rechtspraak worden daarbij de positieve kanten benoemd, maar ook mogelijke knelpunten geïdentificeerd.

Op grond van art. 1:267 lid $1 \mathrm{BW}$ kan beëindiging van het gezag worden uitgesproken op verzoek van de RvdK, het Openbaar Ministerie en degene die de minderjarige tenminste een jaar als behorende tot zijn gezin heeft verzorgd en opgevoed (de pleegouder). In de praktijk wordt het verzoek tot gezagsbeëindiging vrijwel altijd ingediend door de RvdK. In de meeste gevallen ontvangt de RvdK een verzoek tot onderzoek naar de noodzaak van gezagsbeëindiging van de GI die de ondertoezichtstelling (en uithuisplaatsing) uitvoert. ${ }^{760}$ Het is natuurlijk ook mogelijk dat de RvdK zelf in het beschermingsonderzoek naar de noodzaak van een maatregel concludeert dat gezagsbeëindiging zonder voorafgaande maatregel is aangewezen. De tussenevaluatie van de Wet herziening kinderbeschermingsmaatregelen laat zien dat de GI's in het verzoek tot onderzoek naar gezagsbeëindiging steeds beter aangeven

\footnotetext{
${ }^{758}$ Kamerstukken II 2008/9, 32 015, nr.3 (MvT).

${ }^{759}$ Kamerstukken II 2008/9, 32 015, nr.3 (MvT), toelichting onder art. 266 BW.

${ }^{760}$ Lunnemann, Huijer e.a 2018, p. 28.
} 
waarom zij vinden dat gezagsbeëindiging noodzakelijk is. ${ }^{761}$ Ook blijkt dat de RvdK in vrijwel alle zaken waarin gezagsbeëindiging wordt verzocht inhoudelijk beargumenteert waarom de verwachting niet gerechtvaardigd is dat de ouders binnen een voor de minderjarige aanvaardbare termijn in staat zijn de verantwoordelijkheid voor de verzorging en opvoeding te dragen. ${ }^{762}$ Vanuit juridisch-technisch oogpunt kan hieruit worden geconcludeerd dat de wet op dit punt correct wordt toegepast, maar het zegt nog weinig over de inhoudelijke afwegingen die in de praktijk moeten worden gemaakt over de gezagsbeëindigende maatregel. De tussenevaluatie laat zien dat de aanvaardbare termijn als onderdeel van afweging omtrent gezagsbeëindiging ervoor heeft gezorgd dat het opvoedperspectief van de minderjarige nadrukkelijker in de besluitvorming wordt betrokken, maar de praktijk ook voor de nodige uitdagingen stelt. ${ }^{763}$ In het vervolg van deze paragraaf worden deze uitdagingen nader uitgewerkt.

\subsubsection{Het stellen van een concrete termijn}

Wordt de minderjarige in het kader van een ondertoezichtstelling uit huis geplaatst dan is een eerste noodzakelijke stap om een termijn te stellen waarbinnen duidelijkheid moet zijn over zijn opvoedperspectief. De duur van die termijn is cruciaal aangezien hiermee de periode van onzekerheid die de minderjarige naar verwachting aankan wordt begrensd. De aanvaardbare termijn dwingt daarmee in het feite het moment dat een zogenoemd opvoedbesluit moet worden genomen af. Het opvoedbesluit kent geen expliciete wettelijke basis, maar betreft de afweging van de GI of er nog een kans is op terugkeer naar huis, of dat de minderjarige in ieder geval tot meerderjarigheid elders zal opgroeien.

De inhoudelijke bepaling van een termijn die voor een kind als aanvaardbaar kan worden beschouwd is primair een pedagogisch georiënteerde afweging en dient per casus vastgesteld te worden. Daarbij kunnen veel factoren een rol spelen zoals de leeftijd, de persoonlijke kenmerken en draagkracht van het kind, de gehechtheid in het pleeggezin, de specifieke omstandigheden waaronder het kind is opgegroeid, maar ook factoren die toezien op het functioneren van het systeem van jeugdbescherming. De wetgever heeft zich ten aanzien van de termijnstelling beperkt tot de vaststelling dat hoe jonger het kind is, hoe korter de aanvaardbare termijn doorgaans zal zijn. ${ }^{764}$ De tussenevaluatie van de Wet herziening

\footnotetext{
${ }^{761}$ Lunnemann, Huijer e.a. 2018, p. 28.

${ }^{762}$ Lunnemann, Huijer e.a. 2018, p. 28.

${ }^{763}$ Lunnemann, Huijer e.a. 2018, p. 24.

${ }^{764}$ Kamerstukken II 2008/09, 32 015, nr. 3 (MvT).
} 
kinderbeschermingsmaatregelen laat zien dat in de praktijk verschillend wordt omgegaan met het stellen van een aanvaardbare termijn. Zo laten medewerkers van de RvdK weten dat thans veel gevarieerder (op maat) een termijn wordt gesteld, waar vroeger standaard een maatregel voor een jaar werd gevraagd. ${ }^{765}$ Onder medewerkers van de GI's lijkt meer onduidelijkheid te zijn over de interpretatie van de aanvaardbare termijn. Zo geeft een deel van de medewerkers aan bij de bepaling van de aanvaardbare termijn de verwachting omtrent de ouders als uitgangspunt te nemen, terwijl het ontwikkelingsperspectief van de minderjarige centraal zou moeten staan. ${ }^{766}$ Ook wordt aangegeven dat soms gewerkt wordt met standaardtermijnen die worden bepaald aan de hand van de leeftijd van de minderjarige. ${ }^{767}$

Al eerder is gewezen op het risico van een te rigide benadering van de termijnstelling. ${ }^{768}$ Deze rigiditeit ziet op twee aspecten. In de eerste plaats het idee dat bij een bepaalde leeftijd van de minderjarige vaste termijnen horen. Deze zienswijze lijkt voort te komen uit de (begrijpelijke) zoektocht naar houvast door professionals in de praktijk. Hoe kan bij voorbaat vastgesteld worden wat een redelijke termijn is voor minderjarigen om in onzekerheid te blijven? Het ligt dan ook voor de hand dat zwaar geleund wordt op richtlijnen waarin wordt beoogd de professional te ondersteunen bij dergelijke beslissingen. Een veel gebruikt en in de rapporten aangehaald hulpmiddel is de richtlijn Pleegzorg voor jeugdhulp en jeugdbescherming. De richtlijn geeft als vuistregel dat een opvoedbesluit binnen een halfjaar tot maximaal een jaar wordt genomen. ${ }^{769}$ Dit betekent ook dat de aanvaardbare termijn in de regel niet langer veel langer kan zijn. Als immers duidelijk is dat het perspectief van de minderjarige niet bij de ouders ligt, dan moet op basis van de wettelijke systematiek gezagsbeëindiging worden overwogen. Overigens wordt in dezelfde richtlijn Pleegzorg aangegeven dat in het belang van de ontwikkeling van het kind van de aanbevolen termijnen kan worden afgeweken. ${ }^{770}$ Het tweede daarmee samenhangende punt is het risico dat na het verstrijken van de aanvaardbare termijn, als vanzelfsprekend definitief wordt besloten waar de minderjarige opgroeit. Het is niet wenselijk de aanvaardbare termijn zo eng te interpreteren, omdat hiermee overige relevante factoren (anders dan puur het verstrijken van de gestelde termijn) mogelijk onvoldoende aan bod komen. In de rechtspraak is dit soms ook zichtbaar dat een eenzijdige

\footnotetext{
${ }^{765}$ Lunnemann, Huijer e.a. 2018, p. 24.

${ }^{766}$ Lunnemann, Huijer e.a. 2018, p. 24.

${ }^{767}$ Lunnemann, Huijer e.a. 2018, p. 24

${ }^{768}$ Huijer \& Weijers, FJR 2016/40.

${ }^{769}$ Richtlijn Pleegzorg voor jeugdhulp en jeugdbescherming.

${ }^{770}$ Richtlijn Pleegzorg voor jeugdhulp en jeugdbescherming.
} 
focus op de leeftijd van de minderjarige en de daarop gebaseerde aanvaardbare termijn, al snel tot het oordeel kan leiden dat gezagsbeëindiging moet plaatsvinden. ${ }^{771}$

$\mathrm{Al}$ eerder is gepleit het verstrijken van de aanvaardbare termijn bij een uithuisplaatsing te beschouwen als een beoordelingsmoment met diverse mogelijke uitkomsten. Een traject richting gezagsbeëindiging indien duidelijk is dat het opvoedperspectief van de minderjarige elders ligt, of een verdere verlenging van de ondertoezichtstelling met uithuisplaatsing als de mogelijkheid op een terugkeer naar huis nog bestaat. Of, maar dat komt momenteel weinig voor, voortzetting van de plaatsing in het pleeggezin op vrijwillige basis. ${ }^{772}$ Inmiddels is ook in de rechtspraak zichtbaar dat een flexibelere omgang met de aanvaardbare termijn mogelijk is mits de situatie van de minderjarige dit toelaat. Zo wordt in een uitspraak van het gerechtshof Arnhem-Leeuwarden van 29 november 2018 de aanvaardbare termijn uitgesteld. In deze zaak heeft de GI zelf heeft aangegeven dat nog geen goede diagnostiek heeft kunnen plaatsvinden, onder meer doordat de zaak is overgenomen van een andere GI. Pas als dit is uitgevoerd en er zicht is op het perspectief van de kinderen wordt een (nieuwe) concrete termijn vastgesteld waarbinnen duidelijkheid moet zijn. ${ }^{773}$ Ook in verschillende andere zaken tonen rechters zich kritisch indien de onderbouwing van het verzoek tot gezagsbeëindiging primair lijkt te steunen op het tijdsverloop na uithuisplaatsing. ${ }^{774}$ Noodzakelijk is dat binnen de gestelde aanvaarde termijn met voldoende zekerheid is te zeggen dat de ouders met gezag niet tijdig in staat zijn de minderjarige weer op te voeden in de thuissituatie. ${ }^{775}$ Indien dit element om wat voor reden dan ook binnen de termijn onvoldoende is onderzocht, dan dient in ieder geval overwogen te worden om de aanvaardbare termijn te verlengen.

10.5.3 De onzekerheid over het opvoedperspectief van de minderjarige en de noodzaak tot gezagsbeëindiging

De noodzaak tot gezagsbeëindiging moet primair blijken uit de mate van onzekerheid die de minderjarige ervaart. En in het verlengde daarvan, of de maatregel van gezagsbeëindiging aan

\footnotetext{
${ }^{771}$ Zie bv. Gerechtshof Arnhem-Leeuwarden 22 september 2016, ECLI:NL:GHARL:2016:7796, r.o 5.6.

${ }^{772}$ In dit geval behouden de ouders het gezag en is er dus sprake van een plaatsing op vrijwillige basis. Als ouders besluiten om de minderjarige weg te halen uit het pleeggezin staan er geen juridische middelen direct ter beschikking om dit tegen te houden. Dit lijkt dus alleen een te overwegen mogelijkheid als met aan zekerheid grenzende waarschijnlijkheid kan worden vastgesteld dat ouders de plaatsing in het pleeggezin blijven steunen. 773 Gerechtshof Arnhem-Leeuwaren 29 november 2018, ECLI:NL:GHARL:2018:10428, r.o. 5.4.

774 Zie bv. Rb. Limburg 23 oktober 2015, ECLI:NL:RBLIM:2015:9451; Gerechtshof Arnhem-Leeuwarden 21 april 2016, ECLI:NL:GHARL:2016:3302.

${ }^{775}$ Gerechtshof Arnhem-Leeuwaren 29 november 2018, ECLI:NL:GHARL:2018:10428.
} 
zijn belangrijkste doelstelling kan voldoen: het wegnemen van de onzekerheid bij de minderjarige omtrent zijn opvoedperspectief. De aanvaardbare termijn begrenst de periode van onzekerheid die de minderjarige naar inschatting van de professional kan overbruggen zonder (vergaande) ontwikkelingsschade op te lopen. Het verstrijken van de aanvaardbare termijn en een traject richting gezagsbeëindiging zou alleen dan aan de orde mogen zijn als overtuigend kan worden aangetoond dat 1) de minderjarige onzekerheid ervaart 2) die onzekerheid niet langer kan voortduren en 3) het aannemelijk is dat gezagsbeëindiging tenminste een groot deel van de onzekerheid over het opvoedperspectief wegneemt.

Blijkens de memorie van toelichting bij de Wet herziening kinderbeschermingsmaatregelen gaat de wetgever ervan uit dat bij het ontbreken van een perspectief op thuisplaatsing van de minderjarige, een verlenging van de ondertoezichtstelling met uithuisplaatsing onzekerheid omtrent het opvoedperspectief veroorzaakt bij de minderjarige. ${ }^{776}$ Voorop gesteld moet worden dat in de meeste zaken waarin al langere tijd een uithuisplaatsing loopt, het inderdaad aannemelijk is dat de minderjarige onzekerheid ervaart over zijn opvoedperspectief. Zeker in het geval waar de minderjarige is 'ingegroeid' in een pleeggezin, maar de ouders nog het gezag dragen en ook - impliciet of expliciet - de wens koesteren om de minderjarige in de thuissituatie te verzorgen en op te voeden. Daar komt bij dat de onrust en onzekerheid van de minderjarige kan worden versterkt indien hij de wettelijke leeftijd heeft bereikt om te worden gehoord in de gerechtelijke procedure over de mogelijke verlenging van de ondertoezichtstelling en uithuisplaatsing. ${ }^{777}$ Een jaarlijkse gang naar de rechter, waar de minderjarige zijn visie moet geven over de vraag waar hij graag zou opgroeien, kan dan erg belastend zijn.

Er zijn echter ook zaken waarin de onzekerheid die de minderjarige ervaart niet evident is, of althans niet zodanig dat de noodzaak tot gezagsbeeindiging zonder meer is aangetoond. Bijvoorbeeld in het geval de minderjarige al vele jaren in het kader van een ondertoezichtstelling uit huis is geplaatst en volledig is gewend aan de situatie waarin de opvoeding door de pleegouders wordt verzorgd maar er nog wel goed contact is met de ouder. Het aantal zaken waarin dit voorkomt neemt naar alle waarschijnlijkheid fors af aangezien onder de huidige wetgeving langdurige uithuisplaatsingen veel minder vaak voorkomen. Maar zeker kort na inwerkingtreding van de Wet herziening kinderbeschermingsmaatregelen op 1

\footnotetext{
${ }^{776}$ Kamerstukken II 2008/09, 32 015, nr. 3 (MvT).

777 Zie bv. Gerechtshof Arnhem-Leeuwarden 9 maart 2017, ECLI:NL:GHARL:2017:2058, r.o.5.5.
} 
januari 2015 heeft dit regelmatig gespeeld. Het ging dan om zaken waarin de uithuisplaatsing jaar na jaar werd verlengd, zonder dat ontheffing uit het gezag werd overwogen. Onder de gewijzigde wetgeving komen deze zaken in aanmerking voor gezagsbeëindiging omdat veelal duidelijk is dat het opvoedperspectief van de minderjarige in het pleeggezin ligt. Zeker in het geval er al een jarenlange goede samenwerking is tussen de ouder, pleegouders en de GI, kan worden getwijfeld aan de toegevoegde waarde van gezagsbeeindiging. Het aan art. 8 EVRM ontleende subsidiariteitsbeginsel speelt hierbij ook een belangrijke rol. ${ }^{778}$ Indien op minder ingrijpende wijze het gewenste resultaat kan worden bereikt (zekerheid over het opvoedperspectief voor de minderjarige) dan heeft dit de voorkeur.

Cruciaal lijkt daarbij, zoals net genoemd, de opstelling van de ouder met gezag. In diverse zaken is zichtbaar dat de vraag of er sprake is van een duurzame coöperatieve houding van de ouder een een rol kan spelen bij de afweging of gezagsbeëindiging gerechtvaardigd is ${ }^{779}$ Dit is onder meer zichtbaar in een uitspraak van het gerechtshof 's Gravenhage van 28 september 2016:

'Gezien de veilige hechting aan de huidige pleegouders, de goede band die de minderjarige blijkens de omgangsverslagen met haar ouders heeft en het feit dat de ouders niet aan de minderjarige 'trekken', is het hof van oordeel dat het handhaven van het gezag de ontwikkeling van de minderjarige niet zal bedreigen, zodat het verbreken van de gezagsrelatie in strijd zou zijn met artikel 8 EVRM. ${ }^{780}$

In de tussenevaluatie van de Wet herziening kinderbeschermingsmaatregelen komt naar voren dat zowel medewerkers van de RvdK en de GI's tot op zekere hoogte rekening houden met de opstelling van de ouders. ${ }^{781}$ Zo laten medewerkers van de RvdK weten dat ouders gezagsbeëindiging als een straf ervaren in het geval zij op een goede manier invulling geven aan het gezag (op afstand) en niet aan de minderjarige trekken. Dit kan voor ouders een reden zijn om door de teleurstelling helemaal af te haken na gezagsbeëindiging. Medewerkers van de GI geven ook aan dit mee te wegen. Indien ouders zich volledig dreigen terug te trekken

\footnotetext{
${ }^{778}$ Zie in dit verband: EHRM 6 oktober 2015, 58455/13 (N.P t. Moldavië), par. 64-70.

${ }^{779} \mathrm{Vgl}$. Gerechtshof 's-Gravenhage 31 augustus 2016, ECLI:NL:GHDHA:2016:2643; Rb. Overijssel 8 mei 2015, ECLI:NL:RBOVE:2015:3361 en Rb. Overijssel 1 oktober 2015, ECLI:NL:RBOVE:2015:5764; Gerechtshof 's-Gravenhage 28 september 2016, ECLI:NL:GHDHA:2016:2919.

${ }^{780}$ Gerechtshof 's-Gravenhage 28 september 2016, ECLI:NL:GHDHA:2016:2919, r.o. 21.

${ }^{781}$ Lunnemann, Huijer e.a. 2018, p. 23.
} 
als ze geen gezag meer hebben, dan kan dit, als het belang van het kind hiermee is gediend, een argument zijn om geen verzoek tot onderzoek naar gezagsbeëindiging te doen. ${ }^{782}$

Of de feiten en omstandigheden nu uitwijzen dat de minderjarige in onzekerheid verkeert of niet, het lijkt in alle gevallen belangrijk dat de rechter expliciet aandacht besteedt aan dit element. De onzekerheid van de minderjarige in het concrete geval is immers de bepalende factor ten aanzien van het oordeel dat de aanvaardbare termijn is verstreken. In sommige uitspraken is zichtbaar dat de onzekerheid niet nader wordt geconcretiseerd maar wordt aangenomen, terwijl wel (onevenredig) veel aandacht is voor de verwachting omtrent het opvoedershandelen van de ouders. ${ }^{783}$ Het oogt, mede in het licht van de verstrekkende gevolgen van gezagsbeëindiging, mager om ten aanzien van de onzekerheid van de minderjarige alleen te verwijzen naar de visie van de wetgever hierover. Of slechts te benoemen dat de situatie waarin de minderjarige in een pleeggezin is geplaatst en de ouder nog gezag heeft, tot onzekerheid en loyaliteitsconflicten kan leiden bij de minderjarige. ${ }^{784}$ De beëindiging van het gezag van de ouder veronderstelt dat de onzekerheid daadwerkelijk aanwezig is en gelet op de ontwikkeling van de minderjarige niet langer kan duren. Gelukkig zijn er ook veel voorbeelden van uitspraken waarin rechters wel heel concreet aandacht besteden aan de mate van onzekerheid die de minderjarige ervaart over zijn opvoedperspectief. ${ }^{785}$ Het blijft echter een belangrijke aandachtspunt. Uit de rechtspraak blijkt namelijk ook dat rechters wel standaard inhoudelijk beargumenteren waarom de verwachting wel of niet gerechtvaardigd is dat de ouders weer de verantwoordelijkheid voor de verzorging en opvoeding weer zelfstandig kunnen dragen. ${ }^{786}$ Het concreet beargumenteren in hoeverre de onzekerheid van de minderjarige maakt dat de aanvaardbare termijn is verstreken zou eenzelfde automatisme moeten zijn.

\footnotetext{
782 Lunnemann, Huijer e.a. 2018, p. 24.

${ }^{783}$ Zie bv. Gerechtshof s' Hertogenbosch 16 maart 2017, ECLI:NL:GHSHE:2017:1058; Gerechtshof 's-

Gravenhage 10 februari 2016, ECLI:NL:GHDHA:2016:369; Gerechtshof Arnhem Leeuwarden 21 juni 2016, ECLI:NL:GHARL:2016:5119; rb. Overijssel 21 april 2015, ECLI:NL:RBOVE:2015:2652.

${ }^{784}$ Zie bv. Gerechtshof 's-Hertogenbosch 5 september 2019, ECLI:NL:GHSHE:2019:3292.

785 Gerechtshof 's-Gravenhage 2 maart 2016, ECLI:NL:GHDHA:2016:1766; Gerechtshof Arnhem Leeuwarden 16 februari 2016, ECLI:NL:GHARL:2016:1428; Gerechtshof Arnhem-Leeuwarden ECLI:NL:GHARL:2016:9719; Gerechtshof Amsterdam 17 april 2018, ECLI:NL:GHAMS:2018:1315.

${ }^{786}$ Vgl. Gerechtshof Arnhem Leeuwarden 14 april 2016 ECLI:NL:GHARL:2016:2968; Gerechtshof ArnhemLeeuwarden 21 juni 2016, ECLI:NL:GHARL:2016:5119. Gerechtshof 's-Hertogenbosch 16 maart 2017, ECLI:GHSHE:2017:1058.
} 
10.5.4 Het doel van gezinshereniging en de noodzaak tot gezagsbeëindiging

Zonder twijfel heeft de Wet herziening kinderbeschermingsmaatregelen ervoor gezorgd dat de doelstellingen die met de verschillende maatregelen worden nagestreefd duidelijker zijn afgebakend. De ondertoezichtstelling met machtiging uithuisplaatsing is een tijdelijke maatregel waarin wordt gestreefd kind en ouders zodanig te ondersteunen dat thuisplaatsing weer mogelijk is. Raakt thuisplaatsing van de minderjarige uit zicht en wordt duidelijk de onzekerheid van de minderjarige schadelijk is voor zijn ontwikkeling dan dient een gezagsbeëindigende maatregel te worden overwogen. Impliciet wordt daarmee ook bevestigd dat het lang in onzekerheid blijven over de vraag waar de minderjarige mag opgroeien, niet bevorderlijk is voor zijn ontwikkeling. De huidige wettelijke systematiek, meer specifiek de verhouding tussen de ondertoezichstelling/uithuisplaatsing en gezagsbeëindigende maatregel, vereist echter wel een goed functionerend systeem van jeugdhulp. Een systeem waarin tijdig hulp beschikbaar is, het aanbod en de kwaliteit van de jeugdhulp op orde zijn en de minderjarige na uithuisplaatsing in een stabiele gezinsvervangende omgeving kan worden geplaatst. In het systeem van jeugdhulp na inwerkingtreding van de Jeugdwet zijn echter duidelijke problemen zichtbaar waar het gaat om de toegang tot- en het aanbod van jeugdhulp. ${ }^{787}$ Dit leidt, bezien vanuit de wettelijke doelstelling van de maatregelen, tot complicaties bij de afweging rond gezagsbeëindiging.

In de eerste plaats geldt dat voor gezagsbeëindiging gerechtvaardigd kan zijn, de doelstelling van de ondertoezichtstelling met uithuisplaatsing moet zijn komen te vervallen. In de woorden van art. 1:266 lid $1 \mathrm{BW}$ gaat het om het oordeel dat de verwachting niet gerechtvaardigd is dat de ouders binnen een voor de minderjarige aanvaardbare termijn hem in de thuissituatie kunnen verzorgen en opvoeden. Op grond van art. 8 EVRM veronderstelt dit dat de herenigingsdoelstelling die ten grondslag behoort te liggen aan de ondertoezichtstelling/uithuisplaatsing niet meer wordt nagestreefd. ${ }^{788}$ Dit verstrekkende oordeel, waarmee het opvoedperspectief van de minderjarige wijzigt, zou echter pas tot stand mogen komen op het moment dat intensief is geïnvesteerd in een terugkeer van de minderjarige naar huis. Als binnen de gestelde aanvaardbare termijn vanaf de eerste dag na uithuisplaatsing stappen worden gezet om thuisplaatsing te realiseren, dan hoeft een relatief snel oordeel over het opvoedperspectief van de minderjarige geen probleem te zijn.

\footnotetext{
${ }^{787}$ Zie hierover Bruning \& De Boer FJR 2018/46.

${ }^{788}$ Zie over de doelstelling op grond van het EVRM: Aalders FJR 2018/63.
} 
Verschillende onderzoeken laten echter zien dat binnen het gedwongen kader, te vaak niet, of niet tijdig de juiste hulp kan worden geboden aan kind en ouders. De evaluatie van de Jeugdwet laat zien dat het onvoldoende lukt om tijdig passende hulp in te zetten, hetgeen extra problematisch is als het gaat om hulp in gedwongen kader. ${ }^{789}$ Daarnaast worden rechters die moeten beslissen over jeugdbeschermingsmaatregelen geconfronteerd met wachtlijsten en bepaalde vormen van zorg die niet zijn ingekocht door de gemeente. ${ }^{790}$ Dit beeld wordt bevestigd in de evaluatie van de Wet herziening kinderbeschermingsmaatregelen. Rechters bestempelen het niet tijdig op gang komen van de afgesproken hulp als belangrijk knelpunt. ${ }^{791}$ Aangegeven wordt dat hierdoor de besluitvorming aanzienlijk complexer wordt. Het huidige beleid inzake de aanvaardbare termijn vereist de intensieve inzet van hulpverlening vanaf dag één, maar in de praktijk kan daar lang niet altijd aan worden voldaan. ${ }^{792}$ Ook voor medewerkers van de RvdK is dit een belangrijk knelpunt in de besluitvorming over de gezagsbeëindigende maatregel. Zij krijgen zaken aangeleverd van de GI's waarin weliswaar sinds de uithuisplaatsing de nodige tijd is verstreken, maar onvoldoende duidelijk wordt in welke mate is geïnvesteerd in een terugkeer van de minderjarige naar huis. ${ }^{793}$ Een mogelijke oorzaak is dat de minderjarige direct in een perspectief biedend pleeggezin is geplaatst en de zorg zich vooral heeft gericht op het bestendigen van de plek daar. Ook problemen in de uitvoering door de GI zelf kunnen tot de geschetste situatie leiden, zoals frequente wisselingen van gezinsvoogd of een moeizame overdracht van de zaak tussen GI's.

In veruit de meeste zaken lijkt de GI's echter weinig kwalijk te kunnen worden genomen. Zij willen wel de juiste hulp inzetten om de minderjarige en de ouders te ondersteunen maar hulp is niet beschikbaar. Dit beeld wordt bevestigd in een eind 2019 uitgekomen rapport van de Inspectie Gezondheidszorg en Jeugd. ${ }^{794}$ Het rapport schetst een vrij ontluisterend beeld van de wijze waarop uitvoering wordt gegeven aan de jeugdbeschermingsmaatregelen (en in mindere mate de jeugdreclassering). Zo is zichtbaar dat kinderen soms moeten wachten op de uitvoering van een jeugdmaatregel die reeds in opgelegd, vanwege personeelstekort en wachtlijstproblemen. Dit wordt aangeduid met de term 'instroomlijst' of 'minimale variant' ${ }^{795}$ Feitelijk betekent dit dat er zicht is op de veiligheid van het kind, maar niets kan

\footnotetext{
${ }^{789}$ Friele e.a. 2018, p. 52 e.v.

${ }^{790}$ Friele e.a. 2018 , p. 52 e.v.

${ }^{791}$ Lunnemann, Huijer e.a. 2018, p. 33.

${ }^{792}$ Lunnemann, Huijer e.a. 2018, p. 34.

${ }^{793}$ Lunnemann, Huijer e.a. 2018, p. 34.

${ }^{794}$ IGJ en IJenV - november 2019, 'Kwetsbare kinderen onvoldoende beschermd'.

795 IGJ en IJenV - november 2019, 'Kwetsbare kinderen onvoldoende beschermd', p. 12.
} 
worden ondernomen om de ontwikkelingsbedreiging weg te nemen. ${ }^{796}$ Verder wordt geconcludeerd dat normtijden voor het eerste contact en voor het maken van een plan van aanpak niet worden gehaald, waardoor het te lang duurt om te bepalen welke hulp moet worden ingezet. Wat betreft de uitvoering wordt vastgesteld dat jeugdbeschermers er niet of met de grootste moeite in slagen om de hulp in te zetten die nodig is om de ontwikkelingsbedreiging van het kind op te heffen. De hulp is niet beschikbaar, het aanbod is onvoldoende vraaggericht, wordt niet geleverd in de vorm van maatwerk, of het kost erg veel tijd om de hulp te organiseren. ${ }^{797}$ Geconcludeerd wordt dat bij het niet tijdig inzetten van de juiste hulp geen recht wordt gedaan aan de urgentie van jeugdbeschermingsmaatregelen.

Het behoeft nauwelijks betoog dat het gebrek aan hulpverlening problematisch is in het licht van de aanvaardbare termijn en de afweging over de noodzaak van gezagsbeëindiging. Een reëel risico is dat dat de ondertoezichtstelling met uithuisplaatsing als fuik richting gezagsbeëindiging gaat fungeren, een zorg die eerder al door de Raad van State is uitgesproken. ${ }^{798}$ Iedere dag na een uithuisplaatsing telt, aangezien de kansen op hereniging afnemen als de minderjarige langer in een pleeggezin verblijft. Een en ander oogt ook problematisch in het licht van de herenigingsdoelstelling die kan worden ontleend aan het recht op familie- en gezinsleven (art. 8 EVRM). Het EHRM heeft laten zien niet blind te zijn voor de factor tijdsverloop. Zo benadrukt het EHRM dat indien een kind langdurig in een pleeggezin verblijft en een hechte band heeft opgebouwd met de pleegouders, onder omstandigheden voorrang moet worden gegeven aan het belang van het kind om bij de pleegouders te blijven. ${ }^{799}$ Tegelijkertijd laat het EHRM zien wel kritisch te kijken naar de stappen die gezet zijn vanaf het moment van uithuisplaatsing van het kind. Heeft de ouder vorderingen gemaakt en hoeveel tijd is daarover heengegaan? ${ }^{800}$ Hebben de autoriteiten voldoende inspanningen geleverd om het contact tussen kind en ouder te bevorderen ${ }^{801}$ En heeft een periodieke evaluatie plaatsgevonden van de opvoedcapaciteiten van de ouder en de situatie in het pleeggezin waarbij de mogelijkheden tot hereniging van kind en ouder nadrukkelijk zijn overwogen $?^{802}$ Als algemeen uitgangspunt geldt daarbij dat gezien de

\footnotetext{
796 IGJ en IJenV - november 2019, 'Kwetsbare kinderen onvoldoende beschermd'. P. 13.

${ }^{797}$ IGJ en IJenV - november 2019, 'Kwetsbare kinderen onvoldoende beschermd'. p. 13.

798 Zie Huijer FJR 2015/8.

${ }^{799}$ Zie o.a. EHRM 7 augustus 1996, appl. nr. 17383/90 (Johansen t. Noorwegen), par. 78. en EHRM 14 januari 2003, appl. No. 27751/95 (K.A. t. Finland), par. 138.

${ }^{800}$ EHRM 23 september 1994, appl. nr. 19823/92 (Hokkanen t. Finland), par. 58

${ }^{801}$ Zie bv. EHRM 22 juni 1989, appl. nr. $11373 / 85$ (Eriksson t. Zweden), par. 71.

${ }^{802}$ EHRM 6 oktober 2015, appl.nr. 58455/13 (N.P t. Moldavië).
} 
verstrekkende gevolgen van gezagsbeëindiging, alleen in uitzonderlijke gevallen tot deze maatregel mag worden overgegaan. ${ }^{803}$

In 2019 heeft het EHRM de positieve verplichtingen voor de autoriteiten waar het gaat om hereniging van kind en ouders scherp uiteengezet. ${ }^{804}$ In de zaak Strand Lobben t. Noorwegen ging het weliswaar om gedwongen adoptie van een zeer jong kind, maar de uitgangspunten zijn ook zonder meer van toepassing op de situatie waarin door gezagsbeëindiging het kind (vrijwel zeker) definitief elders opgroeit. Gesteld wordt dat een eenzijdige focus op het bestendigen van de plek van het kind in het pleeggezin, zonder de mogelijkheid van hereniging serieus te beproeven of te overwegen, de toets van art. 8 EVRM niet kan doorstaan. ${ }^{805}$ Op 10 maart 2020 heeft het EHRM in twee verschillende zaken tegen Noorwegen een schending geconstateerd van art. 8 EVRM, omdat in de uitvoering van de uithuisplaatsingen het doel van hereniging van het gezin onvoldoende voorop heeft gestaan. ${ }^{806}$ In beide zaken werden de kinderen in pleeggezinnen geplaatst en is volgens het EHRM onvoldoende gezinsbegeleiding geboden en geïnvesteerd in het contact tussen de ouders en kinderen.

Het is echter de vraag wat het ouders oplevert als na zo'n lange periode blijkt dat niet is voldaan aan de vereisten van art. 8 EVRM. Ook als wordt vastgesteld dat het onvoldoende investeren in de terugkeer van een kind naar huis niet in lijn is met art. 8 EVRM, moet de kinderrechter alsnog een belangenafweging met betrekking tot het opvoedperspectief van de minderjarige maken. Zeker als het kind in kwestie is ingegroeid in het pleeggezin, lijkt het zeer onwaarschijnlijk dat een kinderrechter alsnog besluit dat moet worden toegewerkt naar een terugkeer naar huis. Feitelijk is daarmee de mogelijkheid om nog recht te kunnen doen aan het herenigingsbeginsel een gepasseerd station. Dit leidt er dan ook toe dat raadsonderzoekers, hoewel zij aangeven zeer te worstelen met dit dilemma, in deze gevallen vrijwel altijd de keuze maken om toch een verzoek tot gezagsbeëindiging te doen. ${ }^{807}$

Het hoogst haalbare lijkt dat kinderrechters in de periode na de uithuisplaatsing (bijvoorbeeld bij de beoordeling van het eerste verzoek tot verlenging van de uithuisplaatsing) kritisch toetsen of de noodzakelijke stappen zijn gezet om thuisplaatsing te realiseren. Bruning geeft

\footnotetext{
${ }^{803}$ EHRM 6 oktober 2015, appl.nr. 58455/13 (N.P t. Moldavië).

${ }^{804}$ EHRM 30 november 2017, nr. 37283/13 (Strand Lobben e.a. tegen Noorwegen).

${ }^{805}$ EHRM 30 november 2017, appl. nr. 37283/13, (Strand Lobben e.a. tegen Noorwegen) par.2.2.1

${ }^{806}$ Vgl EHRM 10 maart 2020, ECLI:CE:ECHR:2020:0310JUD001465216, (Hernehult $t$. Noorwegen); EHRM 10 maart 2020, ECLI:CE:ECHR:2020:0310JUD003971015, (Pedersen e.a. t. Noorwegen).

${ }^{807} \mathrm{Zie}$ over de dilemma's die raadsonderzoekers ervaren bij de afweging over gezagsbeëindiging: Huijer 2019.
} 
in dat licht aan dat kinderrechters bij gebrek aan tijdige hulp voor kind en ouder, soms de keuze kunnen maken om het verzoek voor korte duur toe te wijzen of te verlengen. ${ }^{808}$ Op die manier kan een vinger aan de pols worden gehouden. Het verandert echter niks aan het onderliggende probleem. Zolang de uitvoeringspraktijk niet op orde is, kan de manier waarop de aanvaardbare termijn nu dwingt spoedig gezagsbeëindiging te overwegen, zeer nadelig uitpakken voor het kind en zijn ouders.

\subsubsection{Het doel van gezagsbeëindiging}

Indien een minderjarige uit huis wordt geplaatst dan heeft een vervangende gezinsomgeving de voorkeur. Dit uitgangspunt is expliciet opgenomen in art. 2.3.6 Jeugdwet waarin staat dat het college zorg draagt dat de jeugdige in geval van een uithuisplaatsing, indien mogelijk, bij een pleegouder of in een gezinshuis wordt geplaatst, tenzij dit aantoonbaar niet in zijn belang is. De Staat dient er zorg voor te dragen dat de minderjarige op een passende plek wordt geplaatst rekening houdend met de achtergrond en behoeften van het kind. Ondanks alle inspanningen die worden geleverd om dit doel te bereiken lukt het lang niet altijd de minderjarige op een plek te laten verblijven waar hij het perspectief heeft langdurig te blijven. Sommige minderjarigen komen vanwege de aanwezigheid van complexe problematiek niet in aanmerking voor een plaatsing in een pleeggezin en verblijven jarenlang in residentiele instellingen. Voor sommige kinderen is pas een stabiele plek beschikbaar na jarenlang verblijf in tijdelijke pleeggezinnen of eindigt de perspectiefbiedende plaatsing in een breakdown. ${ }^{809}$ Daarnaast komt het voor dat de minderjarige wel op een perspectiefbiedende plek verblijft maar dat de RvdK zich zorgen maakt over het pedagogisch handelen van de pleegouders. Zo kunnen er allerlei redenen zijn waarom op het moment dat moet worden besloten over de noodzaak van gezagsbeëindiging de minderjarige niet op een stabiele, perspectiefbiedende plek verblijft.

De wetgever heeft deze mogelijkheid onbesproken gelaten. Volstaan wordt met de vaststelling dat wanneer een minderjarige in een pleeggezin is geplaatst hij zich daar, voor zover mogelijk, volledig en harmonieus moet kunnen ontwikkelen. Dit geldt in het bijzonder voor de situatie waarin het kind reeds op zeer jonge leeftijd in een perspectief biedend

\footnotetext{
${ }^{808}$ Bruning AA 2020/5.

${ }^{809}$ De richtlijn Pleegzorg definieert een breakdown als een voortijdig negatief afgebroken plaatsing. Op basis van onderzoek wordt gesproken van een breakdown percentage van $45 \%$ in Nederland.
} 
pleeggezin is geplaatst; dan dient duidelijkheid te bestaan over zijn opvoed- en ontwikkelingsperspectief. ${ }^{810}$ Uit deze toelichting is goed te herleiden wat de doelstelling is van de gezagsbeëindigende maatregel: het bieden van zekerheid aan de minderjarige ten aanzien van zijn opvoedperspectief. Dit laatste element is van cruciaal belang. Ook als is vastgesteld dat de minderjarige in onzekerheid verkeert, die onzekerheid schadelijk is voor zijn ontwikkeling en na voldoende inspanning duidelijk is dat terugplaatsing bij de ouders met gezag een gepasseerd station is, moet de maatregel nog wel aan zijn belangrijkste doelstelling kunnen voldoen. Uit de tussenevaluatie van de Wet herziening kinderbeschermingsmaatregelen blijkt deze situatie de afweging omtrent gezagsbeëindiging voor raadsonderzoekers en rechters compliceert. ${ }^{811}$ Een deel van de ondervraagde raadsmedewerkers vindt het niet voor de hand liggen gezagsbeëindiging te verzoeken als de onzekerheid over het opvoedperspectief daarmee niet wordt weggenomen. ${ }^{812}$ Ook uit de rechtspraak blijkt dat - in ieder geval een deel van de rechters - niet sec de vraag beantwoordt of de minderjarige voorzienbaar weer thuis kan wonen maar ook het doel van gezagsbeëindiging in de afweging betrekt. Zo oordeelt het gerechtshof Arnhem-Leeuwarden in een uitspraak van 8 november 2016 weliswaar dat de verwachting niet gerechtvaardigd is dat de moeder in kwestie binnen een aanvaardbare termijn de verzorging en opvoeding op zich kan nemen, maar de uithuisplaatsing is zo rommelig verlopen (door overplaatsingen) dat moeder op dit moment de enige figuur is die steun en houvast biedt aan de minderjarigen. ${ }^{813}$ Het verzoek tot gezagsbeëindiging wordt om die reden afgewezen. Het gerechtshof 'sGravenhage wijst in een uitspraak van 17 augustus 2016 het verzoek tot gezagsbeëindiging af omdat de maatregel niet aan zijn belangrijkste doelstelling kan voldoen:

'Naar het oordeel van het hof brengt gezagsbeëindiging in onderhavige zaak echter niet de gewenste duidelijkheid omtrent het toekomstperspectief van de minderjarige. Het hof overweegt daartoe dat uit de overgelegde stukken en het verhandelde ter terechtzitting blijkt dat de minderjarige op dit moment op haar plaats zit bij de gezinshuisouders en aldaar de verzorging en opvoeding krijgt die zij nodig heeft om zich te ontwikkelen, maar dat de opvoeding zeer zwaar is en de gezinshuisouders de situatie per dag bekijken. De minderjarige kan slechts bij de gezinshuisouders blijven tot de gezinshuisouders haar niet meer kunnen helpen' ${ }^{814}$

\footnotetext{
${ }^{810}$ Kamerstukken II 2008/09, 32 015, nr. 3 (MvT), p. 35.

${ }^{811}$ Lunnemann, Huijer e.a 2018, p. 30 e.v.

${ }^{812}$ Lunnemann, Huijer e.a 2018, p. 30 e.v.

${ }^{813}$ Gerechtshof Arnhem-Leeuwarden 8 november 2016, ECLI:NL:GHARL:2016:9065.

${ }^{814}$ Gerechtshof 's/Gravenhage 17 augustus 2016, ECLI:NL:GHDHA:2016:2418, r.o.15.
} 
Daar staan echter ook verschillende zaken tegenover waarin het verzoek tot gezagsbeëindiging wordt toegewezen, terwijl de maatregel naar verwachting niet de gewenste duidelijkheid oplevert voor de minderjarige. ${ }^{815}$ Tekenend in dit verband is een uitspraak van het gerechtshof Arnhem Leeuwarden waarin het verzoek tot gezagsbeëindiging wordt toegewezen ten aanzien van een minderjarige die verblijft op een woongroep die op termijn zal ophouden te bestaan. Het hof legt daarbij zwaar de nadruk op het belang van stabiliteit en continuïteit in de opvoeding, terwijl door gezagsbeeindiging op dat moment die duidelijkheid niet wordt geboden. ${ }^{816}$

\subsubsection{Tussenconclusie}

Met de gezagsbeëindigende maatregel zoals neergelegd in art. 1:266 BW wordt beoogd het opvoed- en ontwikkelingsperspectief van de minderjarige meer centraal te stellen in de besluitvorming. In algemene zin lijkt de maatregel daarin te slagen. In de situatie voor 2015 werden ondertoezichtstellingen met uithuisplaatsing veelal verlengd ook als er geen perspectief was op een terugkeer naar de ouder met gezag. De koppeling tussen de ondertoezichtstelling en de gezagsbeëindigende maatregel (door het aanvaardbare termijn criterium) maakt een scherpere afbakening van de doelen van beide maatregelen mogelijk. De ondertoezichtstelling met uithuisplaatsing als de verwachting gerechtvaardigd is dat de ouders met gezag binnen een aanvaardbare termijn de verzorging en opvoeding kunnen dragen en in beginsel gezagsbeëindiging als deze verwachting niet gerechtvaardigd is. De tijdelijke aard van de ondertoezichtstelling en uithuisplaatsing dient het belang van het kind bij stabiliteit en continuïteit in de opvoeding, zoals verwoord in art. 20 lid 3 IVRK. Gezagsbeëindiging kan in veel gevallen bijdragen aan de gewenste stabiliteit en de minderjarige zekerheid bieden over zijn opvoedperspectief.

Toch zijn in deze paragraaf ook een fors aantal aandachts- en knelpunten benoemd die zien op de besluitvorming over de noodzaak van gezagsbeëindiging. Omdat gezagsbeëindiging in het huidige systeem veel eerder wordt overwogen neemt ook de kans toe op een ongerechtvaardigde inbreuk op het familie- en gezinsleven van kind en ouders. Achtereenvolgens is geconcludeerd dat om een gezagsbeëindigende maatregel mede in het licht van art. 8 EVRM gerechtvaardigd te kunnen laten zijn: de minderjarige daadwerkelijk

\footnotetext{
${ }^{815}$ Vgl. Rb. Noord-Holland 15 januari 2019, ECLI:NL:RBNHO:2019:224; Gerechtshof Arnhem-Leeuwarden 14 juli 2016, ECLI:NL:GHARL:2016:6134.

${ }^{816}$ Gerechtshof Arnhem-Leeuwarden 14 juli 2016, ECLI:NL:GHARL:2016:6134.
} 
onzekerheid moet ervaren over zijn opvoedperspectief; met het oog op die onzekerheid een aanvaardbare termijn moet worden gesteld waar indien de omstandigheden dit vragen flexibel mee om wordt gegaan; dat met voldoende zekerheid kan worden gesteld dat er geen kans is op een terugkeer van de minderjarige naar de ouders met gezag, hetgeen alleen met zekerheid kan worden vastgesteld als voldoende is geïnvesteerd in een terugkeer naar huis; en tot slot dat de gezagsbeëindigende maatregel (ten opzichte van minder ingrijpende maatregelen) de minderjarige de noodzakelijk geachte duidelijkheid geeft over zijn opvoedperspectief. Helaas moet worden geconcludeerd dat niet altijd aan deze vereisten kan worden voldaan omdat de uitvoeringspraktijk van de jeugdbescherming belangrijke tekortkomingen vertoond. Meest problematisch in dit verband lijkt het gebrek aan passende hulpverlening in het huidige systeem. Als na een uithuisplaatsing niet tijdig de juiste hulp kan worden ingezet dan werkt het tijdsverloop van de maatregel in het nadeel van de ouders en minderjarige. Die hebben er op grond art. 8 EVRM recht op dat de overheid alles in het werk heeft gesteld om gezagsbeëindiging, en daarmee een scheiding van kind en ouders met een definitief karakter, te voorkomen.

\subsection{Zorgvuldigheid van het feitenonderzoek}

In de delen I en II van deze studie is aandacht besteed aan het feitenonderzoek in jeugdbeschermingszaken voor de periode tot 2015. Gezien de verstrekkende gevolgen van de oplegging van een ondertoezichtstelling en uithuisplaatsing, is het van belang dat het onderzoek op basis waarvan deze beslissingen worden genomen met de grootst mogelijke zorgvuldigheid tot stand komt. Het onderzoek heeft laten zien dat jarenlange forse kritiek van met name betrokken ouders heeft geleid tot een vergrote aandacht voor de rol van waarheidsvinding in jeugdbeschermingszaken. De kritiek op de besluitvorming leek zich met name toe te spitsen op het vermeende gebrek aan onderscheid tussen feiten en meningen in de jeugdbeschermingsrapportages. Grotendeels onduidelijk bleef echter of de kritiek op dit punt terecht was. In de discussie werd geen aandacht besteed aan de vraag wanneer sprake was van feitelijke informatie wanneer van een vermoeden op basis van de mening/visie van een betrokkene of professional. Het dossieronderzoek in deel II van deze studie heeft tot doel gehad om ten aanzien van het feitenonderzoek door de RvdK in de jaren 2013 en 2014, meer duidelijkheid te verschaffen of feiten en meningen inderdaad door elkaar liepen in de beschermingsrapportage en zo ja, hoe vaak dit voorkwam. 
Na de inwerkingtreding van de Wet herziening kinderbeschermingsmaatregelen en de Jeugdwet op 1 januari 2015 is de kritiek op het feitenonderzoek in jeugdbeschermingszaken geenszins verstomd. Een deel van de cliënten van de Rvdk en de GI's is nog altijd zeer ontevreden over de manier waarop de instanties het feitenonderzoek vormgeven. Zij geven aan dat op basis van onzorgvuldig onderzoek en foutieve informatie ingrijpende beslissingen worden genomen. ${ }^{817}$ Specifiek ten aanzien van de RvdK blijkt dit ook uit de interne klachtenanalyse over het jaar 2017. De analyse laat zien dat bijna de helft van de formeel ingediende klachten betrekking heeft op de inhoud van het raadsonderzoek en het rapport. ${ }^{818}$ De zienswijze van betrokkenen dat informatie die in het kader van onderzoek en rapportage in de jeugdbeschermingsketen wordt verzameld niet correct en zorgvuldig wordt verwerkt, betreft een terugkerende klacht. ${ }^{819}$ In de rapportages wordt volgens de klagers gebruikt gemaakt van vage formuleringen of voor de ouders en minderjarige moeilijk te begrijpen jargon. Hierdoor is een navolgbare weging van de feiten en omstandigheden die hebben geleid tot de beslissing voor de betrokkenen niet mogelijk. Ook wordt aangedragen dat verouderde informatie in rapportages blijft terugkomen en/of dat onduidelijk is uit welke bron de informatie is verkregen. ${ }^{820}$ Het belangrijkste kritiekpunt op dit vlak is (nog steeds) dat geen duidelijk onderscheid wordt aangebracht tussen feitelijke informatie en mening van betrokkenen en informanten. ${ }^{821}$

Het is echter ook duidelijk dat sinds 2015 op het gebied van wetgeving en beleid de nodige stappen zijn gezet om de notie van waarheidsvinding steviger te verankeren in jeugdbeschermingszaken. In deze paragraaf wordt beschreven hoe de discussie over het feitenonderzoek in jeugdbeschermingszaken zich op hoofdlijnen heeft ontwikkeld sinds 2015 en worden de belangrijkste wijzigingen in wetgeving en beleid besproken. Vervolgens worden de resultaten van het dossieronderzoek door de RvdK in 2013 en 2014, afgezet tegen de belangrijkste ontwikkelingen. Doel hiervan is te kijken op welke punten wellicht tegemoet is gekomen aan de verbeterpunten die in het dossieronderzoek zijn gesignaleerd en wat deze bevindingen betekenen voor het feitenonderzoek in jeugdbeschermingszaken nu en in de toekomst.

\footnotetext{
${ }^{817}$ Zie Actieplan 'Verbetering Feitenonderzoek in de Jeugdbeschermingsketen 2018-2021', p. 5.

${ }^{818}$ Het gaat in totaal om 281 klachten die inhoudelijk door de RvdK zijn behandeld op een totaal van 46.556 raadsonderzoeken; Klachtenanalyse 2017 RvdK.

${ }^{819}$ Vgl. de cijfers over 2014 van de RvdK, aangehaald in: Kamerstukken II, 2015/16, 31 839, nr. 510.

${ }^{820}$ Kamerstukken II 2015/16, 31839, nr. 510.

${ }^{821}$ Kamerstukken II 2015/16, 31 839, nr. 510.
} 
10.6.1 De waarheidsplicht van art. 3.3 Jeugdwet

Na het rapport van de Kinderombudsman over waarheidsvinding in 2013 heeft toenmalig staatssecretaris Teeven laten weten de conclusies in het rapport te onderschrijven. ${ }^{822}$ Niet lang daarna is bij de behandeling van de Jeugdwet een amendement ingediend door de leden Van den Burg en Bergkamp waarin wordt voorgesteld een zogenaamde waarheidsplicht voor de RvdK en Bureau Jeugdzorg in art. 3.3 Jeugdwet op te nemen. ${ }^{823}$ De toelichting omtrent de noodzaak van een waarheidsplicht in de Jeugdwet is als volgt:

'Het is belangrijk dat het uitgangspunt van waarheidsvinding een wettelijke grondslag krijgt. Bij een ingrijpende maatregel zoals een kinderbeschermingsmaatregel is het van belang dat de kinderrechter de zaak zoveel als mogelijk kan beoordelen op basis van feiten. De verplichting die uit dit amendement volgt houdt in dat de Raad voor de Kinderbescherming en de gecertificeerde instellingen die de maatregelen uitvoeren zich moeten richten op het verzamelen van feiten, gebeurtenissen en omstandigheden die objectiveerbaar zijn. Dit geldt voor rapportages maar ook voor de verzoekschriften (waaraan de rapportages vaak ten grondslag liggen) aan de kinderrechter (bijv. verzoek machtiging tot uithuisplaatsing of verzoek ondertoezichtstelling). Op basis van dit amendement dient de besluitvorming in de rapportage te zijn onderbouwd, waarbij feiten, visies van betrokkenen en de interpretaties van de Raad of gecertificeerde instelling duidelijk zijn gescheiden'. ${ }^{824}$

Met invoering van de Jeugdwet heeft de waarheidsplicht voor de RvdK en de GI's een plek gekregen in art. 3.3 Jeugdwet. Op basis van dit artikel geldt dat de RvdK en de GI verplicht zijn in rapportages of verzoekschriften de van belang zijnde feiten volledig en naar waarheid aan te voeren. Het is daarbij opvallend dat is gesteld dat waarheidsvinding een wettelijke grondslag moet krijgen, terwijl art. $21 \mathrm{Rv}$ al van toepassing was en nog steeds is op de jeugdbeschermingsprocedure. Zoals in deel I van het onderzoek aangegeven bevat art. $21 \mathrm{Rv}$ de eis voor alle civiele procedures dat partijen de voor de beslissing van de belang zijnde feiten volledig en naar waarheid aanvoeren. De overeenkomsten tussen art. 3.3 Jeugdwet en art. $21 \mathrm{Rv}$ zijn evident, hetgeen ook nadrukkelijk de bedoeling lijkt te zijn van de wetgever. ${ }^{825}$ Voor de interpretatie en toepassing van art. 3.3 Jeugdwet moet aansluiting worden gezocht bij art. $21 \mathrm{Rv}$. Ook voor de toepassing van art. 3.3 Jeugdwet zal dus moeten worden aangetoond dat de RvdK of de GI bewust informatie heeft achterhouden of onjuiste informatie heeft

\footnotetext{
${ }^{822}$ Kamerstukken II 2013/14, 31 839, nr. 347.

${ }^{823}$ Kamerstukken II 2013/14, 33 684, nr 32.

${ }^{824}$ Kamerstukken II 2013/14, 33 684, nr 32.

${ }^{825}$ Kamerstukken II 2013/14, 33 684, nr 32.
} 
verstrekt. De consequenties van het in strijd handelen met de waarheidsplicht door de RvdK en GI zijn zoals art. $21 \mathrm{Rv}$. aangeeft aan de rechter gelaten. Het roept de vraag op wat de toegevoegde is van art. 3.3 Jeugdwet. Hoogstens kan worden betoogd dat de RvdK en de GI expliciet worden genoemd in het artikel hetgeen het belang van waarheidsvinding specifiek voor deze organisaties benadrukt. Daarnaast zou uit art. 3.3 Jeugdwet kunnen worden afgeleid dat de waarheidsplicht wordt uitgebreid tot al het handelen van deze organisaties en niet alleen de feitenvaststelling tijdens de gerechtelijke procedure. ${ }^{826}$ Zonder dat art. 3.3 Jeugdwet in de praktijk wordt uitgewerkt tot een concreet afwegingskader voor het feitenonderzoek lijkt het artikel vooral van symbolische waarde. Tekenend in dit verband is dat binnen de gepubliceerde rechtspraak in de eerste jaren na 2015 geen zaken terugkomen waarin een beroep op schending van de waarheidsplicht, ex art. 3.3 Jeugdwet is gedaan.

Langs een andere weg is in de rechtspraak wel aandacht besteed aan de eisen die kunnen worden gesteld aan de onderzoeken van de RvdK. De Hoge Raad heeft in een uitspraak van 19 oktober 2018 moeten oordelen over de aansprakelijkheid van de RvdK in een zaak waarin de RvdK advies inzake gezag en omgang heeft uitgebracht. ${ }^{827}$ Hoewel het gaat om een aansprakelijkstelling van de RvdK wegens onzorgvuldig dan wel onvolledig onderzoek en geen beroep wordt gedaan op schending van de waarheidsplicht ex art. 3.3 Jeugdwet is deze zaak wel direct relevant voor de maatstaven die kunnen worden gesteld ten aanzien van het onderzoek door de RvdK. In deze zaak heeft de RvdK in het kader van een problematische echtscheiding onderzocht of er reden was om het kind onder toezicht te stellen en advies uitgebracht over de vraag wie van beide ouders het beste met het gezag over het kind zou kunnen worden belast. In eerste instantie wordt eenhoofdig gezag aan moeder toegekend maar in hoger beroep krijgt de vader eenhoofdig gezag toegewezen. De moeder van het kind is daarna een procedure tegen de Staat begonnen. Zij heeft daarin onder meer het standpunt ingenomen dat de RvdK een onrechtmatige overheidsdaad heeft gepleegd omdat de onderzoeken naar de geschiktheid van de vader als opvoeder niet voldoende zorgvuldig zijn geweest. Een belangrijke rol hierbij speelt dat de vader in het verleden is veroordeeld voor ontucht met minderjarigen. Moeder geeft aan dat de RvdK geen deugdelijk onderzoek heeft verricht naar mogelijke risico's voor de minderjarige die kunnen zijn verbonden aan de pedofiele geaardheid van de vader en diens verleden als zedendelinquent. ${ }^{828}$ De rechtbank gaat hier in eerste aanleg niet in mee en vindt dat de onderzoeken van de RvdK voldoende

\footnotetext{
${ }^{826}$ Van den Bosch \& Rijbroek 2020, p. 23.

${ }^{827}$ Hoge Raad 19 oktober 2018, ECLI:NL:HR:2018:1976.

${ }^{828}$ Hoge Raad 19 oktober 2018, ECLI:NL:HR:2018:1976.
} 
zorgvuldig zijn geweest. Het gerechtshof Amsterdam is echter van mening dat de RvdK diepgaander onderzoek had kunnen en moeten doen en om die reden onrechtmatig heeft gehandeld ${ }^{829}$ Onder meer wordt daartoe aangedragen dat de zorgen van de moeder over de handelswijze van vader en daarmee het risico op recidive onvoldoende op waarde zijn geschat. ${ }^{830}$ De Staat der Nederlanden (waar de RvdK als onderdeel van het ministerie van Justitie en Veiligheid toe wordt gerekend) stelt tegen dit oordeel beroep in cassatie in. De Hoge Raad stelt in de eerste plaats het volgende vast:

'Indien de Raad bij de uitvoering van zijn onderzoek onzorgvuldig handelt, kan de Staat (waarvan de Raad onderdeel is) voor de daaruit voortvloeiende schade uit hoofde van onrechtmatige daad aansprakelijk zijn. Daaraan staat niet zonder meer in de weg dat de gestelde tekortkomingen in het onderzoek van de Raad ook aan de familierechter zijn voorgelegd en voor deze geen aanleiding hebben gevormd om van dat onderzoek voor zijn beslissing geen gebruik te maken, of nader onderzoek te gelasten, en tegen diens beslissing geen rechtsmiddel is aangewend.

'In het licht van de vrijheid die de Raad als deskundige toekomt is een onderzoek niet onzorgvuldig op de enkele grond dat dit ook op andere wijze, of met meer of andere middelen, had kunnen worden uitgevoerd. Waar het, bij een verwijt als de moeder de Raad in deze aansprakelijkheidsprocedure maakt, op aankomt is of de Raad heeft mogen menen zich met de uit zijn onderzoek verkregen informatie een verantwoord oordeel te kunnen vormen over hetgeen het belang van het kind vergt. ${ }^{831}$

De Hoge Raad vernietigt het arrest van het gerechtshof Amsterdam en concludeert dat de RvdK zich alleen hoeft te richten op een afweging van de belangen van de ouders indien het belang van het kind dit vergt. Het gerechtshof Amsterdam heeft naar het oordeel van de Hoge Raad zich vooral laten leiden door het belang van de moeder bij geruststelling en het belang van de vader niet verder te worden bevraagd over zijn verleden. ${ }^{832}$ Dit standpunt lijkt in algemene zin verdedigbaar maar wringt toch enigszins in dit concrete geval. De zorgen van moeder, terecht of niet, zijn immers evident ingegeven door haar wens om de belangen van het kind te beschermen. En in veel van dit soort zaken zullen de belangen van kind en ouders dusdanig met elkaar verweven zijn dat een beoordeling van hetgeen in het belang van het kind is, alleen mogelijk is door ook de belangen van de ouders bij de afweging te betrekken.

\footnotetext{
${ }^{829}$ Gerechtshof Amsterdam 9 mei 2017, ECLI:NL:GHAMS:2017:1725.

${ }^{830}$ Hoge Raad 19 oktober 2018, ECLI:NL:HR:2018:1976, r.o. 3.2.1

${ }^{831}$ Hoge Raad 19 oktober 2018, ECLI:NL:HR:2018:1976, r.o. 3.4.5.

${ }^{832}$ Hoge Raad 19 oktober 2018, ECLI:NL:HR:2018:1976, r.o. 3.5.2.
} 
De Hoge Raad stelt tot slot vast dat het gerechtshof Amsterdam ten onrechte heeft gekeken wat de RvdK in het kader van het onderzoek nog meer of anders had kunnen doen. Zij had zich echter moeten beperken tot beantwoording van de vraag of de RvdK met de uit zijn onderzoek verkregen informatie een verantwoord oordeel heeft kunnen vormen over hetgeen het belang van het kind vergde. ${ }^{833}$ De Hoge Raad sluit hierbij aan bij de zienswijze van AGLangemeijer inhoudende 'dat de RvdK als orgaan van de Staat, een beleids- en beoordelingsvrijheid toekomt bij de keuze van de wijze waarop hij zijn onderzoeken inricht. ${ }^{834}$ De rechter in familiezaken moet uiteindelijk beslissen of het advies of verzoek van de RvdK wordt gevolgd. Indien ouders het niet eens zijn met de wijze van onderzoek dan kan dit tijdens het geding aan het rechter worden voorgelegd, eventueel kan een eigen deskundige worden aangedragen of een verzoek tot contra-expertise worden gedaan. ${ }^{835}$ De genoemde beleidsvrijheid moet primair invulling krijgen aan de hand van het interne Kwaliteitskader en toepasselijke protocollen van de RvdK.

\subsubsection{Overige ontwikkelingen ten aanzien van het feitenonderzoek in} jeugdbeschermingszaken

Ondanks de introductie van art. 3.3 Jeugdwet en de geschetste ontwikkelingen in de rechtspraak lijkt vanuit de politiek te worden gezocht naar manieren om de notie van waarheidsvinding sterker te verankeren in jeugdbeschermingszaken. In 2017 heeft de Tweede Kamer een motie aangenomen waarin staat dat moet worden onderzocht of een onderzoeksrechter in de jeugdbeschermingsprocedure van toegevoegde waarde kan zijn. Dit zou noodzakelijk zijn volgens de motie, omdat thans geen effectieve toetsing plaatsvindt of de feiten in de rapportages naar waarheid zijn aangevoerd. ${ }^{836}$ Het is onduidelijk waar deze vergaande conclusie op is gebaseerd, maar aangenomen mag worden dat maatschappelijke kritiek op de besluitvorming in de jeugdbeschermingszaken hierin een belangrijke rol heeft gespeeld. De motie lijkt de huidige positie van de kinderrechter, die als taak heeft het feitenonderzoek te beoordelen, wel erg sterk te marginaliseren.

In de tussenevaluatie van de Wet herziening kinderbeschermingsmaatregelen is een aantal professionals gevraagd of zij het benoemen van een onderzoeksrechter in

\footnotetext{
${ }^{833}$ Hoge Raad 19 oktober 2018, ECLI:NL:HR:2018:1976, r.o. 3.5.3..

${ }^{834}$ Hoge Raad, 15 juni 2018, ECLI:NL:PHR:2018:691 (Conclusie AG-Langemeijer), r.o 2.12.

${ }^{835}$ Hoge Raad, 15 juni 2018, ECLI:NL:PHR:2018:691 (Conclusie AG-Langemeijer), r.o 2.12.

${ }^{836}$ Kamerstukken II 2017-18, 31 839, nr. 568.
} 
jeugdbeschermingszaken wenselijk vindt. De rechters die zijn ondervraagd zien geen toegevoegde waarde in het benoemen van een onderzoeksrechter. ${ }^{837} \mathrm{Zij}$ vinden het onnodig omdat de procedure voldoende mogelijkheden biedt in geval het feitencomplex onvoldoende concreet is en daarnaast wordt gewezen op de reeds toegenomen aandacht voor het consequent scheiden van feiten en meningen in de procedure. Bovendien wordt opgemerkt dat de afweging of een minderjarige ernstig in zijn ontwikkeling wordt bedreigd niet feitelijk is, maar gaat om interpretatie van relevante feiten en omstandigheden. Het introduceren van een onderzoeksrechter in de procedure is voor die afweging volgens de ondervraagden niet van toegevoegde waarde. ${ }^{838}$

Een andere ontwikkeling is dat naar aanleiding van een motie van het Tweede Kamerlid Bergkamp (D66) een aantal regiobijeenkomsten en een afsluitende bijeenkomst is georganiseerd om te komen tot een actieplan waarheidsvinding in de jeugdzorg. ${ }^{839}$ Het actieplan 'verbetering feitenonderzoek in de jeugdbeschermingsketen' is op 6 juni 2018 aan de Tweede Kamer aangeboden. ${ }^{840}$ In het actieplan, opgesteld door Jeugdzorg Nederland in nauwe samenwerking met de cliëntvertegenwoordiger 'LOC zeggenschap in de zorg', wordt een fors aantal actiepunten geformuleerd ter verbetering van het feitenonderzoek. Het actieplan is vormgegeven langs vier actielijnen: een respectvolle bejegening van kinderen en ouders, het informeren en ondersteunen van kinderen en ouders, kwaliteit van onderzoek en rapportage en verkenning van de rechtspositie kinderen en ouders. ${ }^{841}$ Hoewel de actielijnen tenminste voor een deel lijken te overlappen wordt wel een helder beeld gegeven van de problemen die betrokkenen ervaren in de omgang met de jeugdbeschermingsautoriteiten.

Tot slot is in 2020 een inventariserende studie van het Nederlands Jeugdinstituut uitgekomen waarin op verzoek van de minister van Justitie en Veiligheid is gekeken of de rechtsgrond van de ondertoezichtstelling moet worden aangescherpt en of een verdere normering van het feitenonderzoek en het toetsingskader voor kinderrechters noodzakelijk is. ${ }^{842}$ Specifiek ten aanzien van het feitenonderzoek wordt geconcludeerd dat er vanuit de wetenschap en praktijk breed draagvlak lijkt voor een verdere normering van het feitenonderzoek. Het uitgangspunt daarbij zou de 'ernstige bedreigde ontwikkeling van de minderjarige' moeten zijn. Het is niet geheel duidelijk op welke manier dit als leidraad moet dienen voor verbetering van de wijze

\footnotetext{
${ }^{837}$ Lunneman, Huijer e.a. 2018, p. 42.

${ }^{838}$ Lunneman, Huijer e.a. 2018, p. 42.

${ }^{839}$ Kamerstukken II 2016/17 34550 XVI, nr. 85.

${ }^{840}$ Kamerstukken II 2017/18, 31 839, nr. 622.

${ }^{841}$ Kamerstukken II 2017/18, 31 839, nr. 622 (bijlage), p. 8 e.v.

${ }^{842}$ Van den Bosch \& Rijbroek 2020.
} 
waarop het onderzoek wordt uitgevoerd. Er wordt daarbij vooral gewezen op de onzekerheid die de open geformuleerde rechtsgrond van de ondertoezichtstelling met zich meebrengt, hetgeen niet direct van invloed lijkt op de kwaliteit van het feitenonderzoek. Daarnaast wordt gewezen op het belang van het expliciet onderscheiden van feiten, vermoedens en meningen. ${ }^{843}$ Minister Dekker van Rechtsbescherming heeft in een reactie laten weten dat kritisch moet worden gekeken naar de gronden voor de ondertoezichtstelling, waarbij het niet voor de hand ligt de term 'ernstige ontwikkelingsbedreiging' zoals opgenomen in art. 1:255 lid $1 \mathrm{BW}$, verder aan te scherpen. ${ }^{844} \mathrm{Wel}$ zou het feitenonderzoek in de jeugdbeschermingsketen verder moeten worden doorontwikkeld. ${ }^{845}$

10.6.3 De relevantie van het dossieronderzoek naar de feitenvaststelling voor de periode na 2015

Het dossieronderzoek heeft zich gericht op een aantal elementen met betrekking tot het feitenonderzoek in jeugdbeschermingszaken, zoals dat in 2013 en 2014 door de RvdK werd uitgevoerd. Belangrijkste bevinding was dat de RvdK in het overgrote deel van de geanalyseerde zaken de ingebrachte informatie correct verwerkte in de beschermingsrapportage. In de zaken waarin dit niet gebeurde was meestal sprake van mening/visie van een betrokkene of informant die te stellig (feitelijk) werd verwoord door de RvdK. Met andere woorden, binnen het dossieronderzoek zijn een aantal criteria geformuleerd om te bepalen welke informatie als feitelijk kan worden beschouwd en welke informatie als mening/visie betrokkenen.

Dit is ook in de huidige situatie nog steeds van groot belang om tot een verdere normering van het feitenonderzoek te komen. Ondanks de beschreven ontwikkelingen geven wet- en regelgeving geen nadere indicatie geven hoe in de praktijk het onderscheid tussen feiten en meningen moet worden gemaakt. Art. 3.3 Jeugdwet benoemt slechts dat 'de feiten volledig en naar waarheid' moeten worden aangevoerd. In het Kwaliteitskader 2016 van de RvdK is de eis opgenomen dat feiten, visies en de interpretatie daarvan door de RvdK duidelijk van elkaar worden onderscheiden. Een eis die ook al was opgenomen in het Kwaliteitskader 2013 en niet verder lijkt te zijn aangescherpt.

\footnotetext{
${ }^{843}$ Van den Bosch \& Rijbroek 2020, p. 46 e.v.

${ }^{844}$ Kamerstukken II 2020/21 33836 nr. 41, p. 1.

${ }^{845}$ Kamerstukken II 2020/21 33836 nr. 41, p. 1.
} 
Het lijkt nog steeds noodzakelijk dat beleid en regelgeving zich eerst richten op het inhoudelijke onderscheid tussen feiten en meningen en de vervolgvraag of het mogelijk is om aan de hand van criteria bewijsminima te formuleren voor het onderzoek is jeugdbeschermingszaken. Anders blijft de patstelling tussen ouders, cliëntorganisaties en de autoriteiten voortduren. Voor de ouders en overige betrokkenen geldt dat de stelling dat feiten en meningen door elkaar lopen in de rapportages niet kan worden gestaafd omdat criteria om deze stelling te beoordelen ontbreken. Voor de RvdK (en de GI) geldt hetzelfde als wordt aangegeven dat feiten en meningen standaard gescheiden worden beschreven in de rapportages.

\subsection{De rechtspositie van de minderjarige en zijn ouders}

Met invoering van de Wet herziening kinderbeschermingsmaatregelen en de Jeugdwet op 1 januari 2015 hebben meerdere noemenswaardige wijzigingen plaatsgevonden met betrekking tot de rechtspositie van de minderjarige en zijn ouders. In algemene zin is zichtbaar dat beide wetten het belang van een goede rechtspositie van de betrokkenen benadrukken. ${ }^{846}$ Dit blijkt onder meer uit het feit dat wordt gestreefd jongeren en ouders actief te betrekken bij het inventariseren van en de keuze voor de gewenste vormen van hulp die passend zijn. ${ }^{847}$ Een concrete uitwerking hiervan is te vinden in art. 4.1.2. Jeugdwet op basis waarvan geldt dat ouders en betrokkenen (ook in de fase van vrijwillige hulpverlening) als eerste de mogelijkheid moeten krijgen binnen een redelijke termijn een familiegroepsplan op te stellen. De gedachte is dat burgers zelf verantwoordelijkheid kunnen en moeten nemen om problemen in de gezinssituatie onder eigen regie op te lossen. ${ }^{848}$ In bredere zin past deze wijziging in de ontwikkeling om het zelf oplossend vermogen van het gezin en sociale netwerk nadrukkelijker te benutten, veelal aangeduid onder de noemer 'eigen kracht'.

Een belangrijke doelstelling van de Wet herziening kinderbeschermingsmaatregelen is het vergroten van de transparantie richting ouders en kinderen en het vergroten van de doelgerichtheid van de ondertoezichtstelling. ${ }^{849} \mathrm{Om}$ dit te bereiken zijn verschillende wijzigingen doorgevoerd waarvan een deel ziet op de besluitvorming over een jeugdbeschermingsmaatregel en een deel gericht is op de uitvoering van de maatregel. Zo is

\footnotetext{
${ }^{846}$ Zie voor dit uitgangspunt in de Jeugdwet: Kamerstukken II 2012/13, 33 684, nr. 3 (MvT), p. 71 . En voor de Wet herziening kinderbeschermingsmaatregelen: Kamerstukken II 2009/10, 32 015, nr. 3 (MvT).

${ }^{847}$ Kamerstukken II 2012/13, 33 684, nr. 3 (MvT).

${ }^{848}$ Kamerstukken II 2013/14, 33 684, nr. 83.

${ }^{849} \mathrm{Zie}$ in dit verband: Lunnemann, Huijer e.a. 2018 , p. 39 e.v.
} 
zichtbaar dat aan de zijde van de jeugdbeschermingsautoriteiten meer wettelijke bevoegdheden zijn gecreëerd om sturend op te treden in de uitvoering van de maatregelen. De GI kan onder meer op grond van art. 1:263 lid 3 BW de kinderrechter verzoeken een schriftelijke aanwijzing te bekrachtigen. Tegelijkertijd kan een dwangsom worden verzocht bij niet nakoming van de aanwijzing. In de praktijk vermoedelijk belangrijker is de toevoeging van art. 1:265e BW, waarin staat dat verzocht kan worden om gedeeltelijke gezagsoverdracht bij of na uithuisplaatsing. Het geeft de GI de mogelijkheid om op een aantal concrete punten beslissingen te nemen inzake de verzorging en opvoeding van de minderjarige.

Ook de rechtspositie van de ouders met gezag en de minderjarige tijdens de uitvoering van de ondertoezichtstelling is versterkt met invoering van de geschillenregeling. Thans kunnen op grond van art. 1:262b BW geschillen in de uitvoering van de ondertoezichtstelling aan de kinderrechter worden voorgelegd. Bevoegd hiertoe zijn de ouders met gezag, de minderjarige van 12 jaar en ouder, de gezinsvoogdij-instelling, degene die de minderjarige verzorgt en opvoedt als behorende tot zijn gezin of zorgaanbieder of aanbieder van jeugdhulp als in art. 1.1 Jeugdwet. De kinderrechter neemt een beslissing zoals die hem in het belang van het kind wenselijk voorkomt. De geschillenregeling geeft betrokkenen een extra mogelijkheid om invloed uit te oefenen op de uitvoering van de ondertoezichtstelling de maar de toegevoegde waarde is niet zonder meer duidelijk. Wel geldt voor het aanbrengen van een geschil op grond van art. 1:262b BW verplichte procesvertegenwoordiging

Voor dit onderzoek zijn de wijzigingen die zien op de besluitvorming over de noodzaak van een ondertoezichtstelling en uithuisplaatsing het meest van belang. In het vervolg van deze paragraaf worden de belangrijkste wijzigingen in wet- en regelgeving besproken en wordt gekeken hoe deze wijzigingen zich verhouden tot uitkomsten van het dossieronderzoek voor de periode 2013/2014.

10.7.1 De concrete bedreigingen in het verzoekschrift en de beschikking Met inwerkingtreding van de Wet herziening kinderbeschermingsmaatregelen op 1 januari 2015 gelden ten aanzien van de inhoud van het verzoekschrift in jeugdbeschermingszaken 
verschillende aanvullende vereisten. ${ }^{850}$ In de eerste plaats moet op grond van het nieuwe art. 799a lid $1 \mathrm{Rv}$ het verzoekschrift de concrete bedreiging in de ontwikkeling van de minderjarige bevatten alsmede de daarop afgestemde duur waarvoor de ondertoezichtstelling zal gelden. Daarnaast geldt op grond van art. 799a lid $2 \mathrm{Rv}$ dat het verzoekschrift moet vermelden of, en zo ja, op welke wijze de inhoud dan wel strekking van het verzoekschrift met de minderjarige is besproken en welke reactie hij hierop heeft gegeven.

Aanvankelijk werd voorgesteld dat de doelen van de ondertoezichtstelling in het verzoekschrift zouden worden opgenomen, waarna de kinderrechter werd geacht deze doelen ook in de beschikking op te nemen. ${ }^{851}$ Op deze manier werd gestreefd naar een duidelijke legitimatie voor het overheidsingrijpen en bestond de mogelijkheid om concreet te toetsen of de noodzaak bestond de lopende ondertoezichtstelling te continueren. ${ }^{852}$ In het uiteindelijke wetsvoorstel tot herziening van de kinderbeschermingsmaatregelen is na kritiek van diverse instanties het voorstel gewijzigd. Het verzoekschrift moet nu een beschrijving van de concrete bedreiging(en) in de ontwikkeling van de minderjarige bevatten. Het doel van deze toevoeging is het vergroten van de transparantie voor de cliënt en een doelgerichte uitvoering van de ondertoezichtstelling. ${ }^{853}$ Nauw hierop aansluitend is de verplichting voor de kinderrechter om op grond van art. 1:255 lid 4 BW de concrete bedreigingen van de minderjarige in de beschikking op te nemen. Het inzichtelijk maken van bedreiging bevordert de transparantie richting kind en ouders en geeft concrete sturing ten aanzien van de uitvoering van de hulpverlening. Voor de betrokkenen moet op deze manier duidelijker worden welke punten moeten worden verbeterd om tot beëindiging van de ondertoezichtstelling te komen.

Als wordt gekeken naar de resultaten van het dossieronderzoek in deel II van de studie dan is het aannemelijk dat voornoemde wijzigingen in wetgeving voor belangrijke verbeteringen hebben gezorgd. Het dossieronderzoek gericht op de jaren 2013 en 2014 liet zien dat de RvdK in vrijwel altijd concreet invulling gaf aan de bedreiging in de ontwikkeling van de minderjarige. Zo bezien lijkt er op dat punt niet veel winst te halen. Door de aanvullende eis in art. 799a lid $1 \mathrm{Rv}$ wordt echter voor alle betrokkenen als het goed is kort en bondig samengevat in het verzoekschrift welke concrete zorgpunten zijn gesignaleerd. In de oude

\footnotetext{
${ }^{850}$ Besluit van 14 november 2014, houdende vaststelling van het tijdstip van inwerkingtreding van de Jeugdwet, de Invoeringswet Jeugdwet en enkele andere wetten die daarmee verband houden, alsmede van het Besluit Jeugdwet; Stb. 2014, 443.

${ }^{851}$ Zie voor een nadere toelichting: de Ruyter \& Bij1 2008, p. 111 e.v.

${ }^{852}$ Zie voor een toelichting op deze wijziging en het voorontwerp van wet in bredere zin: Bruning \& Kok 2008.

${ }^{853}$ Kamerstukken II 2008/09 32 015, nr. 3 (MvT), p. 39.
} 
situatie werden die zorgpunten meer of minder concreet alleen verwerkt in de vaak lijvige rapportages ter onderbouwing van het verzoekschrift. Dit was veel minder toegankelijk, hetgeen met name voor de doelgroep van ouders en kinderen die met een jeugdbeschermingsmaatregel worden geconfronteerd, een factor van belang is.

Ten aanzien van motivering van beschikkingen lijkt de toegevoegde waarde van het verplicht stellen de concrete bedreiging te benoemen nog duidelijker. In de delen I en II van dit onderzoek is aangetoond dat er al decennialang kritiek was op de motivering van beschikkingen in jeugdbeschermingszaken. De kritiek was dat in veel zaken zou worden volstaan met een standaardmotivering waardoor kind en ouders geen inzicht werd geboden in de inhoudelijke afweging die de kinderrechter heeft gemaakt. Het dossieronderzoek heeft laten zien dat die kritiek voor een deel terecht is geweest. In 135 van 200 geanalyseerde beschikkingen $(67,5 \%)$ werden de concrete bedreigingen in de ontwikkeling van de minderjarige inhoudelijk uitgewerkt. In de overige zaken was op dit punt sprake van een standaardmotivering waarin alleen de rechtsgrond van de ondertoezichtstelling werd benoemd.

De verplichting sinds 1 januari 2015 voor de kinderrechter om de concrete ontwikkelingsbedreiging te benoemen in de beschikking (art. 1:255 lid $4 \mathrm{BW}$ ) moet er voor zorgen dat standaardmotiveringen verleden tijd zijn. De tussenevaluatie van de Wet herziening kinderbeschermingsmaatregelen laat op dit vlak zoals verwacht een positieve ontwikkeling zien, maar er worden ook enkele kanttekeningen geplaatst. ${ }^{854}$ Zo wordt na dossieronderzoek in de tussenevaluatie een percentage van $87 \%$ gevonden van beschikkingen waarin de concrete bedreigingen in de ontwikkeling van de minderjarige zijn genoemd. Dat is een duidelijke stijging ten opzichte van het gevonden percentage in deel II van dit onderzoek ten aanzien van de periode 2013/2014. Het betekent echter ook dat er nog steeds zaken zijn waarin de bedreiging niet concreet wordt gemaakt, terwijl art. 1:255 lid 4 BW hiertoe verplicht. Daarnaast laat de tussenevaluatie zien dat in de beschikking op het verzoek tot verlenging van de ondertoezichtstelling nog slechts in 47,5\% van de onderzochte zaken de bedreiging concreet wordt uitgewerkt. ${ }^{855}$ Hoewel de wet daar niet expliciet toe verplicht, lijkt het bij de verlenging van de ondertoezichtstelling op zijn minst even belangrijk om de ontwikkelingsbedreiging van de minderjarige concreet te maken.

\footnotetext{
${ }^{854}$ Lunnemann, Huijer e.a 2018, p. 39.

${ }^{855}$ Lunnemann, Huijer e.a 2018, p. 39.
} 
10.7.2 Het horen van de minderjarige: belangrijkste ontwikkelingen

In de delen I en II van deze studie is aandacht besteed aan het hoorrecht van de minderjarige in de periode tot 2015, op grond van (inter)nationale wet- en regelgeving. Het hoorrecht van minderjarigen in civiele procedures was en is neergelegd in art. $809 \mathrm{Rv}$. Op basis van dit artikel moeten minderjarigen van twaalf jaar en ouder in gelegenheid worden gesteld om te worden gehoord in procedures, onder de twaalf jaar kunnen minderjarigen hiertoe in de gelegenheid worden gesteld. Vanuit kinderrechtelijk perspectief is art. 12 IVRK cruciaal voor het hoorrecht van minderjarigen. Op grond van artikel 12 IVRK hebben kinderen het recht om hun mening vrijelijk te uiten in alle kwesties die hen aangaan. Aan de mening van het kind moet passend belang worden gehecht in overeenstemming met zijn of haar leeftijd en rijpheid (art. 12 lid 1 IVRK). Daarnaast garandeert art. 12 lid 2 IVRK het hoorrecht van minderjarigen in alle (juridische) procedures. Met de inwerkingtreding van de Wet herziening kinderbeschermingsmaatregelen en de Jeugdwet op 1 januari 2015 is het hoorrect zoals neergelegd in art. 809 Rv. ongewijzigd gebleven. Dit neemt niet weg dat er sinds 2015 belangrijke ontwikkelingen hebben plaatsgevonden met betrekking tot hoorrecht en de participatie van minderjarigen in algemene zin. Het is daarbij duidelijk dat de trend die is beschreven voor de periode tot 2015 zich na 2015 heeft doorgezet. Er is meer aandacht voor het belang van het horen van minderjarigen op alle leeftijden en de manier waarop de mening van de minderjarige nadrukkelijker in de besluitvorming kan worden betrokken. ${ }^{856}$

In 2020 is in opdracht van het WODC een onderzoek gepubliceerd waarin vanuit multidisciplinair perspectief is gekeken naar de wenselijkheid van een uitbreiding van de formele procespositie en het hoorrecht van minderjarigen in familie- en jeugdzaken. ${ }^{857}$ Specifiek ten aanzien van het hoorrecht wordt vanuit juridisch oogpunt geconcludeerd dat met name het hoorrecht van twaalf-minners zou moeten worden verbeterd. Daar wordt op basis van pedagogisch en neuropsychologisch onderzoek aan toegevoegd dat het taalbegrip- en de productie van kinderen geen belemmering vormt om de wettelijke leeftijdsgrens van twaalf jaar te verlagen. ${ }^{858}$ Deze aanbeveling is in lijn met de aanbeveling uit 2016 van de

\footnotetext{
${ }^{856}$ Zie hierover ook Bruning e.a. 2020, p. 81.

${ }^{857}$ Bruning e.a. 2020.

${ }^{858}$ Bruning e.a. 2020, p. 255 e.v.
} 
staatscommissie Herijking Ouderschap om de wettelijke leeftijdsgrens ter verlagen van twaalf naar acht jaar. ${ }^{859}$

Ook is in 2016 vanuit de praktijk het initiatief genomen om minderjarigen onder de twaalf jaar meer te stimuleren gebruik te maken van het hoorrecht. De Rechtbank Amsterdam is gestart met een pilot waarin minderjarigen vanaf 8 jaar in verschillende soorten zaken (waaronder jeugdbeschermingszaken), middels een kindvriendelijke brief worden uitgenodigd gebruik te maken van het hoorrecht. Het is niet bekend gemaakt in welke mate minderjarigen onder de twaalf op de uitnodiging zijn ingegaan maar de pilot is intern succesvol geëvalueerd en inmiddels omgezet in vast beleid. ${ }^{860}$ Om deze minderjarigen op kindvriendelijke wijze te horen zijn verschillende maatregelen genomen met betrekking tot de setting en uitvoering van het kindgesprek. ${ }^{861}$

Tot slot is ook in internationale rechtspraak het toegenomen belang van het hoorrecht van minderjarigen zichtbaar. In het eerste deel van deze studie is beschreven dat het EHRM geoordeeld heeft dat bij een beroep op de ouderlijke rechten onder art. 8 EVRM, gestreefd moet worden naar een eerlijke balans tussen het belang van het kind en die van zijn ouders. ${ }^{862}$ Het realiseren van de rechten van kinderen op grond van het IVRK speelt daarbij een belangrijke rol. Na 2015 heeft het EHRM in diverse zaken geoordeeld dat het niet horen van een kind een schending oplevert van art. 8 EVRM, waarbij expliciet wordt verwezen naar de vereisten op grond van art. 12 IVRK. ${ }^{863}$ Zo stelt het EHRM in zaak M\&M. t. Kroatie dat de autonomie van minderjarigen invulling moet krijgen aan de hand van de vereisten omtrent het horen van minderjarigen op grond van art. 12 IVRK. ${ }^{864}$ Het EHRM heeft hiermee, naar het zich laat aanzien nadrukkelijker dan voorheen, laten zien belang te hechten aan het recht van minderjarige om in juridische procedures gehoord te worden en dat zijn mening serieus wordt betrokken in de besluitvorming.

\footnotetext{
${ }^{859}$ Staatscommissie Herijking Ouderschap 2016, p. 11.

${ }^{860}$ Zie hierover Van Leeuwen FJR 2017/56.

${ }^{861}$ Zie Bruning e.a. 2020, p. $162-163$.

${ }^{862}$ EHRM 23 september 1994, appl. nr. 19823/92, (Hokkanen t. Finland); EHRM 6 juni 1998, appl.nr. 22430/93, (Bronda t. Italie).

${ }^{863}$ EHRM 3 september 2015, ECLI:CE:ECHR:2015:0903J UD001016113 (M\&M t. Kroatië); EHRM 2 februari 2016, ECLI:CE:ECHR:2016:0202JUD007177612 (N.TS. e.a.t. Georgï̈)

${ }^{864}$ EHRM 3 september 2015, ECLI:CE:ECHR:2015:0903JUD001016113 (M\&M t.Kroatië), r.o. 171-172.
} 
10.7.3 De relevantie van het dossieronderzoek voor het horen van de minderjarige door de RvdK en de kinderrechter

Het dossieronderzoek in deel II heeft laten zien dat de RvdK in $73 \%$ van de geanalyseerde zaken blijkens de beschermingsrapportage de minderjarige had gesproken. In een deel van de zaken werd de minderjarige niet gehoord maar werd wel overeenkomstig de eisen van het Kwaliteitskader beargumenteerd waarom het horen geen doorgang kon vinden. In 12,5\% van de geanalyseerde zaken was echter uit het beschermingsrapport niet op te maken of de minderjarige was gehoord. Het is niet waarschijnlijk dat de minderjarige in deze zaken wel werd gehoord. Maar ook als het horen wel had plaatsgevonden voldeed de RvdK hiermee niet aan de eis in het eigen Kwaliteitskader om schriftelijk informatie te verstrekken over het horen van de minderjarige. Het is daarom positief dat met de Wet herziening kinderbeschermingsmaatregelen in art. 799a lid $2 \mathrm{Rv}$ is verankerd dat het verzoekschrift moet vermelden of het verzoek met de minderjarige is besproken en zo ja, welke reactie de minderjarige heeft gegeven. Het wettelijk verplicht stellen informatie te verschaffen over de vraag of de minderjarige is gehoord werkt dwingender dan wanneer deze eis alleen in Kwaliteitskader van de RvdK is opgenomen. Dat blijkt ook uit de tussenevaluatie van de Wet herziening kinderbeschermingsmaatregelen. Het is nog steeds niet zo dat alle minderjarigen worden gehoord, maar in ieder geval wordt vrijwel altijd informatie verstrekt door de RvdK over het wel/niet horen van de minderjarige. ${ }^{865}$

Wat betreft het horen van de minderjarige door de kinderrechter was de belangrijkste conclusie van het dossieronderzoek dat twaalfminners vrijwel nooit werden gehoord bij een verzoek tot ondertoezichtstelling door de RvdK. In de 91 zaken waarin ten aanzien van een twaalf-minner een ondertoezichtstelling met of zonder uithuisplaatsing was verzocht, werd de minderjarige geen enkele keer gehoord. Dit bevestigde het beeld dat de leeftijd van twaalf zoals opgenomen in art. $809 \mathrm{Rv}$ in de praktijk van voor 2015 fungeerde als harde grens.

Het is niet aannemelijk dat dit beeld na 2015 drastisch is gewijzigd. Zoals gesteld is de leeftijdsgrens in art. $809 \mathrm{Rv}$ twaalf jaar gebleven met de wijziging van het jeugdbeschermingsrecht in 2015. En de eerdergenoemde pilot van de Rechtbank Amsterdam, waarin minderjarigen vanaf 8 jaar actief worden benaderd om te worden gehoord, is voorlopig nog niet omgezet in landelijk beleid. Daarnaast geven professionals (waaronder rechters) in recent onderzoek aan dat het waarschijnlijk nog steeds niet veel voorkomt dat twaalfminners

\footnotetext{
${ }^{865}$ Lunnemann, Huijer e.a. 2018, p. 35.
} 
worden gehoord. ${ }^{866}$ Als dit al gebeurt dan is het doorgaans op verzoek van minderjarige zelf. ${ }^{867}$ De conclusie op basis van het dossieronderzoek voor de jaren 2013 en 2014, dat het hoorrecht voor twaalfminners kan worden verbeterd, is derhalve nu nog steeds relevant. In het eerdergenoemde onderzoek van Bruning e.a. waarin is gekeken naar de procespositie en het hoorrecht van de minderjarige worden verschillende scenario's geschetst ter verbetering van het hoorrecht van twaalfminners: vasthouden aan de leeftijd van twaalf jaar maar de uitvoeringspraktijk verbeteren: de leeftijdsgrens verlagen; in iedere zaak een individuele afweging maken van de capaciteiten van de minderjarige; of het kind alleen nog indirect laten horen (bijvoorbeeld door een gedragsdeskundige) en niet meer door de rechter. ${ }^{868}$ Het is duidelijk dat de optie waarin de leeftijdsgrens blijft gehandhaafd maar minderjarigen onder de twaalf actiever worden benaderd het minst ingrijpend is voor de uitvoeringspraktijk. Er blijft echter ook een kans met deze optie dat de informatievoorziening aan twaalfminners over het hoorrecht tekort schiet, waardoor niet alle twaalfminners die het wellicht op prijs zouden stellen om te worden gehoord, ook bij de rechter komen. In het onderzoek wordt dan ook geconcludeerd dat een verlaging van de wettelijke leeftijdsgrens van het hoorrecht van twaalf naar acht jaar de meest wenselijk optie is. ${ }^{869}$

10.7.4 De relevantie van het dossieronderzoek voor het betrekken van de minderjarige in de besluitvorming door de RvdK en de kinderrechter

In het dossieronderzoek in deel II is niet alleen gekeken of de minderjarige werd gehoord door de RvdK en de kinderrechter, maar zijn ook verschillende elementen geanalyseerd die zien op het betrekken van (de mening van) de minderjarige in de besluitvorming. Een eerste en absolute voorwaarde om de minderjarige effectief te kunnen laten participeren tijdens het beschermingsonderzoek is goede informatievoorziening over de besluitvorming. In dat licht is ten eerste geanalyseerd op welke wijze inzage werd gegeven in de conceptrapportage, waarin de onderzoeksafwegingen en de uiteindelijke beslissing werden toegelicht. Het dossieronderzoek heeft laten zien dat in de jaren 2013 en 2014 vrijwel altijd inzage werd gegeven in de conceptrapportage door de RvdK, maar dat de minderjarige voor schriftelijke informatie over de besluitvorming vaak afhankelijk was van zijn ouders. Dit kwam voort uit

\footnotetext{
866 Zie Bruning e.a. 2020, p. 245.

${ }^{867}$ Zie Bruning e.a. 2020, p. 245.

${ }^{868}$ Bruning e.a. 2020, p. 258 e.v.

${ }^{869}$ Bruning e.a. 2020, p. 261.
} 
het feit dat de minderjarige onder de twaalf jaar geen conceptrapportage ontving en de minderjarige tussen de twaalf en zestien, in de regel alleen 'zijn kinddeel'. Het kinddeel bevatte slechts een weergave van het gesprekverslag met de minderjarige, zonder dat nadere informatie over de onderzoeksafwegingen werd beschreven. Naar men mag aannemen vanuit de gedachte dat het te belastend was voor de minderjarige om te worden geconfronteerd met alle informatie uit het rapport. Het dossieronderzoek op dit punt is afgesloten met de kritische conclusie dat er geen overtuigende argumenten zijn waarom de conceptrapportage niet in zijn geheel werd verstrekt aan de minderjarige tussen de twaalf en zestien jaar. Het uitgangspunt dat de minderjarige tussen de twaalf en zestien jaar alleen zijn kinddeel ontvangt is in het Kwaliteitskader 2016 van de RvdK ongewijzigd overgenomen. ${ }^{870}$ De eerder geformuleerde kritiek blijft derhalve onverkort gelden. Het is niet duidelijk waarom de RvdK het uitgangspunt niet omdraait. De minderjarige vanaf twaalf jaar zou dan de gehele conceptrapportage ontvangen tenzij aannemelijk is dat dit in het specifieke geval te belastend of anderszins schadelijk is voor de minderjarige.

Een ander belangrijk element waar in het dossieronderzoek naar is gekeken, was het informeren van de minderjarige door de RvdK in een adviesgesprek. Volgens het toen geldende Kwaliteitskader 2013 moest ieder onderzoek worden afgesloten met een gesprek met de ouder(s)/verzorger(s) en het kind/de jongere over het voorgenomen raadsbesluit, dan wel met een gesprek waarbij inzage in het conceptrapport werd gegeven. Uit het dossieronderzoek is gebleken dat in 130 van de 200 onderzochte zaken $(65 \%)$ het beschermingsrapport geen informatie bevatte over een eventueel adviesgesprek met de minderjarige. Niet uitgesloten is dat in sommige van deze zaken wel een adviesgesprek werd gehouden maar dit niet in het rapport werd vermeld, maar ook dan bleef onduidelijk wat de minderjarige van het besluit vond en welke rol zijn mening in de besluitvorming had gespeeld.

Ook hier lijkt met invoering van de Wet herziening kinderbeschermingsmaatregelen een belangrijke stap voorwaarts te zijn gezet. Zoals eerder aangehaald moet in de huidige situatie op grond van art. 799a lid 2 Rv het verzoekschrift vermelden of het verzoek met de minderjarige is besproken en zo ja, welke reactie de minderjarige op het verzoek heeft gegeven. Met name het feit dat de reactie van minderjarige terug moet komen in het verzoekschrift is verheugend in het licht van de vereisten die voortvloeien uit art. 12 IVRK.

\footnotetext{
${ }^{870}$ Vgl. Kwaliteitskader 2013 RvdK, par. 3.2.11. en Kwaliteitskader RvdK 2016, p. 9., onder punt 6.
} 
De kans dat onduidelijk blijft wat de minderjarige van het verzoek vindt lijkt immers door deze toevoeging in de wet aanzienlijk verkleind.

De tussenevaluatie van de Wet herziening kinderbeschermingsmaatregelen bevestigt deze zienswijze. Op basis van dossieronderzoek bij de Rvdk wordt geconcludeerd dat de RvdK in vrijwel alle zaken aangeeft of het verzoek met de minderjarige is besproken. ${ }^{871}$ Aandachtspunt is dat soms alleen wordt volstaan met de mededeling dat de minderjarige overeenkomstig de eis in art. 799a lid 2 Rv. is gesproken. Op basis van het rapport wordt dan niet duidelijk hoe de minderjarige over het verzoek denkt. Daarnaast blijkt dat de GI in veel minder zaken voldoet aan de plicht om in het verzoekschrift tot verlenging van de maatregel weer te geven of de minderjarige is gesproken en zo ja, welke reactie de minderjarige op het verzoek heeft gegeven. Ook als wordt aangenomen dat in een deel van die zaken het verzoek wel met de minderjarige is besproken wordt hiermee niet voldaan aan de wet op dit punt. Op grond van art. 799a lid $3 \mathrm{Rv}$ geldt de verplichting omtrent de reactie van de minderjarige ook ten aanzien van het verzoek tot verlenging van de uithuisplaatsing (art. 1:265c lid 2 BW). Vreemd genoeg ontbreekt het verzoek tot verlenging van de ondertoezichtstelling (art. 1:260 lid 1 BW) in de lijst met verzoeken zoals opgenomen in art. 799a lid 3 Rv. Maar aangenomen kan worden dat ook het verzoek tot verlenging van de ondertoezichtstelling hier onder moet vallen. De wetgever heeft art. 799a lid 2 Rv. immers ingevoerd om te garanderen dat de minderjarige voor en tijdens de ondertoezichtstelling wordt geïnformeerd en zijn mening kan geven. Daarnaast stelt het de kinderrechter in staat (beter dan voorheen) de mening van de minderjarige in zijn beslissing te betrekken. ${ }^{872}$

In her verlengde hiervan verdient een ander punt nog aandacht. Passend belang hechten aan de mening van de minderjarige veronderstelt ook dat de minderjarige kennis kan nemen van de wijze waarop zijn mening het besluitvormingsproces heeft beïnvloed. Deze terugkoppeling naar de minderjarige is nog lang niet vanzelfsprekend. Het dossieronderzoek over de jaren 2013 en 2014 liet zien dat de mening van de minderjarige niet standaard werd meegewogen bij de onderzoeksafwegingen van de RvdK in het beschermingsrapport. Hoewel de invoering van art. 799a lid 2 Rv. een duidelijk verschil lijkt te hebben gemaakt waar het gaat om het weergeven van de mening van de minderjarige verplicht het niet tot een inhoudelijke weging van de mening van de minderjarige. Het gaat wellicht wat ver om dit ook als eis op te nemen in art. 799a Rv maar het is wel een nastrevenswaardig doel. In een besluitvormingsproces

\footnotetext{
${ }^{871}$ Lunnemann, Huijer e.a. 2018, p. 35.

${ }^{872}$ Kamerstukken II 2008/09 32 015, nr.3 (MvT).
} 
waarin het kind centraal behoort te staan mag ook worden verwacht dat de mening van het kind een belangrijke plek inneemt. Zeker in het beschermingsrapport van de RvdK is alle ruimte om weer te geven hoe de minderjarige aankijkt tegen het verzoek én wat de RvdK vervolgens met die mening heeft gedaan.

Tot slot heeft het dossieronderzoek laten zien dat rechters voor 2015 af en toe in de beschikking op het verzoek tot ondertoezichtstelling/uithuisplaatsing aandacht besteedden aan de mening van de minderjarige. In $11 \%$ van de onderzochte beschikkingen werd de mening van de minderjarige ten aanzien van de verzochte maatregel expliciet weergegeven. Naar aanleiding van het dossieronderzoek is geconcludeerd dat mede in het licht van art. 12 IVRK het mogelijk en wenselijk is voor de kinderrechter om vaker de mening van de minderjarige mee te wegen in de beschikking.

$\mathrm{Na} 2015$ is er ten aanzien van dit element wettelijk niets veranderd, maar de toegenomen aandacht voor de participatie van minderjarigen in procedures werkt ook hier door. Zo is er in de literatuur de nodige aandacht besteedt aan de mogelijkheden voor de rechter om de minderjarige te informeren over de rol die zijn mening heeft gespeeld in de besluitvorming. De beschikking wordt daarin aangewezen als de meest voor de hand liggende plek om uitleg te geven aan de minderjarige. ${ }^{873}$ De rechter zou in de beschikking, bij voorkeur in kindvriendelijke taal uit kunnen leggen hoe hij tot zijn beslissing is gekomen en hoe hij de mening van het kind heeft meegewogen. Een aangedragen nadeel hiervan is dat het formuleren in eenvoudige, voor het kind begrijpelijke taal ten koste kan gaan van de juridische precisie die onontbeerlijk is om tot een overtuigende en deugdelijke motivering te komen. ${ }^{874}$ Dit hangt natuurlijk wel in overwegende mate af van de leeftijd en het ontwikkelingsniveau van de minderjarige. Het is de vraag of voor de groep minderjarigen van twaalf jaar en ouder de gekozen formulering zodanig aangepast moet worden dat de juridische precisie daar ernstig onder hoeft te lijden. Voor minderjarigen onder de twaalf wordt het vermoedelijk een stuk lastiger om kindvriendelijke taal en juridische precisie samen te laten gaan. Een interessant alternatief is dan ook in de beschikking een apart onderdeel op te nemen waarin het kind in passende taal wordt geïnformeerd over de beslissing van de kinderrechter. Op die manier behoeft de juridische argumentatie niet aangepast te worden, omdat het kinddeel van de beschikking apart wordt bijgevoegd. ${ }^{875}$ Dit zijn interessante opties die ervoor

\footnotetext{
${ }^{873}$ Zie Lieber FJR 2018/40.

${ }^{874}$ Zie Lieber FJR 2018/40.

${ }^{875}$ Zie Lieber FJR 2018/40.
} 
kunnen zorgen dat het 'passend belang hechten' aan de mening van de minderjarige (art. 12 IVRK) ook zichtbaar wordt in de afwegingen van de kinderrechter.

\subsubsection{Tussenconclusie}

In deze paragraaf is gebleken dat de Wet herziening kinderbeschermingsmaatregelen heeft gezorgd voor belangrijke verbeteringen waar het gaat om de rechtspositie van de minderjarige (en in mindere mate zijn ouders) tijdens het beschermingsonderzoek en in de gerechtelijke procedure. In de eerste plaats omdat sinds 2015 in de wet is vastgelegd dat de concrete bedreigingen in de ontwikkeling van de minderjarige moeten worden vastgesteld in het verzoekschrift en de beschikking op het verzoek tot ondertoezichtstelling. Voor verzoekschriften geldt deze eis op grond van art. 799a lid $1 \mathrm{Rv}$ en voor de beschikking op grond van art. 1:255 lid 4 BW. Vooral ten aanzien van de motivering van beschikkingen lijkt dit een belangrijke verbetering aangezien hier in de periode voor 2015 nog lang niet altijd een concrete uitwerking van de ontwikkelingsbedreiging plaatsvond. Vervolgens zijn de belangrijkste wijzigingen beschreven ten aanzien van het hoorrecht van de minderjarige in de procedure bij de RvdK en de kinderrechter. Voor de horen van de minderjarige tijdens het beschermingsonderzoek is van belang dat met de Wet herziening kinderbeschermingsmaatregelen art. 799a lid $2 \mathrm{Rv}$ is ingevoerd. Dit artikel verplicht de RvdK (onder meer) in het verzoekschrift te vermelden of, en zo ja op welke wijze de minderjarige is gesproken. Het zou dus niet meer mogelijk moeten zijn dat in het beschermingsrapport of het verzoekschrift geen informatie is te vinden over het horen van de minderjarige tijdens het beschermingsonderzoek. Ten aanzien van het horen van de minderjarige door de kinderrechter is er wettelijk gezien weinig veranderd. De leeftijd van twaalf jaar zoals opgenomen in art. $809 \mathrm{Rv}$ is in stand gebleven en onderzoek na 2015 bevestigt dat minderjarigen onder de twaalf jaar nog steeds weinig worden gehoord door de kinderrechter. Toch lijkt hier langzaam verandering in te komen, blijkens initiateven vanuit de rechtspraak om minderjarigen onder de twaalf jaar actiever te gaan informeren over de mogelijkheid om gehoord te worden door de kinderrechter. 


\section{Conclusies en aanbevelingen}

\subsection{Inleiding}

Ieder kind heeft het recht om zich op harmonieuze wijze te ontwikkelen in een omgeving waarin voldoende bescherming en zorg wordt geboden. Nederland lijkt daar als plek bij uitstek geschikt voor. Op het gebied van armoede, veiligheid, gezondheid, onderwijs en andere aan welvaart gerelateerde factoren scoort Nederland consequent hoge rapportcijfers. Daarnaast blijken Nederlandse kinderen in vergelijking met kinderen in andere welvarende landen een hoge mate van tevredenheid te ervaren over hun eigen leven. ${ }^{876}$ Gemiddeld genomen is dit een prachtige uitkomst maar vermoedelijk weinig representatief voor de groep kinderen die in aanraking komt met het systeem van jeugdbescherming. Dit zijn kinderen die wel opgroeien in armoede en onveiligheid. Kinderen die vanaf jongs af aan niet lijken bij te sturen, in affectief opzicht worden verwaarloosd, of juist in de puberteit zonder duidelijke aanwijzing ernstig ontsporen. Opvallend vaak betreft het ook kinderen die klem zitten tussen strijdende ouders. Het voorgaande leidt echter niet vanzelfsprekend tot de conclusie dat een jeugdbeschermingsmaatregel gerechtvaardigd is. In iedere afzonderlijke zaak zal moeten worden aangetoond waarom de ernst van de situatie en het gebrek aan resultaat op basis van vrijwilligheid een jeugdbeschermingsmaatregel noodzakelijk maken.

In dit onderzoek is gekeken naar verschillende juridische aspecten in de besluitvorming ten aanzien van kinderen waarvan de overheid meent dat zij - om wat voor reden dan ook ernstig in hun ontwikkeling worden bedreigd. Het onderzoek bevindt zich daarmee op het domein van de trias pedagogica: de driehoeksverhouding waarbinnen de rechten en plichten ten aanzien van opvoeding tussen kind, ouders en de overheid wordt bepaald. Als belangrijkste uitgangspunt heeft daarbij te gelden dat ouders de primaire verantwoordelijkheid dragen voor de verzorging en opvoeding van de minderjarige. Slechts indien op basis vrijwilligheid onvoldoende kan worden gedaan om de ontwikkelingsbelangen van de minderjarige veilig te stellen, komt aan de overheid op grond van art. 3 lid 2 IVRK de plicht toe de minderjarige de noodzakelijke zorg en bescherming te bieden.

Het doel van het systeem van jeugdbescherming is het waarborgen van een opvoedings- en leefsituatie die voldoet aan minimale vereisten zodat de minderjarige zich op een gezonde en

${ }^{876}$ UNICEF Office of Research 2013, Innocenti Report Card 11, p. 39. 
evenwichtige wijze kan ontwikkelen. De jeugdbeschermingsautoriteiten hebben de taak een goede balans te vinden tussen de negatieve verplichting zich te onthouden van ongerechtvaardigde inmenging in het gezinsleven, en de positieve verplichting de minderjarige te beschermen tegen schadelijke invloeden. De inzet van een jeugdbeschermingsmaatregel maakt inbreuk op de fundamentele rechten van de minderjarige en zijn ouders, in het bijzonder het in art. 8 EVRM neergelegde recht op eerbiediging van het privé, familie en gezinsleven. Het feit dat met de inzet van een jeugdbeschermingsmaatregel wordt beoogd de minderjarige te helpen relativeert geenszins de ernst van de inbreuk die wordt gemaakt op de rechten van kind en ouders. Van de overheid, meer specifiek de jeugdbeschermingsautoriteiten, mag daarom worden verwacht dat op basis van zorgvuldig onderzoek een goed beargumenteerd en juridisch kloppend besluit wordt genomen over de noodzaak van een jeugdbeschermingsmaatregel.

Het onderzoek naar de rechtvaardiging van jeugdbescherming is inhoudelijk gestoeld op drie componenten: De wijze waarop het materiële jeugdbeschermingsrecht door de RvdK in het beschermingsrapport en de kinderrechter in de beschikking is toegepast; de zorgvuldigheid van het onderzoek naar de noodzaak van een ondertoezichtstelling en uithuisplaatsing door de RvdK; en tot slot de wijze waarop invulling is gegeven aan de rechtspositie van de minderjarige (en in mindere mate zijn ouders), tijdens het beschermingsonderzoek door de RvdK en in de gerechtelijke procedure. Het onderzoek, waarin deze inhoudelijke componenten worden uitgewerkt bestaat uit drie delen. De eerste twee delen behandelen het recht zoals dat van toepassing was op jeugdbeschermingszaken in de jaren 2013 en 2014. De delen I en II hebben geleid tot beantwoording van de volgende hoofdvraag:

In hoeverre was de wijze waarop de RvdK en de kinderrechter in de jaren 2013 en 2014 de rechtvaardiging van de ondertoezichtstelling met of zonder machtiging uithuisplaatsing hebben vormgegeven in overeenstemming met de toen geldende (inter)nationale wet- en regelgeving?

\subsection{Samenvattende conclusies per onderdeel ten aanzien van de rechtvaardiging van jeugdbescherming in de jaren 2013 en 2014}

De conclusies ten aanzien van de rechtvaardiging van jeugdbescherming in de jaren 2013 en 2014 worden gegeven aan de hand van de indeling die ook is gehanteerd voor de uitwerking van het dossieronderzoek. Achtereenvolgens wordt een overzicht gegeven de volgende vier 
elementen: 1) de rechtvaardiging van de ondertoezichtstelling; 2) de rechtvaardiging van de uithuisplaatsing; 3) de zorgvuldigheid van het feitenonderzoek door de RvdK; 4) de rechtspositie van de minderjarige (en zijn ouders) in de jeugdbeschermingsprocedure.

\section{1) Rechtvaardiging van de ondertoezichtstelling}

In het dossieronderzoek gericht op de jaren 2013 en 2014 is in de eerste plaats gekeken hoe door de RvdK in het beschermingsrapport en de kinderrechter in de beschikking, invulling hebben gegeven aan de wettelijke gronden van de ondertoezichtstelling. Op grond van art. 1: 254 lid 1 (oud) BW kon de minderjarige in die periode onder toezicht worden gesteld als was voldaan aan twee cumulatieve gronden: er moest sprake zijn van een ernstige bedreiging van de zedelijke of geestelijke belangen of gezondheid van de minderjarige en andere middelen moesten hebben gefaald, of naar was te voorzien, falen.

Conclusies ten aanzien van de onderbouwing van de ernstige bedreiging van de zedelijke of geestelijke belangen of gezondheid van de minderjarige

Het oordeel of een minderjarige in het concrete geval ernstig in zijn zedelijke of geestelijke belangen of gezondheid werd bedreigd, behoorde in de visie van de wetgever grotendeels invulling te krijgen in de praktijk.In het dossieronderzoek is gekeken of de $\operatorname{RvdK}$ in het beschermingsrapport aan de hand van concrete zorgpunten inhoudelijk beargumenteerde waar de ernstige bedreiging van de zedelijke of geestelijke belangen of gezondheid van de minderjarige uit bestond. Het dossieronderzoek heeft laten zien dat het beschrijven de zorgpunten in de ontwikkeling van de minderjarige tot de kern hoort van ieder beschermingsrapport. In vrijwel alle geanalyseerde zaken $(99,5 \%)$ heeft de RvdK en overzicht gegeven van de zorgpunten op kind- en/of ouderniveau. Waarom de gevonden zorgpunten een ernstige bedreiging opleverden van de zedelijke of geestelijke belangen van de minderjarige werd in het overgrote deel van de geanalyseerde zaken door de RvdK onderbouwd. Nadere analyse van de zaken waarin de RvdK niet, althans niet concreet deze belangrijke stap zette, heeft uitgewezen dat de focus hier primair op de zorgen ten aanzien van de ouders lag. Geconcludeerd is dat het belangrijk was voor de RvdK om ook in zaken waarin de zorgen vooral voort leken te komen uit een doen en nalaten van de ouders, de koppeling te maken naar de ontwikkeling van de minderjarige. In algemene zin rechtvaardigde het dossieronderzoek echter de conclusie dat de RvdK voldoende concreet en diepgaand beschreef waarom er sprake was een ernstige bedreiging van de zedelijke of geestelijke belangen of gezondheid van de minderjarige. 
Vervolgens is gekeken of de kinderrechter in de beschikking op het verzoek tot ondertoezichtstelling inhoudelijk aandacht besteedde aan de ernstige bedreiging van de zedelijke of geestelijke belangen of gezondheid van de minderjarige. Voor het onderzoek is als uitgangspunt gehanteerd dat de kinderrechter gezien de ernst van de inbreuk op het familie- en gezinsleven van kind en ouders en de ongelijke verhouding tussen de procespartijen, niet zou mogen volstaan met een standaardmotivering in de beschikking. Het dossieronderzoek heeft uitgewezen dat in 67,5\% van de geanalyseerde beschikkingen een inhoudelijke onderbouwing werd gegeven ten aanzien van de ernstige bedreiging van de zedelijke of geestelijke belangen of gezondheid van de minderjarige. In de overige zaken bood de kinderrechter geen inzicht in de feiten en omstandigheden die hadden geleid tot het oordeel dat er sprake was van een ernstige bedreiging van de belangen van de minderjarige.

\section{Conclusies ten aanzien van de onderbouwing van het (voorzienbaar) falen van andere} middelen

De tweede cumulatieve grond voor oplegging van een ondertoezichtstelling onder oude wetgeving zag op de rechtmatigheid van de inzet van gedwongen hulpverlening. Het (voorzienbaar) falen van andere middelen als in art. 1:254 lid 1 oud BW veronderstelde dat moest worden aangetoond dat op basis van vrijwilligheid niet het noodzakelijke resultaat was behaald, of zou kunnen worden behaald voor de minderjarige. Hiermee was in de rechtsgrond van ondertoezichtstelling concreet uitwerking gegeven aan het algemene uitgangspunt dat een jeugdbeschermingsmaatregel als ultimum remedium moet worden beschouwd. Het dossieronderzoek heeft laten zien dat de RvdK in een groot deel van de geanalyseerde zaken het resultaat van andere middelen (vrijwillige hulpverlening) uitwerkte in de beschermingsrapportage. In 91,5\% van de geanalyseerde beschermingsrapporten beargumenteerde de RvdK in hoeverre vrijwillige hulpverlening had gefaald, of naar was te voorzien, zou falen. Van de zaken waarin de RvdK inhoudelijk aandacht besteedde aan de rechtsgrond van de ondertoezichtstelling op dit punt, ging het in 20,8\% van de zaken om de verwachting dat vrijwillige hulpverlening onvoldoende effect zou sorteren. Als aandachtspunt is daarbij gesignaleerd dat de RvdK ook enkele keren besloot een verzoek tot ondertoezichtstelling in te dienen terwijl vrijwillige hulpverlening was opgestart, maar nog geen duidelijkheid was over het resultaat. Tot slot heeft het dossieronderzoek laten zien dat de oorzaak van het falen van andere middelen, een ondergeschikte rol speelde in de besluitvorming door de RvdK. Er werd bovenal gekeken of vrijwillige hulp was ingezet en of 
de ontwikkelingsbedreiging daarmee was weggenomen. Was dit niet het geval, dan kwam de zaak in aanmerking voor een ondertoezichtstelling, ook als de ouders en de minderjarige goed meewerkten aan de vrijwillige hulpverlening. Zo is uit de analyse gebleken dat de RvdK in $35.5 \%$ van de zaken waarin een ondertoezichtstelling werd verzocht, aangaf dat alle betrokkenen de vrijwillig hulp accepteerden.

De analyse van de beschikkingen op het verzoek tot ondertoezichtstelling heeft uitgewezen dat de tweede cumulatieve grond voor oplegging van de ondertoezichtstelling (het falen of voorzienbaar falen van andere middelen - art. 1:254 lid 1 oud BW) beduidend minder vaak inhoudelijk werd getoetst door de kinderrechter, dan de toets met betrekking tot de ernstige bedreiging van de zedelijke of geestelijke belangen of gezondheid van de minderjarige. Slechts in 69 van de 200 geanalyseerde beschikkingen (34,5\%) werd inhoudelijk de noodzaak van een ondertoezichtstelling onderbouwd door aandacht te besteden aan de pogingen tot hulpverlening die in het vrijwillig kader waren ondernomen

\section{Conclusies ten aanzien van de doelen van de ondertoezichtstelling}

De ondertoezichtstelling is een tijdelijke maatregel gericht op de ondersteuning van de minderjarige en zijn ouders en het versterken van de gezinsband. De wettelijke doelstelling van de ondertoezichtstelling op grond van art. 1:257 oud BW vormde het kader waarbinnen concrete (werk)doelen moesten worden gesteld om de geconstateerde ontwikkelingsbedreiging weg te nemen. In het onderzoek is het belang benadrukt van het stellen van concreet geformuleerde doelen gericht op de gewenste ontwikkelingsuitkomst voor de minderjarige, door de RvdK. Hoe concreter de door de RvdK gestelde doelen, hoe duidelijker voor de betrokkenen het zou zijn welke stappen gezet moesten worden om de bedreiging in de ontwikkeling van de minderjarige weg te nemen, zodat de ondertoezichtstelling kon worden opgeheven. In het rapportageformat dat door de RvdK werd gebruikt voor beschermingsonderzoeken in 2013 en 2014, werd expliciet gevraagd welke doelen behaald moesten worden om de ontwikkelingsperspectieven van de minderjarige veilig te stellen.

De analyse van dossiers heeft laten zien dat de RvdK in 92,5\% van de zaken doelen stelde. De manier waarop de doelen door de RvdK in de beschermingsrapporten werden beschreven, heeft echter wel geleid tot een aantal kritische conclusies. Zichtbaar is dat vaak werd gewerkt met 'standaarddoelen', die zodanig algemeen waren geformuleerd dat ze op iedere willekeurige zaak van toepassing konden zijn en daardoor geen eindpunt van de maatregel markeerden. Naast de geringe specificiteit van de gestelde doelen was ook lang niet altijd 
sprake van doelen gericht op de gewenste ontwikkelingsuitkomsten. Zo was er sprake van negatief geformuleerde doelen, dus gericht op het verbieden of opheffen van het problematische gedrag van de minderjarige en/of zijn ouders. Ook was zichtbaar dat doelen en middelen door elkaar werden gehaald. Bijvoorbeeld doordat werd aangegeven dat hulpverlening nodig was voor de minderjarige, zonder dat daarbij werd vermeld wat met de inzet van hulpverlening moest worden bereikt. Er is geconcludeerd dat duidelijker en concreter aangegeven kon worden welke doelen moesten worden behaald om de bedreiging voor de minderjarige weg te nemen, juist omdat het dossieronderzoek ook liet zien dat de bedreiging in de ontwikkeling vaak wel uitvoering en concreet werd beschreven door de RvdK.

\section{2) Rechtvaardiging van de uithuisplaatsing}

Indien er geen andere mogelijkheid bestaat om de belangen van de minderjarige te beschermen, dan kan de minderjarige in het kader van de ondertoezichtstelling uit huis worden geplaatst. De rechtsgrond van de uithuisplaatsing was in 2013/2014 neergelegd in art. 1:261 oud BW. Op grond van dit artikel kon de minderjarige dag en nacht uit huis worden geplaatst indien dit noodzakelijk was in het belang van de verzorging en opvoeding of tot onderzoek naar diens geestelijke of lichamelijke gesteldheid. Voor een uithuisplaatsing moest een indicatiebesluit worden overlegd waarmee de aanspraak op de noodzakelijke zorg kon worden geeffectueerd. Het dossieronderzoek heeft laten zien dat in een fors aantal zaken waarin de RvdK als verzoeker van de machtiging uithuisplaatsing een indicatiebesluit moest overleggen, geen indicatiebesluit is aangetroffen in het digitale registratiesysteem van de RvdK. Daarmee is niet per definitie gezegd dat in deze zaken geen indicatiebesluit is overlegd. Ook is zichtbaar dat er onder raadsonderzoekers verschillend werd gedacht over de noodzaak van een indicatiebesluit indien het een plaatsing betrof binnen het netwerk, maar niet bij de andere ouder met gezag. De indicatiebesluiten die wel zijn aangetroffen voldeden voor het overgrote deel aan de inhoudelijke eisen die op grond van art. 6 lid $1 \mathrm{Wjz}$ aan het indicatiebesluit werden gesteld. Terugkijkend is geconcludeerd dat de toegevoegde waarde inhoudelijk van het indicatiebesluit niet zonder meer duidelijk was. Zo was het beschrijven van het problematiek van het gezin een herhaling van zetten, aangezien dit al zeer uitvoerig in het beschermingsrapport gebeurde. Bovenal leek de functie van het indicatiebesluit de vaststelling van de coördinatie en financiering van de noodzakelijke zorg en het fungeerde niet primair als extra waarborg tegen ongerechtvaardigd overheidsingrijpen middels een uithuisplaatsing. 
Conclusies ten aanzien van de onderbouwing van de noodzaak tot uithuisplaatsing

De noodzaak tot uithuisplaatsing moest blijken uit het feit dat minder ingrijpende alternatieven dan een scheiding van kind en ouders onvoldoende waren om de bedreiging in de ontwikkeling van de minderjarige weg te nemen. Dit uitgangspunt was impliciet terug te vinden in art. 1:261 oud BW op basis waarvan de 'noodzaak' van een uithuisplaatsing in het belang van de verzorging en opvoeding van de minderjarige moest blijken. Het noodzakelijkheidsvereiste volgde ook uit toepasselijk verdragsrecht. Het in art. 8 EVRM neergelegde recht op eerbiediging van het familie- en gezinsleven bracht met zich mee dat alle relevante en minder ingrijpende alternatieven voor een uithuisplaatsing moesten zijn onderzocht door de autoriteiten. Ook uit art. 9 IVRK volgde de noodzakelijkheidseis indien een kind gedwongen van zijn ouders wordt gescheiden. Daarnaast verplichtte art. 8 EVRM de autoriteiten voldoende te investeren in de band tussen kind en ouder en te streven en in alle fasen van de besluitvorming nadrukkelijk aandacht te besteden aan de mogelijkheid van een spoedige hereniging.

In het dossieronderzoek is gekeken hoe de RvdK in het beschermingsrapport en de kinderrechter in de beschikking in 2013 en 2014 de noodzaak tot uithuisplaatsing onderbouwden. Het dossieronderzoek heeft geleid tot de conclusie dat de onderbouwing van de noodzaak uithuisplaatsing in het licht van de zojuist beschreven vereisten mager was. In de beschermingsrapporten leek de afweging omtrent de uithuisplaatsing een extra stap in het kader van de besluitvorming over de ondertoezichtstelling en niet zozeer een zelfstandige en diepgaande afweging. Meer specifiek is gebleken dat in 59,8\% van de geanalyseerde zaken concreet door de RvdK werd beargumenteerd waarom minder ingrijpende alternatieven om de uithuisplaatsing te voorkomen geen optie meer waren. Voor wat betreft de beschikking op het verzoek tot machtiging uithuisplaatsing is aangegeven dat de kinderrechter niet zou mogen volstaan met een standaardmotivering gezien de verstrekkende gevolgen van de uithuisplaatsing voor het kind en de ouders. Het dossieronderzoek heeft laten zien dat kinderrechters niet standaard, maar wel in de meeste zaken de noodzaak tot uithuisplaatsing inhoudelijk onderbouwden in de beschikking. In $78 \%$ van de geanalyseerde zaken werd een inhoudelijke motivering gegeven specifiek met betrekking tot de uithuisplaatsing van de minderjarige.

Daarnaast is gebleken dat de RvdK in $68 \%$ van de geanalyseerde zaken aandacht besteedde aan de kans op hereniging en daarmee het opvoedperspectief van minderjarige na uithuisplaatsing. In de overige zaken werd vrijwel alleen aandacht besteed aan de problemen 
in de thuissituatie die tot dat moment waren gesignaleerd. De mogelijkheid tot hereniging na uithuisplaatsing - een afweging die op grond van art. 8 EVRM onderdeel zou moeten zijn van de besluitvorming - bleef daarmee onbesproken. Op basis van deze bevindingen zijn de volgende twee conclusies getrokken ten aanzien van de onderbouwing van de noodzaak tot uithuisplaatsing. Ten eerste lijkt het erop dat de rechtsgrond van de uithuisplaatsing zoals was neergelegd in art. 1:261 oud BW onvoldoende duidelijk makkte welke elementen terug moesten komen in de afweging over de noodzaak van een uithuisplaatsing. Uit art. 8 EVRM volgde wel concreet dat de noodzaak zou moeten blijken uit het feit dat minder ingrijpende alternatieven geen optie meer zijn, maar dit uitgangspunt vormde kennelijk geen standaard onderdeel van het beoordelingskader van de RvdK en de kinderrechter. Ten tweede bleek het opvoedperspectief van de minderjarige na uithuisplaatsing nog geen vast onderdeel van de besluitvorming over de uithuisplaatsing, terwijl dit bij zou kunnen dragen aan de rechtvaardiging voor de inzet van een uithuisplaatsing.

\section{Conclusies ten aanzien van de plaatsing in een accommodatie voor gesloten jeugdzorg} Voor de plaatsing van een minderjarige in een accommodatie voor gesloten jeugdzorg golden in 2013/2014 verschillende eisen op grond van de Wet op de Jeugdzorg. Op grond van art. $29 \mathrm{~b}$ lid $3 \mathrm{Wjz}$ kon een machtiging worden verleend indien sprake was van ernstige opgroeien opvoedingsproblemen die de ontwikkeling van de minderjarige naar volwassenheid ernstig belemmerden en opneming en verblijf noodzakelijk was om te voorkomen dat minderjarige zich onttrok of zou worden onttrokken aan de noodzakelijke zorg. Daarnaast behoefde de gewenste machtiging gesloten jeugdzorg instemming van een gekwalificeerde gedragswetenschapper die de minderjarige kort tevoren had onderzocht (art. 29b lid 5 Wjz).

Deze aangescherpte eisen op grond van de Wet op de Jeugdzorg lieten zich rechtvaardigen door het feit dat de machtiging een inperking van de persoonlijke vrijheid van de minderjarige inhield (art. 5 EVRM en art. 37b IVRK). In het dossieronderzoek is gekeken of, en zo ja hoe voornoemde wettelijke vereisten werden toegepast in de besluitvorming van de RvdK en de kinderrechter over een gesloten machtiging. Gezien het geringe aantal zaken in de steekproef (18) waarin een gesloten machtiging werd verzocht, moeten de bevindingen van het dossieronderzoek met de nodige voorzichtigheid worden geïnterpreteerd. Ten aanzien van de gronden zoals opgenomen in art. 29b lid $3 \mathrm{Wjz}$ heeft de analyse uitgewezen dat de nadruk in de besluitvorming door de RvdK lag op de ernstige ontwikkelingsproblematiek van de minderjarige. Het risico op onttrekking aan de noodzakelijke zorg werd blijkens het 
dossieronderzoek in slechts $50 \%$ van de geanalyseerde zaken inhoudelijk onderbouwd in het beschermingsrapport. Een aangedragen verklaring hiervoor is dat in het beschermingsrapport geen aanvullende onderzoeksvragen gericht op de gronden in de Wet op de Jeugdzorg werden gesteld door de RvdK. Hierdoor nam de kans toe dat het risico op onttrekking aan de noodzakelijke zorg niet expliciet werd uitgewerkt.

Wat betreft de instemmingsverklaring is gebleken dat in vrijwel alle zaken een persoonlijk gesprek tussen de gedragswetenschapper en de minderjarige heeft plaatsgevonden en dat het onderzoek doorgaans actueel was. Naar aanleiding van de analyse van de instemmingsverklaringen is wel de vraag opgeworpen of deze konden worden beschouwd als voldoende onafhankelijk en inhoudelijk van toegevoegde waarde voor de afweging over de gesloten plaatsing. Zo begonnen de voor dit onderzoek geanalyseerde instemmingsverklaringen met de voorgedrukte tekst luidende dat de gedragswetenschapper kon instemmen met het oordeel van Bureau Jeugdzorg dat een gesloten plaatsing noodzakelijk was. Dit wekte niet de indruk van een onafhankelijk oordeel waarbij de nodige distantie werd gehouden van het oordeel van Bureau Jeugdzorg. Het aantal geanalyseerde zaken is echter te gering geweest om hier stevige conclusies aan te verbinden.

\section{3) Zorgvuldigheid van het feitenonderzoek door de RvdK}

In het dossieronderzoek is een klein deel van de wijze waarop de RvdK de aangedragen informatie selecteerde, beoordeelde en aanleverde ten behoeve van de rechtspleging geanalyseerd. Belangrijk in dit verband was art. $21 \mathrm{Rv}$ op basis waarvan de RvdK als verzoeker in de jeugdbeschermingsprocedure gehouden was de voor de beslissing van belang zijnde feiten volledig en waarheid aan te voeren. In het Kwaliteitskader van de RvdK dat gold in 2013 en 2014 werden nog enkele aanvullende eisen gesteld ten aanzien van de wijze waarop de informatie door de RvdK werd verkregen en verwerkt. Zo gold de eis dat de informatie die was ingebracht door informanten tijdens het beschermingsonderzoek werd geaccordeerd en gedateerd. Het dossieronderzoek heeft laten zien dat in $97 \%$ van de geanalyseerde zaken de informatie was geaccordeerd en in 97,5\% van de zaken de datum werd vermeld waarop de informatie was ingebracht door de geraadpleegde informanten. De enkele keer dat dit niet gebeurde leek het te gaan om incidentele slordigheden.

Daarnaast gold als eis dat in de rapportages een duidelijk onderscheid werd gemaakt tussen feiten en meningen en de interpretatie van de RvdK van die gegevens. Het dossieronderzoek heeft uitgewezen dat de RvdK in 92,5\% van de geanalyseerde zaken de informatie die door informanten werd ingebracht correct weergaf bij de afweging van de onderzoeksvragen. Dit 
betekent dat zowel de vastgestelde feiten als zorgen en vermoedens ook als zodanig werden benoemd. In 7,5\% van de zaken was de interpretatie van de onderzoeksgegevens door de RvdK niet geheel, maar doorgaans wel voor het grootste deel correct. In de zaken waarin de interpretatie van onderzoeksgegevens niet geheel correct was, ging het met name om zaken waarin bepaalde vermoedens, te stellig, dus als feitelijke informatie werden gepresenteerd. Enerzijds heeft de analyse hiermee aangetoond dat in veruit de meeste zaken de informatie juist werd geïnterpreteerd door de RvdK. De kritiek vanuit met name ouders en overige betrokkenen dat de RvdK in de beschermingsrapportage geen onderscheid maakte tussen feiten en meningen, lijkt daarmee voor een deel te moeten worden genuanceerd. Anderzijds geeft de uitkomst van het dossieronderzoek toch enige reden tot zorg. In de analyse is gekeken naar informatie die de RvdK zelf verzamelde (van informanten en de betrokkenen) en vervolgens interpreteerde in het kader van de onderzoeksafwegingen. Hoe de informatieverwerking van de verschillende ketenpartners liep bij overdracht van dossiers viel buiten het bereik van het dossieronderzoek, maar hier lijkt de kans op een onjuiste interpretatie en verwerking van de onderzoeksgegevens het grootst. Daarnaast is geconcludeerd dat de foutmarge op dit vlak gering is voor de RvdK, aangezien foutief geïnterpreteerde informatie ouders en minderjarigen nog jarenlang kan achtervolgen.

\section{4) De rechtspositie van de minderjarige en zijn ouders}

De wijze waarop de minderjarige (en zijn ouders) worden betrokken in de besluitvormingsprocedure van de RvdK en in de gerechtelijke procedure is van groot belang. Aangezien de minderjarige in civiele procedures procesonbekwaam is, vindt participatie bovenal plaats door uitoefening van het hoorrecht. Voor het hoorrecht in procedures is art. 12 IVRK cruciaal. Artikel 12 IVRK garandeert kinderen het recht om hun mening vrijelijk te uiten in alle kwesties die hen aangaan. Aan de mening van het kind moet passend belang worden gehecht in overeenstemming met zijn of haar leeftijd en rijpheid (art. 12 lid 1 IVRK). Daarnaast geldt het recht om te worden gehoord voor minderjarigen in alle (juridische) procedures.

In het dossieronderzoek is gekeken hoe tijdens het beschermingsonderzoek door de RvdK en in de gerechtelijke procedure uitvoering werd gegeven aan het hoorrecht van minderjarigen. Er is daarbij een onderscheid gemaakt tussen het horen van de minderjarige (op grond van nationale wet- en regelgeving) en het betrekken van de (mening van de) minderjarige in de besluitvorming. Blijkens het Kwaliteitskader van de RvdK dat in 2013 en 2014 werd gehanteerd, gold als uitgangspunt dat iedere minderjarige werd gehoord tijdens het 
beschermingsonderzoek. Was horen onmogelijk (bijvoorbeeld in geval van zeer jonge kinderen) dan moest de minderjarige worden geobserveerd. Bleek ook dit niet mogelijk dan diende het beschermingsrapport in ieder geval een inhoudelijke toelichting te bevatten over de reden van het niet horen/observeren. Uit het dossieronderzoek is naar voren gekomen dat dit niet in alle zaken overeenkomstig voornoemde regels in het Kwaliteitskader 2013 van de RvdK gebeurde. In $73 \%$ van de zaken werd de minderjarige gehoord. In 14,5\% van de zaken werd de minderjarige niet gehoord of geobserveerd maar werd wel inhoudelijk toegelicht waarom het horen/observeren achterwege was gebleven. In 12,5\% van de zaken werd in de beschermingsrapportage echter niks vermeld over het horen van de minderjarige.

Vervolgens is geanalyseerd op welke wijze de minderjarige (en zijn ouders) werden geïnformeerd over- en betrokken bij de besluitvorming van de RvdK in het beschermingsonderzoek. De focus heeft daarbij gelegen op de de mogelijkheden tot participatie van de minderjarige, maar omdat de minderjarige in bepaalde gevallen afhankelijk was van zijn ouders, is ook enige aandacht geschonken aan de positie van de ouders. In de eerste plaats is gekeken of de minderjarige en zijn ouders inzage kregen in de conceptrapportage. Uit het dossieronderzoek is naar voren gekomen dat ouders vrijwel altijd inzage kregen in de conceptrapportage. In 94,5\% van de zaken werd in het beschermingsrapport vermeld dat de conceptrapportage naar ouders was opgestuurd of overhandigd tijdens het adviesgesprek. In 2,5\% van de zaken bleek dit niet mogelijk maar vermeldde de RvdK wel duidelijk waar dit aan lag. In 3\% van de zaken bleek geen informatie over de mogelijkheid tot inzage in de rapportage opgenomen.

Voor de minderjarige lag dit wezenlijk anders en werd afhankelijk van de leeftijd wel of geen inzage gegeven in de conceptrapportage. De minderjarige onder de twaalf jaar kreeg in de regel geen inzage in de conceptrapportage. Het was dus kennelijk aan de ouders om de minderjarige - voor zover hier behoefte aan was - te informeren over de besluitvorming in de beschermingsrapportage. De minderjarige van 16 jaar en ouder ontving het conceptrapport, mits zijn belang zich hier niet tegen verzette. De minderjarige tussen de twaalf en zestien jaar ontving in de regel alleen 'zijn kinddeel'. Het kinddeel bevatte slechts een weergave van het gesprekverslag met de minderjarige, zonder dat nadere informatie over de onderzoeksafwegingen werd beschreven. Kennelijk werd op deze manier getracht de minderjarige in bescherming te nemen en niet (teveel) te belasten met de doorgaans gevoelige informatie die in de rapporten terugkwam. Hoewel daar enig begrip voor valt op te brengen, zorgde deze werkwijze er wel voor dat de minderjarige nauwelijks inzicht kreeg in de 
schriftelijke overwegingen die ten grondslag hebben gelegen aan het besluit. Het is de vraag of de RvdK hier niet te terughoudend is geweest.

Afsluitend is voor wat betreft de beschermingsprocedure bij de RvdK gekeken of een adviesgesprek werd gehouden met de minderjarige en zijn ouders. Volgens het

Kwaliteitskader 2013 van de RvdK werd ieder beschermingsonderzoek afgesloten met een adviesgesprek met de minderjarige en zijn ouders/verzorgers. Het dossieronderzoek heeft uitgewezen dat in de meeste zaken met de ouders een persoonlijk dan wel telefonisch adviesgesprek werd gehouden (80\%). In een deel van de zaken bleek dit niet mogelijk volgens de toelichting van de RvdK in het beschermingsrapport, bijvoorbeeld omdat ouders onbereikbaar waren. In 14\% van de geanalyseerde zaken vermeldde het beschermingsrapport niets over een adviesgesprek. Ten aanzien van het adviesgesprek met de minderjarige, werd in veel minder zaken informatie opgenomen door de RvdK. In maar liefst $65 \%$ van de geanalyseerde zaken was in het beschermingsrapport geen informatie hierover opgenomen. Ook al ging het in een deel van deze zaken om minderjarigen onder de twaalf jaar, de uitkomst is weinig positief in het licht van de uitgangspunten die kunnen worden ontleend aan art. 12 IVRK. In veel zaken is immers geheel onduidelijk gebleven of de minderjarige was gesproken, en zo ja, hoe hij tegen het voorgenomen raadsbesluit aankeek.

Ten aanzien van het horen en het betrekken van de (mening van de) minderjarige in de gerechtelijke procedure is in de beschikkingen naar twee elementen gekeken. De wijze waarop in 2013 en 2014 uitvoering werd gegeven aan het hoorrecht van de minderjarige op grond van art. $809 \mathrm{Rv}$. en de vraag of in de beschikkingen de mening van de minderjarige expliciet werd meegewogen door de kinderrechter. Laatstgenoemd element is als belangrijk aangemerkt omdat de beschikking de minderjarige de mogelijkheid bood kennis te nemen van de rol die zijn mening had gespeeld in de beslissing van de kinderrechter.

Het dossieronderzoek heeft in de eerste plaats het beeld bevestigd dat minderjarigen in jeugdbeschermingszaken onder de twaalf jaar niet of nauwelijks door de kinderrechter werden gehoord. Op grond van art. 809 Rv bestond en bestaat de mogelijkheid daartoe, maar het initiatief om gebruik te maken van het hoorrecht leek primair bij de minderjarige zelf te liggen. In 91 van de 200 zaken in het dossieronderzoek ging het om een minderjarige onder de twaalf jaar en in geen enkele zaak werd gebruik gemaakt van het hoorrecht. Logischerwijs zag het beeld voor minderjarigen van twaalf jaar en ouder er heel anders uit. Zij moesten op grond van art. $809 \mathrm{Rv}$ in de gelegenheid worden gesteld om te worden gehoord. Het dossieronderzoek heeft laten zien dat in $97,2 \%$ van de zaken met zekerheid is te zeggen dat de 
minderjarige in de gelegenheid werd gesteld om te worden gehoord. In een heel groot deel van deze zaken werd de minderjarige ook daadwerkelijk gehoord, in een klein deel van de zaken gaf de minderjarige zelf aan hier geen gebruik van te willen maken. In 2,8\% van de zaken vermeldde de beschikking niks over het horen van de minderjarige.

Tot slot is geanalyseerd in hoeveel van de beschikkingen de mening van de minderjarige onderdeel uitmaakte van inhoudelijke afwegingen van de kinderrechter. Het dossieronderzoek laat heeft laten zien dat de kinderrechter in $11 \%$ van de beschikkingen expliciet aandacht besteedde aan de mening van de minderjarige. Hiermee is aangetoond dat het opnemen van de mening van de minderjarige in 2013 en 2014 nog een prille ontwikkeling was. Naar het zich liet aanzien werd hier door kinderrechters nog terughoudend gebruik van gemaakt om de minderjarige niet onnodig te belasten of in een lastige positie te brengen ten opzichte van zijn ouders. Tegelijkertijd heeft het dossieronderzoek laten zien dat het de onderbouwing van de beslissing van de kinderrechter sterk ten goede kwam als de mening van de minderjarige wel nadrukkelijk werd meegewogen.

\subsection{Samenvattende bevindingen en reflecties op de jeugdbeschermingspraktijk vanaf 2015}

In deel III van het onderzoek is aandacht besteed aan de toepassing van het jeugdbeschermingsrecht vanaf 1 januari 2015. Doel hiervan is de relevantie van de onderzoeksresultaten over de jaren 2013/2014 te bepalen voor het jeugdbeschermingsrecht vanaf 2015. In hoeverre zijn belangrijke kritiekpunten die zijn geconstateerd ook thans nog relevant en op welke punten zijn door wijzigingen in wetgeving en beleid die kritiekpunten inmiddels verminderd of weggenomen? Om dit doel te bereiken zijn de resultaten van het dossieronderzoek waarin is gekeken naar de rechtvaardiging van een ondertoezichtstelling met of zonder uithuisplaatsing in de jaren 2013/2014 afgezet tegen de belangrijkste resultaten van de in 2018 gepubliceerde tussenevaluaties van de Wet herziening kinderbeschermingsmaatregelen en de Jeugdwet en zijn overige ontwikkelingen in beleid en praktijk besproken. In deel III van het onderzoek is de tweede hoofdvraag beantwoord:

In hoeverre zijn de in dit onderzoek voor de periode 2013/2014 getrokken conclusies ten aanzien van de rechtvaardiging van de ondertoezichtstelling met of zonder machtiging uithuisplaatsing nog steeds relevant, gelet op de doorgevoerde wijzingen in de jeugdbeschermingswetgeving en uitvoeringspraktijk? 
Het antwoord op deze vraag wordt gegeven aan de hand van de eerder gehanteerde volgorde. Achtereenvolgens komen de volgende vier elementen aan bod: 1) de rechtvaardiging van de ondertoezichtstelling; 2) de rechtvaardiging van de uithuisplaatsing; 3) de zorgvuldigheid van het feitenonderzoek door de RvdK; 4) de rechtspositie van de minderjarige (en zijn ouders) in de jeugdbeschermingsprocedure.

\section{1) Rechtvaardiging van de ondertoezichtstelling}

De rechtsgrond van de ondertoezichtstelling is met de Wet herziening kinderbeschermingsmaatregelen op diverse punten gewijzigd. Op grond van art. 1:255 lid 1 BW kan de kinderrechter een minderjarige onder toezicht stellen van een gecertificeerde instelling indien: de minderjarige zodanig opgroeit dat hij in zijn ontwikkeling ernstig wordt bedreigd; de zorg die in verband met het wegnemen van de bedreiging noodzakelijk is voor de minderjarige of voor zijn ouders of de ouder die het gezag uitoefenen door dezen niet of onvoldoende wordt geaccepteerd; en de verwachting gerechtvaardigd is dat de ouders of de ouder die het gezag uitoefenen binnen een gelet op de persoon en ontwikkeling van de minderjarige aanvaardbaar te achten termijn, de verantwoordelijkheid voor de verzorging en opvoeding, bedoeld in art. 1:247 lid 2 BW, in staat zijn te dragen. In deel III van het onderzoek is voor alle drie de gewijzigde gronden gekeken hoe deze worden toegepast in de praktijk sinds 2015 en wat deze toepassing betekent voor de resultaten die in deel II van dit onderzoek zijn gevonden ten aanzien van de toepassing van de gronden in de jaren 2013 en 2014.

De eerste wijziging in de rechtsgrond van de ondertoezichtstelling beoogt geen inhoudelijke verandering in de besluitvorming over de ondertoezichtstelling te bewerkstelligen. De ernstige bedreiging van de zedelijke of geestelijke belangen of gezondheid (art. 1:254 lid 1 oud BW) is nu gewijzigd in de overkoepelende term 'ernstige ontwikkelingsbedreiging'. De grond laat nog evenveel ruimte aan de praktijk om zelfstandig een afweging te maken over de ernst van de bedreiging. Dit betekent dat een zekere mate van rechtsonzekerheid op dit punt onvermijdelijk is. Daarnaast blijft het risico aanwezig dat in de besluitvorming de zorgen omtrent de minderjarige onvoldoende concreet worden gemaakt, zonder dat dit gevolgen heeft voor de vraag of een ondertoezichtstelling gerechtvaardigd is. Zonder deze negatieve elementen te negeren is uiteindelijk toch geconcludeerd dat de rechtsgrond van de ondertoezichtstelling op dit punt geen aanpassing behoeft. De flexibiliteit die thans worden geboden is belangrijk om de minderjarige in uiteenlopende situaties te kunnen beschermen. Daarnaast heeft het dossieronderzoek in deel II van deze studie laten zien dat de RvdK in 
2013 en 2014 in de regel uitgebreid en concreet beschreef op basis van welke zorgen een ernstige ontwikkelingsbedreiging aanwezig aan. Het is aannemelijk dat de RvdK dit na 2015 nog steeds doet. Geconcludeerd is dat het beste kan worden geprobeerd de onzekerheid die voortkomt uit het gebruik van deze open norm te verkleinen. Zoals dit onderzoek heeft laten zien is het mogelijk bepaalde situaties te identificeren waarin het risico groter is dat de ontwikkelingsbedreiging niet concreet wordt onderbouwd. Bijvoorbeeld de situatie zoals in deel II van dit onderzoek is geïdentificeerd, waarin geen zorgen werden gevonden ten aanzien van het functioneren van de minderjarige. In de werkprocessen van de ketenpartners zou deze kennis kunnen leiden tot verfijning in de besluitvorming door dit soort gevallen te herkennen en vervolgens extra kritisch te zijn ten aanzien van de onderbouwing.

De tweede wijziging in de rechtsgrond van de ondertoezichtstelling heeft ervoor gezorgd dat het (voorzienbare) falen van hulpverlening (art. 1:254 lid 1 oud BW) is vervangen door het wettelijk vereiste 'het niet of onvoldoende accepteren van de noodzakelijke zorg' (art. 1:255 lid 1 onder a BW). In deel III van het onderzoek is op basis van de beschikbare onderzoeksgegevens en kennis over de toepassing in de praktijk kritisch geoordeeld over deze wijziging. Zowel het dossieronderzoek als de tussenevaluatie van de Wet herziening kinderbeschermingsmaatregelen hebben laten zien dat er een behoorlijke groep ouders is die de noodzakelijk zorg voldoende accepteert, maar waar de RvdK toch de noodzaak ziet van een ondertoezichtstelling. De wettelijke grond knelt hier ogenschijnlijk maar in de praktijk lijkt dit te zijn 'opgelost' door het oprekken van het begrip acceptatie door de RvdK, de GI en kinderrechters. Het voldoende accepteren van de noodzakelijke zorg betekent dan dat de ouders en minderjarige deze zorg zodanig accepteren en benutten dat het gewenste effect (het wegnemen van de ernstige ontwikkelingsbedreiging, cursief $\mathrm{JH}$ ) wordt bereikt. Het is niet aannemelijk dat de wetgever het begrip 'acceptatie' zo ver heeft willen oprekken en het kan in de praktijk ook leiden tot lastig te doorgronden conclusies. Bijvoorbeeld in zaken waarin ouders zich al jaren voldoende coöperatief opstellen maar de RvdK en de kinderrechter toch concluderen dat de noodzakelijke zorg niet voldoende wordt geaccepteerd, omdat anders geen ondertoezichtstelling opgelegd kan worden.

Het voorgaande maakt duidelijk dat de kans op een wisselende interpretatie van het begrip 'acceptatie' aanwezig is. De tussenevaluatie van de Wet herziening kinderbeschermingsmaatregelen bevestigt dit en laat zien dat er ook professionals zijn die wel een strikte interpretatie kiezen. Een wisselende opvatting over de invulling van het begrip acceptatie leidt tot meer rechtsonzekerheid voor de betrokkenen. Tot slot is het ook 
aannemelijk dat de vraag of de noodzakelijke zorg wel of niet voldoende wordt geaccepteerd leidt tot meer interpretatieverschillen en discussies in de rechtszaal. In het licht van het voorgaande verdient het overweging om het oude resultaatgerichte begrip 'het (voorzienbaar) falen van hulpverlening', weer als tweede grond voor de ondertoezichtstelling in de wet op te nemen.

De derde wijziging in de rechtsgrond van de ondertoezichtstelling is de toevoeging van het aanvaardbare-termijn criterium (art. 1:255 lid 1 onder b BW). De aanvaardbare termijn dwingt om het opvoedperspectief van de minderjarige te betrekken in de besluitvorming. Die afweging speelt echter pas indien de minderjarige in het kader van een ondertoezichtstelling uit huis wordt geplaatst. In dit onderzoek is daarom de vraag gesteld wat de functie van de aanvaardbare termijn is als de ondertoezichtstelling niet gecombineerd wordt met een uithuisplaatsing. Het antwoord op die vraag is dat de aanvaardbare termijn in zaken waarin alleen een ondertoezichtstelling wordt verzocht inhoudelijk weinig lijkt toe te voegen aan de besluitvorming over de noodzaak van een ondertoezichtstelling. Raadsonderzoekers geven aan er vanuit te gaan dat bij een kale ondertoezichtstelling per definitie is voldaan aan de aanvaardbare termijn omdat het opvoedperspectief (nog) niet ter discussie staat. Ook in de rechtspraak is aangenomen dat inhoudelijk pas een termijn wordt gesteld in een uithuisplaatsing wordt uitgesproken. Het roept de vraag op of niet duidelijker in de jeugdbeschermingswetgeving tot uitdrukking zou moet worden gebracht dat de aanvaardbare termijn zich richt op het opvoedperspectief van de minderjarige en daarmee ziet op de situatie waarin de minderjarige uit huis wordt of is geplaatst.

\section{2) Rechtvaardiging van de uithuisplaatsing}

De rechtsgrond van de machtiging uithuisplaatsing is inhoudelijk niet gewijzigd met de Wet herziening kinderbeschermingsmaatregelen. Op grond van huidig art. 1:265b BW geldt nog steeds dat de minderjarige uit huis kan worden geplaatst indien dit noodzakelijk is in het belang van de verzorging en opvoeding van de minderjarige. In dit onderzoek is beargumenteerd dat deze noodzaak op grond van art. 8 EVRM op tenminste twee punten geconcretiseerd zou moeten worden in de besluitvorming. In de eerste plaats de noodzaak aandacht te besteden aan alternatieve, minder ingrijpende middelen ter voorkoming van een uithuisplaatsing. En ten tweede, de noodzaak aandacht te besteden aan het opvoedperspectief van de minderjarige en daarmee de mogelijkheden tot hereniging van kind en ouders. Het dossieronderzoek heeft laten zien dat beide elementen onvoldoende werden betrokken in de besluitvorming van de RvdK over de noodzaak van uithuisplaatsing. Na 2015 zijn er 
duidelijke verbeteringen doorgevoerd in de besluitvorming over de uithuisplaatsing ten aanzien het opvoedperspectief van de minderjarige. De aanvaardbare termijn dwingt de verzoeker (in dit geval de RvdK) een verwachting uit te spreken over de mogelijkheid dat kind en ouders op termijn worden herenigd. Dit geldt echter niet voor het onderbouwen van de noodzaak tot uithuisplaatsing door concreet te beschrijven waarom minder ingrijpende alternatieven niet afdoende zijn. De rechtsgrond zou beter tot uitdrukking moeten brengen dat de noodzaak tot uithuisplaatsing primair moet blijken uit het feit andere minder ingrijpende alternatieven zijn overwogen en onvoldoende zijn. Concreet betekent dit dat de verzoeker niet alleen moet afwegen of een uithuisplaatsing kan worden voorkomen, maar ook dat als wordt besloten een verzoek tot uithuisplaatsing in te dienen, dat wordt gestreefd naar de minst ingrijpende oplossing.

\section{3) Zorgvuldigheid van het feitenonderzoek}

In dit onderzoek is naar voren gekomen dat de discussie over het streven naar waarheidsvinding in jeugdbeschermingszaken na 2015 onverminderd heeft voortgeduurd. Een deel van de cliënten van de Rvdk en de GI's is nog altijd zeer ontevreden over de wijze waarop het feitenonderzoek in jeugdbeschermingszaken wordt uitgevoerd. De wetgever heeft hierop gereageerd door met invoering van de Jeugdwet de notie van waarheidsvinding specifiek voor de RvdK en de GI's een wettelijke grondslag te geven. In art. 3.3 Jeugdwet is thans de plicht opgenomen voor de RvdK en de GI's om in rapportages en verzoekschriften de van belang zijnde feiten volledig en naar waarheid aan te voeren. In het onderzoek is geconcludeerd dat de toegevoegde waarde van deze waarheidsplicht niet zonder meer duidelijk is. In de eerste plaats omdat 3.3 Jeugdwet vrijwel identiek is aan art. $21 \mathrm{Rv}$ op basis waarvan alle partijen in civiele procedures gehouden zijn de feiten volledig en naar waarheid aan te voeren. Hoogstens kan worden betoogd dat de RvdK en de GI's expliciet worden genoemd in art. 3.3 Jeugdwet hetgeen het belang van waarheidsvinding specifiek voor deze organisaties benadrukt. Daarnaast zou uit art. 3.3 Jeugdwet kunnen worden afgeleid dat de waarheidsplicht wordt uitgebreid tot al het handelen van deze organisaties en niet alleen tijdens de gerechtelijke procedure. Ook voor art. 3.3 Jeugdwet geldt echter dat alleen bij een evident onzorgvuldige of onjuiste informatieverwerking door de RvdK en de GI's schending van de waarheidsplicht in beeld zou kunnen komen. Daarnaast is zichtbaar dat het Kwaliteitskader 2016 van de RvdK geen aangescherpte eisen bevat ten aanzien van het feitenonderzoek. Evenals in het Kwaliteitskader 2013 wordt vermeld dat feiten, visies en 
meningen en de interpretatie daarvan door de RvdK duidelijk van elkaar te onderscheiden moeten in de rapportage.

Hiermee lijkt de discussie over het feitenonderzoek door de RvdK en de GI's niet verder te komen. In het onderzoek is betoogd dat eerst duidelijk zal moeten worden hoe in het feitenonderzoek inhoudelijk het onderscheid wordt gemaakt tussen feiten en meningen. Voor de ouders en overige betrokkenen geldt dat de stelling dat feiten en meningen door elkaar lopen in de rapportages niet kan worden gestaafd omdat criteria om deze stelling te beoordelen ontbreken. Voor de RvdK (en de GI) geldt hetzelfde als wordt aangegeven dat feiten en meningen standaard gescheiden worden beschreven in de rapportages. Het dossieronderzoek kan als richtsnoer dienen voor de beoordeling van de vraag wanneer informatie feitelijk is en wanneer een mening/visie en of deze informatie inderdaad niet door elkaar loopt in de rapportages. Dat is mogelijk binnen de kaders van de huidige wet- en regelgeving die van toepassing is op jeugdbeschermingszaken.

\section{4) Rechtspositie van de minderjarige en zijn ouders in de jeugdbeschermingsprocedure}

Het dossieronderzoek heeft diverse knelpunten aan het licht gebracht waar het ging om het horen, informeren en betrekken van de minderjarige en zijn ouders tijdens het beschermingsonderzoek en in de gerechtelijke procedure, Ten dele zijn deze knelpunten verminderd of weggenomen door wijzigingen in wetgeving en beleid. Zowel met invoering van de Jeugdwet als met de Wet herziening kinderbeschermingsmaatregelen is het belang van een goede rechtspositie van de minderjarige en zijn ouders benadrukt. Voor dit onderzoek is met name van belang dat in het besluitvormingsproces in jeugdbeschermingszaken duidelijker de concrete bedreigingen in de ontwikkeling van de minderjarige moet worden benoemd. Voor verzoekschriften is opnemen van de concrete bedreiging in de ontwikkeling van de minderjarige nu verplicht op grond van art. 799a lid 1 Rv. Aansluitend hierop dient de kinderrechter in de beschikking op het verzoek tot ondertoezichtstelling ook de concrete bedreiging in de ontwikkeling van de minderjarige op te nemen (art. 1:255 lid $4 \mathrm{BW}$ ). Ten aanzien van de motivering van de beschikkingen maakt dit waarschijnlijk het grootste verschil nu het dossieronderzoek heeft uitgewezen dat voor 2015 nog regelmatig werd volstaan met een standaardmotivering.

Ook met betrekking tot het hoorrecht van de minderjarige in de procedure bij de RvdK en de kinderrechter zijn positieve wijzigingen doorgevoerd. Voor de horen van de minderjarige tijdens het beschermingsonderzoek is van belang dat met de Wet herziening kinderbeschermingsmaatregelen art. 799a lid $2 \mathrm{Rv}$ is ingevoerd. Dit artikel verplicht de RvdK 
(onder meer) in het verzoekschrift te vermelden of, en zo ja op welke wijze de minderjarige is gesproken. Het dossieronderzoek heeft aangetoond dat voor 2015 de RvdK in 12,5\% van de geanalyseerde in het beschermingsrapport geen informatie had opgenomen over de vraag of de minderjarige was gehoord. Na 2015, zo blijkt ook uit de tussenevaluatie van de Wet herziening kinderbeschermingsmaatregelen wordt in ieder geval goed gedocumenteerd of het horen wel of niet heeft plaatsgevonden.

Het wettelijk hoorrecht voor minderjarigen in familierechtelijke procedures is na 2015 ongewijzigd gebleven. Op grond van art. $809 \mathrm{Rv}$ geldt nog steeds dat de minderjarige onder de twaalf jaar in gelegenheid kan worden gesteld om te worden gehoord door de kinderrechter. Is de minderjarige 12 jaar of ouder dan moet hij in de gelegenheid worden gesteld om te worden gehoord. De bevindingen op grond van het dossieronderzoek ten aanzien van het hoorrecht van de minderjarige zijn derhalve nog steeds relevant. In het dossieronderzoek is geconstateerd dat geen enkele minderjarige binnen de steekproef jonger dan twaalf jaar was gehoord door de kinderrechter. Deze uitkomst bevestigde het beeld dat het horen van twaalf-minners slechts sporadisch voorkwam. Onderzoek gericht op de periode na 2015 laat zien dat het horen van twaalf-minners nog steeds bij uitzondering plaatsvindt. Wel is geconstateerd dat hier langzaam verandering in lijkt te komen. Zo heeft de Rechtbank Amsterdam sinds 2016 het initiatief genomen om minderjarigen vanaf 8 jaar actiever te gaan benaderen met de vraag of zij gebruik wensen te maken van hun hoorrecht. Daarnaast wordt in diverse onderzoeken geadviseerd de wettelijke leeftijdsgrens voor het horen van minderjarigen te verlagen van twaalf naar acht jaar.

In het dossieronderzoek in deel II van deze studie is niet alleen gekeken of de minderjarige is gehoord door de RvdK en de kinderrechter, maar zijn ook verschillende elementen geanalyseerd die zien op het betrekken van (de mening van) de minderjarige in de besluitvorming. Geconstateerd is dat hier duidelijke verbeteringen mogelijk waren. Zo kreeg de minderjarige feitelijk pas vanaf 16 jaar volledig inzage in de conceptrapportage en was in een meerderheid van de zaken onduidelijk of het voorgenomen verzoek tot ondertoezichtstelling/uithuisplaatsing met de minderjarige was besproken in een adviesgesprek. Ook hier lijkt met invoering van de Wet herziening kinderbeschermingsmaatregelen een belangrijke stap voorwaarts te zijn gezet. Zoals eerder aangehaald moet in de huidige situatie op grond van art. 799a lid 2 Rv het verzoekschrift vermelden of het verzoek met de minderjarige is besproken en zo ja, welke reactie de minderjarige op het verzoek heeft gegeven. Met name het feit dat de reactie van minderjarige 
terug moet komen in het verzoekschrift is verheugend in het licht van de vereisten die voortvloeien uit art. 12 IVRK. De tussenevaluatie van de Wet herziening kinderbeschermingsmaatregelen laat zien dat na 2015 in vrijwel alle zaken door de RvdK wordt aangegeven of het verzoek met de minderjarige is besproken. Aandachtspunt is dat het daar soms bij blijft, terwijl de wet ook verplicht aan te geven welke reactie de minderjarige heeft gegeven.

Tot slot heeft het dossieronderzoek laten zien dat rechters voor 2015 af en toe in de beschikking op het verzoek tot ondertoezichtstelling/uithuisplaatsing aandacht besteedden aan de mening van de minderjarige. In 11\% van de onderzochte beschikkingen werd de mening van de minderjarige ten aanzien van de verzochte maatregel expliciet weergegeven. Naar aanleiding van het dossieronderzoek is geconcludeerd dat mede in het licht van art. 12 IVRK het mogelijk en wenselijk is voor de kinderrechter om vaker de mening van de minderjarige mee te wegen in de beschikking. Er zijn geen onderzoeksgegevens op basis waarvan kan worden geconcludeerd of dit percentage na 2015 is toegenomen. Wel is duidelijk dat de ontwikkelingen van de afgelopen jaren wijzen op toegenomen aandacht voor de manier waarop de minderjarige beter geïnformeerd kan worden over de rol die zijn mening in de besluitvorming heeft gespeeld. In de literatuur wordt de beschikking aangewezen als de meest voor de hand liggende plek hiervoor. Mogelijkheden om de minderjarige beter te informeren zijn het uitwerken van de beschikking in kindvriendelijke taal of het opnemen van een apart deel in de beschikking waarin de minderjarige uitleg krijgt over de beslissing.

\subsection{Afsluitende aanbevelingen}

Dit onderzoek heeft diverse knelpunten aan het licht gebracht waar het ging om de rechtvaardiging van de ondertoezichtstelling, de rechtvaardiging van de uithuisplaatsing, de zorgvuldigheid van het feitenonderzoek en de rechtspositie van de minderjarige en zijn ouders. Deel III van het onderzoek heeft laten zien dat door wijzigingen in wetgeving en beleid vanaf 2015 de geconstateerde knelpunten voor een deel zijn weggenomen. Duidelijk is echter dat de gewijzigde jeugdbeschermingswetgeving niet alle knelpunten heeft weggenomen en op bepaalde punten ook weer heeft gezorgd voor nieuwe knelpunten. Onder meer is uitgebreid aandacht besteed aan de uitdagingen die in de praktijk sinds 2015 zijn ontstaan bij de afweging tussen gezagsbeperking en gezagsbeëindiging. 
Tot slot worden op basis van de conclusies een aantal aanbevelingen geformuleerd gericht op een (verdere) verbetering van de rechtvaardiging van de ondertoezichtstelling en de uithuisplaatsing.

\section{1) Rechtvaardiging van de ondertoezichtstelling}

a. Tracht de onzekerheid over de toepassing van de wettelijke grond 'ernstige ontwikkelingsbedreiging' te verkleinen

Het onderzoek heeft laten zien dat de flexibiliteit die de rechtsgrond van de ondertoezichtstelling op dit punt biedt als keerzijde heeft, dat onvoldoende duidelijk is wanneer in het concrete geval de ontwikkelingsbedreiging van de minderjarige ernstig genoeg is om een ondertoezichtstelling te rechtvaardigen. Dat was zo onder de jeugdbeschermingswetgeving van voor 2015 en is na de wettelijke herziening in 2015 zo gebleven. Tegelijkertijd lijkt er aan de zijde van de wetgever, in de uitvoeringspraktijk en onder betrokkenen duidelijk behoefte aan meer zekerheid over de afwegingen omtrent de ernst van de ontwikkelingsbedreiging. De weg om dit bereiken ligt niet in een verdere aanscherping van de wet, maar gekeken moet worden of beter inzichtelijk kan worden gemaakt hoe de zorgen ten aanzien van de ontwikkeling van de minderjarige in de praktijk worden gewogen. In dit onderzoek is hiervoor een eerste aanzet gegeven. In eventueel vervolgonderzoek zou het van toegevoegde waarde zijn ook vanuit gedragswetenschappelijk perspectief naar de invulling van de ernstige ontwikkelingsbedreiging van de minderjarige in jeugdbeschermingszaken te kijken.

\section{b. Zorg dat de concrete bedreiging in de ontwikkeling van de minderjarige ook moet worden} benoemd in de beschikking op een verlengingsverzoek

Het onderzoek heeft laten zien dat de verplichting om de concrete bedreigingen in de ontwikkeling van de minderjarige op te nemen in het verzoekschrift tot ondertoezichtstelling (op grond van art. 799 lid $1 \mathrm{Rv}$ ) en in de beschikking op het verzoek (art. 1:255 lid 4 BW) positief bijdraagt aan de onderbouwing van de noodzaak van een ondertoezichtstelling. Zeker in de beschikking lijkt nu veel minder vaak te worden volstaan met een standaardmotivering ten opzichte van de periode voor 2015. De wettelijke plicht om de concrete bedreigingen in de beschikking op te nemen is echter niet in de wet opgenomen voor de beschikking op het verzoek tot verlenging van de ondertoezichtstelling. De tussenevaluatie van de jeugdbeschermingswetgeving heeft laten zien dat bij de beschikking op het verzoek tot 
verlenging van de ondertoezichtstelling het percentage zaken waarin de kinderrechter de concrete bedreigingen opneemt, ver wegzakt. Het is net zo belangrijk in deze gevallen de bedreigingen concreet te maken aangezien de minderjarige en zijn ouders dan zien waar ze na (vaak een jaar) ondertoezichtstelling staan.

c. Wijzig de wettelijke grond 'het niet, of onvoldoende accepteren van de noodzakelijke zorg' op een zodanige manier dat het resultaat van de eerdere hulpverlening weer centraal komt te staan

De rechtsgrond van de ondertoezichtstelling op dit punt (art. 1:255 lid $1 \mathrm{BW}$ ) beoogt een duidelijke grens te markeren tussen het vrijwillig kader en de gedwongen hulpverlening. Op basis van dit onderzoek en de evaluatie van de jeugdbeschermingswetgeving moet worden geconcludeerd dat 'het niet of onvoldoende accepteren van de noodzakelijke zorg' hiervoor niet het juiste criterium lijkt. De wetgever is er kennelijk van uitgegaan dat een ondertoezichtstelling alleen bestemd moet zijn voor de groep ouders (en minderjarigen) die nergens aan willen meewerken. Daarmee is onvoldoende onderkend dat er ook een behoorlijke groep ouders en minderjarigen is die de noodzakelijke zorg wel accepteert en ook bereid is dit te blijven doen, maar dat toch de noodzaak wordt gezien van een ondertoezichtstelling. Een resultaatgerichte formulering (waarbij het de vraag is of het woord 'falen' zoals in de wet was opgenomen voor 2015 de meest passende formulering is), lijkt beter aan de sluiten bij de afwegingen die in de praktijk moeten worden gemaakt over de noodzaak van het gedwongen kader.

\section{d. Stimuleer de toetsing van alle cumulatieve gronden in de rechtsgrond van de ondertoezichtstelling}

Het onderzoek heeft laten zien dat de RvdK en de kinderrechter voor 2015 in het kader van de ondertoezichtstelling vaker inhoudelijk aandacht besteedden aan de bedreigde ontwikkeling van de minderjarige dan aan het vereiste dat de hulpverlening had gefaald of voorzienbaar zou falen. Met de Wet herziening kinderbeschermingsmaatregelen in 2015 is juist in de wet opgenomen dat in verzoekschriften en beschikkingen duidelijk(er) moet worden aangegeven waar de concrete bedreigingen in de ontwikkeling van de minderjarige uit bestaan. Dat geldt niet voor de tweede cumulatieve grond voor de ondertoezichtstelling waarin tot uitdrukking komt dat vrijwillige hulpverlening onvoldoende is om de bedreiging in de ontwikkeling weg te nemen. Het verdient aanbeveling dat de RvdK en de kinderrechter ook deze grond consequent toetsen, bovenal omdat het onderzoek heeft laten zien dat als het verzoek tot 
ondertoezichtstelling wordt afgewezen, dit gebeurt omdat onvoldoende vast is komen te staan dat vrijwillige hulpverlening heeft gefaald.

\section{e. Overweeg om in de wet beter tot uitdrukking te laten komen dat de aanvaardbare termijn} ziet op een situatie waarin de minderjarige uit huis wordt of is geplaatst

Het onderzoek heeft aangetoond dat de aanvaardbare termijn zoals thans neergelegd in de rechtsgrond van de ondertoezichtstelling inhoudelijk ziet op de afweging over het opvoedperspectief van de minderjarige. In de tussenevaluatie van de Wet herziening kinderberschermingsmaatregelen en in de rechtspraak is bevestigd dat een aanvaardbare termijn pas wordt gesteld en een verwachting over het opvoedperspectief van de minderjarige wordt uitgesproken op het moment dat de minderjarige uit huis wordt geplaatst. De functie van de aanvaardbare termijn in het kader van een 'kale' ondertoezichtstelling lijkt afwezig, omdat in die situatie het opvoedperspectief van de minderjarige niet ter discussie staat. Voor een zo effectief mogelijk functionerend systeem van jeugdbeschermingsmaatregelen is het belangrijk dat de wettelijke gronden zo goed mogelijk aansluiten bij de afwegingen die in de praktijk gemaakt moeten worden. In dit licht verdient het aanbeveling de aanvaardbare termijn in de rechtsgrond van de uithuisplaatsing op te nemen.

\section{2) Rechtvaardiging van de uithuisplaatsing}

a. Laat in de rechtsgrond van de uithuisplaatsing beter tot uitdrukking komen hoe de noodzaak van een scheiding van kind en ouders moet worden aangetoond Het dossieronderzoek heeft aangetoond dat de onderbouwing van de noodzaak tot uithuisplaatsing (zeker in vergelijking met de onderbouwing van de noodzaak tot ondertoezichtstelling) summier was. De beginselen van subsidiariteit en proportionaliteit die kunnen worden ontleend aan het recht op familie- en gezinsleven (art. 8 EVRM) kwamen onvoldoende tot uiting in de besluitvorming van de $\mathrm{RvdK}$ en de kinderrechter. Zo is geconcludeerd dat onvoldoende aandacht werd besteed aan alternatieven om de uithuisplaatsing te voorkomen en mocht een uithuisplaatsing toch noodzakelijk worden gevonden, waarom de specifieke vorm van plaatsing noodzakelijk was voor de minderjarige. In 2015 is de rechtsgrond van de uithuisplaatsing niet gewijzigd, terwijl als in de huidige 
situatie een uithuisplaatsing wordt opgelegd, ook veel eerder en nadrukkelijker wordt gekeken of gezagsbeëindiging in het belang is van de minderjarige. Het verdient daarom aanbeveling het noodzaakcriterium in de rechtsgrond van de uithuisplaatsing (art. 1:265b BW) te concretiseren. In de rechtsgrond zou beter tot uitdrukking kunnen worden gebracht dat de noodzaak moet blijken uit het feit dat andere, minder ingrijpende alternatieven onvoldoende zijn om belangen en veiligheid van de minderjarige te waarborgen. Daarnaast zou de verzoeker steeds moeten beargumenteren waarom een specifieke machtiging noodzakelijk is.

\section{b. Overweeg om de aanvaardbare termijn als tweede cumulatieve grond aan de rechtsgrond} van de uithuisplaatsing toe te voegen

Deze aanbeveling is reeds besproken bij de aanbevelingen ten aanzien van de ondertoezichtstelling. De vraag of de verwachting gerechtvaardigd is of de ouders weer de verantwoordelijkheid voor de verzorging binnen een voor de minderjarige aanvaardbare termijn kunnen dragen of dat het opvoedperspectief van de minderjarige elders ligt, wordt beantwoord als een uithuisplaatsing wordt verzocht of is opgelegd. Door de aanvaardbare termijn neer te leggen in de rechtsgrond van de uithuisplaatsing (art. 1:265b BW) wordt ook beter tot uitdrukking gebracht in de wet dat, hoewel de uithuisplaatsing als middel wordt beschouwd binnen de ondertoezichtstelling, het om een zelfstandige afweging gaat met verstrekkende gevolgen voor de betrokkenen.

\section{c. Overweeg in het Burgerlijk Wetboek op te nemen dat de uithuisplaatsing primair in het} teken moet staan van een hereniging van de minderjarige en zijn ouders

In het Burgerlijk Wetboek is alleen voor de maatregel van ondertoezichtstelling een wettelijke doelstelling opgenomen. Het bieden van hulp en steun aan kind en ouder teneinde de ontwikkelingsbedreiging weg te nemen (art. 1:262 BW) is zonder meer ook relevant voor de uitvoering van de uithuisplaatsing maar benoemt onvoldoende expliciet dat binnen de uithuisplaatsing gestreefd moet worden naar een terugkeer van de minderjarige naar huis. Onder de huidige wetgeving is het doel van hereniging van het gezin nog belangrijker geworden, aangezien gezagsbeëindiging nadrukkelijk in beeld komt indien hereniging niet haalbaar is gebleken. In de huidige uitvoeringspraktijk is zichtbaar dat in de uitvoering van de uithuisplaatsing soms onvoldoende wordt geïnvesteerd in een terugkeer van de minderjarige naar huis, onder andere omdat passende hulpverlening niet tijdig beschikbaar is. Het doel van hereniging van het gezin opnemen in de wet lost laatstgenoemd probleem niet op, maar kan er wel voor zorgen dat de autoriteiten in alle fasen van het 
besluitvormingsproces scherp(er) toetsen of de maatregel overeenkomstig de doelstelling wordt of is uitgevoerd.

\section{3) Rechtvaardiging van gezagsbeëindiging}

a. Zorg dat in het verzoek en de beschikking tot gezagsbeëindiging de mate van onzekerheid die de minderjarige ervaart wordt geconcretiseerd

Gezagsbeëindiging kan op basis van de wet worden overwogen indien de minderjarige ernstig in zijn ontwikkeling wordt bedreigd en de verwachting niet gerechtvaardigd is dat de ouders of de ouder die het gezag uitoefenen binnen een gelet op de persoon en ontwikkeling van de minderjarige aanvaardbaar te achten termijn, de verantwoordelijkheid voor de verzorging en opvoeding, bedoeld in art. 1:247 lid 2 BW, in staat zijn te dragen. De aanvaardbare termijn wordt primair bepaald door te kijken naar de mate van onzekerheid die de minderjarige ervaart over zijn opvoedperspectief. Het verstrijken van de aanvaardbare termijn veronderstelt derhalve dat overtuigend kan worden aangetoond dat de minderjarige onzekerheid ervaart en die onzekerheid met het oog op zijn ontwikkeling niet langer kan voortduren. Dat de minderjarige onzekerheid ervaart over zijn opvoedperspectief na uithuisplaatsing is aannemelijk maar niet vanzelfsprekend. Aangezien deze onzekerheid de belangrijkste grondslag voor beëindiging van het gezag vormt is het belangrijk dat de mate van onzekerheid in iedere zaak afzonderlijk wordt aangetoond (en niet slechts wordt aangenomen).

\section{b. Overweeg in de wet op te nemen welk doel met de gezagsbeëindigende maatregel wordt} nagestreefd

Uit de toelichting van de wetgever over de maatregel van gezagsbeëindiging is het doel dat met de maatregel wordt nagestreefd te herleiden: het creëren van stabiliteit en continuïteit in de opvoedsituatie van de minderjarige waardoor de onzekerheid ten aanzien van de vraag waar zijn opvoedperspectief ligt wordt weggenomen. In de praktijk blijkt gezagsbeëindiging niet altijd aan deze doelstelling te kunnen voldoen, bijvoorbeeld omdat een stabiel perspectiefbiedend pleeggezin (nog) niet beschikbaar is voor de minderjarige, op het moment dat wordt besloten over het verzoek tot gezagsbeëindiging. In de praktijk wordt verschillend gedacht over de vraag of gezagsbeëindiging gerechtvaardigd kan zijn als de minderjarige hierdoor geen duidelijkheid krijgt over zijn opvoedperspectief. Het is opvallend dat in de wet niet aangeeft welk doel met de gezagsbeëindiging (en de daarmee verbonden voogdijmaatregel) wordt nagestreefd. 


\section{4) Zorgvuldigheid van het feitenonderzoek}

Benut art. 3.3 Jeugdwet om tot een integraal afwegingskader te komen voor feitenonderzoek De wijze waarop in het dossieronderzoek over de periode 2013 en 2014 is gekeken naar de feitenverzameling kan een richtsnoer bieden bij de nadere bepaling hoe informatie in jeugdbeschermingszaken moet worden gewogen en beoordeeld. Het is in dit licht noodzakelijk dat meer duidelijkheid komt over wat in het kader van jeugdbeschermingszaken wordt beschouwd als feitelijke informatie en waar het gaat om de mening of visie van een informant of betrokkene. Op dit moment is nergens in de wet maar ook niet in de bredere discussie over waarheidsvinding aandacht besteed aan het inhoudelijke onderscheid tussen feiten en meningen. Zonder verheldering van dit onderscheid kan het feitenonderzoek niet verbeterd worden. Een concreet uitgewerkt toetsingskader met als grondslag 'de waarheidsplicht' van art. 3.3. Jeugdwet maakt het mogelijk de kwaliteit van het feitenonderzoek nadrukkelijker te toetsen.

\section{5) Rechtspositie van de minderjarige en zijn ouders}

a. Overweeg aanpassing van de wettelijke leeftijdgrens van het hoorrecht van minderjarigen In het onderzoek is geconstateerd dat minderjarigen jonger dan twaalf jaar ten aanzien van het verzoek tot ondertoezichtstelling niet of nauwelijks werden gehoord door de kinderrechter. Deze uitkomst bevestigde het beeld dat het horen van twaalf-minners slechts sporadisch voorkwam. Onderzoek gericht op de periode na 2015 heeft laten zien dat het horen van twaalf-minners nog steeds bij uitzondering plaatsvindt. Wel lijkt hier langzaam verandering in te komen. De Rechtbank Amsterdam heeft sinds 2016 het initiatief genomen om minderjarigen vanaf 8 jaar actiever te gaan benaderen met de vraag of zij gebruik wensen te maken van hun hoorrecht. Daarnaast wordt in diverse onderzoeken geadviseerd de wettelijke leeftijdsgrens voor het horen van minderjarigen te verlagen van twaalf naar acht jaar. Er lijken vanuit juridisch, gedragswetenschappelijk- en neuropsychologisch perspectief geen belemmeringen om de leeftijdsgrens te verlagen. 
b. Overhandig als RvdK de gehele conceptrapportage aan de minderjarige vanaf twaalf jaar tenzij dit niet in zijn belang is

Het dossieronderzoek heeft laten zien dat in de bestreken onderzoeksperiode vrijwel altijd inzage werd gegeven in de conceptrapportage door de RvdK, maar dat de minderjarige voor schriftelijke informatie over de besluitvorming vaak afhankelijk was van zijn ouders. Dit kwam voort uit het feit dat de minderjarige onder de twaalf jaar geen conceptrapportage ontving en de minderjarige tussen de twaalf en zestien, in de regel alleen 'zijn kinddeel'. Het kinddeel bevatte slechts een weergave van het gesprekverslag met de minderjarige, zonder dat nadere informatie over de onderzoeksafwegingen werd verstrekt. In het Kwaliteitskader 2016 van de RvdK is dit uitgangspunt ongewijzigd overgenomen. Geconcludeerd is dat er geen overtuigende argumenten zijn om de minderjarige niet vanaf twaalf jaar de volledige conceptrapportage te geven. Als dit aantoonbaar niet in zijn belang is zou de RvdK altijd nog kunnen besluiten alleen het kinddeel te overhandigen. 


\section{Summary in English}

In the Dutch system of child protection, children can be offered protection by applying one of the child protection orders. Imposing a child protection order means an interference with the right to respect for family life of children and parents. This $\mathrm{PhD}$ thesis studies the justification of child protection. Legal justification of child protection refers here to the substantiation of the need for a family supervision order, with or without placement into care. Two different parts of the decision making process in child protection cases have been analysed. First of all, the report of the Child Protection Board that is part of the request to the court to impose a family supervision order. And second, the written judgment of the Youth Court judge concering the requested child protection order by the Child Protection Board.

This research can be divided into three parts. In the first part (Chapters 2-4) the child protection legislation that applied in 2013 and 2014 is described. The procedural requirements that applied to the child protection procedure in the aforementioned years and the most important criteria for the fact-finding investigation by the Child Protection Board are described in Chapter 2. In Chapter 3 attention is paid to the legal position of the minor and his parents in the child protection procedure. According to Dutch child protection law, minors are considered incapable of autonomously participating in legal proceedings. Due to the minor's procedural incapacity, his legal position is mainly fulfilled by the right to be heard. On the basis of national legislation and applicable treaty law (in particular article $12 \mathrm{CRC}$ ), the most important elements of the right to be heard of minors are described. Chapter 4 elaborates on the legal grounds and legal objectives of the child protection measures as they applied in 2013 and 2014. The legal grounds in the Dutch Civil Code ultimately determine when the facts and circumstances are such that a child protection measure is justified. In addition, the objectives pursued by the family supervision order and the placement of the child are equally important when it comes to the justification of child protection in practice.

The principles and criteria that are described form the basis for the analysis of the reports by the Child Protection Board and the Youth Court judgments in the second part of this thesis. The second part concerns an emperical study focusing on the application of child protection law in practice. In Chapter 5 the methodology of the emperical part of this study is discussed. A random sample of 200 cases from the Child Protection Board was taken, 100 cases involving a request for a family supervision order and 100 cases involving a request for a family supervision order combined with a request for a placement into care. Three different elements of legal justification are systematically examined. First, the way in which the legal 
grounds and objectives are applied by the Dutch Child Protection Board and the Youth Court Judge in the decision making process (Chapters $6 \& 7$ ). Secondly, a number of aspects are analysed that are related to the fact-finding investigation that is carried out by the Child Protection Board. Third, the procedural position of children and the implementation of their right to be heard in child protection procedures was studied (Chapter 8).

In Chapter 9 parts one and two of the research are briefly summarized and the first central research question is answered: to what extent was the justification of a family supervision order, with or without a placement of the child into care, by the Child Protection Board and the Youth Court judge in accordance with the (inter)national legislation and regulations applicable in 2013 and 2014?

The emperical research shows there was only small chance that the justification of child protection by the Child Protection Board and the Youth Court judge in any individual case was substandard on all fronts examined. In 2013 and 2014, the safeguards based on national and international laws and regulations were already integrated to a certain extent in the assessment framework of the Child Protection Board and the Youth Court judge. However, specific shortcomings have been identified with regard to the application of substantive child protection law, the implementation of the fact-finding investigation by the Child Protection Board and the procedural position of the minor and his parents.

Important legislative amendments with regard to the child protection legislation came into force on the first of January 2015. This led to a significant shift of the legal conditions for the family supervision order and the discharge of parental authority. Also on the first of January 2015 a new Youth Act came into force. The Youth Act lays down the rules regarding responsibility for prevention, support and care (including child protection) for minors and parents in case of upbringing and/or parenting problems. With both legislative amendments, the legislator aimed at a more effective and efficient system of youth care and child protection. The purpose of the third and last part of this thesis is twofold. In the first place, to provide a general description of the changes that have been made to legislation and policy that are relevant to this study. Secondly, the results of the emperical research focusing on the justification of child protection in 2013 and 2014 were used to reflect on the most important changes in legislation and policy since 2015. What the specific changes mean for the results with regard to the legal conditions and objectives of the child protection orders, the factfinding investigation by the Child Protection Board and the procedural position of the minor and his parents, is therefore discussed in Chapter 10. 


\section{Literatuurlijst}

Aalders 2018

Aalders, H.C.M., 'De rechtspraktijk inzake gezagsbeëindiging vanuit kinderrechtelijk

perspectief', FJR 2018/63.

Van Aken 2007

Aken, C. van. Junger, M., Verhoeven, M., Aken, M. A. G. van, \& Deković, 'The interactive effects of temperament and maternal parenting on toddlers' externalizing behaviors', Infant and Child Development 2007.

Alink 2011

Alink, L., Van Ijzendoorn, R., Bakermans-Kranenborg, M., Pannebakker, F., Vogels, T., Euser, S., De tweede nationale prevalentiestudie mishandeling van kinderen en jeugdigen (NPM-2010), Universiteit Leiden, TNO 2011.

Angius 2015

Angius, M., 'Family life in spagaat', FJR 2015/14.

Antokolskaia 2013

Antokolskaia, M.V., 'Van politiek gestuurde wetgeving naar evidence based wetgeving: Nog een lange weg te gaan', in: Van Boom, W., Giesen, I., Verheij, Capita Civilologie. Handboek empirie en privaatrecht, Den Haag: Boom Juridische Uitgevers, 2013.

Asser 2006

Asser, W.D.H. ; Damen, L.J.A. ; Knigge, G. / Partijautonomie of materiële waarheid? bijdragen afscheidssymposium G. Knigge d.d. 15 september 2005. Den Haag : Boom Juridische uitgevers, 2006 (CRBS-reeks).

Asser \& Vranken 1995

Asser, V. \& Vranken, J.B.M., Mr. C. Asser's handleiding tot de beoefening van het

Nederlands burgerlijk recht, Algemeen deel [2], Zwolle: W.E.J. Tjeenk Willink 1995.

Baeke 2009

Baeke, J.A.H., De Boer, R., Bremmer, P.J.J., Duenk, M., Kroon, D.J.J., Loeffen, M.M., Mobach, C.E., Schuyt, M., Evaluatieonderzoek Wet op de Jeugdzorg, BMC-groep.

Bakker \& Bentem 2012

Bakker, R. \& Bentem, B., 'Het indicatiebesluit: waarborg of formaliteit', in: Forder, C., 
Duijst, W., Wolthuis, A., Kindvriendelijke opsluiting. Gesloten plaatsing in het licht van mensenrechten. Stichting NJCM-Boekerij 53: Leiden 2012.

Bartelink 2013

Bartelink, C., Addink, A., Udo, N., Van der Haar-Bolwijn, F., Van Yperen, T., Betrouwbaar en valide beslissen over uithuisplaatsing, Utrecht: Nederlands Jeugdinstituut 2013.

Uit Beierse, Logtenberg \& Rietbergen 2010

Uit Beierse, J., Logtenberg, K., Rietbergen, M., Zorg om de jeugdzorg, Boom Lemma Uitgevers 2010.

Uit Beierse 2016

Uit Beierse, J., 'Jeugdigen in justitiële jeugdinrichtingen en jeugdzorgplus: gescheiden, maar ook een andere rechtspositie?', FJR 2016/9.

Berends 2010

Berends, I.E., Campbell, E.E., Wijgergangs, E., Bijl, B., Bescherming bekeken. Een onderzoek naar ontwikkelingen en regionale verschillen in het aantal ondertoezichtstellingen en machtigingen uithuisplaatsingen, PI Research/WODC 2010.

Blaak 2012

Blaak, M., Bruning, M.R., Eigenraam, M., Kaandorp, M., Meuwese, S., Blaak e.a., Handboek Internationaal Jeugdrecht, Leiden: Defence for Children 2012.

De Bock 2011

De Bock, R. H., Tussen waarheid en onzekerheid (diss. Universiteit Tilburg), Deventer: Kluwer 2011.

Boele Woelki 2015

Boele-Woelki, K.,'Europees en internationaal familierecht', in:

Schrama, W. M., Antokolskaia, M. V., \& Ruitenberg, G. C. A. M. (2015). Familierecht: Een introductie ( $2^{\mathrm{e}}$ editie), Den Haag: Boom Juridische uitgevers.

De Boer \& Bruning 2018

De Boer, R., \& Bruning, M.R., 'Eerste evaluatie jeugdwet vanuit juridisch perspectief', FJR 2018/46.

Van den Bosch \& Rijbroek 2020

Van den Bosch, H., \& Rijbroek, B., 'De wettelijke kaders van de jeugdbescherming. 
Inventariserende studie naar de heersende opvattingen over aanscherping van de rechtsgronden voor kinderbeschermingsmaatregelen', Nederlands Jeugdinstituut 2020.

\section{Van Boom 2013}

Van Boom, W.H., 'Empirisch privaatrecht: enige beschouwingen over de rol van empirisch onderzoek in de hedendaagse privaatrechtswetenschap', TPR 2013/1.

Brands-Bottema 1988

Brands-Bottema, G.W., Overheid en opvoeding (diss. Amsterdam, UvA), Arnhem: Gouda Quint 1988.

De Bruijn-Luckers 1994

De Bruijn-Luckers, M.L.C.C., EVRM, minderjarigheid en ouderlijk gezag (diss. Universiteit Leiden), Tjeenk Willink: Zwolle 1994.

Bruning 2001

Bruning, M.R., Rechtvaardiging van kinderbescherming (diss. VU Amsterdam), Deventer:

Kluwer 2001.

Bruning 2007

Bruning, M.R., 'Equality of arms bij jeugdbescherming', FJR 2007/1.

Bruning 2010

Bruning, M.R., 'Toekomst jeugdzorg', FJR 2010/58.

Bruning 2011

Bruning, M. R., 'De ondertoezichtstelling herzien - snellere bemoeienis met meer rechtswaarborgen', $A A$ 2011, p. 779-788.

Bruning 2012

Bruning, M. R., 'Bijzondere curator: we want more!', FJR 2012/68.

Bruning 2019

Bruning, M. R., GS Personen- en familierecht, art. 1:255 BW, aant. 8.5, actueel tot 16-92019.

Bruning 2020

Bruning, M.R., 'Zorg om de jeugdzorg; kinderrechters aan zet?', AA 2020/5. 
Bruning \& Liefaard 2009

Bruning, M. R., \& Liefaard, T., 'Ontwikkelingen en knelpunten in de gesloten jeugdzorg', FJR 2009/42.

Bruning, Liefaard \& Vlaardingerbroek 2014

Bruning, M. R., Liefaard, T. \& Vlaardingerbroek, P., Jeugdrecht en jeugdhulp, ( $7^{\mathrm{e}}$ herziene druk), Amsterdam: Reed Bussiness Education 2014.

Bruning \& van der Zon 2013

Bruning, M., \& Van der Zon, K., 'Out of home, out of right? Rechten van minderjarigen bij uithuisplaatsing', NJCM bulletin 2013/39.

Buysse 2010

Buysse, W., Hilhorst, N., Broeders, A.-M., Loef, L., Gezinsbegeleiding in vrijwillig en gedwongen kader, Amsterdam: DSP-groep/WODC 2010.

Cardol, Galama \& Kuipers 2013

Cardol, G., Galama, I., Kuipers, M., 'Herziening maatregelen van kinderbescherming', FJR 2013/41.

Cardol \& Van Rheenen 2012

Cardol, G., Van Rheenen, A., 'De instemmingsverklaring: waarborg of formaliteit', in:

Forder, C., Duijst, W., Wolthuis, A., Kindvriendelijke opsluiting. Gesloten plaatsing in het licht van mensenrechten. Stichting NJCM-Boekerij 53: Leiden 2012.

Cleiren 2001

C.P.M. Cleiren, 'Waarheid in het strafrecht: niet tot elke prijs', in: C.P.M. Cleiren, R.H. de Bock en C.J.M. Klaassen, Het procesrecht en de waarheidsvinding, preadviezen voor de Nederlandse Vereniging voor Procesrecht, Den Haag: Boom Juridische uitgevers 2001

Coenraad 2015

Coenraad, L., 'Procesrecht' In: Antokolskaia, M. V., \& Schrama, W. M., Familierecht. Een introductie 2 de druk. Den Haag: Boom Juridische uitgevers 2015.

Colpin 2000

Colpin, H., L. Vandemeulebroecke en A. de Munter, 'Opvoeding in eenoudergezinnen: een 
overzicht van de onderzoeksliteratuur', in: 'Tijdschrift voor Orthopedagogiek,

Kinderpsychiatrie en Klinische Kinderpsychologie', 25, p. 31-44. Bucx, F, 2000.

Daly 2011

"The right of children to be heard in civil proceedings and the emerging law of the European

Court of Human Rights", International Journal of Human Rights 2011, volume 15, nr. 3, 447.

Davids 2010

Davids, W.E.M., 'Verstandelijk gehandicapten met een kinderwens: De afweging tussen zelfbeschikking, maatregelen en preventie', FJR 2010/5.

Dekovic \& Prinzie 2014

Dekovic, M., Prinzie, P., 'De rol van het gezin in de ontwikkeling van antisociaal gedrag', In:

Weijers \& Eliaerts 2014, Achtergronden van jeugdcriminaliteit, Den Haag: BJU, 2014.

Dekker 2016

Dekker, M., Effectiviteit aan de horizon: Een studie rond onderzoek naar resultaat op het gebied van de justitiële kinderbescherming in Nederland tussen 1945 en 2005. (diss.

Rijksuniversiteit Groningen 2016)..

Detrick 1999

Detrick, S., A commentary on the UN Convention on the Rights of the Child (diss. VU Amsterdam), Den Haag: Kluwer 1999.

Doek 1972

Doek, J. E., Vijftig jaar ondertoezichtstelling. Schets van het ontstaan en ontwikkeling van een maatregel van kinderbescherming (diss. Amsterdam VU), Zwolle:Uitgeversmaatschappij Tjeenk Willink 1972.

Doek 1980

Doek, J.E., Het kind en zijn recht, beschouwingen over en voorstellen tot verbetering van de rechtspositie van het kind, Rotterdam: Kooyker Wettenschappelijke Uitgeverij 1980.

Doek 1988

Doek, J.E., 'Ondertoezichtstelling en het belang van het kind: een toverformule in het kwadraat?', in: A. v.d. Linden en P. Vlaardingerbroek (red), Met het oog op het belang van het kind, Deventer: Kluwer, 1988. 
Doek 2008

Doek, J. E., 'De herziening jeugdbescherming: IVRK-proof?, in: Bruning, M. R., \& Kok, J. (red.), Herziening kinderbeschermingsmaatregelen. Commentaren op het voorontwerp van wet. FJR Congesbundel, Deventer: Kluwer 2008.

Doek \& Slagter 1976

Doek, J.E., Slagter, S., Meer rechten voor minderjarigen. Beschouwingen over een toekomstige rechtspositie voor minderjarigen. Utrecht 1976.

Dorenberg 2014

Dorenberg, V.E.T., 'Transitie jeugdzorg: een thematische beschouwing van de gevolgen voor de jeugd-GGZ en de jeugd-LVB', FJR 2014/61.

Dorhout 2012

Dorhout, P., 'Afwijzing verzoek voorlopige ondertoezichtstelling in verband met levensvatbaarheidsgrens ongeboren vrucht', FJR 2012/50.

Dorsselaer 2010

Dorsselaer, M. van, M. de Looze, E. Vermeulen-Smit S. de Roos, J. Verdurmen, T. ter Bogt en W. Vollebergh, Gezondheid, welzijn en opvoeding van jongeren in Nederland. HBSC 2009. Utrecht, Trimbos-instituut.

Van Emmerik 2005

Van Emmerik, M., 'Toepassing van het kinderrechtenverdrag in de Nederlandse rechtspraak', NJCM-Bulletin, 2005, nr. 6

Fiege 1993

Fiege, M., De autonomie van de minderjarige in het recht : een onderzoek naar de materiële en processuele handelingsonbekwaamheid van minderjarigen (diss. UvA), Arnhem: Gouda Quint 1993.

Forder 2008

Forder, C., 'Gaat het voorontwerp van de Wet herziening kinderbeschermingsmaatregelen te ver of juist niet ver genoeg? Het voorontwerp getoetst aan het Europees Verdrag voor de Rechten van de Mens, in: Bruning \& Kok (red.), Herziening kinderbeschermingsmaatregelen. Commentaren op het voorontwerp van wet. FJR Congesbundel, Deventer: Kluwer 2008. 
Forder 2012

Forder, C., in:Weijers, I., Parens Patriae en prudentie. Grondslagen van jeugdbescherming (oratie Utrecht), Amsterdam, SWP Uitgeverij 2012.

Forder 2013

Forder, C., GS Personen- en familierecht, commentaar op art. 1:254 BW, actueel tot 1-32013.

Friele 2018

Friele, R. D., Bruning, M.R., Bastiaanssen, I.L.W., De Boer, R., Bucx, A.J.E.H, De Groot, J.F., Pelivahn, T., Rutjes, L., Sondeijker, F., Van Yperen, T.A., Hageraats, R., Eerste evaluatie Jeugdwet. Na de transitie nu de transformatie. Den Haag: ZonMw, januari 2018.

Goderie 2004

Goderie, M., Steketee, M., Mak, J., Wentink, M., Samenplaatsing van jongeren in justitiële jeugdinrichtingen, Utrecht: Verwey-Jonker Instituut, 2004.

De Graaf, Limbeek, Bahadur \& Van der Meij 2012

De Graaf, C., Limbeek, N. M. C. , Bahadur, N.N., Van der Meij, N., De toepassing van het Internationaal Verdrag voor de Rechten van het Kind in de Nederlandse rechtspraak, Ars Aequi Libri Nijmegen 2012.

Gras 2010

Gras, E. 'Heroverweging van artikel 1:234 BW inzake de handelingsonbekwaamheid van minderjarigen', in: Rechten van het kind en autonomie, Nijmegen: Ars Aequi Libri 2010.

Groenhuijsen 2007

Groenhuijsen, E.A., 'Horen of luisteren, het kind in scheidings- en omgangszaken', FJR 2007/101.

De Groot 2008

De Groot, G., Het deskundigenadvies in de civiele procedure (Recht en Praktijk nr. 165), Deventer: Kluwer 2008.

De Groot 2011

De Groot, G., Waarheidsvinding in het civiele (proces)recht, in: Preadviezen Nederlandse Juristen Vereniging 2012, Deventer: Kluwer 2012. 
Ter Haar 2011

Ter Haar, J., 'Kan de minderjarige zelfstandig over zijn arbeidsinkomsten beschikken?', FJR 2011/15.

Hammerstein, De Bock \& Asser 2017

Hammerstein, A., De Bock, R. H., Asser, W. D. H., Modernisering burgerlijk bewijsrecht, Boom Juridisch: Den Haag 2017.

Hepping 2017

Hepping, K., e.a. , 'Rechtsbijstand van ouders in de jeugdbeschermingsprocedure in het licht van EHRM-jurisprudentie', in: Schrama, W. M. (red.), Actuele ontwikkelingen in het familierecht, Ars-Aequi - UCERF reeks 11, 2017.

Huijer 2014

Huijer, J. I., 'Waarheidsvinding in de jeugdbescherming: een juridisch perspectief', $N J B$ $2014 / 673$.

Huijer 2015

Huijer, J.I., 'Herziening kinderbeschermingsmaatregelen: op naar een nieuwe ondertoezichtstelling', FJR 2015/8.

Huijer \& Weijers 2012

Huijer, J. I., \& Weijers, I., 'Tekortkomingen bij de uithuisplaatsing', NJB 2012/2238.

Huijer \& Weijers 2016

Huijer, J. I., \& Weijers, I., 'De aanvaardbare termijn in jeugdbeschermingszaken', FJR $2016 / 40$.

Van der Heide 2010

Heide, K. van der , 'Thuiswonende deelnemers uit éénoudergezin presteren minder in het middelbaar beroepsonderwijs', in: Bevolkingstrends, le kwartaal 2010. Den Haag: Centraal Bureau voor de Statistiek.

Van IJzendoorn 2008

Van IJzendoorn, M. Opvoeden over de grens. Gehechtheid, trauma en veerkracht. Amsterdam: Boom, 2008. 
De Jong-De Kruijf 2019

De Jong-de Kruijf, M.P., Legitimiteit en rechtswaarborgen bij gesloten plaatsing van kinderen (diss. Universiteit Leiden), Boom Juridisch 2019.

De Jong-de Kruijf \& Van der Zon 2015

De Kruijf- de Jong, M.P. \& Van der Zon, K., 'Hoger beroep tegen een uithuisplaatsingsbeslissing en de rol van de minderjarige. TREMA 2015-11.

Jonker 2015

Jonker, M., Van Spaendonck, R., Tigchelaar, J., 'Religie en cultuur in familierechtelijke beslissingen over kinderen, Familie \& Recht, 2015/9.

Juffer 2010

Juffer, F., Beslissingen over kinderen in problematische opvoedingssituaties. Inzichten uit gehechtheidsonderzoek, Sdu uitgevers, Research Memoranda 2010, nr. 6.

Kalidien 2016

Kalidien, S. N., Criminaliteit en Rechtshandhaving, WODC 2016.

Kalverboer 1996

Kalverboer, M., Onderzoek naar de wijze van rapporteren over opvoedings- en verzorgingsproblematiek bij de Raad voor de Kinderbescherming, Direktie Noord (diss. RUG).

Kalverboer \& Zijlstra 2006

Kalverboer, M.E. ; Zijlstra, A.E., Het belang van het kind in het Nederlands recht; voorwaarden voor ontwikkeling vanuit een pedagogisch perspectief. Amsterdam : SWP Uitgeverij, 2006.

Kentie \& Hendriks 2013

Kentie, D.J.D., \& Hendriks, J.A.M., 'Artikel 1:250 BW, de bijzondere curator, in het belang van vechtscheidingskinderen?', EB 2013/93.

De Kinderombudsman 2013

De Kinderombudsman, Is de zorg gegrond?, 10 december 2013.

De Kinderombudsman 2014

De Kinderombudsman, Vechtende ouders, het kind in de knel, 31 maart 2014. 
Klaassen 2001

Klaassen, C. J. M., 'Het burgerlijk procesrecht en de waarheidsvinding', in: Cleiren, C.P.M.;

Bock, R.H. de; Klaassen, C.J.M. (red.), Het procesrecht en de waarheidsvinding, Den Haag :

Boom 2001.

Koens 1994

Koens, M.J.C., Jeugdigen in de knel. Maatregelen van jeugdbescherming in de toekomst (oratie Maastricht), Deventer: Kluwer, 1994.

Koens 2006

Koens, M. J. C., 'De familierechter: een lijdelijk en/of leidend rechter?, FJR 2006/49.

Kok 2017

Kok, J., 'Wet herziening kinderbeschermingsmaatregelen: een analyse van eerste rechtspraak', FJR 2017/36.

Kok, Van den Berg \& Cardol 2003

Kok, J., Van den Berg, M., Cardol, G., 'De toetsende taak OTS: nieuwe ronde nieuwe kansen?, FJR 2003, p. 74.

Komen 1999

Komen, M. , Gevaarlijke kinderen - kinderen in gevaar: De justitiële kinderbescherming en de veranderende sociale positie van jongeren, 1960-1995, SWP:Utrecht, 1999.

Kramer 2018

Kramer, M., 'Jeugdbescherming 2.0: voldoende samenhang Wet herziening kinderbeschermingsmaatregelen en Jeugdwet?', FJR 2018/28.

De Langen 1973

De Langen, M., Recht voor jeugdigen : Onderzoek naar rechten en rechtsbeginselen in het jeugdrecht, Alphen aan den Rijn: Samsom, 1973

Lansdown 2005

Lansdown, G., The evolving capacities of the child, Florence: Unicef: Inocenti research centre 2005.

Van Leuven \& De Klerk 2013

Van Leuven, C.A.R.M., \& De Klerk, M.J., 'Formele en informele rechtsingang(en) minderjarige', $E B$ 2013/32. 
Lieber 2018

Lieber. J.H., 'De rechter en de taal van het kind', FJR 2018/40.

Liefaard 2008

Liefaard, T., Deprivation of Liberty of Children in Light of International Human Rights Law and Standards (Dissertatie, Faculteit der Rechtsgeleerdheid, VU Amsterdam). Antwerpen: Intersentia 2008.

Liefaard 2015

Liefaard, T., 'Procespositie minderjarige', FJR 2015/12.

Liefaard \& Rap 2018

Liefaard, T. \& Rap, S., 'Hoezo kindvriendelijk? Over 'child-friendly justice' ter bevordering van effectieve participatie van kinderen in juridische procedures en besluitvorming', FJR 2018/41.

Van der Linden 2009

Van der Linden, A.P, Ten Siethoff, F.G.A, Zeijlstra-Rijpstra, A.E.I.J, Jeugd en recht. Bohn Stafleu van Loghum: Houten 2009.

Lunnemann, Huijer, Bel \& Lunnemann 2018

Lunnemann, K., Huijer, J.I., Bel, K., Lunnemann, M., Tussenevaluatie Wet herziening kinderbeschermingsmaatregelen, WODC 2018.

Mertens 1993

Mertens, N. M., De ondertoezichtstelling en andere maatregelen van kinderbescherming. Een dossieronderzoek, WODC 1993.

Meyer-Leu 2011

Meyer-Leu, Y., Lemola, S., Daeppen, J., Deriaz, O., Gerber, S., ‘Association of moderate alcohol use and binge drinking during pregnancy with neonatal health', Alcoholism: clinical and experimental research, Vol. 35-No. 9, 2011.

Mink 2012

Mink, E.A., 'De procespositie van de minderjarige in de civiele procedure', EB 2012/41.

Odink 2013

Odink, R., 'Verlenging van de ondertoezichtstelling en uithuisplaatsing: dilemma's in de 
praktijk', in: Bruning \& Liefaard (red.). De ondertoezichtstelling 90 jaar - versleten of vitaal?, Sdu Uitgevers: Den Haag 2013.

Van Ommeren 2012

Van Ommeren, F., 'Een andere visie op de verhouding tussen publiek- en privaatrecht - Van

de 'gemene rechtsleer' naar de 'gemeenschappelijke rechtsleer', $A A$ 2012, 562.

Oosterbaan 2016

Oosterbaan, P.F., Van Huizen, R., Den Outer, B., Rapportage uitvoering compensatieregeling woonplaatsbeginsel 2016, (https://vng.nl/files/vng/nieuws_attachments/2015/20151009rapportage-_uitvoering-_compensatieregeling-_woonplaatsbeginsel_v2.pdf).

Parkes 2013

Parkes, A., Children and International Human Rights Law: The Right of the Child to be Heard, Routledge 2013.

Pieters 2012

Pieters, I.J., 'Waar staat de bijzondere curator in het huidige rechtsbestel inmiddels?', FJR 2012/36.

PI Research \& Van Montfoort 2009.

PI Research \& Van Montfoort, A. Handboek Deltamethode Gezinsvoogdij: De nieuwe methode voor de uitvoering van de ondertoezichtstelling. Duivendrecht/Woerden: PI Research/Van Montfoort 2009.

Prinsen 2012

Prinsen, P.J.A, 'Herziening maatregelen van kinderbescherming', FJR 2012/86.

Pulles 2014

Pulles, G., Vijfentwintig jaar IVRK en de Nederlandse rechter, Oisterwijk: Wolf Legal Publishers 2014.

Pulles \& Worst 2012

Pulles, G.J.W. \& Worst, L. J. C.M, 'Doorwerking van het IVRK: de wetgever geeft het voorbeeld', FJR 2012/64.

Quik-Schuijt 2015

Quik-Schuijt, A.M., 'Drang in de jeugdzorg', FJR 2015/51. 
Rap 2013

Rap, S., The participation of juvenile defendants in the youth court (diss. Universiteit Utrecht) 2013.

Rood-de Boer 1983

Rood-de Boer, M., 'De nieuwe grondwet en het kiesrecht van ontzette ouders', FJR 1983, p. 87-89.

De Roos 2001

Roos, S. de, F. Bucx en M. Geijer, 'Gezondheid en probleemgedrag van kinderen: de rol van ouders en de bredere opvoedomgeving', in: Bucx, F. Het Gezinsrapport. Den Haag, Sociaal en Cultureel Planbureau, 2011.

Rutten 2005

Rutten, S., Cultuur en familierecht in eigen kring, Preadvies voor de Nederlandse Vereniging voor Rechtsvergelijking, Deventer Kluwer 2005.

De Ruyter \& Bijl 2008

De Ruyter, D.J. \& Bijl, B., 'Doelen van de ondertoezichtstelling', in: Bruning \& Kok (red.), Herziening kinderbeschermingsmaatregelen. Commentaren op het voorontwerp van wet. FJR Congesbundel, Deventer: Kluwer 2008.

Satink 2018

Satink, A.E.J, 'De Raad voor de Kinderbescherming en de bestrijding van ernstige en (mogelijk) fatale kindermishandeling in het licht van de nieuwe gemeentelijke verantwoordelijkheid', FJR 2018/24.

De Savornin Lohman 2000

Savornin Lohman, J. de, Bruning, M.R., Goderie, M.J.H., Nieborg, S.M.A., Steketee, M.J., Graaf, P. de (medew.), Huntjens, K. (medew.), Met recht onder toezicht gesteld. Evaluatie herziene OTS-wetgeving, WODC 2000.

Seinen 2014

Seinen, C.J.A., 'De gevolgtrekking die hij geraden acht. Sancties op schending van de waarheidsplicht', TCR 2014/3, p. 84-95.

Slot 2002

Slot, W., Theunissen, A., Esmeijer, F. J., Duivenvoorden, Y., Een onderzoek naar de doelmatigheid van de ondertoezichtstelling, VU: Amsterdam, 2002. 
Slot 2008

Slot, W., 'Herziening kinderbeschermingsmaatregelen in een ontwikkelingsperspectief', in: Bruning \& Kok (red.), Herziening kinderbeschermingsmaatregelen. Commentaren op het voorontwerp van wet. FJR Congesbundel, Deventer: Kluwer 2008.

Slot 2013

Slot, W., 'Wat werkt bij de ondertoezichtstelling en komt dit tot zijn recht in de nieuwe wettelijke kaders', in: Bruning \& Liefaard (red.). De ondertoezichtstelling 90 jaar - versleten of vitaal?, Sdu Uitgevers: Den Haag 2013.

Slot \& Van Montfoort 2008

Slot, N. W., \& van Montfoort, A. Handboek Deltamethode Gezinsvoogdij. De nieuwe methode voor de uitvoering van de ondertoezichtstelling. Utrecht: MOgroep.

Staatscommissie Herijking ouderschap 2016

Staatscommissie Herijking ouderschap, Kind en ouders in de 21ste eeuw, Den Haag 2016.

Stams 2010

Stams, G.J.J.M, Top-van der Eem, M., Limburg, S., Van Vugt, E.S., Van der Laan, P.H., Implementatie en doelmatigheid van de Deltamethode Gezinsvoogdij, Amsterdam:

Kohnstamm Instituut 2010.

Steketee 2003

Steketee, M., Annuska, M., Overgaag, M., Lunnemann, M., Minderjarigen als procespartij?, Verwey-Jonker Instituut: Utrecht 2003.

Stolker 2002

Stolker, C., 'Ja geleerd zijn jullie wel', NJB 2002/78.

Van Teeffelen 2007

Van Teeffelen, P.A.J.Th., 'Vertrouwelijk of geheim kinderverhoor?', EB 2007/41.

Tjong Tjin Tai 2018

T.F.E. Tjong Tjin Tai, GS Burgerlijke Rechtsvordering artikel 19 Rv., aant. A2., actueel t/m 29-5-2018.

Vlaardingerbroek 1994

Vlaardingerbroek, P., 'Allegro ma non troppo. De versterking van de rechtspositie van jeugdigen. Een overzicht', RM Themis, 2014, nr. 10. 
Vlaardingerbroek 2004

Vlaardingerbroek, P., 'Van jeugdhulp/jeugdbescherming naar jeugdzorg', FJR 2004/101.

Vlaardingerbroek 2007

Vlaardingerbroek, P., 'Kinderen eerst, ouders laatst?', FJR 2007/2.

Vranken 1997

Vranken, J. B. M., 'Vertrouwen en rechtszekerheid in het overeenkomstenrecht. Preadvies voor de Vereniging voor de Vergelijkende Studie van het recht van België en Nederland', In: Vranken, N. Verheij, \& J. de Hullu (editors), Vertrouwensbeginsel en rechtszekerheid in Nederland. Deventer: Tjeenk Willink, 1997.

Vranken 2014

Vranken, J.B.M., Mr. C. Assers handleiding tot de beoefening van het Nederlands burgerlijk recht. Algemeen deel : Een synthese, Deventer: Kluwer, 2014.

Vranken \& Van Dijck 2011

Vranken, J.B.M., Van Dijck, G., 'Law and ... bewegingen: Een slotbeschouwing', Weekblad voor privaatrecht, notariaat en registratie, 142(6910)

Vroom-Cramer 2014

Vroom-Cramer, B.M., 'Het belang van het indicatiebesluit bij de uithuisplaatsing van minderjarigen', FJR 2014/6.

Weijers 2012

Weijers, I., Parens Patriae en prudentie. Grondslagen van jeugdbescherming (oratie Utrecht), Amsterdam, SWP Uitgeverij 2012.

Weijers 2016

Weijers, I. Rotjeugd. Een pedagogisch perspectief op straffen en beschermen. Amsterdam: SWP, 2016.

Wiarda 1971

Wiarda, J., Jeugdbeschermingsrecht, Staatsuitgeverij, 's-Gravenhage 1971.

Van Wijk 1999

Van Wijk, H., Hoezo noodzakelijk. Rechtsgronden voor kinderbeschermingsmaatregelen, Amsterdam: THELA THESIS, 1999. 
Van Zanten \& Brenninkmeijer 2011

Van Zanten, M., \& Brenninkmeijer, A.F.M., 'Waarheidsvinding: van groot belang in de jeugdbescherming', FJR 2011/76.

Wortmann 1995

Wortmann, S. 'Ouderlijk gezag en omgang', FJR 1995/9.

Wortmann 2013

Wortmann, S., 'Het EVRM in de praktijk', in: Bruning \& Liefaard (red.). De

ondertoezichtstelling 90 jaar - versleten of vitaal?, Sdu Uitgevers: Den Haag 2013.

Wortmann 2019

Wortmann, S., 'Perspectieven voor het familie- en jeugdrecht', FJR 2019/61.

Zeijl 2005

Zeijl, E., M. Crone, K. Wiefferink, S. Keuzenkamp en M. Reijneveld, Kinderen in Nederland. Den Haag/Leiden, SCP/TNO Kwaliteit van Leven, 2005. 


\section{Kamerstukken}

Kamerstukken II 1919/20, 409, nr. 3 (MvT).

Kamerstukken II 1963/64, 7753, nr. 3 (MvT).

Kamerstukken II 1979/80, 16 127, nr. 3, (MvT).

Kamerstukken II 1989/90, 21 309, nr. 2.

Kamerstukken II 1991/92, 22 487, nr. 3 (MvT).

Kamerstukken II, 1992/93, 22 487, nr.6.

Kamerstukken II 1992/93, 23 003, nr. 3.

Kamerstukken II 1992/93, 23 012, nr. 2.

Kamerstukken II 1992/93, 23 012, nr. 3.

Kamerstukken II 1992/93 23 003, nr. 4.

Kamerstukken II 1993/94 23 003, nr. 5.

Kamerstukken II 1999/2000, 26 855, nr. 3.

Kamerstukken II 2001/02 26016, nr. 19.

Kamerstukken II 2001/02, 28 168, nr. 3 (MvT).

Kamerstukken II 2003/04, 29200 VI, nr. 116.

Kamerstukken II 2005/06, 30145, nr. 5.

Kamerstukken II 2005/06, 30145, nr. 6.

Kamerstukken II 2005/6, 30 316, nr. 3. (MvT).

Kamerstukken II 2005/06, 30 644, nr.3 (MvT).

Kamerstukken II 2008/09 32 105, nr. 2.

Kamerstukken II 2008/9, 32 015, nr.3 (MvT).

Kamerstukken II 2009/10, 31 839, nr. 58.

Kamerstukken II 2010/11, 32 015, nr. 47. 
Kamerstukken II 2010/11， 32 015, nr. 49..

Kamerstukken II 2010/11, 32 856, nr. 3 (MvT).

Kamerstukken II 2010/11, 32015, nr. 39.

Kamerstukken II 2010/11, 32015, nr. 40.

Kamerstukken II 2012/13, 33 684, 3 (MvT), p. 54.

Kamerstukken II 2013/14, 33 684, nr 32.

Kamerstukken II 2013/14, 33983, nr. 2.

Kamerstukken II 2013/14, 33 684, nr.99.

Kamerstukken II 2013/14, 31 839, nr. 347.

Kamerstukken II 2013/14, 33 983, nr 3 (MvT), p.4.

Kamerstukken II 2014/15, 31 839, nr. 480

Kamerstukken II 2015/16, 31 839, nr. 510.

Kamerstukken II 2015/16, 34279, nr. 4, p. 2-3.

Kamerstukken II 2016/17 34550 XVI, nr. 85.

Kamerstukken II 2017/18, 31 839, nr. 568.

Kamerstukken II 2017/18, 31 839, nr. 622.

Kamerstukken II 2020/21 33836 nr. 41.

Kamerstukken II 2018-2019, 35 219, nr. 3.

\section{Rechtspraak Europees Hof voor de Rechten van de Mens}

EHRM 24 maart 1988, appl. No. 10465/83 (Olsson I/Zweden).

EHRM 22 juni 1989, appl. No. 11373/85.(Eriksson t. Zweden,)

EHRM 27 november 1992, appl. No. 13441/87 (Olsson II t. Zweden)

EHRM 26 mei 1994, appl. No. 16969/90 (Keegan t. Ierland) 
EHRM 23 september 1994, appl. nr. 19823/92, (Hokkanen t. Finland).

EHRM 7 augustus 1996, appl. No. 17383/90 (Johansen tegen Noorwegen).

EHRM 6 juni 1998, appl.nr. 22430/93, (Bronda t. Italie).

EHRM 13 juli 2000, Appl. Nrs. 39221/98 \& 41963/98 (Scozzari t. Italie).

EHRM 26 februari 2002, appl. nr. 46544/99 (Kutzner t. Duitsland)

EHRM 12 juli 2002, appl.no. 25702/94 (K. en T / Finland).

EHRM 17 december 2002, ECLI:NL:XX:2002:AF497 (Venema t.. Nederland)

EHRM 14 januari 2003, appl. No. 27751/95 (K.A. t. Finland)

EHRM 8 juli 2003, appl. nr. 30943/96, (Sahin t. Duitsland).

EHRM 8 juli 2003, appl.nr. 31871/96 (Sommerfeld t. Duitsland).

EHRM 8 april 2004, nr. 11057/02, NJ 2005, 186 (Haase t. Duitsland).

EHRM 9 mei 2006, app. Nr. 18249/02, (C. t. Finland)

EHRM 12-09-2006, ECLI:NL:XX:2006:AZ1538 (Moser t. Oostenrijk).

EHRM 26 oktober 2006, appl. nr. 23848/04, (Wallova \& Walla t. Tsjechie);

EHRM 18 december 2008, Appl. Nr. 39948/06 (Saviny t. Oekraine).

EHRM 24 september 2012, appl. No. 35141/06 (Levin t. Zweden)

EHRM 3 september 2015, appl. nr. 10161/13, (M. \& M. t. Kroatie);

EHRM 6 oktober 2015, appl.nr. 58455/13 (N.P/Moldavië).

EHRM 2 februari 2016, ECLI:CE:ECHR:2016:0202JUD007177612 (N.TS. e.a./Georgië)

EHRM 30 november 2017, nr. 37283/13, (Strand Lobben e.a. tegen Noorwegen.

EHRM 10 maart 2020, ECLI:CE:ECHR:2020:0310JUD003971015, (Pedersen e.a. $t$. Noorwegen).

EHRM 10 maart 2020, ECLI:CE:ECHR:2020:0310JUD001465216, (Hernehult $t$. Noorwegen). 


\section{Nationale rechtspraak}

\section{Hoge Raad}

HR 30 april 1928, NJ 1928, p. 1217.

HR 14 februari 1929, NJ 1929, 825.

HR 31 mei 1963, NJ 1966, 337.

HR 2 december 1982, NJ 1984/306.

HR 20 november 1987, NJ 1988, 657.

HR 10 maart 1989, NJ 1990/24.

HR 23 maart 1990, NJ 1991/149.

HR 23 maart 1990, NJ 1991/150.

HR 4 juni 1993, NJ 1993/659 (Vredo/Veenhuis).

HR 25 september 1998, ECLI:NL:HR:1998:ZC2714

HR 13 november 1998, NJ 1999/147.

Hoge Raad 13 april 2001, ECLI:NL:HR:2001:AB1009.

HR 25 oktober 2002, NJ 2003/171.

HR 24 januari 2003, ECLI:NL:PHR:2003:AF0204, m.nt. S.Wortmann.

HR 13 juli 2007, NJ 2007/586 (De Oorsprong/Gem. Utrecht).

HR 7 september 2007, NJ 2007/465, r.o. 3.4 (conclusie A-G Langemeier).

HR 21 mei 2010, ECLI:NL:HR:2010:BL7043.

HR 14 oktober 2011, ECLI:NL:HR:2011:BR5151, m.nt. S.F.M. Wortmann

HR 31 mei 2013, ECLI:NL:HR:2013:BZ5422.

HR 1 november 2013, ECLI:NL:HR:2013:1084, m.nt. S. Wortmann.

HR 12 september 2014, ECLI:NL:HR:2014:2665, (conclusie A-G F.F. Langemeijer),

HR 5 december 2014, ECLI:NL:HR:2014:3535, NJ 2015/57, m.nt. S. Wortmann.

HR 21 mei 2010, ECLI:NL:HR:2010:BL7043.

HR 16 februari 2018, ECLI:NL:HR:2018:218. 
HR 19 oktober 2018, ECLI:NL:HR:2018:1976.

\section{Gerechtshof}

Gerechtshof Amsterdam 23 juni 1970, NJ 1970/458.

Gerechtshof Arnhem 19 januari 1993, NJ 1994, 711.

Gerechtshof 's-Hertogenbosch 8 september 1999, NJ 401.

Gerechtshof 's-Gravenhage 25 oktober 2000, ECLI:NL:GHSGR:2000:AB0139.

Gerechtshof 's-Gravenhage 2 december 2009, ECLI:NL:GHSGR:2009:BK8239.

Gerechtshof Leeuwarden 4 oktober 2011, ECLI:NL:GHLEE:2011:BT7523.

Gerechtshof Arnhem-Leeuwarden 22 maart 2012, ECLI:NL:GHARN:2012:BW5429.

Gerechtshof Amsterdam 11 maart 2014, ECLI:NL:GHAMS:2014:1504.

Gerechtshof ‘s-Hertogenbosch 16 juni 2016, ECLI:NL:GHSHE:2016:2425.

Gerechtshof 's-Gravenhage 13 januari 2016, ECLI:NL:GHDHA:2016:40.

Gerechtshof 's-Gravenhage 10 februari 2016, ECLI:NL:GHDHA:2016:369.

Gerechtshof Arnhem-Leeuwarden 16 februari 2016, ECLI:NL:GHARL:2016:1428.

Gerechtshof 's-Gravenhage 2 maart 2016, ECLI:NL:GHDHA:2016:1766.

Gerechtshof Arnhem Leeuwarden 14 april 2016 ECLI:NL:GHARL:2016:2968.

Gerechtshof Arnhem-Leeuwarden 21 april 2016, ECLI:NL:GHARL:2016:3302.

Gerechtshof 's-Gravenhage 13 januari 2016, ECLI:NL:GHDHA:2016:40.

Gerechtshof Arnhem-Leeuwarden 21 juni 2016, ECLI:NL:GHARL:2016:5119.

Gerechtshof Arnhem-Leeuwarden 14 juli 2016, ECLI:NL:GHARL:2016:6134.

Gerechtshof 's-Gravenhage 17 augustus 2016, ECLI:NL:GHDHA:2016:2418.

Gerechtshof 's-Gravenhage 31 augustus 2016, ECLI:NL:GHDHA:2016:2643.

Gerechtshof Arnhem-Leeuwarden 22 september 2016, ECLI:NL:GHARL:2016:7796.

Gerechtshof 's-Gravenhage 28 september 2016, ECLI:NL:GHDHA:2016:2919. 
Gerechtshof Arnhem-Leeuwarden 8 november 2016, ECLI:NL:GHARL:2016:9065.

Gerechtshof Amsterdam 9 mei 2017, ECLI:NL:GHAMS:2017:1725.

Gerechtshof Arnhem-Leeuwarden 9 maart 2017, ECLI:NL:GHARL:2017:2058

Gerechtshof 's-Hertogenbosch 16 maart 2017, ECLI:GHSHE:2017:1058.

Gerechtshof Arnhem-Leeuwarden 12 september 2017, ECLI:NL:GHARL:2017:8172.

Gerechtshof Amsterdam 17 april 2018, ECLI:NL:GHAMS:2018:1315.

Gerechtshof Arnhem-Leeuwaren 29 november 2018, ECLI:NL:GHARL:2018:10428.

Gerechtshof s-Hertogenbosch 5 september 2019, ECLI:NL:GHSHE:2019:3292.

\section{Rechtbank}

Rb. Alkmaar 5 september 2007, ECLI:NL:RBALK:2007:BB3871.

Rb. Breda 2 maart 2007, ECLI:NL:RBBRE:2007:BA0701.

Rb. Zwolle 8 december 2008, LJN BG8871.

Rb. Utrecht 30 oktober 2009, ECLI:NL:RBUTR:2009:BK1598.

Rb. Maastricht 2 juni 2010,ECLI:NL:RBMAA:2010:BM7024.

Rb. Leeuwarden 18 mei 2011, LJN BR2117.

Rb. Den Haag 11 maart 2013, ECLI:NL:RBDHA:2013:BZ7295.

Rb. Amsterdam 29 april 2014, ECLI:NL:RBAMS:2014:155;

Rb. Overijssel 21 april 2015, ECLI:NL:RBOVE:2015:2652.

Rb. Overijssel 8 mei 2015, ECLI:NL:RBOVE:2015:3361.

Rb. Overijssel 1 oktober 2015, ECLI:NL:RBOVE:2015:5764.

Rb. Limburg 23 oktober 2015, ECLI:NL:RBLIM:2015:9451.

Rb. Noord-Holland 15 januari 2019, ECLI:NL:RBNHO:2019:224. 


\section{Dankwoord}

Na jaren van onderzoek, waarbij ik een aanzienlijk deel van mijn onderzoekstijd op het landelijk hoofdkantoor van de Raad voor de Kinderbescherming in Den Haag heb doorgebracht, is dit promotietraject nu afgerond. Een bijzondere afronding, want door de maatregelen die nu (november 2020) zijn getroffen in het verband met het coronavirus speelt een groot deel van het werkzame leven zich af online. Zo ook de verdediging van dit proefschrift. Ik hoop dat anderen in de nabije toekomst weer met familie, collega's en vrienden deze bijzondere mijlpaal kunnen vieren in het Academiegebouw te Utrecht, maar tegelijkertijd ben ik ook dankbaar dat ik überhaupt kan promoveren. Op deze plek wil ik een aantal personen bedanken, die door middel van hulp en aanmoediging hebben bijgedragen aan de totstandkoming van dit proefschrift. In de eerste plaats wil ik mijn promotoren zeer hartelijk danken voor de betrokkenheid en begeleiding tijdens het promotietraject. Ido Weijers, jij hebt mij de kans gegeven in 2012 om als docent en onderzoeker bij de Universiteit Utrecht aan de slag te gaan. In de daaropvolgende jaren hebben wij nauw samengewerkt op het gebied van onderwijs en onderzoek. Ook na je emeritaat in 2016 hebben we onze plezierige samenwerking kunnen voortzetten en ben je een geweldige begeleider geweest van dit traject. Het was en is een voorrecht om samen te werken en van je te leren en ik hoop in de toekomst samen nog vele koffiebarretjes (Ido latte macchiato - Joost cafe doppio) onveilig te kunnen maken. Katharina Boele-Woelki, zeer veel dank voor de (vaak razendsnelle) en inhoudelijk zeer waardevolle feedback tijdens dit promotietraject. Jouw enorme kennis, oog voor detail en inzicht ten aanzien van de structuur en inhoud, zijn onmisbaar geweest bij de totstandkoming van dit proefschrift.

Daarnaast wil ik professor Jessica Asscher, professor Mariëlle Bruning, Goos Cardol, professor Wendy Schrama en professor Paul Vlaardingerbroek hartelijk bedanken voor de bereidheid zitting te nemen in de promotiecommissie. Jullie uitgebreide en constructieve commentaar heeft dit proefschrift naar een hoger niveau getild.

Daarnaast bedank ik graag mijn paranimfen Kristien Hepping en Marloes Huijer. Kristien al sinds jaar en dag mijn inhoudelijk steengoede maar bovenal fijne collega in de minor jeugdbescherming en jeugdcriminaliteit. Marloes al 31 jaar mijn lieve zus. Bedankt beiden dat jullie ook in deze bijzondere tijd hebben bijgedragen aan de voorbereidingen op de promotie.

Ook een woord van dank wil ik richten tot mijn collega's van de Universiteit Utrecht, in het bijzonder mijn fijne collega's bij het Utrecht Centre for European Research into Family Law 
$(U C E R F)$. Daarnaast zijn de overige collega's van het Molengraaff Instituut voor Privaatrecht, met wie ik in de achterliggende jaren prettig heb samengewerkt (en vooral eindeloos veel afstudeerwerken heb beoordeeld), mijn dank verschuldigd. Zonder anderen tekort te willen doen moet ik Merel Jonker in het bijzonder noemen, die mij in de laatste, moeilijke fase van het promotietraject heeft gesteund en met raad en daad heeft bijgestaan. Ook een woord van dank voor een aantal personen die strikt genomen geen collega's zijn. De tijd die ik heb doorgebracht bij de Raad voor de Kinderbescherming heb ik als bijzonder prettig en inspirerend ervaren, mede dankzij Ingeborg Galama, Madelon de Vries, Marijke Klarenberg, Meta Kuipers, Goos Cardol en Hans van de Donk.

Ik ben aangekomen bij mijn familie en vriendenkring. Mijn dierbare vrienden met wie ik binnen en buiten Utrecht menig gastronomisch hoogtepunt en hachelijk avontuur heb mogen beleven. Dank oud-Bankanen en Bankanen voor jullie interesse, steun en de broodnodige afleiding. Daarnaast bedank ik ook mijn familie, in het bijzonder mijn lieve zus, mijn zwager en mijn schoonfamilie.

Tot slot een speciaal woord van dank voor mijn geweldige ouders. Het bestuderen van honderden jeugdbeschermingszaken leert ook dat een zorgeloze jeugd met liefde en aandacht geen vanzelfsprekendheid is. Wat ben ik dankbaar lieve papa en mama. Jullie zijn altijd zo goed voor me geweest en jullie hebben mij - ook zeker tijdens dit traject - door dik en dun gesteund. Michelle en Jesse, ik draag dit proefschrift aan jullie op. Lieve Michelle, zonder jouw liefde, betrokkenheid en geduld was dit boek nooit tot stand gekomen. Lieve Jesse, jij hebt in wetenschappelijke zin bijzonder weinig bijgedragen aan dit boek, maar wat breng jij een hoop plezier en geluk in ons leven.

Rotterdam, najaar 2020 


\section{Curriculum Vitae}

Joost Izak Huijer werd geboren op 26 januari 1987 te Vlaardingen. Hij haalde zijn atheneumdiploma in 2004 aan het Thorbecke Lyceum te Rotterdam. Hierna studeerde hij rechten aan de Universiteit Utrecht. In 2012 voltooide hij de master Strafrecht met als specialisatie het jeugdstrafrecht. Sinds 2012 is hij als docent en onderzoeker verbonden aan de Universiteit Utrecht. Hij is verantwoordelijk voor het onderwijs op het terrein van het jeugdrecht, zowel de civiel- als strafrechtelijke kant. Daarnaast begeleidt hij studenten op het terrein van het erfrecht en personen- en familierecht. Als onderzoeker is hij onder meer betrokken geweest bij de tussenevaluatie van de Wet herziening kinderbeschermingsmaatregelen in 2018. Daarnaast is hij sinds 2020 lid van de redactie van het Tijdschrift voor Familie- en Jeugdrecht en auteur voor de Groene Serie Personen- en Familierecht. 